\title{
HORST LÖSSLEIN
}

\section{Royal Power in the Late Carolingian Age}

Charles III the Simple and His Predecessors
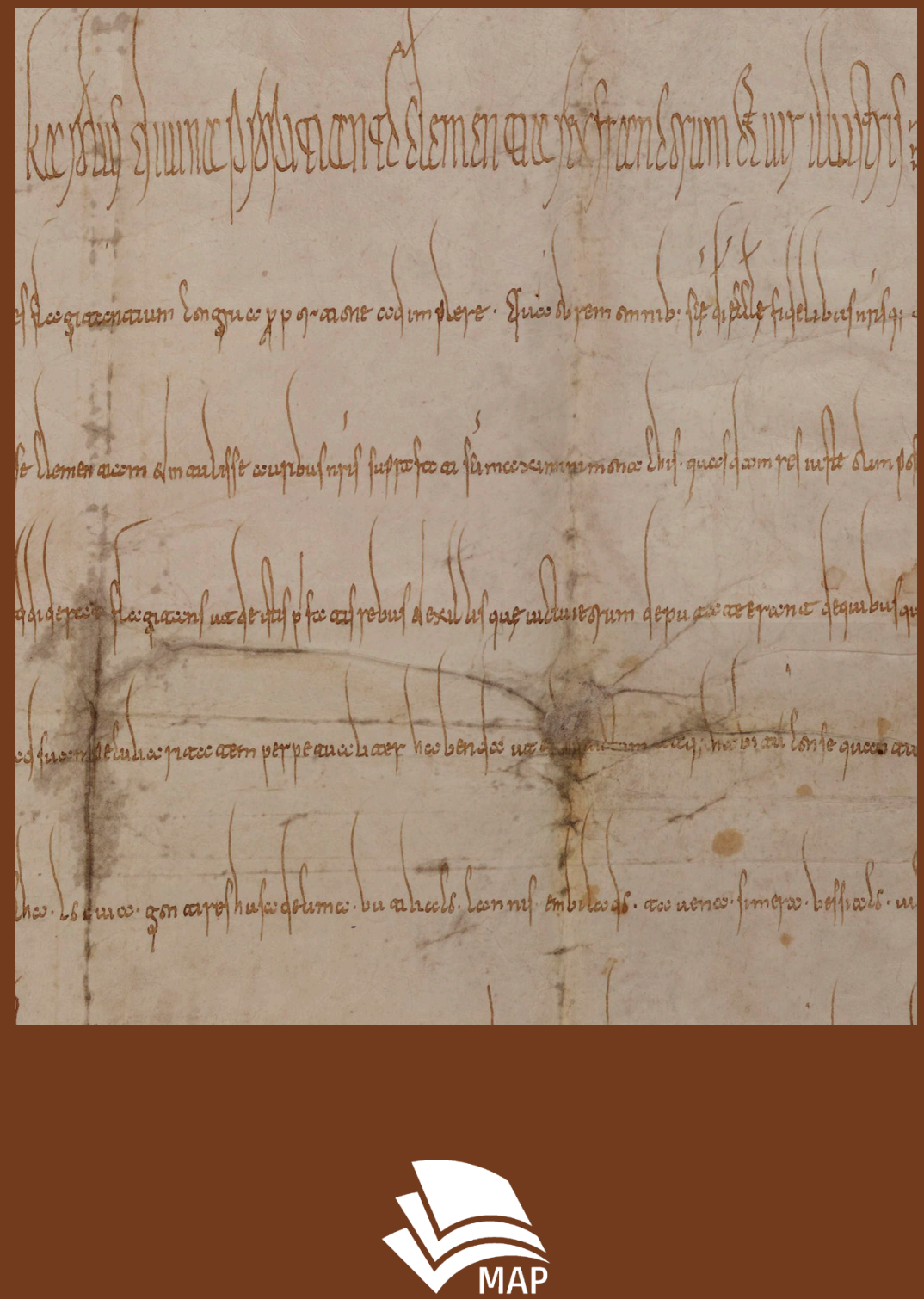
Horst Lößlein · Royal Power in the Late Carolingian Age 


\section{Published by Modern Academic Publishing (MAP) 2019}

Modern Academic Publishing (MAP) is an initiative from the University of Cologne that contributes to the digital humanities, in the field of electronic publishing. MAP is led by Prof Dr Gudrun Gersmann, Chair of Early Modern History.

The MAP partners, the University of Cologne and the Ludwig-Maximilians-Universität Munich (LMU), are funding the open-access publication of selected dissertations and post-doctoral monographs by humanist scholars of both universities. The main target of MAP is combining the support of highly awarded researchers at an early stage of their career with new digital formats of publishing in the humanities.

www.humanities-map.net
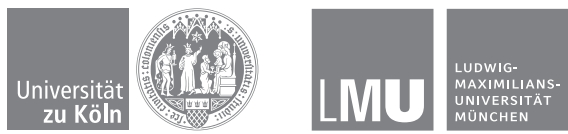
Horst Lößlein

\section{Royal Power in the Late Carolingian Age}

Charles III the Simple and His Predecessors 
Published by

Modern Academic Publishing

University of Cologne

Albertus-Magnus-Platz

50923 Cologne, Germany

Funded by the Ludwig-Maximilians-Universität Munich

Text @ Horst Lößlein 2019

This work is licensed under the Creative Commons Attribution BY 4.0. To view a copy of this license, visit http://creativecommons.org/licenses/by/4.0/. This license allows for copying any part of the work for personal and commercial use, providing author attribution is clearly stated. Figures may have different licenses. These will have been identified in the caption to relevant content.

First published 2019

Accepted as a dissertation at the Université de Limoges and Ludwig-MaximiliansUniversität Munich 2017

Cover image: "Karolus divina propitiante clementia rex Francorum et vir illustris", detail of a royal diploma of Charles III the Simple for Saint-Maximin of Trier, issued 1st January 912 at Metz, Bibliothèque nationale de France, Latin $9264 \mathrm{~N}^{\circ} 12$, [03.08.2015], Permalink: https://gallica.bnf.fr/ark:/12148/btvlb52505561w/f25.image (accessed 31.10.2018), CC0 1.0.

Bibliographic information of the German National Library

The German National Library lists the title in the German National Bibliography; to view detailed bibliographic information, visit http://dnb.dnb.de.

ISBN (Hardcover): 978-3-946198-48-2

ISBN (EPUB): 978-3-946198-49-9

ISBN (Kindle): 978-3-946198-50-5

ISBN (PDF): 978-3-946198-51-2

DOI: https://doi.org/10.16994/ban

Production \& publishing platform provided as part of the Ubiquity Partner Network Ubiquity Press Ltd, Unit 2N, 6 Osborn Street, London, E1 6TD, United Kingdom

To read the free, open access version of this book online, visit https://doi.org/10.16994/ban or scan this QR code with your mobile device: 
Meiner Familie 



\section{Contents}

Preface $\quad X I$

Summary XIII

Abbreviations $\quad$ XV

Introduction $\quad 1$

Possibilities and limits of late Carolingian rule 6

The functioning of royal power 9

$\begin{array}{ll}\text { Analytical approach } & 17\end{array}$

I. Becoming king: The questions of legitimacy and support 21

I.1 Charles' claim to the throne 21

I.1.1 Louis the Stammerer's two marriages 22

$\begin{array}{lll}\text { I.1.2 The question of Louis' succession } & 25\end{array}$

I.1.3 Passing over Charles 28

I.1.4 A Robertian on the throne 32

$\begin{array}{lll}\text { I.1.5 Carolingian blood matters } & 37\end{array}$

I.2 Close supporters and distant allies 39

I.2.1 Archbishop Fulk of Reims 39

I.2.2 The network elevating Charles 44

I.2.3 The motives behind the rebellion 50

I.2.4 The cohesion of the network 53

I.2.5 Allies sought within the realm 55

$\begin{array}{lll}\text { I.2.6 Allies sought outside the realm } & 62\end{array}$

$\begin{array}{lll}\text { I.2.7 A network of different layers } & 68\end{array}$

I.3 Conclusion 70

II. Changes in the political landscape:
From Louis the Stammerer to Odo

II.1 Old elites: Louis II the Stammerer 79

II.2 Rival factions: Louis III and Carloman II 89

II.3 New faces on the rise: Charles the Fat 101

II.4 Resistance, integration and rebellion: Odo 111

II.5 Conclusion: Continuities and changes 121

III. Networks of royal power: Charles the Simple 127

III.1 General overview 127

III.1.1 Charles' itinerary 130

III.1.2 Contacts with distant regions 134

III.1.3 Using diplomas to demonstrate Carolingian legitimacy? 142 
III.2 Breaking it down: Networks of royal power 149

III.2.1 Close associates and allies $\quad 151$

III.2.1.1 The first years 151

III.2.1.2 Shifting balances 154

III.2.1.3 A new balance 157

III.2.1.4 Lotharingia 162

III.2.1.5 The early Lotharingian network 169

III.2.1.6 A king of two regna? 175

$\begin{array}{lll}\text { III.2.1.7 The later years } & 178\end{array}$

III.2.1.8 Liberty of choice? 187

III.2.2 Family and friends 191

III.2.3 The role of the marchiones 205

III.3 Conclusion: The development of

Charles' network and its dissolution 222

IV. Relations with other rulers 233

IV.1 Creating cooperation: Louis the Stammerer 233

IV.2 Carolingian networks: Louis III and Carloman II 236

IV.3 Structural weaknesses: Odo 240

IV.4 Possibilities and limits of royal power: Charles the Simple 243

IV.5 Conclusion 259

$\begin{array}{ll}\text { V. The Viking problem } & 261\end{array}$

V.1 Viking incursions and royal measures

V.1.1 Going on the offensive:

V.1.2 Strategies of containment: Odo 274

V.1.3 Return to the old strategies: Charles the Simple 277

$\begin{array}{lll}\text { V.2 Diplomatic solutions } & 281\end{array}$

V.2.1 Dudo's De moribus et actis primorum Normanniae ducum 281

V.2.2 The treaty of Saint-Clair-sur-Epte 284

V.2.3 Using an old solution in a new way 289

V.3 Conclusion 292

VI. Conflicts, rebellions and the role of trust 295

VI.1 Solving conflicts: The role of interest groups 299

VI.2 Rulers and nobles: Breaches of trust 308

VI.3 Speaking justice: Symbolic acts 316

VI.4 Against the king: Questioning the right to rule 330

VI.5. Conclusion 334 
Conclusion

Bibliography

353

Primary Sources 353

Secondary Sources 360

Index

395 



\section{Preface}

Die vorliegende Untersuchung wurde im Wintersemester 2016/2017 an der Faculté des Lettres et des Sciences Humaines der Université de Limoges und der Fakultät für Geschichts- und Kunstwissenschaften der Ludwig-Maximilians-Universität München als Dissertation unter dem Titel „Possibilities of Royal Power in the Late Carolingian Age: Charles III the Simple“ angenommen. Für die Publikation wurde sie geringfügig überarbeitet und neu erschienene Literatur nach Möglichkeit berücksichtigt.

Die Université de Limoges und die Région Limousin haben die Arbeit an dieser Studie mit einem Stipendium unterstützt. Dankbar bin ich zudem den Monumenta Germaniae Historica in München, bei denen ich zuletzt nicht nur im Rahmen eines Editionsprojektes wertvolle Erfahrungen sammeln durfte, sondern vor allem auch Zugang zur großartigen Institutsbibliothek erhalten habe.

Zutiefst verpflichtet bin ich meinen Doktoreltern, Professor Dr. Irmgard Fees und Professor Dr. Philippe Depreux. Sie haben mir diese Studie ermöglicht, mir den Weg gewiesen, mich gefördert und mir mit Rat und Tat zur Seite gestanden. Dank gebührt in diesem Zusammenhang darüber hinaus Professor Dr. Régine Le Jan, Professor Dr. Geneviève Bührer-Thierry, Professor Dr. Knut Görich, Professor Dr. Simon MacLean, Professor Dr. Jacques Péricard und Dr. Anne Massoni für mancherlei Hinweise und Unterstützung sowie ihre Mitwirkung an der Disputatio. Hilfe habe ich auf die eine oder andere Art und Weise auch von einer ganzen Reihe weiterer Personen erhalten, von denen ich gerne die folgenden nenne: Professor Dr. Bertrand Lançon, Dr. Tobie Walther, Dr. Johannes Bernwieser, Dr. Hélène Caillaud, Sarah Ewerling, Lucile Jaeck, und Anna Nierhoff. Hervorzuheben ist jedoch vor allem Dr. Fraser McNair, dessen Korrekturen, kenntnisreichen Hinweisen und scharfsinniger Kritik ich außerordentlich viel zu verdanken habe. Auch drei weitere Personen seien besonders hervorgehoben: Natascha Wanninger, für ihre Freundschaft und für ihre sprachlichen Korrekturen, Fabien Cerbelaud von der Université de Limoges für die fantastischen von ihm erstellten Karten sowie Dr. Claudie Paye für ihre Anleitung durch den Publikationsprozess.

Herzlicher Dank geht darüber hinaus an Professor Dr. Martina Hartmann, nicht nur für die Möglichkeit in den Hallen der Monumenta Germaniae Historica $\mathrm{zu}$ arbeiten, sondern auch für die mir dabei eingeräumten Freiheiten und die Unterstützung.

Schließlich danke ich meinen Freunden-unter ihnen insbesondere Dr. Hannes Hain-die mich in den vergangenen Jahren unterstützt, mit mir gelacht und gelitten haben und mit mir ungezählte Kilometer auf verschiedensten Gewässern gerudert sind. Die letzten Worte seien jedoch meiner Familie gewidmet: Ohne sie, ihre Liebe und ihre Zuversicht hätte ich diese Arbeit weder beginnen noch beenden können. 



\section{Summary}

Charles III the Simple (893/898-923) only became king when nobles rebelling against the Robertian Odo were in need of a candidate for the West Frankish throne. Posthumously born to Louis II the Stammerer, he was of Carolingian blood and thus able to provide the rebellion with an appearance of legitimacy. The rebels on the other hand offered Charles the opportunity of a lifetime: after 14 years of being ignored by the leading nobles of the West Frankish realm, he was finally able to succeed his father. Yet, while his reign lasted for 25 years, it ended how it had started and Charles was deposed by a rebellion led by Robert of Neustria. The circumstances of Charles' elevation and deposition are among the reasons for his image as a weak king, unable to control the nobles, and why he counts as a prime example of the "decline and fall" of the Carolingian empire towards the end of the 9th century. Yet, what does "weak king" mean? Modern scholarship has long discarded the view of kingship as a question of royal orders and noble obedience. Instead, it is understood as the result of a process involving both the ruler and those around him. Successful kingship depended on the ruler's ability to integrate the nobles into this process, to mediate between their and his own interests and to create consensus.

This understanding serves as basis for this new approach to fathoming out the possibilities and limits of late Carolingian royal power. First, the focus is set on the relations between the king and the nobles around him, interpreting royal actions as the result of their interactions. Second, the customary hierarchy of the source material is inverted. Royal diplomas, ideally suited to reveal the networks of royal power, are placed at the centre of the analysis and subjected to rigorous contextualisation, treating narrative sources as secondary. Third, the timeframe of this study is extended back to the late 870s, covering the decades during which the political landscape of the West Frankish realm underwent drastic changes that determined the framework for Charles the Simple's rule. Thus, not only these developments are revealed, but also comparisons can be made.

Charles' first task after he became the sole king of the West Frankish realm was to integrate his old opponents into his rule. This meant that he had to bridge the old rivalry between these individuals and his allies from the struggle with Odo, allies who now occupied key positions in the circle around him. A dominating group of nobles agitating against their political rivals at the royal court was nothing new and can also be observed during the reigns of Louis the Stammerer and his sons Louis III and Carloman II. Under Charles the Fat this situation changed. The emperor was able to promote men of his own choice since his power base was located in the East Frankish realm and, equally important, key members of this dominating group such as Hugh the Abbot and Gauzlin died. Death also opened the door to new political solutions for Charles the Simple. In his case it was the murder of his key supporter, Fulk of Reims, 
which allowed him to integrate his most important opponent into his rule: Robert of Neustria.

Ensuring Robert's cooperation was certainly a crucial factor to Charles' rule. Yet, his dependency on the marchio (or others like him, notably William the Pious or Richard the Justiciar) should not be overestimated. Early on, Charles was able to create a network of alliances that served as a counterweight. However, to stabilise the realm in the long run, such opposition needed to be overcome. Charles' remarkable gift in integrating Robert and other powerful nobles into his rule is demonstrated by the great successes of his rule: the change in strategy towards the Northmen represented by the treaty of Saint-Clair-sur-Epte as well as the integration of the leading Lotharingian nobles into the circle around him after the acquisition of the regnum was accomplished without estranging those of the Western realm. This acquisition also reveals how his political room for manoeuvre had increased compared to his predecessors: given to Louis the Younger as a lease after the death of Louis the Stammerer, Charles' brothers efforts to regain the regnum had been thwarted by their dependency on the alliance with the East Frankish rulers to defend the realm against the Northmen and the rebellious Boso. Charles, unhindered by such alliances, was able to pursue his interests much more aggressively against his neighbours. However, the lack of such alliances meant that he missed out on their stabilising effects in regard to the relations between him and his nobles, a circumstance he tried to correct when his relations with the said nobles deteriorated.

The key to understanding this deterioration lies in the importance of trust in the relations between the ruler and the nobles around him. The rebellion against Odo was the result of a crisis of trust that developed when Odo repeatedly acted against the interests and expectations of the West Frankish nobles. Similarly, Charles also appears to have developed a strong tendency to emphasise his majesty and royal prerogative towards the end of his rule, his famous favouring of the illliked Hagano being but one example. Yet, where Odo also achieved suppression of the rebellion by taking actions that restored trust in him, Charles continued on his path up to the point where even his closest allies turned away from him. Thus, Charles' neglect of ensuring the cooperation of the nobles and the creation of consensus deprived him of the foundations of his rule and marked the limits of his royal power. 


\section{Abbreviations}

$\begin{array}{ll}\text { BNF } & \text { Bibliothèque nationale de France } \\ \text { D, DD } & \text { Royal diplomas, MGH Diplomata or Chartes et diplômes } \\ \text { A } & \text { Arnulf } \\ \text { ChB } & \text { Charles II the Bald } \\ \text { ChF } & \text { Charles III the Fat } \\ \text { ChS } & \text { Charles III the Simple } \\ \text { CmII } & \text { Carloman II } \\ \text { HI } & \text { Henry I } \\ \text { KoI } & \text { Conrad I } \\ \text { LCh } & \text { Louis IV the Child } \\ \text { LIII } & \text { Louis III } \\ \text { LoI } & \text { Lothar I } \\ \text { LoII } & \text { Lothar II } \\ \text { LP } & \text { Louis the Pious } \\ \text { LS } & \text { Louis II the Stammerer } \\ \text { Merov } & \text { Merovingian kings } \\ \text { Odo } & \text { Odo } \\ \text { OI } & \text { Otto I } \\ \text { Prov } & \text { Kings of Provence } \\ \text { Ra } & \text { Raoul } \\ \text { RoI } & \text { Robert I } \\ \text { Z } & \text { Zwentibold }\end{array}$

DDN

JL

Recueil des actes des ducs de Normandie. Ed. Fauroux, Marie.

Jaffé/Loewenfeld: Regesta pontificum Romanorum (bis 1198), ed. Jaffé, Philipp, 2nd edition reworked by Wilhelm Wattenbach, Samuel Loewenfeld, Ferdinand Kaltenbrunner and Paul Ewald, Leipzig 1885-1889.

MGH

Capit.

Conc.

Const.

Epist.

Monumenta Germaniae Historica

Font. Iur. Germ.

Capitularia regum Francorum

Concilia

Constitutiones et acta publica imperatorum et regum Epistolae

Fontes iuris Germanici antiqui in usum scholarum separatim editi

Poetae Lat. Poetae Latini medii aevi

SS

Scriptores

SS rer. Germ. Scriptores rerum Germanicarum in usum scholarum separatim editi

SS rer. Germ. N.S. Scriptores rerum Germanicarum, Nova series PL

Patrologia Latina 



\section{Introduction}

Karolus stultus ("the Stupid" or "the Foolish") and Karolus follus ("the Crazy"), but also Karolus pius ("the Pious") and Karolus sanctus ("the Saint") of the cognomina that 11th to 13th century authors attributed to Charles III, who in modern times is called "der Einfältige" in German, "le Simple" in French and "the Simple" in English. The meaning of the most common byname, simplex, has long been analysed by Bernd Schneidmüller, ${ }^{2}$ who notes that it carried a positive meaning up until the 1lth century, depicting a virtue rather than carrying the negative connotations that became dominant later and which are still reflected in its modern translations. Recently, however, Geoffrey Koziol has criticised Schneidmüller's results as revisionist. ${ }^{3} \mathrm{He}$ argues that simplex is a word typically associated with monks, equated with "innocence" and thus conveys the image of a disadvantaged ruler. According to him, it was Charles' naivety which was perceived as having caused him to fall into Count Heribert II's hands-the event that branded him as simplex in the eyes of the medieval chroniclers. ${ }^{4}$ However, Koziol's own judgement differs fundamentally: "Charles went down in West Frankish histories as 'simple' because once defeated at Soissons, he trusted the word of the count of Vermandois and foolishly walked into a trap. But Charles was anything but simple. He was one of the most intelligent and complex of the Carolingians." ${ }^{\prime \prime}$ Charles the Simple as a kind of failed genius? This assessment is far removed from the judgement of Auguste Eckel, author of the first and so far the only study of the Carolingian's reign, who depicted him as "naturellement bon, un peu faible de caractère et crédule, mais ne manquant, au besoin, ni dénergie ni de volonte'" and even more removed from that of Ernst Dümmler, who described him as incompetent, unwarlike and far less intelligent than his grandfather Charles the Bald, yet ambitious all the same. ${ }^{7}$ Of course, those latter characterisations are mainly based on Charles the Simple's final failure, his deposition at the hands of the nobles and his inglorious capture by Count Heribert II of Vermandois in 923. Also, perhaps, episodes described by the late 10th century authors Richer of Saint-Remi ${ }^{8}$ and Dudo of Saint-Quentin ${ }^{9}$ may have been influential.

1 Eckel, Charles, 140-144 (appendix I) with the sources. Other cognomen used are insipiens, hebes and parvus, but also minor, sanctus and pius.

2 Schneidmüller, Einfältigkeit.

3 Koziol, Politics.

4 Koziol, Politics, 461-465.

5 Koziol, Politics, 529.

6 Eckel, Charles, 139.

7 Dümmler, Geschichte III, 436.

8 For example on Charles' relation to Hagano, Richer, I, c. 15, 51-52: Nam cum multa benignitate principes coleret, precipua tamen beatitudine Haganonem habebat, quem ex mediocribus potentem effecerat, adeo ut magnatibus quibusque longe absistentibus ipse regio lateri solus hęreret, pilleum etiam a capite regis sepissime sumptum, palam sibi imponeret.

9 I refer to the famous foot kiss by a Northman, who instead of kneeling down before the king, lifted the latter's foot to his own mouth, making the king fall on his back. Dudo, De moribus II, c. 29, 169: 
Evaluating Charles' reign is a difficult task indeed. Louis II the Stammerer's third son, posthumously born by his second wife Adelaide, Charles disappears from the sources for ten years after his birth, although undoubtedly there would have been plenty to report about him. Passed over for the throne after the deaths of his half-brothers Louis III and Carloman II, as well as that of his relative Charles III the Fat, it is only due to the ascent of the Robertian Odo to the throne in 888 that the sources permit a second glimpse at Charles in the context of the new king's first visit to Aquitaine. Then again the sources remain silent about him for another five years until he suddenly reappears in Reims being crowned king himself by a group of nobles around the archbishop of Reims, Fulk, who were in rebellion against Odo. Over the following four years, a war ensued in which the Robertian's military superiority became increasingly evident. Nevertheless, in the end, the two parties reached an "astonishing"10 agreement: Charles not only remained king over a part of the realm, but would also succeed Odo on the throne-an event that took place only some months later, when the latter died in late 897.

The narrative sources do not tell us much about Charles' reign. The Annales Vedastini alongside Regino of Prüm's chronicle, our main contemporary sources for the late 9th century, break off in the year 900 while the annals of Flodoard, the sole record of the early 10th century, only resume the narration in 919 . While the former are mostly neutral towards Charles, some remarks should be made on the latter. In his annals, Flodoard betrays a hidden bias against Charles. An example of this is his portrayal of Charles as a king who repeatedly violates God's laws by attacking his enemies on the most important Christian holidays and ruthlessly devastating the realm that had been entrusted to him. ${ }^{11}$ One can hardly doubt that Charles did pillage his opponents' possessions and did not halt his war to celebrate Pentecost; yet Flodoard's silence on what his enemies were doing speaks volumes. It is hard to imagine that their actions differed in any way from those of the king they tried to depose. ${ }^{12}$ While his annals are not propaganda, they are victims of the circumstances of their creation, namely the dominance of Charles' enemies. ${ }^{13}$

Francorum igitur precibus compulsus, jussit cuidam militi pedem regis osculari. Qui statim pedem regis arripiens, deportavit ad os suum, standoque defixit osculum, regemque fecit resupinum. Itaque magnus excitatur risus magnusque in plebe tumultus.

10 Schneidmüller, Karl III., 27.

11 Flodoard, Annales 922, 7: Anno DCCCCXXII, Karolus regnum Lothariense, ob persecutionem Gisleberti et Othonis, rapinis, sacrilegiis atque incendiis, etiam in tempore Quadragesimae, sicut et tota hieme vastat. Flodoard, Annales 923, 13: Et in crastinum, die dominica, hora jam sexta praeterita, Francis dehinc illa die proelium non sperantibus, plurimis quoque prandentibus, Karolus Axonam transiit, et super Rotbertum cum armatis Lothariensibus venit.

12 Other examples for Flodoard's unrealiability would be his clearly wrong mention of a united front of the West Frankish nobles against Charles (see Lecouteux, Contexte II, 289-292) and his refusal to depict Charles as king after the coronation of Robert apart from his death notice in 929 (Flodoard, Annales 929, 44: Karolus quoque rex apud Perronam obiit.) On the careful choice of titles by Flodoard, see Jacobson, Titel.

13 Lecouteux, Contexte II, 287-298. On his bias against Charles, see also Jacobsen, Flodoard, 15-16 and Glenn, Politics, 207. 
Thus, Flodoard's account does not lose its credibility, but we should be aware that as often as he reported some events, he also turned a blind eye to others. ${ }^{14}$

As mentioned, for most of his reign there exist hardly any sources at all. Therefore, we know about two of the main events of Charles' rule almost exclusively from the meagre accounts composed east of the Rhine, later narratives, like those of the aforementioned Richer of Saint-Remi and Dudo of Saint-Quentin and Charles' royal diplomas. In an event traditionally dated to 911, after the battle of Chartres, Charles granted the Northmen under Rollo a territory that was to become the heart of the future duchy of Normandy by the treaty of Saint-Clairsur-Epte. Later during the same year, Charles became king of Lotharingia when the nobles of this regnum chose the Carolingian over the new king of Eastern Francia, Conrad I. Flodoard alone provides more detailed information about the last years of Charles' reign, which were overshadowed by different conflicts. In Lotharingia, the king fought Count Gislebert while in the West the nobles around Odo's brother Robert rebelled against him. This latter conflict proved to be fatal for Charles' reign: the nobles made Robert their new king and even after his death shortly afterwards in the battle of Soissons, they chose his son-in-law, Raoul, over Charles. Seeking new allies, Charles put himself in the hands of Count Heribert II of Vermandois, was imprisoned and was then used by the count to exert pressure on Raoul until his death in 929.

It may be because of the general lack of sources for Charles' reign that scholars have devoted little attention to him and his reign. Since Auguste Eckel produced a biographical analysis in $1899,{ }^{15}$ only Geoffrey Koziol has published a number of articles $^{16}$ and dedicated parts of his monography on the politics of memory and identity to him. ${ }^{17}$ That is not to say that Charles' time, its problems and its general developments have been completely ignored by scholarship. A number of studies on specific aspects of this period have been brought forward, covering key political figures like Archbishop Heriveus of Reims,${ }^{18}$ Count Heribert II of Vermandois ${ }^{19}$ and Count Hagano ${ }^{20}$ or key events such as the conflict around the episcopal siege of Liège in $920 / 921^{21}$ or the conversion of the Northmen under Rollo. ${ }^{22}$ Most commonly, however, Charles has been treated as one amongst many rulers in general surveys ${ }^{23}$ or handbooks. ${ }^{24}$

14 For the biases of Flodoard's other great work, the History of the Church of Reims, see chapter III.3.

15 Eckel, Charles.

16 Koziol, Robert; Koziol, Charles the Simple; Koziol, Charles.

17 Koziol, Politics.

18 Schmitz, Heriveus.

19 Schwager, Graf.

20 Depreux, Comte.

21 Zimmermann, Streit.

22 Guillot, Conversion.

23 For example Hlawitschka, Lotharingien; Schneidmüller, Tradition and Guillot, Formes.

24 For example Schneidmüller, Karl and Bruand, Francie. 
Scholarly discussion about the reign of Charles the Simple revolves around three main axes. The first concerns the general state of the realm, that is to say, the balance of power between the king and the nobles. The old view, emphasising the infidelity of the nobles towards the king as the main problem of Charles' reign, ${ }^{25}$ reading royal-noble relations as a constant struggle for power, ${ }^{26}$ has long been challenged and modified. For example, Bernd Schneidmüller, although still close to the old readings, has brought forward the creation of a new ministerial class created from the Lotharingian lower nobility by Charles, which was supposed to act as a counterweight to the powerful higher nobility. ${ }^{27}$ More influential was Karl Ferdinand Werner's proposal of cooperation between the king and the highest nobles in relation to the emergence of the principalities in the West Frankish realm. According to him, in return for giving those powerful men a vice-regal position, Charles would have gotten their support and thus stabilised his reign. ${ }^{28}$ While the overall image of powerful nobles becoming marchiones and controlling large parts of the regnum has been generally accepted, ${ }^{29}$ Werner's suggestion that this system was consciously and purposely created by Charles has been criticised. Instead, it has been emphasised that the foundations of this development had already been laid earlier, during the reigns of his immediate predecessors ${ }^{30}$ or even during the reign of Charles the Bald ${ }^{31}$ and that his grandson Charles the Simple only slowly succumbed to circumstance. ${ }^{32}$ Thus, his rule is not seen as having been built upon the investiture of powerful individuals as his surrogates, but founded on changing alliances with different groups of nobles. ${ }^{33}$ Further criticism of Werner's hypothesis highlights the differences in Charles' control over the various regions of the realm. While intense in the area north of the Loire, south of the river his rule would have been no more than nominal. ${ }^{34}$

A second line of thought revolves around the problem of Charles the Simple's legitimacy and its influence on his position as king. His father's two marriages and their validity have always been subject to scholarly study, ${ }^{35}$ yet whether this actually played a role in late 9th century politics remains controversial. Those emphasising its importance claim it was the reason why Charles had been passed over for the throne, at least in $883 / 884,{ }^{36}$ or why he underlined his Carolingian decent

25 Eckel, Charles.

26 Classic Dhondt, Études.

27 Schneidmüller, Tradition. In a later publication however (Schneidmüller, Karl) we find no more traces of this idea.

28 Werner, Westfranken and Werner, Ursprünge.

29 See, for example, also Guillot, Formes.

30 Guillot, Formes.

31 Sassier, Hugues.

32 Kienast, Vasallität.

33 Ehlers, Anfänge. Like Schneidmüller, Ehlers later changed his view and supported a view closer to Werner's (Ehlers, Strukturen).

34 Riché, Carolingiens.

35 For example Eckel, Charles, 1-2.

36 Hlawitschka, Lotharingien. 
once he had become king in order to strengthen his rule. ${ }^{37}$ Charles certainly seems to have possessed a strong consciousness of his family background and of questions of legitimate and illegitimate birth-according to Geoffrey Koziol, this latter also resulted in a distinct dislike of his half-brothers Louis III and Carloman II. ${ }^{38}$ However, while this emphasis on his Carolingian heritage seems to be the general consensus of scholarship, the political significance of Charles' problematic legitimacy is more often doubted than stressed. In particular, other reasons have been brought forward concerning its role in the royal succession, ${ }^{39}$ thus questioning the political significance of Carolingian legitimacy for the late Carolingian age.

A third discussion centres on the reasons for the final failure of Charles' reign, which culminated in his deposition. Some scholars attribute the rebellion of the nobles solely to the promotion of Charles' intimate Hagano. ${ }^{40}$ Others interpret the king's favourite as an example of a general policy pursued by Charles, emphasising the royal prerogative to choose his councillors, as opposed to the seemingly more successful strategies of Berengar I or Henry the Fowler, who acted as primus inter pares. ${ }^{41}$ Still others argue for a change in the structure of Charles' rule, caused by more aggressive royal policies against the leading nobles. ${ }^{42}$ This view of a change in royal politics has been criticised by Geoffrey Koziol as an argument a silencio based on the lack of sources for most of Charles' reign. In turn, he argues that Charles' rule was characterised by a constant rivalry between the king and Robert of Neustria. ${ }^{43}$ In this context, special roles have been attributed to the effects of the treaty of Saint-Clair-sur-Epte as well as to the acquisition of Lotharingia. Thus, Rollo's investiture with the pagi along the Seine is sometimes interpreted as an effort to establish a counter-balance against Robert. ${ }^{44}$ Similarly, the extension of Charles' rule over Lotharingia, while sometimes seen as having had a stabilising effect on his reign, ${ }^{45}$ is more commonly interpreted as having had a negative influence on his relations with nobles from the Western realm. Royal presence in Lotharingia is supposed to have led to a shift of Charles' main power base away from Western Francia, which resulted in him being estranged from the Western nobles ${ }^{46}$ or, at least, in an increased competition for influence at the royal court, thus destabilising the newly found balance. ${ }^{47}$

37 Schneidmüller, Tradition and even stronger Schneidmüller, Karl. This thought has been taken up Brühl, Deutschland and Koziol, Canons.

38 Koziol, Canons.

39 See for example Brühl, Deutschland; Sassier, Hugues; Offergeld, Reges pueri and Bruand, Francie. Ehlers, Anfänge and Riché, Carolingiens do not discuss the problem at all.

40 Eckel, Charles; Riché, Carolingiens. Against this view Brühl, Deutschland, who reads the reproaches of the nobles because of Hagano as mere pretexts for their rebellion.

41 Le Jan, Élites et révoltes, 418-419 and Royaume, 93-94.

42 Werner, Westfranken; Ehlers, Anfänge.

43 Koziol, Charles; Koziol, Politics.

44 Le Jan, Élites et révoltes, 418; Plassmann, Normannen, 75-76.

45 Werner, Origines; Sassier, Hugues.

46 Schneidmüller, Tradition and Bruand, Francie.

47 Schneidmüller, Karl; Ehlers, Strukturen and Le Jan, Élites et révoltes, 418. 
This reading of Charles' reign as a struggle for power between the king and the leading nobles points to the wider discourse among scholars over the structures of Carolingian rule and the diminution of royal power over the course of the 9th century. Step by step, the boundaries for the beginning of this decline have been moved from the last years of Charlemagne's reign ${ }^{48}$ to the end of that of Louis the Pious, ${ }^{49}$ then to the death of Charles the Bald ${ }^{50}$ and finally to the deposition of Charles the Fat. ${ }^{51}$ However, there are some important gaps left in the study of late Carolingian kingship. Leaving aside Charles the Simple, for Louis the Stammerer and his sons Louis III and Carloman II no published studies exist at all ${ }^{52}$ and the sole monograph on the reign of Eudes dates back to $1893 .{ }^{53}$ This lack of modern analysis may be a reason why the period after 888 is often still assessed as a time when royal rule is supposed to have suffered from a crisis of legitimacy and authority. ${ }^{54}$ Especially concerning the reign of Charles the Simple, these assessments are often particularly pessimistic, with Gerhard Schmitz's (already rather dated) conclusion about the restraints placed on his rule representing the low point. According to him, Charles' "Handlungsfähigkeit nach innen und nach außen [war] nicht nur begrenzt, sondern fast aufgehoben. Letztlich hatte sein Königtum nur so lange Bestand, wie die großen Vasallen es zu tolerieren bereit waren; Unterstützung konnte Karl von ihnen nicht erhoffen, einen Konflikt mit ihnen aber auch nicht riskieren, denn dessen Ausgang war bereits zu Ungunsten des Königs vorprogrammiert." ${ }^{55}$

\section{Possibilities and limits of late Carolingian rule}

Schmitz aims to capture what in more general terms can be described as the king's room for manoeuvre or, to apply another term, as his Handlungsspielraum. This latter concept provides a great basis for the exploration of the limitations a ruler was subject to and the possibilities available to him in political situations. However, while this term is frequently used especially by German historians, attempts to actually define its meaning and to use the concept behind it as an analytical tool are, given the number and variety of publications on the matter, very rare. ${ }^{56}$

48 Ganshof, Fin.

49 De Jong, Penitential state.

50 Nelson, Charles.

51 MacLean, Kingship.

52 Closest are the introduction of Bautier, Recueil Louis II, Louis III et Carloman II and Werner, Gauzlin as well as the chapters III.3.1.-3.2. of Offergeld, Reges pueri.

53 Favre, Eudes. Not counting Guillot, Étapes, a study limited to Odo's accession to the throne.

54 Le Jan, Élites et révoltes; Le Jan, Royaume and Falkowski, Monarchie. Against this reading, see now McNair, Development, esp. part I.

55 Schmitz, Heriveus, 82.

56 Examples for its usage without outlining its meaning are Haverkamp, Einführung; Fössel, Königin; Widder, Margarete "Maultasch"; Huber, Handlungsspielraum; Stickler, Handlungsspielraum. 
"Political Handlungspielraum is the sum of possible options of action which can be implemented successfully by the political decision-maker" ${ }^{\prime 7}$ is a simple definition used by political scientists. The existence of Handlungsspielraum is therefore bound to two conditions: a) a political situation requiring the political actor to become active and b) this actor having at least two different options that may lead to success and that he can choose from.

However, the range of options available to the actor is subject to certain constraints. ${ }^{58}$ One of these is the human limitations of the actor himself. The knowledge available to him is limited, as are his cognitive abilities to process this knowledge in regard to the possible consequences of his options. Thus, he only acts under "bounded rationality" 59 Hence, human nature itself limits the actor's options by preventing him from knowing about all of them and everything about them. Yet, there are also other constraints to his pool of options. In sociological approaches Handlungsspielraum defines the degree of freedom of an individual embedded into a society. "The more choices this individual has in decision situations, the more limited the restrictive conditions, the bigger is the Handlungsspielraum." 60 Thus, the decision-making individual is conceived as part of a bigger group, a society, which in turn limits his options. The practical philosopher Werner Stegmaier has included these restrictive conditions in his own definition: "A [Handlungs] spielraum is the 'space' of a movement limited by rules, in which another, 'playful' movement, not subject to these rules, in this sense a 'play' free of rules, becomes possible; in short: the regulated limits of unregulated behaviour. 'Within' these limits the behaviour may very well be subject to its own rules." 61 Thus, if an individual decision-maker is part of a greater community, he is subject to the rules existing in this society. Each of his actions underlies these predefined rules, yet, within these rules a certain space for own choices exists, which may possibly be dependent on other rules. The rules existing in a society are defined by whether other members of said society will consider the actual action decided upon as normatively and cognitively appropriate or inappropriate. ${ }^{62}$ Therefore, as a set, the rules existing

Resch, Freiheit, gives some thoughts on the restrictions of individual Handlungsspielräume. Notable exceptions are Auge, Handlungsspielräume and Poguntke, Handlungsspielräume.

57 "[Politischer Handlungsspielraum ist] die Menge möglicher Handlungsoptionen, die politische Handlungsträger umzusetzen in der Lage sind.” Sattler and Walter, Handlungsspielraum, 465.

58 See Tilly and Goodin, It depends.

59 Simon, Human Nature, 294.

60 "Handlungsspielraum bezeichnet das Maß an Freiheit, welches die gesellschaftliche Einbettung dem Individuum belässt. Je mehr Alternativen in einer Entscheidungssituation zur Verfügung stehen, je geringer die einschränkenden Bedingungen, desto größer ist der Handlungsspielraum." Lautmann, Handlungsspielaum, 271.

61 Stegmaier, Philosophie, 221: “Ein Spielraum ist ein durch Regeln begrenzter 'Raum' einer Bewegung, in dem eine nicht diesen Regeln gehorchende 'spielerische' Bewegung, ein in diesem Sinn von Regeln freies 'Spiel' möglich wird, kurz: eine geregelte Grenze ungeregelten Verhaltens. 'Innerhalb' der Grenze kann das Verhalten wohl eigenen Regeln gehorchen.”

62 March and Olsen, Logic, 479. See also Lagroye, Sociologie, 168-171, who argues that these rules are also influenced by the party acting within the society. While this is certainly correct for the 
in a society constitute the framework defining appropriate behaviour within this society. Thus, each decision taken is the result of a process of negotiations to which rules apply and regarding which of those rules are to be considered stronger. ${ }^{63} \mathrm{In}$ some cases, this framework limits the possibilities of how to act in certain situations, while in others a large pool of options may exist. The range of these options within a given framework is expressed by the term Handlungsspielraum.

However, these frameworks are not static. ${ }^{64}$ Rules may change over time and actions that have been considered acceptable before can, in similar situations at later points, become unacceptable and vice versa. Especially in times of crisis and disorientation, the existing framework is questioned and shifts within it may take place. ${ }^{65}$ It would also be wrong to assume that at any given time only one framework exists which determines the appropriateness of actions for any member of the society. In fact, different frameworks may coexist at the same time, each with its own set of rules. An example for these would be rules of behaviour stemming from one's perception of oneself, that is to say, from one's identity. These often collide with frameworks provided by society, thus leading to behaviour outside the limits of what is generally considered appropriate. ${ }^{66}$ This is especially the case in less stable and well-defined political systems, ${ }^{67}$ such as those existing in the late Carolingian era.

Hence, sounding out Handlungsspielraum is a process of negotiation between different systems of rules. However, this implies that there is a certain degree of flexibility inherent to these rules. Following Philippe Buc, it seems appropriate not to speak of "rules," but rather of "norms" to emphasise this aspect. ${ }^{68}$ When referring to the realisation of these processes of negotiation, we can go even further and introduce another nuance. In the end, these processes are not only determined by the norms of the participating actors, but by their expectation that their opposite knows, acknowledges and acts not only according to his own norms, but takes also those of the other participants into consideration. This expectation can be described as trust, with the assumed probability that this expectation will be met by the other according to the degree of trust in the other ${ }^{69}$ Hence, the existence of a certain degree of trust can be described as the prerequisite for negotiating since

macro-environment described by Lagroye (the Church or another big organisation partaking in the political competition), this influence would be rather limited when it comes to individuals.

63 Crozier and Friedberg, Acteur, 36-37.

64 March and Olsen, Logic, 485-489.

65 Eder, Societies. See Lagroye, Sociologie, 49-53 for the influence of a society's environment on its development.

66 Orren and Skowronek, Iconography. On the role of appropriateness in the decision-making process, see also Lazega, Appropriateness.

67 March and Olsen, Logic, 482.

68 Buc, Review, 253, responding to the term "Spielregeln" introduced by Gerd Althoff to the historiography. On the development of "Spielregeln", see Kamp, Macht, 1-10.

69 On the concept of trust and its implications, see the introduction to chapter VI. 
it ensures the willingness to cooperate ${ }^{70}$ and thus becomes an important part for determining one's Handlungsspielraum within a society.

When determining the possibilities and limitations of late Carolingian rule this leads to another question. The result of these negotiations is not only a question of the norms of each individual actor and of the trust existing between the participants. The strength of the individuals' identities also plays a role, as does the assessment of the situation as well as the available resources to realise any option. ${ }^{71}$ The importance of the last point is revealed when taking into consideration that this process of negotiation was not always one of equal interaction in the late Carolingian age. Late Carolingian politics were a constant flux of negotiations between the interests of the king and the nobles and, therefore, as Simon MacLean put it, "potentially unstable." ${ }^{2}$ Each of these negotiations can be read as sounding out the possible ways of action, for the ruler as well as for the other nobles participating in the decision-making process or affected by their results. If the latter disliked the royal actions, they would offer resistance, either forcing an adjustment to or even change of the royal politics (possibly even by changing the king himself) or else being forced by the king to submit to his view. Thus, the royal Handlungsspielraum was not only determined by norms, but also by the capacity the king had to enforce his own norms over those of others. This even goes so far as to limit the importance of trust: overwhelming power on one side could simply leave no other option than to submit. The ratio of the power between the ruler and the nobles opposing his politics thus defined the possibilities and limits of royal power. When asking for these possibilities and limits during the late Carolingian era, it is therefore best to start by analysing the actual functioning of royal power during this time.

\section{The functioning of royal power}

The traditional starting point in analysing the potential power of any Carolingian king is the royal fisc. ${ }^{73}$ The lands under direct royal control had originally been created by taking over the Roman civitates and imperial estates during the 5 th century and later supplemented by the Carolingian family lands when they superseded the Merovingians as the ruling dynasty. From the fisc, the kings drew the resources to equip their soldiers, to supply the court on its travels through the realm and to maintain their palaces and estates, the latter standing as reminders of

70 For the importance of trust in interpersonal relations, see, for example, Marzano, Confiance.

71 March and Olsen, Institutions, 22; March and Olsen, Logic, 492-493 and Gulati and Srivastava, Agency.

72 MacLean, Kingship, 96.

73 On the problems associated with the fisc, see Barbier, Fisc. Fundamental also Brühl, Fodrum and Barbier, Palatium. 
their authority even in their absence. ${ }^{74}$ Trying to establish the extent of the fisc at any given moment, however, poses problems that are impossible to solve. Almost all of our knowledge concerning royal property derives from the royal diplomas donating parts of it to individuals and institutions, ${ }^{75}$ telling us only which parts the king had decided to part with and not how much he actually possessed and controlled. Yet, it seems clear that it was concentrated around the palaces and in the core regions of royal power, ${ }^{76}$ while those parts given away were often situated outside these heartlands, where they would have been difficult to control. ${ }^{77}$ But the fisc did not simply undergo a process of continual diminution through grants; it was also replenished by acquisition, inheritance, gifts or confiscation of property in cases of treason, all of which were hardly ever documented by royal charters. Thus, the fisc was in constant flux and, given the gaps in our sources, any attempt to reconstruct it at a certain moment or shorter period must prove futile. ${ }^{78}$ In any case, the landed possessions only provided part of the royal income. Other wealth was also drawn from different fiscal rights on trade, such as tolls and markets, or from minting, which is equally impossible to quantify. ${ }^{79}$ In times of war, plunder and tribute could be obtained from the defeated, which provided an important means of rewarding armies ${ }^{80}$ Finally, becoming ever more important during the second half of the 9th century, the kings could also access the resources of ecclesiastical institutions, churches and abbeys, both being under royal protection and therefore open to royal influence. ${ }^{81}$

Counts were charged with the care of the royal estates, as well as keeping the peace in their counties, doing justice, putting royal decrees into practice and raising levies for royal campaigns, thus transmitting royal power to every corner of the realm. ${ }^{82}$ West of the Rhine, these counties appear to have been often centred on the old Roman civitates; east of the river, they were newly created and oriented towards landscape and settlement structures. However, within these counties enclaves existed, chiefly landed possessions of ecclesiastical institutions that had been granted royal immunity. Still others were created by the control of the unfree by the free. Since counts only had jurisdiction over the free, those areas which

74 Renoux, Architecture, 25.

75 On these donations, see Dhondt, Études and Ganshof, Note.

76 Barbier, Palatium, 28.

77 Martindale, Kingdom; Barbier, Palatium, 50-53; Innes, State, 204 and Airlie, Palace, 11.

78 Although efforts have been made: concerning Charles the Simple, see Eckel, Charles, 41-43 and concerning the region between the Loire and Moselle, Barbier, Palatium (although covering the period from the 5 th to the 10 th century and not at a specific moment).

79 Endemann, Markturkunde, 105-61, Nelson, Charles, 19-40. On the Carolingian economy in general, see Devroey, Economy and Verhulst, Economy. On tolls, see Adam, Zollwesen.

80 Reuter, Plunder.

81 Nelson, Kingship, 389-391 and West, Reframing, 42-44.

82 Nelson, Kingship, 410-411; Innes, State and West, Reframing, 20. For an early example of the idea of the counts (or better, office holders in general, including ecclesiastical ones like bishops) being agents of the king, controlled by him and deriving their ministerium from him, see Guillot, Ordinatio. 
were inhabited only by the unfree remained outside their direct control. ${ }^{83}$ While the importance of these offices is clear, more interesting for us is the question of royal control over the office holders. One possibility for the kings to exercise control was to install counts of their choosing. However, the ability to do so appears to have been limited. Most of these cases documented by the sources occurred when the county system was introduced in newly conquered territories and even then, the choice often fell on local nobles, since they had to rely on their own resources and connections to fulfil their tasks. ${ }^{84}$ Another possibility was to take control of a county after its count had died. For a long time, scholars assumed that, from Charles the Bald's capitulary of Quierzy at the latest,$^{85}$ the office of count had become hereditary. ${ }^{86}$ While this reading misses the true character of the clause, which in fact confirms the royal prerogative to control succession, ${ }^{87}$ nevertheless, the passing of a county from father to son already appears to have been common practice for a long time ${ }^{88}$ Actual royal control over the countships appears to have ranged between these two extremes. The redistribution of counties was a generally accepted right of the king, as long as he could claim that the office holder had failed to properly fulfil his duties. ${ }^{89}$ Kings certainly claimed to exercise influence in such matters, yet whether they were actually able to implement their view differed from case to case..$^{90}$

Next to the counties, a parallel and at least as important administrative system existed based on ecclesiastical organisation. Episcopal power was typical of the way Carolingian society worked, as it was situated at the frontiers between the profane and the sacral worlds and thus reached into both. ${ }^{91}$ Apart from their spiritual responsibilities, within their dioceses bishops were also responsible for keeping public order and speaking justice. Like the counts, they participated in public assemblies and political decision making and provided, probably more reliably than the counts, ${ }^{92}$ substantial resources for royal politics. ${ }^{93}$ Like counts they acted as royal legates, like counts they acted as conduits of royal power. However, unlike

83 Deutinger, Königsherrschaft, 148-149.

84 Nelson, Charles, 51.

85 MGH Capit. II, N² 281, c. 9, 358.

86 For the development of this idea dating back to Montesquieu, see Bourgeois, Capitulaire, 155-205. The idea is still prevalent among scholars, see for example Werner, Naissance, 432.

87 As already pointed out by Bourgeois, Capitulaire. See also Guillot and Sassier, Pouvoirs I, 144-145.

88 Nelson, Charles, 53-54.

89 As laid down in the treaty of Coulaines 843 (MGH Conc. III, N 3, c. 3, 16). Guillot and Sassier, Pouvoirs I, 141-145. For the treaty of Coulaines, see Apsner, Vertrag, chapter I. On the process of the investiture of counts as well as on their deposition, see Depreux, Investitures.

90 Deutinger, Königsherrschaft, 153-158; Glansdorff, Comites, 24-31 and Nelson, Charles, 54.

91 Bührer-Thierry, Épiscopat, 147.

92 Nelson, Kingship, 390.

93 An example would be Heriveus of Reims who, according to Flodoard's History of the Church of Reims, aided Charles the Simple with 1.500 men against the Hungarians (Flodoard, HRE IV, c. 14, 407). For episcopal lordships, see Kaiser, Bischofsherrschaft. For episcopal participation in royal assemblies and decision-making, see Eichler, Reichsversammlungen, 29-38 and 73-76. 
that of the counts, episcopal investiture was officially regulated by canonical law, that is to say, their election resided with the clergy and people of their respective dioceses. ${ }^{94}$ Reality, of course, was different, as Carolingian kings often aimed to install their own candidates. ${ }^{95}$ For example, Charles the Bald exercised close control over the sees of Reims, Sens and Rouen. ${ }^{96}$ Therefore, while the royal role in these elections led to conflicts with important ecclesiastical dignitaries, most often both parties appear to have sought a consensual agreement, resulting in the West Frankish realm in the integration of the royal prerogative into the canonical procedure of the appointment of a new bishop. ${ }^{97}$ Besides the king, the local nobility also had its say in the elections, trying to raise their own candidates, often relatives, to the episcopal throne. This did not necessarily counteract royal aspirations since the member of a local family might well be the choice of the king too if said family belonged to the circle of his own supporters. ${ }^{98}$ Thus, episcopal succession presents itself as the competition of various, sometimes opposing, interests, yet it was one with seemingly more possibilities for the rulers to install candidates of their choice.

Limiting our view to resources and offices, however, fails to portray the functioning of Carolingian kingship. As has already come through in the previous comments, we can make out its true basis: relations between the king and the nobles. ${ }^{99}$ Counts and bishops provided resources and transmitted royal power even into the distant regions of the realm, but royal control over both was limited. The kings tried to influence elections and install their own candidates, yet to succeed, they depended on the cooperation of the local nobility. In the words of Martin Gravel: “L'Empire carolingien doit être conçu comme un réseau de relations, comme l'enchevêtrement des liens du baptême, du sang, de l'alliance, de l'amitié, de la servitude et d'une multitude de fidélités." ${ }^{100}$ Only by creating bonds between themselves and the nobles, by creating consensus about their kingship in general and each individual decision, could their rule succeed ${ }^{101}$ Kingship was not simply the giving of orders, but necessarily needed to show consideration for the interests of those involved. In consequence, ruling consisted of constant

94 On the development of the royal investiture, see Schieffer, Entstehung, 10-26.

95 See Schieffer, Bischofserhebungen.

96 Bührer-Thierry, Épiscopat, 153. His influence on the episcopal sees in the south of his realm on the other hand, appears to have been almost inexistent.

97 An example of this is Hincmar's letter to Louis III in 881 (Migne, PL 126, col. 112B): in electione episcopi assensio regis sit, non electio. See also Schieffer, Bischofserhebungen.

98 Basic for the episcopal election in Western Francia, de la Tour, Élections. More recent also Erkens, Bischofswahl; Schieffer, Bischofserhebungen; Bührer-Thierry, Épiscopat and Deutinger, Königsherrschaft, 111-128. On episcopal power, see Kaiser, Bischofsherrschaft and Patzold, Episcopus. On royal-episcopal relations, see Bührer-Thierry, Évêques.

99 Rosenwein, Politics; Innes, State and Innes, Charlemagne, 86.

100 Martin Gravel, Distances, 413.

101 On consensus in medieval rule, see Hannig, Consensus; Schneidmüller, Konsensuale Herrschaft; Apsner, Vertrag; Patzold, Konsens; Deutinger, Königsherrschaft; Nelson, Carolingians and Le Jan, Élites carolingiennes. 
negotiations between different interests and each balance found between these interests was fragile and in need of constant care. ${ }^{102}$

A key factor for the relations between the king and his nobles was the distribution of honores, that is to say, land and offices. ${ }^{103}$ The former could be part of the fisc, belong to abbeys or churches or be confiscated from disloyal nobles; the latter could be counties or, more often, abbeys, commonly in the form of lay abbacies. Receiving a donation from the king reinforced the bond between himself and the receiving noble, ${ }^{104}$ who then acted as a conduit of royal power, transmitting the ruler's will even to the frontiers of the realm. This does not mean that donations created loyalty. Far more often, they are instead the sign of already existing ties. For example, in border regions, small and unimportant abbeys were granted to influential nobles to install trusted men in potentially endangered zones, thus ensuring royal control over these areas. ${ }^{105}$ Hence, giving away honores served to create and expand networks of power consisting of a larger number of individuals who would lend their support to the king. These networks were the means to exercise control over the realm and to transmit royal power even into regions that hardly ever saw the king in person. ${ }^{106}$

But to reduce the relations between the king and the aristocracy to a mere model of giving (making donations) and taking (withdrawing honores in the case of infidelity) would mean to limit our view. Besides honores, influence, partaking in the decision-making process, could draw the nobles to the king. In the ideal court as described by Hincmar, the king was surrounded by close advisors with whom he discussed the affairs of the realm before deciding on which measures to take. ${ }^{107}$ This circle only consisted of those closest to the king, those in the possession of the most Königsnähe. ${ }^{108}$ As Hincmar notes, these men close to the king participated in the decision-making process and thus were able to influence its outcome. ${ }^{109}$ Therefore, being close to the king directly translated into political power. As we have already noted, the nobles close to the king served as conduits, transmitting the royal will into the regions of the realm. This also worked the other way round, with locals coming to the respective noble asking him to bring their

102 MacLean, Kingship, 75; Becher, Gedanken.

103 On the importance of donations of the fisc, see Dhondt, Études and Ganshof, Note. On their assumption of a dissolution of the fisc, see above. On the role of exchange in the relations between the king and the nobles, see Le Jan, Histoire, 305-306.

104 On the role of honores in the investiture, see Depreux, Investitures, 172-175.

105 Nelson, Charles, 57; MacLean, Kingship, 90 and Helvétius, Abbatiat, 285-286 and 297-298. See also the studies of Werner, Adelsfamilien; Rosenwein, Politics and Innes, State on the installation of nobles in certain regions to transmit royal power.

106 Wickham and Reuter, Introduction, 1-16. On these networks, see also Althoff, Verwandte 134-181 and Werner, Adelsfamilien.

107 Hincmar, De ordine palatii, c. VI, 82-90, esp. 82-86. On the different types of assemblies and their importance, see Althoff, Colloquium and Eichler, Karolingische Höfe.

108 Nelson, Kingship, 403-404.

109 On the role of advisors and their influence see also Althoff, Kontrolle. 
wishes to the king. ${ }^{110}$ Thus, having access to the king meant to possess the ability to grant this access also to others or, in other words, to exercise control over the access to the king. ${ }^{111}$ Like participating in political decisions, this was a further guarantee of political power since, on the one hand, it allowed the noble in question to influence the topics being discussed in the circle around the king and, on the other hand, strengthened his position at home. Since only he could provide access to the ruler, the petitioners needed to court his favour. Being close to the king and thus managing the affairs of the realm, being able to influence the decisions made at court and controlling the access to him was certainly an incentive for cooperating with the king that was at least as strong as getting donations from him. ${ }^{112}$

These thoughts can be developed even further: Stuart Airlie has argued that royal service not only served noble self-interest in honores and offices but also became a constitutive factor of noble identity..$^{113}$ Belonging to those around the king, counselling him and serving him, meant being part of the most privileged elite, a status that elevated them not only over their peers but also over their relativesthose with whom they were in competition for social advancement and proximity to the king. Their own and their family's past actions served as sources of legitimacy and so did the prospect of future deeds done in service of the king, creating a line of continuity stretching from the times past to the times to come. Social status depended on how one was perceived by other nobles around oneself, and for contemporaries the significance of one's family depended first of all on its connections with the royal household and its access to the court. ${ }^{114}$

However, this leads to another problem: who belonged to these other nobles? Trying to find a convincing, all-encompassing definition for "aristocracy" proves to be a fruitless undertaking. To be noble meant to belong to the leading members of the society. In some cases this was undisputable but in others it was hard to draw the line. "Nobility' was a moral distinction, a moral distinction which (as moral distinctions usually do) tended to reflect social status. To be 'noble' in this sense was to exercise social power in the proper manner."115 Thus, the aristocracy consisted of individuals for whom belonging to this group depended on their own behaviour and the acknowledgement of their status by other members of the same group. ${ }^{116}$ Access to this group was open while within it a hierarchy existed in which advancement was possible. ${ }^{117}$ When talking about the aristocracy, we there-

110 Hincmar, De ordine palatii, c. IV, 67.

111 On the access to the king, see Althoff, Verwandtschaft; Scior, Ohr; Garnier, Kultur, 24-28 and Depreux, Hiérarchie.

112 See, for example, Rosenwein, Politics, 249 and Scior, Ohr.

113 Airlie, Semper fideles.

114 Airlie, Semper fideles, 133-134. See also Le Jan, Famille, 32-57 on noble identity and the recent contribution of Bougard, Bührer-Thierry and Le Jan, Élites.

115 Innes, State, 83. On the problem of "aristocracy," see Innes, State, 82-85 and most of all Goetz, Nobilis.

116 For a sociological definition of "group", see Tajfel and Turner, Identity.

117 On factors determining the position within the hierarchy, see Depreux, Überlegungen, esp. 94-95. 
fore should avoid imagining one single block in opposition to the ruler, but rather think of individuals and groups consisting of relatives and friends ${ }^{118}$ competing with each other for social advancement. ${ }^{119}$

Crucial for social advancement was the cooperation with the king. As Régine Le Jan expresses it: "Le roi carolingien fut le pivot de la circulation des honneurs et des richesses, contrôlant la hiérarchie sociale par le système du don, imposant la mobilité et la fidélidé en confisquant les honneurs pour cause d'infidélité."120 The king was the pivot in the competition for influence over the affairs of the realm as well as the source of noble identity. He could take advantage of his position within this system by choosing his councillors and promoting them at his pleasure. Yet, there were limits to his choices. Having reached a certain level within the hierarchy, the nobles not merely passively hoped for the king's goodwill. From their own self-conception they derived a right to be treated according to their position, to take part in the affairs of the realm and to receive honores. ${ }^{121}$ What is revealed here is a complex system of sometimes diverging claims. On the one hand was the king, exerting his right to choose whom to favour and further, on the other hand, was the noble, deriving from his already elevated position the belief that he needed to be chosen by the king. This system of relations between the king and the nobles was an unstable one, one that needed constant care and one in which there was often no ideal choice which could satisfy all parties involved, only one that would limit the damage done within a bigger part of the network.

Our comments up to this point have been aimed at casting some light on the functioning of royal power and the determining factors in the relations between the king and the nobles. However, the political landscape of the late 9th century underwent some important changes that need to be taken into consideration when studying this period. Since the reign of Charles the Bald, within Western Francia some nobles had created large conglomerates of honores that were to become the future principalities. ${ }^{122}$ The original perception of these developments by Jan Dhondt, ${ }^{123}$ who promoted the idea of the "rise of the aristocracy" as a struggle of two opposing powers-the Carolingian kings and "the aristocracy"- has since been questioned and modified. For example, Karl Ferdinand Werner emphasised royal consent in this development, describing the principalities as sub-kingdoms led by nobles in vice royal positions who exercised powers delegated by the kings. ${ }^{124}$ Furthermore, as Simon MacLean in his study on the reign of the Emperor

118 On such groups, see Althoff, Verwandte; Althoff, Amicitiae; Le Jan, Famille, 77-85 and Epp, Amicitia.

119 Airlie, Semper fideles, 133.

120 Le Jan, Royaume, 91.

121 MacLean, Kingship, 15 and Althoff, Kontrolle, 302 and 329-330.

122 Examples for studies in this field are Werner, Enquêtes; Sassier, Recherches; Bur, Formation; Robbie, Emergence and McNair, Development. General assessments are provided by Dhondt, Études and Dunbabin, France. For criticism on the concept of "principality," see McNair, Development, 14-20.

Werner, Westfranken, 738-379. 
Charles III "the Fat" has explained: "Carolingian kings and emperors had always been accustomed to dealing with powerful aristocratic individuals, and not with the 'aristocracy' (or individual aristocratic families) as a monolithic entity." 125 The rise of powerful individual nobles was not something that was only typical of the late Carolingian period. Kings already had had to cope with such individuals and managed to integrate them into their rule. Therefore, we should not perceive this period as a constant struggle between the "aristocracy" and the kings, but rather as one in which their cooperation, their joint work towards a well-ordered world, should be emphasised. ${ }^{126}$

This is not to claim that the framework of late Carolingian politics was static. Duke Boso, who in 879 convinced the local nobles at Mantaille to elect him king, struck a first blow against the functioning of this system. Although married to a Carolingian princess, he destroyed the illusion of a Carolingian monopoly on kingship and made the office targetable for other ambitious nobles. ${ }^{127}$ In addition, noble families became more and more autonomous from the royal centre as the noble self-conception became increasingly detached from royal service and instead depended on family traditions and property rights. ${ }^{28}$ They now developed a dynastic identity and began to ascribe their power not to royal generosity but to God's will. ${ }^{129}$ This effect became pronounced when in 888 kings came to power in the former Carolingian regna whose kinship with the Carolingian family was at best problematic. To name only two examples, in Eastern Francia, Arnulf of Carinthia, an illegitimate son of Carloman of Bavaria, now assumed power while in Western Francia, Odo, a Robertian without a single trace of Carolingian blood, made his move for the throne. Carolingian legitimacy remained a strong argument in the political theatre ${ }^{130}$, but from now on one could also become king by possessing sufficient power to impose oneself on the other nobles.

These two developments, the rise of individual nobles amassing honores with royal consent on the one hand and the loss of the Carolingian monopoly on the throne on the other, may have commenced independently of each other, yet by the end of the 9th century, they were inseparably linked. Boso had only been able to claim a crown because he had already risen to a position from which he was able to do so, yet he had chosen a moment in which the Carolingian monopoly still stood unwavering. However, his rebellion was a first crack in the dam which broke nine years later when dynastic coincidences had done away with all legitimate male Carolingians north and south of the Alps, apart from a nine-year-old boy, Charles the Simple. These developments, the weakening of Carolingian legitimacy and the increasing power of some nobles in combination with their growing emancipation

126 West, Reframing, 100-102.

127 Airlie, Semper fideles. On Boso's rebellion, see also chapter VI.4.

128 Airlie, Semper fideles, 139-140.

129 Le Jan, Royaume, 90.

130 Le Jan, Royaume, 88. 
from the crown, led to a shift in the relations between the king and the nobles which started to unhinge the old system. ${ }^{131}$

\section{Analytical approach}

While it is undeniable that such shifts took place, the basis of royal power did not fundamentally change. Its basic principles remained intact and ensured the cooperation of the nobles. The better they were integrated into the king's rule, the better the royal will was transmitted even into the most distant corners of the realm. When it comes to determining royal influence, this understanding also has a major impact on the value of the royal itinerary. It has been rightfully noted that in the late 9th/early 10th century, West Frankish kings were limited in their travels to the north-east of their realm, ${ }^{132}$ yet the conclusion that their sphere of action was as limited is misleading. As long as the king was in contact with nobles from the regions outside the radius of his movement, he could influence the local politics. Thus, analysing royal power means that an approach focused merely on direct royal actions is too limited. Defending the realm, dealing with conflicts and ensuring the royal prerogative certainly can be used as benchmarks for the possibilities of royal power, ${ }^{133}$ yet these actions are only the surface of the underlying network of nobles centred around the ruler. An analysis of the possibilities and limits of royal power has to take these two levels into consideration.

Networks can be understood as ensembles consisting of individuals (or groups) who are linked with each other by social relations, ${ }^{134}$ or in other words, are expressed by the sum of their interactions and connections. ${ }^{135}$ While they do constitute rather stable collectives, ${ }^{136}$ the individuals belonging to a network can compete with each other. ${ }^{137}$ This means that networks are dynamic structures which develop over time and which may become fragile up to the point of breaking even under the occurrence of only minor pertubances. ${ }^{138}$ Therefore, when analysing networks the focus has to be set on the nature of the relations between the different actors, ${ }^{139}$

131 On this, see also Le Jan, Famille and the conference proceedings Bougard, Feller and Le Jan, Élites; Depreux, Bougard and Le Jan, Élites as well as Falkowsky and Sassier, Monde.

132 Kienast, Wirkungsbereich.

133 See for example Le Jan, Élites and Royaume, using royal control over the distribution of honores, or Althoff, Spielregeln, 21, who focuses on conflict situations to determine the ruler's Handlungsspielräume. See also Auge, Handlungsspielräume, 8, according to whom each of a rulers decisions, each measure enacted, whether made consciously or not and whether successful or not, was subject to the judgement of the nobles, allowing us to use their consequences as a margin to determine the possibilities and limits of royal power.

134 Rosé, Reconstitution, 207; Preiser-Kapeller, Calculating, 101-102.

135 Preiser-Kapeller, Calculating, 103; Dumézil, Culture, 556-557.

136 Dumézil, Culture, 556-557.

137 Hitzbleck and Hübner, Netzwerkgrenzen, 8-9; Hitzbleck, Verflochten, 21-24.

138 Preiser-Kapeller, Calculating, 102.

139 Stegbauer, Netzwerkanalyse. 
or in the case of this study, on those between a ruler and the nobles in contact with him. Only by analysing these in regard to continuity, intentionality and quality can the position of an individual within a network be determined. ${ }^{140}$ Based on this analysis, within a network different zones, or layers, can be identified, as defined by these relations: ${ }^{141}$ while frequent and intense contacts between a ruler and a noble indicate the importance of this noble for the ruler and their central position within the network, a single contact might not even be deemed sufficient to place a noble within the network at all.

This leads to a key problem of network analysis for historians and especially for those studying early medieval history. Even in best-case scenarios, the sources available are so scarce that it becomes questionable whether the identification of general structures and developments is possible at all. ${ }^{142}$ While the scarcity of sources is especially true for the late Carolingian era, there is one type of source that offers considerable advantages when it comes to analysing networks and determining the relations between individuals: charters and specifically royal diplomas. ${ }^{143}$ They not only allow us to establish relations between individuals (in the case of the royal diplomas the ruler and the nobles petitioning and receiving these), but also offer insight into the quality, frequency and intensity of these relations. ${ }^{144}$ Therefore, these royal diplomas form the basis of those parts of this study dealing with the networks of royal power while narrative sources are used to complement and contextualise the information gained from the diplomas. This approach also allows us to mitigate the problems caused by the gap in said narrative sources between 900 and 919 .

While this study is dedicated to exploring the possibilities of Charles the Simple's royal power, his rule cannot be fully understood without going further back

140 Hitzbleck, Verflochten, 31-35. Similar also Preiser-Kapeller, Calculating, 103, who focuses on the category, intensity, frequency and dynamics of interactions and relations. Rosé, Reconstitution, 207-208, emphasises the importance of the number of relations of an individual within a network, the geographical proximity between two individuals in contact with each other and whether an individual acts as an intermediary for others. We consider the last point as one of the key factors for our own analysis.

141 Hitzbleck and Hübner, Netzwerkgrenzen, 9, emphasising the implications of these for the limits of a network.

142 Preiser-Kapeller, Calculating, 103; Hitzbleck and Hübner, Netzwerkgrenzen, 8. Furthermore, certain biases may also be caused by the nature of some kinds of sources. Letters, for example, while providing unique insight into the relation between individuals, owe their existence to the regional distance between composer and recipient. Using letters as the main basis for a network analysis may therefore lead to a bias towards those relations over others, in which contact did not depend on written exchange but was mainly oral. Hitzbleck, Verflochten, 31-32.

143 On the advantages of charters for network analysis and the methodology see Rosé, Reconstitution, 212-213. Rosé has demonstrated that the methods of digital data analysis can also be used for research on early medieval history. On the drawbacks of digital data analysis of networks such as the problem to portray the dynamics of relations, see for example Lemercier, Time. Considering these drawbacks as well as the fragementary nature of the sources at our disposition and our need to contextualise each diploma and each appearance, we have refrained from using digital data analysis for our own study.

144 On the interpretation of diplomas see chapter II, introductory remarks. 
to the 870s, to the times of his father, Louis II the Stammerer, his brothers Louis III and Carloman II, to the Emperor Charles III the Fat and finally to the Robertian Odo. It was during their reigns that the frameworks determining at least the early years of Charles the Simple's own developed. Taking the study back to the years following the death of Charles II the Bald allows us to make comparisons between Charles the Simple's reign and those of his predecessors and to reveal the continuities and changes without having to revert to the questions of "structures" often used in research on the 9th and 10th centuries. It allows us to analyse the reasons for Charles' very late succession to his father and the basis of his kingship (chapter I), to reveal the networks of royal power and the ruptures they underwent before and during Charles' reign (chapters II and III) and to use the results gained from these to assess the rulers' actions towards their neighbours, the Northmen, and their own nobles (chapters IV, V and VI). ${ }^{145}$ Each chapter of this study adds another layer to the analysis of the relations between rulers and nobles and thus to the possibilities and limits of royal power in the late Carolingian age. ${ }^{146}$

145 On the importance of relations between different actors, for the context of their actions and the analysis of their room for manoeuvre, see Preiser-Kapeller, Calculating, 105.

146 This approach means that we will return to the same events at numerous times over the course of this study, leading to certain redundancies. Given the advantages of being able to assess each event and each action from different perspectives and in different contexts, this is a price we consider to be worth paying. 



\section{Becoming king: The questions of legitimacy and support}

In hindsight, Charles III the Simple's accession to the throne appears as a surprise. Born posthumously as Louis II the Stammerer's third son, he was passed over in the royal succession no less than four times until finally, a rebellious noble faction chose him as king. Although the ensuing war was lost, he was nevertheless confirmed as king and succeeded the victorious Odo shortly thereafter. This brief account raises a number of questions which serve as a starting point to understand Charles' rule and the possibilities and limits of his royal power. Why was Charles passed over in the royal succession so many times? Or, in other words, why did the nobles rebelling against Odo chose Charles as their king when seemingly his claim to the throne was weak enough to be ignored until that moment? This, in turn, leads to the issue of the composition and structure of the network these nobles formed and to the question of their various motives. Essentially, this means examining the basic conditions under which Charles became king: to evaluate the nature of his legitimacy as well as its importance as an argument in the politics of the West Frankish realm and to analyse the composition and cohesion of the network of nobles elevating him to the throne.

\section{I.1 Charles' claim to the throne}

When Archbishop Fulk wrote his letter to King Arnulf of the East Frankish realm in 893, announcing Charles' elevation to the throne and asking for the king's support, he made some remarks concerning certain rumours that had apparently reached Arnulf's ears, according to which Charles was not Louis II the Stammerer's son. Fulk, however, assured the king that these rumours were unfounded, and that in fact the young Carolingian resembled his father in a way that made his descent above suspicion. ${ }^{1}$ From what we know from the sources, these rumours, probably spread by Odo's supporters to contest Charles' claim to the throne, were never spread again. It is nevertheless interesting to note the way they were constructed. Undoubtedly referring to his posthumous birth, they denied Louis' parentage and consequently Charles' Carolingian blood, the basis of his claim. This strategy certainly made sense, yet it is surprising that they did not attack the youth's legitimacy in any other way.

1 Flodoard, HRE IV, c. 5, 382: Denique, quod audierat ipsi Arnulfo dictum fuisse, quod hic Karolus filius Ludowici non fuerit, asseverat neminem se posse credere fore, qui, eum si viderit et parentum ipsius effigiem cognoverit, non recognoscat illum de regia processisse progenie; quedam quoque patris sui Ludowici signa gestare, quibus agnoscatur filius ipsius fuisse. 


\section{I.1.1 Louis the Stammerer's two marriages}

The problem of the legitimacy of Charles' birth, or more precisely that of his father's two marriages, has long been the subject of scholarly discussion. ${ }^{2}$ Louis the Stammerer and his own father, Charles II the Bald, had had a difficult relationship. Several times, the son had revolted against the father, been reconciled and then revolted again. ${ }^{3}$ During one of these cases in 862, Louis, following the advice of some of his supporters, had married Ansgarde, daughter of Count Harduin and sister of Odo, count of Châteaudun, one of his close supporters. ${ }^{4}$ Louis' revolt was subsequently put down, but the marriage with Ansgarde remained, soon to bear fruit in the form of two sons, Louis III and Carloman II, as well as a daughter, Hildegard. Some time later, Charles forced his son to abandon his wife and marry Adelaide, daughter of one of Charles' own close supporters, the Burgundian magnate and count of the palace, Adalard. ${ }^{5}$ This count's importance is also underlined by his appearance in the capitulary of Quierzy from 877, in which Charles laid down preparations for his journey to Italy: Adalard was among those appointed to stay close to Louis during the emperor's absence and was also in charge of the royal court of justice. ${ }^{6}$

According to Karl Ferdinand Werner, Adalard, and consequently Adelaide, came from an old family, going back to Bego, count of Paris, who had restored and reformed the abbey Saint-Maur of Fossés and died on the 28th October 816 , and his wife Alpais, daughter of Louis the Pious. In addition, Bego's nephews, Count

2 Eckel, Charles, 1-2; Brühl, Hinkmariana II, 60-77; Hlawitschka, Lotharingien, 221-240 and Werner, Nachkommen, 438-441.

3 For details see Kasten, Königssöhne, 443-465.

4 Annales Bertiniani 862, 91. For the circumstances of the revolt see Nelson, Charles, 204 and Kasten, Königssöhne, 446-449. For the family of Odo of Châteaudun see Levillain, Essai.

5 Regino, Chronicon 878, 114. On Adalard's paternity of Adelaide see Werner, Nachkommen, 429-441. The date of the divorce of Louis and Ansgarde as well as his remarriage with Adelaide remains debated. While Regino states that Charles forced the divorce and presented Louis with his new wife-to-be, Hincmar's Annales Bertiniani remain quiet on the subject, undoubtedly out of political considerations (Offergeld, Reges pueri, 344 with n. 146). Brühl, Hinkmariana II, based on an early 11th century source, proposed that these events in fact took place only after the death of Charles the Bald in 877 and were forced upon Louis not by his father, but by an influential party of nobles opposing him as part of their agreement to Louis' succession. This theory has been resolutely opposed by Werner, Nachkommen, 437-441, followed by Hlawitschka, Lotharingien, 225-228, and Bautier, Recueil Louis II, Louis III et Carloman, XXVIII, n. 2. Brühl defended his theory in another article (Miszellen, 355-370). Offergeld seems unconvinced by Brühl's arguments, yet does not deny the theory, due to it being "politically more plausible" and chronologically possible. He proposes that the marriage might well have been forced on Louis by the nobles before the death of Charles and without his knowledge or consent, comparable to the resistance of the nobility against the emperor's Italian policy (Offergeld, Reges pueri, 345-346).

6 MGH Capit. II, N ${ }^{\circ} 281$ c. 17, 359. Before, Adalard had already served as missus. Recueil SaintBenoît I, N $24,57$.

7 Charles the Simple calls him genitricis nostrae proavus (DChS 108). On this count see also Depreux, Prosopographie, 120-122 and Depreux, Dimension. 
Gerard of Vienne ${ }^{8}$ and Adalard the Seneschal, uncle of Charles the Bald's first wife Ermentrude, ${ }^{9}$ were influential under Charles the Bald. Bego's son Leuthard held the county of Paris and his second son Eberhard became well established in northern Burgundy, while his daughter Susanna ${ }^{10}$ married a certain Wulfard, who fathered yet another Wulfard, count of Angoulême, and finally Adalard, Adelaide's father."1 Adelaide also had a brother, also named Wulfard, who became abbot of Flavigny and was a member of the royal chancellery. ${ }^{12}$ The family also branched out into southern Lotharingia ${ }^{13}$ and had relatives in Aquitaine. ${ }^{14}$ Louis' marriage to Adelaide thus tied him to an important family with close links to his father. It also ensured the continuing influence of the faction of nobles Adalard belonged to, even after the death of Charles.

However, the circumstances of the two marriages gave rise to questions concerning their validity and thereby also the legitimacy of the offspring produced from each. Hincmar's Annales Bertiniani refrain from even mentioning the subject. Neither the divorce nor Charles' birth is mentioned and while the archbishop refers to the queen, he does not use her name, thus giving the impression that nothing had changed. ${ }^{15}$ The archbishop did not entirely succeed in his endeavour to hush up the affair, however. When treating Louis' meeting with Pope John VIII at Troyes in 878, he reports how the pope crowned Louis as king (Charles the Bald had died the year before), yet refused his explicit request to do the same for his wife, still not mentioning her name. ${ }^{16}$ John's own position on the matter is less clear than it appears at first sight. While he refused to crown Adelaide, he nevertheless stayed with Louis and his wife for several weeks. His refusal, therefore, seems not to have been taken badly, and appears more to have been the result of an unwillingness to take a clear position in the issue.

Louis himself, as the incident with John VIII shows, did his best to establish Adelaide as queen. Yet, when considering his own succession, he did not disinherit

8 The Girart de Roussillon of the famous Chanson de Geste.

9 On this personage see Lot, Mélanges and Depreux, Prosopographie, 80-82.

10 In opposition to Werner, Nachkommen, 433, Hlawitschka, Anfänge, 166-168 with n. 64, argues that Susanna was not the daughter of Alpais, but descended from an earlier (unknown) marriage of Count Bego, thus avoiding the problem of Louis the Stammerer and Adelaide being cousins of the 6 th degree.

11 Werner, Nachkommen, Exkurs II, 429-441. On the family see also Le Jan, Famille, 442, table $\mathrm{N}^{\circ} 57$ "La descendance de Gérard de Paris" adding Wulfgrim, Imo and Hildeburg to the children of Wulfard and Susanna.

12 Bautier, Recueil Louis II, Louis III et Carloman, LXV-LXVIII.

13 Hlawitschka, Anfänge, 164-168.

14 Werner, Nachkommen, Exkurs II, 435-436.

15 This behaviour of the archbishop appears in stark contrast to his attacks on Lothar II concerning the latter's marriage. See Brühl, Hinkmariana II.

16 Annales Bertiniani 878, 227. On this Befestigungskrönung see Brühl, Hinkmariana II, 63 with n. 31. Werner, Nachkommen, 440, followed by Offergeld, Reges pueri, 344, argued that this refusal to crown Adelaide was due to the uncanonical character of the marriage, Louis and Adelaide being related in the 6th degree. Le Jan, Famille, 320 in contrast points out that marriage of this type was widely tolerated and practiced. 
his sons by Ansgarde. In the treaty of Fouron, made with Louis the Younger, king of Eastern Francia, and negotiated with the consent of the magnates, he considered them equal to any male children he might have in the future. ${ }^{17}$ His sons' personal importance to him can also be deduced from a letter to Archbishop Hincmar in which the king asked for the cleric's aid for them. ${ }^{18}$ Furthermore, their political relevance is underlined by the fact that the king used Carloman to strengthen his ties to the powerful Boso by means of a marriage alliance. However, on his deathbed, Louis suddenly changed his plans for the succession and appointed his oldest son Louis III as his sole heir. ${ }^{19}$ This gave rise to a complicated situation, and thereby provided ample opportunity for those looking to gain an advantage to impose their own view of things. The legitimacy of Louis and Carloman was questionable to those who considered Louis the Stammerer's marriage with Adelaide valid. On the other hand, if this second marriage were uncanonical, the same doubts would be cast on any male offspring from that union..$^{20}$

Indeed the legitimacy of the boys was soon openly questioned. Not even a year later, in October 879, Boso of Vienne proclaimed himself king, ${ }^{21}$ arguing, as Regino reports, that the throne was vacant due to the absence of legitimate heirs to King Louis, ${ }^{22}$ thus claiming that neither of Louis' marriages had been valid. However, an inspection of the circumstances of this new claim reveals the purely opportunistic character of this reasoning. With Louis dead, yet without any drop of Carolingian blood himself, Boso needed an argument explaining why he himself could now claim the throne. He constructed a claim by simply casting away that of Louis' sons, to one of whom, Carloman, he had engaged his daughter only a year earlier at Troyes. ${ }^{23}$

17 MGH Capit. II, N² 246 c. 3, 169: Si autem vos mihi superstes fueritis, filios meos Hludowicum et Karlomannum et alios, quos divina pietas mihi donare voluerit, ut regnum paternum quiete tenere possint, similiter et consilio et auxilio, prout melius potueritis, ut adiuvetis rogo.

18 Flodoard, HRE III, c. 19, 261.

19 Annales Bertiniani 879, 234-235. Kasten, Königssöhne, 483, on the other hand, interprets the treaty of Fouron not as a decision to divide the realm among Louis' sons, but only as an "Eventualklausel" securing the rights of all the sons to follow their father in case of the death of the eldest. Accordingly, Louis would not have changed his succession plans at the last moment, but simply followed the tradition of the ordinatio imperii and the preferential treatment of the eldest son. She states that Louis, remembering his own succession problems, thought that his son Louis would be more likely to follow him if he were to be the only candidate. The treaty of Fouron, however, does not differentiate between the sons; they are all equally to hold their father's realm after his death and there is no mention of any preferred succession of the eldest, Louis. See also Offergeld, Reges pueri, 351, n. 164.

20 As has been argued by Hlawitschka, Lotharingien, 235, for Charles the Simple. Undoubtedly, this problematic situation also shaped Charles' own youth, with would serve to explain his distinctive consciousness for legitimacy, brilliantly analysed by Koziol, Canons, 173-178.

21 On him and these events, see chapter VI.4.

22 Regino, Chronicon 879, 144. In Boso's electio Louis' sons are being passed over, Boso arguing that no suitable person (except for himself) could be found to succeed Louis. MGH Capit. II, N² 284 C, 368.

23 Annales Bertiniani 878, 229. See also Werner, Gauzlin, 425. 


\subsubsection{The question of Louis' succession}

As we can see, due to the questionable status of Louis the Stammerer's marriages, Charles' legitimacy certainly offered possibilities to attack his claim. Nevertheless in 893, and in contrast to Boso fourteen years earlier, Odo's supporters chose not to exploit this issue but to question the paternity of Louis. So did the questionable legitimacy of Louis the Stammerer's sons carry any political relevance at all? It has been argued that, due to the questions over the validity of both of Louis the Stammerer's marriages, the decision to crown the sons from his marriage with Ansgarde invalidated any rights Adelaide's offspring might have had, thus explaining why Charles was passed over in the royal succession at least after the death of his brothers. ${ }^{24}$ An analysis of the royal successions between 879 and 898 will help to cast some light on this question.

It is possible Charles was even passed over in 879 , before his birth. After Louis the Stammerer's death in April, the leading nobles around Hugh the Abbot did not follow his last wishes and crown his eldest son Louis, but called in an assembly at Meaux to discuss future proceedings. ${ }^{25}$ Yet before Hugh and his allies were able to put any plan into action, a rival group around the former archchancellor Gauzlin had already assembled bishops, abbots and other important noblemen at Creil, inviting Louis the Younger, the partner of the treaty of Fouron, to come to the kingdom. ${ }^{26}$ According to Hincmar, Gauzlin acted out of a thirst for revenge and ambition; yet his real motive appears to have been his rivalry with Hugh the Abbot. ${ }^{27}$ While the latter has been made out as the driving force behind Louis the Stammerer's decision that only his eldest son should succeed him, Gauzlin appears to have favoured a partition of the realm between both Louis and Carloman. ${ }^{28}$

Faced with Louis the Younger invading the realm, in May, Hugh's faction sent envoys to the king at Verdun. In the subsequent treaty, Louis the Younger received Lotharingia in return for his withdrawal from the realm and a guarantee that the rest of the Western kingdom would remain with Louis the Stammerer's sons. ${ }^{29}$ This agreement indicates that Hugh's and Gauzlin's factions had also come to terms by this point. However, whether this meant a return to the original arrangement of Fouron, securing the succession of all of Louis' sons and thus including the possibility of rule for another prince from the pregnant Adelaide, or whether

24 Hlawitschka, Lotharingien, 235-240, argues strongly in favour of this reading. The argument has been revived by Schneidmüller, Karl III., 25, although he does not add new points to the discussion.

25 Annales Bertiniani 879, 235. The Annales Vedastini $(879,44)$ report that the group around Hugh wanted both sons to succeed. Whether their account is correct remains an open question, for events took another turn.

26 Annales Bertiniani 879, 235-236. We will discuss these factions in more detail in chapter II.2. For a thorough reconstruction of these events, see Werner, Gauzlin, 406-437.

27 Werner, Gauzlin, 422-428.

28 Werner, Gauzlin, 420-422.

29 Annales Bertiniani 879, 236-238; Annales Vedastini 879, 44. 
the succession was now restricted to the older sons of Ansgarde is not clear from the sources. In any case, Hugh and his allies failed to put the terms of the agreement into practice and Gauzlin again summoned Louis the Younger. The latter, occupied with the succession to his brother Carloman of Bavaria, promised only to return to the Western kingdom as soon as he could. ${ }^{30}$ At this point, and just before Adelaide gave birth to Charles, Hugh and his allies sent for Archbishop Ansegisus of Sens to anoint and crown Louis and Carloman. ${ }^{31}$

As Thilo Offergeld has rightly noted, Hugh's faction could have delayed the coronation for a few more weeks to wait for Adelaide's delivery. ${ }^{32}$ The threat posed by a potential second intervention on the part of Louis the Younger was certainly crucial in provoking Hugh to act, yet Offergeld is right to wonder whether Adelaide's imminent delivery might not also have contributed to Hugh's decision. ${ }^{33}$ Unusually, Charles' birth was noted by the sources, a fact that points towards its political importance. ${ }^{34}$ Moreover, the boy certainly had at least some support: his closest relatives did try to further his rights. As Regino notes, he was named by his mother after his grandfather, Charles the Bald. ${ }^{35}$ During the 9th century, a strong tendency had developed to give possible heirs to the throne a name from a very exclusive corpus: Pippin, Louis and Lothar, Carloman and Charles. ${ }^{36}$ The choice to name the boy Charles therefore was not random, but followed a political program, emphasising the legitimate birth of the child and his right to the throne, further strengthened through linking him to his ancestors Charlemagne and Charles the Bald. After Adelaide, one should also consider her brother Wulfard, abbot of Flavigny. Wulfard had risen under Louis the Stammerer, becoming first notarychancellor, then archchancellor, succeeding Gauzlin in early April 879. ${ }^{37}$ Yet, for almost two years following the death of Louis, the office of archchancellor seems to have remained vacant, and the first diploma of Carloman II was witnessed only by the notary Norbert. ${ }^{38}$ Only at the beginning of 881 does Wulfard appear again as archchancellor, ${ }^{39}$ at the moment when Carloman was staying near his abbey in the

30 Annales Bertiniani 879, 238. See also Werner, Gauzlin, 427-430 on the subject, dealing with the difficulties of the biased and incomplete account given by Hincmar.

31 Annales Bertiniani 879, 238-239; Annales Vedastini 879, 45.

32 Offergeld refers to a number of later examples, after the death of Louis X in 1316 and of Charles IV in 1328 , when the question of succession was indeed delayed until the respective widows had given birth. The case of Empress Agnes in 1057, when the Duchy of Bavaria remained vacant until her pregnancy ended, is also similar. Offergeld, Reges pueri, 363, n. 204.

33 Offergeld, Reges pueri, 359-360.

34 Schieffer, Väter, 155.

35 Regino, Chronicon 878, 114.

36 On the subject of Carolingian names see Becher, Arnulf, 665-668.

37 DLS 31, 29th March or 10th April 879. See also Bautier, Recueil Louis II, Louis III et Carloman II, LXVII-LXVIII.

38 DCmII 49, 30th November 880.

39 DCmII 50, 12th February 881. Wulfard appears to have regained his office between 30th November 880 (DCmII 49) and this date. See also Bautier, Recueil Louis II, Louis III et Carloman II, LXVIII. 
Nivernais between the first and second campaign against Duke Boso. ${ }^{40}$ It therefore seems likely that the party around Adelaide, amongst them Wulfard, lost its position at court with the death of Louis and subsequent assumption of power on the part of Hugh the Abbot. Wulfard apparently only regained his office after the revolt of Boso, when Hugh and Carloman needed the Nivernais as a base for their campaign against him. He may have become part of the inner circle around the king very quickly, as two intercessions in Carloman's diplomas show. ${ }^{41}$ If Wulfard indeed had lost his office due to his support for his nephew, it seems safe to deduce that a part of the price for reassuming his old position at the court would have been to renounce Charles' claim.

Certainly, at the moment of Louis' and Carloman's coronation, Charles' claim was a mere possibility. Yet, given the political tensions at that moment, it does not seem unreasonable to assume that Hugh wanted to avoid the possibility of any further complications by creating a fait accompli. The coronation of Ansgarde's sons, however, did not solve the problem of Gauzlin's faction. Since both boys remained with Hugh, the spirit of the agreement with the abbot and his allies-as well as Louis the Younger-had been violated, for the realm had not been divided between the brothers. Louis again invaded the realm and joined forces with those of Gauzlin, forcing Hugh to confirm the treaty of Fouron. The partition of the realm followed only a couple of months later, in March 880, at Ribemont. Louis, under the tutelage of Gauzlin and his allies, would rule over Francia and Neustria; Carloman, guided by Hugh and his party, Burgundy and Aquitaine. ${ }^{42}$ Charles, no longer a hypothetical figure but an actual claimant, was not mentioned.

Did the questionable legitimacy of Louis the Stammerer's sons play any role in these events? As already noted, Boso was the only one to deny their claim to the throne, at the moment he himself reached out for the crown. His was a general attack, not differentiating between the sons of Ansgarde and Adelaide-indeed, how could he if his aim was to create a situation in which he would not appear as a usurper denying a legitimate heir his right to the throne? The behaviour of the other leading nobles is more interesting. Did they cast aside Charles because they considered him illegitimate in comparison to his brothers? ${ }^{43}$ Louis the Stammerer had done his best to strengthen Adelaide's position at court while at the same time also promoting his succession by his sons from Ansgarde. ${ }^{44}$ The most important document in this matter is the treaty of Fouron, securing the succession of sons from both marriages. As the leading nobles of the realm had been included in this

40 Bautier, Recueil Louis II, Louis III et Carloman II, LXVIII.

41 DCmII 61, 1st December 880-before 6th September 881, (together with Hugh the Abbot and Count Wido) and DCmII 59, 29th August 881.

42 Annales Bertiniani 880, 241-242; Annales Vedastini 880, 47.

43 Hlawitschka, Lotharingien, 235. According to him, once the nobles had opted for Louis and Carloman and therefore acknowledged Louis the Stammerer's marriage with Ansgarde as valid, they would in turn have automatically considered Charles as illegitimate.

44 See above. 
decision, the treaty seems to reflect the official position of the court. ${ }^{45}$ Of course, this might have changed with Louis the Stammerer's death. Eduard Hlawitschka has argued that in fact Gauzlin and his allies leant towards Louis the Younger because of their doubts concerning the legitimacy of Louis and Carloman, thus denying their right to the throne. Hugh's faction, on the other hand, focused on the preservation of the independence of the Western realm. ${ }^{46}$ Yet, as Karl Ferdinand Werner has argued, Gauzlin was most probably one of the driving forces behind the treaty of Fouron and had supported Ansgarde earlier on, ${ }^{47}$ with no source mentioning such doubts being the motive for his turn to Louis the Younger.

It indeed seems that, for the most part, pragmatic reasons determined the courses of action of the leading factions around Hugh and Gauzlin. Hugh had opted for a single king, or, if necessary, for two, with both of them being under his control. Gauzlin urged for a real partition of the realm that would leave one of the boys in his care. Had Charles been born earlier, before or just after his father's death, he would undoubtedly have played a role in the political rivalry. Yet then, in September 879, none of the factions was in need of another claimant, especially since, given the high mortality rates among infants, supporting Adelaide's new baby might soon have left them without a candidate. ${ }^{48}$ The final solution to the conflict, the treaty of Ribemont and the partition of Amiens, agreed in March 880 , was the natural consequence of these early decisions: Given the political situation with two rival factions, there was also no need for a third candidate. It was therefore a mere question of political expediency as to whose claims were to be recognised or be disposed of ${ }^{49}$ Charles, in any case only a baby, simply did not fit into the plans of the policymakers and thus was passed over in the succession for the first time..$^{50}$

\section{I.1.3 Passing over Charles}

Over the course of the next ten years, three more occasions arose in which Charles could have become king and yet was passed over in the succession. On 5th August 882, his older half-brother Louis III died, yet the Frankish nobles turned towards Ansgarde's younger son, Carloman II. ${ }^{51}$ Two years later, after the latter had also passed away, their choice fell on Emperor Charles III the Fat, son of Louis the

45 MGH Capit. II, N²46, 169. See Werner, Gauzlin, 423.

46 Hlawitschka, Lotharingien, 221-240. Earlier also Sickel, Thronfolgerecht, 129-130 and Boehm, Rechtsformen, 328. Parisot, Royaume, 433-434 and Dümmler, Geschichte III, 116 considered legitimistic reasons as a plausible assumption.

47 Flodoard, HRE III, c. 19, 261. See also Werner, Gauzlin, 421-422 and 423-424 with n. 96.

48 See also Offergeld, Reges pueri, 364-365. In addition, an infant king would have been an unprecedented situation.

49 Werner, Gauzlin, 426.

50 See also Offergeld, Reges pueri, 365 .

51 Annales Vedastini 882, 52. 
German and by then ruler of the East Frankish kingdom, Lotharingia and Italy. Another four years later, after the death of the emperor, Charles was the last surviving male Carolingian, yet Odo, a powerful noble from the Robertian family, seized power. The transition to the Robertion family did not go unchallenged. A group of nobles from Francia first invited Wido of Spoleto to take the crown, but then turned to Arnulf of Carinthia before the former had even crossed the Alps. In none of these cases is Charles mentioned as a possible candidate by the sources.

Why did the nobles chose to ignore Charles and to opt for other candidates instead? Archbishop Fulk in 893 argued in a letter to Arnulf that he had not supported the young Carolingian in 888 because of his youthful age, which made him unfit to rule, especially in the face of the threat posed by the Northmen. ${ }^{52}$ This argument was persued in older research ${ }^{53}$-yet as the examples of Louis the Blind in Provence and Louis the Child in the Eastern kingdom show, boys of Charles' age could be crowned kings if the nobility agreed on them..$^{54}$ Eduard Hlawitschka, on the other hand, argued that Adelaide's son Charles lacked legitimacy once the nobles had declared his brothers as kings. According to him, only one of Louis the Stammerer's marriages could be valid, and the nobility had decided that it would be the one to Ansgarde, thereby making Charles an illegitimate child. ${ }^{55}$ However, as discussed, no sources indicate that the nobility had ever seriously questioned Charles' legitimacy. It might have been used as an argument against him, yet was certainly not the main issue which prevented him from being chosen as king. ${ }^{56}$ Rivalries between the Rorgonid group close to the emperor and Adelaide's family have been made out as the reason behind the call to Charles the Fat in $884,{ }^{57}$ but again, no sources indicate that this was the case. Concerning this succession, it has recently also been claimed that the magnates preferred a weak and mostly absent ruler, allowing them to follow their own interests. ${ }^{58}$ Yet, as Simon MacLean's study of the emperor has shown, Charles the Fat's policies towards the nobility in no way differed from those of his predecessors ${ }^{59}$ and this argument can be dismissed accordingly.

The absence of Charles the Simple from the sources concerning the question of the subsequent successions is striking and appears to indicate that he simply was

52 Flodoard, HRE IV, c. 5, 381: Quod, quando Karolus imperator decessit, et idem Arnulfus regimen huius regni suscipere noluit, hic Karolus adhuc admodum corpore simul et scientia parvulus existebat nec regni gubernaculis idoneus erat et instante immanissima Nordmannorum persecutione periculosum erat tunc eum eligere.

53 For example Dümmler, Geschichte III, 233; Eckel, Charles, 3 and Favre, Eudes, 78.

54 Offergeld, Reges pueri, 405.

55 Hlawitschka, Lotharingien, 235-236.

56 On the question of how to deal with illegitimate children, see Kasten, Chancen.

57 Werner, Nachkommen, 441 and Werner, Gauzlin, 455-458.

58 Offergeld, Reges pueri, 407. This reading appears to be influenced by older research following Dhondt, Études, seeing the nobility as opposed to any rule other than their own (See MacLean, Kingship, 13, on that question).

59 MacLean, Kingship, 77-79. 
not seriously considered as a potential ruler. In 882 , as well as in 884 , the realm had been under the immediate threat of Viking attacks, and the sources reflect a consistent unity amongst the nobility when they decided to ask first for Carloman and two years later for Charles the Fat. Louis III had won a battle against the Northmen at Saucourt in 881 that had forced that group of Vikings into Lotharingia ${ }^{60}$ and had concluded a treaty with Hasting and the Northmen along the Loire in 882. ${ }^{61}$ Just before his death, he appears to have prepared a campaign against the group now devastating the neighbouring regnum; and the nobles now invited Carloman to take over the realm and the army as fast as he could. ${ }^{62}$ Their haste demonstrates that, despite Louis' last measures, the realm was far from secure: Hasting and his group returned to haunt the coast ${ }^{63}$ while the other group also returned and took position in the Condé from where they then devastated the countryside. ${ }^{64}$ Considering the previous rivalry between the groupings around Hugh and Gauzlin, the decision to unite the realm under Carloman after his brother's death may seem surprising, all the more so as Gauzlin appears to have played an important part in it. ${ }^{65}$ Hugh's influence at court, despite his rival's return, remained untouched, at least for the time being. Gauzlin stood back for a moment, yet soon resumed his office as archchancellor and became bishop of Paris. ${ }^{66}$ Facing the Viking threat, the two factions had seemingly found an agreement acceptable to both sides. Carloman would rule the entire kingdom, led by both groups in concert.

The situation two years later was not much different. Carloman, following fruitless efforts to defeat the Northmen, had finally concluded a treaty with them, paying a huge tribute for them to leave the realm. Yet, according to Regino of Prüm, when he suddenly died, the Vikings returned, claiming that the agreement had lost its validity with the king's demise. Faced with the option of either paying them again or fighting them, the magnates chose to send for the emperor, Charles III the Fat. ${ }^{67}$ Once again, the sources emphasise the unity with which the decision to invite the emperor to the crown was taken. ${ }^{68}$ As before, we find that

60 Annales Vedastini 881, 50-51. The victory is also mirrored by the famous Ludwigslied.

61 Annales Vedastini 882, 52.

62 Annales Bertiniani 882, 246: Primores autem regni expeditum nuntium miserunt ad Karlomannum, mandantes $u t$, relictis qui Viennam obsiderent et seditioni Bosonis resisterent, ipse quantotius ad eos uenire festinaret, quoniam hostiliter ipsi praeparati erant in occursum Nortmannorum, qui ciuitates Coloniam et Treueris cum monasteriis sibi contiguis iam incensas haberent...

63 Annales Bertiniani 882, 247.

64 Annales Vedastini 882, 52.

65 See his role in the reading of Carloman's oath to the realm. MGH Capit. II, N² 285, 370 (legente Gauzeleno) and Werner, Gauzlin, 452-453.

66 Werner, Gauzlin, 453-454. Offergeld, Reges pueri, 373, speaks of a "schnelle und reibungslose Herrschaftsübernahme Karlmanns im Nordreich," while at the same time admitting the loss of power by Gauzlin's party. While it seems correct that Carloman's accession to his brother's throne went smoothly and quickly, the integration of the North into his realm posed some severe problems. See chapter II.2.

67 Regino, Chronicon 884, 121-122.

68 Regino, Chronicon 884, 122: Territi huiuscemodi mandatis optimates regni ad Carolum imperatorem missos dirigunt eumque ultro in regnum invitant. See also Annales Vedastini 884, 56: Franci 
Hugh and Gauzlin played key parts in the process, with other important magnates from the Paris region and Neustria acting alongside them. ${ }^{69}$ The former factions now being at peace with each other, only one candidate was needed, and Emperor Charles appeared as a logical choice considering the Viking threat.

Charles the Fat had already been in contact with the West Frankish magnates in the summer of 879, when Archbishop Hincmar of Reims had asked him to adopt one of Louis the Stammerer's sons and to take care of the boys and the affairs of the realm, a matter in which Hugh was also involved. ${ }^{70}$ Hincmar's letter was followed by a meeting in October between Louis, his brother Carloman and Charles at Orbe. However, the question of whether one of the boys really was adopted by Charles remains open. ${ }^{71}$ The archbishop sent another letter to Charles, probably at the end of 879 or the beginning of $880,{ }^{72}$ making the same request and asking him to provide tutors for the adolescents. ${ }^{73}$ Whether Hincmar's successor, Fulk, pursued these plans any further is not known, but he was also in contact with the emperor as early as June $884 .^{74}$ Charles thus had connections with the highest ranks of the West Frankish nobility long before Carloman's untimely death.

The emperor became quickly and widely accepted in the Western realm. As the diplomas he issued during his two visits to the West show, he possessed a wide-ranging network of support. ${ }^{75}$ This unity he inspired amongst the leading magnates of the realm, especially in view of the past rivalries between the different factions, was without a doubt the biggest point in his favour. If Charles the Simple, still a mere five years old, had been made king, a divided nobility fighting for control over the child and therefore a regency might reasonably have been expected. Charles the Fat, on the other hand, had proven his capability to integrate

capiunt consilium et Theodericum comitem Italiae dirigunt ad imperatorem Karolum, uti veniat in Franciam. In contrast to Regino, the annals do not make a direct connection between the Viking threat and the decision for Charles the Fat.

69 MacLean, Kingship, 102-115. He also argues against Werner's reading that Hugh's influence massively declined towards the end of Carloman's reign and that his role under Charles the Fat became marginal. MacLean, Kingship, 104-105 and Werner, Gauzlin, 455.

70 Flodoard, HRE III, c. 24, 327. On the political background of the letter see Schneider, Erzbischof, 35.

71 Annales Bertiniani 879, 240. That Carloman is described as adopticii filii nostri in one of Charles' later diplomas (DChF 145) seems to support such an outcome. It is noteworthy however that this is the only reference to Carloman under this expression out of his mere three mentions in Charles the Fat's diplomas (DDChF 122, 145 and 149, with only DChF 145 being clearly composed by the chancellery). Moreover, that Charles did not mention this fact at the assembly at Ponthion in 885 during his first visit to the Western kingdom, but instead waited until October 886 after the siege of Paris was ended, arouses suspicion about the value of the diploma as proof for the adoption. It seems to me that Charles, under these special circumstances, tried to construct a special connection to the Western kingdom.

72 Hlawitschka, Lotharingien, 234, n. 34.

73 Migne, PL 125, cols. 989-994. On Hincmar's idea behind the adoption see Kasten, Königssöhne, 487-488 and Schneider, Suche, 415-419. Kasten seems to overestimate Hincmar's influence during this time, however.

74 DChF 106, Metz, 30th June 884.

75 MacLean, Kingship, 100-101. 
the other parts of the Carolingian empire under one ruler and it could be expected that he would also succeed in doing so in West Francia. ${ }^{76}$ The equilibrium among the magnates was new and potentially fragile and, in the face of the Viking threat, no-one seems to have been ready to risk a new civil conflict. Finally, this unity also points to another issue: the emperor seems to have had a claim to the West Frankish throne strong enough to go uncontested. His succession to the throne appears to have come so naturally that Archbishop Fulk of Reims, when explaining to the emperor Arnulf in 893 the reasons why he had not previously supported Charles the Simple's claim to the throne, referred only to the situation after the emperor's death, not to that after Carloman's. ${ }^{77}$

\section{I.1.4 A Robertian on the throne}

Three times had Charles been passed over in the succession so far and three times political reasons appear to have been predominant. In 879/880, the factions had already settled on their positions before Charles had been born and therefore had no need for him. In 882 and 884, the Viking threat created an atmosphere that enforced political unity amongst the leading nobles. The sudden deaths of Louis III and Carloman II were thus followed by quick decisions concerning the succession question, and in each case the candidate behind whom the nobles could rally the most easily appears to have been chosen. This in turn implies that Charles lacked sufficient support. By way of explanation, his youth and the problem of the legitimacy of his birth have been brought forward. Both may have played a role, yet other examples demonstrate that they were certainly not a hindrance.

This was even more the case in 888 after the death of Charles the Fat. As Regino of Prüm famously noted: "After his death the kingdoms which had obeyed his authority, just as though a legitimate heir were lacking, dissolved into separate parts and, no longer waiting for a natural lord, each decided to create a king from its own guts." ${ }^{38}$ The death of the emperor had created a vacuum which was now used by a number of powerful nobles to seize the crown: Arnulf of Carinthia, illegitimate son of Carloman of Bavaria, in the East Frankish realm; Berengar, son of Eberhard of Friuli in Italy; and Odo, son of Robert the Strong in the West Frankish kingdom, to name but three. Over the preceding years a "crisis of authority" ${ }^{\text {" had }}$

76 MacLean, Kingship, 120-122. See also the positive accounts of Charles the Fat by Regino, Chronicon 888, 128-129, and Abbo, Bella I, 18, v. 48-52 and II, 98, v. 442-443. On Abbo's view of Charles see MacLean, Kingship, 55-62.

77 Flodoard, HRE IV, c. 5 380-383: De hoc etiam, quod idem rex in culpa trahebat, quare non id ante fecissent, reddit rationem, quod, quando Karolus imperator decessit, et idem Arnulfus regimen huius regni suscipere noluit...

78 Regino, Chronicon 888, 129: Post cuius mortem regna, que eius ditioni paruerant, veluti legitimo destituta herede, in partes a sua compage resolvuntur et iam non naturalem dominum prestolantur, sed unumquodque de suis visceribus regem sibi creari disponit.

79 Airlie, Nearly Men, 26. 
developed, a legitimacy deficit of the Carolingian dynasty resulting from the continuous threat generated by Vikings, Hungarians and Saracens as well as the quick series of successions since the deaths of Charles the Bald and Louis the German. When Boso had initiated his own coronation in 879, four Carolingian rulers had allied themselves to crush this attempt. ${ }^{80}$ Their alliance demonstrates how serious they considered the threat to be ${ }^{81}$ Boso's case had unlocked the door for all those who wanted to challenge the Carolingian monopoly on kingship, and the death of Charles the Fat, which left his realms without an heir, ${ }^{82}$ pushed it wide open.

One of the new kings, and in our case the most interesting one since he claimed the West Frankish throne for himself, was Odo, son of Robert the Strong, ${ }^{83}$ who had risen from count of Paris to marchio of Neustria under Charles the Fat. Odo had proven himself a more than capable military leader during the siege of Paris in 886 and, due to his family ties and his proximity to Charles, he had acquired the inheritances not only of Gauzlin, ${ }^{84}$ but also of Hugh the Abbot after their deaths. As such, Odo united the military command over Neustria with the counties Tours, Angers and Blois, as well as the abbeys of Saint-Martin of Tours and Marmoutiers, with the county of Paris and the abbey of Saint-Denis. ${ }^{85}$ In his person, therefore, the Western kingdom now had a magnate powerful enough to dominate the other nobles and be able to legitimise himself through military victory.

80 Annales Vedastini 880, 47.

81 Airlie, Nearly Men, 26.

82 Airlie, Semper fideles, 139-140. On the efforts of the emperor to avoid this situation, see MacLean, Kingship, 129-198.

83 Robert the Strong, one of the leading magnates under Charles the Bald, at the time of his death holder of a march in Neustria. On him see Kalckstein, Robert; Werner, Robertiens and Baccou, Débuts.

84 Gauzlin and Odo may have been related via Odo's wife Theodrada. Werner, Gauzlin, 213.

85 On the rise of Odo see Werner, Gauzlin, 461-462; Guillot, Étapes, 200-207 and MacLean, Kingship, 50-55 and 64-66. Guillot argues that Odo had usurped royal prerogatives even before the deposition of Charles the Fat, based on a letter collection dating to 887 and the Gesta Pontificium Autissiodorensium. MacLean argues against Guillot's view and, using charter evidence, emphasises Odo's proximity to the emperor. Odo's taking over of the Neustrian command is mentioned by Regino, Chronicon 887, 126-127. The counties Tours, Angers and Blois seem to be indicated by the reference made by the Annales Vedastini $(886,62)$ telling us that he was given his father's honores (Robert the Strong had been count of Tours and Angers (Dhondt, Études, 93-94. See also Werner, Robertiens, 21, who adds the counties of Blois and Châteaudun to the list. It was also proposed that Robert held Marmoutiers as a lay abbot, based on his identification with the illustris viri Rotberti in DChB 147. On this subject, however, see Baccou, Débuts, who argues that this was in fact another Robert.) Viscounts of all three counties appear in one of Odo's private charters, the same which also names him as abbot of Saint-Martin of Tours (Recueil Eudes, $N^{\circ} 55$. See Favre, Eudes, 72-74, for the identifications of the witnesses). For his abbacy over Marmoutiers, see Favre, Eudes, 77, n. 1, referring to Martène, Histoire Marmoutier II,1 [ms], 26 (= BNF lat. 12867-12880). Odo is named count of Paris in a charter for the church Notre-Dame of Paris (Cartulaire Notre-Dame de Paris I, 298-299, N XVI). He had probably become count of Paris in succession to Conrad by the end of 882 or the beginning of 883. Favre, Eudes, 15. For Saint-Denis, see Werner, Gauzlin, 461 with n. 220 and Gallia Christiana IX, cols. 448-449 for Morienval, where Robert succeeded count Theoderic of Vermandois as abbot. Saint-Amand seems to have been passed on directly to Robert (Series Abbatum S. Amandi Elnonensis, 386). 
However, this same situation also offered new opportunities for Charles the Simple. If the problem of his mother's marriage to Louis the Stammerer had thus far been an issue for the nobility, now, in the face of the lack of other Carolingians, his claim by blood was stronger than that of any others, and his position thus changed dramatically. It is therefore hardly coincidental that Charles reappears in the sources at this very moment. Once Odo had consolidated his rule in the North and overcome the initial opposition, he moved to Aquitaine, where he met with Ramnulf II of Poitiers. ${ }^{86}$ The latter also brought Charles to the meeting and swore an oath not only for himself, but also for the Carolingian, "lest anything evil be suspected of him." ${ }^{87}$ Ramnulf himself might have attempted to take the crown for himself, although this is only reported by the Annales Fuldenses ${ }^{88}$ It is clear, however, that Odo considered Charles a threat, and this threat could only stem from Charles' Carolingian blood.

This is also emphasised by other sources. "And when at the day mentioned above they gathered at Reims, they placed him on his father's throne, consecrating him king" 89 the Annales Vedastini report for the year 893 when the rebellious faction around Archbishop Fulk finally crowned Charles. This reference to his Carolingian descent undoubtedly reflects the official standpoint of the group: it is the same argument used by Archbishop Fulk in his letter to Arnulf from the same year, in which he named Charles the last descendant of the royal family, whose predecessors and brothers had been kings. ${ }^{90}$ Fulk's argument however should not be taken out of context. The archbishop was defending himself against the accusation of unjust rebellion. Charles' claim served to justify his own actions while he presented Odo as "a stranger to the royal family [who] had tyrannically abused the

86 The claim that Charles' mother Adelaide had married Ramnulf (e.g. Ewig, Kaiser, 580) has been successfully refuted by Werner, Nachkommen, 455, n. 17. Adelaide's father's relatives in Aquitaine (see above) may be an explanation for his stay there. Werner, Nachkommen, 436, further adduces Ramnulf's opposition to Odo as a reason, but this appears to be an argument based on the assumption that Charles only went to Ramnulf after Odo's coronation. Since there is no evidence of Charles' whereabouts before this mention in the sources, this remains mere speculation. Fulk's tutorship of Charles as mentioned by Richer, Historiae I, c. 16, 53 is not contemporary and appears to be an interpretation made in hindsight, a projection of the situation after 893 to the period of Charles' boyhood.

87 Annales Vedastini 889, 67: Post nativitatem vero Domini cum paucis Francis Aquitaniam perrexit, ut sibi eos sociaret. Quo audito Ramnulfus dux maximae partis Aquitaniae cum sibi faventibus venit ad eum, adducens secum Karolum puerum, filium Hludowici regis, et iuravit illi quae digna fuerunt, simul et de ipso puerulo, ne quid mali de eo suspicaretur.

88 Annales Fuldenses (Ratisbon continuation) 888, 116. Brühl, Deutschland, 374, believes this account. Favre, Eudes, 122, n. 1 and Werner, Westfranken, 229, are doubtful. The account has been rejected by Hlawitschka, Lotharingien, 86 and Kienast, Herzogstitel, 175. We hesitate to dismiss the account completely, even though it seems odd that an East Frankish source should be the only one to know about Ramnulf's ambition to become king.

89 Annales Vedastini 893, 73: Et die supra dicti Remis adunati eum in paterno solio benedictum in regem collocant.

90 Flodoard, HRE IV, c. 5, 381: ...quem solum post ipsum de regia ipsius habebant progenie et cuius predecessores ac fratres extiterant reges. And again 382: ...vel in hunc regie prosapie Karolum... and ...propterque rectum congruumque regii generis principatum... 
royal power." 91 The argument of Charles' legitimacy was therefore not only used to emphasise his claim, but also to deny Odo's right to rule.

This last point mattered more to Fulk than enforcing the rights of the Carolingian youth. The opportunistic nature of his argument becomes clear from the archbishop's behaviour in 888. After the death of the emperor, a group based in Francia and Burgundy, centred on Archbishop Fulk, ${ }^{92}$ invited Fulk's relative, Wido of Spoleto ${ }^{93}$ to the realm, only to abandon him even before he arrived. ${ }^{94}$ Wido was still crowned as the choice of a number of Burgundian nobles by Bishop Geilo of Langres, but returned to Italy on the news of Odo's coronation..$^{95}$ Odo, for his part, seems to have been able to bring the resisting nobles from Francia over to his side using promises and threats; ${ }^{96}$ however, he failed to quickly integrate them under his rule. Soon after, Fulk, together with Count Baldwin II of Flanders and the latter's cousin, Abbot Rodulf97, turned towards Arnulf, king of the East Frankish kingdom, and invited him to the Western realm..$^{98}$ Negotiations were still in progress when Odo won a decisive victory against the Vikings at Montfauçon. ${ }^{99}$ On hearing this, Arnulf refused Fulk's offer "without council or conciliation."100 Instead he opted for the victor of Montfauçon and not only invited him to a meeting, but also sent him a crown soon after. Fulk's party immediately disintegrated,

91 Flodoard, HRE IV, c. 5, 381: Odonis [...] qui ab stirpe regia existens alienus, regali tirannice abusu fuerit potestate...

92 The Annales Vedastini $(888,64)$ clearly identify Archbishop Fulk of Reims as the leader of this group. Referring to the coronation of Wido, they state that a few Burgundian nobles chose him as king. Since some relatives of Wido lived near Langres, it can be assumed that the annals refer to them, not only in this context, but also later, when they report that, on his return to Italy, Wido was accompanied by those who decided to follow him. See also Hlawitschka, Die Widonen, 24 with n. 12. Whether Fulk's later allies Count Baldwin II of Flanders and his cousin Abbot Rodulf already formed part of the group at this point must remain open.

93 Fulk and Wido were related by blood: Flodoard, HRE IV, c. 3, 376. Fulk assured the pope quod non illum tantum diligeret pro consanguinitatis necessitudine, qua illi devinctus habebatur, verum multo magis, quia huius pape venerator et amator existeret. See also Schneider, Erzbischof, 7-21 and Hlawitschka, Kaiser, 193 with n. 31. How they were actually related cannot be established.

94 On the decision to abandon Wido, see Schneider, Erzbischof, 45.

95 Annales Vedastini 888, 65.

96 Annales Vedastini 888, 65. The way the annals describe the situation leaves no doubt that Fulk and his allies were amongst those who now submitted to Odo's rule: Odo vero rex Francos, qui suo nolebant se subdi dominationi, partim blanditiis, partim terroribus sibi sociari festinabat.

97 On their parentage see Favre, Famille, 160.

98 Annales Vedastini 888, 65. Fulk was also accompanied by the bishops Dodilo of Cambrai, Honoratus of Beauvais and Heitilo of Noyon, as well as Archbishop John of Rouen (chased out of his bishopric by the Vikings). They all figure in a charter of Archbishop Liutpert of Mainz for Abbot Bovo of Corvey issued probably during the council of Mainz in June 888 (MGH Conc. V, $\left.\mathrm{N}^{\circ} 26,267\right)$.

99 Schneider, Erzbischof, 49-50, has argued convincingly that the negotiations started at Worms and continued during the assembly of Frankfurt. Odo's victory occurred on the 24th June. Arnulf stayed at Frankfurt until at least 3rd July (DA 34), so that the news of the battle would have reached him there before he made his final decision.

100 Flodoard, HRE IV, c. 5, 380-381: Commemorans, quod decedente Karolo imperatore, huius Arnulfi avunculo, in ipsius Arnulf servitium fuerit profectus, cupiens eius suscipere dominium et gubernationem, sed ipse rex eum sine ullo consilio vel consolatione dimiserit. 
leaving him no other option but to submit to Odo for a second time. ${ }^{101}$ The "primacy of the royal blood" the archbishop used as an argument five years later ${ }^{102}$ thus appears not to have played a role in the succession crisis of 888; Fulk first opted for his own relative, Wido of Spoleto, and then turned to Arnulf of Carinthia.

Fulk, of course, was aware of this hole in his argument when he wrote his letter. In his defence he claimed that in 888 Charles had been too young in body and wisdom to govern the realm and that the Viking threat made it too dangerous to choose him as king. ${ }^{103}$ Yet Boso's son Louis had succeeded his father in 887 at an even younger age and so too would Arnulf's own son Louis only a few years later. While the Viking threat might be more credible, the question arises whether, given his young age in 888 as well as in 893 , it would have been Charles who commanded the army and not his advisers around Fulk. His half-brother Carloman, for example, remained dependent on the groups around Hugh the Abbot and Gauzlin even after he had been given the arms of manhood ${ }^{104}$ and in the years following his own coronation the sources emphasise the role of those "who were with Charles."105 The archbishop's arguments are thus revealed as mere afterthoughts, excuses to Arnulf for his own behaviour five years earlier.

This, however, does not answer the question why Fulk and his allies turned to Wido of Spoleto and Arnulf instead of elevating Charles. The cause may have been partly practical: Charles simply might not have been available, since he was with Ramnulf II of Poitiers. ${ }^{106}$ Yet other reasons probably carried more weight. In contrast to 893, Fulk's party seems to have been rather weak in 888 . Apart from the suffragan bishops of Reims, Fulk was supported by only Baldwin II of Flanders and Baldwin's cousin Abbot Rodulf. ${ }^{107} \mathrm{He}$ still lacked the support a man as powerful as Count Heribert I could provide, ${ }^{108}$ as well as connections outside Francia. ${ }^{109}$ Fulk's party was therefore limited to candidates who could not only serve as rallying points for other discontented magnates, but who also brought with them their

101 Annales Vedastini 888, 65-66. Arnulf seems to have subsequently influenced Odo to accept Fulk and the rest of his allies back into his fidelity. In Autumn Odo was crowned at Reims. Annales Vedastini 888, 67.

102 Flodoard, HRE IV, c. 5, 382: ...propterque rectum congruumque regii generis principatum...

103 Flodoard, HRE IV, c. 5, 381: Et idem Arnulfus regimen huius regni suscipere noluit, hic Karolus adhuc admodum corpore simul et scientia parvulus existebat nec regni gubernaculis idoneus erat et instante immanissima Nordmannorum persecutione periculosum erat tunc eum eligere.

104 Offergeld, Reges pueri, 402-403.

105 For example Annales Vedastini 894, 74: Cumque hi qui cum Karolo erant viderent se non habere unde ei resistere... noctu civitatem egressi cum suo rege ad Arnulfi regis auxilium cum suo rege se contulerunt. And 895, 76: At hi qui cum Karolo erant conferunt se ad Zuendebolchum eique partem regni consentiunt, uti veniat et iuvet Karolo suo consobrino. Offergeld, Reges pueri, 453-459.

106 So Offergeld, Reges pueri, 415.

107 Flodoard, HRE IV, c. 5, 380-381.

108 No source indicates whether Heribert I formed part of this alliance in 888. Even if he did, he was not as powerful as he would be in 893 , since it was only in $888 / 889$ that he started to accumulate honores. On this process, see Werner, Untersuchungen V and Schwager, Graf, 26-28.

109 For a detailed analysis of the alliance of 893, see below. 
own connections, like Wido of Spoleto, or had a power base sufficient to fight Odo, like Arnulf. Since Charles could provide neither of them, he was disqualified as a candidate.

\section{I.1.5 Carolingian blood matters}

We can now return to our initial question: why did Odo's supporters in 893 deny Louis the Stammerer's paternity instead of attacking Charles where he was more vulnerable, the problem of the legitimacy of his birth, as Boso had done in 879 ? Four times Charles had been passed over in the royal succession until he finally became king. In the first three cases, the political circumstances-the rivalry between the factions of Hugh the Abbot and Gauzlin and the Viking threat-could be made out as the main reasons. Charles fell victim to his late birth when the political decisions concerning the succession of his father had already been taken. Once marginalised, he simply did not possess enough political support to have his claim enforced. Whether this was due to the problem of the validity of Adelaide's marriage to Louis the Stammerer has to remain an open question, although the political realities appear to have carried enough weight on their own for him to be cast aside time after time.

Be that as it may, the death of Charles the Fat in 888 changed the field dramatically. With Odo, a man now reached for the crown who drew his legitimation not from his blood, but from his victories against the Northmen. ${ }^{110}$ Does this mean that by the end of the 9th century Carolingian legitimacy had lost its importance? The emperor's death had created a vacuum due to a lack of heirs and there being no agreed-upon succession, while Boso's example from 879 had already demonstrated that the Carolingian monopoly on kingship was not set in stone. Odo, making use of his prestige, won by defending the realm against the Northmen, now went down the same path and attempted to fill the vacuum. This new legitimation by victory allowed him to declare his claim while his political connections and his resources enabled him to enforce it. Yet, the immediate challenges also reveal the limits of his support and the fragility of his position. These challenges also show how weak the power of Carolingian legitimacy had become at that point, for Fulk and his allies decided against supporting Charles-who was now passed over for a fourth time-and instead opted first for Wido and then for Arnulf.

It would be wrong, however, to underestimate the force of Carolingian traditions. They remained an essential part of royal behaviour and representation: the carefully phrased language of Odo's diplomas and promissio sets him in line with his Carolingian predecessors and attempts to negate the different nature of his

110 On the importance of the prestige won from warfare for Carolingian kingship, see Scharff, Gott, 265-276. 
kingship, thus trying to create the impression of uninterrupted continuity.111 $\mathrm{He}$ had himself crowned at Compiègne, ${ }^{112}$ the palace that had become so important under Charles the Bald that it was called Carlopolis by later writers. ${ }^{113}$ His promissio ${ }^{114}$ was based on those of Louis the Stammerer and Carloman II, ${ }^{115}$ assuring the audience that in fact nothing had changed. Immediately after his coronation he took possession of the Carolingian insignia stored at Saint-Denis. ${ }^{116}$ In short, Odo did his best to appear no different from his predecessors. He used the force still inherent in the Carolingian tradition to strengthen his rule. Having no Carolingian blood to legitimise himself, he at least wanted to appear as a Carolingian since Carolingian traditions offered a legitimation more durable and reliable than that based on victory, which depended on the fortunes and misfortunes of the battlefield. How strong the Carolingian argument still was can also be deduced from Fulk's letter to Arnulf. ${ }^{117}$ The archbishop certainly did not crown Charles out of deeply held principles of Carolingian legitimism - we will return to his motives later-yet his use of the Carolingian card in opposition to Odo's "strangeness" shows how much weight Charles' blood still carried in political discourse. ${ }^{118}$

This was Charles the Simple's opportunity. Having been passed over in the royal succession four times and lacking political support he could not have expected to leave his political backwater soon. Now, however, Odo's lack of Carolingian blood and the absence of other male Carolingians-apart from the also questionable Arnulf and Louis of Provence, Boso's son with the Carolingian princess Ermengard-improved his position considerably. Because of his claim, Charles was the ideal candidate, not for a normal succession, but for any opposition challenging the Robertian's rule. His blood made him an ideal rallying point for all those discontented with the Robertian. This was why Odo's supporters did not use the issue of the legitimacy of Charles' birth against him but brought forward doubts about Louis the Stammerer's paternity. In doing so, they attacked Charles where he had his advantage over Odo: his Carolingian blood that, even considering his possibly questionable legitimacy, made him superior to his opponent. Because Carolingian traditions remained strong, simply questioning Charles' legitimacy did not

111 Schneidmüller, Tradition, 109. On the continuities in form see Mersiowsky, Urkunde, 214-223. See also Airlie, Élites, on the takeover of Carolingian practices by important nobles.

112 Annales Vedastini 888, 64.

113 Koziol, Politics, 541-544.

114 Recueil Eudes, 209-211.

115 Favre, Eudes, 91-92.

116 Schneidmüller, Tradition, 110-116. Schneidmüller furthermore refers to similarities of legends and symbols on seals and coins as well as the links to his predecessors created by Odo's diplomas. Schneidmüller, Tradition, 120 summarises: "Odo war es gelungen, karolingische Tradition für seine Zwecke zu adaptieren. Verschiedene äußere Zeichen der Königsherrschaft sind beredte Zeugnisse für die robertinischen Bemühungen, Herrschaft in ihrer Kontinuität zu begreifen. Odos Herrschaftspraxis und Herrschaftsverständnis kommen in vielem einer völligen Imitation karolingischer Vorbilder gleich."

117 See also Airlie, Élites, 428-429.

118 On the limits of Carolingian legitimacy as a political concept, see Airlie, Nearly Men, 30. 
suffice. Charles' Carolingian blood had to be denied entirely, since it was the pillar on which his claim rested.

\section{I.2 Close supporters and distant allies}

Even relatively recently, the members of the alliance elevating Charles to the throne have been described as lacking constancy and principles, driven mainly by self-interest. ${ }^{119}$ Yet the war which ensued between the Carolingian's supporters and Odo lasted more than four years and, in the end, Charles not only kept his crown, however small his realm may have been, but it was also agreed that he would succeed the Robertian upon the latter's death. If this network was indeed so fragile, why had the conflict lasted so long and ended with such a positive result for Charles? It would appear that the motives of the alliance's members in opposing Odo and supporting Charles were strong enough to create a certain level of group cohesion, a cohesion that proved sufficient to withstand even great pressure from the Robertian. However, scholars rarely produce their arguments out of thin air. What, then, are the reasons for the image of the alliance as unprincipled and inconstant?

\section{I.2.1 Archbishop Fulk of Reims}

The best starting point for an analysis of this network is one of its principal agents, the oft-mentioned Archbishop Fulk of Reims, who we saw acting against Odo in 888. Fulk first appears in the sources accompanying Charles the Bald to Rome in 875. Two years later he became abbot of Saint-Bertin and was among those to whom the emperor entrusted his realm and his son Louis in the capitulary of Quierzy. ${ }^{120} \mathrm{He}$ seems to have spent the following years at the royal court ${ }^{121}$, yet his actual influence is hard to determine since he neither figures in royal diplomas nor is mentioned by the narrative sources. After Hincmar's death he became archbishop of Reims, which seems to indicate closeness with the dominating factions around Hugh the Abbot and Gauzlin. ${ }^{122}$ Despite his new position, his influence at court remains hard to trace. Soon after his ordination, he wrote a letter recommending King Carloman to Pope Marinus I. ${ }^{123}$ In summer 884, he visited Charles the Fat

119 Offergeld, Reges pueri, 425: "Die folgenden Jahre sollten zeigen, daß die Großen sich ihre Unterstützung von Fall zu Fall neu abringen ließen; eine verläßliche oder gar gesinnungsfeste Gefolgschaft hat Karl nie besessen.” Similar Schneider, Erzbischof, 112.

120 Schneider, Erzbischof, 22-23.

121 Flodoard, HRE IV, c. 4, 379.

122 Schneider, Erzbischof, 25-27.

123 Flodoard, HRE IV, c. 1, 363-364. 
in Metz to ask for the restoration of possessions in Thuringia, ${ }^{124}$ which indicates that he had connections outside the realm, but again does not shed light on his actual influence in the politics of the West Frankish court. Once the emperor had become ruler in the West as well, Fulk sent him a letter asking for his help in the defence of Paris against the Northmen, ${ }^{125}$ yet, as before, this letter says more of Fulk's ambition to gain a preeminent position than his actual influence. ${ }^{126}$ Instead, Charles' reign saw the rise of Odo, who favoured the church of his relative, Archbishop Walter of Sens. Fulk's opposition to Odo might thus be seen in the context of the struggle between the sees of Reims and Sens for the primacy of the Gallic church. ${ }^{127}$ Yet this solution seems too narrow, as it fails to consider the archbishop's political ambitions, demonstrated by his invitation to Wido of Spoleto to take the crown after the death of Charles the Fat before turning to Arnulf of Carinthia. Fulk, as archbishop of Reims, seems to have claimed a central position in West Frankish politics that had been denied to him during the reigns of Carloman II and Charles the Fat. Odo's power, on the other hand, was firmly rooted in his Neustrian possessions and honores, while the position at his side was occupied for now by Count Theoderic of Vermandois. ${ }^{128}$ Under the rule of the Robertian, Fulk could not hope to gain the influence on royal affairs which Odo himself had wielded under Charles the Fat. It was a lack of proximity to the new king which frustrated his political ambitions and provoked his resistance.

Aware of the archbishop's ambitions, Odo followed a policy of appeasement and integration, trying to deal with the root cause of the resistance initially shown by Fulk and the nobles around him. Count Baldwin II had already submitted to Odo before the Robertian met with Arnulf. ${ }^{129}$ After the meeting, in a well-enacted ceremony, Odo was crowned for a second time at Reims, ${ }^{130}$ probably by Fulk himself ${ }^{131}$ who also received a diploma for his church. ${ }^{132}$ Odo then moved on to spend Christmas at Saint-Vaast, one of the abbeys of Abbot Rodulf, one of Fulk's allies when he had turned to Arnulf. In 890, the abbot also received a diploma through the intercession of Odo's wife, Theodrada. ${ }^{133}$ Another diploma went to

DChF 106, 30th June 884.

Flodoard, HRE IV, c. 5, 380.

See also Schneider, Erzbischof, 38.

Offergeld, Reges pueri, 412. On the subject of the primate of the Gallic Church see Schramm, König, 113-114. During his lifetime, Hincmar had unsuccessfully fought for the primate of Reims.

8 Theoderic is mentioned as Odo's most important supporter by the Annales Vedastini $(888,64)$. Soon after, he appears as Odo's emissary to Arnulf. Annales Vedastini 888, 65. On him see Werner, Untersuchungen V, 89-91.

Annales Vedastini 888, 66.

Guillot, Étapes, 215-216.

Schneider, Erzbischof, 58-59.

DOdo 31, probably dating to 891/892. See Schneider, Erzbischof, 94, n. 92. At some point during his reign, Odo also made a grant to the Church of Reims for the celebration of his anniversary (DOdo 47).

133 DOdo 20. 
Bishop Dido of Laon, ${ }^{134}$ a suffragan of the church of Reims. Dido, as well as Honoratus of Beauvais and Riculf of Soissons, accompanied Fulk to a large assembly at Verberie in $892 .{ }^{135}$ Whether Count Heribert I, who was to become one of Charles' most important allies, ${ }^{136}$ had supported Odo or had joined the ranks of Fulk's allies cannot be answered, but just after Christmas 889, he appeared in one of the kings diplomas as "one of our great men." 137 Odo's reign certainly does mark Heribert's ascent: from 888 onwards he became count of Meaux, the Vexin, the Mézerais and Soissons, while his brother Pippin acquired the county of Beauvais. ${ }^{138}$ Odo's network in the Francia is dealt with in the next chapter, so for the moment we shall simply note that, among those the Robertian tried to integrate into his rule, we can find at least two-Fulk and Heribert-who were to become the leading members of the revolt against him.

For the next few years however, nothing indicates that the two were fundamentally opposed to Odo. Heribert, who was close to the king at the end of 889, unfortunately disappears from the sources. Fulk, on the other hand, remains much more visible. After his final submission to the king, he mostly appears to have cooperated with Odo. The Visio Karoli ${ }^{139}$ probably written at Reims, endorses the right of Louis of Provence to the imperial crown and may be a sign that Fulk tried to promote Louis as a candidate for the West Frankish throne, which would indicate his continuing ambition to claim a central role in the realm's politics. With that said, the question is still not resolved satisfactorily. ${ }^{140}$ More important for the political situation in the realm was the struggle for the episcopal see of Langres. After the death of Bishop Isaac, the clergy and people of Langres had chosen the deacon Teutbald and asked Pope Stephen V to consecrate him, against the will of the metropolitan Aurelian of Lyon, who should have been the one to consecrate the new bishop. ${ }^{141}$ Stephen refused the demand, as he did not want to interfere with the archbishop's rights, and instead advised Aurelian to consecrate Teutbald, unless he happened to have any personal objections to him. If that were to be

DOdo 29. Whether Dido had opposed Odo with his metropolitan is not clear, as he does not appear to have accompanied Fulk to meet Arnulf. Later on he can be found close to the king when he refused to absolve the captured Walker of Laon (Flodoard, HRE IV, c. 6, 392-393). Even after the rebellion of 893, Dido stayed loyal to Odo, defending Laon against Charles and Zwentibold in 895. Annales Vedastini 895, 76.

135 DOdo 30. In addition to these bishops, the archbishops Walter of Sens and Wido of Rouen were also present. Of the suffragans present, Honoratus of Beauvais would stay loyal to Odo even after Fulk's revolt, trying to excommunicate count Aledramnus (Flodoard, HRE IV, c. 6, 394).

136 See below.

137 DOdo 16 (30th December 889), 76: ...proceribus nostris Hubaldo et Heriberto...

138 Werner, Untersuchungen V, 92-100.

139 Visio Karoli, 458.

140 See Hlawitschka, Lotharingien, 100-106, in favour of this reading. Following him and providing an assessment of the chances of the project is Schneider, Erzbischof, 69-72. Critical is Pokorny, Brieffragment, 617. MacLean, Kingship, 166 also follows Hlawitschka's arguments. See also Dutton, Politics, 233-251, who dates the Visio to 888.

141 Flodoard, HRE IV, c. 1, 367-368. 
the case, by papal order no other bishop might be appointed in the meantime. Furthermore, Stephen sent Bishop Oirannus of Senigallia as his legate to mediate between the two parties. ${ }^{142}$ On Oirannus' arrival at Lyon, Aurelian sent him on to Langres with the promise to proceed there himself as soon as possible, which he then failed to do. When his refusal to follow the pope's commands became apparent, the clergy and people of Langres sent another letter to Rome, once more asking Stephen to consecrate Teutbald. The pope, still unwilling to interfere with Aurelian's rights, now sent a letter to the archbishop to enquire about his reasons for refusing Teutbald. ${ }^{143}$ Once again Aurelian did not respond; instead, he, together with his suffragans and Archbishop Bernuin of Vienne, now consecrated the cleric Argrim as bishop. ${ }^{144}$ Only then did the pope send instructions-this time to Fulk - to consecrate Teutbald, ${ }^{145}$ in turn prompting Odo to send an embassy to Rome. Fulk, for his part, informed Stephen that he would not act before the return of the embassy ${ }^{146}$ Early in 891, Teutbald was finally consecrated and installed as bishop of Langres. Eduard Hlawitschka has interpreted Fulk's role in the affair as that of a leading actor who tried to install his protégé, Teutbald, in Langres, acting against Odo's candidate, Argrim, and finally successfully depriving the king of an important foothold in northern Burgundy. ${ }^{147}$ However, as Rudolf Pokorny has shown, neither Fulk's purported backing of Teutbald nor Odo's for Argrim can be supported by evidence. ${ }^{148}$ Whether and how the archbishop of Reims finally acted is indeed unclear; from his only appearance, it seems that he did indeed cooperate with the king.

The picture is clearer in a number of other cases in which Fulk seems to have supported Odo's policies. In 892, the king participated in a synod concerning a dispute between the abbess Hildegard and a certain Hermingard. ${ }^{149}$ Likewise, the archbishop and his suffragans Dido of Laon, Honoratus of Beauvais and Riculf of Soissons were present at a royal assembly at Verberie, where they sat in judgement over the case of the monk Aginus with the archbishops, Walter of Sens and Wido of Rouen. ${ }^{150}$ Finally, Fulk sided with the king against Baldwin II of Flanders in the conflict over the abbeys of Saint-Vaast and Saint-Bertin: after taking counsel from four of his suffragans, Fulk ordered Bishop Dodilo of Cambrai to dissuade the count from continuing with his course of action and threatened his followers

142 Flodoard, HRE IV, c. 1, 368.

143 Flodoard, HRE IV, c. 1, 368.

144 The consecration of Argrim is noted in a letter of Pope John IX to the clergy and people of Langres (Gallia Christiana IV, cols. 540, JL 3520) and a letter of Pope Benedict IV also to the clergy and people of Langres (Gallia Christiana IV, cols. 540, JL 3528) and, without mentioning Argrim's name, Flodoard, HRE IV, c. 1, 368. See also Schneider, Erzbischof, 85, n. 59.

145 Flodoard, HRE IV, c. 1, 368.

146 Flodoard, HRE IV, c. 1, 369.

147 Hlawitschka, Lotharingien, 99-106.

148 Pokorny, Brieffragment, 613-620.

149 Flodoard, HRE IV, c. 6, 389 and 390. Of Hildegard and Hermingard nothing further is known.

150 DOdo 30. 
with anathema if he did not give in. ${ }^{151}$ When Dodilo failed to obey, Fulk held a synod to deal with the matter and wrote directly to Baldwin, threatening him with excommunication. ${ }^{152}$ Until late in the year, Fulk seems to have supported Odo's rule-and even profited from it. When the monks of Saint-Bertin, having refused Baldwin as their new abbot, received Odo's permission to make their own choice, they elected Fulk as abbot. ${ }^{153}$

However, it is worthwhile to note another dispute, also related to the death of Abbot Rodulf. Rodulf had not only held the abbeys of Saint-Vaast and SaintBertin, but also Cysoing and the relics of Saint Calixtus. Before his death, Rodulf had placed both under the protection of the church of Reims. Yet, once Rodulf died, his sister's husband, Hucbald, one of Odo's closest allies in Francia, ${ }^{154}$ took the abbey under his control. Fulk wrote to the pope to ask him for advice on the matter, to demand a confirmation of the donation and to threaten all opponents with excommunication. ${ }^{155}$ In his answer, reported by Flodoard, Pope Formosus did indeed confirm Cysoing as the possession of the church of Reims; however, there is no mention of any threats of excommunication. ${ }^{156}$ This may indicate that Hucbald had given up his claim on the abbey by the time of Formosus' reply. However, relations between the archbishop and the count remained tense even after the affair was resolved. When Fulk instructed Dodilo of Cambrai to fetch Calixtus' relics from Arras and transfer them to Saint-Quentin, Dodilo chose to seize the relics, making Fulk fear that he would hand them over to Hucbald. ${ }^{157}$ Both abbey and relics finally ended up in the possession of the archbishop, as Flodoard states, ${ }^{158}$ but whether this happened under Odo or under Charles remains open. It is nevertheless worth noting that Fulk, just before he decided to revolt against Odo, was in conflict with one of the king's main supporters in Francia. In general

151 Flodoard, HRE IV, c. 6, 391.

152 Flodoard, HRE IV, c. 7, 396-397.

153 Folcwin, Gesta Abbatum S. Bertini Sithensium, c. 98, 624. Before becoming archbishop of Reims, Fulk had previously been abbot of Saint-Bertin.

154 Hucbald was married to Heilwich, daughter of Eberhard of Friuli and sister to Abbot Rodulf. On him see Grierson, Maison, 257 and Le Jan, Famille, 50 and 443. Odo and Hucbald were already in contact before 888. Bischof, Anecdota, $\mathrm{N}^{\circ} \mathrm{V}, 131-132$. In this letter, the widow of the lay abbot of Saint-Symphorien of Orléans complains that Odo and Hucbald had interfered with her rights and possessions. The letter also names Hucbald as count of Senlis, against the older literature wrongly depicting him as count of the Ostrevent (Grierson, Origine, 111). Hucbald appears in DDOdo 16 (proceres noster), 38 (in omnibus fidelis noster ... comes) and 48 (a deperditum). His nephew Heriveus appears as notary in Odo's diplomas from DOdo 36 (894, May 2) onwards.

155 Flodoard, HRE IV, c. 1, 371. Sot, Historien, dates Fulk's letter to Formosus to winter 891/892. Since it makes reference to events taking place after the death of Abbot Rodulf (5th January 892, Annales Vedastini 892, 70), the letter was probably composed in January or February 892.

156 Flodoard, HRE IV, c. 2, 373. The letter was composed after Easter 892 (23rd April), as it makes reference to the coronation of Lambert of Spoleto.

157 Flodoard, HRE IV, c. 6, 392. Sot, Historien, followed by the editors of the MGH-edition (391, n. 34), dates this letter to 893. Since the letter refers to the death of Abbot Rodulf and Fulk states that he planned to re-transfer the relics to Cysoing once peace was restored, the second half of 892 seems equally likely.

158 Flodoard, HRE IV, c. 8, 399. 
however, Fulk cooperated with Odo in cases such as the succession of Langres and supported him against Baldwin II; while the Visio Karoli, despite all the problems of interpreting it, might be read as a sign of his continuing ambitions.

Yet does this mean that Fulk wholeheartedly supported Odo's rule? As he indicates in his letter, it was not until late 892 that he was approached by a group of discontented nobles for advice. ${ }^{159}$ The origins of this newest conspiracy against Odo seem indeed to have been quite recent, at least as concerns the archbishop. ${ }^{160}$ However, this passage also shows that Fulk was perceived as someone who would not betray such discontent-which would indicate that he was not part of Odo's most inner circle-and, in addition, that he was thought likely to support this new opposition. The archbishop, despite his cooperation with Odo, was apparently known for having had a negative attitude towards the king. At the same time however, the king himself seems to have continued to be oblivious to this, as he, on the advice of that very same group, decided to leave Francia and march to Aquitaine just before they openly rebelled against him. ${ }^{161}$ Fulk figured as a rallying point for the opposition and his cooperation with Odo was therefore probably motivated less by actual conviction than by necessity in the face of political realities. As the year 888 had proven, opposition against Odo needed stronger support than he could mobilise on his own. This, of course, does not mean that Fulk only bided his time, waiting for an opportunity to rebel. Cooperation could also be beneficial, as him becoming abbot of Saint-Bertin for a second time shows. ${ }^{162}$ Under different circumstances, cooperation might have given the archbishop the political influence he aspired to.

\subsubsection{The network elevating Charles}

This leads us to the network that was now formed to elevate and support Charles. According to Regino of Prüm, most of the Francian nobles renounced Odo to follow the new king ${ }^{163}$ yet this statement should be read with great care. Several bishops from the archdiocese of Reims remained loyal to the Robertian and a number of counts from the area did not side with Fulk either, most prominently Odo's old ally Count Hucbald of Senlis. ${ }^{164}$ Within the group, the archbishop occupied the most prominent role. We have already seen him become a rallying

159 Flodoard, HRE IV, c. 5, 380.

160 Schneider, Erzbischof, 104.

161 Annales Vedastini 892, 72-73.

162 See above. Apart from Saint-Bertin, Fulk also received the abbey of Avenay from Odo. Flodoard, HRE IV, c. 8, 399.

163 Regino, Chronicon 892, 140: Odone rege in Aquitania commorante Francorum principes ex permaxima parte ab eo deficiunt, et agentibus Folcone archiepiscopo, Heriberto et Pippino comitibus in Remorum civitate Carolus filius Ludowici ex Adalheide regina, ut supra meminimus, natus in regnum elevatur.

164 On the bishops see below. Hucbald figures in DOdo 38 (13th January 894-12th January 895). 
point for those discontented with Odo's reign. After the rebellion began, he did his best to further Charles' cause by using his contacts with popes and kings. ${ }^{165}$ Fulk's central position is also reflected by the Annales Vedastini, which repeatedly mention him as one of the leaders, being close to Charles ${ }^{166}$ and acting as legate to Arnulf. ${ }^{167}$ After Fulk, Count Heribert occupied a key position. Having risen under Odo and now holding several counties, he was mentioned by Fulk as one of those who approached him before the rebellion. ${ }^{168}$ Regino of Prüm names him as one of the leaders of the rebellion, next to his brother Pippin and Archbishop Fulk ${ }^{169}$ and later he appears as a military leader ${ }^{170}$ and chief negotiator. ${ }^{171}$ His defection to Odo in 896 seems to have hit Charles especially hard. Relations between him and the count appear to have deteriorated so much that, a year later, Heribert was the only noble who had left Charles' side who the sources mention to be formally reconciled with the Carolingian. ${ }^{172}$

Unmentioned by the narrative sources yet at the same time prominent in both of Charles' surviving diplomas from the years of the rebellion is another key actor: his mother Adelaide. That Carolingian queens could possess political influence is well known yet hard to assess in individual cases. ${ }^{173}$ In Adelaide's case, she intervened remarkably often in Charles' diplomas-thirteen times ${ }^{174}$ in the 31 charters that have survived as originals or copies-until her death in $901 .{ }^{175}$ Only three times is she named queen (regina), but all of the diplomas name her as "our mother" (genitrix nostra), with epithets varying from "venerable" (venerabilis) to "dearest" (carissima) and "most beloved" (dilectissima) and even "sweetest" (perdulcissima). ${ }^{176}$ Her importance thus does not seem to have stemmed from

165 Correspondence concerning Charles with Pope Formosus: indicating Charles' coronation: Flodoard, HRE IV, c. 2, 374. Asking for the pope's mediation with Arnulf, Odo and Lambert of Spoleto: HRE IV, c. 3, 875, and HRE IV, c. 3, 376. To Arnulf the aforementioned letter dating to 893 and another in 894, assuring him of their good intentions: Flodoard, HRE IV, c. 5, 383. To Wido asking him to protect Charles: Flodoard, HRE IV, c. 5, 383-384.

166 Annales Vedastini 893, 73: Post pascha Domini Fulcho archiepiscopus et Heribertus comes assumentes Karolum regem cum omni exercitu disponunt [ire] contra Odonem regem...Annales Vedastini 893, 74: Karolus vero cum Fulcone Remis repedavit.

167 Annales Vedastini 895, 75-76.

168 Flodoard, HRE IV, c. 5, 381.

169 Regino, Chronicon 892, 140-141.

170 Annales Vedastini 893, 73.

171 Annales Vedastini 895, 77.

172 Annales Vedastini 896, 77 and 897, 79.

173 See Hartmann, Königin, 162-167.

174 DDChS 5, 7, 10, 11, 14, 15, 22, 23, 27, 32, 35, 39 and 41.

175 Adelaide died on 18th November, in all probability 901, since DChS 41, 9th November 901 marks her last appearance in the sources. Hlawitschka, Ahnen II, 238.

176 DChS 5, 6: karissimae et venerabilis genitricis nostre Adeleydis; DChS 7, 10: venerabilis et carissimae genitricis nostrae Adelheidis; DChS 10, 16: dilectissimae genetricis nostrae Adelais; DChS 11, 18: venerabilis genetrix nostra Adelheidis regina; DChS 14, 25: predulcissime genitricis nostre Adeleidis; DChS 15, 27: perdulcissimae genitricis notrae Adeleidis; DChS 22, 43: venerabilis genetrix nostra Adheleydis regina; DChS 23, 46: venerabilis genetricis nostre Adheleidis; DChS 27, 57: venerabili genitrice nostra Adheleide; DChS 32, 68: dulcissime genitricis nostre Adelheidis regine; DChS 35, 
her position as queen. The special character of her appearances will be addressed again at a later point. ${ }^{177}$ For the moment, it suffices to note that all of the nobles she intervened with had connections to the court independent from her, as in the cases of Fulk, ${ }^{178}$ his suffragan bishops Honoratus of Beauvais and Rudolf of Laon ${ }^{179}$ and the counts Ecfrid ${ }^{180}$ and Erkanger. ${ }^{181}$ While she was certainly important, it does not automatically follow that her importance was based on her own political connections. Rather, it seems that, based on her role as his mother, she was Charles' closest advisor during these years, and that the diplomas reflect her influence on the young king.

As we have seen, Fulk and Heribert were both integrated into Odo's rule. Although not part of Odo's innermost circle, they were nevertheless in contact with the king. Another instigator of the rebellion was part of this inner circle, the man who led the group approaching the archbishop of Reims: Anskeric, the bishop of Paris, the king's archchancellor in succession to the rebellious abbot Ebolus of Saint-Denis. ${ }^{182}$ Little is known about Anskeric. His brother was Count Tetbert of Meaux and he may have had relatives in the Langrois. ${ }^{183}$ A marriage alliance with Pippin, father of Count Heribert I of Vermandois, has also been suggested, which would explain the connection between the bishop and the count. ${ }^{184}$ In addition, a later source, the Carmen de pontificibus romanis, indicates that he was related to Charles the Simple. ${ }^{185}$ Politically, Anskeric seems initially to have been in competition with Gauzlin for the office of bishop of Paris, failing to secure it on the death of Angelwinus. He nonetheless appeared at the court of Charles the Fat in 885 as episcopus vocatus. ${ }^{186}$ Charles' support allowed him to succeed to the episcopal see upon the death of Gauzlin. ${ }^{187}$ His proximity to the emperor and his position in Paris are both emphasised by the fact that, when the Vikings arrived at the city in 887 to demand the tribute promised to them in return for lifting the siege the year before, it was Anskeric who went to Charles, ${ }^{188}$ before negotiating their passage to

75: dulcissima genitrix nostra Adeleidis; DChS 39, 83: dulcissima genitrix nostra Adeleydis; DChS 41, 90: dilectissima genitrice nostra Adeleide.

177 See chapter III.2.2.

178 DChS 5.

179 DChS 10, 8th February 898.

180 DChS 35, 31st October 900.

181 DChS 39, 21st August 901.

182 Flodoard, HRE IV, c. 5, 381. The last diploma with Ebolus as archchancellor is DOdo 28 (25th July 891), followed by DOdo 30 (30th September 892), which features Anskeric in the same position. In DOdo 33 (28th May 893) Adalgar, bishop of Autun, has succeeded Anskeric.

183 Bautier, Recueil Eudes, XXVIII.

184 Werner, Untersuchungen V, 95-102.

185 Mansi, Concilia XVIII, col. 110. Formosus to Anskeric of Paris: Sacrilegos quosdam sacrati culminis atros carptores, summi capitis clarissima membra attemerare ausos, anathematis ense recisos notificans, monet hunc nodos dignae addere multae sceptrigeri quoque cognati pro culmine certet. See also Favre, Eudes, 151, n. 4.

186 DChF 116.

187 Bautier, Recueil Eudes, XXVI-XXVII.

188 Annales Vedastini 887, 63. 
Burgundy. ${ }^{189}$ Once Odo had become king, Anskeric joined his operations against the Vikings with his own troops. ${ }^{190} \mathrm{He}$ appears shortly afterwards as abbot of SaintGermain of Auxerre, ${ }^{191}$ intervened for Bishop Argrim of Langres before the king ${ }^{192}$ and finally became archchancellor in $892 .{ }^{193}$ Thus the bishop's political importance can hardly be overestimated, an importance he also possessed within Charles' inner circle after the rebellion had begun. He now became the Carolingian's new archchancellor, the same role he had held at Odo's court. ${ }^{194}$ However, Charles' only other diploma surviving from the years of the rebellion, dating to the summer of 896, names neither him nor any other as archchancellor, ${ }^{195}$ indicating that he had left Charles' side. When this happened, however, is not clear. It may have occurred at the very time that Heribert and Fulk defected from the Carolingian. In any case, this appears not to have had any lasting consequences for their relationship. After Fulk's death, Anskeric immediately resumed his old office. ${ }^{196}$

Taking the office as an indicator of importance, we can also add another count to the men close to the Carolingian. A certain Elduin appears as count of the palace in a private charter of Richard the Justiciar in $896 .{ }^{197}$ His presence there can be explained by the negotiations taking place between Charles and Richard, with Elduin acting as the former's legate. This would also emphasise his importance at Charles' court at that moment, furthered by the circumstance that Heribert, Fulk and others had submitted to Odo earlier during that year.

Other counts also participated in important negotiations. Treating with Odo in 895, Heribert was accompanied by Erkanger and Ecfrid. ${ }^{198}$ Little is known about either of them. Ecfrid was one of those who first approached Fulk in late $892^{199}$ and

Abbo, Bella II, 96, v. 411-415. Bautier, Recueil Eudes, XXVII, suggests that the Northmen were prohibited from using the Marne, as Anskeric's brother Teutbert was count of Meaux.

190 Abbo, Bella II, 102, v. 485-488.

191 DOdo 12.

192 DOdo 15.

193 DOdo 30, 30th September 892. See also Bautier, Recueil Eudes, XXV-XXIX.

194 DChS 5, 26th September 894, 7.

195 DChS 7, 25th July 896, preserved as original.

196 DChS 30, 23rd June 900.

197 21st December 896. Cartulaire Montiéramey, 18, $\mathrm{N}^{\circ}$ 12. The charter (XII calendas januarii, anno IIII regnante Karolo, Francorum rege) can either be dated to 896 or 901. In 901, however, William the Pious had become Charles' count of the palace (Recueil Cluny I, 83-84, N 74, 29th November 901, is signed by William as principis et comiti palatio), making the later dating impossible. That Elduin was Charles' count of the palace and not Odo's can be deduced from the dating, which names the former as king. It seems possible that this Elduin is identical with Count Hilduin who, towards the end of Carloman II's reign, received a part of the royal fisc in Tournai (DCmII 86). On this Hilduin as count in the Noyonnais see Vercauteren, Étude, 244-245.

198 Annales Vedastini 895, 77.

199 Flodoard, HRE IV, c. 5, 381. Favre, Eudes, 184, Schneider, Erzbischof, 107 and Offergeld, Reges pueri, 842 see in him the count of Artois; Eckel, Charles, 11, identifies him as count of Arras. Vanderkindere, Formations I, 46, is more careful; he also considers the position of Abbot Rodulf, and argues that he was not the count of, but a count in the Artois, e.g. of the Ostrevant or Douai. Lauer, Recueil Charles III, 74, n. 2, identifies him as count of the Hièmois and lay abbot of SaintÉvroult, without giving any further reasons. 
is also attested in the sources in connection with Baldwin II's rebellion after the death of the abbot Rodulf. At the time, the monks of Saint-Vaast first sent him to ask after the king's will, only then to choose Baldwin as abbot on the advice of a certain Everbert. ${ }^{200}$ That Fulk chose to mention him in his letter nonetheless indicates that Ecfrid was of some political importance. Erkanger, generally identified as count of Boulogne, had served as Gauzlin's legate in 886 when he went to seek Duke Henry's help against the Northmen. ${ }^{201}$ Like Heribert, he left Charles' side in $896 .{ }^{202}$ Heribert's brother, the already mentioned Pippin, also belonged to this circle of men carrying some political weight while probably not belonging to the group of central decision makers.

Also interesting is the case of yet another count, Aledramnus. He was sent to Arnulf by Fulk before Charles' coronation, only to be excommunicated by Bishop Honoratus of Beauvais soon after. ${ }^{203}$ The choice of Aledramnus as emissary to Arnulf was by no means coincidental. Since the last decade of Charles the Bald's reign, the count had been a leading member of the Frankish nobility, appearing prominently in diplomas of Charles the Bald, Louis the Stammerer and Charles the Fat. ${ }^{204}$ During Charles the Fat's reign, he and his brother, Count Theoderichimself a very important ally of Odo-led the advance guard during the emperor's march on Paris. ${ }^{205}$ Moreover, Aledramnus was related not only to Charles the Simple, ${ }^{206}$ but also to Odo, whose wife Theodrada was Aledramnus' daughter. ${ }^{207}$ The count thus was a political heavyweight, well connected in the highest circles. Choosing him as emissary to Arnulf sent a powerful message to the realm: Aledramnus' support tied the reign of the young Charles to the reigns of his father and grandfather and demonstrated that even Odo's closest supporters-even members of his own family-rallied around the young Carolingian.

The mention of the Lotharingian Count Reginar Longneck at Charles' side in 895 is difficult to assess. In his fight with Odo, Charles and his supporters had concluded an alliance with the Lotharingian king, Zwentibold. Having united their forces, they now besieged Laon, where, as the Annales Vedastini report, "Reginar Longneck, count, marchio, accepting bad advice, left Charles and went to Zwentibold." ${ }^{208}$ This phrasing indicates that he, although a Lotharingian noble,

200 Annales Vedastini 892, 70.

201 Annales Vedastini 886, 59.

202 Annales Vedastini 896, 77.

203 Flodoard, HRE IV, c. 5, 383 and c. 6, 394.

204 DChB 356 (293: dilectus nobis, illustris comitis et ministerialis nostri) and DChB 347 (273: dilectissimus nobis ministerialis, dilectus comes et ministerialis noster), DLS 28 (84: carissimus nobis comes and dilectus propinquus noster comes) and DChF 120 (190: dilectus nobis comes).

205 Abbo, Bella II, 90, v. 328-329.

206 As becomes clear of DLS 28. Lot, Notes, 150, supposed that Aledramnus was related to Louis' wife Adelaide, Le Jan, Famille, 256, n. 230 sees a direct tie to Louis.

207 Favre, Eudes, 202-203 and Le Jan, Famille, 237. Settipani, Préhistoire, 404-405 notes Theodrada's origin as unknown.

208 Annales Vedastini 895, 76: Zuendebolchus vero rex et Karolus cum exercitu veniunt Laudunumque obsidione cingunt. Balduinus vero comes et Hrodulfus frater eius necnon et Ragnerus non bono 
had previously supported Charles. Reginar appears to have held possessions in the Western kingdom ${ }^{209}$ and had married Charles' sister Ermentrude around 888, the latter probably dying around 892, after the birth of her daughter Cunigunde. ${ }^{210}$ Whether he had joined Charles at the beginning of the rebellion or only later cannot be established. It seems plausible that, due to his connections to both Charles and Zwentibold, he had established the link between the two, yet, lacking further evidence, this is mere speculation. Since, during the rebellion, he is not mentioned before nor after this incident, it appears best to assume that his importance within the network supporting Charles was limited to a shorter period around the conclusion of the alliance with Zwentibold.

Less problematic, but certainly of more peripheral importance within the network, were other men: Gauzfrid's sons, nephews of Gauzlin and relations of the Ramnulfids in Aquitaine, ${ }^{211}$ belonged to the initial group approaching Fulk; ${ }^{212}$ the otherwise unknown Count Adalung was killed accompanying the archbishop to a meeting with Arnulf. ${ }^{213}$ From the archdiocese of Reims the bishops Heitilo of Noyon, Herilandus of Thérouanne and, soon afterwards, Mancio of Chalons ${ }^{214}$ joined the ranks, along with Bishop Teutbald of Langres in northern Burgundy. ${ }^{215}$ The example of the archdiocese of Reims, however, also demonstrates the limits of this new network. A number of suffragans did not agree with the policy of their

consilio accepto Karolum reliquerunt et se ad Zuendebolchum contulerunt. For Baldwin and his brother see below.

209 An assumption that can be traced back through the literature at least to Stein, Geschichte, 199, but has never been actually proven. It seems likely however, since Regino of Prüm reports that when Zwentibold banned Reginar from the kingdom, he took all his honoribus, hereditatibus, quas in suo regno habebat (Chronicon 898, 145), indicating that he also held others outside his realm. Situating them in the West would explain why Reginar turned to Charles on more than one occassion. See also Parisot, Royaume, 542 and Hlawitschka, Lotharingien, 175. Barth, Herzog, 32, claims that Reginar held property south-east of Orléans. How he comes to this conclusion unfortunately remains unclear.

210 Renn, Grafenhaus, 10-12 and Hlawitschka, Ahnen II, 235. Reginar's son Gislebert stemmed from a second marriage with Albrada. On the old claim that Reginar was a descendent of Lothar I (Werner, Nachkommen, p, 412 and Settipani, Préhistoire I, 264) see Hlawitschka, Ahnen II, 231-236. According to him, there is no evidence that Reginar did indeed stem from the marriage between his father Count Gislebert and Lothar's daughter. He furthermore argues that neither the royal diplomas of Louis the Child or Charles the Simple make mention of a kinship with Reginar, nor do Reginar's own charters.

211 Le Jan, Famille, 445, table $N^{\circ} 61$.

212 Flodoard, HRE IV, c. 5, 381.

213 Annales Vedastini 895, 75-76; Regino, Chronicon 895, 143.

214 Schneider, Erzbischof, 108. Unfortunately Schneider does not give any sources for this statement. Herilandus of Thérouanne was Fulk's favourite for the empty episcopal siege of Châlons-enChampagne (Flodoard, HRE IV, c. 3, 377-378) before he ordinated Mancio (Flodoard, HRE IV, c. 3,377$)$. Heitilo of Noyon seems to have been Fulk's confidant in the case of the transfer of the relics of Saint Calixt (Flodoard, HRE IV, c. 6, 391-392) and received a diploma from Charles in 898 (DChS 2), both of which may indicate that he also supported Fulk and thereby Charles after 893. Schneider also adds Riculf of Soissons to the list, which could not be confirmed.

215 Teutbald had sent a legate to Charles' coronation. Afterwards, Fulk asked him to enquire about the position of Richard of Burgundy and of the Aquitanian nobles. Flodoard, HRE IV, c. 6, 395. 
metropolitan: Dido of Laon as well as Honoratus of Beauvais stayed loyal to the king $^{216}$ as, possibly, did Otgar of Amiens. ${ }^{217}$

We have so far described different layers of the network forming to rebel against Odo and elevating Charles to his father's throne. The innermost core consisted of Charles' mother Adelaide, Archbishop Fulk of Reims, Bishop Anskeric of Paris and Count Heribert of Vermandois. In the next layer were men like Heribert's brother Pippin, Count Aledramnus, the Count of the Palace Elduin, Count Erkanger, Count Ecfrid and possibly also Reginar Longneck if he indeed belonged to Charles' supporters. Undoubtedly to the outer rim belonged those primarily in contact with the men from the inner core or those whose base lay a greater distance from Francia: Count Adalung, Fulk's suffragan bishops Heitilo, Herilandus and Mancio, Bishop Teutbald and the sons of Gauzfrid. In the Annales Vedastini this group is most often referred to as "those who were with Charles," 218 indicating, as Thilo Offergeld has shown, their influence on the actions of the king. Whenever political decisions had to be made, the annals emphasise their role as a group and only mention Charles when they indicate simple geographical movement. ${ }^{219}$ "Those who were with Charles" are thus opposed to the fideles who were accompanying and counselling Odo. The Robertian made his own policies; Charles seems to have been a boy-king dominated by those around him.

\subsubsection{The motives behind the rebellion}

What was it that brought these nobles together ${ }^{220}$ Adelaide, we may reasonably presume, wanted to further her son. Fulk had received at least two abbeys since

216 See above, chapters I.2.1, n. 134 and I.2.2, n. 203. Whether Dodilo of Cambrai also stayed loyal to Odo as Schneider, Erzbischof, 108, claims, is doubtful. Many of Fulk's letters accuse Dodilo of opposition to the archbishop, yet none does so in the context of the rebellion against Odo. Furthermore, as Cambrai was part of the kingdom of Lotharingia, Dodilo was not even a subject of Odo, but of Arnulf and later on of Zwentibold.

217 No source mentions Otgar as Odo's supporter. In 900, however, he appears as a witness in one of Odo's brother Robert's private charters (Recueil Robert et Raoul, $N^{\circ} 42$ ), issued at a moment when the marchio was at conflict with Charles. See chapter III.2.2.1.

$218 \mathrm{Hi}$ qui cum Karolo erant, for example Annales Vedastini 894, 74. For further references see Offergeld, Reges pueri, 454.

219 Offergeld, Reges pueri, 454-455.

220 Scholars have made different attempts to explain their opposition, especially concerning Archbishop Fulk. Eckel, Charles, 9, portrayed Fulk as a defender of Carolingian legitimacy. Favre, Eudes, saw a claim of the church of Reims on the abbey of Saint-Martin of Tours as a reason for the archbishop's opposition (6), as well as his desire to unite all of the archdiocese's suffragans under the rule of one king, Arnulf (101-102). Offergeld, Reges pueri, 411-412, emphasises the rivalry between the church of Reims and the church of Sens. Schneider, Erzbischof, 54-55, does not see any plausible reason for the archbishop's opposition. It was suggested by Schneider, Erzbischof, 109-110, and emphasised by Schneidmüller, Tradition, 123, that the party supporting Charles was to a great extent dominated by members of the Carolingian family. In particular, they singled out the counts Heribert and Pippin, direct descendants of Bernard of Italy, as well as Bishop Teutbald of Langres. Within the group which we have distinguished as Charles' core supporters, this does not appear to 
Odo had become king, Saint-Bertin and Avenay, yet, as we have argued, had not made it into the king's inner circle. In Fulk's case, it is indeed most likely that his political ambitions were the root of his opposition to Odo. A new king could certainly offer more than Odo would ever be able to, be it in honores or, more importantly, influence on royal decision making. From the beginning, Odo's rule had not been based on general consent, but rather on his Neustrian possessions and connections, as well as some support from the likes of Theoderic of Vermandois and Archbishop Walter of Sens, who thereby increased their influence over the king. ${ }^{221}$ Only after his victory against the Normans and his recognition by Arnulf was Odo able to impose his rule over the whole of the realm. That Odo did his best to integrate former opponents, such as Fulk, shows that he was well aware of their importance for the stability of his realm. However, they would never have been able to assume a position equal to that of the king's first supporters. Charles, on the other hand, was just a boy on the brink of manhood and so far without any significant support. Backing him would have meant that Fulk and Heribert would be able to exert that very same influence that was denied to them under Odo. ${ }^{222}$

Yet, this focus on the assumed political ambitions falls short when it comes to explaining the motives of other members of the network. Anskeric and Count Heribert, for example, were powerful men in key positions and close to Odo, the former only recently having been promoted to archchancellor and the latter rapidly becoming one of the leading magnates in Francia. Others, like Heribert's brother Pippin, undoubtedly joined because of their personal connections to those in the inner core, while in the case of men like the counts Aledramnus and Ecfrid we simply do not know enough to make a proper judgement. There is Fulk's letter to Arnulf to take into consideration however. At two points Fulk makes remarks concerning Odo's behaviour. First, Anskeric, so Fulk claims, came to him asking for his advice concerning "insupportable" commands from the king. And second, that those who had approached him also asked him for advice about what to do concerning the "evil" Odo wanted to do to the sons of Gauzfrid. ${ }^{223}$ These remarks may of course only have been pretexts, yet it is worthwhile pursuing this thought further.

be an overly large proportion. The image only changes if we add, as Schneider and Schneidmüller do, Baldwin II of Flanders and his brother Rodulf, Reginar Longneck and the descendants of Ramnulf II of Poitiers to the group's allies. However, we will later show that these men cannot be so added. Following Offergeld, Reges pueri, 425, we might in addition add that most of the nobles of the region were in fact related to the Carolingians, so that the (supposed) high concentration of them in the group can hardly be surprising.

221 Guillot, Etapes, 210.

222 In this tenor Kienast, Vasallität, 467-468 and Offergeld, Reges pueri, 425.

223 Flodoard, HRE IV, c. 5, 381: Preterea, quod audierat huic regi suggestum, quia contra fidelitatem ipsius et propter privatum hoc egerit commodum, infert, quod Asclericus ipse, qui hec iactitasse videbatur, antequam de re huiuscemodi aliquid idem archiepiscopus agere conaretur, venerit ad se presentibus Heriberto et Ecfrido comitibus et consilium simulque auxilium quesierit, quid agere deberet de iussionibus Odonis, qui res importabiles ei precipiebat. Ex parte quoque filiorum Gosfridi consilium petierit de malo, quod eis Odo facere conabatur... 
During 892, the year leading up to the rebellion of Fulk and his allies, two conflicts broke out in different parts of the realm. In the Francia, on the death of Abbot Rodulf, Baldwin II of Flanders claimed his cousin's abbeys of Saint-Vaast and Saint-Bertin for himself. ${ }^{224}$ In the following months, not only did the monks of the former declare for the count, but Odo's own relative, Walker, whom he had entrusted with the castle of Laon, did so as well. Castle and city both fell soon enough and Walker was condemned to death by judgement of the nobles who were present. Odo refused to pardon him. In addition, and probably at the instigation of the king, Bishop Dido of Laon also withheld spiritual support from Walker during his last hours. ${ }^{225}$ The conflict with Baldwin continued nevertheless. Even deeper rifts in Odo's political order were caused by the succession of Ramnulf II at Poitiers. ${ }^{226}$ Ramnulf had an illegitimate son, Ebalus Manzer, who was well connected at court: his uncle, Ebolus, abbot of Saint-Denis, ${ }^{227}$ served as Odo's archchancellor, a fact which probably helped secure Odo's recognition of his succession. ${ }^{228}$ In early 892, however, Odo decided to grant Poitiers to Count Altmar, ${ }^{229}$ thus provoking the revolt of Abbot Ebolus and his brother Gauzbert, who took up their nephew's claim. Soon after, he revoked his earlier decision and installed his own brother Robert instead of Altmar at Poitiers, in turn leading to a revolt of the latter. By this point, the group of nobles surrounding Fulk of Reims had crowned the young Charles king, meaning that the rebellion would henceforth demand Odo's entire attention.

These different conflicts which broke out against Odo, in Francia as well as with Count Baldwin in Flanders and the Ramnulfids in Aquitaine, may have been to a great part independent of each other, but they may also have been a consequence of deeper problems with Odo's rule. The source of his legitimacy as ruler of the whole realm had been his ability to protect it against the Northmen. Yet, by 892 , the symbolic capital of the victories of the siege of Paris and the battle of Montfauçon had been used up by his inability to more than temporarily contain the Vikings or divert their incursions by paying them off. ${ }^{230}$ Furthermore, the conflict between Baldwin and Odo reveals a strong mistrust ${ }^{231}$ of the count towards the king. Baldwin refused Odo's initial proposal to come to terms peacefully while

224 Annales Vedastini 892, 71. On this conflict, see also chapter VI.2 and Lößlein, Ressources.

225 Annales Vedastini 892, 72; Regino, Chronicon 892, 139-140; Flodoard, HRE IV, c. 6, 392.

226 For a detailed study of the conflict, see chapter VI.2.

227 Ramnulf and Ebolus were brothers. Regino, Chronicon 892, 140: Post haec in Aquitaniam proficiscitur contra Ramnulfum et fratrem eius Gozbertum et Ebulonem abbatem de sancto Dionisio et alios nonnullos... Annales Vedastini 892, 73: At ubi fines attigit Aquitaniae, Ebulus, eius adventum praesciens, in fugam versus interfectus est iuxta quoddam castellum lapide; frater quoque eius Gozbertus post haec obsessus atque in brevi vitam finivit.

228 On Abbot Ebolus see Bautier, Recueil Eudes, Introduction, XXI-XXV.

229 Altmar supported Odo even before he became king. He appears as the first witness in a charter Odo issued for Saint-Martin in 887 (DOdo 55).

230 Annales Vedastini 889-891, 67-70. See also Favre, Eudes, 120-138 and Sassier, Hugues, 59 and chapter IV.2.

231 On the importance of trust, see chapter VI. 
later on, in 895, the king's determination to rebuild trust in him becomes visible when he returned Saint-Vaast to the count without concluding a peace treaty. ${ }^{232}$ This mistrust was probably rooted in Odo's actions as king. The conflict around the succession at Poitiers shows Odo acting against the interests of those close to him. ${ }^{233}$ In addition, also the king's decisions in the case of his own relative, Walker, whom he had entrusted with the castle of Laon but who had made peace with Baldwin, can be noted. Walker was sentenced to death, but then, according to the Annales Vedastini, the king did not pardon him. ${ }^{234}$ That the annals make note of this event reflects that, in this case, Odo did not act according to common expectations, but rather violated them. In this context, we can also safely assume that the denial of absolution to Walker by Bishop Dido of Laon was the king's doing as well.

Against this background, Anskeric's claim that the king had ordered him to do intolerable things, as reported in Fulk's letter to Arnulf, makes sense. Whether this had actually happened or not did not matter, nor did the actual content of these orders. Odo's own actions appear to have already created an atmosphere in which such accusations could easily be believed, as there were enough other examples of his intolerable behaviour to give them credibility. By the end of 892, Odo had not only lost his legitimacy as victor against the Normans, but may also have been deeply mistrusted by many important nobles. Next to the political ambitions of Fulk and some of his allies, this possible crisis of trust in the king may well serve as an answer to why so many nobles from Francia chose to oppose Odo.

\subsubsection{The cohesion of the network}

A brief account of the ups and downs of the rebellion will allow us to draw some conclusions about the strengths and weaknesses of the alliance which had formed around Charles. After Fulk and his allies had elevated Charles to the throne, they mobilised an army to march against Odo. The following encounter ended without any blood being shed after all parties withdrew. In autumn Odo managed to surprise Charles' group and force them out of the realm. Yet, in another surprising march, the allies returned to Francia in September and an armistice was concluded until Easter 894. ${ }^{235}$ The end of the armistice saw both sides gathering their forces, with Odo besieging Charles at Reims. Leaving the city garrisoned, Fulk and

232 For a detailed study of the conflict, see chapter VI.2, were we further elaborate on these thoughts.

233 See chapter VI.2.

234 Annales Vedastini 892, 72: Nam antea Walkerus eius consobrinus castrum Ludunensium, quod a rege perceperat, per tirannidem obtinuit, sed rex castellum obsedit ipsamque civitatem mox cepit. Et post paucos dies diiudicatus, sed rex non sibi praevidit, capite eum iussit truncari; contrary to the annals Regino (Chronicon 892, 139-140) reports that Walker was executed because he had drawn his sword against the king in a public assembly.

235 Annales Vedastini 893, 73-74. 
his allies took the young Carolingian and moved to meet Arnulf, who acknowledged him as king and sent Lotharingian troops to support him. Encountering Odo, however, the Lotharingians refrained from fighting him and returned home, forcing Charles to seek refuge with Richard the Justiciar in Burgundy, where he was pursued by Odo, although without success. Deprived of their supplies in Francia and now in conflict with Richard, Charles' allies then went to devastating the region. ${ }^{236}$

In 895, events took a new turn, as Arnulf succeeded in installing his son Zwentibold as king in Lotharingia. In return for the promise of a part of the Western realm, Zwentibold agreed to an alliance with Charles and joined forces with him to besiege Laon, forcing Odo to withdraw behind the Seine. The alliance between Charles and Zwentibold, however, soon became fragile and those who were with Charles sent to Odo to open negations: Charles should be granted a part of the realm, they themselves should receive the king's peace. Odo's subsequent return to Francia forced Zwentibold back to Lotharingia. The negotiations between Odo and Charles' supporters continued until Easter $896,{ }^{237}$ while Odo remained in control of almost the whole of Francia apart from Reims, leaving Charles' party short of supplies to get through the winter. Charles' allies now withdrew to the Moselle and warred against Baldwin of Flanders and his brother Rodulf. In 896, the negotiations finally came to an end and Odo was willing to agree to the terms proposed the year before, leaving Charles the part of the realm held by his supporters at that time. The decisive assembly, however, was disrupted by Count Rodulf, leading Heribert and Erkanger to abandon Charles and go over to Odo, soon, although reluctantly, followed by Fulk. Charles sought refuge in Lotharingia once more and aimed to create an alliance with a group of Northmen led by Hundeus when his remaining supporters reopened negotiations with Odo. This time, they succeeded: peace was restored, Charles was granted a part of the realm and "promised more"; in the context of the developments soon to come, this was undoubtedly the right to succeed Odo. ${ }^{238}$

Several observations can be drawn from this account: a) After the initial success of Charles' party, Odo's military superiority soon became evident. He managed to drive his opponents out of Francia and brought their strongholds under his control, thus depriving them of their bases of supply. b) Their own weakness evident, Charles' supporters sought out potential allies from the beginning-here we have seen Arnulf, Richard, Zwentibold and Hundeus' Northmen. We will turn

237 Annales Vedastini 895, 75-77.

238 Annales Vedastini 897, 78-79: ... Verum post haec hi qui cum Karolo erant, videntes suam paucitatem et nullum tutum habere locum refugii, iterum ad Odonem regem dirigunt, quatinus ad memoriam reduceret, quod senior eorum filius esset sui quondam senioris, et partem aliquam ei ex paterno regno concederet. At vero rex cum consilio suorum respondit se illi velle misereri, si sibi liceret; et intercurrentibus nuntiis venit Karolus ad eum; quem ille benigne suscepit, deditque ei tantum e regno, quantum sibi visum fuit, promisitque maiora et remisit eum ad locum suum... 
to them and others in detail further below. c) Several of these allies soon turned into enemies. d) Despite his superiority on the battlefield, Odo appears to have had a fundamental interest in re-establishing peace with Charles and his allies. e) Negotiations appear to have been complicated, starting in 895 and taking most of that and the following year. The initial proposition from Charles' allies appears to have been the basis for the final agreement: a partition of the realm and the reentering of those who had supported him into Odo's peace. f) Only one moment occurred when defections actually took place: after the failure of the negotiations in 896, when almost all of Francia had been lost to Odo and no more potential allies were on the horizon.

Given all this, the cohesion of the group around Charles appears remarkable. Only after three and a half years of war, after having lost their bases and without the prospect of other potential alliance partners, and at the same time embroiled in conflict with Baldwin and his brother, did members of the network go over to Odo. Despite the constant setbacks, Fulk and Charles' other supporters demonstrated a notable ability to seek out allies against Odo. While their own strength evidently would not suffice to prevail against the Robertian, in alliance with Zwentibold they succeeded in forcing Odo out of Francia. Even by itself, this sufficed to pose a constant threat to Odo and to divert him from other duties, such as defending the realm against the Northmen, as the Annales Vedastini remark. ${ }^{239}$ Thus Odo was as interested in coming to terms with the rebels as they were-the only question remaining was what price would have to be paid.

\section{I.2.5 Allies sought within the realm}

Charles' network of supporters was certainly stronger than that which had tried to elevate Wido of Spoleto and then Arnulf back in 888, yet it still was not in a position to guarantee success in imposing a new king. Other possible allies had to be sought out, within and beyond of the realm. The most obvious course was to look to those already in conflict with Odo-the Ramnulfids and Baldwin II of Flanders. In its entry describing late 892, the Annales Vedastini mention "others" who joined up with the prospective rebels around Fulk to convince Odo to leave Francia. ${ }^{240}$ The Ramnulfides have often been linked to the rebellion ${ }^{241}$ and it might indeed be that they are the "others" here, yet, as no other source indicates a con-

239 Annales Vedastini 896, 78: Ac per idem tempus iterum Nortmanni cum duce Hundeo nomine et quinque barchis iterum Sequanam ingressi; et dum rex ad alia intendit, magnum sibi et regno malum accrescere fecit.

240 Annales Vedastini 892, 72: Franci vero, qui dudum Odoni regi infesti fuerant, sociatis sibi aliis, ut possent compleri quae volebant, suaserunt regi, ut relicta Francia hiemandi gratia peteret Aquitaniam, ut Francia, quae tot annis afflicta erat, aliquatenus recuperare posset; et quia Ramnulfus obierat, et quia Ebulus et Gotbertus ab illo disciverant, eos aut sibi resociaret aut de regno suo pelleret aut vita privaret.

241 Schneider, Erzbischof, 110 and Schneidmüller, Tradition, 123. 
nection between the two groups, this must remain mere speculation. In any case, the Ramnulfid leaders Ebolus and his brother Gauzbert died soon after, ${ }^{242}$ thus ending the possibility of further cooperation.

Baldwin, on the other hand, had already been allied with Fulk in the succession of 888, when they and Abbot Rodulf, the count's cousin, ${ }^{243}$ had approached Arnulf to take the West Frankish crown. ${ }^{244}$ After the death of Rodulf in 892, Baldwin, against Odo's will, claimed his cousin's abbeys, Saint-Vaast and Saint-Bertin, for himself. ${ }^{245}$ Fulk quickly became involved in the ensuing conflict. He and his suffragans threatened all those who communicated with the count with anathema ${ }^{246}$ and sent another letter to Baldwin himself in which they reproached him for his misdemeanours and asked him to repent, threatening him with excommunication if he did not comply. ${ }^{247}$ However, although Baldwin still offered resistance to Odo at the end of 892, in another letter composed at a synod at Reims the bishops seemed to be much more obliging. The count was informed that he had indeed been excommunicated for his deeds, but that this excommunication had been suspended for the time being, due to possible advantages for state and church. ${ }^{248}$ The conclusion that Fulk wanted to spare Baldwin in order to leave open the possibility for him to join the ranks of the conspiracy against Odo comes to $\operatorname{mind}^{249}$ and indeed the count and his brother are found at Charles' side in $895 .{ }^{250}$ Yet nothing indicates when they had actually allied themselves with the group around the Carolingian. The siege of Laon, however, certainly saw the end of their cooperation. Baldwin and his brother Rodulf went over to Zwentibold and fought Odo on their own when Charles' allies started negotiations with the Robertian. ${ }^{251}$ Over the winter of 895/896, when Charles and Odo had agreed upon an armistice, fighting ensued between Charles and Baldwin, ${ }^{252}$ indicating that the rift between the two groups had become serious.

In 896 Rodulf also appeared at an assembly which concluded long lasting negotiations between Charles' supporters and Odo. Odo had finally agreed to leave

242 Annales Vedastini 892, 73.

243 On their parentage see Favre, Famille, 160.

244 Annales Vedastini 888, 65.

245 Annales Vedastini 892, 70-71.

246 Flodoard, HRE IV, c. 6, 391.

247 Flodoard, HRE IV, c. 7, 396-397.

248 Flodoard, HRE IV, c. 7, 397: Item ad eundem cum coepiscopis suis scribens ex synodo Remis habita dominice incarnationis anno DCCCXCII. [...] Unde communi decreto episcoporum iudicatum fuerat eum auctoritatis canonice anathemate feriendum, sed quoniam et ecclesie et publicis regni utilitatibus videbatur accommodus, censura suspenditur adhuc animadversionis ecclesiastice recogitandique sibi et emendandi spatium reservatur et obsecratur per misericordiam dei, ut ab hac praesumptione animum revocet nec amplius iram dei contra se provocet, ne illi quodammodo gladium praebeat, et cetera.

249 Schneider, Erzbischof, 104 and Schröder, Synoden, 119.

250 Annales Vedastini 895, 76. When exactly they joined Charles' side cannot be established from the sources.

251 Annales Vedastini 895, 76.

252 Annales Vedastini 896, 77. 
Charles the part of the realm his followers had owned before the war, when Rodulf disrupted the assembly and caused the whole agreement to fail. ${ }^{253}$ The question arises: why did the intervention of Rodulf, who belonged neither to Charles' side nor Odo's, have such dire consequences? The only possible explanation is that the negotiations sought not only a solution for the conflict between Odo and Charles, but a general peace including Baldwin and his brother. This meant that an arrangement satisfying all three parties had to be found. When Rodulf derailed the negotiations, we can conclude that a decision was close to being made that would have been to his disadvantage. It seems safe to assume that, during their conflict with Charles' supporters, Baldwin and Rodulf had taken over honores belonging to or claimed by Charles' followers. This was definitely true for honores belonging to Odo's allies in the region: Saint-Quentin, now occupied by Rodulf, had been in the possession of the son of Count Theoderic, one of Odo's most loyal followers. A general peace would have meant that some or all of these honores would have had to be returned to their original owners-something that Rodulf would not agree to. The problem was solved over the following winter when Baldwin's brother was killed in battle with Heribert. ${ }^{254}$ In 897, the different parties, including Baldwin, came to agreements similar to those of the year before and peace was finally restored. However, the underlying conflicts, Baldwin's desire to extend his influence in the North and his enmity with Heribert continued. 255

When trying to determine Baldwin's and his brother's position concerning Charles, the central point is not their timing for joining the Carolingian's side, but that they had already been in conflict with Odo before the start of the rebellion. Their behaviour during these years does not point towards a fundamental opposition to Odo per se, but their aim to extend their influence in the north-east of Francia. The contentious point between Baldwin and Odo was the abbey of SaintVaast, which Baldwin had claimed for himself after his cousin Rodulf's death. ${ }^{256}$ Furthermore, Rodulf had used the confusion in Francia to acquire Saint-Quentin, something that Odo could not tolerate either, since the abbey had been in the hands of the son of one of his closest supporters. Both Baldwin and Rodulf appear as independent actors in the political arena of Francia, their support for Charles

253 Annales Vedastini 896, 77: Odo rex placitum cum suis fidelibus habuit, volens partem regni, quam eius fideles tenuerant, Karolo concedere. Sed Rodulfus comes omne illud placitum disrupit; unde Heribertus et Herkengerus, omnibus iam perditis, contulerunt se ad regem Odonem, paucique relicti sunt cum Karolo. Did Rodulf participate in the assembly or disrupt the proceedings from the outside? The former seems to be the case: if the negotiations had only been interrupted by an attack by Baldwin's brother, then why were they not renewed shortly after, especially since Odo seems to have been close to agreeing to terms acceptable to Charles' supporters? Instead, many of them now changed sides, which leads us to conclude that they had lost all hope that, after the failure caused by Rodulf, a solution could be found.

254 Annales Vedastini 896, 78.

255 Annales Vedastini 897, 78-79. In 898, Baldwin, due to Heribert's presence at Charles' side, only sent a legate to the Carolingian's coronation (Annales Vedastini 898, 79). In 899 Baldwin attacked Péronne against Charles' explicit will (Annales Vedastini 899, 81).

256 For this conflict, see chapter VI.2. 
not aimed at disposing Odo but at increasing the pressure on the king to come to terms with them.

The character of Baldwin's support for Charles brings us to another group of nobles whose position has been the object of scholarly discussion ever since the publication of an article by Jean-Pierre Brunterc'h. ${ }^{257}$ Following Charles' coronation, the Annales Vedastini report that:

\begin{abstract}
After Easter Archbishop Fulk and Count Heribert took King Charles and set out with all the army they could muster against King Odo. Richard, William and Altmar came against them with a considerable army. Against whom King Odo did not hesitate to come. And he sent [messengers] to those who were with Charles, ordering that by his guarantee they should make amends for whatever wrong they had done them and remember the oaths they had sworn to him. ${ }^{258}$
\end{abstract}

Until Brunterc'h's article, it had been assumed that Richard (the Justiciar), William (the Pious) and Altmar (of Poitiers) came to support Charles and oppose Odo, ${ }^{259}$ a reading that would be supported by the circumstance that both William and Altmar had been involved in the conflict ensuing around the succession of Ramnulf II at Poitiers in 892. ${ }^{260}$ However, Brunterc' $h$ argues that, in fact, the three magnates were allies of the king, having joined him in April or May 893 at the latest. ${ }^{261} \mathrm{He}$ translates this passage of the annals as " $\mathrm{A}$ l'encontre de ces derniers (= Richard-Guillaume-Adémar), le roi Eudes vint sans tarder et dépêcha ses représentants à ceux qui étaient avec Charles, leur enjoignant de réparer par son gage tout ce qu'ils avaient commis contre eux (= Richard-Guillaume-Adémar) et de se souvenir du serment qu'ils lui avaient prêté." Odo, therefore, assumes the role of a mediator, offering his guarantee to Richard, William and Altmar for deeds done by Fulk and his allies. ${ }^{262}$ Brunterc' $h$ further links the three magnates' alliance with Odo to a number of measures taken by the king: Richard was given the abbey of Saint-Germain of Auxerre, most probably in 893 or $894,{ }^{263}$ while William received the abbey of Saint-Julien of Brioude by March 894 at the

258 Annales Vedastini 893, 73-74: Post Pascha Domini Fulcho archiepiscopus et Heribertus comes assumentes Karolum regem cum omni exercitu disponunt [ire] contra Odonem regem, veneruntque contra eos Richardus, Willelmus et Hadamarus, habueruntque exercitum copiosum. Contra quos rex Odo venire non distulit. Misitque ad eos qui cum Karolo erant mandans ut quicquid in eis deliquissent per suum eis vadium emendarent et memores essent sacramenti quae sibi iuraverant.

259 For example Eckel, Charles, 11, Chaume, Origines, 376, Kienast, Vasallität, 471. This reading was supported by Altmar and William being in conflict with Odo during 892. See below.

260 See chapter VI.2.

261 Brunterc'h, Naissance, 81.

262 Brunterc'h, Naissance, 107, n. 121.

263 Sassier, Recherches, 7. 
latest. ${ }^{264}$ Finally, Bishop Adalgarius of Autun became Odo's new archchancellor before 28th May $893 .^{265}$

While this reading of the events has subsequently been accepted by scholars, ${ }^{266}$ Steven Robbie has recently brought up a new argument, challenging Brunterc' h's view that Adalgarius had been a close supporter of Richard. ${ }^{267}$ According to him, in light of their previous behaviour, both were "more likely at loggerheads tha[n] natural collaborators." ${ }^{268}$ He proposes an alternative reading: Richard, William and Altmar indeed came up in support of Charles and Odo successfully made haste to dissuade them. ${ }^{269}$ Robbie's analysis can be used as a starting point for further thoughts: while Brunterc' h's reading does agree with the syntax, he may be overly precise with his translation-the Annales Vedastini are known to contain grievous grammatical errors. ${ }^{270}$ It is hard to imagine what wrongs Fulk's party had done to the three magnates that would require compensation and royal mediation; at the same time William and Altmar (and possibly Richard as well) were in conflict with Odo himself. ${ }^{271}$ In addition, why should the annalist emphasise that Odo did not hesitate to march against them, when he already had the support of these powerful men? Finally, while it is certain that Saint-Germain of Auxerre and Saint-Julien of Brioude came under the control of Richard and William respectively, these acquisitions cannot be dated precisely enough to determine whether Odo had already granted them before Easter 893. That these grants were related to these events is indeed possible; however, another explanation seems more plausible, especially considering that over the next few years neither William nor Altmar appear again in the struggle between Charles and Odo, while Richard subsequently behaved like "a loose cannon," as Steven Robbie put it. ${ }^{272}$ Richard, William and Altmar were not Odo's allies at that particular moment, but nothing indicates that they supported Charles. In fact, Fulk asked Bishop Teutbald of Langres to inquire into the attitude of Richard and the Aquitanians. ${ }^{273}$ If they had been allied, this would not have been necessary. It seems therefore most likely that they marched up north with an army as a third party, one that would offer itself to the highest bidder. Odo

266 Guillot and Sassier, Pouvoirs I, 162-165 and Koziol, Politics, 228.

267 Brunterc'h, Naissance, 82.

268 Robbie, Emergence, 46.

269 Robbie, Emergence, 46.

270 Rau, Quellen II, 6.

271 See above. Indeed, it seems much more likely that Odo sent his envoys to Fulk and his allies demanding them to compensate him for their wrongdoings towards him and asking for guaranties against further misbehaviour.

272 Robbie, Emergence, 47.

273 Flodoard, HRE IV, c. 6, 395. 
then won the race by granting these magnates important abbeys, buying not their support, but their neutrality. ${ }^{274}$

Neither William, Altmar nor Richard can therefore be linked to Charles and his supporters at the beginning of the rebellion. At least two of them, William and Altmar, had already been in conflict with Odo and none of them appears to have fundamentally opposed his rule. Like Baldwin and his brother Rodulf, they used the chaos in Francia to enforce their claims. Faced with the rebellion of Fulk and his allies, Odo needed to pacify this conflict; it did not challenge his rule as such, but prevented him from concentrating his forces in Francia. While Altmar soon returned to Odo's side, the image is less clear for William. ${ }^{275}$ A charter from SaintJulien of Brioude dates to "the fifth year of the reign of King Charles," ${ }^{\text {"276 }}$ corresponding to 897 and therefore the year of the final agreement between Charles and Odo. ${ }^{277}$ Unfortunately, the charter, while naming William as lay abbot, does not indicate whether he was present at that moment or had had a hand in the proceedings in any other way. We might therefore suggest, although with great care, that in 897 William was in contact with Charles and thus increased the pressure on Odo.

Richard, despite the agreement with Odo, became repeatedly involved in the conflict. In 894, Charles and his allies were forced to leave Francia and seek shelter with Richard in Burgundy. Odo followed them, but failed to secure a victory in battle. It was undoubtedly during this campaign that he stayed at Flavigny, issuing a diploma for the abbey of Montiéramey. ${ }^{278}$ This was not only an attempt to prevent Charles' supporters from establishing a new base in northern Burgundy, where Adelaide's family had connections. ${ }^{279}$ It also affirmed Odo's control of the Troyes region, where Montiéramey, as well as the donated goods, were located. Furthermore, the intervention of Count Hucbald in the diploma was a symbol of Odo's own ties to and control over Francia, the heartland of Charles' supporters. Finally, his stay at Flavigny might also be taken as a gesture against Richard, who, after the death of Bishop Adalgarius of Autun, Odo's archchancellor, had installed

274 This conclusion is also supported by a charter issued by Abbess Ava, sister of William, in which the villa of Cluny is exchanged for an allod in Einville. Its date reads anno primo certantibus duobus regibus de regno Odono vidilicet et Karolo (Originaux Cluny, No 2, 26-29). The charter was issued on 9th November 893 (the certantibus-fighting, struggling-argues against a date of 897, which has also been put forward: the two kings are unlikely to have been fighting after the settlement of 897) - several months after William and the others are supposed to have allied themselves with Odo. Yet, at that moment, the count recognised both the Robertian and the Carolingian as kings. Since this charter was issued before William's first charter for Saint-Julien of Brioude (see chapter I.2.5, n. 264), we might even suggest that the settlement with Odo had not been fully implemented by November 893 , leading to the discontent of the count.

275 See also chapter VI.2.

276 Grand Cartulaire, $\mathrm{N}^{\circ}$ CCCXXXVII, 96: anno V regnante Karolo rege.

277 Kienast, Vasallität, 466, n. 1654, taking in conseridation the terms of office of Provost Eldefredus and Deacon Bernardus, both named in the charter.

278 DOdo 38. On the date see also the comment of Bautier, Recueil Eudes, 160-161.

279 Werner, Nachkommen, 432. Adelheid's brother Wulfard had been abbot of Flavigny. See also above. 
Walo, brother of his right hand man Manasses, in this see, although the community had elected Aquinus, the provost of Flavigny. ${ }^{280}$

Whether Charles' party had originally intended to move as far south as Richard's lands remains an open question, but, without a doubt, Odo's campaign did not leave them much of a choice. Even if Richard actually agreed to an alliance with Charles' party, it did not hold for long. By the end of 894, Manasses had attacked Bishop Teutbald of Langres, who had opposed the installation of Walo at Autun, and blinded him. ${ }^{281}$ Since Teutbald had been close to Fulk both sides entered into conflict. ${ }^{282}$ Odo, at this point if not earlier, had changed his strategy from trying to overwhelm his opponents by force to depriving them of their bases of supply, taking their possessions in Francia. ${ }^{283}$ The situation of Charles' supporters turned desperate. Without supplies from Richard they were now forced to live off the land, leading to a wave of violence and devastation, emphasised by all contemporary witnesses. ${ }^{284}$

This did not mean the end of contact between Charles and Richard. In the winter of 895/6, a meeting in southern Lotharingia took place at Remiremont. ${ }^{285}$ Emperor Lambert and King Rudolf signed next to Charles, yet also present were Manasses and Rampo. Manasses was the right hand man of Richard the Justiciar and Rampo was involved in the blinding of Bishop Teutbald of Langres. In this affair, Fulk had not only tried to protect his relative Rampo, but had also done his best to delay the excommunication of Richard and Manasses demanded by the pope. ${ }^{286}$ Whether Charles gained any actual support during this time is not apparent from the sources, but he remained in contact with Richard. In late 896, Richard and Charles were still negotiating, as is signalled by the presence of the count of

280 Hlawitschka, Lotharingien, 134. Futhermore, it is possible that at the time Troyes was already in the hands of Richard, thus strengthening this assumption. The first indication that the count was in control of the city, however, only stems from December 896, when he dispensed justice in favour of abbot Berthard of Montiéramey at the placitum of Courtenois (21st December 896; Cartulaire Montiéramey, $\mathrm{N}^{\circ} 12,18$ ). See also Crété-Protin, Église, 307-308, who misdates the event to January.

281 Annales Vedastini 894, 75. See also Hlawitschka, Lotharingien, 134-135.

282 Pope Formosus, upon being confronted with Richard's crimes not only against Teutbald, but also against archbishop Walter of Sens, excommunicated Richard, Manasses and Rampo and demanded the bishops do the same (Flodoard, HRE IV, c. 3, 377). Fulk did not question the decision to excommunicate the first two, but defended the innocence of his relative Rampo (Flodoard, HRE IV, c. 3, 376-377).

283 Annales Vedastini 895, 75.

284 Annales Vedastini 895, 75: Burgundiam acriter depopulati sunt. Regino, Chronicon 893, 141: Et sic alternatem ex utraque parte multi pereunt, ingens malicia, innumerabiles rapinae et assiduae predae fiunt. Flodoard, HRE IV, c. 53, 455-456: Tempore, quo inter reges Odonem et Karolum graves agebantur Francorum in regno discordie, per hanc accasionem licito rapine et depredations fiebant, confusum erat fasque nefas, nusquam Deu aut humanarum timor legume, sed vi et potential universa constabant.

285 Liber Memorialis Remiremont, 21, fol. 11v. Karolus rex iuuenis, Lanbertus imperator, Rodulfus rex, Rampo, Vuitbertus, Rotrudis, Adeldrudis, Siifridus, Gotdofridus, Manases, Eldigarius ep., Folco ep., Uuilerius, Lehutaldus. For the dating and identifications, see Hlawitschka, Lotharingien, 147-152. On the motivation of Rudolf, king of Upper Burgundy, see Demotz, Bourgogne, 96-97.

286 See chapter I.2.5, n. 282. 
the palace Elduin at Richard's court. ${ }^{287}$ Since the charter is dated by Charles' reign, we can conclude that Richard did not favour Odo at that moment. ${ }^{288}$ Once peace in Francia was restored, Richard also re-entered the king's favour. A diploma dating to October 897 shows him at Odo's court, honouring him as "Richard, our illustrious and beloved count." ${ }^{\text {289 }}$

To summarise, we should note that, inside the realm, two leading nobles appear to have allied themselves with Charles' supporters: Baldwin of Flanders, together with his brother Rodulf; and Richard the Justiciar. Neither alliance lasted for long and at least for some time the rebels ended up in open conflict with both parties. This points towards the general character of these coalitions. They came into being because both sides hoped to profit from each other in their individual struggles against Odo. That they proved to be only short lived and were superseded by hostilities was the result of the fundamental differences in the nature of their opposition to the king. Neither Baldwin nor Richard aimed at replacing Odo with another king. Both fought to extend their influence. In the end, under which king they would achieve this did not matter. This freed their own policies from the restrictions the members of the network' suffered from. They could change sides whenever they deemed it profitable. Fulk and the others had to remain with Charles or abandon everything they fought for.

\section{I.2.6 Allies sought outside the realm}

Those who were with Charles not only sought allies from within the realm, they also looked for supporters from outside. Such support could come from the kings of Eastern Francia, Lotharingia (once it had become independent under Zwentibold), Italy, Upper Burgundy, Provence and the pope. By the end of 896, Fulk had turned to almost all of them, and in some cases more than once. The first choice was Arnulf, whose superiority had already been acknowledged by Odo in 888. Fulk's letter to him was not only meant to soothe Arnulf's anger over the coronation and to prevent him from intervening in Western Francia. It was also aimed at winning his trust and getting him to renounce his support for Odo while recognising Charles, and, finally, obtaining material support. That this also meant accepting Arnulf's superiority did not really matter at that moment, as long as

287 Cartulaire Montiéramey, $\mathrm{N}^{\circ} 12,18$ (21st December 896).

288 One could add to this a charter from Saint-Julien of Brioude (Grand Cartulaire, $\mathrm{N}^{\circ}$ CCCXXXVII, 96), where William the Pious was lay abbot and which dates anno V regnante Karolo rege (corresponding with 897 taking in conseridation the terms of office of Provost Eldefred and Deacon Bernard, both named in the charter; Kienast, Vasallität, 466, n. 1654). The charter names William as lay abbot, but does not otherwise indicate whether he was present at that moment or had had a hand in the proceedings in any other manner. We may therefore assume, although only with great care, that also William was in contact with Charles or putting pressure on Odo at that moment.

289 DOdo 42 (21st October 897, Nanteuil-le-Haudouin), 180: Richardus, illustris dilectusque nobis comes. Richard asked for goods in Atuyer to be granted to a certain Gislebert. 
Arnulf confirmed Charles as the legitimate king and thus demonstrated that his claim was just. In 893, Fulk's efforts to win Arnulf for Charles' cause proved futile, yet a year later the king finally changed his position and agreed to meet Charles at an assembly at Worms ${ }^{290}$ Fulk and his allies brought rich gifts and Charles was benignly received. The Carolingian made a promissio of which nothing further is known, whereupon Arnulf granted him the kingdom of his father and even provided military assistance. ${ }^{291}$

Arnulf's motivation to change his course so completely has been the subject of ample discussion. ${ }^{292}$ Most convincing so far is the pragmatic view of Arnulf's situation offered by Thilo Offergeld. According to his argument, Odo's position had been strengthened by his recent successes against Charles. In contrast, the latter would have been, as his promissio shows, open to a more complete submission under Arnulf's supremacy. Furthermore, it would have been in Arnulf's interest to keep the conflict between the two rivals going, not least to secure the Lotharingian frontier. To shift his support to the weaker party would therefore have been a reasonable decision. ${ }^{293}$ However, a few additions can be made to this reading. Odo's position should not be overestimated. He had succeeded in appeasing Aquitaine and prevented Richard the Justiciar from joining his enemies' ranks, but he had failed in crushing the rebellion in Francia, as well as in solving the ongoing conflict with Baldwin II of Flanders. The peace talks at Reims might have brought these conflicts to an end, which would have left Odo his full strength to pursue whatever other goals he might have had at that moment. This outcome had the potential to pose a threat to Arnulf himself, who had only recently returned from Italy without achieving anything decisive. Even worse, on his march back home he had also failed to suppress King Rudolf of Upper Burgundy and almost led his army into disaster while crossing the Alps ${ }^{294}$ How weak his position actually was at that moment is revealed by his subsequent failure to gain the consent of the Lotharingian nobles to the installation of his son Zwentibold as their king at a

290 Nothing is known of any preliminary talks between Charles' allies and Arnulf. Nevertheless it seems likely that talks of this sort took place before the actual meeting (Schneider, Erzbischof, 134).

291 Annales Vedastini 894, 74; Regino, Chronicon 893, 141. The promissio is only mentioned by Flodoard, HRE IV, c. 5, 383.

292 On this subject, see Offergeld, Reges pueri, 433-435. One interesting aspect to note: as Hlawitschka, Lotharingien, 129, remarks, the Annales Vedastini and the Annales Fuldenses (Ratisbon continuation, 125) stress the kinship between Arnulf and Charles, as does Fulk's letter to Arnulf. Based on this fact, Hlawitschka argues that this issue played a crucial role in Arnulf's decision to support Charles, a reading that has been criticised by Schneider, Erzbischof, 137 and Offergeld, Reges pueri, 433-434. The emphasis of the annals on their kinship should not be read as a reflection of Arnulf's actual reasoning, but as a reflection of the official argumentation presented at Worms to justify the king's decision.

293 Offergeld, Reges pueri, 435.

294 Annales Fuldenses (Ratisbon continuation) 894, 124. Regino's report about the campaign (Chronicon 894, 142) is much more positive. Arnulf's campaign in Rudolf's Burgundy does not seem to have inflicted grave destruction on the region. See Demotz, Bourgogne, 95-96. 
meeting at Worms. ${ }^{295}$ Fulk's offer, that Arnulf acknowledge and support Charles in return for Charles' acceptance of his supremacy, would not only have prolonged the conflict in the West and secured the Lotharingian border from any possible threats, but would also have served to demonstrate Arnulf's superiority to his own nobles, thereby strengthening his rule after a series of failures. Turning to Charles, therefore, was a pragmatic course of action not chiefly because of Odo's strength, but because of Arnulf's own problems.

The military support provided by Arnulf appears to have been composed of the levies of some Lotharingian bishops and counts from the Meuse area. ${ }^{296}$ Once this host encountered Odo, however, the Lotharingians decided to keep their amicitia with the Robertian and refused to confront him. ${ }^{297}$ The leading members of Charles' party seem to have been well aware of this problem and did their best to keep the Lotharingians on Charles' side. A diploma of Charles issued at Attigny, ${ }^{298}$ an important royal palace on the Aisne, is a sign of their endeavours. At the request of Charles' mother Adelaide and Archbishop Fulk, Charles restored parts of the fisc of Arches in Porcien to Bishop Franco of Liège. It has long been assumed that this was done because Franco had been part of the Lotharingian forces which supported Charles, ${ }^{299}$ but the actual reasons run deeper. In fact, as a diploma of Charles the Fat shows, ${ }^{300}$ Franco had been close to Odo's brother Robert. This new diploma, therefore, was issued to demonstrate to those other Lotharingians who had ties with the Robertians, that at least Franco would not leave Charles' side in the upcoming confrontation. Furthermore, it was a sign that the kind of fidelity shown by the bishop would be rewarded not only materially, but also with honour, as demonstrated by the intervention of Adelaide. ${ }^{301}$ As we have seen, this did not prove entirely successful. Confronted with Odo's army, the Lotharingians refused to fight for Charles. However, they did not abandon Charles right away either. From the account of the Annales Vedastini, it seems that they treated with Odo. Before they left to return home, they secured Odo's departure as well, thus depriving him of the opportunity to crush the rebellion at that moment.

Arnulf's next intervention in West Frankish affairs took place in the following year, when he responded to the devastation in Burgundy caused by the war by

295 Regino, Chronicon 894, 142. The Annales Fuldenses do not note this event.

296 Offergeld, Reges pueri, 435.

297 Annales Vedastini 894, 74-75; Regino, Chronicon 893, 141.

298 DChS 5, 26th September 894.

299 E.g. Kienast, Vasallität, 474.

300 DChF 105, dated to 884. In this diploma, Franco and Robert both ask the Emperor to grant a manse to Robert's fidelis Sanctio. The identification of this count with Odo's brother has been made by Wollasch, Gerard, 63, unfortunately without giving any further arguments. However, later on the only interventions made by Robert in Lotharingia during the reign of Charles the Simple are both connected to the church of Liège (DDChS 65 and 81), so that an earlier relation between Robert and the church-as demonstrated by DChF 105-seems very likely.

On the role of Adelaide's interventions, see chapter III.2.2. 
inviting both Odo and Charles to meet him. ${ }^{302}$ As in the previous year, his intervention may partly have been motivated by internal affairs. After his failure to install his son Zwentibold as king of Lotharingia, he now planned a second attempt. Having one or even both of the West Frankish kings acknowledging his superiority would aid his cause and their presence at Zwentibold's coronation would also help to secure his son's new position. While Odo responded, coming with rich gifts, Fulk's party decided not to accept the invitation. ${ }^{303}$ Instead, the archbishop sent a letter to assure Arnulf of the validity of the promissio, given by Charles the year before, and announced the preparation of an attack on Odo. ${ }^{304}$ In consequence, Odo was received with all honours by Arnulf, returning home after the coronation of Zwentibold. On his way back, he encountered Fulk, who was finally on his way to Arnulf with further gifts. Fulk escaped but Count Adalung, who had accompanied him, was killed and the baggage lost. ${ }^{305}$ Why had Fulk's party not responded to Arnulf's invitation earlier? It has been proposed that they refrained from doing so since the atrocities committed in Burgundy, which were the reason for Arnulf's call to Odo and Charles, had been their doing. ${ }^{306}$ This may have been the case, but it is also possible that after the visit to Worms the year before, it had not seemed likely that Charles was in danger of losing Arnulf's acknowledgment of his kingship. Only when the news spread that Odo had accepted the invitation and had been received amiably did it became apparent that a letter would not suffice and therefore Fulk hastened to Worms to limit the damage already done.

If Odo had hoped to deprive Charles of support from the East by his presence at Worms, he failed. Zwentibold, newly installed on the Lotharingian throne, did not hesitate to seize the opportunity when Charles' supporters offered him parts of the Western kingdom and allied himself with Charles. ${ }^{307}$ Together they launched an attack on Laon to which Odo was incapable of responding. His forces exhausted, he withdrew over the Seine, leaving the defence of Laon to Bishop Dido. ${ }^{308}$ Without pressure from Odo, however, the alliance between Charles' party, which by this point had been reinforced by Count Baldwin and his brother Rodulf, and Zwentibold did not hold. The count of Flanders went over to Arnulf's son, and subsequent rumours of a plot to assassinate Charles then led to a final break. Zwentibold left the camp and later concluded a separate peace treaty with Odo. ${ }^{309}$ The events at Laon, however, do not seem to have caused lasting damage to the

302 Annales Vedastini 895, 75.

303 Annales Vedastini 895, 75; Regino, Chronicon 895, 143.

304 Flodoard, HRE IV, c. 3, 383.

305 Annales Vedastini 895, 75-76; Regino, Chronicon 895, 143.

306 Hlawitschka, Lotharingien, 136. For other speculations see Favre, Eudes, 173 and Eckel, Charles, 17.

307 Annales Vedastini 895, 76; Regino, Chronicon 895, 143.

308 Annales Vedastini 895, 76.

309 This can be established from Zwentibold's restitution of the abbey of Salone to Saint-Denis in January 896 (DZ 7). 
relations between Charles and Zwentibold. When in 896 Charles was forced to flee from Western Francia, he sought refuge in Lotharingia. ${ }^{310}$

Besides Arnulf and Zwentibold, Fulk also turned to Wido of Spoleto. His relative, whom he had invited in 888 to take over the realm only to abandon him shortly after, had briefly been considered as an alternative candidate to Charles yet again. ${ }^{311}$ This option seems to have been dismissed quite quickly, probably because five years earlier Wido had proven that he was not able to bring together sufficient support on his own and was unlikely to be acknowledged as king by a majority of the leading nobles. ${ }^{312}$ Charles, on the other hand, even if he could not provide any resources on his own, had Carolingian blood which could serve to legitimise the rebellion and was more likely to serve as a rallying point for other nobles than Wido. Instead, Fulk wrote a new letter to Wido, congratulating him on having been crowned emperor (two years earlier) and asking him to protect and support Charles. ${ }^{313}$ Furthermore, he warned him of Arnulf preparing a campaign against him. ${ }^{314}$ This was undoubtedly meant as a sign of Fulk's good will, aimed to make Wido ready for an alliance. Whether this endeavour was crowned with success we do not know, since the sources do not mention a response on Wido's part. In any case, given his warning that Arnulf would soon invade Italy, it seems debatable whether the archbishop actually expected the emperor to intervene in Western Francia. ${ }^{315}$ It appears more likely that Fulk's true purpose was to gain Wido's acknowledgement of Charles and to demonstrate that Charles kingship was legitimate.

It is likely that, in late 895 , when the negotiations with Odo entered their final stage, Fulk renewed his diplomatic efforts to win royal support for Charles. The young king met with Wido's son, Emperor Lambert, and King Rudolf of Upper Burgundy at Remiremont. ${ }^{316}$ For most of the year, Lambert had been targeted by the archbishop as a potential ally ${ }^{317}$ and the meeting at Remiremont was undoubtedly the result of these endeavours. Lambert himself probably hoped to win military support against Arnulf ${ }^{318}$ and the same was likely also true for Rudolf, who himself was on the defensive against Zwentibold in the north and the kingdom of Boso's son Louis in the south. ${ }^{319}$ The Remiremont meeting demonstrates the

310 Annales Vedastini 896, 78.

311 Flodoard, HRE IV, c. 5, 381-382.

312 It is not clear from Fulk's letter who brought up the idea of inviting Wido for a second time. Fulk's contact with Wido appears to have ceased after 888. Hlawitschka, Lotharingien, 121 with n. 31.

313 Flodoard, HRE IV, c. 5, 383-384.

314 Flodoard, HRE IV, c. 5, 384.

315 Already Kienast, Vasallität, 473, posed the question of what Fulk actually expected to gain from Wido.

316 Liber Memorialis Remiremont, 21, fol. 11v. For the dating and identifications, see Hlawitschka, Lotharingien, 147-152.

317 See below, Fulk's letter to Pope Formosus, in which the archbishop asked for Formosus' help in gaining Lambert's friendship for Charles.

318 Hlawitschka, Lotharingien, 152-155.

319 Demotz, Bourgogne, 96-97. 
range of Fulk's connections, but at the same time it also betrays that the only allies Charles could find at that moment were as much in need of help as he himself was. As Eduard Hlawitschka remarked:

Daß die [...] bedrängten Herrscher [...] sich bei ihrem Treffen mitsamt ihrem Gefolge in das Gedenkbuch in Remiremont einschreiben ließen, kann nicht verwundern. Erwartete man doch von dem mit der Einschreibung verbundenen Gebetsgedenken nicht nur zukünftiges Heil, sondern Gottes Hilfe in der Gegenwart. Und diese war ihnen bitter not. ${ }^{320}$

Pope Formosus was also deeply involved in Fulk's endeavours to win support for Charles' cause. He appears to have been the only one to quickly recognise Charles as king, congratulating him on his elevation, granting him the panem benedictum and giving him some counsel ${ }^{321}$ while at the same time trying to mediate a peaceful solution with Odo. Formosus proposed that both parties agree to a ceasefire, with Fulk travelling to Rome and the Gallic bishops working towards re-establishing peace. ${ }^{322}$ Fulk's plans were different: he asked the pope to win Arnulf's support for Charles and to threaten Odo not to devastate the realm, ${ }^{323}$ without success. Arnulf seized the possessions of the church of Reims while Odo continued his efforts of suppressing the revolt. ${ }^{324}$ Fulk, nevertheless, redoubled his efforts of increasing diplomatic pressure on Odo after the negotiations for an agreement had begun. In another letter to Formosus he asked him again to write to Odo as well as all the nobles to urge them to keep the peace and acknowledge Charles' hereditary right or at least give him a part of the realm. ${ }^{325}$ As he had done in the cases of Arnulf and Odo, the archbishop also tried to use Formosus as a mediator between Charles, Wido and, after Wido's death, Lambert. ${ }^{326}$ At least in Lambert's case, the pope appears to have indeed spoken for Charles and probably contributed to the realisation of the alliance. Formosus' death, however, brought an end to Fulk's influence in Rome. From the beginning, his successor Stephen VI, who exhumed Formosus to accuse him of perjury, reproached the archbishop for not coming to Rome and threatened him with the penalties of canon law if he chose not to be present at a synod later in $896 .^{327}$

320 Hlawitschka, Lotharingien, 153.

321 Flodoard, HRE IV, c. 3, 374: Item huic quoque regi Karolo congruam dirigens admonitionem eiusque congratulans eminentie atque devotioni, quam rex idem se significaverat erga sedem apostolicam gerere, qualiter ei sit in regno agendum, succincte lucideque demonstrat. Quem petierat ei panem benedictum pro pignere mittens et de itinere prefati presulis nostri ad sedem apostolicam monens. This, however, did not mean that Formosus stopped recognising Odo as king, addressing him as rex in other letters. See next note.

322 Flodoard, HRE IV, c. 2, 374 and Flodoard, HRE IV, c. 3, 374. In both letters Odo is designated as rex.

323 Flodoard, HRE IV, c. 3, 375.

324 Flodoard, HRE IV, c. 3, 375.

325 Flodoard, HRE IV, c. 3, 376.

326 Flodoard, HRE IV, c. 5, 383-384; Flodoard, HRE IV, c. 3, 376.

327 Flodoard, HRE IV, c. 4, 378. On the circumstances, see Schneider, Erzbischof, 159-162. 
The key figure in finding support from potential allies outside the realm was, as we have seen, Archbishop Fulk, who used his contacts in the East and in Italy. Very much like the support Charles' allies won from nobles inside the realm, these coalitions resulted from short term goals on both sides and were not based on longterm common interests. Fulk was interested in gaining ideological and material support for the rebellion, Arnulf in demonstrating his superiority and Zwentibold in enlarging his realm. The contacts with Wido, Lambert and Rudolf appear not to have brought about any practical advantage, as their individual interests were too different. Lambert and Rudolf seem mostly to have been interested in joining forces against Arnulf instead of uniting against Odo. Pope Formosus' role should be assessed in the same way. His voice for peace appears to have gone unheard, his letters to Odo and Arnulf concerning Charles seem to have remained without effect. However, all of these contacts also tell us something about how Charles' coronation was perceived outside Western Francia: Arnulf, while initially reluctant, nevertheless acknowledged the Carolingian as king. Pope Formosus did so without hesitation, yet at the same time continued to call Odo rex as well. Wido, Lambert and Rudolf also had no problem with Charles being one of them, a king. We will return to the implications of that observation in our conclusion to this chapter.

\subsubsection{A network of different layers}

The network of men rebelling against Odo consisted, as we have argued, of different layers. In the centre were men like Archbishop Fulk of Reims, Bishop Anskeric of Paris and Count Heribert of Vermandois, all powerful nobles from Francia. The archbishop, as we have seen, appears to have been mainly driven by political ambition. The same may have been true for Heribert and the others as well, yet this has to remain an assumption. It is, however, remarkable that all of them appear to have been more or less well integrated into Odo's rule, the bishop of Paris even serving as the king's archchancellor. As an explanation, we have proposed that they were blocked by others already within Odo's most inner circle from achieving their goal of gaining more influence at the royal court, of entering this same circle. Since these others had already been there before Odo became king, they were able to defend their position and thus block the advance of the likes of Fulk and the others.

However, this explanation seems to be unsatisfactory in the case of those not belonging to the inner core of the network forming against Odo. While in some cases the participation of individual members can be explained by personal relations to those in the centre-for example Heribert's brother Pippin and the suffragan bishops of the diocese of Reims-in other cases their participation cannot be explained so easily. To assume that they were also driven by their ambitions would mean to fall back on thought patterns long discarded by scholarship that suppose that the relations between the kings and the nobles were characterised 
only by a constant struggle for power. In addition, taking the case of Bishop Anskeric into consideration, who was already at the centre of Odo's court, the motive of political ambitions seems to fall short of explaining the entirety of the rebellion. Seeking a more satisfying explanation, we have argued that another common trait of the rebels was their distrust in Odo, which was caused by a series of ill-received actions on his part. Whatever it was, it was a strong glue that held these men together. Only when everything was apparently lost, when their lands had been occupied by Odo and the negotiations seemed to have failed, did the network begin to disintegrate.

At the beginning of this chapter, we have referred to the perception of this network as being highly fragile. This image is not entirely wrong. Yet it does not apply to the core group of rebels but to the alliances they formed with men outside their own network. As they were too weak on their own to overcome Odo, they sought out potential allies. Within the realm these were men who had already been in conflict with Odo or were about to challenge him. In any case, while sharing a common enemy - the king - these nobles did not share a common goal with the rebels. They were defending their claims or trying to extend their influence, but they did not challenge Odo's rule per se. The same is also true of the allies Fulk sought outside the realm. Whether it be Arnulf and Zwentibold or Lambert and Rudolf, they all were driven by factors relating to their own advantage, not by the goal of overthrowing Odo. It was therefore in the nature of these alliances of convenience to break as soon as the common goal proved to be weaker than individual interests.

Consistent with this image is the fact that, at the very end of the rebellion, Charles and his remaining supporters made contact with yet another potential ally who did not fit neatly into the groups otherwise sought out within and beyond the realm. In 896, a group of Northmen under a leader called Hundeus had taken the opportunity presented by the ongoing fighting, between Rodulf and Baldwin on the one side and Odo and Heribert on the other, to return to Francia. Their strength quickly increasing, they installed themselves on the Oise and then turned towards the Meuse, from where they were finally driven back towards the Seine by the king. Charles now turned to them, baptising Hundeus at Easter. Over the summer, the Normans plundered the Seine region without encountering any further resistance. ${ }^{328}$ A letter from Fulk indicates his reaction when he discovered that Charles had planned an alliance with the Vikings: should Charles proceed with the alliance, the archbishop not only threatened that he would stop supporting him, but he would also encourage others to do the same, and, furthermore, he would excommunicate the Carolingian. ${ }^{329}$ No further evidence exists that this

329 Flodoard, HRE IV, c. 5, 384-385. While Fulk mentions rumours about plans to forge an alliance between Charles and the Normans, the Annales Vedastini only report that Hundeus was brought to Charles to be baptised. 
alliance was ever carried out, ${ }^{330}$ yet the plans appear to be the logical result of the policy Charles and his supporters had pursued during the rebellion: lacking sufficient strength by themselves, they took every opportunity to ally themselves with others who could aid them in bolstering Charles' claim, provide them with men and resources, or at least distract the forces of the Robertian.

\section{I.3 Conclusion}

In this chapter, we have addressed two questions: the reasons why Charles was passed over from his birth up until 893 and the composition and nature of the network that finally elevated him to his father's throne. Charles, as we have seen, was born just a few months too late, when the political decisions surrounding the succession to Louis the Stammerer had already been taken. His birth was certainly noted, yet it was not relevant to the royal succession for a long time. Once in his political backwater, Charles remained there after the deaths of his brothers and, in 888, when, after the death of Charles the Fat, non-Carolingian kings rose to take the crowns of the respective regna. Even then, Charles appears to have lacked substantial political support, as no source shows him being considered as a candidate by any faction.

Did the problem of his birth play a role in the decisions against his succession? Louis the Stammerer, forced by his father Charles the Bald, had rejected his first wife Ansgarde to marry Charles' mother Adelaide and thus created a situation in which the legitimacy of both marriages was questionable. Indeed, as we have seen, Pope John refused to crown Louis' second wife when they met at Troyes. Yet Louis himself, up until just before his death, did his best to ensure the equal succession of his sons from both marriages and the general consensus at court appears to have been in accordance with this policy. In fact, the only time when the legitimacy of Louis' sons was questioned was in 879 when Boso had himself crowned king. He argued that he could do so due to the vacancy of the throne in the absence of any legitimate heirs, thus claiming that neither Louis' marriage with Ansgarde nor that with Adelaide had been valid. However, only the year before, Boso had betrothed his daughter to Louis' younger son Carloman and, therefore, to one of the boys he now denied the right to rule.

Charles, as discussed, does not appear to have been a viable candidate in the subsequent royal successions. Nevertheless, and whether or not his legitimacy was doubted, he remained quiet, biding his time. The moment might have come in 888: Charles the Fat's deposition and death had left the question of succession

330 If we assume that Hundeus' baptism preceeded Fulk's letter, the archbishop's threats may have been the reason why the alliance was dropped. While he was not with Charles anymore, he still possessed considerable political weight to either aid the Carolingian by influencing Odo and his allies or to hamper him by using his connections against him. 
open and Hugh the Abbot and Gauzlin, who had dominated politics over the past decade, were dead. This time, however, the Robertian Odo took the crown in Western Francia. His claim was not uncontested. A party around Archbishop Fulk and Count Baldwin of Flanders invited first Wido of Spoleto and then Arnulf of Carinthia to be king. Odo prevailed, but another five years later was again challenged by a group around Fulk, who this time crowned Charles king.

The death of Charles the Fat, leaving the different realms without Carolingian heirs, created a vacuum that was used by the most powerful magnates to make themselves kings. Their claims were based on their resources and their political networks. Arnulf, additionally, could rely on his illegitimate Carolingian blood while Odo could also make a case because of his victories against the Northmen. The Carolingian dynasty might have come to an end at that moment, yet Carolingian traditions and the idea of Carolingian legitimacy remained strong constitutive factors. In Western Francia, Odo behaved like a Carolingian king, trying to negate the difference in blood that separated him from his predecessors. This strength of the Carolingian idea was Charles the Simple's chance. Whatever doubts there might have been about the legitimacy of his father's marriages, he was of Carolingian blood and, as Louis the Stammerer's son, he had an undeniable claim to the crown of Western Francia. All he needed was political support to claim his throne.

That support came in the form of a strong party based mainly in Francia and centred on Archbishop Fulk of Reims, Bishop Anskeric of Paris, Count Heribert of Vermandois and Charles' mother, Adelaide. Several layers of other group members who formed the core party now elevating Charles to the throne have been identified. This group distinguished itself from other groups also in conflict with the Robertian through its cohesion and its fundamental opposition to Odo. It was strong enough to challenge Odo's right to rule, yet too weak to prevail and thus in constant need of other allies. They found those within and beyond the realm, leading to a number of alliances of convenience which fell apart as soon as the common goal proved to be smaller than the individual interests. Some of the leaders of the party seem to have been motivated by political ambition, yet this argument appears to fall short when considering the entirety of the group now rebelling against Odo. We have proposed that another motive of the rebels was a lack of confidence in the new king, caused by a series of acts that were perceived as norm-breaking behaviour.

Carolingian legitimism, on the other hand, does not appear to have been a driving motive of the leading nobles. All of them had aligned themselves with Odo before the rebellion, with some even being part of his innermost circle. When Fulk and Baldwin had opposed Odo in 888, their choice had not been Charles but Fulk's relative Wido and then Arnulf. That is not to say that Carolingian legitimacy did not play a role in Charles' coronation. It did, and in fact it was the only reason why the party around Fulk chose Charles as their candidate. What Fulk's party needed was a claimant around whom they could rally and who would attract other potential supporters. This was where the interests of Charles and those of 
Fulk and his allies came together: Charles had the claim that they needed to legitimise their revolt against Odo, to demonstrate to the world the justness of their cause. There may or may not have been doubts about the legitimacy of Charles' birth, yet his Carolingian blood was undeniable and could serve as an argument against the Robertian Odo. Fulk's letter to Arnulf shows how this argument was used. The throne was Charles' by right of heritage, whereas Odo was nothing but a stranger to the royal family. How strong Charles' claim was and how well it served the rebels around Fulk is also demonstrated by the behaviour of the pope and the other kings of the Frankish world. Pope Formosus immediately acknowledged Charles as king and treated him as having equal standing with Odo. Kings like Arnulf may have taken a bit longer to come around, but in the end the result was the same. They accepted Charles as one of their own, as their peer, whose right to the crown was undeniable.

Thus, Charles' blood served to legitimise the rebellion of Fulk and his allies against Odo while giving himself the opportunity to leave the political backwater in which he had been stuck since his birth. How strong this claim was is also demonstrated by the willingness of the pope and the other kings to acknowledge him. This, however, did not mean that from then on they renounced Odo's right to be king. Western Francia, for the time being, had two kings who had to find a way to coexist. The result of the final negotiations between Odo and Charles' supporters is known: Charles was given a part of the kingdom and promised even more. ${ }^{331}$ To grant Charles some part of the realm had been one of the two key demands of the rebels from as early as 895 . The "promise for more" was a new addition, which is usually interpreted as an agreement that the Carolingian would succeed Odo as sole king of the realm upon the Robertian's death, ${ }^{332}$ since Odo requested everybody to hold Charles' fidelity only a few months later when on his deathbed. ${ }^{333}$

Why would Odo, victorious after three and a half years of warring, agree to such "surprising" 334 terms with the defeated Charles instead of promoting his own brother's succession? The Viking threat and his own weariness to continue the fight, possibly related to his sickness, have been brought forward, as well as arguments that Odo wanted to create a buffer zone against the aggressive Zwentibold

331 Annales Vedastini 897, 79: Et intercurrentibus nuntiis venit Karolus ad eum; quem ille benigne suscepit, deditque ei tantum e regno, quantum sibi visum fuit, promisitque maiora et remisit eum ad locum suum.

332 The final accord has often been read as a humiliation for Charles (Favre, Eudes, 190; Kienast, Vasallität, 484; against Favre already Eckel, Charles, 25 with n. 5), due to the wording of the Annales Vedastini (897, 79: At vero rex cum consilio suorum respondit se illi velle misereri, si sibi liceret) and the assumed reduction of the part of the realm granted to him by Odo. However, the expressions used by the annals to describe the actual conditions are almost the same. Furthermore, any differences in the size of the part of the realm that Charles was to receive are mere reconstructions by scholars based on assumptions and therefore cannot be used as a basis for an evaluation of the treaties. In any case, if the final treaty did include the succession agreement, which part of the realm Charles was now given becomes of only marginal importance.

333 Annales Vedastini 897, 79.

334 Schneidmüller, Karl III., 27 and Offergeld, Reges pueri, 444 (“astonishing”). 
or to limit Arnulf's influence. ${ }^{335}$ It might be added that Odo's own position in Neustria was not as stable as believed. At some point during his rule there, ${ }^{336}$ a certain Roger had usurped Le Mans, earlier held by Count Berengar, holder of a second march in Neustria. ${ }^{337}$ Odo's brother Robert had then, with the aid of the king's troops, laid siege to the city and installed a certain Gauzlin as count. Gauzlin, however, failed to hold Le Mans and soon Roger returned-only to be excommunicated by Bishop Gunter-without much success. Roger remained in Le Mans and the bishop spent the rest of his life without ever being able again to enter the city. ${ }^{338}$ Odo had not only failed to establish his candidate in his own backyard, but his position in Neustria was now threatened by a hostile Roger.

While Odo's position was vulnerable, the return of the great Viking army to the continent in 896 threatened to undermine his own legitimacy even more. Having focussed his forces on dealing with Baldwin of Flanders and Charles, Odo had neglected the defence of the realm, as was criticised by the Annales Vedastini. ${ }^{339} \mathrm{~A}$ continuation of the conflict would mean risking the basis of his own legitimacy: his ability to protect the realm from the Northmen. Therefore, Odo needed to restore peace in the realm, a task he then addressed with vigour. Baldwin finally re-entered the peace of the king ${ }^{340}$ and Richard now appeared at Odo's court in Francia, where he was honourably received. ${ }^{341}$ Charles, on the other hand, may

335 Eckel, Charles, 27 concerning the Northmen; Favre, Eudes, 191 and Schneider, Erzbischof, 169 for the buffer zone; Schneidmüller, Tradition, 119 with n. 85 as to Arnulf's influence. See also Offergeld, Reges pueri, 444-445 with an overview.

336 Probably after 892, since Berengar appears together with Robert in a private charter in June 892 (Recueil Robert et Raoul, App. I, No 27). At the time of the usurpation, Berengar was probably already dead. Barton, Power, 69, n. 27. It is most commonly assumed that these events are related to the events in Francia and that Roger was sent to Le Mans by Charles the Simple's party. See for example Kaiser, Bischofsherrschaft, 455.

337 Guillotel, Autre marche, 9-10.

338 On this "war of Le Mans" see Werner, Untersuchungen III, 280 and Barton, Power, 63-77. Barton argues for Berengar not being count of Le Mans, but of Rennes (69 with n. 27) and that Roger was sent to Le Mans by Charles the Simple. This latter view is based on Roger being married to Charles' aunt Rothild and that "it is hard to believe that a mere adventurer with no patron would attempt to seize the county of Maine for himself" (71). While this is certainly possible, given the lack of sources this has to remain mere speculation.

339 Annales Vedastini 896, 78: Ac per idem tempus iterum Nortmanni cum duce Hundeo nomine et quinque barchis iterum Sequanam ingressi; et dum rex ad alia intendit, magnum sibi et regno malum accrescere fecit. Similar also Abbo, Bella II, 110, v. 583-588:

En iterum misero gemitu loquor affore sevos

Allofilos. Terram vastant, populosque trucidant,

Circumeunt urbes pedibus, regnantis et aedes,

Ruricolas prendunt, nexant et rans mare mittunt.

Rex audit, nec curat Odo; per verba respondit

$O$, quam responsi facinus.

340 Annales Vedastini 897, 79. Rodulf, Baldwin's brother, had been killed the year before (Annales Vedastini 896,78 ). In contrast to 896 , the negotiations now seem to have taken place independently of each other.

341 DOdo 42 (21st October 897, Nanteuil-le-Haudouin). Richardus, illustris dilectusque nobis comes asked for goods in Atuyer to be granted to a certain Gislebert. 
have been beaten by late 896 , yet he nonetheless remained as a rallying point for Odo's enemies. Furthermore, despite having made his peace with Odo, Archbishop Fulk continued to use his influence at court in support of the Carolingian and it seems possible that others did so as well. ${ }^{422}$ The core of Charles' party was characterised by a strong cohesion and Fulk in particular had proven to be energetic in his attempts to strengthen the network. Even if it was now ripped apart, its remnants still possessed enough political influence to exert pressure on Odo, whose own power had also suffered from the drain of the war.

Indeed, Odo had always been open to negotiations. In 895 , when Charles' supporters sent envoys proposing terms, the Robertian "agreed most willingly" ${ }^{433}$ and when the talks came to an end a year later, Odo was about to grant the Carolingian a part of the realm. ${ }^{344}$ Therefore, it seems that Odo did-at least from 895 onwards-acknowledge Charles' claim as his father's heir and recognise him as a king. Another issue also appears to have been solved early on: when Fulk and his allies rebelled against Odo, they denied the Robertian's own kingship. The negotiations also included that the rebels were to re-enter into Odo's fidelity, meaning that they no longer denied his right to rule. In addition, that Charles would be given a part of the realm had been agreed early on and only the details remained subject to negotiations. ${ }^{345}$ More important, however, was the question of Odo's succession, since its solution also determined whether the partition of the realm would be permanent or only temporary. On Odo's death, his brother Robert, who had already taken over most of Odo's honores in $888,{ }^{346}$ might have had a claim to the throne too. However, Odo himself, when he had reached for the crown, had been opposed by large parts of the realm. The symbolic capital of his Viking victories legitimised his new position, but in the end it had been his Neustrian honores which provided him with the necessary resources to impose his claim. Robert had no such legitimation and we should not assume that, just because Odo had

342 Indeed, Fulk writes in his letter that he would do his best to convince others to turn away from Charles if he continued with his plans to ally himself with the Normans (Flodoard, HRE IV, c. 5, 385: Sciatis enim, quia, si hoc feceritis et talibus consiliis adquieveritis, numquam me fidelem habebitis, sed et, quoscumque potuero, a vestra fidelitate revocabo et cum omnibus coepiscopis meis vos et omnes vestros excommunicans eterno anathemate condempnabo.). Nothing indicates that those "others" were still with Charles. In fact, since the circle around Charles had greatly diminished, and Fulk himself indicates that this circle was behind the plans to forge an alliance, those "others" are much more likely to be found at Odo's court than with Charles.

343 Annales Vedastini 895, 76: Hi vero qui cum Karolo erant videntes se inminui et, ut ferunt, quia Zuendebolchus cum suis Karolum privari vitam cogitabant, ab ipsa obsidione legatos [ad] Odonem mittunt, ut partem regni, qualemcumque ei placuerit, Karolo et eis consentiat atque eos in pace recipiat. Quod rex libentissime annuit, indeque adunato exercitu in Franciam repedavit.

344 Annales Vedastini 896, 77.

345 For a long time scholars have tried to establish the part of the realm given to Charles. Favre, Eudes, 190 and Kienast, Vasallität, 482-483 argue for Laon, Schneider, Erzbischof, 167-169 for most parts of the archdiocese of Reims. In the end, as Eckel, Charles, 26 already stated, due to the lack of sources the question cannot be answered. In any case, since Charles succession in the event of Odo's death had been agreed upon at the same time, the solution would only have been temporary. Saint-Denis at least appears to have remained with Odo. Koziol, Charles, 374. 
become king that he had created a new dynasty-Robert's claim as his brother's heir was thus likely to be challenged. In the end, it would have been up to the nobles to decide upon the issue, ${ }^{347}$ many of whom either followed their own interests like Richard the Justiciar and William the Pious, or supported Charles. Settling the question of succession in favour of Charles, whose claim was undeniable, was thus a pragmatic course of action, avoiding future conflicts.

When Odo died a couple of months later, this was the starting point for Charles' sole reign. In the absence of other Carolingian rulers, Charles' blood had become the crucial factor for his final elevation to the throne. It gave him a claim that was impossible to deny and thus distinguished him from other, non-Carolingian, candidates and claimants. In the end, it paved his way to the throne of Western Francia and was the basis for his recognition by his peers and the pope. Within the realm, the network around Archbishop Fulk and Count Heriber ${ }^{348}$ formed his old and future power base. This group, however, while cohesive and powerful, had proven too weak to be the sole pillar of his rule in times of conflict. During the time of the fight with Odo, the network had depended on alliances with other powerful nobles like Richard the Justiciar and Baldwin of Flanders. To integrate them under his rule would be the crucial task of the next years of Charles' reign.

347 On 9th and early 10th century royal successions see Becher, Dynastie. Becher argues that successions were not simply a question of dynastic rights, but much more of the dominating influence of the nobles. The right of inheritance was used as an argument, but the final decision was to be made by the aristocrats (Becher, Dynastie, 198). Becher did not include the Robertians in his analysis; however, the situation in 892/893 ties in very well with his conclusions.

Odo had reconciled Heribert with Charles. Annales Vedastini 897, 79. 



\section{Changes in the political landscape: From Louis the Stammerer to Odo}

Belonging to the inner circle around the ruler meant having influence on the political decisions taken there as well as being permitted a certain amount of control over access to the king and, thus, over the political agenda. This influence increased if a ruler's capacity to exert control over the political affairs of the realm was diminished, for example when he was too young to wield actual power or at moments when the old ruler had died and his succession was open to debate. The period of roughly 20 years after the death of Charles the Bald until Charles the Simple's accession as sole king of the Western realm was one of five very different rulers quickly succeeding each other. Each succession implicated alterations in the framework determining the relations between the ruler and the nobles around him. The ascents of new rulers to the throne were not the only factors causing shifts in the political landscape however. Also, the composition of the networks of nobles around the rulers changed. Rivalries opened up and were bridged, nobles once influential died or had to leave the court while others rose.

Hence, determining the possibilities and limits of royal power necessitates the exploration of these networks. Who formed part of these networks and how could each individual's position in these networks be described? As in the previous chapter, this approach reveals how the individual nobles interacted not only with the king, but also with each other, at times forming alliances and factions to influence the politics of the realm. These different interactions characterise two very different groups which should not be confused: depending on their proximity to the ruler; one formed layers around him which often consisted of nobles who were rivals with each other, the other aimed to increase influence on the ruler by allying itself to other nobles sharing the same interests and could stretch over the different layers. These groups could certainly be identical and the degree of congruency between them was crucial for the amount of control groups of nobles could win over the royal politics.

Analysing networks, of course, presents a number of problems. Sources for the period covered in this chapter are richer than during the 25 years that were to follow, yet are still far from abundant and allow us only small glimpses of the proceedings at court. Consequently, our results will always only partially reveal the actual networks. The nature of one of our major sources, the royal diplomas, poses another problem. As our sources indicate, many more diplomas seem to have been issued than have actually survived to the present, a loss that increases the problems of our analysis. In addition, while coincidence certainly played a role in regard to which diplomas have been preserved (and which have not), the chance of survival was much better in ecclesiastical institutions. ${ }^{1}$ This leads to a

1 Esch, Überlieferungs-Chance; Johanek, Herrscherdiplom; Merta, Laien. Koziol, Politics, 307 argues that chance played much less of a role than has generally been assumed so far, due to 
certain distortion of the overall image in favour of spiritual dignitaries within the royal networks. Furthermore, we need to consider how royal charters should be read. The study of royal diplomatic is a field that has seen massive change since the 19th century. They are no longer seen as mere remnants of day-to-day rule, a kind of bureaucratic paperwork, so to speak. ${ }^{2}$ Instead, their issuance is now considered as something special-to receive one was meant to have been, in the true meaning of the word, "a privilege." Expressions were carefully selected for their political meaning, its layout equally carefully chosen to transmit royal dignity and authority, while the handing over of the physical document was embedded in a well thought-out public ceremony. Diplomas, therefore, not only served to secure legal rights, but are also reflections of royal authority in the symbolic communication between the king and his nobles. ${ }^{4}$ This becomes even more true in the late Carolingian period as the spatial distribution of the recipients and temporal distribution of the issuing of diplomas became more and more concentrated around certain regions and moments. These concentrations are by no means random and reflect real political developments and events. ${ }^{5}$ In this context, royal diplomas gain another dimension of meaning: they are instruments of politics, issued at special moments. They are symbols of the political relations between the king and certain individuals, notably the petitioners and the recipients. Geoffrey Koziol recently argued that these diplomas should be considered as "performatives," a kind of memorial, reminders of already existing or newly forged alliances, of peace treaties, confirmations of honours or claims to another kingdom. ${ }^{6}$

However, overgeneralising this view comes with the danger of placing too much emphasis on the relations expressed by an individual diploma. While the intervention of an important noble for an ecclesiastical institution certainly reflects the importance of this noble and his relation to the king, the institution itself did not necessarily have a special bond connecting it to the ruler. Often, diplomas were also sought for more basic reasons, to have rights confirmed or possessions added. ${ }^{7}$ When using the evidence of the diplomas, therefore, we have to ask in each case what the nature of the relations between the nobles asking for them and the kings delivering them were. Cross-referencing diplomas with other sources helps to establish the importance of the individuals appearing in them and can

the importance of diplomas, ecclesiastical institutions had a special interest in preserving them. Critical Merta, Auctoritae, 300, n. 6 and Irmgard Fees in her forthcoming article.

2 Guyotjeannin, Diplomatique, 19. Good overviews of the changes are offered by Koziol, Politics, 18-41 and Mersiowsky, Urkunde, 1-42.

3 Huschner, Kanzlei, 358-359. On the process of the deliverance of a diploma, see Mersiowsky, Urkunde, 647-661.

4 Keller, Herrscherurkunden; Koziol, Politics, 40-62; Mersiowsky, Urkunde, 661-666. On the influence of the king on the actual text of diplomas, see Scharer, Herrscherurkunden and Kikuchi, Representations.

5 Koziol Politics, 68-69.

6 Koziol, Politics, 40-62.

7 This view is emphasised, for example, by Kölzer, Diplomatik, 24. 
aid in casting some further light on these relations. Titles and epithets used to describe individual nobles in royal charters point towards the special importance of certain individuals, as in the case of the word "beloved" (dilectus) or in the use of the superlative. ${ }^{8}$ These words do not always have to be taken literally, as a true indication of personal closeness, since they may equally be used to express the rank a noble took within the hierarchy at court. For us, however, this distinction does not matter too much, since even if the nature of their influence on the king was different, it was visible and real.

\section{II.1 Old elites: Louis II the Stammerer}

On the verge of leaving for his second Italian campaign, Charles the Bald held an assembly at Quierzy during which the famous capitulary of 877 was issued. The main purpose of the measures outlined in the capitulary were to constrain Charles' son, Louis the Stammerer, ${ }^{9}$ who was installed as king, yet at the same time surrounded with Charles' fideles and other nobles of his choosing. ${ }^{10}$ Thus, for example, the count of the palace, Adalard, was entrusted with the royal seal and ordered to remain with the prince at all times. ${ }^{11}$ Adalard, given his office, was a politically influential man at court, whose importance is further emphasised by him being, at Charles' instigation, the prince's new father-in-law. He was not the only one mentioned by the capitulary, however. A large number of nobles were commanded to stay close to the prince at all times, while others were to join him should he move to certain regions. ${ }^{12}$ Three bishops were charged with keeping Charles informed about the state of the realm and his son's activities. ${ }^{13}$ Given the importance of these tasks, we can assume the nobles mentioned within the capitulary, like Adalard, represented a group possessing both considerable political importance during the emperor's last years and proximity to him. Therefore, the capitulary offers us an insight into the circle of nobles present at Charles' court during the last years of his reign and we use it extensively hereafter to point out certain continuities within the circles of leading nobles during the following reigns.

However, the system created to keep Louis in check appears to have been flawed. Some of the most important nobles, such as Hugh the Abbot, Count Boso of Vienne and Count Bernard of Auvergne, had not been present at the assembly of Quierzy. ${ }^{14}$ Hugh, figuring prominently in the emperor's last diplomas, ${ }^{15}$ held

8 Brunner, Fürstentitel, 198-203.

9 Nelson, Charles, 249.

10 Annales Bertiniani 877, 212-213.

11 MGH Capit. II, N² 281 c. 17, 359.

12 MGH Capit. II, N² 281 c. 15, 359.

13 MGH Capit. II, $\mathrm{N}^{\circ} 281$ c. 25, 360.

14 See Hincmar's letter to Louis the Stammerer, Migne, PL 125, col. 986.

15 DDChB 437 and 438, 12th July 877, 478 and 481: Hugo abbas, noster fidelis atque propinquus. 
the military command against the Northmen on the Loire. ${ }^{16}$ Even more important was Boso, ${ }^{17}$ whose sister had become first Charles' concubine and then his wife. ${ }^{18}$ After Charles' first Italian campaign, he had been made the equivalent of a viceking in Italy, married the daughter of Louis $\mathrm{II}^{19}$ and from that point on intervened frequently in imperial charters with epithets and titles emphasising his proximity to the emperor. ${ }^{20}$ Finally, Bernard of Auvergne was, next to Bernard of Gothia, one of the most powerful men in Aquitaine. Both of them had been assigned to Louis the Stammerer in 872, when he became king of Aquitaine. ${ }^{21}$ The capitulary which separated the nobles into different groups, of which one was to remain at all times with Louis and hence possessed significantly more influence on the affairs of the realm than the others, therefore might be expected to have created rifts among the nobles. And indeed, the new order did not hold for long. Charles, having arrived in Tortona and waiting for Hugh the Abbot, Boso, Bernard of Auvergne and Bernard of Gothia, who Charles had ordered to follow him, received the news that they had joined a conspiracy against him. ${ }^{22}$ None of these men had been assigned to remain with Louis at all times. Consequently, Janet Nelson proposes that their refusal to come to Charles' aid was meant to draw him back over the Alps and re-establish the status quo. According to this argument, the problem was not their proximity to Charles himself, but their position at Louis' court should the emperor die in Italy. ${ }^{23}$

This fear was not without reason. When Charles died upon his forced return to the North, the first thing Louis tried to do was to create his own power base by handing out honores to other nobles, ${ }^{24}$ thus provoking resistance from those who felt cast aside by him. A letter from Hincmar to the new king reveals the leaders of the opposition that now assembled at Montaimé: Hugh the Abbot, Boso, Bernard of Auvergne and Bernard of Gothia, who were now joined by two of Charles' key personnel, Abbot Gauzlin and Count Conrad of Paris. ${ }^{25}$ Gauzlin, abbot of Jumièges, Saint-Amand and Saint-Germain-des-Prés, had served as the emperor's archchancellor since $867^{26}$ and had probably also drawn up the

16 Annales Bertiniani 866, 132. See also Regino, Chronicon 867, 93 who tells us that Hugo abba in locum Ruotberti substitutus est.

17 On Boso's position under Charles the Bald, see also chapter VI.4.

18 Annales Bertiniani 869, 167 and 870, 169.

19 Nelson, Charles, 242-243.

20 For example DDChB 441 (1st August 877, 489: Bosone carissimo nostro), 443 (11th August 877, 496: Bosoni carissimi ducis nostri), 444 (around 11th August 877, 498: Boso, dux et missus Italiae sacrique palacii nostri carissimus archiminister), 458 (end 875-877, 512: illustris atque insignis ducis videlicet Bosonis et dilectissimi ministerialis nostri) and 460 (876-early 877, 513: Bosonis comitis, ducis Italiae et sacri palatii nostri archiministri).

21 Annales Bertiniani 872, 185-186. On this, see Nelson, Charles, 231-232.

22 Annales Bertiniani 877, 216.

23 Nelson, Charles, 252.

24 Annales Bertiniani 877, 218.

25 Annales Bertiniani 877, 218 and Migne, PL 125, col. 987.

26 On his early career and importance at Charles' court see Werner, Gauzlin, 406-411. 
capitulary of Quierzy. ${ }^{27}$ Conrad had acted as Charles' legate in negotiations with the Northmen, ${ }^{28}$ although his importance is probably best captured by the epithets used to describe him in a diploma issued in the wake of the battle of Andernach. He was "our fidelis, associated with us by family propinquity, Conrad, most noble count" as well as "our dearest and most familiar." ${ }^{29}$ Interesting enough, these two apparently had no connection with the Italian affair. Quite the contrary, Gauzlin and Conrad had both belonged to the group originally intended to stay close to Louis. Therefore, with one stroke, the new king managed to upset not only those already in fear of losing their influence at court once the emperor was dead, but also those who were meant to stay close to him. Both groups accordingly united against him and forced him to give in. Louis was crowned king but had to agree to hand over even more honores ${ }^{30}$ and to give a promissio about his future conduct to the nobles. ${ }^{31}$ In the end, it was the nobles who made Louis king, not the designation by his father. ${ }^{32}$

Hincmar's account in the Annales Bertiniani is full of references to leading nobles and councillors urging and advising the king. For example, according to him, Hugh the Abbot urged Louis to cross the Seine and come to his aid against the Northmen as well as against the counts Gauzfrid and Emeno. ${ }^{33}$ Soon afterwards, the king was reconciled with Gauzfrid at the instigation of some of his councillors. ${ }^{34}$ Assessing these references however is rather problematic. Hincmar's annals were by no means an objective account of what had happened. The archbishop had a distinctive political position and phrased the annals accordingly, manipulating documentary evidence and omitting facts if it helped to further his case. ${ }^{35}$ Especially during his later years, he emphasised the necessity of consensus between the king and the nobles-no king should rule alone but be advised and counselled by chosen members of the nobility. The clearest evidence of his conviction is of course his De ordine palatii, but he expressed his thoughts also in his letters: “The

27 Nelson, Charles, 248.

28 Annales Bertiniani 876, 210-211.

29 DChB 412 (4th September 876), 423: ...fidelem nostrum et parentele propinquitate conjunctum, Chunradum, nobilissimum comitem... and ...nobis carissimo et familiarissimo... On his parentage with Welf, see Nelson, Charles, 246, n. 110.

30 Annales Bertiniani 877, 219.

31 Annales Bertiniani 877, 219 and MGH Capit. II, N² 283, 363-365.

32 On the relation between the king and the nobles see Schramm, König, 53-58 and Kienast, Vasallität, 415-417.

33 Annales Bertiniani 878, 222: Ac, suadente Hugone abbate et markione, perrexit ultra Sequanam, tam pro auxilio Hugonis contra Nortmannos quam et pro eo quod filii Gozfridi castellum et honores filii Odonis quondam comitis inuaserunt, ac quia Imino, frater Bernardi markionis, Ebrocensem ciuitatem usurpans, multas depraedationes circumcirca in illis regionibus exercebat, insuper et Eiricum more Nortmannico depraedari praesumpsit.

34 Annales Bertiniani 878, 222: Sed miserante Domino aliquantulum conualescens, satagentibus quibusdam consiliariis suis et amicis Gozfridi, uenit ad eum isdem Gozfridus, adducens secum filios suos, ea conditione ut castellum et honores quos inuaserant Hludouuico regi redderent et postea per concessionem illius haberent.

35 Nelson, Annals, 35. 
general disposition of the realm' must depend, not on any one man, but on 'the judgement and consent of many."'36 Hincmar's references in the annals are therefore hardly surprising: they reflect the same thought pattern and were meant to show how kingship should work.

However, the question remains, whether the archbishop's account represents the actual relations between Louis and the nobles surrounding him. For example, Hincmar tells us that, while treating with Pope John at Troyes, Louis ordered the bishops Frotar and Adalgarius to ask John to confirm his father's diploma that handed the realm over to him. In turn, the pope asked for the confirmation of another diploma that granted Saint-Denis to the Church of Rome. According to Hincmar, this was a forgery produced by the very same bishops and other councillors of the king, ${ }^{37}$ which would indicate that the nobles around Louis were behind the initial request of the king in order to provide the pope with an opportunity to present his own charter. Equally, a visit of Louis to the pope was made at the instigation of some of the councillors, probably leading to the excommunication of Emeno. ${ }^{38}$ When Louis met with Boso after the synod, he was in the company of several of his most important councillors, resulting in the betrothal of his son Carloman to Boso's daughter. ${ }^{39}$ Furthermore, the distribution of the honores of Bernard of Gothia is said to have been made with their counsel. ${ }^{40}$ In all of these cases, Louis is shown to have acted in close cooperation with those around him. As argued, this concords well with Hincmar's own convictions of how a kingdom should be run and does, in all probability, reflect the reality of Louis' court. ${ }^{41}$ There is, however, a second layer to this. In all of these cases Louis' actions directly reflect the interests of those around him, the most obvious case being the conspiracy with the forged diploma, meant to deprive Gauzlin of Saint-Denis. However, should we take this as a sign of the influence the nobles exercised over Louis? Depriving Bernard of Gothia of his honores certainly intensified the tensions between the king and the count and might not have been in Louis' best interest if he was to seek a peaceful solution. ${ }^{42}$ Yet at the same time, distributing Bernard's honores among those around him also served his purpose since it reinforced his relations with

36 Nelson, Hincmar, 25-26. See there also for the quote. Flodoard, HRE III, c. 26, 343: Item pro sollicitudine, quam tempore Ludovici regis nuper defuncti susceperat idem Teudericus de filiis ipsius regis, ne moleste acciperet, si eum commoneret causa dilectionis vigilem esse debere apud filios eiusdem regis; ostendens quia non solum grandis praesumptio, sed etiam magnum periculum est, uni soli generalem regni dispositionem tractare sine consultu et consensu plurimorum... In a similar tenor also Hincmar, De ordine palatii, c. VI-VII, 82-96.

37 Annales Bertiniani 878, 227-228.

38 Annales Bertiniani 878, 228.

39 Annales Bertiniani 878, 229.

40 Annales Bertiniani 878, 229-230. For the conflict between Bernard of Gothia and Louis the Stammerer see chapter VI.1.

41 On the cooperation between the king and the nobles, see Hannig, Consensus fidelium, Schneidmüller, Konsensuale Herrschaft and Patzold, Konsens. For the late Carolingian period, see also MacLean, Kingship.

42 See chapter VI.1 on Louis the Stammerer's position. 
the same men who were to take up their arms to subdue the count. ${ }^{43}$ Similarly, the betrothal between Louis' son Carloman and Boso's daughter tied the latter closer to him. Nevertheless, taking into considering the way Louis' reign had started, how these nobles had enforced their will on the new king and how the king's decisions concur with their own interests, we can deduce that they still possessed a distinctive political leverage over him.

Who were these men exercising such influence on Louis? Hincmar's alreadymentioned letter is a good starting point for an analysis of this inner circle. Of the six nobles he named as most important, three also appear in the king's diplomas. Most notable is Hugh the Abbot, who requested three diplomas for his abbeys, and was named "glorious abbot" and "our relative"; while another three charters, in which he did not appear, were issued for monasteries under his control. ${ }^{44} \mathrm{Con}$ sidering that he held the command along the Loire, a diploma for the cathedral church of Tours may also have been issued at his request, ${ }^{45}$ although due to the lack of further evidence this must remain a mere possibility. Boso, apart from the betrothal of his daughter to Louis' son Carloman, intervenes in two charters, described as "our beloved $d u x$ " and "our dearest $d u x$ " respectively, for the church of Lyon and the abbey of Tournus under abbot Geilo. ${ }^{46}$ A lost diploma for SaintMartin of Autun may also have been related to him. ${ }^{47}$ Gauzlin, who served as archchancellor for most of the reign, ${ }^{48}$ intervened together with Queen Adelaide in a royal charter for the church of Paris, while the abbey of Saint-Denis, which came under his control at the beginning of Louis' reign, received another diploma. ${ }^{49}$ Given the offices they held at court, their appearances in Hincmar's annals and the epithets used to describe them in the royal diplomas, we can already tell that these men held important positions at court. The same was probably also true for Bernard of Auvergne since he was not only amongst those receiving the honores of Bernard of Gothia, ${ }^{50}$ but was also charged with protecting Louis' son and successor, Louis, when the king felt his death approaching. ${ }^{51}$ Bernard of Gothia, in turn,

43 Annales Bertiniani 879, 234.

44 At his request: DDLS 6, 11 (27: ...fidelis nostri Hugonis scilicet gloriosi abbatis...) and 15 (44: ...venerandus vir, noster quoque propinquus, Hugo, religiosus abba...). For Saint-Martin of Tours: DDLS 12 and 14. For Saint-Germain of Auxerre DLS 36.

45 DLS 39.

46 DDLS 20 (Lyon), 66: ... dilecti ducis nostri Bosonis... and 27 (Tournus), 81: ...carissimi ducis nostri Bosoni...

47 DLS 34. We can link the diploma to Boso assuming that at the point of its delivrance he held it. DChB 444, around 11th August 877 names a certain Badilo as abbot for Saint-Martin. The diploma is issued at Boso's intervention, showing his earlier connection to the abbey. Soon after the abbey must have passed into Boso's hands, since in 879 he exchanged it with Theoderic the Chamberlain (Annales Bertiniani 879, 235). Saint-Martin appears to have been one of these abbeys. See Bulliot, Essai, 141.

48 His last appearance is DLS 30 (8th February 879). In DLS 31 (29th March/10th April 879) Wulfard serves as archchancellor.

49 DDLS 8 (Saint-Denis) and 9 (church of Paris).

50 Annales Bertiniani 878, 229-230.

51 Annales Bertiniani 879, 234. 
quickly lost his honores and was eliminated from the inner circle. Finally, during Louis' reign Count Conrad disappears from the sources, thus making it impossible for us to draw any further conclusions.

Bernard's loss of his honores points us towards a rift among the leading nobles that emerged almost immediately after Louis' accession to the throne. When Hugh the Abbot called on the king to cross the Seine, he did so as a consequence of two conflicts: $:^{52}$ one with Gauzfrid, Gauzlin's brother; ${ }^{53}$ and another with Emeno, the brother of Bernard of Gothia. ${ }^{44}$ Thus, in both conflicts, the rebellious nobles were closely related to men who had, up until then, been key figures in the political affairs of the realm. Gauzlin was able to reconcile his brother with the king, ${ }^{55}$ something that Emeno might also have hoped for from his own brother. Bernard, however, had entered into conflict with Archbishop Frotar of Bourges ${ }^{56}$ around the same time and both he and his brother were excommunicated at the synod of Troyes in $878,{ }^{57}$ at the same moment that Bernard lost his honores. ${ }^{58}$ Soon after, he also became the target of a military campaign. ${ }^{59}$ Thus, Bernard had clearly been eliminated from the circle around the king. Gauzlin's influence was also diminishing. At Troyes he became the target of a conspiracy to deprive him of Saint-Denis, ${ }^{60}$ followed by the loss of the office of archchancellor in early $879 .{ }^{61}$ Linking of the cases of Bernard and Gauzlin has been proposed since both of them belonged to the Rorgonid family. ${ }^{62}$ While this link by kinship should not be overinterpreted in regard to both of them pursuing the same goals,${ }^{63}$ the family ties between the two did play an important role as a means to mediate a solution to the conflict. ${ }^{64}$ Gauzlin himself was apparently not directly involved in either of the cases, since he was able to use his influence at court to mediate a favourable outcome for his brother. This he failed to do for Bernard, probably because at this point his position at court had already come under pressure. In any case, two parties appear to have formed, struggling for influence at court: Hugh the Abbot, Boso and Bernard of Auvergne on the one hand, and at least Gauzlin and Count Conrad on the other.

While the group around Gauzlin remains in the shadows, the one around Hugh is more visible due to its presence at court and hence we can adduce a number of the other nobles that were part of it. Next to Hugh, its most important member

52 For these conflicts see chapter VI.1.

53 Werner, Gauzlin, 406-409.

54 Annales Bertiniani 878, 222.

55 Annales Bertiniani 878, 222.

56 MGH Epist. VII, N 135, 118-119.

57 Annales Bertiniani 878, 228; MGH Epist. VII, Nº 142, 122.

58 Annales Bertiniani 878, 229-230.

59 Annales Bertiniani 879, 234.

60 Annales Bertiniani 878, 228.

61 Bautier, Recueil Louis II, Louis III et Carloman II, LXIII.

62 Werner, Gauzlin, 406 and 417-422.

63 Against an overinterpretation of this family connection, see MacLean, Kingship, 104.

64 On Gauzlin's and Bernard's connection, see chapter VI.1. 
certainly was Count Theoderic the Chamberlain, undoubtedly the Theoderic who was named in the capitulary of Quierzy as part of the group to remain with the prince. His importance at court becomes clear from a number of cases: like Bernard of Auvergne, he also profited from the distribution of Bernard of Gothia's honores ${ }^{65}$ on at least one occasion he demanded a royal diploma; ${ }^{66}$ and finally, he belonged to those accompanying Louis' heir while conducting the campaign against Bernard. ${ }^{67}$ Considering his affiliation with the group around Hugh, we must, nonetheless, be careful. While the sources do indeed indicate his cooperation with this group in the case of Bernard of Gothia and he certainly joined forces with them from that moment on, his earlier importance at court may also have been rooted in a personal relationship with Louis himself. In other nobles' cases, the connection with the dominating circle is more apparent, although their political importance appears to have been of a more limited nature. For example, Archbishop Ansegisus of Sens figured as the leader among the bishops paying homage to Louis the Stammerer after his coronation, ${ }^{68}$ indicating that he kept some of the influence he had gained during the last years of Charles the Bald, when he, Odo of Beauvais and Actard of Tours replaced Archbishop Hincmar of Reims at court. ${ }^{69}$ However, his association with the group around Hugh is only noted after Louis' death, when he crowned Louis III and Carloman II at Ferrières on their behalf. ${ }^{70}$ Archbishop Frotar of Bourges, who had been the target of Bernard of Gothia, together with Bishop Adalgarius of Autun participated in the conspiracy against Gauzlin at Troyes, where the two of them handed over a precept to the pope on the king's behalf. ${ }^{71}$ Adalgarius also received two diplomas for his church, one of them issued at the request of Count Theoderic, who by then had become count of Autun ${ }^{72}$ thus not only marking his access to the king but also his connection to the inner circle around Hugh. The same was true for Archbishop Aurelian of Lyon, for whose church Boso demanded a diploma. ${ }^{73}$ Also closely connected with Boso was Abbot Geilo of Tournus, the future bishop of Langres, who received another diploma at the count's intervention. ${ }^{74}$ Finally, we can also add Bishop Walter of Orléans as well as the counts Goiram and Ansgar (probably the count of Oscheret) to the list. Walter was yet another of the nobles who had been assigned in the

66 DDLS 29, 23rd January 879 and possibly 33 (deperditum), both for the church of Autun.

67 Annales Bertiniani 879, 234.

68 Annales Bertiniani 877, 220.

69 Nelson, Charles, 241-242.

70 Annales Bertiniani 879, 238-239; Annales Vedastini 879, 45.

71 Annales Bertiniani 878, 227-228: Frotarius autem et Adalgarius episcopi attulerunt in conuentu episcoporum papae Iohanni praeceptum per quod pater suus Hludouuico regnum tradiderat, petentes ex ipsius parte ut priuilegio suo ipsum preceptum confirmaret. John in turn demanded the confirmation of the (forged) charter, which would have given the Church of Rome control over Saint-Denis. 
capitulary of Quierzy to accompany Louis when he entered the Seine region and was now granted another royal charter, ${ }^{75}$ thus pointing to his continuing importance. More importantly, however, he and the two counts were sent to Louis the Younger to negotiate on behalf of the group around Hugh after Louis the Stammerer's death. ${ }^{76}$ Apart from Theoderic, all of these men appear to have been part of an outer layer of the dominating circle. Their influence at court remains more or less obscure since none of them appears in the direct vicinity of Louis. In the case of Ansegisus, his mention can also be explained by his importance to the Gallic Church ${ }^{77}$ while Frotar's and Adalgarius' appearances at court may as likely have been the result of the ecclesiastical proceedings of the synod of Troyes, as was probably also Aurelian's. ${ }^{78}$ Finally, the two counts only appear after the king's death.

Louis' contacts were not limited to those belonging to the dominating groups of Hugh and Gauzlin. As we have already discussed in the context of Theoderic the Chamberlain, certain nobles also drew or might have drawn their position at court from a personal connection to the king. Examples of this mainly come from the family of Louis' second wife, Adelaide, who can be found intervening in a diploma for Saint-Médard of Soissons. ${ }^{79}$ Related to her was Count Aledramnus, who Louis granted a rich gift of property naming him "our dearest" and "our beloved relative." ${ }^{80}$ In his case, a connection with Gauzlin is also discernible which certainly did not hurt his position at court. Both were captured after the battle of Andernach ${ }^{81}$ and Aledramnus made a donation to Gauzlin's abbey of Saint-Denis in $879 .{ }^{82}$ Finally, just before Louis' death, Adelaide's brother Wulfard became the new archchancellor in the succession to Gauzlin. ${ }^{83}$ While he was certainly appointed with the consent of the leading group around Hugh, his being chosen was undoubtedly more due to his relationship to the king: once Louis died, he appears to have lost the office again. ${ }^{84}$

Unrelated to the king but holding a position independent from Hugh and his allies were Bishop Odo of Beauvais, one of Charles the Bald's confidants who had been assigned to remain close to Louis in the capitulary of Quierzy, and a certain

75 DLS 40 (deperditum).

76 Annales Bertiniani 879, 236-237; Annales Vedastini 879, 45.

77 On the primacy of the church of Sens (and Ansegisus), see Schramm, König, 112-114. The importance of the archbishops of Sens within the Gallic Church becomes evident from their role in the royal coronation, a role that was heavily opposed by the Archbishop Hincmar of Reims and his successors.

78 Aurelian's presence at Troyes is indicated by his subscription of the synodal acts. MGH Conc. V, $\mathrm{N}^{\circ} 9,104,135,140$.

79 DLS 30.

80 DLS 28, 84: ...carissimum nobis comitem nomine Aletramnum... and ...praefato dilecto propinquo nostro Aletramno... On him see chapter I.2.2.

81 Annales Bertiniani 876, 209.

82 Lot, Notes, 150.

83 DLS 31, 29th March, 10th April 879. On him see also chapter I.1.2.

84 Bautier, Recueil Louis II, Louis III et Carloman II, LXVII-LXVIII. 
Count Albuin. When he felt his death approaching, Louis entrusted the two of them with the royal sword, crown and the rest of the royal insignia, to be brought to his son Louis III, who was to be crowned and anointed. When they heard of the king's death, they handed over the insignia to Count Theoderic and quickly left. ${ }^{85}$ That Odo and Albuin did not remain with Theoderic seems to indicate that they kept their distance from the dominating circle. Difficult to place is Bishop Wala of Auxerre, one of the bishops assigned to advise Louis when entering the Seine region in the capitulary of Quierzy. At an unknown moment, the church of Auxerre received a diploma from the king ${ }^{86}$ which points towards a continuing connection between the royal court and the bishop. Yet, whether this connection was determined by the dominating groups around the king or was independent from them remains unclear. Once Wala had died, Wibald, a cleric who had been educated at the palace school of Charles the Bald, succeeded him at Louis' instigation. ${ }^{87}$ After the king's death, from one of his successors he obtained a royal charter concerning a private donation he made to the congregation of his church. In this diploma he established a prayer service for Louis commemorating his death day, ${ }^{88}$ which may be read as a sign of a closer connection between him and the king. In the context of episcopal succession, another see also needs to be considered. Early in 878, Bishop Willebertus of Châlons died and was succeeded by a certain Berno. ${ }^{89}$ It seems likely that Berno was well connected at the royal court since Hincmar asked him in 879 to intervene on his behalf before the kings and Hugh the Abbot ${ }^{90}$ and since he later received diplomas both from Carloman II and Charles the Fat. ${ }^{91} \mathrm{Had}$ Berno, like other bishops of the time, previously belonged to the royal chapel? In 877 , Charles the Bald issued a diploma for the abbey of Marchiennes at the request of "Berno, the venerable deacon of the palace, our beloved ministerialis."92 It seems at least possible that the two Bernos were identical and that Louis managed to lift another cleric from the palace on an episcopal see. Whether in both of these cases this was entirely his own choice or whether the circle around Hugh had had a hand in their appointments has to remain unanswered.

85 Annales Bertiniani 879, 235-236.

86 DLS 35 (deperditum).

87 Gesta Pontificum Autissiodorensium I, 163.

88 Gesta Pontificum Autissiodorensium I, 165. The date of the royal diploma is not given by the gesta. Wibald was invested as bishop 5th April 879 (five days before Louis the Stammerer's death) and died 12th May 887 (Gesta Pontificum Autissiodorensium I, 166, n. 327). This leaves Carloman II and Charles the Fat as possible rulers to have issued said charter. The description of the charter as regio precepto does not exclude the Emperor Charles, since the Gesta also note that Wibald, because of his death, was not able anymore to obtain another royal diploma (165: Quod multa cum difficultate peregit, sed regale preceptum quod ex eo adeptus fuerat, mors inmatura possidere prohibuit.).

89 Willebertus died 2nd January 878. Duchèsne, Fastes III, 98.

90 Flodoard, HRE III, c. 23, 317-318. See also below.

91 DCmII 76 and DChF 150.

92 DChB 435 (11th July 877), 473: ...Bernonem venerabilem diaconum palatium, dilectum ministerialem nostrum... 
Finally, there is Archbishop Hincmar of Reims himself to consider. During Charles the Bald's last years, he had fallen out of royal favour and, as we have seen, been replaced by a number of other men. ${ }^{93}$ After the emperor's death, Hincmar addressed a number of letters to Louis, offering his counsel. ${ }^{94}$ When Louis' efforts to create his own power base by handing out honores was resisted by the leading nobles, Hincmar advised him to refer himself to their leaders. ${ }^{95}$ This advice was less a sign of support for the rebels than a simple acknowledgement of political realities ${ }^{96}$ as well as possibly an attempt to gain a foothold within the group of dominant nobles by siding with them. The archbishop's importance was underlined when he consecrated and crowned Louis king. ${ }^{97}$ He continued to send Louis more letters on political affairs and also played an important role at the synod of Troyes. ${ }^{98}$ Yet despite all this, his actual influence at court remained limited and he appears not to have belonged to Louis' inner circle. All in all, he was someone who carried some political weight but was never in the actual centre of political decision making, although cooperating with the king and those close to him. ${ }^{99}$

So far, we have been able to identify different groups of nobles at the king's court. The groups around Hugh the Abbot and, to a lesser degree, Gauzlin appear to have dominated the inner circle around the king, using their influence to further the interests of their associates. However, another group can also be identified-although in this case this term may be misleading since there are no signs of an inner cohesion or even cooperation-which had independent access to the king and probably, at least in the case of his close relatives, like his wife Adelaide, also exerted some political influence. The existence of this last group demonstrates that the king was able to maintain a certain liberty in choosing those close to him and was not entirely dependent on the groups dominating the court. Royal contacts went even further, encompassing large parts of the realm. Shortly after his coronation, Bishop Arnaldus of Toul ${ }^{100}$ and soon thereafter Abbot Ansbald of Prüm ${ }^{101}$ received diplomas, representing royal contacts with Lotharingia. From Burgundy came Abbot Odo of Vézelay, ${ }^{102}$ from Aquitaine Abbess Ava of Sainte-Croix ${ }^{103}$ and the abbey of Solignac ${ }^{104}$ also received a royal charter. The synod of Troyes presented the chance for a large number of ecclesiastic dignitaries to

93 Nelson, Charles, 241-242.

94 Devisse, Hincmar, 967.

95 Annales Bertiniani 877, 218 and Migne, PL 125, col. 987.

96 Devisse, Hincmar, 968-973.

97 Annales Bertiniani 877, 219.

98 Devisse, Hincmar, 975-978.

99 Devisse, Hincmar, 978-979 and McCarthy, Hincmar, who provides a detailed study of Hincmar's relations with the king.

100 DLS 4 (9th December 877).

101 DLS 7 (19th or 24th March 878).

102 DLS 5 (15th December 877).

103 DLS 13 (4th July 878 ).

104 DLS 38 (deperditum). 
demand confirmations and grants. Among them were not only the bishops Abbo of Nevers ${ }^{105}$ and Lambert of Mâcon ${ }^{106}$ from Burgundy but also Archbishop Sigebod of Narbonne $e^{107}$ and his suffragan Frodoynus of Barcelona ${ }^{108}$ from Septimania and the Spanish March, while other diplomas went to the church of Girona ${ }^{109}$ and the abbeys Notre-Dame of Arles-sur-Tech ${ }^{110}$ and San-Esteban de Banolas. ${ }^{111}$ However, these were contacts that can easily be explained by regular day-to-day work related to the administration of the realm and therefore they do not betray any larger political influence of their recipients at the royal court.

\section{II.2 Rival factions: Louis III and Carloman II}

After the death of Louis the Stammerer, the tensions between the groups around Hugh the Abbot and Gauzlin rose and turned into open conflict. Since both of Louis' sons were under Hugh's control, Gauzlin decided to call Louis the Younger into the realm. At the same time, the composition of the two groups changed. In the case of Gauzlin, the contact with Bernard of Gothia-if it had ever been strong-now appears to have ceased completely. Instead, until the division of the realm at Amiens, the sources emphasise Gauzlin's cooperation with Count Conrad of Paris..$^{112}$ By early 880 , their base of support amongst the nobility appears to have weakened considerably. ${ }^{113}$ Meanwhile, the alliance around Hugh also began to crumble in the wake of the succession crisis. Early on the group still held together: Hugh mediated an exchange of honores between Boso and Theoderic, ${ }^{114}$ while Hincmar also mentions the three of them acting together in the face of Louis the Younger's intervention. ${ }^{115}$ However, Boso broke away from them soon after, having himself crowned king at Mantaille on the 15th October 879, and taking with him a number of nobles belonging to the wider circle. Boso's electio is signed, among others, by Archbishop Aurelian of Lyon, Bishop Adalgarius of Autun und Abbot Geilo, ${ }^{116}$ two of whom we have already identified earlier as having a close

DLS 18.

106 DLS 19.

107 DLS 22.

108 DLS 17.

109 DLS 21.

110 DLS 16.

111 DLS 23.

112 Annales Bertiniani 879, 235-236, and again in 880, 240; Annales Vedastini 879, 44 and 880, 46.

113 Annales Bertiniani 880, 240: Hludouuicus rex Germaniae una cum uxore sua ab Aquis in istas partes iter arripuit et usque ad Duziacum uenit, ubi Gozlenus et Chuonradus obuiam illi uenerunt, quam plurimis iam de illorum complicibus ab illorum societate retractis.

114 Annales Bertiniani 879, 235.

115 Annales Bertiniani 879, 236-237.

116 MGH Capit. II, N² 284, 369. 
connection with him. Adalgarius acted as archchancellor for Boso, ${ }^{117}$ Geilo was granted a diploma shortly after ${ }^{118}$ and also became bishop of Langres in early $880 .{ }^{119}$ Furthermore, Bernard of Auvergne's position in relation to Boso is uncertain. In a charter issued by Boso "after the death of the most glorious King Louis," Bernard appears as one of the witnesses, ${ }^{120}$ but soon after he joined the fight against Boso. ${ }^{121}$ In the light of this, it is very possible that the final settlement of Ribemont and the partition of Amiens was necessitated not only by the intervention of Louis the Younger, but also by the diminishing support both sides received from the nobility. Louis III, from then on with Gauzlin, was to rule over Francia and Neustria; Carloman, remaining with Hugh, received Burgundy and Aquitaine. ${ }^{122}$

The actual influence each of these groups had on the kings, before and after the partition, is hard to assess. Once crowned, both Hincmar and the Annales Vedastini emphasise the independent actions of both Louis and Carloman. ${ }^{123}$ Yet once we turn from the narrative sources towards Hincmar's letters, the image changes, as Thilo Offergeld has shown. ${ }^{124}$ Just after the death of Louis the Stammerer, in a letter to Count Theoderic the Chamberlain, the archbishop argued for a broader basis to support the regency of the late king's sons. ${ }^{125}$ Moreover, two other letters reveal his idea of involving Charles the Fat in their tutelage. The first letter, addressed to Charles, describes Louis and Carloman as "orphan boys without a father" in need of a "mature, prudent and rational guardian." 26 The second letter, prefacing the first, was addressed to Hugh the Abbot, trying to win his support for the plan. ${ }^{127}$ Hincmar, of course, aimed at regaining his lost influence at court and may therefore have exaggerated the young kings' dependence. Yet, the way he passes over them in these letters, disregards them as underage boys completely dependent on those around them, as children who still needed to be educated, seems nevertheless to reflect the common opinion. Otherwise his arguments would hardly have

117 Poupardin, Recueil Provence, IX. According to Poupardin, Aurelian also became archchancellor for a short period. The diploma naming him as such (DProv 17), however, has been revealed to be a forgery by Bautier, Recueil Eudes, CXLIV-CXLVI.

118 DProv 19 (8th December 879, for Saint-Philibert and Geilo).

119 Bautier, Recueil Louis II, Louis III et Carloman II, 108.

120 DProv 16 (25th July 879), 31: ... post obitum Hludovici gloriosissimi regis... On the identification of Bernard, see Zielinski, Regesten III,4, N²741, 122. Bernard was related to Boso's wife Ermengard.

121 Annales Bertiniani 880, 243.

122 Annales Bertiniani 880, 241.

123 Offergeld, Reges pueri, 382-383.

124 Offergeld, Reges pueri, 383-392.

125 Flodoard, HRE III, c. 26, 343. See also Offergeld, Reges pueri, 384.

126 Migne, PL 125, c. 1, cols. 989-990: ... et istos juvenes, reges nostros, propinquos vestros, et pupillos sine patre loco filiorum teneatis, et eis regnum ab antecessoribus illorum successione dimissum per suggestionem primorum regni hujus disponatis, et qui de primoribus cuique illorum convenient ordinetis. And c. 2, col. 991: Istis juvenibus fidelibus filiis vestris, regibus nostris, maturos ac prudentes atque sobrios bajulos singulis constituite, qui oderint avaritiam, et eos verbo et exemplo justitiam diligere doceant...

127 Flodoard, HRE III, c. 24, 327. 
been convincing. Thus, the letters are a strong indicator that, at least in $879 / 880,{ }^{128}$ Louis and Carloman were entirely in the hands of those nobles around them.

Hincmar's own weak position at court put him in a difficult position. He had crowned Louis the Stammerer only two years earlier, yet in 879 it was the Archbishop of Sens who had consecrated Louis and Carloman at Ferrières. As Hincmar's letters to Theoderic and Hugh show, he did his best to influence royal politics, yet whether his efforts actually produced any result seems doubtful. ${ }^{129}$ The conflict surrounding the episcopal see at Noyon provides us with further insight. After the death of Bishop Raginelm, Hincmar, aiming at limiting royal influence to the confirmation of the final candidate, requested a free canonical election. ${ }^{130}$ Hincmar did not appear at court in person, but, apart from writing to the kings ${ }^{131}$ and Hugh the Abbot, ${ }^{132}$ he also repeatedly asked Bishop Berno of Châlons to intervene on his behalf. ${ }^{133}$ In the end, Hincmar had his way and Heitilo was elected according to the canons, as the archbishop had pressed for. ${ }^{134}$ It is interesting to note that the archbishop did not himself address the kings or Hugh the Abbot, but had one of his suffragan bishops mediate for him. Both letters sent to Berno indicate that the bishop was present at the royal court at the time. Furthermore, we can assume that Hincmar's choice in using Berno was not only because the bishop happened to be present at court, but because the archbishop considered him as a suitable intermediary. Following this thought, it seems plausible that Berno had certain connections at court that would allow him to better influence the decision makers in Hincmar's interest than Hincmar himself would have been able to at that time. If, as we have proposed above, Berno had been a member of the royal chapel before his appointment as bishop of Châlons, this would serve as an explanation as to why this was the case. In any case, his connections to the leading members of the court appear to have been better than the archbishop's, who therefore chose to involve him in the matter of the see of Noyon.

\section{Louis III}

Sources for Louis III's short reign are rare since hardly any diplomas have survived to the present day. When Louis moved south to suppress Boso's revolt, Gauzlin was charged with the command against the newly returned Vikings in Francia; ${ }^{135}$ he also became the king's new archchancellor. ${ }^{136}$ His importance as one of the leading magnates thus remained unbroken. Of Count Conrad nothing further is pueri, 385-386.

129 On the adoption plans see chapter I.1.3.

130 Flodoard, HRE III, c. 24, 326-327.

131 Flodoard, HRE III, c. 19, 260-261.

132 Flodoard, HRE III, c. 24, 326-327.

133 Flodoard, HRE III, c. 23, 317-318.

134 Devisse, Hincmar, 984-985. For a detailed study see Ehrenforth, Hinkmar.

135 Annales Vedastini 880, 47.

136 DLIII 43. 
known up until his death towards the end of Louis' reign. ${ }^{137}$ Either his position remained unchanged or he was replaced by a new face, another Count Theoderic, Theoderic of Vermandois. ${ }^{138}$ Theoderic was the brother of the well-connected Count Aledramnus who we have identified as an important figure in the court of Louis the Stammerer. He may have owed Aledramnus his entrance into the circle dominating the court. Since he would not have been able to achieve such success at court had he opposed Gauzlin, he must have started to cooperate with him at a very early stage. It was probably also through his own and Aledramnus' influence, in connection with Gauzlin's, that the Robertian Odo, son of Robert the Strong and maybe already Aledramnus' son-in-law, was appointed count of Paris following Count Conrad's death. ${ }^{139}$ In the context of the quarrel between Louis III and Hincmar concerning the succession of Bishop Odo at Beauvais, the archbishop named Theoderic as one of the king's most important councillors, which indicates his ascent had occurred already before Conrad's death. ${ }^{140}$ Finally, in 882, when nobles from Lotharingia offered Louis the realm, the king turned down their offer but sent Theoderic with an army to aid them against the Northmen. ${ }^{141}$ Thus, the leading nobles at Louis' court appear to have been Gauzlin, Theoderic and possibly Conrad until his death.

At first, Hincmar appears to have cooperated with Louis and this group of nobles, but relations began to deteriorate, as is demonstrated by the conflict over the succession of the deceased Odo of Beauvais. At Hincmar's request, Louis granted the people and clergy of Beauvais the right to elect their bishop; later, again in accordance with the archbishop, he refused their candidate. At that point, Hincmar's and Louis' positions clashed. While the king insisted on his right to name the candidate-he opted for Audacher, notary in the royal chancellery ${ }^{142}$ - the archbishop did his best to institute a new solution..$^{143} \mathrm{He}$ wanted to install a council of five bishops, chosen by himself, to decide upon the new bishop. Hincmar supported a certain Roger while Audacher was excommunicated. In the end, the conflict was only ended by Hincmar's and Roger's deaths. ${ }^{144}$ The archbishop certainly

137 22nd March 882. Chaume, Origines, 310 and Dümmler, Geschichte III, 133.

138 To be distinguished from Theoderic the Chamberlain, as Werner, Untersuchungen V, 102 with n. 59 and Gauzlin, 208 with n. 150a, has shown.

139 Werner, Gauzlin, 451, for Gauzlin. We add Theoderic and Aledramnus since the former later belonged to Odo's firmest supporters while Odo married the latter's daughter, Theodrada. Favre, Eudes, 202-203 and Le Jan, Famille, 237. Settipani, Préhistoire, 404-405 notes Theodrada's origin as unknown. Favre, Eudes, 15 suggests the early 880 s as date for the marriage.

140 Bautier, Recueil Louis II, Louis III et Carloman II, 116. On the letter, the position of Hugh the Abbot (definitely not at Louis' court since DCmII 54 (4th June 881) shows him at Pouilly-surLoire) and the identification of Theoderic, see Werner, Gauzlin, 206-208.

141 Annales Bertiniani 882, 245-246. On this, see also MacLean, Response, 30-38.

142 Bautier, Recueil Louis II, Louis III et Carloman II, LXXII-LXXIII. Audacher had already been active under Charles the Bald, for whom he also served as legate to the pope (Annales Bertiniani 877, 215). On him, see also Tessier, Recueil Charles le Chauve III, Introduction, 85-87.

143 Schmitz, Hinkmar, 467 and 478.

144 Devisse, Hincmar, 985-989. See also Schmitz, Hinkmar and Guyotjeannin, Episcopus, 13. 
did not take his exclusion from an influential position at court well, and appears to have had a private feud with Gauzlin. ${ }^{145}$ This explains why one of Louis' greatest successes, his victory against the Northmen at Saucourt, almost appears as a defeat in Hincmar's annals..$^{146}$

There is only one more noble left to mention in Louis' network: Welf, abbot of Saint-Riquier, who received a diploma probably during the preparations for the campaign leading up to Saucourt. ${ }^{147}$ Welf, "venerable abbot and our dearest kinsman", also held Sainte-Colombe and had been assigned in the capitulary of Quierzy to constantly remain with Louis the Stammerer. He thus belonged to the important nobles of the realm-and he was Count Conrad's brother. ${ }^{148} \mathrm{He}$ was related to Louis through Welf's and Hugh's aunt, the Empress Judith, second wife of Louis the Pious and mother of Charles the Bald. His presence in the diploma is therefore unsurprising. He was not only related to the king, but also, and more importantly, to one of the nobles dominating the royal inner circle. His influence, however, did not last long. Like his brother, he died before Louis, in his case 13th November $881 .{ }^{149}$

\section{Carloman II}

Much better documented than the reign of Louis III is that of his brother, Carloman II. Carloman's years as ruler of the southern division of the realm saw the continuation of the alliance around Hugh the Abbot and Theoderic the Chamberlain. Hugh's dominant role becomes clear from the Annales Vedastini, which names him as the mediator of the treaty of Ribemont. ${ }^{150}$ Two of Carloman's royal diplomas saw him intervening, as "our dearest venerable abbot", for the church of Narbonne and simply as "venerable abbot" for the king's chaplain Arveus, while in a third he served as ambasciator for the abbey of Saint-Florent. ${ }^{151}$ Theoderic appears in the same role in a diploma for the church of Autun ${ }^{152}$ and was probably also behind a diploma for Saint-Martin of Autun. ${ }^{153}$ The wider circle of their supporters also remains visible: Archbishop Frotar of Bourges intervened on behalf of

145 Werner, Gauzlin, esp. 447-450.

146 Annales Bertiniani 881, 244: Hludouuuicus [...] reuersus est in partem regni sui contra Nortmannos. Qui uastantes omnia in suo itinere, Corbeiae monasterium et Ambianis ciuitatem aliaque sancta loca occupauerunt. De quibus non modicam partem occisis ceterisque fugatis, et ipse Hludouuicus una cum suis retrorsum, nemine persequente, fugam arripuit, diuino manifestante iudicio quia quod a Nortmannis fuerat actum non humana sed diuina uirtute patratum extiterit. See also Werner, Gauzlin, 437.

147 DLIII 43 (30th December 880, Compiègne), 112: ...Guelfo, venerabilis abbas et consanguineus noster carissimus....

148 Poupardin, Royaume, 355-356.

149 Poupardin, Royaume, 356 with n. 3.

150 Annales Vedastini 880, 46.

151 DDCmII 54 (138: ... karissimi nostri venerabilis abbatis Hugonis...), 55 (144: Hugo venerabilis abba hoc ambassavit) and 61 (162: ... Hugonis venerabilis abbatis).

152 DCmII 49.

153 DCmII 83 (deperditum). 
the abbey of Beaulieu ${ }^{154}$ and properties in Berry and the Nivernais were restored to Bishop Walter of Orléans. ${ }^{155}$ Two other figures joined the royal circle: one was Abbot Wulfard of Flavigny, Adelaide's brother, who again became archchancellor. ${ }^{156}$ $\mathrm{He}$ intervened alone for the fidelis Rainardus ${ }^{157}$ and together with Hugh the Abbot for the chaplain Arveus in another. ${ }^{158}$ While the first diploma seems to indicate a close connection to Carloman, his return to the office of archchancellor was certainly more due to an alliance he concluded with Hugh and his circle, ${ }^{159}$ as seems to be indicated by their joint intervention. This last diploma also figures the other remaining important noble: Wido, "our beloved count"160, who completed the list of those intervening for the chaplain. This Wido may have been either the brother of Count Ansgar of Oscheret, who we have already met as an associate of Hugh; or another Wido from Burgundy who later appears to have been close to Richard the Justiciar. The first Wido followed his brother and Wido of Spoleto to Italy in 888 , where he died in battle. ${ }^{161}$ The second accompanied Richard at the assembly of Varennes ${ }^{162}$ and also witnessed two of his private charters. ${ }^{163}$ Either way, the epithets of the diploma and his intervention with Hugh and Wulfard indicate Wido's political importance and his link to the circle around Hugh.

Apart from these remarks, the rich corpus of diplomas preserved from Carloman's reign allows us to make some further observations. As during his father's reign, Carloman was sought out by a number of ecclesiastical dignitaries from Septimania and the Spanish march. Archbishop Sigebod of Narbonne and Bishop Theotarius of Girona again received charters for their churches, ${ }^{164}$ as did the abbey of Notre-Dame of Arles-sur-Tech. ${ }^{165}$ In addition, Saint-Polycarpe and SainteCécile were now granted diplomas. ${ }^{166}$ Similarly, Bishop Abbo of Nevers and Abbot Odo of Vézelay again appeared at the royal court: ${ }^{167}$ along with Archbishop Frotar's intervention, further examples of the king's contacts in Aquitaine. Also interesting are a number of appearances closely connected to the advancement of the campaign against Boso: Bernard of Auvergne, Boso's brother Richard and bishops Adalgarius of Autun, Geilo of Langres and Ratbert of Valence, all of whom had

DCmII 62.

155 DCmII 53.

156 See chapter I.1.2.

157 DCmII 59.

158 DCmII 61.

159 Wulfard's return to court was certainly also related to the campaigns against Boso since his abbey, Flavigny, was a valuable asset in this fight. Bautier, Recueil Louis II, Louis III et Carloman II, LXVIII.

160 DCmII 61, 162: ... Widonis dilecti nobis comitis...

161 Gesta Berengarii Imperatoris, 22-23.

162 DProv 28 and Hlawitschka, Lotharingien, 95.

163 Chronicon S. Benigni Divionensis, 113 and Cartulaire Montiéramey, № 12, 18.

164 DDCmII 54 (Narbonne), 58 and 93bis.

165 DCmII 60.

166 DDCmII 52 (Saint-Polycarpe) and 57 (Sainte-Cécile).

167 DDCmII 50 (Nevers) and 51 (Vézelay). 
supported Boso when he took the crown. ${ }^{168}$ Bernard received the county of Mâcon the moment it was taken from Boso ${ }^{169}$ thus indicating that, if he had indeed supported Boso, he now had switched to the Carolingian alliance that had formed against the usurper. His affiliation with the group around Hugh is less clear, although his son Norbert became Carloman's new notary. ${ }^{170}$ Over the following year, charters from Saint-Julien of Brioude, which, although he never was its abbot, appears to have been under his control, ${ }^{171}$ were dated after Charles the Fat instead of Carloman. ${ }^{172}$ Richard and Adalgarius acted together in a diploma for the church of Autun, Carloman's first preserved charter, dating to 30th November $880 .{ }^{173} \mathrm{In}$ the same diploma, Theoderic the Chamberlain served as ambasciator, thus linking together the three most important men of the area. Richard, addressed as count of Autun, was now either granted the county or at least recognised as its count, Adalgarius was its bishop and Theoderic held important abbeys in the area. ${ }^{174} \mathrm{Next}$ in line was Ratbert of Valence, who joined Carloman's court between November 880 and July $881,{ }^{175}$ followed by Geilo of Langres. ${ }^{176}$ Thus, Boso's own network is revealed to have been extremely fragile, with key figures such as his own brother and his archchancellors deserting him as soon as the united power of the Carolingian kings became apparent. However, not all of those who were now reaccepted into Carloman's peace remained close to the king. In particular, Richard's position is far from clear. As Hincmar reports, the new count of Autun brought Boso's wife and daughter to Autun after Vienne had fallen, ${ }^{177}$ yet nothing indicates explicitly that it was he who captured the city. ${ }^{178}$ Moreover, that he brought his brother's family to Autun is not a sure indication that he supported Carloman wholeheartedly. He may also have done so to keep them out of the reach of the royal court after Boso's death. ${ }^{179}$ Be that as it may, for the next few years Richard disappears from our sources, indicating that he did not play an important part in the affairs of the realm. However, his appearance in the royal diplomas, like those of the other nobles from Burgundy originally supporting Boso, marks the reintegration

168 See above. Richard appears in Boso's last charter before his coronation (DProv 16).

169 Annales Bertiniani 880, 243.

170 Bautier, Recueil Louis II, Louis III et Carloman II, LXXIII-LXXV.

171 Lauranson-Rosaz, Auvergne, 54-55.

172 Cartulaire Brioude $\mathrm{N}^{\circ}$ s 197 and 260, 208 and 270: Anno primo quod (domnus) Karolus sumpsit Imperium. MacLean, Kingship, 69. Brioude continued to date after Charles the Fat even after the emperor's death. Auzias, Aquitaine, 418 and 541-548.

173 DCmII 49, 124: ...Rikardi comitis Augustidunensis...

174 Annales Bertiniani 879, 235.

175 DCmII 85, confirming donations made by Boso to Ratbert's foundation Charlieu (DProv 22).

176 DDCmII 56 (18th July 881) and 63 (8th August 882).

177 Annales Bertiniani 882, 247: Dum autem in eodem procinctu degeret, mense septembrio nuntiatum est illi certo nuntio quia, capta Vienna, uxorem Bosonis et filiam eius Richardus, frater ipsius Bosonis, ad comitatum suum Augustudunsensem adductam habebat.

178 For example Offergeld, Reges pueri, 379 and Robbie, Emergence, 30, who assume that it was Richard who finally captured Vienne from Boso's men.

179 After September 882, nothing indicates any further political actions from Boso. Bautier, Origines, 61-67. 
of Boso's old powerbase into Carloman's rule. At least in the Autunois, Theoderic the Chamberlain played a key role in these proceedings and served as a direct link to the dominant group around Hugh the Abbot.

\section{The realm reunited}

Once Louis III had died, Carloman also took over the Northern kingdom at the invitation of the nobles from Francia. ${ }^{180}$ Hincmar's use of the expression "great men of the realm" (primores regni) in this context points towards a unified action of the leading magnates, which leaves us to conclude that Gauzlin, as well as Theoderic of Vermandois, were involved in the issue. In fact, Gauzlin does appear in the petition of the bishops to Carloman made at Quierzy ${ }^{181}$ where the young king renewed the promissio he and his brother had given two years earlier. Undoubtedly, both groups had made an arrangement to set aside their rivalry and embark on a course of cooperation. However, Hincmar also tells us that Carloman, after an initial campaign against the Northmen, was not able to muster sufficient forces to fight them due to the absence of Hugh the Abbot and the withdrawal of several powerful nobles of Francia from the new king. ${ }^{182}$ Shortly after Carloman had been called to the North, the old frictions appear to have surfaced again. This does not mean however that the new king found himself completely isolated in Francia. Hincmar himself, for example, was among those who continued to support Carloman. ${ }^{183}$ This is hardly surprising: as soon as Louis died, the archbishop had once again renewed his efforts to gain influence at court, composing the famous De ordine palatii for Carloman. ${ }^{184}$ However, his death shortly afterwards deprived him of any possible profit.

This period, marked by the absence of nobles from Francia from Carloman's court, lasted for over a year. Efforts were certainly made to overcome this situation, as the succession of Fulk, abbot of Saint-Bertin and member of the royal court since the times of Charles the Bald, ${ }^{185}$ to Hincmar at Reims demonstrates. Being well connected both at court and among the Frankish nobility, he might have been installed as a mediator between the king and the withdrawn nobles. Yet, the integration of the North only succeeded after Gauzlin had been made

180 Annales Bertiniani 882, 246-247: Primores autem regni expeditum nuntium miserunt ad Karlomannum, mandantes ut, relictis qui Viennam obsiderent et seditioni Bosonis resisterent, ipse quantotius ad eos uenire festinaret, quoniam hostiliter ipsi praeparati erant in occursum Nortmannorum... Ipsi autem parati erant illum recipere et se illi commendare; sicut et fecerunt.

181 MGH Capit. II, N² 285, 370.

182 Annales Bertiniani 882, 249.

183 Annales Bertiniani 882, 250.

184 Devisse, Hincmar, 989, Gross and Schieffer, Hinkmar, 10. The original title of the work appears indeed to have been Admonitio Hincmari Remorum archiepiscopi ad episcopos et ad regem Karlomannum per capitula.

185 Flodoard, HRE IV, c. 4, 379, tells us that Fulk had been trained the aula palatii. Fulk's earlier importance is also reflected by his appearance in the capitulary of Quierzy, where he was named among those who were to remain close to Louis the Stammerer. See MGH Capit. II, N 281 c. 17, 359 and above. 
archchancellor around August 883, an office that had remained vacant since the death of Wulfard almost two years earlier. ${ }^{186}$ His appointment certainly helped to ease tensions and create links to other nobles, thus providing the court with an influential lever. The final agreement seems to have been reached at the assembly of Ver about half a year later. Carloman's capitulary, ${ }^{187}$ a renewal of the one he had issued in February 883, ${ }^{188}$ placed the king in line with his predecessors and emphasised his claim to rule over the entire realm. ${ }^{189}$ In the wake of the assembly, he issued a diploma at Compiègne, the most important Carolingian palace of the Western realm, at the request of three of the North's leading nobles, Bishop Berno of Châlons, Bishop Angelwinus of Paris and Count Theoderic of Vermandois, ${ }^{190}$ demonstrating the newly won support of Francia for the king. That Hugh's party now agreed on allowing other nobles into the circle around the king was undoubtedly also due to the threat posed by the Northmen. Before the assembly of Ver, the leading nobles had already gathered at Compiègne, where they decided to open negotiations with the Vikings. According to the Annales Vedastini, they finally settled on a tribute of 12.000 pounds of silver, a sum to be collected from the entire realm. ${ }^{191}$ Participation in the decision making at court was undoubtedly the price the nobles from Francia asked for contributing their part of the tribute.

The takeover of the Northern realm does not seem to have weakened Hugh the Abbot's position at court. In November 882, it was he who went to meet Charles the Fat at Worms to negotiate the return of parts of Lotharingia to Carloman, a fruitless endeavour. ${ }^{192}$ His dominance in the royal diplomas-after the unification of the realms Hugh intervened six times ${ }^{193}$ and received another two diplomas for himself ${ }^{194}$ - has led to the belief that he wielded more or less absolute control over the royal chancellery. ${ }^{195}$ This seems to be an exaggeration, since most of these charters were issued after Gauzlin had become archchancellor. However, according to the Annals of Sainte-Colombe of Sens, he held the monarchiam clericatus in

186 The last diploma mentioning Wulfard as archchancellor was issued 881, September 2nd (DCmII 93bis). Wulfard probably died immediately afterwards, his death date known as 6th September (Bautier, Recueil Louis II, Louis III et Carloman II, LXVIII with n. 3). The office afterwards remained vacant, notary Norbert referring to Wulfard as post obitum... (DDCmII 62 and 63).

187 MGH Capit. II, $\mathrm{N}^{\circ} 287,371-375$.

188 MGH Capit. II, $\mathrm{N}^{\circ} 286,370-371$.

189 MGH Capit. II, No 287, 371: Karlomannus gratia Dei rex omnibus venerabilibus episcopis, abbatibus, comitibus, iudicibus omnibusque sanctae Dei ecclesiae et nostris fidelibus. Cum ad palatium Vernis anno dominicae incarnationis DCCCLXXXIV, anno autem regni nostri quinto, indictione secunda, mense Martio convenissemus et pars fidelium nostrorum nobiscum, placuit, ut quaedam statuta sacrorum canonum necnon quaedam capitula antecessorum nostrorum renovarentur...

190 DCmII 76 (13th March 884).

191 Annales Vedastini 884, 55. The beginning of the armistice at the Feast of the Purification of the Virgin (2nd February) indicates that the negotiations had already started before, the assembly of the nobles deciding upon them therefore had taken place before the assembly of Ver.

192 Annales Bertiniani 882, 249.

193 DDCmII 66, 70, 71, 72, 78 and 89.

194 DDCmII 77 and 87.

195 Bautier, Recueil Louis II, Louis III et Carloman II, LVIII-LIX. 
palatio, ${ }^{196}$ a phrasing that more or less applies to the office of archchaplain. ${ }^{197}$ Setting offices or control over the royal chancellery aside, Hugh's importance during this period is probably best captured by two royal diplomas, one calling him "our tutor and great protector of our realm"198, the other installing a prayer service at Rethondes not only for Carloman's brother Louis, but also for the "most venerable" and "most reverend" Abbot Hugh:199 a singular honour during Carloman's reign. Thus, his role at court appears to have been more central than ever.

Despite his importance, we should not forget that other men also held influential positions at court. We have already mentioned Gauzlin's return to the office of archchancellor in August 883 and can add to this a diploma for his abbey of Saint-Germain-des-Prés ${ }^{200}$ as well as him serving as ambasciator in another royal charter. ${ }^{201}$ In addition, Theoderic of Vermandois entered into very close association with the king after the settlement with the Northern nobles. It was by no means a coincidence that he was among those appearing in the first diploma after the assembly of Ver, honoured as "our greatly beloved."202 This was undoubtedly a consequence of the central role he had assumed during the reign of Louis III. Like Gauzlin, he also received another royal charter, in his case for his abbey of Morienval. ${ }^{203}$ Theoderic's intervention for Bishop Berno of Châlons in the first diploma also indicates that, at least by now, Berno, who "stands out in the government of our realm and in very useful counsel and aid", ${ }^{204}$ not only possessed some influence at Carloman's court, but also had joined the circle of nobles originally dominating that of Louis III. The same diploma also saw the intervention of Bishop Angelwinus of Paris, ${ }^{205}$ another one of those assigned to remain with Louis

196 Annales S. Columbae Senonsensis 882, 104. The annals appear to have been contemporary. Heine, Geschichtsquellen II, 342.

197 Offergeld, Reges pueri, 369 with n. 220. Positive on Hugh being archchaplain also Fleckenstein, Hofkapelle, 146 and 163. Critical Löwe, Hinkmar, 207. On the office of archchaplain at the West Frankish court, see Tessier, Diplomatique, 56-57 and Bautier, Chancellerie, 15-18.

198 DCmII 71, 183: ...venerabili Hugone abbate, tutore nostro ac regni nostri maximo defensore...

199 DCmII 89, 228: ...venerabilissimo Hugone... and ...reverentissimo abbate Hugone...

200 DCmII 93. It is possible however, that in 883 Gauzlin had already passed on Saint-Germain to his nephew Ebolus. See below, chapter II.3, n. 234.

201 DCmII 79.

202 DCmII 76, 198: ... Teuderico comite valde dilectus nobis...

203 DCmII 90.

204 DCmII 76, 198: ...qui nobis in principio regni nostri et consilio et auxilio satis proficuus et fidelis extitit...

205 DCmII 76. This diploma is dated by Bautier to 13th March 884 and states that Bishop Angelwinus of Paris (DCmII 76, 198: venerabilis scilicet Angelwinus Parisorum episcopus) appeared together with count Theoderic in front of Carloman to support a request of Berno, bishop of Châlons. However, it so far assumed that Angelwinus died 8th December 883 (Duchesne, Fastes II, 475 with reference to Depoin, Essai, 222), refering to Angelwinus' death day noted in the necrologies of Saint-Denis and Argenteuil (Molinier, Obituiare I,1, 333 and 351). The year is not given by those and has instead been deducted from the Translatio S. Mederici, 110, which states that Anno Incarnationis Domini nostri J. C. DCCCLXXXIV studiosus Dei cultor Sacerdos memoratae Ecclesiae nomine Theodebertus adiit venerabilem Gozlinum Abbatem atque urbis Parisicae Antistitem..., meaning that by the time of the translation (supposedly 29th August 884) Gauzlin had already 
the Stammerer by the capitulary of Quierzy, signalling that he had also joined the group around Gauzlin and Theoderic.

Nobles from the southern regions who had belonged to the group around Hugh remained influential. Theoderic the Chamberlain appeared again in connection with the church of Autun, serving as ambasciator, ${ }^{206}$ and was also granted a diploma for his abbey, Saint-Martin of Autun ${ }^{207}$ The position of Archbishop Frotar of Bourges, who intervened together with Hugh the Abbot for the church of Marseille, ${ }^{208}$ appears to have remained unchanged. Bishop Walter of Orléans received two more diplomas for his own church, both of them at Hugh's intervention. ${ }^{209}$ Count Wido continued to be important, being described as "our highly beloved and illustrious count."210 Count Ansgar of Oscheret, who had belonged to the group around Hugh three years earlier when he had been part of a legation to Louis the Younger, ${ }^{211}$ now

succeeded Angelwinus as bishop. This reading is also backed by the account of the Annales Vedastini $(884,54)$ which read Anno Domini DCCCLXXXIIII. Per idem tempus mortuo Engelwino Parisiorum episcopo Gauzilinus abba subrogatur in sedem eius.

This, however, would leave us with a dead bishop appearing before the king. Therefore, two dates have to be examined: that of the diploma and that of the translation. The former date reads as Data III idus martii, indictione II, anno II regni Karlomanni regis in Frantia (DCmII 76, 198). We can agree without any hesitation with Bautier's conclusion that the second year of Carloman's reign in Francia corresponds with the year 884 (his brother Louis having died on the 5 August 882), even more so as the date also matches the year of the indiction. Alternatively, setting aside the indiction and the in Frantia, we could also read the date as 13th March 881, calculating from his first coronation at Ferrières. This, however, would mean that Carloman would have been at Compiègne at that moment, since the diploma was issued there. According to Hincmar however, at this moment Carloman was in Burgundy, fighting Boso (Annales Bertiniani 881, 243-244: Anno incarnationis dominicae 881 remanente Karlomanno cum suis contra Bosonis seditionem, Hludouuicus, frater eius, reuersus est in partem regni sui contra Nortmannos.), which also corresponds with Carloman's diplomas. The date 13th March 884 therefore appears to be correct. The text of the Translatio on the other hand is less clear: it does give 884 as the year, but only for the moment at which the priest Theodebert approached Gauzlin to propose the translation of the relics. But in fact, between this moment and the actual translation, some time seems to have passed, so that the die depositionis $S$. Mederici, in qua praefatus sacerdos id facere disposuerat, could also have taken place the following year. This also leads to another problem, the die depositionis S. Mederici, which could either mean the day of Saint Merry's death (29th August) or the day of the translation of the body (which according to Mabillon, Acta Sanctorum Benedicti III,1, 14, n. c was celebrated 22nd January).

We therefore propose to date Angelwinus' death not to have been 8th December 883 but 884 . If Gauzlin succeeded him within a couple of weeks, this would still have left enough time for Theodebert to initiate the translation, which then would have taken place in 885 , either early in January or late in August. However, this would mean that Gauzlin was by no means appointed bishop of Paris by Carloman (as Werner, Gauzlin, 216 assumed) since the latter had already died 5th or 6th December 884 (Bautier, Recueil Louis II, Louis III et Carloman II, 210), but succeded him during a period of interregnum, before Charles the Fat arrived in the realm. This solution, of course, assumes that the account of the Annales Vedastini is wrong.

206 DCmII 68

207 DCmII 83.

208 DCmII 72.

209 DDCmII 70 and 71.

210 DCmII 88, 226: ... illuster comes nobisque admodum dilectus...

211 Annales Bertiniani 879, 236-237. 
reappeared in two diplomas, in which he was connected to Theoderic the Chamberlain and Count Robert of Troyes. ${ }^{212}$ Finally, we may also add Bishop Adalgarius of Autun, who had rejoined Carloman after having supported Boso's rebellion, to this circle, although his connection to the court probably depended on his relationship with Theoderic and Ansgar, who served as ambasciatores in the royal charter granted to his church. ${ }^{213}$ Despite the integration of the North, the circle around Hugh thus continued to be extremely present at the royal court.

Thus Carloman's united court saw the continuing dominance of the groups that had formed years earlier around Hugh the Abbot and Gauzlin. Yet, again, access to the king was not limited to the nobles belonging to these groups. The aforementioned Robert of Troyes appears to have had connections to Ansgar of Oscheret, yet his own position at court-he demanded three diplomas for the abbey of Montiéramey during Carloman's entire reign ${ }^{214}$ - was probably more determined by his relation to the king himself, since he was married to Gisela, Louis the Stammerer's daughter from Ansgarde and thus Louis' and Carloman's sister. ${ }^{215}$ Another interesting case is that of a certain Erifons, another "illustrious fidelis" of the king. ${ }^{216} \mathrm{He}$ only appeared in Carloman's last diploma, probably issued just after the king had been fatally wounded. In the face of his inevitable death, Carloman wished to make donations to Saint-Crépin of Soissons in atonement for his sins. ${ }^{217}$ The choice of words and Erifons' presence at the king's side just before his death, as well as his being charged with the implementation of the measures laid down in the diploma (he also served as ambasciator at Gauzlin's order ${ }^{218}$ ), indicate that he, like Robert, enjoyed a more personal connection to the king than those of the other nobles dominating the court. The same is also possible for Abbot William of Croix-Saint-Ouen, who is described as "our highly beloved and illustrious fidelis William" when he demanded a royal charter for his abbey. ${ }^{219}$ Nothing further is known about this abbot; however, as the way he is described shows, he appears to have been held in some esteem by the king, either because of his political importance, or his personal relationship with him. In two other cases, those of the

212 DDCmII 68 (as ambasciator with Theoderic) and 81 (Robert).

213 DCmII 68.

214 DDCmII 65, 80 and 81. None of these diplomas are datable, therefore making it impossible to determine at what point Robert had entered the court.

215 On him, see Saint-Phalle, Comtes, 157-158. He is often addressed as count of the palace by scholars. This seems to stem from him being described as minister palatinus et abbas Beati Lupi in a private charter issued by himself for the abbey of Montiéramey (Giry, Études, 129, $\mathrm{N}^{\circ} 14$ ). Whether this really indicates that he served as count of the palace remains unclear. See also Saint-Phalle, Comtes, 157 with n. 26.

216 DCmII 79, 212: ...illuster fidelis noster...

217 See also the commentary of Bautier, Recueil Louis II, Louis III et Carloman II, 210-212.

218 DCmII 79, 213: Erifonnus, jubente Gauslino, hoc ambasciavit.

219 Baudot, Abbaye, 19-21 (16th August 884, Verberie), here 19: ...illuster fidelis noster Guillelmus, admodum nobis dilectus... Baudot identified the abbot as William the Pious, Bernard of Auvergne's son (Baudot, Abbaye, 10), albeit without giving any reasons. However, it seems unlikely that Bernard's son should have held an abbey in the north-east of Neustria. 
counts Hilduin ${ }^{220}$ and Alardus, ${ }^{221}$ due to the loss of the diplomas that recorded their appearances at court, statements about their relation to the king or their connections to the dominating circle cannot be made at all.

However, while the likes of Robert and Erifons appear to have been close to Carloman, their political influence must have been limited. They had connections to the circle around Hugh and Gauzlin, but either only to second-rank nobles, as in the case of Robert's connection to Ansgar of Oscheret, or in a subordinate role, like Erifons to Gauzlin. The leading members of the circle, on the other hand, distinguish themselves by their frequent interventions for churches, abbeys and individuals, in some cases for those which were close to the regions where they themselves held important honores, such as Hugh's interventions for the church of Orléans ${ }^{222}$ while in others there was no connection at all. Institutions far from the royal court, like Saint-Sauveur of Alfa or the church of Marseille, now sought out the inner circle to gain access to the king. ${ }^{223}$

These latter institutions point us to a last observation concerning Carloman's reign over the united realm. While he remained within Francia from September 882 onwards, his connections with the regions south of the Loire remained intact. We have already shown the presence of nobles from Burgundy at his court. To these we can add a number of appearances from Aquitaine and Septimania. Archbishop Frotar of Bourges was certainly the most important of the king's contacts in Aquitaine, but Carloman was also sought by representatives of the abbey of Solignac $^{224}$ and the abbess Adalgard of Sainte-Croix of Poitiers. ${ }^{225}$ In Septimania next to Saint-Sauveur of Alfa also Archbishop Sigebod of Narbonne, who had been present at court in 881 , was in contact with the king, sending a legate to demand a further diploma for his Church. ${ }^{226}$ Contacts with the south of the realm are thus shown to have remained intact.

\section{II.3 New faces on the rise: Charles the Fat}

After Carloman's sudden death early in December 884, the West Frankish nobles sent for Emperor Charles the Fat to take over the realm. ${ }^{227}$ Up until his deposition by East Frankish nobles four years later, Charles had visited the West only twice. His initial voyage to receive the homage of the Western nobles brought him

220 DCmII 86 (deperditum).

221 DCmII 91 (deperditum).

222 DDCmII 70 and 71.

223 DDCmII 66 (Saint-Sauveur, intervention by Hugh the Abbot) and 72 (Marseille, intervention by Hugh and Fortar of Bourges).

224 DCmII 69.

225 DCmII 74.

226 DCmII 73.

227 See chapter I.1.3. 
from Italy via Lotharingia to Ponthion. ${ }^{228}$ In 886 , he undertook a campaign to relieve Paris from a Viking siege, an endeavour that ended in him negotiating the payment of tribute and allowing the Northmen access to Burgundy. ${ }^{229}$ However, contacts with the West Frankish elite were not limited to these periods. On various occasions, he was sought out by individual nobles while absent from the realm, ${ }^{230}$ visits that signal special relations between them and the emperor.

According to the Annales Vedastini, the decision to call Charles into Francia was made by the Franks, who sent Theoderic of Vermandois to the emperor. ${ }^{231}$ Of course, the wording of the annals does not have to be taken literally and there may indeed have been nobles who opposed the choice. However, since there are no further reports of any such opposition, the leading men seem to have backed the call, a supposition evident from the fact that in Theoderic they chose one of their own as leader of the delegation. During the interregnum, both Hugh the Abbot and Gauzlin continued to exercise considerable influence: Hugh sent envoys to the Northmen now returning to the realm, ${ }^{232}$ while Gauzlin secured the vacant see of Paris for himself ${ }^{233}$ and installed his nephew Ebolus as abbot of Saint-Germaindes-Prés. ${ }^{234}$ Given the unity shown by the Frankish nobles, both appear to have favoured the emperor as Carloman's successor. In the case of Gauzlin, it is also worth pointing out the connections he had made after his capture in the battle of Andernach to nobles from the East Frankish kingdom ${ }^{235}$ and which he already had used after the death of Louis the Stammerer. That he did indeed exert his influence on Charles' behalf may also be indicated by the speech Abbo attributed to him in his famous poem, praising the emperor's qualities. ${ }^{236}$ indicates that he had become its abbot at least twelve years earlier. See also Bautier, Recueil Eudes,
XXII. It seems generally assumed that Gauzlin passed Saint-Germain-des-Prés to his nephew Ebolus when he became bishop of Paris. Waquet, Abbon, 21, n. 3.

235 Annales Bertiniani 879, 235-236.

236 Abbo, Bella I, v. 48-52, 18:

Urbs mandata fuit Karolo nobis basileo, Imperio cujus regitur totus prope kosmus Post Dominum, regem dominatoremque potentum, Excidium per eam regnum non quod paciatur, Sed quod salvetur per eam sedeatque serenum. 
While the part these men took in the decision to call the emperor seems to be clear, assessing their influence at Charles' court poses considerable problems. Hugh the Abbot appears only once in the sources before his death when his absence from the emperor's first campaign against the Northmen due to an illness is noted. ${ }^{237}$ Whether this illness was indeed the real issue or just a pretext to cover a loss of influence must remain an open question. Posthumously, however, he is mentioned several times. The Annales Fuldenses describe Hugh and Gauzlin both as "abbots and leading commanders of Gaul, on whom the Gauls had placed all their hopes against the Northmen," whose whose deaths had encouranged the enemy and led to the new attack. ${ }^{238}$ However, this note clearly confuses the chronology-Hugh and Gauzlin only died at the time of the siege of Paris-and reads more like a laudatio on both their lives rather than on their actual political importance during the year preceding their deaths. Similarly, Hugh's posthumous appearances in Charles the Fat's diplomas ${ }^{239}$ may do him honour, but only reflect the memory of a man who had shaped West Frankish politics for a long time and are, moreover, linked to abbeys that had been under his control for a long time. However, there is one event that possibly casts some light on Hugh's position at the imperial court: when the second campaign against the Northmen was organised, raising levies in Neustria and Burgundy, regions where Hugh had been most influential, the command went to Ragenold, the dux of Maine (dux Cinomannicus), instead of Hugh. ${ }^{240}$ This may of course have been due to his already mentioned illness, although it seems just as likely that Hugh's influence was finally on the wane.

In the case of Gauzlin, who Simon MacLean considers one of the key figures in what he labelled the "North Frankish circle, ${ }^{241}$ we encounter the same problematic situation. His prominent role in the defence of Paris against the Northmen is well attested by the Annales Vedastini and Abbo's Bella Parisicae Urbis, yet is easily explained by his leading role as bishop of the city and does not necessitate any proximity to Charles. ${ }^{242}$ More promising is a phrasing in the Translatio S. Mederici, stating that Gauzlin could not take part in the translation because he was occupied with various duties in service of the realm, ${ }^{243}$ although this may relate to

237 Annales Vedastini 885, 56.

238 Annales Fuldenses (Mainz continuation) 886, 104: Interea Hugo et Gozilin, abbates et duces praecipui Galliae regionis, in quibus omnis spes Gallorum contra Nordmannos posita erat, defuncti sunt. Unde Normanni audaciores effecti et de sua munitione egressi omnique regione potiti venationes et varios ludos nullo prohibente exercebant.

239 DDChF 143 (Saint-Aignan), 145 (Saint-Germain of Auxerre), 161 (Saint-Martin of Tours).

240 Annales Vedastini 885, 57.

241 MacLean, Kingship, 102-105.

242 MacLean's final argument in favour of Gauzlin considers that Charles' diploma for Saint-Maur of Fossés (DChF 149) was related to Gauzlin, the abbey having been founded by Gauzlin's father Rorico and also held the latter's grave. This seems to be a confusion between Saint-Maur and the closely related abbey of Glanfeuil, which indeed was founded by Rorico. On the two abbeys, see Koziol Politics, 156-161 and 481.

243 Translatio S. Mederici, 111: ... saepe dictus Episcopus variis regni utilitatibus occupatus adesse minime potuit. 
his participation in the campaigns against the Northmen in 885. His influence in Francia best becomes visible in the letters he sent to Count Erkanger, asking him to fetch help from the emperor. ${ }^{244}$ Yet, while this episode certainly underlines his good relations with leading members of the Frankish nobility, it does not allow us to draw any conclusions on his standing with the emperor. Did Gauzlin use an intercessor because he feared a direct approach would not yield the intended results?

Finally, Theoderic and his brother Aledramnus appear as military leaders in the context of the siege of Paris. Aledramnus took over command of the fortress built at Pontoise but was soon forced to withdraw to Beauvais. ${ }^{245}$ In Abbo's poem, both he and Theoderic are named as leading a force of 600 men to a victory against the Northmen in the course of the siege, most likely the same force that had been sent by the emperor to the aid of Paris. ${ }^{246}$ At least in the second case, it seems clear that they had received their orders from the emperor. Aledramnus can also be seen at the emperor's court, the only one among the nobles mentioned so far who came to meet Charles on his first journey to the West, intervening together with a certain Bishop Warnulf in favour of the church of Chalon-sur-Saône as "our beloved count" at Gondreville. ${ }^{247}$ Warnulf's see is unknown, ${ }^{248}$ although his description as "our most beloved bishop" indicates his importance for Charles. Aledramnus' connection to Warnulf further emphasises his own role in the emperor's network in the Western realm. So far, the two brothers emerge as the only Westerners who appear to have been close to the emperor.

In contrast, to most of those who had formed the dominant circle at Carloman's later court, Bernard of Auvergne, who had been an important ally to them although never visible for a long period at the royal court, appears to have quickly entered into the circle around the emperor and received a very honourable welcome. He intervened on behalf of the church of Lyon together with the emperor's closest advisor, Bishop Liutward of Vercelli. He is described as "most illustrious marchio," a very rare title that further underlines his importance. ${ }^{249}$ The diploma also seems to acknowledge Bernard's control over Lyon, ${ }^{250}$ appearing to be another concession made by the emperor to tie the most powerful man in Aquitaine to him and likely the result of their long established contact if the charters from Saint-Julien of Brioude can indeed be interpreted in this way.

244 Annales Vedastini 886, 59.

245 Annales Vedastini 885, 57-58. The report of the annals led to the belief that Aledramnus was count of the Vexin, where Pontoise is situated (Kalckstein, Geschichte, 472), or of Beauvais (Favre, Eudes, 19). Lot, Notes, 150, considers him as count of Laon, due to DLS 28, in which he was given property in the Laonnais. MacLean, Kingship, 106 names him as count over all three.

246 Abbo, Bella II, v. 315-329, 88-90.

MacLean, Kingship, 106.

247 DChF 120, 190: ....dilectus nobis comes...

248 DChF 120, 190: ... dilectissimus nobis presul... See, for example, Depreux, Prosopography, 100, n. 9.

249 DChF 123 (20th June 885, Etrepy), 196: ... illustrissimus marchio...

250 Auzias, Aquitaine, 419-420 and Kienast, Herzogstitel, 165-166 with n. 10, 1. 
Among those seeking out the emperor, we can also find two others who belonged to the circle dominating Carloman's court. In the aftermath of the siege of Paris, both Bishop Berno of Châlons and Count Ansgar of Oscheret requested diplomas. ${ }^{251}$ Ansgar's appearance points towards a wider circle of nobles in Upper Burgundy on which Charles now relied. He intervened together with Count Milo of Langres for the provost of the church of Langres, the see of Bishop Geilo. The latter was the single largest recipient of the emperor's diplomas within the West Frankish kingdom, ${ }^{252}$ a key figure in the emperor's control over Upper Burgundy. ${ }^{253}$ It is not only the number of royal charters, however, that characterises the importance of see and bishop for Charles. Geilo was one of the first to meet the emperor, intervening on behalf of Saint-Bénigne and Saint-Etienne of Dijon, ${ }^{254}$ both of which indicate his influence in the region. His requests were also supported by Liutward of Vercelli ${ }^{255}$ and even Charles' wife, the empress Richgard. ${ }^{256}$ Finally, Geilo was one of the few who did not wait for the emperor to come to the West, but sought him out on two occasions when he was in the East. ${ }^{257}$ The relation between Geilo, Milo and Ansgar, as demonstrated by the intervention of the latter two for the provost of Langres, appears to have been a close one. After the emperor's death, all three of them belonged to the supporters of Wido of Spoleto. ${ }^{258}$

Contact with nobles from Upper Burgundy was not limited to these three, however. Robert of Troyes, whose contact with Ansgar we mentioned above, had died in the defence of Paris but was succeeded by his nephew Adelelm, ${ }^{259}$ who continued to support the besieged Parisians. ${ }^{260}$ Considering Robert's close relations with the abbey of Montiéramey, it does not seem too far-fetched to assume that it was at Adelelm's request that Charles now issued another diploma for the monastery. ${ }^{261}$ Two more royal charters were petitioned for by a certain Count Rudolf and his son Pippin. ${ }^{262}$ In both diplomas, property in northern Burgundy, Bar and

251 DDChF 150 (Berno) and 155 (Ansgar).

252 DDChF 117 (Saint-Bénigne of Dijon) and 118 (church of Dijon), 129, 147, 152, 153 and 154 (church of Langres); 162 went to Saint-Philibert of Tournus, but was requested by Bishop Geilo for his former abbey. On Geilo, see also Bautier, Diplômes, 216-230. Bautier's depiction of Geilo as a man without personal morals (Bautier, Diplômes, 216 and 223) has been critisised as anachronistic by MacLean, Kingship, 110-111, who points out that Geilo's rise under several different masters was indeed rather common at that time.

253 MacLean, Kingship, 114.

254 DDChF 117 and 118 (20th May 885, Granges).

255 DDChF 129 and 153.

256 DChF 154.

257 DDChF 129 (at Lorsch) and 162 (at Kirchen).

258 Geilo crowned Wido at Langres (Annales Vedastini 888, 64). Milo and Ansgar followed Wido back to Italy. Favre, Eudes, 85.

259 Abbo, Bella I, v. 438-455, 48-50.

260 Abbo, Bella II, v. 209-216, 80-82.

261 DChF 141 (deperditum).

262 DDChF 116 and 137. MacLean, Kingship, 109 identifies this Rudolf as marchio of Upper Burgundy. This seems to be unfounded since Rudolf is not known to have had a son named Pippin (see Demotz, Bourgogne, 36). 
the Lassois, was given to fideles, which points towards them being local counts. Finally, Bishop Agelmar of Chalon-sur-Saône ${ }^{263}$ and the new abbot of Saint-Martin of Autun, Gregory, belonged to those in contact with the king. ${ }^{264}$

Two groups can be distinguished among the nobles mentioned so far. The old core, which had formed the inner circle around Carloman and his predecessors, was still intact and cooperated with the emperor. However, at the same time their influence at Charles' court is impossible to determine. Of its members, only Aledramnus appears in the emperor's diplomas while the connections of Hugh, Gauzlin and Theoderic with Charles remain in the dark. All of them were strongly involved in West Frankish affairs, most notably in the fight against the Northmen. Yet, at the same time, their influence in royal politics appears to have diminished, probably caused in large part by Charles' absence from the realm, depriving them of the opportunity to influence the decision-making process at court. On the other hand, for Bernard of Auvergne, always more an associate than a constant member of the old circle, not much appears to have changed. His position had increasingly become more distant from court, and apparently mainly focused on affairs in Aquitaine. Here, he acted for the emperor as a local power broker, channelling the royal will into the region south of the Loire via his own connections. ${ }^{265}$

At the same time, we can note the rise of other nobles, such as Geilo of Langres, who now became a key figure in securing Upper Burgundy for the emperor. Geilo, like Ansgar of Oscheret, had already been in contact with the dominating circle, yet now his position appears to have been much more central and, most of all, independent of them. And there were other men who rose through the emperor's protection. The most interesting example is Ragenold, according to the Annales Vedastini the $d u x$ of Maine. ${ }^{266}$ When he was killed, the newly assembled army made up of contingents from Neustria and Burgundy dispersed, indicating that he had been its leader. That the death of the commander led to the end of the entire campaign was not extraordinary ${ }^{267}$ In 866 , Robert the Strong's death in combination with Ramnulf's injury lead to the dispersal of their force ${ }^{268}$ and similarly in 887 Duke Henry's death in battle was followed by his army returning home. ${ }^{269}$ All of these nobles appear to have held key positions at the head of their respective armies in which they could not easily be replaced. In the case of Ragenold however, the question arises as to how he had become the leader of such an army. No sources indicate that he belonged to the circle of nobles dominant at court. It has been suggested that he might have been a relative of Gauzlin, ${ }^{270}$ yet how close

264 DChF 122.

265 See also MacLean, Kingship, 69-70.

266 Annales Vedastini 885, 57.

267 See also Leyser, Warfare, 39-40.

268 Annales Bertiniani 866, 130-131.

269 Regino, Chronicon 887, 126.

270 Werner, Adelsfamilien, 142 and Werner, Gauzlin, 457-459. 
this relationship was remains unclear. The only thing we know for certain about him is that he was in conflict with Bishop Lambert of Le Mans, who excommunicated him during 883-885 due to him having appropriated Church income. ${ }^{271} \mathrm{He}$ was certainly a powerful noble based in Neustria, possibly the leader of a march against the Bretons and Northmen. ${ }^{272}$ Although our sources do not mention any influence of the emperor in the assembling of the army, it seems very unlikely that he was not involved at least in the appointment of its commander. As the annals of Saint-Vaast report, the army consisted of forces of "all who were in Neustria and Burgundy," ${ }^{273}$ pointing to a large-scale operation. Given that Hugh the Abbot, who held honores in both regions, appears to have been passed over as commander, it seems likely a central authority - the emperor-was behind its organisation. Ragenold thus would have been Charles' choice, undoubtedly based on his position, experience and, if indeed correct, his relation to Gauzlin. But most of all, it was also a choice to appoint someone new to a key position in the defence of the realm.

Ragenold was not the only new noble Charles appointed-or had to appointfollowing the deaths of Hugh the Abbot and Gauzlin. Anskeric, who now became bishop of Paris, is another example. He was the brother of Count Tetbert of Meaux and appears to have competed with Gauzlin for the see of Paris upon Angelwinus' death. ${ }^{274} \mathrm{He}$ was also one of the first to meet with Charles upon his initial visit to the West, intervening with Count Rudolf and his son Pippin on behalf of a fidelis from Upper Burgundy, ${ }^{275}$ thus establishing contact at a very early moment. Hence, Anskeric appears to have recommended himself to Charles at a very early point, while his nomination also shows the interest of the emperor in installing trusted men in key positions in the realm. The connection between the two also became apparent in 887, when Anskeric met Charles to take over the tribute due to the Northmen..$^{276}$

However, the most important man promoted by the emperor was without a doubt Odo, son of Robert the Strong. Olivier Guillot, in an article dedicated to the Robertian's early career, claimed that, after the siege of Paris, Odo was exercising royal prerogatives such as distributing honores in the Western realm despite Charles still ruling. ${ }^{277}$ This, however, was convincingly refused by Simon MacLean, who in turn argues for a close cooperation between the count and the emperor instead of a political rivalry for power, ${ }^{278}$ a view we also follow. Odo had succeeded Conrad as count of Paris some years earlier but remained invisible during

Actus pontificum Cenomannis, 339-340.

Guillotel, Marche, 12.

Annales Vedastini 885, 57: Inter haec omnes qui morabantur Neustria atque Burgundia adunantur et collecto exercitu adveniunt quasi debellaturi Nortmannos.

See chapter I.2.2.

DChF 116. See also chapter II.3, n. 262.

Annales Vedastini 887, 63.

Guillot, Étapes, 203-206 and Formes, 61-62.

MacLean, Kingship, 49-55. 
that time. He appears to have been politically close to Gauzlin ${ }^{279}$ and they acted together in the defence of Paris, as becomes clear from Abbo's poem. ${ }^{280}$ Besides Gauzlin, he also enjoyed the support of Theoderic and Aledramnus since he married the latter's daughter Theodrada, probably during the early $880 \mathrm{~s} .{ }^{281}$ His role became of central importance only after the bishop's death, when he took over responsibility for the city. ${ }^{282}$ Contact with Charles may have been established even before the emperor took over the West, since Odo's brother Robert appears to have held a countship at Namur ${ }^{283}$ and had intervened in one of Charles' diplomas two years earlier. ${ }^{284}$ Robert's importance at court becomes even clearer from the phrasing used to describe him in the charter, "our most loyal noble man count Robert", the use of a superlative generally being reserved for special cases. ${ }^{285}$ After the siege of Paris was lifted, Charles granted Odo the honores of his father Robert the Strong, ${ }^{286}$ namely the counties along the Loire together with the abbeys SaintMartin of Tours and Saint-Aignan. A number of diplomas issued on this occasion, confirming an exchange for Saint-Aignan and confirming the property and immunity of the church of Tours, ${ }^{287}$ further document Odo's newly won importance. His key position in the emperor's West Frankish affairs is underlined by a diploma for Saint-Martin issued at his request at Kirchen in June $887 .{ }^{288}$ It was a confirmation of a charter from Odo two months earlier, in which he returned property to the monks. ${ }^{289}$ However, the parts copied by the royal chancellery contain the prayer services for himself and his father Robert the Strong, ${ }^{290}$ an almost unique concession in the emperor's diplomas. ${ }^{291}$ The choice to appoint Odo-apart from

Favre, Eudes, 13; Werner, Gauzlin, 451, MacLean, Kingship, 108.

Abbo, Bella I, v. 40-46, 16-18.

See chapter I.2.2. The date of the marriage is suggested by Favre, Eudes, 15.

As shown for example the desperation of the inhabitants during the time of Odo's absence from the city. Annales Vedastini 886, 60-61: Odo vero, videns affligi populum, clam exiit de civitate, a principibus regni requirens auxilium et, ut imperatori innotescerent velocius perituram civitatem, nisi auxilium ei daretur. Dehinc regressus ipsam civitatem de eius absentia nimis repperit merentem.

MacLean, Kingship, 108. See also chapter III.2.1.

DChF 105 (May/June 884), 169: ...vir nobilis Rotbertus comes fidelissimus noster...

On the use of epithets, see Brunner, Fürstentitel.

Annales Vedastini 886, 62; Regino, Chronicon 887, 126.

DDChF 143 (27th October 886) and 146 (29th October 886). MacLean, Kingship, 109 assumes that both diplomas were issued before Odo was installed in his father's honores. However, both date to late October 886, most certainly at the same moment or after the installation of Odo in Neustria. DChF 139 (22nd August 886) for Saint-Martin of Tours, which is further viewed by MacLean as showing that Odo was already in a close relationship with the emperor before, only indicates that he had given the abbey some property at some point earlier (224: ...Noviento, quam Odo integerrie ad peculiare fratribus contulit.). The circumstance that the charter was demanded by a group of monks and not Odo or their abbot points towards the conclusion that the succession of Hugh the Abbot was still unresolved. The same accounts for DChF 145, in which monks of Saint-Germain of Auxerre likewise requested the confirmation of their properties and rights.

DChF 160 (16th June 887).

DOdo 55 (April 887).

DChF 160, 206.

1 MacLean, Kingship, 53. Bishop Liutward is the only other case. DChF 92. 
his brother's connection to the imperial court-is not surprising. When Charles the Bald had installed Odo's father in the region, he had also settled some of Robert's supporters there. ${ }^{292}$ As Karl Ferdinand Werner has shown, these same men were still in place when Odo took over and supported him. ${ }^{293}$ Charles' diploma for Saint-Martin of Tours, issued after Hugh the Abbot's death, tells us that Odo had given property to the monks ${ }^{294}$ and his intervention with Bishop Adalard of Tours for the latter's church ${ }^{295}$ indicates that the two, at least after Odo's appointment, were close as well. Hence, Odo appears to have been well connected in the area and was therefore an ideal choice for the vacant position along the Loire. In addition to the bishopric of Paris, Charles thus secured another key position in the Western realm for himself.

Charles tried to use all opportunities presented to him to set up men of his choice in central positions and to tie them to him. In the case of the see of Auxerre, the emperor tried to install his candidate Teutbert, yet failed when Bishop Walter of Orléans intervened. ${ }^{296}$ Instead, Herfrid, one of Walter's relatives, ${ }^{297}$ was elected. The Gesta Pontificum Autissiodorensium do not know of Teutbert, but report that Herfrid was the royal candidate. ${ }^{298}$ Of course the Gesta are not an entirely reliable source. ${ }^{299}$ Nevertheless, it would seem possible that, encountering Walter's resistance, Charles altered his decision and settled for a candidate who was also agreeable to the bishop of Orléans. In this case, it seems likely that the emperor's lost diploma for the church of Auxerre was issued at Herfrid's request ${ }^{300}$ and that, like Anskeric, Herfrid would then have been one of the emperor's men. Concerning the appointment of bishops, it has also been suggested that the elevation of Walter's nephew, another Walter, to the see of Sens was also initiated by Charles. ${ }^{301}$ Finally, at Paris, Charles seems to have favoured Abbot Ebolus of Saint-Germaindes-Prés, Gauzlin's nephew, for whose abbey he issued a diploma. ${ }^{302}$ It also appears that, upon Gauzlin's death, Ebolus was given control over the deceased's other abbeys, namely Saint-Denis and Jumièges ${ }^{303}$ indicating that Charles tried to tie the abbot even closer to him. In addition to these men, the emperor also strengthened his relations with other nobles. The fight against the Northmen had left a number

Annales Bertiniani 866, 126: Karolus Rotberto comiti abbatiam Sancti Martini ab Engilwino ablatam donat et eius consilio honores qui ultra Sequanam erant per illius complices dividit.

293 Werner, Untersuchungen IV.

294 DChF 139. See chapter II.3, n. 287.

295 DChF 146.

296 Bischoff, Anecdota, N IV, 129-130. Letter of Walter of Orléans to the clergy of Auxerre, recommending them not to vote for Teutbert.

297 Gesta Pontificum Autissiodorensium I, 169.

298 Gesta Pontificum Autissiodorensium I, 169-171.

299 See Janin, Heiric.

300 Kehr, Kanzlei, 33. The deperditum is mentioned by DChS 42.

301 MacLean, Kingship, 116.

302 As becomes clear of DChS 45.

303 Werner, Gauzlin, 461; Bautier, Recueil Eudes, XXIII. On Ebolus see also the studies of Poupardin, Note and Levillain, Abbé. On his relations, see Oexle, Bischof. 
of counties vacant and thus provided Charles with various honores to distribute among men of his choice, which he did before returning to the East, ${ }^{304}$ although unfortunately nothing further is known about these measures.

In addition to these more intense contacts, we can also make out a number of other nobles and institutions seeking out Charles. Archbishop Fulk of Reims had already communicated with the emperor in 883 , when he asked him to intervene on his behalf with the pope to be given the pallium and a confirmation of the privileges of his Church. ${ }^{305} \mathrm{~A}$ year later, he successfully requested the restoration of goods in Thuringia and Lotharingia to the abbey of Saint-Remy of Reims when the emperor was visiting the western regions of his realm. ${ }^{306}$ Once Charles had taken over Francia Occidentalis, however, Fulk does not appear to have belonged to those enjoying imperial favour. Flodoard only records one letter from this time, probably dating to between February and July 886 due to its references to the siege of Paris. In this, he urged Charles to protect the realm and painted a picture of the consequence of the loss of the city in the darkest colours. ${ }^{307}$ According to Gerhard Schneider, this was a sign of his interest in the wider affairs of the realm and his claim for the primacy of the church of Reims. ${ }^{308}$ While this letter may indeed have contributed to the emperor's intervention, it is more likely that the pleas from Gauzlin and Odo carried more weight.

Apart from Fulk, Charles was also sought out by other churches and abbeys throughout the realm. From Septimania came Bishop Theotarius of Girona to receive a confirmation of the properties and rights of his church. ${ }^{309}$ Charles restored property alienated from the Aquitainian abbey of Saint-Agricol and Saint-Vital. ${ }^{310}$ In Burgundy, he did the same for the canons of Saint-Vincent of Mâcon at the request of their bishop, Letard. ${ }^{311}$ Another bishop from Burgundy, Emmensus of Nevers, received a confirmation for his new foundation at Cusset, ${ }^{312}$ as did Abbot Bonifatius of Sainte-Seine for his own abbey. ${ }^{313}$ Finally, in the North, Saint-Maur of Fossés ${ }^{314}$ and Saint-Médard of Soissons ${ }^{315}$ were granted diplomas. This last case

304 Annales Vedastini 886, 62.

305 Flodoard, HRE IV, c. 5, 380. In particular, the confirmation of the privileges appears to have been a central problem. Schneider, Erzbischof, 33-34.

306 DChF 106 (30th June 884, Metz).

307 Flodoard, HRE IV, c. 5, 380: Memoratque civitatem Parisiorum, quam caput asserit et introitum regnorum Neustrie atque Burgundie, barbarica cingi obsidione citoque capiendam, nisi dei subventum fuerit clementia. Que si capta fuerit, totius dispendium regni se perpessuros, tamque periculose hec iam mala grassari, ut a predicta urbe Remos usque nichil tutum remanserit; nulla nisi perversorum christianorum barbarisque consentientium secura sit habitatio, quorum multi christianam deserentes religionem paganorum se societati coniunxerant ac tuitioni subdiderant.

308 Schneider, Erzbischof, 38.

309 DChF 148.

310 Kehr, Urkunden Karls III., XVI, referring to DOdo 49.

311 DChF 151.

312 DChF 138.

313 DChF 140

314 DChF 149.

315 DChF 163. 
appears to have been more of a personal matter, the emperor donating a villa to the abbey for the sake his soul as well as those of his ancestors and predecessors. ${ }^{316}$ The abbey was also the burial place of Duke Henry, one of his closest advisors and his most important commander, who had been killed the year before, ${ }^{317}$ which may also have been a reason for the emperor's choice to grant the diploma. This is a rather limited number of contacts, yet considering that Charles only visited the West on two occasions and for very short periods of time, these diplomas nevertheless demonstrate that the emperor, like his predecessors, was in contact with all parts of the realm.

\section{II.4 Resistance, integration and rebellion: Odo}

The death of Charles the Fat had left a vacuum at the centre of West Frankish politics. For the first time since the death of Louis the Stammerer, nobles formed rival factions, each trying to establish their own candidate on the throne. Odo's main supporter is identified by the Annales Vedastini as Count Theoderic of Vermandois, ${ }^{318}$ which is hardly surprising considering their relationship. Theoderic also served Odo shortly afterwards as an ambassador to Arnolf, ${ }^{319}$ his last appearance in the sources. By 895, he was dead and his honores had been passed on to his son. ${ }^{320}$ Odo's brother Robert was also a key figure in these events; Odo appears to have passed on the majority of his honores to Robert upon becoming king. No contemporary source actually mentions this procedure, but the Annales Sancti Germani Parisiensis note that, in 888, Robert became count of Paris, ${ }^{321}$ he furthermore appears as abbot of Saint-Martin of Tours around that time ${ }^{322}$ and finally is addressed as "our senior" by Viscount Garnegaud of Blois. ${ }^{323}$ Moreover, the other viscounts of the Robertian counties along the Loire, Hucbert, Hardrad and Hatto were now in close contact with the king's brother, as a number of private charters from Angers and Tours show. ${ }^{324}$ The honores having been passed on, Odo nevertheless maintained contact with the Neustrian bishops. Raino of Angers received two diplomas, ${ }^{325}$ the church of Orléans, where his notary Throannus

316 DChF 163, 265: ...quod ob remedium animae nostrae ac progenitorum nostrorum regum scilicet praedecessorum nostrorum...

317 Regino, Chronicon 887, 126. Regino's date is off by one year.

318 Annales Vedastini 888, 64: Verum, ut diximus, Franci divisi, aliqui Widonem, qui partibus Fulchonis archiepiscopi favebant, alii Odonem, inter quos Theodericus comes eminebat, in regno statuere contendebant.

319 Annales Vedastini 888, 65.

320 By 895, Saint-Quentin was in the hands of his son (Annales Vedastini 895, 77). Theoderic's control of Saint-Quentin is documented by the Sermo in tumulatione SS Quintini, 272.

321 Annales S. Germani Parisiensis 888, 167.

322 DOdo 19.

323 Favre, Eudes, 96, n. 5 and pièces justificatives VI, 244: ... senioris nostri domini Rotberti comitum...

324 Cartulaire Angers, N XV, 37-39; Favre, Eudes, Preuves IV and DRoI 37.

325 DOdo 17 and 39. 
became bishop after Walter's death, ${ }^{326}$ received another ${ }^{327}$ while a judgement favoured the archbishop of Tours. ${ }^{328}$ Robert's power was further increased when Odo installed him as count of Poitiers in around $892^{329}$ and although he does not appear in any of the datable diplomas before $893^{330}$ nor in the major narrative sources, he was certainly one of the pillars his brother's rule rested on.

Among the others supporting Odo in those early days was an old acquaintance of his, Count Hucbald of Senlis. The two of them are named by a widow complaining to the archbishop of Sens that they had interfered with her rights and possessions. ${ }^{331}$ Hucbald's central role also becomes evident from three of Odo's diplomas, in which he intervened for various important abbeys, namely SaintHilaire of Poitiers, Montiéramey and Saint-Maur of Fossés. ${ }^{332}$ In these, his proximity to the king is further underlined by expressions such as "our procer" and "our fidelis in all affairs." Also close to Odo at this time was his kinsman ${ }^{333}$ Count Altmar, who before 888 had signed one of Odo's charters for the church of Paris next to him and Robert ${ }^{334}$ and who now also witnessed one of Robert's private charters. ${ }^{335} \mathrm{~A}$ few years later, after the death of Ramnulf II of Poitiers, Odo installed him as count of Poitiers ${ }^{336}$ as part of an attempt to tighten his grasp on northern Aquitaine. Altmar rebelled soon after when Odo withdrew the county from him to hand it over to his brother Robert. He took Poitiers by force ${ }^{337}$ and allied himself with William the Pious and Richard the Justiciar. ${ }^{338}$ Odo and Altmar appear to have come to an agreement soon afterwards, since Altmar appears alongside Robert as marchio in a diploma handing over the abbey of Saint-Hilaire of Poitiers to Bishop Egfred. ${ }^{339}$ According to Eduard Favre, this Altmar was the same who held the abbey Saint-Médard of Soissons in $900 .^{340}$ His identification however seems to be partially based on a forgery indicating that, in 893 , Odo had donated property to the abbey ${ }^{341}$ The Altmar in control of Saint-Médard of Soissons is generally thought to have held Arras, where he took over Saint-Vaast in 899, ${ }^{342}$ while

326 Bautier, Recueil Eudes, XXXVI.

327 DOdo 30Bis.

328 DOdo 19.

329 Abbo, Bella II, v. 545-546, 106.

330 DOdo 25 (16th June 891) is a forgery, probably based on an authentic diploma. See Bautier's commentary, 114-117.

331 Bischof, Anecdota, $\mathrm{N}^{\circ} \mathrm{V}, 131-132$.

332 DDOdo 16 (76: ...proceribus nostris, Hubaldo et Heriberto...), 38 (161: ....in omnibus fidelis noster, Hucbaldus comes...) and 48.

333 Abbo, Bella II, v. 535-541, 106. See also Settipani, Préhistoire, 404, n. 24.

334 Cartulaire Paris, $\mathrm{N}^{\circ} 52,70-71$.

335 DOdo 55 (April 887).

336 Ademar, Chronicon III, c. 21, 141. See also Kienast, Vasallität, 462.

337 Abbo, Bella II, v. 544-547, 106-108.

338 Annales Vedastini 893, 73-74. See chapter I.2.4.

339 DOdo 50 (15th October 893-3rd January 898).

340 Favre, Eudes, 15-16, based on Flodoard, HRE IV, c. 10, 402.

341 DOdo 52.

342 Annales Vedastini 899, 81. 
the Altmar close to Odo appears to have been mainly active south of the Loire. ${ }^{343}$ While we therefore have to refuse Favre's identification, Altmar, nevertheless, like Robert and Hucbert, belonged to a group close to the new king whose members owed their influence to their earlier connections to him.

Other allies came from the circle of men elevated by Charles into central positions. The new archbishop of Sens, Walter, carried out his first coronation at Compiègne ${ }^{344}$ and became royal archchancellor in $894 .{ }^{345}$ Whether two other men, Bishop Anskeric of Paris and Abbot Ebolus of Saint-Denis, belonged to Odo's very first allies remains unknown. From June 889 onwards, however, they belonged to the group of his most important supporters. Anskeric, "our most beloved", a phrase that emphasises his proximity to the king, received two diplomas for his abbey Saint-Germain of Auxerre. ${ }^{346}$ Thus, his presence at Odo's side not only meant that Paris was tied even closer to the king, but also that he had a foothold in Burgundy, where local nobles and bishops had originally opted for Wido of Spoleto. Anskeric's Burgundian connections were probably also the reason for his intervention on behalf of Bishop Argrim of Langres, whose appearance at Odo's court in December 889 marked an important victory for Odo. Argrim's predecessor Geilo was one of those who had opposed the Robertian: it was he who had crowned Wido king and therefore Argim's support for Odo meant that the king had obtained the support of Langres. ${ }^{377}$ Furthermore, Anskeric was the brother of Count Tetbert of Meaux and thus strengthened Odo's relations with the nobles of Francia even more. It may have also been due to his influence that, after Tetbert's death, the county passed to Heribert I, who was probably related to the brothers. ${ }^{348}$ Finally, Anskeric's proximity to the king is emphasised by his serving as ambasciator in a diploma for the church of Narbonne $e^{349}$ and becoming archchancellor in 892 in succession to Abbot Ebolus. ${ }^{350}$

Ebolus appears as archchancellor in Odo's first preserved diplomas, dating to 13th June $889 .{ }^{351}$ Next to Gauzlin and Odo, Ebolus had been one of the leaders of the defence of Paris, particularly after Gauzlin's death and in times of Odo's absence from the city. ${ }^{352}$ Ebolus' role in Odo's bid for the throne is difficult to ascertain. His brother Ramnulf II of Poitiers certainly did not side with Odo and only submitted early in $889 ;^{353}$ it is even possible that he himself had aspirations erabilis episcopi reverendique eorumdem monachorum abbatis, nobis valde dilectissimi...

347 Annales Vedastini 888, 64.

348 Werner, Untersuchungen V.

349 DOdo 24.

350 DOdo 30.

351 DDOdo 2 and 3.

352 Abbo, Bella II, v. 163-167, 78.

353 Annales Vedastini 889, 67. 
for the crown. ${ }^{354}$ When Odo went to Aquitaine to meet with Ramnulf, he took only a few men with him. The meeting between the two was undoubtedly preceded by negotiations in which Ebolus, due to his connections to both parties, must have played a key role. Whether he had already become Odo's archchancellor must remain unclear, yet his appointment ensured that the king had a direct link to the most important man in Aquitaine. After the death of Archbishop Frotar of Bourges, Ebolus was also given control over Saint-Hilaire of Poitiers, further strengthening Odo's connection to the most important family in Aquitaine. By the end of 889 , his petition in favour of the abbey was supported by the intervention of the counts Hucbald and Heribert, ${ }^{355}$ thus publicly placing him at the core of the king's network of close associates.

We have already mentioned Heribert's close association with the king and can thus refrain from going into any further detail. ${ }^{356}$ By furthering Heribert, Odo increased his grasp on Francia even more. Control over this region was decisive since it not only held the rich remnants of the Carolingian fisc, but also the palaces and abbeys closely tied to the memory of their family, most notably Charles the Bald's Compiègne, which Odo chose as the place for his coronation. But Francia was also the region where the resistance against Odo had been most fierce: Archbishop Fulk had led the party in favour of Wido and shortly afterwards allied himself with Abbot Rodulf of Saint-Vaast and Saint-Bertin and his cousin Baldwin II of Flanders. ${ }^{357}$ This party started to dissolve only after Odo's victory over the Vikings at Montfauçon and his acknowledgement by Arnulf, when Baldwin submitted himself to the king. ${ }^{358}$ Fulk and Rodulf followed soon after. Odo's second coronation at Reims indicates at least the archbishop's consent, even if not his participation in the ceremony. ${ }^{359}$ Fulk later received two diplomas for his church ${ }^{360}$ while his overall behaviour towards the king, as argued, shows general cooperation. ${ }^{361}$ Rodulf was soon integrated into Odo's reign. His request for a confirmation of the monk's mensa was supported by Queen Theodrada, her only appearance in the royal diplomas. ${ }^{362}$ The moment of the charter's deliverance may have been motivated by the Northmen's return to the Seine-Oise region in $890,{ }^{363}$ necessitating the abbot's cooperation with the king. Securing Francia was probably also the motivation behind

354 Annales Fuldenses (Ratisbon continuation) 888, 116: ...deinceps Ramnolfus se regem haberi statuit. See also chapter I.1.4.

355 DOdo 16 (14th December 889). The identification of the Ebolus in the diploma with Ebolus of Saint-Denis is disputed. We follow Bautier, Recueil Eudes, XXIII and 74-75. Different on this matter Favre, Eudes, 33, n. 10.

356 See chapter I.2.1.

357 Annales Vedastini 888, 64-65.

358 Annales Vedastini 888, 66.

359 Schneider, Erzbischof, 60-62 and Guillot, Étapes, 215-216.

360 DDOdo 31 and 47.

361 See chapter I.2.1.

362 DOdo 20 (21st May 890).

363 Annales Vedastini 890, 68. 
the appointment of Odo's relative, Walker, as commander of the castle of Laon, ${ }^{364}$ as was a diploma for Bishop Dido of the same city, guaranteeing the security of the immunity of the Church's buildings and houses from intrusion by royal agents. ${ }^{365}$ By placing men closely associated with him in central positions, as well as by appeasing former opponents, Odo thus secured Francia for himself.

\section{Burgundy and Aquitaine}

Burgundy, as mentioned, was, besides Francia, the region where Odo's rival for the crown, Wido of Spoleto, had found most of his support. Geilo of Langres crowned him, the counts Milo and Ansgar followed him back to Italy. Winning the acknowledgement of the Burgundian nobles and forging links with its most important representatives were therefore vital when it came to securing Odo's rule over the realm. By June 889, the first steps had been taken. At Odo's first major assembly at Orléans, the king issued a large number of diplomas for recipients from Burgundy, Aquitaine and Septimania, marking his acknowledgement as king over the entire realm. Among those coming from Burgundy were Abbot Odo of Vézelay, ${ }^{366}$ who had already requested diplomas from Louis the Stammerer and Carloman II, and Abbot Biltgerius, who now received a royal charter for his abbey of Saint-Philibert of Tournus. ${ }^{367}$ Even after Geilo had become bishop of Langres, he had preserved strong links with his former abbey, as his intervention on its behalf in front of Charles the Fat demonstrates. ${ }^{368}$ Biltgerius' presence at Odo's court therefore, like that of Geilo's successor Argrim half a year later ${ }^{369}$ is a sign that the core region of Wido's support had now chosen to submit to Odo. A final key figure in the area was Bishop Adalgarius of Autun, who, not unlike Odo of Vézelay, we have already seen at the courts of Louis the Stammerer and Carloman II. While under Carloman his role in firmly establishing royal control over the region was undoubtedly important, especially during the efforts to suppress Boso's revolt (like many others, Adalgarius had originally been one of Boso's supporters), and at Odo's court he seems to have risen quickly to an even more central role. Property was restored to his church ${ }^{370}$ and in 893 he replaced the rebellious Anskeric as royal archchancellor, ${ }^{371}$ thus providing the king with a direct link to the Burgundian nobility. Considering the endeavours of Richard the Justiciar, who around the same time had formed an alliance with two of Odo's enemies, William the Pious of Aquitaine and Altmar of Poitiers, ${ }^{372}$ this measure was surely meant to provide Odo with a finger on the pulse of events in Burgundy.

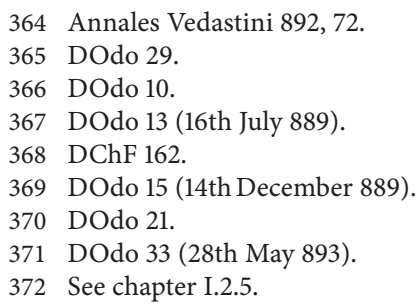


In the case of Aquitaine, we have already noted the importance of Odo's relative, Count Altmar, as well as that of Abbot Ebolus, the royal archchancellor and brother of Ramnulf II of Poitiers, who, according to Ademar of Chabannes, from then on entertained close relations with the king and probably also introduced Count Gerald of Aurillac, one of his close supporters, to the royal court. ${ }^{373}$ After the king had come to an agreement with Ramnulf, abbots Theoderic of Solignac and Gerulf of Beaulieu appeared at the royal court to ask for diplomas. ${ }^{374}$ Again, like Odo of Vézelay, both had been regular visitors to the royal court, acknowledging the rule of Louis the Stammerer and Carloman II, thus demonstrating that Odo had now been accepted as their successor. However, more importantly, both cases also demonstrate that Odo could now also rely on the approval and support of another political heavyweight in the area, Archbishop Frotar of Bourges. In the case of Solignac he acted as ambasciator, while we have already seen him closely associated with Beaulieu in the time of Carloman II. ${ }^{375}$ Further support appears to have come from a certain Count Hugh, to whom Odo gave the honores of the rebellious William the Pious in 892. ${ }^{376}$ In Aquitaine, as in Burgundy, we can therefore observe the king's attempts to establish links allowing him to remain in touch with the local nobility. These could be via important local nobles whom he tied to himself by giving them offices and honores, or men from the circle already surrounding him, who he now tried to install in key positions in the region.

Finally, at the assembly at Orléans in July 889 we can make out a large number of contacts in Septimania and the Spanish March, most notably Bishop Ermemirus of Girona ${ }^{377}$ and Count Sunyer of Ampurias, ${ }^{378}$ representatives of one of the most influential families in the coastal Pyrenees, ${ }^{379}$ both of whom were intervening together on behalf of the abbey Saint-Polycarpe. The latter was not the only monastery in the South receiving a diploma on that occasion. In the case of SaintPaul of Fontclara, ${ }^{380}$ Odo pulled out all the stops to demonstrate to the realm that he was willing to act like a king. With the consent of his closest fideles, ${ }^{381}$ as the charter makes special note of, the king granted the abbey the complete scope of royal attention: confirmation of its property, protection, immunity, the liberty to choose its abbot and some parts of the fisc in the area. In turn, he asked for a regular prayer service to be held for him, his family and the realm, thus not only taking care of his eternal soul, but at the same time ensuring that his rule was remembered in the South. Contact with the far South remained strong after this, with regulars such as Archbishop Theodard of Narbonne and Ememirus' successor at

Ademar, Chronicon III, c. 21, 141.

Do 2 and 4.

377 DDOdo 5 and 7.

378 DOdo 7.

379 D’Abadal, Comtes, 249. On his family, see Lewis, Development, 109-110.

380 DOdo 6.

381 DOdo 6, 32: ... simul cum procerum nostrorum fidelium consensu... 
Girona, Servus Dei, petitioning on behalf of their churches at the royal court ${ }^{382}$ as well as other new appearances such as the abbots Sunifred of La Grasse, Aduvirus of Notre-Dame of Amer and Tenericus of Saint-Martin of Mont-Redon. ${ }^{383}$

Only very few of these men coming from so far away to seek out the king are likely to have wielded considerable influence at the royal court. Yet their presence is a good indicator that the nobles of the entire realm co-operated with the king. This image is also confirmed by the synod of Meung-sur-Loire and the assembly of Verberie in the early 890s. The synod saw the presence of no less than five archbishops and nine bishops, representing Neustria, Francia, Burgundy, Aquitaine and Septimania. ${ }^{384}$ The assembly appears to have been smaller: the original sentence against a monk from Montiéramey, which was confirmed in a later diploma, ${ }^{385}$ had been pronounced by the archbishops of Reims, Sens and Rouen as well as three bishops from Francia, ${ }^{386}$ two of whom, Dido of Laon and Honoratus of Beauvais, later remained loyal to Odo. At the same time, the synod of Meung, marking the acceptance Odo enjoyed in the entire realm like no other event, also appears as a turning point. From 890 onwards, the overall number of diplomas issued by Odo dropped. This, of course is hardly surprising since after this point the initial visits from nobles to acknowledge the new king and to receive confirmations and grants had taken place and diplomatic activity came down to a more normal level. However, it is worth noting that after 892 visits from the distant regions of the realm, as far as the evidence allows us to surmise, ceased entirely. The conflicts breaking out in 892 and the coronation of Charles the Simple early in 893 appear to have deeply affected the stability of Odo's reign. Nobles and ecclesiastical institutions seem to have laid low, waiting for events to unfold.

\section{The later years}

The same years also saw a massive change in Robert's role at court. During the first years of Odo's reign he certainly occupied a key role in his brother's policies. However, after 892, deep ruptures appeared in the circle of supporters the king had constructed to support his reign. Theoderic had probably already died and Aledramnus, Altmar, Ebolus, Anskeric and Heribert were in open rebellion, leaving only Count Hucbald, whose description as "our fidelis in all affairs"387 was undoubtedly not chosen by chance but reflected the contemporary problems of Odo's reign. The king renewed his efforts to increase his base of support, nominating Adalgarius of Autun as his archchancellor, but had to resort back to

382 DDOdo 24 (Narbonne), 27 and 28 (Girona).

383 DDOdo 17 (La Grasse), 23 (Notre-Dame) and 32 (Saint-Martin).

384 DDOdo 26. Present were the archbishops of Sens, Bourges, Tours and Narbonne. In terms of bishops we can note those of Albi, Autun, Béziers, Chartres, Clermont, Girona, Nevers, Orléans and Carcassone. Archbishop Adaldus (of Sens, 927-932) appears to have signed at a later point. Schröder, Synoden, 106.

385 DOdo 30.

386 The bishops of Laon, Beauvais and Soissons.

387 DOdo 38 (894), 161: ... in omnibus fidelis noster... 
Archbishop Walter of Sens when the former was poisoned. Walter certainly carried some political weight, but he did not offer the same connections that Ebolus and Adalgarius had possessed. The weight of influence within Odo's innermost circle therefore shifted massively in favour of Robert, who, in May 893, appeared for the first time in one of Odo's diplomas as "our beloved brother and illustrious count and marchio," intervening on behalf of the abbey of Cormery. ${ }^{388}$ In half the diplomas issued from 893 onwards, Robert either intervened or acted as petitioner. ${ }^{399}$ When, in Neustria, Roger usurped Le Mans, it was Robert who led the army to liberate the city and installed a new count. ${ }^{390}$ Apart from in Neustria, Robert also acted on the king's behalf in Francia, where he played a key role in the king's dealings with Count Baldwin concerning the matter of the abbey of Saint-Vaast. ${ }^{391}$ As the Annales Vedastini report, Robert acted as mediator between his brother and the count: in 895 he accompanied Baldwin's emissaries on their return to the king and received the keys to the abbey when Odo ordered his men to evacuate it. ${ }^{392}$ This indicates that he enjoyed the trust not only of his brother, but also of the count. And indeed, when Baldwin finally submitted to Odo, it was again Robert who had convinced him to do so. ${ }^{393}$ It may be that even earlier he had mediated between the opposing parties of a conflict, this time between his brother and Charles' allies. When, in 894, Odo had made his camp in front of Reims and negotiations were being carried out, it was not he who gave hostages to Charles' party, but Robert, ${ }^{394}$ thus acting as a guarantor of Odo's good will and behaviour. During the second half of Odo's reign, Robert had become his brother's right hand.

Other contacts of Odo during the same period were-as far as we can tellmostly motivated by the political events unfolding at the same time. Altmar was reintegrated by Odo's acknowledgment of his position in the north of Aquitaine, as demonstrated by his intervention together with Robert on behalf of the bishop of Poitiers. ${ }^{395}$ William the Pious, involved in the conflict around the succession of Ramnulf's son Ebalus Manzer at Poitiers, appears to have been neutralised by the grant of Saint-Julien of Brioude. ${ }^{396}$ The diploma issued at the request of the bishop of Clermont for the church of Saint-Agricol and Saint-Vital ${ }^{397}$ was probably also meant to strengthen the ties with the count of Auvergne. Another royal charter issued in July 894 at the request of Bishop Franco of Nevers ${ }^{398}$ may be read as an

DOdo 33 (28th May 893), 146: ... dilectus noster frater atque illustris comes et marchio... DOdo 50 (15th October 893-3rd March 898) also ascribes him the title.

389 DDOdo 33, 34, 40, 41 and 50.

390 Actus Pontificum Cenomannis, 343. See also chapter I.3.

391 On the role of mediators in conflicts, see Althoff, Colloquium, 176-180.

392 Annales Vedastini 895, 77.

393 Annales Vedastini 897, 79.

394 Annales Vedastini 894, 74.

395 DOdo 50.

396 Cartulaire Brioude, $N^{\circ} 182,194-195$. For the date see Brunterc' $h$, Naissance, 104-105.

397 DOdo 49.

398 DOdo 37 (11th July 894). 
attempt to gain a foothold in the border region between Aquitaine and Burgundy, a contact which could be used to observe the ongoings of both William and Richard the Justiciar.

Richard the Justiciar, despite belonging to one of the most noble families of the realm, the Bosonids, ${ }^{399}$ brother to Richilde, Charles the Bald's second wife, ${ }^{400}$ and Boso, the emperor's closest supporter, ${ }^{401}$ had originally only inherited a few possessions in northern Burgundy. However, his birth had brought him close to the centres of decision making, knowing the most important people and in turn being known by them. ${ }^{402} \mathrm{~A}$ first step was his support for the Carolingian cause against his brother Boso, for which he was rewarded with the county of Autun and probably also the abbey of Saint-Symphorien, over which he appears as abbot in a private charter some years later. ${ }^{403}$ In $887 / 888$, he further improved his political connections by marrying Adelaide, sister of the most powerful man in Upper Burgundy, Rudolf, ${ }^{404}$ soon to be king of the same region. Up until 893, his focus appears indeed to have been on his new brother-in-law's regnum as well as Provence, where his nephew Louis now occupied the throne. ${ }^{405}$ A judicium held at Varennes, judging that the monks of Gigny were to be restored possessions they had originally received from King Rudolf, but which had been subsequently alienated by a vassal of the queen, shows Richard in the company of Louis' mother Ermengard. ${ }^{406}$ It seems likely that on this occasion Richard mediated between the interests of his brother-in-law, Rudolf, and his sister-in-law, Ermengard. ${ }^{407}$ Relations with the latter appear to have been equally good: in her son's Louis' coronation charter from Valence, Richard appears as the boy's guardian. ${ }^{408}$

Around the same time, Richard seems to have started to construct a network of support stretching over northern Burgundy. A number of charters and entries show him in the company of local nobles: a donation made by him, probably at a local assembly, to the abbey of Saint-Bénigne of Dijon ${ }^{409}$ was witnessed by Bishop Teutbald of Langres, the counts Girbald, Wido and Radulf as well as by Viscount

399 On the family, see Bouchard, Blood, 74-97.

400 Annales Bertiniani 870, 169. On Richilde, see Hyam, Ermentrude and Richildis, 153-168 and Hartmann, Königin, 119-121.

401 On Boso, see among others Airly, Nearly Men and Bautier, Origines.

402 Robbie, Emergence, 29.

403 Recueil Saint-Symphorien $N^{\circ} 3,13-14$, dating to October 885-887. Whether Richard had joined the army of Charles the Fat to relieve Paris cannot be determined from the sources.

404 Bouchard, Bosonids, 415.

405 Robbie, Emergence, 36. He (37-38) also assumes that Richard supported the coronation of Wido of Spoleto in 888 . However, the sources do not mention him and the supporters of Wido in Burgundy are much more likely to be identified with his relatives who then followed him to Italy (Annales Vedastini 888, 65 and Pokorny, Brieffragment, 620).

406 DProv 28. See Robbie, Emergence, 41, who reads this judgement as "placatory towards Rudolf."

407 Demotz, Bourgogne, 98.

408 MGH Capit. II, N² 289, 377.

409 Chronicon S. Benigni Divionensis, 113. 
Madelgaud of Oscheret. ${ }^{410}$ Count Wido also accompanied Richard at Varennes, together with Count Ragenar, Richard's nephew and brother of his most important supporter, Manasses. ${ }^{41}$ The latter can also be found together with his wife in an entry dating to 890 in the Liber Memorialis of Remiremeont, along with King Louis and his mother Ermengard, Richard and his wife Adelaide, as well as William the Pious of Aquitaine. ${ }^{412}$ By early 893, Richard had become the most powerful noble in Burgundy, a fact that can be deduced from Flodoard referring to him as princeps of Burgundy. ${ }^{413}$ Up until this point, however, leaving Teutbald aside, Richard's support consisted only of laymen-the bishops of the region seem to have preferred Odo, who they joined at the synod of Meung-sur-Loire. ${ }^{414}$

Richard's big opportunity arose when the party around Fulk rebelled against Odo and crowned Charles king. His political connections first paid off just after the rebellion when Richard, William and Altmar joined their forces to see what could be won from the contesters. ${ }^{415}$ That they acted together at this moment can hardly be surprising. As we have seen, William and Richard already appeared together in the entry from Remiremont three years earlier. Fulk's letter to Teutbald, asking the bishop to inquire about their intentions ${ }^{416}$ points to them forming a union during the early 890s. The subsequent agreement with Odo brought Richard the possession of Saint-Germain of Auxerre. ${ }^{417}$ This, however, did not put an end to his ambitions: in the wake of events in Francia, he now turned to more violent means to expand his influence in Burgundy.

The first victim of his new endeavours was Bishop Adalgarius of Autun, Odo's archchancellor and a key royal supporter in the region, who was poisoned and replaced by Manasses' brother Walo, thus ensuring Richard's control of this see as well as the abbey of Flavigny, previously held by Adalgarius. ${ }^{418}$ Soon after, Teutbald of Langres was attacked and blinded by Manasses himself, acting on behalf of

410 Robbie, Emergence, 38. In the conflict over the episcopal see of Langres, Teutbald seems to have been the choice of the locals (Flodoard, HRE IV, c. 1, 367-368).

411 DProv 28. On the identification of the Burgundian nobles at Varennes, see Hlawitschka, Lotharingien, 95-96 and Hlawitschka, Textkritisches, 256-257. Robbie, Emergence, 39-40, argues against Hlawitschka's reading. Manasses and Ragenar appear to have been Richard's nephews from an unknown sister. See Hlawitschka, Lotharinigien, 242, n. 4 and Bouchard, Blood, 192-193.

412 Liber Memorialis Remiremont, 4, fol. 3v. and Hlawitschka, Lotharingien, 243-9. Manasses later also appears in another entry together with his other brother Rampo and Charles the Simple. Liber Memorialis Remiremont, 21, fol. 11v. See also Hlawitschka, Lotharingien, 147-152.

413 Flodoard, HRE IV, c. 6, 395: Rogat etiam sibi remandari de Richardo Burgundionum principe et de Aquitanis, quod eum contigerit scire, et cetera.

414 MGH Conc. V, N³3, 289-292. Present were the bishops Adalgar of Autun, Herfrid of Auxerre and Archbishop Walter of Sens. At the same time, the only connection between Odo and Richard is DOdo 25, which, according to Bautier (Recueil Eudes, 114-117), is either a forgery or a complete re-edition of later times.

415 See chapter I.2.5.

416 Flodoard, HRE IV, c. 6, 395.

417 Sassier, Recherches, 7.

418 MGH Conc. V, N³8, 314-318 and Series abbatum Flaviniacensium, 502. On the role of Walo, see Bouchard, Cartulary, 78. 
Richard, because he had obstructed Walo's installation as bishop. ${ }^{419}$ Teutbald died soon after, upon which Argrim, who seems to have acknowledged Richard's dominance, returned to the see. ${ }^{420}$ Finally, Odo's cousin Archbishop Walter of Sens was imprisoned for nine months by Richard and Manasses, only being released upon the king's intervention and the provision of hostages by the people of Sens. ${ }^{421}$ It is probably at this time that Richard also gained control of the abbey of SainteColombe of Sens ${ }^{422}$ and became count of Auxerre ${ }^{423}$ and Troyes. ${ }^{424}$ By the end of Odo's reign in 897, Richard had become one of the major players in West Frankish politics, a player who needed to be integrated into the king's rule if, after the years of conflict with Baldwin of Flanders and the alliance around Fulk supporting Charles, Odo wanted to restore a stable peace. Odo's last dated diploma from 21st October $897^{425}$ indicates that indeed a solution had been found. Richard not only obtained a rich grant of fiscal property for one of his fideles, but was also depicted as "our beloved and illustrious count", a combination of epithets that otherwise was only used for Robert. ${ }^{426}$

\section{II.5 Conclusion: Continuities and changes}

Thus, the two decades following the death of Charles the Bald were marked by continuities and changes in the networks around the successive rulers. The reigns of Louis the Stammerer and his sons Louis III and Carloman II were shaped by a circle of very dominant nobles. The origins of this circle date back to the last years of Charles the Bald and formed when Louis attempted to create his own bases of support by handing out honores to nobles of his own choice. The key actors in this circle are the well-known Hugh the Abbot, Gauzlin, Boso of Vienne, Theoderic the Chamberlain, Bernard of Auvergne, Bernard of Gothia and Conrad of Paris. Soon, however, this circle began to fall apart due to rivalries for influence at court and control of Louis' sons; the rebellion of Boso weakened it further. Moreover, from 879 onwards, Bernard of Auvergne appears to have taken a more individual course, more detached from the royal court, where he was hardly present. This movement was halted, to some extent, by the

419 Annales Vedastini 894, 75; Flodoard, HRE IV, 377. See also Pokorny, Brieffragment, 612-613.

420 Duchèsne, Fastes II, 190-191. Argrim later appears together with Richard and Manasses at Charles' court (DChS 55).

421 Chronicon S. Petri Vivi Senonensis 896, 96; Annales S. Columbae Senonensis 895, 104.

422 Based on the assumption of an existing sincere charter as the basis for the forgery of DOdo 25. On memories for Richard at Sens, see Robbie, 20-27.

423 Sassier, Recherches, 7 and 9-10. Later on, Manasses' other brother Ragenar became viscount of Auxerre.

424 Saint-Phalle, Comtes, 155. According to him, Richard took control of Troyes just before his attack on Sens. See also Crété-Protin, Église, 307-308.

425 DOdo 42, 180: ... illustris dilectusque nobis comes...

426 DOdo 33, 146: ... Robertus, dilectus noster frater atque illustris comes et marchio... 
reconciliation of Hugh and Gauzlin after Louis III's death, a time that also saw the addition of Theoderic of Vermandois to the group. Nevertheless, by the time of Charles the Fat, the group had narrowed down to only three members, Hugh the Abbot, Gauzlin and Theoderic.

Indeed, by the middle of the 880 s, the death or breaking away of almost all of its members-by 888 only Theoderic was still alive-led to a radical change in the political landscape. Even before the deaths of Hugh the Abbot and Gauzlin, Charles the Fat had shown his will to pursue a novel course by the appointment of Ragenold of Maine as commander of the army against the Northmen, a noble apparently not belonging to the previously existing inner circle at court. After the siege of Paris, Charles used the opportunity created by their and other important nobles' deaths to create his own new network of support by installing men of his choice in central positions and tying others to him by handing over honores. These were typically not new comers, but had started their ascent, like Geilo of Langres and Odo, under Charles' predecessors. He selected them because they represented the ideal choices to create the maximum effect with the least effort: they were already tied into the local politics and possessed their own networks and connections that the emperor could now use as conduits of his royal power without creating discontent or larger frictions among the West Frankish nobility.

After Charles' death, Odo's own claim was opposed by two different groups allying themselves against him. On the one hand, we find nobles from Francia who had been present at the emperor's court, although without playing any politically significant role, notably the new archbishop of Reims, Fulk, Abbot Rodulf of Saint-Vaast and Saint-Bertin, as well as the latter's cousin Count Baldwin of Flanders. The other group consisted of a network of nobles from Burgundy, centred on Bishop Geilo, one of the key figures in the late Charles' network. On the other hand, Odo's own basis of support was an alliance consisting of the last remnants of the old group around Hugh and Gauzlin like Theoderic of Vermandois, those installed and furthered by the emperor in the Paris region as well as relatives and old acquaintances from Neustria and Francia. This drifting apart of nobles formerly belonging to the inner circle of a ruler's predecessor is at first sight reminiscent of the rivalries breaking out during the reign of Louis the Stammerer. However, there appears to have been a crucial difference. Hugh and Gauzlin had known each other for a long time at Charles the Bald's court and learned to cooperate with each other. When their position was threatened by Louis the Stammerer, they quickly joined with others to form an alliance enforcing their interests. The groups opting for Odo and Wido of Spoleto consisted of key actors within Charles the Fat's network of support and therefore were a parallel to the rivalry between Hugh and Gauzlin. However, while the emperor's court was certainly a centre for political decisions, due to Charles absence from the Western realm it never became a rallying point for the West Frankish nobles. Thus, contacts between nobles from the different regions were much more based on a personal level and were certainly not as intense as before. The inner cohesion of the circle around Charles the Bald 
was hence weakened. In addition, the question of succession, open due to the lack of a "natural heir", ${ }^{27}$ meant there was no common candidate whose favour the nobles could seek, thus depriving them of another rallying point.

Odo himself did his best to integrate those nobles originally opposing him into his rule. By allowing certain nobles into his inner circle, he used them as a means to connect with other members of their families-his first archchancellor, Abbot Ebolus, for example, was the brother of Ramnulf II of Poitiers-or to gain access to their local networks-as in the case of his third archchancellor Adalgarius of Autun. However, by the crisis years of $892 / 3$ at the latest, weight within this circle was shifting considerably. After the rebellion of several of its key members, the position of Odo's brother Robert became extremely dominant. Access to the king without Robert appears to have been hardly possible —or desired.

Those nobles with less political influence at court than the main actors we have treated so far are also interesting. Under Louis the Stammerer and his sons, this group consisted mainly of nobles cooperating with the circle around Hugh and Gauzlin, most of all Archbishop Frotar of Bourges, the bishops Walter of Orléans and Adalgarius of Autun as well as Count Ansgar of Oscheret. However, next to them, especially under Louis the Stammerer, we are also able to identify a number of nobles whose connection with the inner circle is less apparent. Count Aledramnus and Abbot Wulfard of Flavigny were related to the royal family, Bishop Berno of Châlons was probably a former member of the royal chancellery. These cases demonstrate that, at least on this level, the king also possessed certain liberties to shape the circle surrounding him. In particular, kinship opened the door for those who also had other connections, as is shown by the case of Count Robert of Troyes under Carloman II. This, of course, does not mean that these men formed a counter-weight against the influence of the key actors. Berno of Châlons, for example, seems to have been well connected to them and Wulfard later allied himself with them to enter their midst. In many of these cases, to whom they actually owed their influence at court is uncertain. If Count Wido, who rose under Carloman II, was indeed Count Ansgar's brother, he would have had a direct link to the group around Hugh and might have owed his influence to them as much as to the king.

This group of secondary nobles was more in flux than that of the dominating circle. Wido and Robert of Troyes, for example, disappeared again with Carloman, as did Count Rudolf with his son Pippin under Charles the Fat. However, there is also some consistency within this group: notably, Frotar of Bourges, Aledramnus, Ansgar, Berno and also Bishop Geilo of Langres appear time and againundoubtedly because their links to the court depended not only on the king, but also on their associations with the group around Hugh and Gauzlin. After the death of these two, however, this group also fell apart. Count Ansgar, for example,

427 Regino, Chronicon 888, 129: Post cuius mortem regna, que eius ditioni paruerant, veluti legitimo destituta herede, in partes a sua compage resolvuntur et iam non naturalem dominum prestolantur, sed unumquodque de suis visceribus regem sibi creari disponit. 
supported Wido of Spoleto and followed him to Italy where he became marchio of Ivrea. Count Wido, to give another example, if it was indeed the same Wido, associated himself with Richard the Justiciar soon after.

Finally, continuities and changes can also be found at the lowest level of contact, that is to say, visits of nobles and representatives of ecclesiastical institutions whose main interest appears to have been obtaining royal diplomas confirming their rights and possessions or to receive donations. Institutions belonging to this group include abbeys such as Solignac, Beaulieu, Vézelay and Saint-Maur of Fossés. All of these institutions seem to have had an especially strong bond to the royal centre and to the unity of the realm. ${ }^{428}$ This was undoubtedly also true for the visitors from Septimania and the Spanish March, who, due to their location on the border region with Muslim Spain, seem to have tried to found their identity on tying themselves to a larger political and historical entity, that is to say, the West Frankish realm. ${ }^{429}$ In the individual cases, however, very profound reasons may also have been behind their motivation to travel the huge distances to the royal court. Often local disputes about landed property and rights arose around new foundations in the area ${ }^{430}$ while the local nobility also tried to gain control over the episcopal sees. For example, in the case of Odo's early diplomas for Septimania, the presence of Count Sunifred and Bishop Ermemirus of Girona was the result of a conflict between the count and Archbishop Theodard of Narbonne, triggering in turn the appearance of the archbishop and his own candidate, Servus Dei. ${ }^{431}$ The Septimanians thus sought the king because they needed a monarch to defend their own interests against their rivals. ${ }^{432}$

While contacts with Septimania were strong, those with Aquitaine appear rather limited, focusing only on a small number of bishoprics and abbeys. This concurs with the evidence we have from the earlier 9th century. Aquitaine, despite Charlemagne's efforts to tie it more closely to the crown by installing new counts, bishops and abbots, had a strong tradition of independence, undoubtedly furthered by the practice of Carolingian kings of making it a sub-kingdom for their sons. Diplomas for Aquitanian recipients are thus rather scarce and the contact between the king and the local nobles was ever more attenuated. ${ }^{433}$ This points us towards another case, however. Burgundy, in contrast to Aquitaine, was among the regions of the West Frankish realm with the closest ties to the royal centre. Its nobles were some of the most influential at court and both churches and abbeys frequently received royal diplomas. The reign of Odo, however, marks a distinc-

428 Koziol, Politics, 92-93.

429 Remensnyder, Remembering.

430 Jarrett, Power.

431 Schröder, Synoden, 122-123, 128-138 and 186-189; Bautier, Dissidence and Recueil Eudes, 21-27; Koziol, Politics, 93-94.

432 Koziol, Politics, 497.

433 Kienast, Wirkungsbereich and Lauranson-Rosaz, Roi, 414-416. See also Levillain, Recueil Peppin I et Peppin II, Introduction; Collins, Pippin I; Lauranson-Rosaz, Auvergne, 40-58; Martindale, Charles; Martindale, Kingdom; Nelson, Charles, 231-232; Gournay, Rouergue, 42-61. 
tive change in these relations. The support Wido of Spoleto enjoyed in the area is a sign of the opposition of the local nobility to Odo. The king did his best to open channels of communication by bringing nobles with regional connections, such as Anskeric and Adalgarius, into his inner circle. Here, however, the Robertian had to compete with other men who tried to tie the local nobility to themselves. Wido of Spoleto, of course, was the first; yet more significant was Richard the Justiciar, who built up his own network of support around 890 and started to expand his influence by violent means in 893 , thus installing himself as an intermediate layer between himself and the royal centre, a development that we will further explore in the following chapter. 



\section{Networks of royal power: Charles the Simple}

After his "restoration" as king (as his diplomas put it ${ }^{1}$ ), Charles was confronted with the effects of the struggle for the crown. According to the Annales Vedastini, Odo, when he felt his death approaching, called upon the nobles of the realm to serve Charles loyally. ${ }^{2}$ Odo's efforts to ease the transition of the crown from himself to the young Carolingian indicate that he was far from certain about how his newly established order would hold up against the shifts within the noble hierarchy brought about by Charles' succession. Odo's reign had been marked by the rivalry of the nobles who had supported his own coronation with the group around Archbishop Fulk. While Odo attempted to integrate these men into his rule after their rebellion, Charles' succession opened another window of opportunity for them to renew their rivalry and increase their influence in royal politics in West Francia. Even more, over the past years, Richard the Justiciar had risen in Burgundy, equalling William the Pious in Aquitaine in power. Their integration into the rule would be another difficult task for Charles. This leads to the first of the questions to be addressed in this chapter. How did Richard's new position affect Charles' rule in Burgundy? Or, more precisely, how did it affect Charles' contacts to the nobles of the region and his own movements? In a wider context looking for answers to these questions means to analyse Charles' itinerary as well as his diplomatic activity in terms of temporal and spatial distribution. The second set of questions deals with the problem of how Charles managed to integrate both his old supporters and Robert (as well as Richard and William) into his rule. Or to put it another way, this means addressing both Charles' own understanding of kingship and the importance he attributed to his Carolingian heritage as well as his ability to manipulate the noble networks around him. His rule lasting 25 years already indicates a remarkable capacity to deal with these problems and his ability to adapt to changes brought about by the deaths of key figures within the network, the necessity of integrating new nobles such as after the acquisition of Lotharingia or by shifts under the surface caused by changes of the relations between individual nobles.

\section{III.1 General overview}

A total of 120 diplomas are preserved from Charles the Simple's reign, 27 as originals, 81 in copies and another 13 as deperdita. ${ }^{3}$ These numbers, although at first

1 From 8th February 898 (DChS 10) onwards, almost all of Charles' diplomas date not only after his regnal years (anno ... regnante), but also of those of his reinstatement to power (redintegrante). See also Wolfram, Herrschertitel, 71-72.

2 Annales Vedastini 897, 79: Qui dum languor per dies singulos incresceret, onmibus rogare coepit, ut Karolo servarent fidem.

3 For an overview of Charles the Simple's diplomas (and changes compared to Lauer's edition), see Lößlein, Urkunden. 


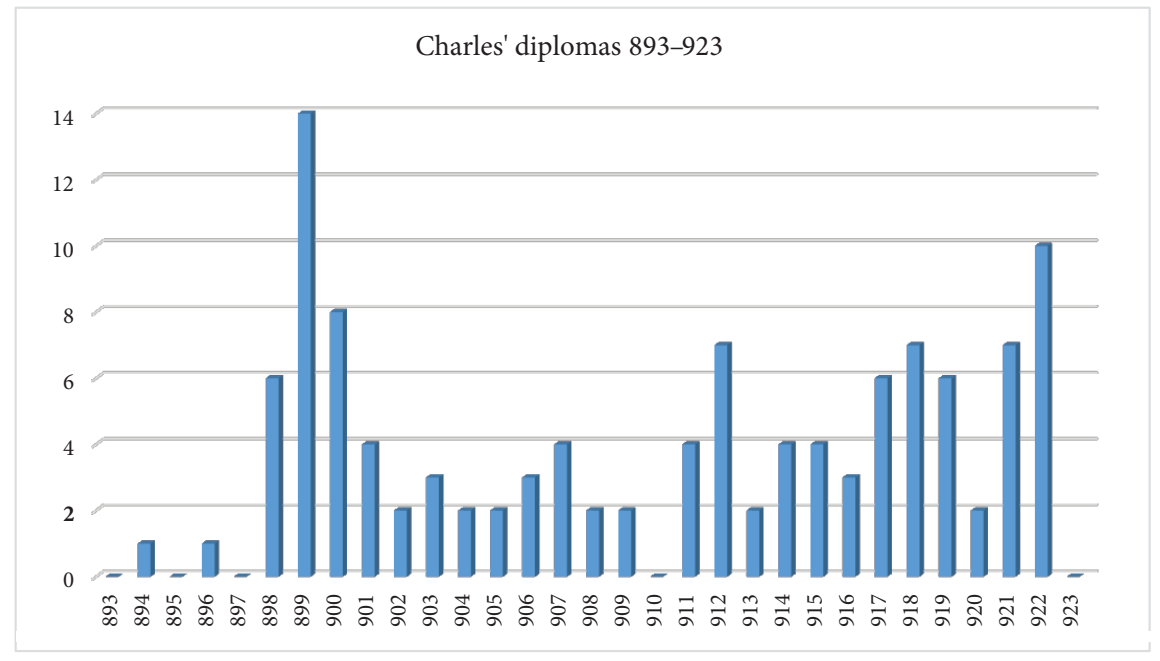

Figure 1: Number of diplomas per year issued by Charles, CC BY 4.0.

glance impressive, are of course problematic in several ways. First, they represent only a fraction of those which were issued originally. ${ }^{4}$ Furthermore, quite a number of these diplomas lack dating formulae, making it impossible to allocate them to a specific moment or place. In other cases, the charters have been interpolated or even rewritten, meaning that they have to be read with even greater care than usual. Also, this ostensibly impressive number of diplomas appears much less so when averaged over the entire reign. Out of the 120, 116 can be attributed to the years 898-922, averaging 4.6 diplomas per year. In comparison, 36 diplomas $^{5}$ of Louis the Stammerer are preserved, averaging 24 diplomas per year, 44 of Carloman $\mathrm{II}^{6}$, resulting in an average of 7.8 and finally 50 in total of Odo or 5 diplomas per year. Louis' reign, of course, is exceptional due to its shortness, but the reigns of Carloman and Odo show that the average number of diplomas per year diminished over the last two decades of the 9th century. ${ }^{7}$ However, the average is perhaps as misleading as the overall total number of diplomas since neither number reflects the fact that there were concentrations of diplomas at certain moments or periods of time. As can be seen in the chart, there are high concentrations of diplomas during Charles' reign, most notable during the first three years of his rule, from the end of 911 to 912 , from 917 to 919 and finally during 921 and 922 .

4 See chapter II, introductory remarks.

5 We omit DDLS 1, 2, 3 and 24 from our count, since the first two were issued under the reign of Charles the Bald, the third is actually Louis' promissio and the fourth the treaty of Fouron.

6 Omitting DDCmII 64, 67 and 75, Carloman's renewed promissio and two capitularies while adding a diploma unknown to the editor. See Baudot, Abbaye.

7 This trend was continued under Charles' successors. Kienast, Wirkungsbereich, 546-547 and 552. 
Most of these concentrations seem, at first glance, to be linked to certain events: to Charles' accession to the throne in 898 , to the acquisition of Lotharingia in late 911 and to the conflicts with Count Gislebert and the rebellions of the nobles from the West from 919 to 922 . However, at second glance, these links are less clear. For example, during the first two years only five diplomas were issued for beneficiaries in Francia ${ }^{8}$ while thirteen went to Septimania and the Spanish March. ${ }^{9}$ Only in 900 can a significant rise in recipients from the North be noted ${ }^{10}$. We will return to this observation later; for the moment, it is worth keeping in mind that, like Odo ten years earlier, ${ }^{11}$ interest in Charles as king was actually rather limited during the first year of his reign and that contacts with nobles in Francia only intensified after two years had already passed. ${ }^{12}$ At the end of his reign, Charles' diplomatic activity was already visibly rising in 917 and 918 although the conflict with Gislebert only started in 919. A closer look at the beneficiaries in these cases reveals the issue: out of the thirteen diplomas issued during these years, six are closely linked to the passing of Queen Frederuna, confirming her donations or establishing memorial services for her and Charles. ${ }^{13}$ Frederuna is also the cause for a sudden spike of diplomatic activity in 907 , the year of their marriage, with two royal charters being closely linked to the event. ${ }^{14}$ Again, we will return to these diplomas at a later point.

Periods of low diplomatic activity can be distinguished from these high concentrations, especially the years from 902 until the end of 911 (with the exception of 907) and from 913 to 916 . By comparing these two periods, we can mark a rise in the average number of diplomas issued per year. For the first period this gives us an average of $2,{ }^{15}$ for the second of $3.3,{ }^{16}$ an increase that can be attributed to the acquisition of Lotharingia which provided Charles with a greater base of support for his own network and increased the demand for royal charters. And, indeed, six of the diplomas issued during these years went to Lotharingian recipients while the rest went to those from the Western realm, thus giving a new average for the latter of 1.8 diplomas per year. While the acquisition of the regnum Hlotharii therefore

8 DDChS 2, 10, 11, 16 and 18.

9 DDChS 6, 13, 14, 15, 19, 20, 22, 23, 24, 25, 26, 27 and D'Abadal, Catalunya II,2 375-377. D'Abadal dates the deperdita identified by him to $898 / 899$ or after 911 . The years $898 / 899$ appear to be most probable, likely as part of the diplomas issued at Tours-sur-Marne.

10 Compared to three in both 898 and 899 (DDChS 2, 10, 11, 16, 18 and 21, the last one going to Aquitaine), we can now note at least eight diplomas for the North (DDChS 28-35, possibly also DChS 8, issued after 900).

11 Odo's earliest datable diploma only dates to 13 th June 889 , so about 18 months after he had taken the crown.

12 Charter reception as a sign of acceptance of the royal sovereignty has been suggested by Mersiowsky, Reappraisal.

13 DDChS 87, 90, 91, 93, 95 and 96.

14 DDChS 56 and 57.

15 From 902 to the end of 911 (without 907), 18 diplomas have been preserved. This does not include DDChS 67 and 68, which were issued in December 911 and mark the acquisiton of Lotharingia.

16 From 913 to 916 thirteen diplomas were issued. 
had an impact on the overall activity, relations with the West apparently suffered only very little.

\section{III.1.1 Charles' itinerary}

The same problem of having a very limited number of diplomas in comparison to the length of the reign also makes it impossible for us to establish a proper royal itinerary. ${ }^{17}$ Due to the lack of narrative sources for most of Charles' rule, there are necessarily large gaps in our knowledge about the whereabouts of the king at certain moments. This problem is increased by the fact that a number of diplomas, as already mentioned, cannot be dated properly or lack a mention of the place of their issuance; furthermore, there are also those cases where the name of the place given in the diploma could not be attributed to a modern location. While a study of the details of Charles' itinerary therefore becomes impossible, we can, nevertheless, take a look at the general picture. As before, it is worthwhile distinguishing between the periods before and after the acquisition of Lotharingia. From Charles' diplomas, we can see that he remained almost exclusively within the region between Seine, Loire and Lotharingia. There were, however, some exceptions: a visit to Saint-Benoît-sur-Loire brought Charles to the southern borders of Robert's power base in Neustria ${ }^{18}$ and two others to Troyes and to Melay close to Richard's in Burgundy. ${ }^{19}$ Within Francia, the most important palace is Compiègne, where we can make note of no less than nine stays. ${ }^{20}$ This is hardly surprising since Compiègne had become the most symbolically loaded royal centre in the Western realm, expanded by Charles the Bald and furnished with a chapel shaped after the one Charlemagne had constructed at Aachen. ${ }^{21}$ Next to Compiègne, the palaces of Verbery, Ponthion, Attigny and Corbeny as well as the castrum of Laon appear on Charles itinerary. ${ }^{22}$

17 On these problems, see also Brühl, Fodrum, I, 220-222 and 231; Bautier, Itinéraires, 99-100. McKitterick, Charlemagne, 188-197, has questioned the possibility of reconstructing the royal itinerary from diplomas. Based on a new evaluation of the dates and places given by Charlemagne's diplomas and by comparing them to those indicated by the narrative sources, she claimed that in some cases the Carolingian could not have been present in person when his diplomas were issued. This conclusion would have far reaching consequences for the research on the royal chancery and on royal itineraries. However, McKitterick's analysis has been rejected by Kölzer, System, who demonstrated, by newly scrutinising her evidence, that Charlemagne could indeed always have been present when his diplomas were delivered.

18 DDChS 34-35.

19 DDChS 38 and 47.

20 DDChS 11, 31, 42, 45, 49, 50, 55, 61 and 60.

21 On the importance of Compiègne, see Schneidmüller, Tradition, 101-105; Airlie, Palace and Koziol, Politics, 541-548.

22 In total nine stays. DDChS 30 and 32-33 (Verbery), 29 and 48 (Ponthion), 56 (Attigny), 53 (Corbeny) as well as 51, 54 and 60 (Laon). On the dominance of palaces within Charles' itinerary, see also Brühl, Fodrum, I, 48-53. 


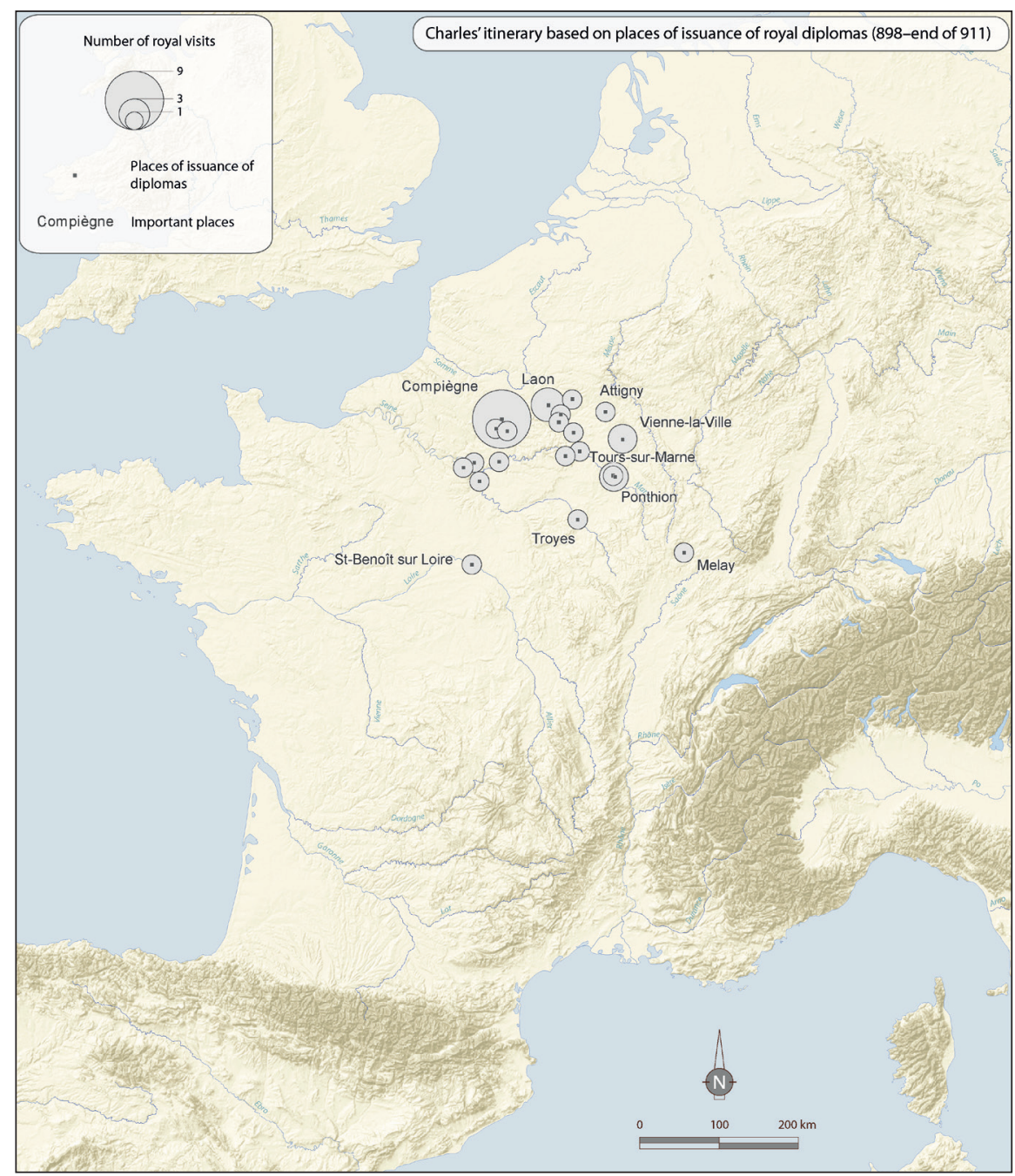

Figure 2: Charles' itinerary based on places of issuance of royal diplomas (898-end of 911). (C) Fabien Cerbelaud)

Charles can also be seen to have stayed in other important places, particularly Saint-Denis, Reims and Saint-Benoit-sur-Loire ${ }^{23}$ while the remaining stays were in different villae.

After the acquisition of Lotharingia the situation in the West remains unchanged. Charles' activities again appear to have been limited almost exclusively to Francia itself, apart from one exception in 914, when he issued three diplomas 
near Le Mans. ${ }^{24}$ What is new is the extension of his activities east of the Meuse, where they cover most of his new realm. This second half of Charles reign saw a diminishing role of Compiègne in favour of other palaces, especially Attigny and Herstal. ${ }^{25}$ Within Lotharingia, Charles also made use of a number of other palaces, for example Thionville and Gondreville, but also-and more important in symbolic terms-Aachen and Nimwegen. ${ }^{26}$ Both in the West and in Lotharingia, a number of cities and important monasteries were visited as well, Laon and Metz most of all, but also Soissons, Reims, Noyon, Toul and Saint-Denis ${ }^{27}$.

Charles' frequent stays at the old Carolingian palaces tie in well with the practices of his predecessors. Compiègne, of course, had been dominant since the times of Charles the Bald. Louis the Stammerer and Odo were both crowned and anointed there, ${ }^{28}$ Louis III celebrated Easter and Christmas at the palace twice during his short reign, ${ }^{29}$ Carloman II made it his sedes regni once he took over the North ${ }^{30}$ and all four of them issued various diplomas there.$^{31}$ Next to Compiègne, numerous other palaces were also in use, ${ }^{32}$ amongst them Quierzy, ${ }^{33}$ Gondreville $^{34}$ and Verbery. ${ }^{35}$ The differences from Charles' reign, however, can easily be tracked by studying the global picture of his predecessors' diplomas. Louis the Stammerer started his short reign at Compiègne and in Francia, then moved via Paris to Tours from where he joined the pope at Troyes before finally directing himself to

24 DDChS 77-79. The first two of these diplomas, DDChS 77 and 78 (19th June 914), were issued in villa Ruio. Lauer proposes that this might have been a mistake made when the copies of the original diploma were produced, meaning that in fact the diploma did not read Ruio but Rivo which he identified with Rupt in the departement Haute-Marne (Recueil Charles III, 172, n. 1 and 174, n. 1). The third diploma (21st June 914), was issued in a villa Collega, identified by Lauer as Collège, departement Sarthe, commune de Sablé (Recueil Charles III, 176 and 321). Unfortunately, Lauer did not reveal his reasons for this identification. My own efforts to confirm the identity of the villa Collega with Collège (Sarthe) with the help of the various Dictionnaires Géographiques have revealed the existence of quite a number of places called Collège in the entire North of modern France, yet none show any connection to a villa Collega (nor the existence of a villa Ruio). Given that all three diplomas were issued within three days, the villa Ruio and the villa Collega must have been in close vicinity to each other (on average, the king and his entourage travelled 20-35 km a day, Reinke, Reisegeschwindigkeit), which would render the identification of Rupt as villa Ruio/ Rivo impossible if we put faith in Lauer's identification of Collège (Sarthe). Doing so would mean that in June 914 Charles left Francia for a journey to the very west of his realm.

25 We can note five stays at Attigny (DDChS 76, 86, 89, 93 and 110), four at Herstal (DDChS 84, 85, 100-101 and 106) and four at Compiègne (DDChS 80, 92, 108-109 and 122).

26 DDChS 74, 83 and 103 (Thionville), 82 (Gondreville), 90-91 and 127 (Aachen) as well as 87 (Nimwegen).

27 DDChS 95, 98 and 111 (Laon), 69, 73 and 81 (Metz), 99 and 105 (Soissons), 87-88 (Reims), 112 (Noyon), 70 (Toul) as well as 97 (Saint-Denis).

28 Annales Bertiniani 877, 220; Annales Vedastini 888, 64.

29 Annales Bertiniani 880, 242 and 882, 245; Annales Vedastini 880, 49.

30 Bautier, Itinéraires, 103-104.

31 DDLS 3-5 and 31, DLIII 43, DDCmII 66-67, 72-73 and 76, DOdo 14.

32 For a detailed study, see Bautier, Itinéraires.

33 E.g. DCmII 64.

34 DLS 29.

35 Baudot, Abbaye; DCmII 78, DOdo 20. 


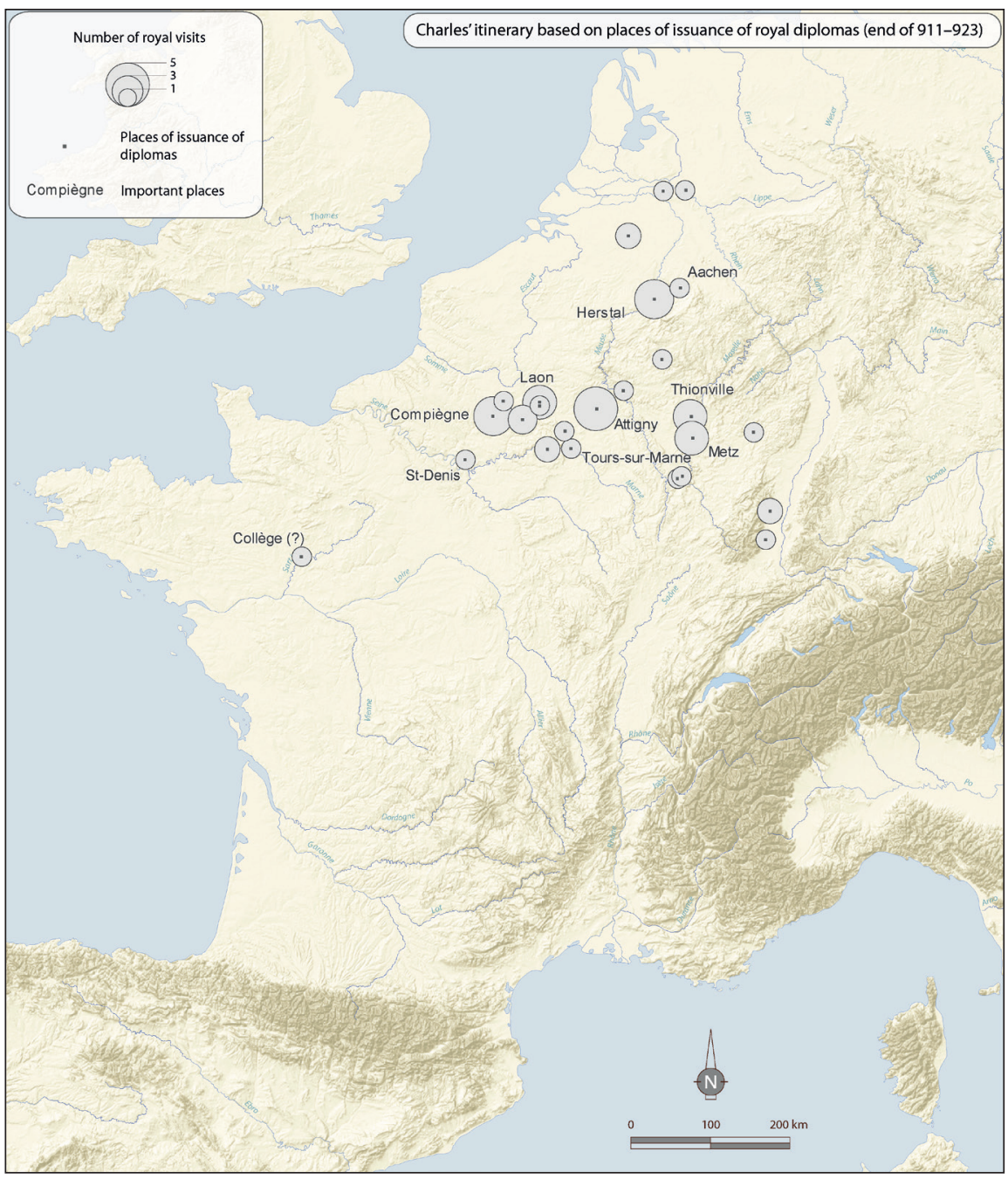

Figure 3: Charles' itinerary based on places of issuance of royal diplomas (end of 911-923). (c) Fabien Cerbelaud)

Lotharingia and back to Francia. ${ }^{36}$ Carloman II spent the first half of his reign in Burgundy and the Aquitanian borders, campaigning against the rebellious Boso. Once his brother died and he had joined the nobles in the North, he stayed in Francia to fight the Northmen. ${ }^{37}$ Odo's diplomas reveal him remaining mostly

36 Bautier, Recueil Louis II, Louis III et Carloman II, XXIV-XXXI.

37 Bautier, Recueil Louis II, Louis III et Carloman II, L-LVI. Only three diplomas were issued by Louis III (and only one, DLIII 43, of them mentions date and place), rendering the reconstruction of his itinerary based on his diplomas impossible. 
within his Neustrian possessions, at Orléans, ${ }^{38}$ Tours, ${ }^{39}$ Paris $^{40}$ and Chartres ${ }^{41}$ as well as in villae along the Loire. ${ }^{42}$ As becomes clear from these brief summaries, certain shifts took place between the death of Charles the Bald and the time of Charles the Simple. While Louis the Stammerer still travelled over large parts of the realm, Francia, Neustria and Burgundy, Neustria became excluded under his son Carloman II. Odo, of course, is an anomaly in this process. Due to his own power base being in Neustria, under him, Francia became less visited than before. Burgundy saw fewer and fewer royal visits after Carloman had moved to the North. Odo himself only came to the region in pursuit of Charles ${ }^{43}$ while the latter, once he became the sole king of the Western realm, did not travel further south than Troyes and Melay. The regions south of the Loire hardly saw any visits at all, leaving aside Odo's military campaigns in 889 and $892 .{ }^{44}$ From the death of Charles the Bald onwards, the royal movements were therefore more and more limited to Francia and only the acquisition of Lotharingia brought a change to this picture.

\section{III.1.2 Contacts with distant regions}

The limitation of the royal movements to a certain region, however, does not automatically point towards a loss of contact with the nobles from other parts of the realm. As we have seen in the previous chapter, contacts with nobles from the various regions remained on a constant level up until the second half of Odo's reign, when contacts with Burgundy in particular, which up until that point had been very strong, started to cease. At first glance, this process did not continue under Charles, with a number of diplomas going to Saint-Martin of Autun, Saint-Germain of Auxerre, Saint-Clément of Auxerre, Saint-Bénigne of Dijon, the churches of Autun, Auxerre and Langres as well as to Richard's right-hand man Manasses during the first half of his reign ${ }^{45}$ while after the acquisition of Lotharingia other diplomas went to Richard's son Hugh the Black ${ }^{46}$ and to Saint-Philibert of Tournus. ${ }^{47}$ At second glance, however, this image changes: with one or possibly two

DDOdo $1-9,17,23-24$ and 41.

DDOdo 19 and 39.

40 DDOdo $10-13,34,35$ and 36.

41 DOdo 16.

42 Meung-sur-Loire, DDOdo 22 and 27-28; Cosne-sur-Loire, DOdo 30. See also, Bautier, Recueil Eudes, CLIV-CLVII and Bautier, Itinéraires, 105.

43 Annales Vedastini 894, 75; DOdo 38.

44 Kienast, Wirkungsbereich, 531-539.

45 DDChS 32 and 59 (Saint-Martin of Autun), 38 (Saint-Germain of Auxerre), 3 (Saint-Clement of Auxerre), 8 (Saint-Bénigne of Dijon), 33 (Autun), 31 and 42 (Auxerre), 55 (Langres) and 43 (Manasses).

46 DChS 79.

47 DChS 82. 
exceptions, ${ }^{48}$ all the diplomas going to Burgundy were issued at the request of Richard himself or for members of his family. From the mid-890s onwards, Richard hence acted as an intermediary between the king and the local Burgundian nobility, taking over control of the access to the royal court. This process can be best studied using the Gesta Pontificum Autissiodorensium. Bishop Herfrid of Auxerre, who appears three times in Charles' diplomas and is indeed the only noble to request royal diplomas for a Burgundian institution without Richard's intervention, had been installed by Charles the Fat. ${ }^{49}$ In 910, his successor Geran, belonging to a family based in Soissons, was the choice of Richard and his partisans, ${ }^{50}$ even if they still sought Charles' approval. Geran was followed by men originating not only from the area, but also coming from Richard's own abbeys, Sainte-Colombe and Saint-Germain of Auxerre. In their cases, the Gesta make no more mention of the king, while the marchio's role is increasingly emphasised. ${ }^{51}$ But Richard's growing power in the area was not only reflected in how bishops were chosen. Both Herfrid and Geran did their best to regain control over estranged possessions. Whereas the former did so by requesting diplomas from the king and bulls from the pope without any mention of Richard,$^{52}$ the latter only acted on the explicit permission of the magnate when he went to see Charles. ${ }^{53}$

Contacts with Neustria had, as far as we can tell, been rather limited since the death of Charles the Bald, the main recipients being the Saint-Martin of Tours, ${ }^{54}$ Saint-Aignan of Orléans $s^{55}$ and the respective cathedral churches of both Tours ${ }^{56}$ and Orléans. ${ }^{57}$ This practice also continued under Charles the Simple, with one important change. As Richard channelled contact with nobles from Burgundy, in Neustria contact between the king and local elites appears to have been controlled by Robert. This was certainly not entirely new, since Hugh the Abbot had intervened frequently in the royal diplomas of Louis the Stammerer and Carloman II

DChS 42. Possibly also DChS 3, which is only mentioned by the Gesta Pontificum Autissiodorensium I, 173, as being issued per deprecationem Hermenberti. If Richard was indeed not involved in this second case, it would tie in well with DChS 42, which was also issued solely at the request of Bishop Herfrid.

49 Gesta Pontificum Autissiodorensium I, 169-171.

50 Gesta Pontificum Autissiodorensium I, 185. The election of Geran was pressed forward by Ragenar, viscount of Auxerre and Manasses' brother.

51 Gesta Pontificum Autissiodorensium I, 201-205 and 209. According to the Gesta, Geran's successor Betto had become abbot of Sainte-Colombe of Auxerre with Richard's consent before becoming bishop at the marchio's intervention. He was succeeded by Gualdricus, a member of a noble family from Auxerre, who had been monk at Saint-Germain of Auxerre. The Gesta note that he uoluntate atque licentia precellentissimi domni Richardi principis ab uniuerso clero et populo futurus appetitur et adclamatur episcopus.

52 Gesta Pontificum Autissiodorensium I, 173. See also DChS 3.

53 Gesta Pontificum Autissiodorensium I, 199-201.

54 DDLS 12, 14 and 15; DCmII 87, DDChF 139, 160 and 161; DDOdo 9 and 41.

55 DChF 143.

56 DLS 39 and DChF 146.

57 DLS 40; DDCmII 53, 70 and 71; DOdo 30BIS. 
on behalf of ecclesiastical institutions along the Loire. ${ }^{58}$ The diplomas of Charles the Fat for these abbeys and churches were all intervened for by Odo, although the emperor's charter for the church of Tours was also petitioned by its archbishop, Adalard. ${ }^{59}$ The next step in this development then becomes evident under Charles the Simple, with direct contact between the king and the local elites ceasing completely. There are, of course, numerous charters for Saint-Martin and SaintAignan, yet all of them were issued at the request of Robert, the only possible exception being one diploma for Saint-Serge of Angers under Abbot Raino, which is only preserved as deperditum, neither mentioning Robert nor Raino. ${ }^{60}$ The same applies for Charles' only known diploma for a cathedral church along the Loire, Saint-Maurice of Tours, which mentions Robert but not the archbishop-again, bear in mind that the diploma is lost and only referred to in a diploma issued by Louis VII in 1157 or $1158 .{ }^{61}$ The marchio, on the other hand, as becomes evident from his private charters, maintained close relations with the local bishops from Orléans, Nantes, Angers and, most of all, Tours. ${ }^{62}$ Close contact with Robert instead of the king, however, was not was not only held by the local bishops, but also by the viscounts of the Robertian counties along the Loire: Atto, Guarnegaud, Fulk, Rainald and later Theobald frequently appear witnessing Robert's charters. ${ }^{63}$ Neustria, or at least the counties and bishoprics along the Loire, seem to have been entirely under Robert's control. Yet, there is one important exception: a diploma for Saint-Évroult in today's western Normandy figures Count Hugh of Maine. ${ }^{64}$ Given the earlier conflict between Odo and Robert on the one side and Roger, Hugh's father, on the other, ${ }^{65}$ this is hardly surprising. We will return to this diploma later on, for now however, it is worth noting that, during the early years of Charles' reign, not all of Neustria was under Robert's direct control. After 911, this image changes. Next to bishops and viscounts, counts from the region begin to

58 DLS 15 (for Saint-Martin of Tours), DDCmII 87 (for Saint-Martin), 70 and 71 (for the church of Orléans).

59 DDChF 139, 160 and 161 (Saint-Martin of Tours), 143 (Saint-Aignan of Orléans) and 146 (church of Tours).

60 DDChS 46, 49, 98 and 101 for Saint-Martin of Tours (DChS 63 for Saint-Martin is a forgery, see Noizet, Pratique, 100-110). DDChS 77 and 78 for Saint-Aignan of Orléans. DChS 4 for Saint-Serge of Angers is a deperditum-only the confirmation of a donation made by a certain Adalberge by Charles is noted.

61 DChS 9. Lauer, Recueil Charles III, 13.

62 DDRoI 40 (Ebernus of Tours), 42 (Ebernus of Tours, Raino of Angers, Fulcher of Nantes and Berno of Orléans), 43 (Ebernus of Tours), 47 (Ebernus of Tours, Anselm of Orléans and Isaias of Nantes) and charter from 31st March 914, Werner, Untersuchungen I, 286-289 (Anselm of Orléans). On the very problematic DRoI 47, see Leveque, Actes, Dufour's comment and Guyotjeannin, Notice, 680-686, the last two arguing in favour of the charter's sincerity.

63 DDRoI 41 (Atto, Guarnegaud and Fulk), 42 (Atto, Guarnegaud, Fulk and Rainald), 47 (Fulk), 48A (Fulk and Tetbald) and charter from 31st March 914, Werner, Untersuchungen I, 286-289 (Fulk).

64 DChS 35.

65 See chapter I.3. 
appear in Robert's charters, among them Hugh of Maine, ${ }^{66}$ indicating that Robert had found even broader support by then. Hence, Neustrian cooperation with the king increasingly depended solely on a good understanding with the powerful marchio of the Loire counties.

Contacts with Aquitaine, as we have already seen, had always been limited and now became even more so with all of the earlier reliable contacts ceasing completely. The Archbishop of Bourges cannot be found at Charles' court, ${ }^{67}$ nor did the abbeys of Solignac, Beaulieu or Poitiers receive any royal charters. Two of Charles' diplomas indicate the presence of Aquitaine's most powerful noble, William the Pious, the son of Bernard of Auvergne, at court. ${ }^{68}$ The first one went to Count Gerald of Aurillac's newly founded abbey in the same town, with William serving as ambasciator. ${ }^{69}$ Probably around the same time, according to the Vita Geraldi, William had, without success, tried to persuade Gerald to abandon royal service and to commend himself to him instead. ${ }^{70}$ This episode apparently did not affect relations between the two since Gerald continued to support William on various occasions. ${ }^{71}$ The other diploma sees William acting together with Robert of Neustria, restoring estranged property in the Limousin to the latter's abbey of Saint-Denis, ${ }^{72}$ thus casting some light on the connection between two of the most powerful nobles of the realm but not providing us with any further insight into relations between Charles and the Aquitainian elite. Interesting in this context, however, is a lost diploma for the abbey of Conques, which supposedly confirmed the abbey's property at the request of its abbot Rodulf. ${ }^{73}$ Abbot Rodulf also appears in the Vita Geraldi as being connected with Gerald, acting as his intermediary in a conflict with Count Raymond..$^{74}$ Furthermore, another diploma was issued in 919 at the request of Count Seguin of Nevers. ${ }^{75}$ Seguin's predecessor, Rather, seems to have wavered between William the Pious and Richard the Justiciar ${ }^{76}$ while Seguin himself can be seen in contact with William's nephew and successor, William the

66 DDRoI 47 (Gauzlin, Heriveus and Gauzbert; Gauzlin and Gauzbert may have been sons of the Rorgonide Gausfred, Dhondt, Études, 318 and 322), 48A (Herbert and Gauzlin) and charter from 31st March 914, Werner, Untersuchungen I, 286-289 (Hugh of Maine).

67 He did, however, have contact with Robert. Charter from 31st March 914, Werner, Untersuchungen I, 286-289, witnessed by Archbishop Geruntius of Bourges.

68 A third, often meant to figure William the Pious (e.g. Stieldorf, Marken, 214), DChS 102, is a forgery. See the Lößlein, Diplôme.

69 DChS 21.

70 Vita Sancti Geraldi Auriliacensis I, c. 32, 180.

71 Vita Sancti Geraldi Auriliacensis I, c. 32, 180 and I, c. 33, 180.

72 DChS 50.

73 DChS 44.

74 Vita Sancti Geraldi Auriliacensis II, c. 28, 234.

75 DChS 99 (30th September 919). The diploma grants property belonging to the count to a certain fidelis, Eptino, and his wife.

76 Chaume, Origines, 367, n. 3 and 402, n. 1. This is disputed by Charrier, Histoire, 56, who believes Nevers to have been under the control of William the Pious up until 918, when he was succeeded by Seguin, although he does not cite any sources. 
Younger: together they witnessed a charter for Cluny. ${ }^{77}$ Charles' contacts with Aquitaine therefore appear to have been dominated by a circle mostly in close contact with the Williamides. There is one notable exception however. A diploma dating to $909^{78}$ figures one of William's opponents at court-Raymond, at that point still count of Nîmes and Albi, but later succeeding his father as count of Toulouse. ${ }^{79}$ The Tolosan family was one of the Williamide's major opponents in southern Aquitaine, gaining supremacy over Septimania after William the Pious' death. ${ }^{80}$ Hence contacts with Aquitaine were, as before, tenuous and as far as the few diplomas we have tell us, limited to two factions, the circle around William the Pious and the Tolosan counts.

Septimania itself, apparently the target of these two factions, constitutes a complete contrast to Aquitaine, having, despite its distance from the royal court, one of the highest densities in diplomas over the two halves of Charles' reign. Septimanian elites had, as we have seen, a very particular interest in obtaining royal charters. The number of diplomas issued for nobles from the region is therefore hardly surprising, yet worth a couple of further thoughts. As in the preceding reigns, we find the churches of Narbonne ${ }^{81}$ and Girona ${ }^{82}$ among the recipients. Besides these institutions, a number of abbeys from the region also appeared repeatedly before the kings: Saint-Polycarpe, for example, received charters from Carloman and Odo; ${ }^{83}$ Notre-Dame of La Grasse and Santa-Maria of Amer from Odo and Charles the Simple; ${ }^{84}$ while San-Esteban of Bagnolas was granted diplomas from Louis the Stammerer and Charles. ${ }^{85}$ For others, their contact with the king appears to have dated back much further. Caunes, represented by its abbot Hilderic, and Saint-Chinian under Abbot Bera had last seen royal charters under Charles the Bald; ${ }^{86}$ Elne under Emperor Lothar. ${ }^{87}$

77 Recueil Cluny I, N²75, 270-271. The charter does not indicate when it was issued. Since it contains the phrase pro remedio scilicet anime Wilgelmi senioris nostri defuncti, necnon et pro salute ipsius nepotis comitis seniorisque nostri domni Wilgelmi... it was issued after the death of William the Pious but during the lifetime of William the Younger, hence between 6th July 918 and 12th December 926. While Bruel proposes the year 926, Chaume dates the charter to around 920. Neither, however, give any further reasons.

78 DChS 61.

79 Lot, Fidèles, 116-120. See also Débax, Stratégies, 137.

80 Lewis, Development, 182-186; Dunbabin, France, 59-60; Caille, Vicomtes, 50-51.

81 DDChS 14, 23, 24 and 119. It is also worth pointing out a letter from Archbishop Agio of Narbonne to the bishops Agambert and Elefons, in which, having heard of their journey to the royal court, he asks them to obtain a diploma from the king on his behalf (HGL V, $\mathrm{N}^{\circ} 47$, col. 145). Elefons also appears in DChS 102, a forgery (see Lößlein, Diplôme), while Agambert also signs the proceedings of the synod of Attilian in 902 (Schröder, Synoden, $\mathrm{N}^{\circ}$ 19, 160). The sees of both of these bishops are unknown.

82 DDChS 19 and 120.

83 DCmII 52 and DOdo 7.

84 DOdo 18 and DDChS 20 and 60 for La Grasse and DOdo 23 and DChS 116 for Santa-Maria of Amer.

85 DLS 23 and DChS 85.

86 DDChB 44 (Saint-Chinian) and 456 (Caunes).

87 DDChS 15 and 26. 
The large number of diplomas issued for recipients from Septimania can be explained in part by the interests of the local elites demanding them. Saint-Polycarpe and San-Esteban of Bagnoles, for example, were in a long-term conflict over some property originally given to the latter, but claimed by the former. ${ }^{88}$ In the case of San-Juan-de-las-Abadesas, Abbess Emma seems to have feared that after the death of her father Wifred, who had founded the abbey, her brother Sunyer might try to estrange its property. Charles' diploma was only one of several measures she took to protect her abbey's property. ${ }^{89}$ However, while these local interests certainly can serve to explain the individual diplomas, they fall short when it comes to explaining certain other anomalies. With some exceptions, ${ }^{90}$ all of these diplomas were issued in 898, 899 and 922. The ones from 898 reflect Septimanian elites paying homage to the new king and obtaining royal charters in return, similar to what happened during the reigns of Louis the Stammerer, Carloman II and Odo. In the first diploma in June 898, a certain Theodosius received parts of the fisc, comital rights and immunity in parts of the counties of Narbonne, Roussillon and Bésalu. ${ }^{91}$ In November, two more diplomas were issued, this time for the churches of Narbonne and Elne, with a confirmation of goods in the former case and generous grants in the latter. ${ }^{92}$ Both churches were represented by envoys, as the respective (arch-)bishops had not appeared in person.

In both 899 and 922, however, the diplomas for the distant South were issued over a short period of time, about a fortnight in the first case and a week in the second. ${ }^{93}$ Even more remarkable is that, on both occasions, the charters were given in the same place, a villa which had originally belonged to the royal fisc but had been given to the church of Tours by Louis the Stammerer, ${ }^{94}$ situated south of Reims, the modern Tours-sur-Marne. The second occasion, in particular, raises questions. From 919 onwards, Flodoard's annals give us a detailed account of events in Western Francia, allowing us to track the king's movements through his realms. In June 922, Charles' reign was in crisis. The king was fighting both Count Gislebert and the Western nobles who had rebelled against him. Both sides gathered their forces on the Marne and were encamped some distance from each other. Flodoard then notes that Charles attacked Reims at Pentecost ${ }^{95}$ in 922 corresponding to the 9th of June. In the midst of a military campaign that would prove decisive for his reign, the king then decided to issue a remarkable number of diplomas at the

88 Bautier, Recueil Eudes, 34-36.

89 Jarrett, Power. On the family, see also D’Abadal, Comtes; Lewis, Development, 109-110 and 143-152 and Vones-Liebenstein, Katalonien, 491-501.

90 DDChS 60 (La Grasse, dating to 908) and 85 (Bagnoles, dating to 916).

91 DChS 13.

92 DDChS 14 and 15. On the interpolations of DChS 14, see Bautier, Recueil Eudes, 106-111 and Chastang, Lire, Chapter II. After removing the interpolated parts, only the confirmation of a donation made by Louis the Stammerer remains.

93 DDChS 19-27 (29th May-14th June 899) and 115-120 (31st May-7th June 922).

94 Barbier, Palatium, 546. DLS 39.

95 Flodoard, Annales 922, 9. 
very place where he had already done so for recipients from the same area 23 years earlier. Why would he do such a thing?

By studying the diplomas issued on both occasions more closely, some further issues attract attention, especially concerning the diplomas for the churches of Elne and Narbonne. The two diplomas for Elne ${ }^{96}$ and three of those issued for Narbonne ${ }^{97}$ seem to form a particular group, which in the case of Narbonne also includes diplomas from Carloman II and Odo. ${ }^{98}$ With the exception of Odo's charter, all the others appear to have been heavily interpolated when they were transcribed into the cartulary of the church of Narbonne during the archiepiscopacies of Wifred of Cerdagne (1019-1079) and Berengar of Narbonne (1156-1162), rendering them highly suspicious. ${ }^{99}$ All five of these diplomas, however, share a common phrasing, complaining about "the poverty of [the archbishop's] bishopric, since both his own see and nearly all the churches of his diocese are ruined, to the point that he can never restore them by himself." 100 While this may indeed have been the case when Carloman II used the formula for the first time, ${ }^{101}$ by the late 890 s, this period of impoverishment had ended long ago. As the Vita Sancti Theodardi notes, the archbishop requesting the charter from Carloman had managed to rebuild the cathedral only a few years later, with the construction work probably beginning in 885 or $886{ }^{102}$ At least in the case of Narbonne, by Charles the Simple's time, the formula was most probably unfounded. The use of the formula therefore must

96 DDChS 15 and 26.

97 DDChS 14, 23 and 119.

98 DCmII 54 and DOdo 24.

99 See Bautier, Recueil Eudes, 106-110, criticised by Tessier, Recueil Louis II, 131. The cartulary has been studied extensively by Chastang, Lire, who confirmed and refined Bautier's position (Chastang, Lire, 239-267). Setting aside the interpolations, Charles' diplomas appear to have been mere confirmations of Carloman's. Against this reading, Koziol, Politics, 494-495, pointing out that the identical framing formulae of the diplomas is not ground for suspicion. Since the formula in question (see next note) is also to be found in two other diplomas for the church of Elne, issued at the same time but not part of the same cartulary, we can indeed accept these formulae to be genuine, while otherwise following Bautier and Chastang, leaving us to assume that the actual charters issued by Charles did no more than confirm Carloman's.

100 Translation from Koziol, Politics, 495. The phrasing in the diplomas vary slightly from each other: DChS 14, 25: ...innotuit nobis per quosdam sui fideles quemadmodum sua sedes et pene omnes ecclesie ejusdem civitatis ruine jam proxime existebant, ita ut per ipsum nullatenus possent restaurari... DChS 15, 27: ... innotuit nobis per quendam suum fidelem quemadmodum sua sedes et pene omnes ecclesię ejusdem sedis ruinę tam proximę existebant, ita ut per ipsum nullatenus possent restaurari... DChS 23, 46: ... innotuit nobis de paupertate sui episcopatus et quemadmodum sua sedes et pene omnes ecclesie ejusdem civitatis ruine jam proxime existebant, ita ut per ipsum nullatenus possent restaurari... DChS 26, 55: ...innotuit nobis de paupertate sui episcopatus et quemadmodum sua sedes et pene omnes ecclesie ejusdem loci ruine jam proxime existebant, ita ut per ipsum nullatenus possent restaurari... DChS 119, 280: ... innotuit nobis de paupertate ejusdem episcopatus et quemadmodum ipsa sedes et pene omnes ecclesiae ejusdem civitatis ruinae jam proximae existebant, ita ut per ipsum nullatenus possent restaurari...

101 DCmII 54, 138: ... innotuit nobis de paupertate sui episcopatus et quemadmodum sua sedes et pene omnes aecclesiae ejusdem civitatis ruinae jam proximae existebant, ita ut per ipsum nullatenus possent restaurari...

102 Vita Sancti Theodardi, 152 E. Bautier, Recueil Eudes, 108. 
have had another reason, which is most likely to be found not on the part of the bishops, but on that of Charles. In these diplomas, Charles could portray himself as the restorer and protector of the Church, as true king of the realm. This reading is further emphasised by the grants made in the various diplomas. The first charter for Elne grants, next to some properties, half of various incomes, among them the market and the salines-rights that were also confirmed to the church of Narbonne. The second diploma, issued one year later, was even more generous, granting the cathedral of Elne all the churches of the Roussillon and the Conflent, in addition to a number of other properties. In 899, Charles reinforced the immunity of ecclesiastical servants in the church province of Narbonne, prohibiting any officials from forcing them to attend lay courts and from levying taxes from their possessions. ${ }^{103}$ One of the most interesting phrasings, however, can be found in a diploma issued in 922 for the church of Girona, donating to the church "the little belonging to our royal power" because of the fidelity shown by its bishop, Guigo. ${ }^{104}$ The message was clear: remain loyal to the crown and you will be rewarded with whatever is left. Given Charles' current situation, that was clearly a message aimed at those who so far had remained with him.

Perhaps this is the solution to the question of why Charles would issue such a number of diplomas for distant recipients at such a crucial point of his campaign against the rebel nobles. He did this to reinforce his links with his followers, to demonstrate to them that he was the true king, willing to act in favour of those who supported him, protecting the church and handing out generous rewards. Also present at Tours-sur-Marne were monks from Saint-Thierry of Reims, ${ }^{105}$ who could have relayed this to Charles opponents, thus ensuring that the message also reached those who might be willing to return to their rightful king. Both the place and the target of the demonstration were partly due to the contingencies of the situation. Tours-sur-Marne was close by; Bishop Guigo, who interceded for every single one of the 922 diplomas, ${ }^{106}$ had belonged to Charles' chapel before becoming bishop of Girona. ${ }^{107}$ But the place, time and recipients mirror the circumstances of 899 closely enough for it to be likely that there was more to the issuance of these diplomas. In 922, Charles used the opportunity offered to him by circumstance to reenact the assembly that had taken place in 899 , to remind the realm of the beginnings of his reign.

If it is likely that Charles' initiative was behind the issuance of the 922 diplomas, it seems probable that the same is also true for the 899 assembly. Why, for example,

DChS 24.

104 DChS 120, 285: Supra quae praefato episcopo Wigoni suaeque eclesiae [...] pro remedio animae nostrae ac genitorum nostrorum, ob nimiam etiam fidelitatem quam illum erga nos cernimus habere, largimur perpauca nostrae regali jure competentia potestati...

105 DChS 115, 31st May 922.

106 DDChS 116-120, with the exception of DChS 119 for the church of Narbonne, all name the recipients as Guigo's fideles. Two deperdita, identified by D'Abadal for the abbey of Saint-Quirze, D'Abadal, Catalunya II,2 384 and 472-473, probably also belonged to these diplomas.

107 HGL V, col. 124-125. Schröder, Synoden, 178-179; Magnou-Nortier, Société, 322-333. 
would Archbishop Arnust of Narbonne travel to see the king-from whom he had already obtained a confirmation of his possessions and rights half a year earlier by means of an envoy - to obtain another diploma guaranteeing the immunity of the clergymen of his church province from a king who was unlikely to enforce his order in such a distant province? ${ }^{108}$ We have already shown that, in 899 , Charles used his diplomas to portray himself as the one true king. It, therefore, seems most likely, that Arnust did not seek out the king to demand further confirmation of his rights, but that Charles invited him and other local elites to join him at court. This would have provided Charles with the opportunity for a political mise-en-scène allowing him to demonstrate his royalty to the realm. Of course, many of the other diplomas-like the one for San-Juan-de-las-Abadesas-were undoubtedly issued because the petitioners had a viable interest in obtaining a royal charter. But at Tours-sur-Marne, they seem to have only provided a framework for the king's own message. He used the assembly of Tours-sur-Marne to strengthen his rule by demonstrating his willingness to act like a king.

\section{III.1.3 Using diplomas to demonstrate Carolingian legitimacy?}

The case of the Tours-sur-Marne diplomas leads us to another aspect of how diplomas were used to strengthen Charles' rule. Since the influential work of Bernd Schneidmüller on the power of Carolingian tradition, ${ }^{109}$ it has become the scholarly consensus that Charles was strongly attached to his family's past and especially to the memory of his grandfather, Charles the Bald. ${ }^{110}$ Indeed, there are many indications that Charles did use his Carolingian descent to strengthen his rule by emphasising his legitimacy. Most notable are the changes to the dating clauses of his diplomas after the acquisition of Lotharingia, which refer to the event as "attaining [his] larger inheritance" (largiore vero hereditate indepta). ${ }^{111}$ Describing the new realm as his inheritance was, of course, a statement that was only loosely based on the political realities. Lotharingia had fallen to Charles because its leading nobles preferred his rule to that of Conrad $\mathrm{I}^{112}$ and not because of some

108 See also Koziol, Politics, 494.

109 Schneidmüller, Tradition.

110 Last see Koziol, Politics, 544-548.

111 The change in the dating clause sets in with DDChS 67 and 68, both dating to 20th December 911, the first diplomas Charles issued for Lotharingian recipients, Bishop Stephen of Cambrai and the canons of his Church. From this moment on, the phrase is only omitted in DDChS 112 (20th September 921, church of Châlons) and 122 (29th July 923, Saint-Corneille). In both cases the second addition to the dating line, the redintegrante, is also left out. On the practice of indicating the acquisition of new realms or other important events in the dating clauses, see Wolfram, Herrschertitel, 115. On the changes in Charles' dating clauses, see also Koziol, Politics, 421-483.

112 See below, chapter IV.4. 
special Lotharingian attachment to the Carolingian dynasty. ${ }^{113}$ Nevertheless, this clearly shows that Charles used his heritage to his political advantage by stressing his Carolingian descent and the claims he derived from it. Moreover, in the narratio of his diplomas, Charles hardly ever fails to point out the dynastic links tying him to his ancestors. Direct links are thus established with Charlemagne, his grandfather's grandfather (atavus), Louis the Pious, his great-grandfather (proavus), Charles the Bald, his grandfather (avus), Louis the Stammerer his "begetter" (genitor), Louis III and Carloman II his brothers (fratres). ${ }^{114}$ Usually, such mentions are connected to the confirmation of earlier diplomas or services for the afterlife of his ancestors. However, there is a special case when Charles artificially inserted a mention of his ancestors and his relation to them into one of his diplomas. A charter dating to 917, issued for Saint-Corneille at Compiègne, introduces his ancestors Pippin, Charlemagne and Charles the Bald in the sanction clause, referring to sanctions laid down by them under similar circumstances. ${ }^{115}$ Making such references was, from a purely practical point of view, quite pointless. As Geoffrey Koziol has argued, its only purpose was to demonstrate Charles' descent and place him in a line with his ancestors. ${ }^{116}$

Yet, to what extent Charles really emphasised his Carolingian heritage is much less clear than has been generally assumed by scholars. ${ }^{117}$ Describing predecessors as ancestors-which, after all, they were-was a common practice among Carolingian kings and was equally used by Charles' brother, Carloman II, ${ }^{118}$ and his father, Louis the Stammerer. ${ }^{119}$ Charles' supposed close connection to Charles the Bald, which seems to be based mainly on the large number of his grandfather's appearances in Charles' diplomas-26 out of 120-also crumbles when placed under scrutiny. ${ }^{120}$ This is certainly a significant ratio and it is far greater than for other

113 Parisot, Royaume, 574-578, argued in favour of such an attachment. Against this position, see Hlawitschka, Lotharingien, 198, n. 48 and 202.

114 An early example is DChS 2, dating to 898, 2-3: ...quia veniens vir venerabilis Heidilo [...], obtulit obtutibus nostris auctoritates atavi nostri Karoli et proavi Chludovici, necnon et avi nostri item Karoli imperatoris... Louis the Stammerer and Charles' halfbrothers are, for example, mentioned in DChS 82, 183: ...ob amorem Dei [...], necnon et elemosinam avi nostri imperatoris Karoli seu et Ludowici regis, piissimi genitoris nostri, sive fratrum nostrorum, videlicet Ludowici atque Karlomanni...

115 DChS 91, 209: Quod si quis hanc auctoritatem nostram adversari et nostrae uxoris Friderunae contradictionem refragari conatus fuerit, legem quam statuit Pippinus rex, noster atavus in monasterio Promia, seu Lauduni in puellarum loco, atque noster abavus Karolus imperator augustus in Aquisgrani palatio, necnon et gloriosus similiter imperator Karolus, noster avus, in eodem videlicet Compendiensi coenobio, coactus exsolvat atque usque in adventum Domini damnatus, positus sub maledictione Judae fiat et quod vindicare sibi voluerit minime habeat. See also Schneidmüller, Tradition, 128-129.

116 Koziol, Politics, 547.

117 Schneidmüller, Tradition and Koziol, Politics.

118 For example DDCmII 51, 128 and 74, 193.

119 Among others, DLS 7, 18 and 20, 66.

120 Schneidmüller, Tradition, Anhang, 207-209 counts 33 confirmations of Charles the Bald's diplomas. We count 26, excluding the forgeries DDChS 37 and 107 as well as the rewritten DDChS 46 and 101. Three more, DDChS 25, 27 and 83, are confirmations of Charles the Bald's diplomas, yet fail to mention him. The number may of course be higher, given that among the 120 diplomas we note 13 deperdita. 
kings mentioned in the corpus. For example, Louis the Stammerer, the second most cited ruler is mentioned fourteen times. ${ }^{121}$ Yet, given that only 36 diplomas of Louis are known, compared to about 460 from Charles the Bald, Charles the Simple's connection to his father seems to have been much more important than the one to his grandfather. ${ }^{122}$ It is helpful to compare these numbers to the practice of other kings. For example Charles' half-brother Carloman names Charles the Bald nine ${ }^{123}$ and Louis the Stammerer seven times ${ }^{124}$ in 44 diplomas while Louis the Stammerer in turn quotes Charles the Bald fifteen times. ${ }^{125}$ The ratio of mentions to the total number of diplomas known indeed seems to indicate that Charles' own practice of mentioning Charles the Bald (and his own father) was not more developed than that of his predecessors. ${ }^{126}$ This conclusion ties in well with another finding. While Charles' and his grandfather's diplomas went, in large parts, to the same ecclesiastical institutions, there are numerous cases where the former fails to mention the latter, most notably in the five diplomas issued for SaintDenis. ${ }^{127}$ Confirming the acts of past rulers-among them Charles the Bald-and installing prayer services for them was certainly important for Charles. However, his practice was not substantially different from his predecessors.

While the observations we have made so far apply to Charles' entire reign, there were some significant changes in his diplomas following the acquisition of Lotharingia. Most prominent is the change of his intitulation to rex Francorum, vir illustris, ${ }^{128}$ a phrasing derived from diplomas issued by Pippin, Charlemagne and Carloman. ${ }^{129}$ When trying to interpret this change in regard to Charles' use of Carolingian tradition to strengthen his rule, however, we should take into consideration at which audience the diplomas were directed. From the little that is known about how diplomas were issued and used, it seems that they were meant

121 DDChS $12,14,19,20,23,32,33,42,60,75,82,85,119$ and 120 . Not included are the highly problematic DDChS 46 and 101.

122 Koziol, Politics, 498, explains this with Charles' endeavour to rehabilitate his father.

123 DDCmII 51, 52, 62, 66, 68, 73, 77, 82 and 87.

124 DDCmII 51, 54, 66, 68, 74 and 87.

125 In 36 diplomas. DDLS 4, 5, 7, 8, 9, 13, 15, 17, 18, 19, 20, 23, 27, 30 and 39.

126 Odo, to name another example, mentions Charles the Bald ten times in 50 diplomas (DDOdo 1, $9,10,11,15,18,20,30,32$ and 41$)$. Louis the Stammerer, on the other hand, is only mentioned twice (DDodo 11 and 41).

127 DDChS 10, 47, 50, 66 and 89. Other examples are the diplomas for Saint-Remy (DDChS 87 and 88), Saint-Germain of Auxerre (DChS 38) and Saint-Bénigne of Dijon (DChS 8) as well as some of diplomas for Saint-Martin of Tours (DDChS 49 and 98), Saint-Amand (DDChS 54 and 110) and Saint-Martin of Autun (DChS 59). Similarly, none of the diplomas issued for the church of Châlons (DDChS 29 and 112) mention Charles the Bald and only one out of two for the Churches of Autun (DChS 31) and Paris (DChS 57) do. Most of these diplomas are confirmations of recent restitutions or grants. However, as the example of DChS 91(see above) shows, if Charles wanted to insert his grandfather or others of his ancestors in his diplomas, he found a way to do so.

128 The change sets in with his first Lotharingian diplomas, DDChS 67 and 68.

129 Wolfram, Herrschertitel, 116-118. Charlemagne's diplomas use rex Francorum, vir inluster as intitulatio from 769 until 774, Carloman's from 769 until 772. Wolfram was apparently not aware of its use by Pippin. 
to be presented and probably read aloud to a larger community. ${ }^{130}$ Yet, who, apart from some specialists familiar with early Carolingian diplomas and, what is more, with diplomas from such a short period of time, would have recognised the allusion made to his illustrious ancestors? Charles dropped the vir illustris after only a few months, shortening his new intitulatio to rex Francorum, ${ }^{131}$ which seems to indicate that if he had indeed tried to use the memory of these earlier Carolingians to strengthen his legitimacy, he had soon recognised the futility of this means of doing so.

The new seal and monogram used by the king in 913 pose another problem in this regard. Both imitate those of Charlemagne, ${ }^{132}$ and as visual signs may have been recognised by a wider audience, which may have been able to compare Charles' diplomas with his ancestor's. Hence they may have served the purpose of demonstrating the link between Charles himself and Charlemagne. ${ }^{133}$ However, both are isolated cases taken from one single diploma, ${ }^{134}$ a diploma that appears to have been written not in Charles' chancellery, but in that of Archbishop Ratbod of Trier by a scribe called Theodulf. ${ }^{135}$ This would also explain why this diploma resembles the Lotharingian tradition so much. ${ }^{136}$ Considering that Ratbod had kept his distance to the king up until that point, ${ }^{137}$ this diploma was probably meant as a symbol of the archbishop's entrance into the king's favour. As it was drawn up in Ratbod's chancellery, we may even question whether the seal and monogram were developed at Charles' own court. Likely, they had been presented to the king by the archbishop, to honour him by letting him appear as his ancestor.

While Charles' diplomatic practice does not indicate that he set out to strengthen his rule by putting special emphasis on his Carolingian heritage, he certainly possessed a highly developed sense of legitimacy. The most revealing source, in this regard, is a part of Witger's Genealogia Arnulfi comitis. ${ }^{138}$ The first part, entirely separate to the second part which is dedicated to the family of Arnulf I of Flanders, covers the descendants of the Frankish emperors and kings and

130 On the role of diplomas in public encounters with the king, see Bedos-Rezak, Ritual; Keller, Herrschersiegel; Beyer, Urkundenübergabe; Worm, Beobachtungen; Worm, Strategien; Koziol, Pardon, chapter 9; Koziol, Politics, 33-37.

131 Only DChS 67, 68, 69, 125, 71 and 72 use the rex Francorum, vir illustris. The vir illustris was dropped after 12th April 912, with the exception of Charles' circular to the bishops of his realm (MGH Conc. VI, N²).

132 Lauer, Recueil Charles III, LXXVIII-LXXIX for the monogram and XLVII-XLVIII for the seal.

133 As interpreted by Wolfram, Herrschertitel, 117, Schneidmüller, Tradition, 133.

134 DChS 74.

135 Schieffer, Kanzlei, 139-140, Bautier, Chancellerie, 21, n. 1 and Patzold, Episcopus, 88. Theodulf probably also wrote DDLCh 58 and 68.

136 Wolfram, Herrschertitel, 120.

137 DChS 74 is the first diploma for the church of Trier. On Ratbod's distance to Charles up until 913, see below.

138 Witger, Genealogia. On this genealogy, see Koziol, Charles; Freise, Genealogia; Oexle, Karolinger, 263, n. 61; Génicot, Princes, 220-221, Schneidmüller, Tradition, 85-88. Witger's origin is unknown. In regard to his genealogy, scholars see him either as canon of Saint-Corneille of Compiègne or, in this regard, especially Freise, having a Flamish connection to Arnulf's court. 
was "dictated by King Charles, restorer of Compiègne after two fires."139 As Geoffrey Koziol convincingly argues, Witger used an already existing genealogy when he produced his own draft and only made some further additions for Charles' own successors, meaning that the core part was indeed dictated by the king to the canons of Saint-Corneille. ${ }^{140}$ The genealogy traces the Carolingian family from its origins, giving the same content as others of its kind. It is only when it reaches Charles Martel that the record changes, becoming more detailed than the mere genuit-enumerations of the first five generations. Charlemagne's entry, for example, reads "Emperor Charles fathered Charles, Louis and Pippin, Rotrude and Berta on queen Hildegard, Drogo and Hugh and Rothaid on a concubine." 141 The entry betrays three features of the genealogy: a deep knowledge about the family, the inclusion of daughters in the account and, most importantly, the distinction between children born by queens and those born by concubines. ${ }^{142}$ This detail is found in the entries for Louis the Pious, ${ }^{143}$ Charles the Bald ${ }^{144}$ and Louis the Stammerer ${ }^{145}$ hence, for the lineage holding the West Frankish realm. The other lineages are traced to their respective ends (as marked by the death of the last crowned ruler ${ }^{146}$ ) but are significantly less comprehensive-daughters and illegitimate offspring are omitted here. ${ }^{147}$ Two of these entries are nevertheless remarkable: "King Carloman fathered King Arnulf" 148 and "King Arnulf fathered Louis on Queen Oda, Zwentibold, however, on a concubine." 149 The first entry fails to mention the illegitimate birth of Arnulf which is hinted at only by the fact that his mother is left out. The second entry, on the other hand, is the only one outside the West Frankish line that mentions offspring by a concubine-undoubtedly because Zwentibold was, next to his father, the only illegitimate son to be crowned. And while Arnulf's entry is also the only one to attribute a title to an offspring (i.e. Carloman begat "King" Arnulf), both only mention Arnulf as king, not as emperor.

139 Witger, Genealogia, 302: Hic incipit genealogia nobilissimorum Francorum ymperatorum et regum dictata a Karolo rege Conpendiensis loci restauratore post bina incendia.

140 Koziol, Charles, 172-179.

141 Witger, Genealogia, 302: Karolus ymperator genuit Karolum, Hludovicum et Pipinum, Rotrudim et Bertam ex Hildegardi regina, Drogonem et Hugonem et Rothaidim ex concubina.

142 See also Koziol, Charles, 173-175.

143 Witger, Genealogia, 303: Hludovicus ymperator genuit Hlotharium, Pipinum et Hludovicum Rotrudim et Hildegardim ex Yrmingardi regina, Karolum et Gislam ex Iudith ymperatrice.

144 Witger, Genealogia, 303: Karolus imperator genuit ex Hyrmentrudi regina quattuor filios et totidem filias, id est Hludovicum, Karolum, Karlomannum et Hlotharium, Iudith quoque et Hildegardim, Hirmintrudim et Gislam.

145 Witger, Genealogia, 303: Hludovicus rex genuit Hludovicus et Karlomannum et Hildegardim ex Ansgardi vocata regina, Karolum quoquo postumum et Irmintrudim ex Adelheidi regina.

146 The only exception is the line of Pippin I of Aquitaine which is not continued and thus omits Pippin II.

147 For example, the entry for Louis the German, Witger, Genealogia, 303: Hludovicus rex genuit Karlomannum, Hludovicum et Karolum ex Emma regina.

148 Witger, Genealogia, 303: Karlomannus rex genuit Arnulfum regem.

149 Witger, Genealogia, 303: Arnulfus rex genuit Hlodovicum ex Oda regina, Sendeboldum vero ex concubina. 
The genealogy includes a striking entry, dedicated to Charles' own father: "King Louis fathered Louis and Carloman and Hildegard on the so-called queen Ansgarde, and also, posthumously, Charles and Ermentrude on Queen Adelaide."150 Both cases, the treatment of Arnulf and the slight against his half-brothers, reveals an even more finely tuned sense of legitimacy than the distinction between the offspring of queens and concubines already indicated. Arnulf, despite being born of a concubine, is depicted as a legitimate ruler by simply omitting the circumstances of his birth from the genealogy, yet, at the same time, degraded by denying him the title of emperor. The legitimacy of Charles' brothers, on the other hand, is questioned by the remark on Louis the Stammerer's marriage problem ${ }^{151}$ while at the same time it portrays Charles as their father's true heir because he was born from the legitimate queen.

As argued above, Charles did not emphasise his Carolingian heritage to underline his claim to the throne and his practice of confirming his ancestors' diplomas did not differ from his predecessors. His complicated relations with his brothers, however, seems to be reflected in his diplomas. Carloman II is only mentioned four times, ${ }^{152}$ Louis III only appears once. While in the latter's case this is not surprising - Louis appears to have issued only a very small number of diplomas-the former's case is different. There is a distinctive overlap in institutions that were granted charters from both kings ${ }^{153}$ yet Charles only confirmed three of Carloman's diplomas. ${ }^{154}$ On far more occasions, he clearly excluded him from confirmations of previous charters, such as those issued by his father and grandfather. ${ }^{155}$ Selective citation was certainly not a practice unique to Charles and certainly not one he limited to his brothers' diplomas. ${ }^{156}$ Yet in these cases, there seems to be a particular underlying animosity that even surfaces in the dedication Charles made in another diploma, denying them their rank: "for the salvation of our grandfather Emperor Charles and King Louis, our most pious father, and our brothers, namely Louis and Carloman." ${ }^{157}$ Charles acknowledged his brothers, yet

150 See chapter III.1.3, n. 145. Interestingly, the genealogy omits Charles' third sister, Gisela, who had been married to Count Robert of Troyes and died before 12th December 884. She is mentionned in DCmII 80 as Gislae sororis nostrae. See Settipani, Préhistoire, 317 with n. 861 and 862.

151 See chapter I.1.1.

152 DDChS 23, 82, 105 and 119. DChS 101 does also mention him, yet, as already indicated, is too problematic to use in this context.

153 Churches of Narbonne (DCmII 73, DDChS 14, 23, 24 and 119), Girona (DCmII 58 and 93bis, DDChS 19 and 120), Autun (DCmII 49 and 68, DChS 33) and Châlons (DCmII 76, DDChS 29 and 112), Saint-Martin of Autun (DCmII 83, DDChS 32 and 59), Saint-Germain of Auxerre (DCmII 77, DChS 38), Saint-Martin of Tours (DCmII 87, DDChS 46, 49, 98 and 101), SaintGermain-des-Prés (DCmII 93, DDChS 45, 92 and 94), Morienval (DCmII 90, DChS 105), SaintMaur of Fossés (DCmII 92, DChS 108), Saint-Crépin of Soissons (DCmII 79, DChS 12).

154 DDChS 23, 105 and 119.

155 DDChS 12, 19, 32, 33, 45 and 120. See also Koziol, Charles, 178 with n. 70.

156 Koziol, Charles, 178 with n. 70.

157 DChS 82, 183: ...ob amorem Dei [...] necnon et elemosinam avi nostri imperatoris Karoli seu et Ludovico regis, piissimi genitoris nostri, sive fratrum nostrorum, videlicet Ludowici atque Karlomannni... 
their having become kings while he had been cast aside left its traces. They were family; their royalty, however, was another matter.

Other recent rulers were neglected in Charles' diplomas. ${ }^{158}$ Charles the Fat, for example, is only mentioned three times, ${ }^{159}$ despite Charles issuing a large number of diplomas for the same institutions as the emperor. ${ }^{160}$ However, once again, Charles' practice does not differ much from his predecessors'. Odo mentions Charles the Fat three, possibly four times ${ }^{161}$ in 50 diplomas, Arnulf and Zwentibold in their charters for Lotharingian recipients not at all, Louis the Child only once. ${ }^{162}$ Like the emperor, diplomas from these last three rulers were hardly ever confirmed by Charles: twice in the cases of Arnulf and Zwentibold, once for Louis the Child, ${ }^{163}$ although again there are a large number of institutions that received diplomas from several of them. ${ }^{164}$ However, given that only 21 of Charles' diplomas for Lotharingian recipients are preserved, these numbers may be rather expected than exceptional and hardly differ from the practice under Zwentibold and Louis the Child. ${ }^{165}$ Odo's appearances in Charles' diplomas-three confirmations ${ }^{166}$ and one memorial service ${ }^{167}$-are different to

158 See also Koziol, Politics, 498, according to whom Charles' choices were motivated by his legitimistic convictions.

159 DDChS 45, 55 and 114 as well as the higly problematic DChS 101.

160 Saint-Martin of Tours (DDChF 139, 160 and 161; DDChS 46, 49, 98 and 101), Saint-Martin of Autun (DChF 122; DDChS 39 and 59), Saint-Germain of Auxerre (DChF 145; DChS 38), SaintMédard of Soissons (DChF 163; DDChS 16, 52 and 58), Saint-Aignan of Orléans (DChF 143; DDChS 77 and 78), Saint-Maur of Fossés (DChF 149; DChS 108), Prüm (DChF 100; DDChS 84 and 104), Saint-Maximin of Trier (DChF 133; DChS 69), Andlau (DChF 96; DChS 125), Tournus (DChF 162; DChS 82), Saint-Bénigne of Dijon (DChF 117; DChS 29) and the Churches of Trier (DChF 102; DDChS 74, 81 and 100), Langres (DDChF 129, 147, 152, 153, 154, 155 and 155a; DChS 55), Tours (DChF 146; DChS 9), Girona (DChF 148; DDChS 19 and 120), Liège (DDChF 104 and 105; DDChS 5 and 65), Toul (DDChF 121 and 124; DDChS 70, 71 and 114) and Châlons-en-Champagne (DChF 150; DDChS 48 and 112). On the habit of issuing diplomas for the same institutions as their predecessors, see Koziol, Politics, Chapter 3, 97-118.

161 DDOdo 11, 16, 49 and probably also 20.

162 DLCh 49.

163 DDChS 68 (Zwentibold), 69 (Arnulf), 73 (Louis the Child) and 84 (Arnulf and Zwentibold). DDChS 100 and 103 do mention Arnulf and Zwentibold in the context of judicia.

164 Churches of Trier (DDA 39, 53, 113, 114 and 124; DDZ 4, 18, 20, 21 and 27; DDLCh 2, 17 and 59; DDChS 74, 81 and 100), Toul (DDA 93, 112 and 128; DLCh 7; DDChS 70, 71 and 114), Liège (DA 64; DZ 24; DDLCh 55 and 57; DDChS 5 and 65) and Cambrai (DDA 108? and 127; DZ 23, DDChS 67, 68, 128 and 106) and the abbeys Prüm (DDA 29 and 92; DDZ 2 and 25; DDChS 84 and 104), Saint-Maximin of Trier (DA 10; DDZ 13 and 14; DChS 69), Echternach (DZ 5; DLCh 53; DChS 76), Andlau (DLCh 68; DChS 125) and Saint-Mihiel (DDZ 3 and 8; DDLCh 36 and 62; DDChS 11,73 and 83 ).

165 Zwentibold's 28 preserved diplomas mention Arnulf three, possibly four times (DDZ 2, 14 and 24; the passage in DZ 4 concerning Arnulf appears to have been interpolated). In Louis the Child's 16 diplomas, Arnulf figures four (DDLCh 2, 7, 49 and 57) and Zwentibold three times (DDLCh 57, 62 and 70).

166 DDChS 60, 75 and 105. We exclude the higly problematic DChS 101 from this list.

167 DChS 49. 
the cases above, even if not at first glance. Geoffrey Koziol argued that Charles did not consider Odo a legitimate king. ${ }^{168}$ This conclusion is based on Charles' practice of marking his predecessors as his relatives, ${ }^{169}$ hence naturally excluding Odo. However, these expressions can also be found in earlier diplomas ${ }^{170}$ and tie in well with other expressions common in Louis the Stammerer's and Carloman II's diplomas concerning their royal descent, as we have shown above. The language of Charles' diplomas certainly does not reflect the new situation with a non-Carolingian predecessor, yet to expect that Charles would drop this phrasing only to include Odo into the line seems to be expecting too much. In this context, it is also worth pointing out that the dating clauses of a number of Charles' early diplomas add "in succession to Odo" (in successione Odonis) to the normal dating ${ }^{171}$ demonstrating that he did indeed acknowledge Odo as his legitimate predecessor. ${ }^{172}$ The low number of Odo's appearances certainly shows that he was not one of Charles' favourite kings, yet he certainly did not fall victim to a damnatio memoriae. ${ }^{173}$ Nevertheless, mentions of Odo may indeed have carried a specific weight, given that his brother was one of the most powerful men of the realm and one of the key players at the royal court. We must therefore take mentions of Odo into consideration when moving on to discuss relations between Charles and the marchio.

\section{III.2 Breaking it down: Networks of royal power}

The beginning of Charles' reign as sole king is marked as a "renewal"redintegratio- of his rule, attributed to the divine will by the official language of his diplomas. ${ }^{174}$ For the author of the Annales Vedastini, his installation on the throne was no less consequential. Since the realm had been his father's, it was

168 Koziol, Politics, 500-501.

169 For example DDChS 24, 49 (Nos vero priscorum regum, scilicet parentum nostrorum, morem sequentes...), 35, 75 (...morem praedecessorum, parentum scilicet nostrorum regum, imitari videmur...) and 43, 93 (...predecessorum regum nostrorum siquidem parentum morem et actus imitantes...).

170 For example DDLS 24, 76 (...morem parentum regum videlicet et imperatorum praedecessorum nostrorum sequentes...), 28, 84 (...morem parentum regum videlicet et imperatorum praedecessorum nostrorum sequentes.) and DChF 144, 231 (...morem parentum regum videlicet praedecessorum nostrorum sequentes...).

171 DDChS 13-14, 19-20 and 22-26.

172 See also Falkowski, Contra legem, 228.

173 Likewise, not all of the mentions of Odo can be attributed to Robert's intervention. DChS 60, confirming one his diplomas, was issued for the abbey of La Grasse, far from Robert's power base and without his intervention.

174 Wolfram, Herrschertitel, 115. The formulae seem to be borrowed from Louis the Pious' diplomas issued after 834 . 
just that it should now be his. ${ }^{175}$ However, the annals also note that his accession was acclaimed by an assembly of Franks; hence, despite his claim, Charles still needed the general consent of the nobles. ${ }^{176}$ Odo, already on his deathbed, had tried to ensure this consent by asking the nobles to serve Charles loyally, ${ }^{177}$ probably in accordance with the treaty concluded between him and Charles earlier in 897. However, as a run-through of who was present at Charles' coronation shows, Odo's death-bed appeal to the nobles did not have the desired effect. Archbishop Fulk was present at the coronation, since the ceremony took place at Reims. Count Heribert I's presence is indicated by the Annales Vedastini-he was the reason why Baldwin of Flanders proclaimed his loyalty to the new regime through envoys, rather than coming in person. ${ }^{178}$ Others, however, were missing: Odo's own brother Robert, Richard the Jusiticiar and William the Pious. Robert's absence was probably due to the Northmen, who, after a settlement with Odo, had spent the winter along the Loire ${ }^{179}$ and were now devastating the bordering regions before returning to their ships. After they were gone, Robert met the king and was received honourably. Richard and William, on the other hand, appear to have waited for Robert to act. Only when he had acknowledged Charles as king, did they come to court ${ }^{180}$ indicating that they did not take it for granted that Robert would agree to Charles' being the new king. This is certainly surprising since Robert, given his importance for Odo's rule, undoubtedly had played a major role in the negotiations of 897. However, as would appear from Richard's and William's hesitance, they seem to have harboured certain doubts towards the actual implementation of the treaty. Hence, the episode points us the initial problem of Charles' reign: to find a way to integrate his old opponents who had been key figures of Odo's rule and the other powerful magnates of the realm who had abstained from supporting him during the previous years and to mediate between their interests and those of his old supporters who still formed the core of his network.

175 Annales Vedastini 898, 79: Franci vero rege mortuo die ... Remis conveniunt Karolumque in sede paterna restituunt. This concurs with their account of Charles' first coronation in 893, 73: Mittunt itaque et Karolum regis Hludowici filium, adhuc puerulum, ad dictum placitum venire fecerunt et die supra dicto Remis adunati eum in paterno solio benedictum in regem collocant, omnesque coniurant adversus Odonem regem.

176 On Carolingian successions, see Tellenbach, Grundlagen; Kasten, Königssöhne and Becher, Dynastie.

177 Annales Vedastini 897, 79.

178 Annales Vedastini 898, 79.

179 Annales Vedastini 897, 79. Against this reading Koziol, Charles, 375-376, who argues that the coronation took place in January when the Northmen were still at peace. The account of the $A n$ nales Vedastini (see next note) is not entirely clear on this subject. While the Northmen started devastating Neustria and Aquitaine before returning to their ships in spring, it is left unclear whether they had already started to do so in January.

180 Annales Vedastini 898, 79: Nortmanni vero verno tempore rediere ad naves, vastatam Aquitaniae partem atque Neustriam, insuper plurima eversa castra, interfectis habitatoribus. Post haec Rothbertus comes, frater regis Odoni, venit ad regem; quem rex honorifice suscepit, eiusque fidelis effectus rediit ad sua. Similiter fecit et Richardus, [insuper et Willelmus]. 


\section{III.2.1 Close associates and allies}

\section{III.2.1.1 The first years}

The first years of Charles' reign were marked by a peculiar situation. As indicated by the Annales Vedastini, Robert and Richard were present at the royal court and took part in discussing and planning of affairs of the realm; they were present, for instance, in 900 to organise a campaign against the Northmen. ${ }^{181}$ During these first years, however, neither of them appeared in royal diplomas; although afterwards, first Richard and then Robert become dominant. Instead, diplomas issued during these years tended to be issued to those who had supported Charles during the fight against Odo. Archbishop Fulk and Heribert I occupied prominent positions within the inner circle around the king. The archbishop resumed his service as archchancellor ${ }^{182}$ and intervened before Charles on behalf of the monks of Saint-Amand. ${ }^{183}$ The count, on the other hand, received a diploma for his abbey Saint-Crépin of Soissons, which emphasises his position as one of the king's most important advisors by naming him "our beloved count and abbot",184 and he took part in the council preparing the Viking campaign of $900 .{ }^{185}$ His influence, as well as Fulk's, was also visible one year earlier, when he and the archbishop successfully spoke against Baldwin of Flanders, who, soon after he had been forced to give up Saint-Vaast, approached the king to recover his lost lands. ${ }^{186}$

But also others of Charles' old supporters remained present at court. Bishop Anskeric of Paris appears to have played an important role, becoming Fulk's successor as archchancellor after the latter's murder in $900^{187}$ and acting as Charles' ambassador on two occasions. In 899, he represented the king at a meeting at St Goar with Zwentibold and a legation sent by Arnulf. ${ }^{188}$ A year later, when the conflict between Charles and Robert had broken out, he negotiated with the latter at Tours. ${ }^{189}$ Furthermore, the bishop was granted two diplomas for his church. ${ }^{190}$ The first of these is worth a closer look. It was issued in 907, shortly after Charles' marriage to Frederuna, ${ }^{191}$ who herself intervened on behalf of Anskeric. Frederuna was not the only petitioner, though: besides her, the diploma also makes note of Abbess Gisela of Nivelles, daughter of Lothar II and Charles' cousin, Robert of Neustria, the countess Adelaide-either Robert's daughter and spouse of Herib-

Annales Vedastini 900, 82.

DChS 10, 8th February 898. Lauer, Recueil Charles III, XVI.

DChS 18.

DChS 12, 20: ...dilectus nobis comes et abbas...

Annales Vedastini 898, 79.

Annales Vedastini 899, 81-82.

DChS 30, 23rd June 900. Lauer, Recueil Charles III, XVI-XVII. On the importance of the archchancellor, see Depreux, Prosopographie, 30.

Regino, Chronicon 899, 146-147.

See below, chapter III.2.1.2.

DDChS 57 and 62.

The marriage is made note of in DChS 56, 19th April 907, 122. 
ert II of Vermandois ${ }^{192}$ or the wife of Richard the Justiciar ${ }^{193}$ - the counts Altmar and Erkanger as well as another Robert to who we will turn later on. The presence of Charles' relative and some of the most important nobles of the realm-Robert, of course, but also Adelaide, representative of either Heribert II or Richard as well as Altmar and Erkanger, both of whom were among Charles' closer supportersplaces a special emphasis on the occasion. The small assembly portrayed by this diploma is nothing less than a portrait of the elite of the realm: the most important people at court, enriched with the presence of another member of the royal family and with Anskeric as the diploma's recipient in an especially honourable position. But the charter also provides us with further insight into the continuing influence of Charles' earliest supporters, to whom not only the bishop, but also Count Erkanger had belonged. This was Erkanger's second appearance in Charles' diplomas. In 901, he had intervened on behalf of a certain royal fidelis named Tedricus, ${ }^{194}$ in a diploma that demonstrates well how the old associates formed links with those desiring access to the king.

Another example of the continuing influence of this circle and its involvement in important political decisions and the construction of links to other nobles is another diploma issued at the request of Count Hugh of Maine and Count Ecfrid, another of Charles' early supporters ${ }^{195}$ It was issued at a liturgically propitious time: delivered on the eve of All Saints Day, it indicates that Charles, Hugh and Ecfrid celebrated one of the most important Christian holidays together at the abbey of Saint-Benoît-sur-Loire-as already noted, this was far outside the region the king usually visited-and at a liminal point between Francia and Maine, on the border of Robert's counties. Indeed, the diploma was issued after Robert had left the royal court in anger ${ }^{196}$ and marks Charles' efforts to find allies against the powerful marchio. ${ }^{197}$ Hugh of Maine was the son of Rothild, sister of Louis the Stammerer and abbess of Chelles, and Roger of Maine, who had taken Le Mans and thwarted Odo's and Robert's efforts to install their own man, Gauzlin, in the

192 Werner, Nachkommen, 458. Werner argues for a marriage between Heribert II and a daughter of Robert of Neustria. He identifies this daughter with the countess Adelaide based on a) the circumstance that the abbey of Rebais, which is given to the church of Paris in the diploma, was situated in Meaux, one of Heribert's counties; Adelaide would then represent her husband in the charter b) her position in the diploma after Robert but preceding the other counts $\mathrm{c}$ ) the name Adelaide appearing in Heribert's family in the next generation. On the question of this marriage, see also Settipani, Préhistoire, 225 with n. 242 and 408 with n. 44 . Against this identification Bouchard, Patterns, 16-17, n. 27, who argues that Adelaide would not have been Robert's daughter, but his wife since it was common practice a) for spouses to sign as witnesses next to each other and b) to indicate daughters as such. However, neither Robert nor Adelaide figure as witnesses in the charter, they are mentioned as petitioners in the narratio. See also Hlawitschka, Ahnen II, 383-384 with further literature on this case.

193 Lauer, Recueil Charles III, 123, n. 5, without giving any reasons.

194 DChS 39, 21st August 901.

195 DChS 35, 31st October 900.

196 Annales Vedastini 900, 82.

197 See below. 
city. ${ }^{198}$ Thus, Hugh was Charles' cousin, and in fact the diploma describes him as the king's "beloved kinsman,"199 but, more importantly, he was Robert's enemy.

Others belonging to the old circle around Charles also continued to be present at court. Count Aledramnus intervened together with Bishop Mancio for the latter's church of Châlons ${ }^{200}$ and Bishop Heitilo of Noyon requested two diplomas for his church. ${ }^{201}$ Besides Charles' old friends, however, also other nobles were heard at the royal court. Count Altmar, who we have already seen among the nobles figuring in the diploma of 907, was probably also behind the king's charter for his abbey of Saint-Médard of Soissons. ${ }^{202}$ Furthermore, some of the nobles who had originally supported Odo were now integrated into Charles' rule. The bishops Honoratus of Beauvais and Rudolf of Laon ${ }^{203}$ were among the first to intervene in a royal diploma, in their case on behalf of the monks of Saint-Denis, for a grant of immunity within their new fortification. ${ }^{204}$ This was another diploma of distinctive political importance: the abbey, held by Odo after the death of his chancellor Ebolus, ${ }^{205}$ appears not to have been passed on to his brother Robert. ${ }^{206}$ Odo had made Saint Dionysius his patron ${ }^{207}$ and was even buried in the abbey. Already in 896, Charles had tried to link himself to the saint when he issued a diploma for the abbey of Salonnes, where relics of Dionysos were held, ${ }^{208}$ an abbey that only half a year earlier had been restored by Zwentibold to Saint-Denis. ${ }^{209}$ In his new diploma, Charles now renewed the connection by claiming the saint as his own special patron ${ }^{210}$ and indirectly declaring his own overlordship over the abbey where not only Odo was entombed, but more importantly also his brothers Louis and Carloman and, most importantly of all, Charles the Bald. ${ }^{211}$ Issued at the abbey itself, this diploma was meant as a political symbol, demonstrating that the king

198 On this "war of Le Mans" see Werner, Untersuchungen III, 280-282 and chapter I.3.

199 DChS 35, 75: ... dilectus comes Hugo consanguineus...

200 DChS 29.

201 DDChS 2 and 40.

202 DChS 16, a deperditum dating to 899. Flodoard (HRE IV, c. 10, 402) reports that Altmar held Saint-Médard which he exchanged with Archbishop Fulk for Saint-Vaast after the latter abbey had been taken from Baldwin of Flanders. We assume that Charles issued the diploma before the exchange had taken place.

203 Rudolf had become bishop of Laon at a moment when Odo controlled the city (Flodoard, HRE IV, c. 5, 384 and c. 7,398 ).

204 DChS 10, 8th February 898.

205 Favre, Eudes, 151, n. 1.

206 Also Koziol, Charles, 374.

207 DOdo 34. Over the 9th century, Dionysos had become the most important patron of the West Frankish kings. Große, Saint-Denis, 228. On the importance of Saint-Denis and its connection to Charles the Bald, see Koziol, Politics, 443. On the conflict between Charles and Robert for SaintDenis, see Koziol, Charles, 374-379.

208 DChS 7.

209 DZ 7, 896 January 22. On Salonnes and Saint-Denis, see also Parisse, In Media Francia.

210 DChS 10 (8th February 898), 16: ...peculiaris patroni nostri domni Dionysii...

211 On the development of Saint-Denis as a royal necropolis, see Leistenschneider, Königsgrablege, especially 20-21 for the Caroligian period. On Charles the Bald and Saint-Denis, see Nelson, Mort, 61-64. 
was seizing control of one of the central places associated with kingship and that he now had also gained the support of former opponents. While this is Honoratus' only appearance in Charles' diplomas, Rudolf intervened again in 905, together with a Count Odilard, on behalf of the royal notary, Ernustus, ${ }^{212}$ thus marking his continuing influence.

\section{III.2.1.2 Shifting balances}

The end of this first period, during which the group of Charles' old supporters dominated the circle around the king, ended with the murder of Archbishop Fulk on 17th June 900. Almost immediately afterwards, Charles' first diploma for Richard the Justiciar was issued, ${ }^{213}$ followed by Robert leaving the court. ${ }^{214}$ The close sequence of these events seems to indicate that they were connected to each other. The best way to address this question is to remember Robert's position at court during Odo's last years, as analysed in the previous chapter. In 888 , Robert had taken over most of his brother's honores, most importantly the counties and abbeys along the Loire as well as Paris and the appertaining military command. During the fight against Charles, he had become the most important noble at Odo's court, acting as leader of his armies and negotiating on his behalf. This certainly influenced the way he interpreted his own position within the hierarchy of the nobles and at the royal court. He developed a strong confidence in his abilities and wisdom, a certain "sageness" that had to be acknowledged and used by the ruler. ${ }^{215}$

Charles' succession, however, meant that the political balance in the realm shifted. Integrating powerful nobles into his rule did not necessarily conflict with Charles' own perception of kingship. The language of a number of his diplomas underlines his willingness to take counsel into consideration and take his decisions in accordance with those surrounding him. ${ }^{216}$ However, the position that Robert desired was already taken by the nobles who had supported Charles' claim to the throne from the beginning, the group around Archbishop Fulk and Heribert I of Vermandois. Their presence appears to have made an integration of Robert on the basis of the latter's aspirations impossible. Fulk and Heribert would undoubtedly not have accepted what, in their eyes, must have been a presumption.

\section{DChS 51.}

213 DChS 32, 26th June 900.

214 The account of the Annales Vedastini (900, 81-82) indicates the temporal proximity of both events, placing Robert leaving the court immediately after Fulk's murder and Heriveus' election.

215 Koziol, Robert, 250-251, from Robert's only royal diploma, issued in 923 (DRoI 1). "Sageness" 251.

216 Up until the end of 911: DDChS 10, 16 (cum fidelium nostrorum consensu, venerabilium videlicet episcoporum), 41, 90 (suggerentibus quoque una cum dilectissima genitrice nostra Adeleide et regni nostri primoribus, tam episcopis quam comitbus, ceterisque fidelibus), 49, 108 (cum consilio regni nostri utriusque [ordinis] principum), 53, 115 (a nostris, tam episcopis quam laicis, fidelibus responsa accepimus), 56, 121-122 (fideliumque nostrorum benigne consulta suscipimus) and 57, 124 (Prefatorum igitur principum cognoscentes consilia esse salubria, eorum acquievimus benigne postulationibus atque communi consensu fidelium). 
Their revolt against Odo had, in part, been motivated by their desire to enter the innermost part of the circle around the king and they had been willing to fight for four devastating years to achieve their aim. At this point, giving up this position and, of all people, for their old opponent, would simply not have been possible. Robert had access to the court and certainly played a major role in the decisions made there, as the Annales Vedastini indicate, ${ }^{217}$ but he was denied the position he had occupied under Odo.

The murder of Fulk, however, meant that a power vacuum was created in the inner circle and that a new balance of power needed to be found. Charles' choice, however, did not fall on Robert but on Richard, for whom now a so-far unparalleled sequence of diplomas was issued at the palaces of Verberie ${ }^{218}$ and Compiègne. ${ }^{219}$ In these diplomas Richard was described as "illustrious count and our beloved marchio"220 and "illustrious count and marchio,"221 culminating in the third description as "our beloved and dearest Richard, venerable count."222 At this point, Robert was probably still present at court. As the Annales Vedastini report, it was Richard's most important confidant, Manasses, who made some negative comments about Robert to the king. Robert himself was not present at that moment and only later learnt about these words, taking them as reason to leave. ${ }^{223} \mathrm{We}$ can read this scene as a sign that Richard's influence had already eclipsed that of Robert at court. That Manasses dared to insult him was clearly a sign for Robert that, for the time being, his was a lost cause. Instead of him, Richard now dominated at court, and he and the king celebrated Christmas together at Reims. ${ }^{224}$

We should, however, not solely reduce this second period to one of rivalry between Robert and Richard. Particularly in 900 and 901, Charles did his best to increase the circle around him by concluding new alliances to keep Robert in check. We have already mentioned Charles' visit to Saint-Benoît-sur-Loire, where he met with Hugh of Maine. His cousin was not the only new royal ally, however. Just before Charles issued his first diploma for Richard, he confirmed a grant for

217 Annales Vedastini 900, 81-82.

218 DDChS 32 (26th June 900) and 33 (30th June 900).

219 DChS 31 (after the 30th June 900). Jacques de Font-Réaulx, Diplômes, 42, disagrees with Lauers' dating and corrects it to after 15th July but fails to give any arguments. Lauer's datation is based on the date of Fulk's murder, 17th June, and that the diploma is signed by his successor as archchancellor, Bishop Anskeric of Paris. I would add something else to the analysis: Heriveus, who was ordained by a synod as the new Archbishop of Reims on 6th July (Schmitz, Heriveus, 62 with n. 17), is already replaced as notary by Herluin. Since Heriveus certainly did not leave the chancellery immediately upon Fulk's death, and indeed still served as notary in DDChS 30, 32 and 33 (24th, 26th and 30th June), the diploma was definitely issued after 30th June. See also Bautier, Recueil Eudes, XXIX, n. 2.

220 DChS 32, 68: ...illustris comitis et dilecti markionis nostri...

221 DChS 33, 70: ...comes illustris et marchio... On the interpolations in this diploma, see also Bautier, Recueil Eudes, CLII, n. 1.

222 DChS 31, 65-66: ... dilectus et carissimus nostri Richardus, venerabilis comitis...

223 Annales Vedastini 900, 82.

224 Flodoard, HRE IV, c. 12, 405. 
the church of Saint-Christophe at Paris made by Viscount Grimoard, ${ }^{225}$ indicating that he had won one further supporter in Paris, possibly from one of Robert's own men. In November 901, he confirmed the rights and possessions of Corbie at the request of Count Ermenfrid of Amiens, ${ }^{226}$ brother of its abbot Franco, who had emphasised his independence from Odo by not only displaying his own monogram on the coins minted at the abbey, but also by omitting the name of the king. ${ }^{227}$ This diploma leads us to a private charter Robert issued in September 900 for Saint-Martin of Tours ${ }^{228}$ after he had already left the royal court. Among a large number of other bishops and nobles, this charter was witnessed by Bishop Otgar of Amiens, who "confirmed" (roboravit) it as episcophilax ${ }^{229}$ - two expressions which set him apart in the list of the witnesses. Did Otgar belong to Robert's supporters? While this conclusion comes to mind, we should also point out the presence of Charles' archchancellor Anskeric among those signing the charter, indicating that he tried to mediate between the king and the marchio. ${ }^{230}$ Otgar might thus also have belonged to the royal embassy sent to Robert. If Otgar was Robert's ally, Charles' diploma for Ermenfrid was not only a symbol of his alliance with the count, but also a sign that he had now taken control of the Amienois and was ready to confront Robert's ally in this area. But even if this was not the case, the diploma, nevertheless, remains exceptional for the early years. It was the first time that Charles referred to a larger group of nobles in a diploma, the "first men of our realm, bishops as well as counts and other fideles"231, who (alongside his mother Adelaide) had advised him. This points to a larger assembly at that moment, an assembly that allowed Charles to display his own power and to act as a king by confirming the diplomas of his predecessors: he mentions his grandfather Charles the Bald, Clothar III and his mother, St. Bathilde, ${ }^{232}$ founder of Corbie, as well as bishops and popes. ${ }^{233}$ The assembly at Fresnoy was a demonstration of Charles' kingship, going back to his grandfather and the Merovingians, displaying him as a king who protected the church and listened to his councillors. It was a moment from which he could draw confidence.

In addition to Grimoard and Ermenfrid, we now also find Baldwin of Flanders at Charles' side. Soon after Odo's death, Baldwin had made a new attempt to increase his influence in the north-east of the realm by attacking Péronne. Charles

DChS 30, 23rd June 900. Grimoard is otherwise not known. His grant to Saint-Christophe seems to indicate that he was viscount of Paris.

DChS 41.

Kaiser, Bischofsherrschaft, 601. On the coins, see Doubliez, Monnayage, 283-310, esp. 293.

DRoI 42, 13th September 900, Tours.

DRoI 42, 164: Otgerius episcophilax roboravi. On the use of Greek words in charters from the region see Jarousseau, Évêques, 374. See also McNair, Development, 57.

30 Anskeric had already previously served as Charles ambassador at the meeting of St Goar with Zwentibold and a legation of Arnulf in early 899 (Regino, Chronicon 899, 149-147).

DChS 41, 90: ... regni nostri primoribus, tam episcopis quam comitibus, ceterisque fidelibus...

On her, see Hartmann, Königin, 82-85.

On the bishops and popes, see Lauer, Recueil Charles III, 87 with n. 2-7. 
managed to subdue the count once again and seized Saint-Vaast from him, presenting it to Archbishop Fulk, who exchanged it with Count Altmar. ${ }^{234}$ When Baldwin's subsequent efforts to regain his lost honores were thwarted by the archbishop and Count Heribert, his men murdered Fulk. ${ }^{235}$ Unfortunately, the account of the Annales Vedastini ends shortly after, so we only have Flodoard's report of a synod under Fulk's successor, Archbishop Heriveus, during which Baldwin's men were excommunicated for their deed. ${ }^{236}$ Baldwin, however, was not only spared this punishment, but received a diploma shortly after confirming his new foundation at Bergues-Saint-Winnoc; ${ }^{237}$ he was also given control over Saint-Bertin, ${ }^{238}$ which had been one of his targets in 892 but then had been passed to Archbishop Fulk by Odo. ${ }^{239}$ The disparity between the actions taken against the murderers and those taken against their overlord can be explained by Charles' political situation at that very moment: the outbreak of the conflict with Robert. The king could not risk an open conflict with Baldwin like the year before-on the contrary, he needed all the allies he could possibly muster to keep the marchio of Neustria in check.

\section{III.2.1.3 A new balance}

The second period of Charles' rule, marked by Richard's dominance and Robert's absence from court, lasted until 902/903, when the latter returned while the former disappeared from the royal diplomas. Due to the lack of narrative sources, the reasons for this change are almost impossible to assess however a hypothesis can be brought forward based on Charles' diplomas. As we have argued, over the past decade Richard had obtained a position in Burgundy that had allowed him to establish himself as an intermediary between the local nobles and the king. ${ }^{240}$ The diplomas Charles issued for Burgundian recipients during the first years of his rule seem to indicate that the king acknowledged this state of affairs. While Burgundians did receive diplomas from him, they only did so at Richard's plea. There is one exception, however. In March 902, Charles confirmed the restitution of estranged property at Mailly to the church of Auxerre at the request of its bishop Herfrid. ${ }^{241}$ Is this diploma, which does not mention Richard in any way, a sign that Charles intended to revoke the status quo and re-establish direct contact between himself and the Burgundian nobility, thus threatening Richard's control over the region?

234 Annales Vedastini 899, 81. See also chapter III, n. 202.

235 Annales Vedastini 900, 81-82; Flodoard, HRE IV, c. 10, 402.

236 Flodoard, HRE IV, c. 10, 403.

237 DChS 28.

238 Folcuin, Gesta Abbatum S. Bertini Sithensium, c. 98, 625.

239 Folcuin, Gesta Abbatum S. Bertini Sithensium, c. 98, 624. Fulk, before becoming archbishop of Reims, had already once been abbot of Saint-Bertin and also acted on behalf of the monks before Odo when they refused Baldwin. See also chapter VI.2, Schneider, Erzbischof, 22-25 and Lößlein, Ressources.

240 See chapters II.4 and III.1.2.

241 DChS 42, 14th March 902. 
The diploma for Herfrid was followed by a last one for Richard, delivered four months later in July and granting property to his right-hand man Manasses. ${ }^{242}$ In contrast to the earlier diplomas issued at the marchio's request, it does not use the exceptional honorifics such as "beloved" and "dearest"243 but simply addresses him as "illustrious count." 244 While this change may indicate that relations between Charles and Richard had come under strain, there is also a hint that this diploma may have been intended to signal quite the opposite. It was delivered at Rueil, a villa that had been granted to the abbey of Saint-Denis by Charles the Bald Charles in $875 .{ }^{245}$ This grant had been made in exchange for a prayer service that included the emperor, his second wife Richilde ${ }^{246}$ and, for the first time, Richilde's and Richard's brother Boso, underlining the proximity between the latter and Charles the Simple's grandfather. ${ }^{247}$ Had Rueil been chosen to tie Charles the Simple's relation with Richard to the memory the earlier diploma represented? If we follow these interpretations, in early 902 Charles would have made an attempt to strengthen his own contacts with the Burgundian nobility and thus to weaken Richard's control over the region. This would have led to a deterioration of the relations between him and the marchio and, in turn, to efforts to mend these.

Be it as it may, with the diploma issued at Rueil Charles' rule started to transition into its third phase. From April 903 onwards, not Richard, but Robert became "our highly beloved count," ${ }^{48}$ the most important noble of the realm, who celebrated important Christian holidays with the king-probably Easter and definitely Pentecost, according to the dates on which the respective diplomas were issuedand the one who was received by Charles at the city of Charles the Bald, Compiègne. ${ }^{249}$ Just like Richard before, Robert was now a dominating presence in royal diplomas, receiving four more ${ }^{250}$ between 904 and 911 while also making a prominent appearance in the diploma of $907 .{ }^{251}$ How important Robert had become for Charles is best demonstrated by the first of these diplomas. Issued for Saint-Martin of Tours, it instituted a memorial service not only for Charles himself, but also for

243 See chapter III.2.1.2.

244 DChS 43, 93: ...per deprecationem illustris comitis Richardi... While this is not too far off the earlier DChS 33, 70 in which Richard is described as comes illustris et marchio, DChS 43 also drops the marchio title.

245 DChB 379.

246 On Richilde see Hyam, Ermentrude and Richildis.

247 On Charles the Bald and Boso and this diploma in particular see Airlie, Nearly Men, 33-34.

248 DChS 45, 25th April 903, 96: ...comes nobis admodum dilectus... DChS 46, 98 names Robert vir specialius, amabilis and carissimus, yet cannot, due to its highly problematic nature, be used for our analysis. DChS 47, 6th May 903 repeats the expressions used in DChS 45.

249 DDChS 45 and 46.

250 DDChS 49, 50, 54 and 66.

251 DChS 57. See above. 
Robert and his brother, the lord and king, Odo. ${ }^{252}$ Another diploma again reflects the strength of Robert's new position within the hierarchy of the nobility. Issued for Saint-Denis, it shows William the Pious and Robert acting together. ${ }^{253}$ Robert, despite being named second in the diploma, is clearly the dominating of the two. While William is described as "reverend count" (comes venerandus), Robert is addressed as "count and marchio" (comes et marchisus), thus underlining his superiority in rank-an impression that is further strengthened by William restoring property to Robert's abbey of Saint-Denis. Hence the diploma marks the acknowledgement of Robert's position by one of the most powerful men of the realm.

Robert's dominance, however, does not mean that the old circle around the king had lost all of its influence. While those we labelled as Charles' allies against Robert before 903 only made single appearances in the royal diplomas, some of his older associates remained notable also in the period after 903 . The most obvious example is of course the diploma from 907, in which Anskeric, Erkanger and Altmar appear alongside Robert. ${ }^{254}$ Furthermore, Rudolf of Laon continued to be present at court, intervening together with a Count Odilard for Charles' notary Ernustus. ${ }^{255}$ Two more diplomas for Saint-Médard of Soissons ${ }^{256}$ were undoubtedly issued at the request of Heribert II of Vermandois, who succeeded his father between 900 and $906 .^{257}$ Finally, contact with the church of Paris survived the death of Anskeric. His successor Theodulf was given a diploma in which he himself was addressed as "our beloved and venerable bishop," 258 emphasising his importance to the king. This was not his only appearance in Charles' diplomas. In 918, the king confirmed, along with other property, a donation made by the bishop to Saint-Marcel of Paris. ${ }^{259}$

Even more important was Fulk's successor at Reims, the new Archbishop Heriveus. Heriveus was the nephew of one of Odo's closest supporters, Count Hucbald of Senlis. ${ }^{260}$ It was probably due to this relationship that Heriveus became Odo's notary in 894. ${ }^{261}$ Once Odo died, like Honoratus of Beauvais and Rudolf of Laon, Heriveus joined Charles' side and became the new king's notary under archchancellor Fulk. ${ }^{262}$ Not even three weeks after the murder of Fulk, Heriveus was elected as his successor by a number of bishops from the archdiocese of Reims:

DChS 49, 108: ...in eleemosinam nostri et domni Odonis, quondam regis, germani sui nostrorumque etiam aliorum praedecessorum... ...servitium...ipsa die in memoriam nostri et Odonis regis atque Rotberti praedecessorumque eorum...celebrent...

254 DChS 57.

255 DChS 51.

256 DChS 52, 906 and 58, 11th June 907. Saint-Médard probably passed into Heribert I's hands immediately after Fulk's death.

257 Schwager, Graf, 31 with n. 138.

258 DChS 64, 145: ... dilectus noster ac venerabilis Theodulfus [...] episcopus...

259 DChS 97.

260 Flodoard, HRE IV, c. 11, 403.

261 Bautier, Recueil Eudes, XXXIX.

262

DChS 10, 8th February 898. Lauer, Recueil Charles III, XIX. 
Riculf of Soissons, Dodilo of Cambrai, Otgar of Amiens, Mancio of Châlons, Rudolf of Laon and Otfrid of Senlis. ${ }^{263}$ The only source indicating that Charles had a hand in Heriveus' election as archbishop is Richer, who reports that he succeeded Fulk by "royal grant." 264 Richer's report, however, is based on Flodoard, who does not mention any involvement of the king in the affair while Fulk had done his best to secure the free episcopal election. ${ }^{265}$ Nevertheless, Heriveus appears to have been Charles' choice. That he had belonged to the royal chancellery even after Odo's death certainly indicates that the king trusted him. But more importantly, Heriveus' first official act as bishop was clearly geared towards Charles' political interests. The same synod that elected him archbishop also decided on the fate of Fulk's murderers, excommunicating them while leaving their master, Baldwin of Flanders, unharmed ${ }^{266}$ - a turn of events that perfectly fit in with Charles' own efforts to gain Baldwin as a supporter in the ensuing conflict with Robert.

Heriveus' election also reveals how well he was connected within the ecclesiastic elite of Francia. Six out of nine suffragans voted for him in his election ${ }^{267}$ while the anathem against Baldwin's supporters, issued on the same occasion, was also signed by the others, as well as by Archbishop Wido of Rouen and Bishop Angelrannus of Meaux. ${ }^{268}$ The same bishops, or in some cases their successors, were also present at the council of Trosly in 909. ${ }^{269}$ Apart from Trosly, Heriveus also appears to have organised a number of provincial synods, during which they discussed not only spiritual matters, but also the state of the realm. ${ }^{270}$ While these latter were probably only attended by the suffragan bishops of the church of Reims, Heriveus also kept in contact with important men outside the borders of his province. When Wido of Rouen needed advice in the conversion of the Northmen, he turned to Heriveus. ${ }^{271}$ In 902, the archbishop of Reims met with Archbishop Hatto of Mainz, one of the leading nobles in the regency for Louis the Child, ${ }^{272}$ to confer not only over ecclesiastical affairs but also over those of use for the realm. ${ }^{273}$ Moreover, the archbishop also appears to have been very well connected in the West Frankish elite outside the church. Given his past in Odo's chancellery, it may well have been

263 Flodoard, HRE IV, c. 11, 403-404.

264 Richer, Historiae, I, c. 19, 56: Sepulto vero domno Fulcone metropolitano, Heriueus vir spectabilis et palatinus, episcoporum consensu, et Remensium conibentia in pontificatu regis donatione succedit.

265 See also Schmitz, Heriveus, 63.

266 The excommuncation sentence has been preserved, MGH Conc. V, N 47, 456-458.

267 Flodoard, HRE IV, c. 11, 403-404.

268 MGH Conc. V, N 47, 456-457.

269 MGH Conc. V, N 58, 497-562, 562.

270 Flodoard, HRE IV, c. 14, 407: Conventus denique synodales sepe cum coepiscopis sue dioceseos habuit, in quibus de pace et religione sancte dei ecclesie statuque regni Francorum salubriter competenterque tractavit. On this passage, see also Schröder, Synoden, No $18,157-160$.

271 Guillot, Étapes.

272 Offergeld, Reges pueri, 538-542.

273 Mainzer Urkundenbuch, $\mathrm{N}^{\circ}$ 176, 109-110: ...quaesituri pariter de ecclesiastice documentis discipline regnique utilitatibus. The meeting took place 16th September 902 at Herrici monasterio, probably a place in Lotharingia. See Schmitz, Heriveus, 66 with n. 34 and 35. 
his connections to the Robertians that helped bringing Robert back to Charles' court. His influence within and without the Church is also visible in 920, when, as Flodoard reports, the Frankish counts abandoned Charles. ${ }^{274}$ The circumstance that only the counts protested against the king's relation to his intimate Hagano seems to point to Heriveus' control over the bishops of his diocese. Some of them, like Abbo of Soissons and Bovo of Châlons, were close to Charles and certainly did not need to be convinced to remain loyal, ${ }^{275}$ in other cases however it was probably due to the archbishop that the bishops stood with the king. On the other hand, his connections to the secular nobles become apparent when Flodoard ascribes the settlement found between Charles and the counts to his mediation. ${ }^{276}$

Thus, Heriveus appears to have been a key figure of Charles' reign, well connected within and beyond his province and deeply involved in the politics of the realm. It is therefore hardly surprising that Charles' choice fell on him to succeed Anskeric as archchancellor after his death in 911. ${ }^{277}$ Heriveus held the office up until 919 when he was replaced by Archbishop Roger of Trier, ${ }^{278}$ a development that seems to have left their relation unaffected, as can be seen from the events in 920 as well as from Heriveus' support for Charles in the succession of Bishop Stephen at Liège. ${ }^{279}$ While there may have been tensions between him and the king in $922,{ }^{280}$ the proposed evidence for this is ambiguous. Immediately preceding the breakout of the hostilities, there were negotiations between Heriveus' fideles and the rebels. ${ }^{281}$ Whether this indicates cooperation between Heriveus and the rebels is not clear, however, and it seems at least possible that the intention of the meeting was to win the archbishop as mediator in the ensuing conflict. Soon after, however, Reims did become a holdfast for Charles' enemies. When hostilities broke out, Charles devastated the possessions of the church of Reims along the Meuse. Just before Pentecost, inhabitants of the city stole horses from Charles' army, leading to a futile assault on Reims. Soon after, Robert was crowned king at Saint-Remy. ${ }^{282}$ Flodoard does not directly connect Heriveus to these events. He only mentions the archbishop's death immediately after the coronation, making it appear as a divine sign against the justness of Robert's cause and thus indicating that Heriveus at least

Flodoard, Annales 920, 2.

On these men, see below.

Flodoard, Annales 920, 2: Heriveus autem, Remorum archiepiscopus, accipiens regem cum omnes eum desseruissent, duxit eum ad hospitia sua, in villam quae dicitur Carcarisia. In crastinum vero, venerunt in Crusniacum, Remensis episcopii villam, ibique manserunt donec Remis venirent. Sicque deduxit eum per septem fere menses, usque quo illi suos principes eumque suo restitueret regno.

Lauer, Recueil Charles III, XVII-XVIII.

The last diploma featuring Heriveus as archchancellor dates to 27th June 919 (DChS 101). Occasionally Roger acted as archchancellor before this (DDChS 84, 19th January 916 and 93, 28th April 918). See also Schieffer, Kanzlei, 145, who gives DChS 102 (a forgery) as the last diploma with Heriveus.

Schmitz, Heriveus, 84. See also below and Zimmermann, Streit.

As proposed by Schmitz, Heriveus, 79.

Flodoard, Annales 922, 7-8.

Flodoard, Annales 922, 8-10. 
tolerated the proceedings. ${ }^{283}$ However, Heriveus appears to have been sick for quite some time before his death ${ }^{284}$ and may have lost control over affairs at Reims. ${ }^{285}$ In this context, we should also note the fates of Heriveus' brother and nephew: shortly after the election of the archbishop's successor Seulf, they were accused of having broken their oaths, imprisoned by Heribert II and Robert and deprived of their property. ${ }^{286}$ While the nature of their betrayal remains obscure, it seems possible that they had opted for Charles instead of Robert, which may in turn point towards Heriveus' own convictions. In any case, it seems that there was a strong opposition against Charles within the city and the cathedral, ${ }^{287}$ an opposition over which Heriveus, already on his deathbed, would have had only limited influence.

Robert's integration into Charles' rule in 903 did not mean that the king from then on solely depended on him, but that a balance had been found between him, the circle of Charles' old supporters and the other nobles who had joined this circle after 898 . This new-found stability even allowed for the reintegration of Richard into the royal court without threatening Robert's position. In 907, Richard requested a diploma for Otbert, the provost of Langres, appearing at the royal court together with his right-hand man Manasses and Bishop Argrim of Langres. ${ }^{288}$ Given the date of the diploma, 4th April 907, Charles and Richard seem to have celebrated Easter together at Compiègne, indicating the importance Charles still attributed to Richard and that their relationship had probably not suffered. A year later, Richard received another diploma, this time for Saint-Martin of Autun as "count and illustrious marchio." ${ }^{" 289}$ By 907/908, therefore, Charles had successfully created a finely balanced network of support that included all of the factions that had previously struggled for influence at the royal court.

\section{III.2.1.4 Lotharingia}

In late 911, Charles acquired a new regnum, Lotharingia. Before focussing on his network of support there and the impact this event had on his relations with the Western nobles, we first need to address some questions concerning the nature of this regnum, its borders and how they affected the composition of the Lotharingian nobility. From south to north, Lotharingia' ${ }^{290}$ western border ran along the Saone, making an eastward turn around Chalon-sur-Saone rejoining the river

283 Jacobsen, Flodoard, 16-17.

284 Flodoard, HRE IV, c. 17, 409.

285 See also Jacobsen, Flodoard, 18 and McKitterick, Kings, 233-234.

286 Flodoard, HRE IV, c. 18, 410.

287 Nevertheless, as DChS 121 (31st May 922) for Saint-Thierry of Reims indicates, there was also still a party in Charles' favour.

288 DChS 55 (4th April 907, Compiègne).

289 DChS 59, 127: ...comes et illustris marchio...

290 On the problematic nature of the use of the term Lotharingia, see Schneider, Suche, 14-15. We also follow Schneider's analysis of Lotharingia's borders (Schneider, Suche, 69-114) without including his findings on the southern part of the regnum in Provence and Burgundy since by 893 
eastwards of Gray and then leaving it again to follow the borders of the diocese. North of Langres the frontier crossed the Marne to the west and back, running parallel to the Maas and touching the river north of Mouzon from where it turned to the west, now following the borders of the dioceses of Liège and Cambrai in a westward turn, joining the Scheldt north of Cambrai and following it to the North Sea. Thus, parts of the dioceses of Reims and Langres were part of Lotharingia. ${ }^{291}$ In the east, the Rhine seems have been the border, with some exceptions: Mainz, Worms and Speyer belonged to the Eastern kingdom while Friesland-the modern Holland including the Kennemerland and Utrecht but not Middle and East Friesland-belonged to the regnum Hlotharii. ${ }^{292}$ At Zwentibold's time, Verdun seems to have been the most southern city of Lotharingia, with Besançon being contested by Arnulf and Rudolf of Upper Burgundy, the latter being able to assert his control of the episcopal see by $903 .{ }^{293}$ Northern Alsace seems to have been held by Arnulf, the south by Rudolf. ${ }^{294}$ Thus the Rhine frontier remained stable, Alsace and Friesland constituting what Schneider calls "Bruchlinien."295

Six out of ten Lotharingian dioceses, Strasbourg, Basel, Trier, Cologne, Utrecht and Cambrai, owned territory in other kingdoms, with some having over half of their territory outside Lotharingia. Moreover, for the bishops of Strasbourg, Basel and Cambrai, their respective metropolitans were located outside of the regnum, at Mainz, Besançon and Reims. The Lotharingian churches were thus strongly oriented towards the East and the West. ${ }^{296}$ Like the churches, the nobility had close relations with families outside the regnum. As Régine Le Jan argues, families originating from the Trier area were also implanted into the Verdunois, along the Middle Rhine, in the Vermandois and the Cambrésis, their connections not only surviving the partition of Verdun in 843 but persisting at least until Ottonian times. Other examples of continuing relations would be the Adalberos, descendants of Count Wigeric of the Bidgau and Count of the Palace of Charles the Simple, who provided an archbishop of Reims and bishop of Laon during the 10th century. ${ }^{297}$ To this one could also add King Odo's brother Robert, who had held a county in Lotharingia in the early 880 s; ${ }^{298}$ his nephew, Count Megingaud, who was murdered by Count Alberich in $892,{ }^{299}$ the Lotharingians who held their

they had either become part of the Western kingdom or of Boso's realm. Much shorter but less precise is Parisse, Lotharingie, 34.

291 Schneider, Suche, 75-76.

292 Schneider, Suche, 77-93.

293 Schneider, Suche, 103-104 with Poupardin, Royaume, 26-27.

294 Zotz, Elsaß, 63.

295 Schneider, Suche, 108.

296 Schneider, Suche, 197-181.

297 Le Jan, Aristocratie, 75. On Wigeric's family, see also Parisse, Généalogie.

298 DChF 105. See also chapter II.3.

299 Regino, Chronicon 892, 140. Megingaud had also been close to Archbishop Hincmar (Flodoard, HRE III, c. 26, 340). Archbishop Fulk was also drawn into the affair (Flodoard, HRE IV, c. 3, 375 and c. 6, 389). On the conflict, see Hlawitschka, Lotharingien, 110-111. 
amicitia with Odo, although they were supposed to support Charles the Simple in $894^{300}$ and, of course, Reginar Longneck. ${ }^{301}$ For similar phenomena in the East, we could name Count Gerhard, who married Oda, daughter of Count Otto of Saxony, ${ }^{302}$ or the Konradiner family, who had a strong influence on Lotharingian politics during the first decade of the 10th century. ${ }^{303}$

Did these nobles consider themselves to be Lotharingians and were they attached to the idea of the existence of an entity called Lotharingia? ${ }^{304}$ A middle kingdom was certainly perceived as a separate regnum, although, in reality, this entity proved to be an extremely fragile one. ${ }^{305}$ In fact, it seems that the idea of Lotharingia was created by those foreign to the regnum, ${ }^{306}$ while the Lotharingians themselves had not forgotten the old origin of the region as part of Francia. ${ }^{307}$ Hence, doubts concerning the existence of a specific Lotharingian identity are understandable, ${ }^{308}$ even if some scholars argue in its favour. ${ }^{309}$ It may best serve us if we follow Régine Le Jan, who acknowledges the existence of a Lotharingian identity, but denies it being consistent and describes it as overall too weak to serve as a framework for the development of an independent kingdom. ${ }^{310}$ Thus, Lotharingia presents itself not as a monolithic block resting between two kingdoms in the east and west, but as a region with a fragmented aristocracy, ${ }^{311}$ which latter pursued individual interests by using their relations reaching beyond the borders of the regnum into the neighbouring kingdoms.

These individual interests become apparent under the reigns of Zwentibold and Louis the Child, providing us with the necessary background to understand the implementation of Charles' rule over Lotharingia. During these years, four factions, centred on individuals and families, struggled for control over the regnum: Archbishop Ratbod of Trier, Reginar Longneck, the Matfrid family and the Konradiner. The first to emerge as the leading figure was Ratbod, who became

300 Annales Vedastini 894, 74-75.

301 See chapter I.2.2.

302 Regino, Chronicon 897, 145 and 900, 148.

303 On the Konradiner family, see Jackman, Konradiner; Heidrich, Adelsgeschlecht and Offergeld, Reges pueri, 547-555. Particularly on their influence in Lotharingian affairs, see Hlawitschka, Lotharingien, 189-193 and Boshof, Lotharingien, 144. For other examples see also Margue, Nous, 412-413.

304 Following the basic definition of Henri Tajfel (Tajfel and Turner, Identitiy), a group consists of indiviuals who perceive themselves as belonging to the same social category, possess a certain amount of emotional attachment to this category and agree with the others about their membership and the evaluation of the group.

305 Goetz, Perception.

306 Margue, Nous, 414 and 420.

307 Ewig, Beobachtungen, 349-356, Goetz, Perception, 122 and Margue, Nous, 397. For Regino's perception of Lotharingia, see Goetz, Dux, 96-114.

308 Schneidmüller, Regnum, Brühl, Deutschland, 309 and Schneider, Suche, 273.

309 Anton, Synoden, 118-124 and Bauer, Lotharingien, 640. Against them, see Hartmann, Lotharingien, 142 and Schneider, Suche, 123 and 484.

310 Le Jan, Aristocratie, 75.

311 Le Jan, Aristocratie, 77-79. 
Zwentibold's archchancellor ${ }^{312}$ and appears in four of the king's first diplomas, intervening as "most holy archbishop" and "our beloved" on behalf of Prüm, SaintMihiel, Echternach and his own church. ${ }^{313}$ The following year, however, his influence seems to have suffered considerably. He did not intervene anymore and by the end of the year even lost his position as archchancellor to Hermann of Cologne. ${ }^{314}$ This was undoubtedly caused by the rise of Reginar at the royal court, who, at the same time, received the abbey of Saint-Servais of Maastricht, which had been given to the church of Trier by Arnulf in $889 .{ }^{315}$ Ratbod still remained in contact with the court, however, receiving further diplomas ${ }^{316}$ and slowly regaining his influence and offices, ${ }^{317}$ until May 898, when Zwentibold turned away from Reginar and restored Saint-Servais to the church of Trier. ${ }^{318}$ Under Louis the Child, Ratbod's importance remained unbroken, probably due to an alliance with the Konradiner family ${ }^{319}$ Louis again confirmed his possession of Saint-Servais, ${ }^{320}$ along with a number of other diplomas for the church of Trier. ${ }^{321}$ His influence at court, however, is probably best reflected by his continued service as archchancellor for Lotharingian affairs, ${ }^{322}$ his intervention on behalf of Saint-Evre of Toul ${ }^{323}$ and his personal receipt of a royal gift. ${ }^{324}$

Reginar's first appearance at Zwentibold's side is connected to the king's expedition to the Western realm in support of Charles. When tensions arose between the two kings, Reginar left Charles' side for Zwentibold. ${ }^{325}$ From this point onwards, his star was on the rise. He intervened in front of the king ${ }^{326}$ and received Saint-Servais and Echternach; ${ }^{327}$ the latter, like the former, previously held by

312 Schieffer, Urkunden Zwentibolds, 6. On the Lotharingian chancellery see also Schieffer, Kanzlei.

313 DDZ 2 (5th June 895, for Prüm, 19: ...sanctissimi archiepiscopi Ratboti...), 3 (14th August 895, for Saint-Mihiel, dilectus noster), 4 (25th October 895, for Trier) and 5 (28th October 895, for Echternach, 26-27: ...dilectus archiepiscopus sed et summus cancellarius noster Ratpotus...).

314 DZ 12 (11th November 896) figures Hermann of Cologne in the position usually reserved for the chancellor, yet only referring to him as archchaplain. DZ 13 (28th January 897) sees Ratbod again, DDZ 14-17 note again Hermann.

315 Beumann, Kurswechsel, 430 and DA 53. On Saint-Servais, see also Lößlein, Ressources.

316 DDZ 13 and 14.

317 DZ 18 (5th February 898) figures him acting as archchancellor again, in DZ 19 he intervenes on behalf of the abbey of Werden.

318 Parisot, Royaume, 544. DDZ 20 and 21 for the restoration of Saint-Servatius. On these diplomas, see also Beumann, Kurswechsel.

319 DLCh 17 notes him intervening with Conrad and Gebhard.

320 Lechner, Urkunden, $N^{\circ}$ 554, 871. Parisot, Royaume, 612 apparently did not know of this deperditum. Hlawitschka, Lotharingen, did know about it but considered it to be a mere appeasement for Ratbod without any influence on the actual state of the abbey.

321 DDLCh 2 and 17.

322 Schieffer, Urkunden Ludwigs des Kindes, 84-85.

323 DLCh 49.

324 DLCh 59.

325 Annales Vedastini 895, 76.

326 DZ 7, 22nd January 896, for Saint-Denis.

327 Schieffer, Kanzlei, 31. 
Archbishop Ratbod. ${ }^{328}$ The high point of their relations was undoubtedly reached in late 897, when Reginar spent Christmas with Zwentibold and intervened as "our beloved" for Saint-Evre of Toul. ${ }^{329}$ Reginar's own possessions and honores are hard to track ${ }^{330}$ and widely scattered, but the centre of his influence seems to have been in the Hesbaye and the Hainaut region, as whose count he is most commonly identified but never actually named in the sources. His intervention for an abbey so far from his own possessions underlines his influence at court just like Regino of Prüm's description of him as Zwentibold's "most loyal and only advisor."331 It was probably also due to his influence that, after Megingaud's murderer Alberich had been killed by Count Stephen, Zwentibold intervened and withdrew not only Stephen's own honores, but also those of his supporters, to distribute them amongst his own followers. ${ }^{332}$ Yet this moment also proved to be the zenith of Reginar's influence at Zwentibold's court. Shortly after, the king restored his favour towards Ratbod and, in turn, withdrew all the honores and possessions Reginar held within his realm and ordered him to leave the regnum within a fortnight. ${ }^{333}$ Instead of leaving the realm, the count withdrew to Durfos, sought out allies and called Charles into the realm. ${ }^{334}$ Zwentibold's rule now started to deteriorate. After the negotiations that took place at St Goar early in 899 to settle the conflicts in Lotharingia, the king renewed his efforts to make the count submit, yet not only failed but was also resisted by his bishops, who refused to excommunicate the rebels. ${ }^{335}$ Rejected by the vast majority of the Lotharingian nobles and without the help of his father after Arnulf's death on 8th December 899, Zwentibold sought refuge in devastating the country. The Lotharingian aristocracy chose Arnulf's legitimate son Louis as a replacement king, to whom they paid their homage at Thionville and Aachen. Zwentibold found his end in battle against the Counts Stephen, Gerhard and Matfrid on 13th August 900..$^{336}$

328 Schieffer, Kanzlei, 31 and 45-46.

329 DZ 17, 28th December 897, 48: ... Reginharius dilectus comes noster...

330 Goetz, Dux, 311-314 and Espace, 171 as well as Barth, Herzog, 30-36 and Hope, Development, 201-205.

331 Regino, Chronicon 898, 145: Eodem anno Zuendibolch Reginarium ducem sibi fidissimum et unicum consiliarium, nescio cuius instinctu, a se repulit et honoribus, hereditatibus, quas in suo regno habebat, interdictis eum extra regnum infra XIIII dies secedere iubet.

332 Regino, Chronicon 896, 144 and 897, 144. Hlawitschka, Lotharingien, 110-111 with n. 175 and 176 and Schieffer, Kanzlei, 23-30. Reginar's influence has been proposed by Hlawitschka, Lotharingien, 173. Hlawitschka points out that when Zwentibold did move against the counts, he did start from the Maas region where Reginar had his centre of power. Furthermore, after Zwentibold had turned on Reginar, he drew his support again from the region around Diedenhofen, where, in turn, the Matfrid brothers were based.

333 Regino, Chronicon 898, 145.

334 Regino, Chronicon 898, 145-146; Annales Vedastini 898, 80. Hlawitschka, Herzog, 433, n. 38 is probably right to identify Durfos with Furfoz, close to Dinant, or Fooz, south of Namur, over Doveren, close to Herzogenbosch.

335 Regino, Chronicon 899, 147; Annales Fuldenses (Altaich continuation) 900, 134. On the negative bias of the sources against Zwentibold, see Hartmann, Lotharingien, 126-128.

Regino, Chronicon 900, 148 and DDLCh 2 and 3. 
These latter two belonged to the powerful Matfrid family, ${ }^{337}$ which had its power centre around Metz with more possessions in the Bliesgau and the Speyergau, and influence over the Jülichgau, the Zülpichgau and the Eifelgau, where the third brother Richer became abbot of Prüm in 899.338 Early during Zwentibold's reign, the family was represented at the royal court by Abbot Stephen of Saint-Mihiel. ${ }^{339}$ When Zwentibold went against Count Stephen, the brothers Gerhard and Matfrid supported the latter, in turn losing their honores. ${ }^{340}$ While it seems possible that they soon reentered the king's favour and supported Zwentibold against Reginar, ${ }^{341}$ they turned away from him again after the conference of St Goar-as noted, they killed him in combat. Under Louis the Child, the Matfrids renewed their efforts to extend their influence. Not long after Zwentibold's death, Gerhard married his widow, Oda, daughter of Otto of Saxony and sister of Henry the Fowler, who was to become king of the Eastern realm in $919 .{ }^{342}$ This brought them into competition with the Konradiner family, who had dominated Arnulf's last years ${ }^{343}$ and whose own relative Louis had now become king. ${ }^{344}$ This family, highly involved in the regency for Louis together with Archbishop Hatto of Mainz and Bishop Adalbero of Augsburg, now also held some of the honores the Matfrids had lost in 897, including at least the abbeys of Saint-Maximin and Oeren of Trier. ${ }^{345}$ In addition to these, Gebhard, the leading member of the Konradiner in Lotharingia, whose dominance at court is not only reflected by his numerous interventions in Lotharingian matters ${ }^{346}$ but also by him being described $d u x$ of Lotharingia $^{347}$ in one of Louis' diplomas, held properties in the Wormsgau and was count of Wetterau. ${ }^{348}$ Other Konradiner were given honores in Lotharingia: Eberhard and Otto were given comital rights along the Lower Rhine while their

337 On the earlier importance of the Matfrid family, see Brunner, Fürstentitel, 286-287.

338 Hlawitschka, Lotharingien, 167 with n. 29 and 30. See also Staab, Jugement, 382 for a map of the Matfrids' possessions.

339 DZ 8, 3rd May 896. DLCh 57 describes Stephen as ipsius [Count Gerhard] proximus affini, pointing to a kinship by marriage. Also, under Louis the Child, Stephen remained important, receiving more diplomas for Saint-Mihiel (DDLCh 36 and 62) as well as for his new bishopric Liège (DDLCh 55 and 57).

340 DLCh 59.

341 DLCh 59.

342 Regino, Chronicon 897, 145 and 900, 148. On Oda, see Werner, Nachkommen, 459-460 and Hlawitschka, Anfänge, 59-60.

343 Gebhard and Conrad represented Arnulf at St Goar. See chapter III.2.1.1, n. 188. Hartmann, Lotharingien, 137, also sees their dominance in relation to the accusations of adultery against Arnulf's wife Oda.

344 Louis' mother Oda is generally seen as a member of the Konradiner family (e.g. Werner, Nachkommen, 456). Against this view and pointing to more distant relation between Louis and the Konradiner, Jackman, Konradiner, 136-139 and Jackman, König. On Jackman's work (however not on the passage concerning Oda), see Hlawitschka, Thronwechsel, 201-248. On the Konradiner family, see also Heidrich, Adelsgeschlecht.

345 Regino, Chronicon 906, 150-151.

346 DDLCh 17, 18, 53, 55, 57 and 70.

347 DLCh 20, 126: ... Kebehart dux regni qui a multis Hlotharii dicitur...

348 DDLCh 48 and 71. See also Heidrich, Adelsgeschlecht, 68. 
brother Conrad the Younger, the later king, received the abbey of Kaiserwerth and became count of the Keldachgau. ${ }^{349}$ Overall, they seem to have dominated the Middle Rhine between Worms and Cologne. ${ }^{350}$ The Konradiners' dominance only became contestable when they became involved in the famous feud against the Babenberger ${ }^{351}$ in 906 and this was indeed the moment the Matfrids chose to strike. Gerhard and Matfrid captured Saint-Maximin and Oeren, but soon enough Conrad the Younger mustered an army in Lotharingia and forced them to retreat to the Bliesgau, where an armistice was concluded until the end of the Easter week. In October 906, during the assembly at Metz, the Matfrids were judged and lost their honores. ${ }^{352}$ Nothing further is known of the affair, but it can be assumed that they soon submitted and were reinstated into their holdings. At court, however, their influence remained low: not a single one of Louis' diplomas shows them intervening.

Also present at Metz was Reginar Longneck, ${ }^{353}$ who probably had recovered his honores upon the fall of Zwentibold. His renewed political importance is not only reflected by his own connection with the Konradiner, ${ }^{354}$ but also by two diplomas that confirmed him holding the abbeys of Stavelot and Echternach. ${ }^{355}$ His big moment seems to have come when Konradiner power in Lotharingia was shaken by the death of Gebhard during the battle of Augsburg against the Hungarians in $910 .{ }^{356}$ In a private charter he issued after Gebhard's death to exchange goods with a certain Harduin, he was depicted as "count and missus dominicus as well as abbot."357 Sending missi around the realm to serve as royal legates and thereby as means to relate the royal centre with the local power holders was a practice that, by the early 10th century, had long ceased to exist. ${ }^{358}$ Of course Reginar's charter was not a royal diploma and therefore does not necessarily reflect his actual standing at court. But he at least claimed to be a missus, the link between the nobles of the area and the king. That he could act as such is demonstrated by a number of other charters issued by him, showing him in connection with counts like Wigeric ${ }^{359}$,

349 DDLCh 35 and 73.

350 Goetz, Dux, 317-318.

351 On this feud, see Störmer, Fehde.

352 Regino, Chronicon 906, 150-152 and DDLCh 51 and 57.

353 DLCh 50. Reginar was also present when property of the Matfrids was distributed in 908. DLCh 57.

354 DLCh 57 shows him acting together with Gebhard and Archbishop Hermann of Cologne at Aachen.

355 DLChS 16 and 53.

356 On his death, see Dümmler, Geschichte III, 557 with n. 2.

357 Recueil Stavelot-Malmédy I, N 51, 122: ...comes ac missus dominicus nec non et abba... See also Kienast, Herzogstitel, 376.

358 On their roles see for example Werner, Missus, 192-211.

359 Wampach, Geschichte I,2, N 161, 247-248. 4th February 903-3rd February 904. Wigeric, the new count of the Bidgau. See chapter III.2.1.5, n. 383. 
Otbert $^{360}$, Isaac and Meginhard. ${ }^{361}$ We should therefore consider this charter as a sign of Reginar's importance both at court and within the Lotharingian nobility, which placed him in a position similar to the one Gebhard had held until his death. ${ }^{362}$

\section{III.2.1.5 The early Lotharingian network}

By 911, Reginar appears to have occupied a central position within the Lotharingian nobility, rivalled by Archbishop Ratbod of Trier; while the Matfrid family had lost much of its former influence. It is therefore hardly surprising that Reginar became the centre of Charles' new network within Lotharingia, especially when taking into consideration their earlier contacts before 895 and in 899. As Charles entered his new regnum, Reginar moved southwards from his own powerbase to meet the king on his way to Alsace. For the next months he probably accompanied Charles, thus spending not only Christmas but also Easter with the king. ${ }^{363}$ Reginar was now given control over several abbeys: Saint-Maximin of Trier, ${ }^{364}$ formerly in the hands of the Konradiner family, probably Chièvremont ${ }^{365}$ and, once again, Saint-Servais ${ }^{366}$ of Maastricht, taken from the church of Trier. Ratbod, on the other hand, did not appear in Charles' diplomas until August 913, ${ }^{367}$ indicating that the most important cleric of Lotharingia kept his distance and waited to see how the events would unfold. Consequently, Charles gave no heed to the archbishop's claims and returned the abbey to Reginar, making it clear that it was the count who was in the dominant position. Ratbod's reluctance to acknowledge Charles was probably also why Saint-Maximin was granted to Reginar, who thus gained a foothold within the heart of Ratbod's territory and ensured that the king could extend his influence over the city. ${ }^{368}$ Reginar remained Charles' most important supporter in Lotharingia until his death in 915, as signalled by his appearances in five royal diplomas, ${ }^{369}$ setting him apart from the other nobles not only by the number of his petitions, but also by the use of the marchio title, ${ }^{370}$ otherwise only reserved for Robert and Richard in the West. ${ }^{371}$

360 Recueil Stavelot-Malmédy I, N 50, 120-121. 6th April 907.

361 Recueil Stavelot-Malmédy I, $\mathrm{N}^{\circ}$ 51, 122. 1st June 911. Isaac, count of Cambrai, also appears in Louis' last diploma for Lotharingia, DLCh 76, together with Count Conrad the Younger and Count Warner.

362 See Brunner, Fürstentitel 289-290, Schieffer, Kanzlei, 114-115 and Hlawitschka, Lotharingien 193-194, and last Schneider, Suche, 144. Goetz, Dux, 334 argues for an actual royal office. DDChS 69 (1st January 912) and 72 (12th April 912, Easter Sunday).

364 DChS 69.

365 Hlawitschka, Lotharingien, 202.

366 Lößlein, Ressources.

367 DChS 74.

368 On the use of abbeys to ensure royal power over border regions, see Helvétius, Abbatiat laique.

369 DDChS 69, 72, 76, 65 and 81.

370 DDChS 65, 147 (comes et demarchus) and 81, 181 (marchio strenuus).

371 William the Pious, usually added to the list, is only described as marchio in DChS 102, a forgery. 
The use of the title of marchio raises the question of Reginar's actual position within Lotharingia, since it was otherwise only applied to Robert and Richard in the West-two men whose control over Neustria and Burgundy was rather tight. Comparing the applications of this title, we can make note of remarkable differences concerning the epithets accompanying it. In the West, these were substantially more elaborate: "Richard, our illustrious count and beloved marchio" 372 or "Robert, our most beloved marchio and abbot." 373 In contrast, the epithets used for Reginar remain on a level no different from those used for other nobles, ${ }^{374}$ the exception being the otherwise unused "strenuous" 375 and the more common "illustrious." ${ }^{776}$ Interestingly, Reginar is never described as "beloved." We should also note that, in fact, Reginar is never depicted as a marchio in diplomas in which he intervenes on his own, but only when he appears with the most important man of the West, Robert. This happened on only two occasions, once at an unknown date after April $912^{377}$ and then in August 915. ${ }^{378}$ Both diplomas were issued for the church of Liège to which Robert appears to have had earlier ties. ${ }^{379}$ In the first diploma, Reginar and Robert are depicted in the same way as "count and demarchus"; in the second, the title of "strenuous marchio" is reserved for Reginar alone, while Robert's importance is underlined by the singular description as "our Highness' most loyal executor." 380 The fact that Reginar is only named marchio when appearing with Robert indicates that the use of the title probably relies on Robert and is then extended to Reginar to emphasise his importance at Charles' court by honouring him on par with the Robertian. As Andrea Stieldorf has remarked, for Reginar "marchio" is only used as an honorary title to express a particularly high degree of proximity to the king, not to describe a closely defined official function. ${ }^{381}$

372 DChS 32, 68: ... Richaldi, illustris comitis et dilecti markionis nostri...

373 DChS 78, 175: ... Robertus, dilectissimus nobis marchio atque abbas...

374 DChS 69, 155 (venerabilis), DChS 72, 162 (venerandus). Venerabilis is also used for the counts Guarner, Theoderic and Letard (DChS 67) as well as Count Ricuin of Verdun, who is furthermore described as vir nobilissimus (DChS 73). The venerandus also appears in connection with Count Berengar (DChS 72). On the importance of epithets see Brunner, Fürstentitel, 198-203.

375 DChS 81, 181: ... Raginerus, marchio strenuus...

376 DChS 76, 171: ...Reginarius, illustris comes... Illustris indeed only appears in connection with more important nobles, although not only for Robert and Richard, but also counts like Gerald (DChS 21), Aledramnus (DChS29), Ecfrid (DChS 35) and Ermenfrid (DChS 41).

377 DChS 65, dated by Lauer, Recueil Charles III, 146 to 911-915 and corrected by Font-Réaulx, Diplômes, 43 to 912-913 because of the use of the rex Francorum without the vir illustris. While I do agree with de Font-Réaulx for 912 being the earliest year, I cannot see why the diploma could not have been issued after 913. Since Reginar died in 915 (Parisot, Royaume, 609-610), in accordance with Lauer this would be the last possible year. On this diploma, see also Bonenfant, Malines, 96-108 and Dierkens, Abbayes, 149-151.

378 DChS 81.

379 DChF 105, dated to 884. In this diploma, Franco and Robert both plead the Emperor to grant a manse to Robert's fidelis Sanctio. The identification of this count with Odo's brother has been made by Joachim Wollasch, Gerard, 63.

380 DChS 81, 181: ... Rotbertus, nostre serenitatis exequtor fidelissimus...

381 Stieldorf, Marken, 214-216. 
Reginar was undoubtedly a very powerful man within Lotharingia, royally endowed with several rich abbeys and therefore having enormous resources at his disposal. Yet, the sources do not indicate that he controlled a large number of counties, enjoyed the functions of a wider military command or had any influence on the episcopal sees in his vicinity ${ }^{382}$ - all of which are applicable to different degrees to Robert and Richard in the Western realm. Thus, Reginar's importance to Charles did not so much stem from his control over significant abbatial resources, but from his personal connections to other important Lotharingian nobles like his sons-in-law, Count Berengar and Count Wigeric, who he introduced to Charles' court, ${ }^{383}$ or the counts Otbert, ${ }^{384}$ Isaac and Meginhard. ${ }^{385}$ Charles used Reginar to gain access to his personal network, but Reginar was not an all-dominating figure like Robert in Neustria or Richard in Burgundy. ${ }^{386}$

Indeed, while Reginar was the most prevalent figure in Charles' diplomas within Lotharingia and was honoured by the marchio title, the king's connections to the Lotharingian nobility were by no means channelled through him as in the case of Burgundy and Richard. Charles' initial journey to his new regnum shows a large variety of contacts covering most of Lotharingia. His first contact was with Bishop Stephen of Cambrai, ${ }^{387}$ who not only received two diplomas but also came with a group of counts, Guarner, Theoderic ${ }^{388}$ and Letard, the latter probably count of the Moselgau. ${ }^{389}$ In the south, Charles first passed through the territories of the

382 Reginar does appear together with different bishops in Charles' diplomas (as before under Zwentibold and Louis the Child), namely Stephen of Liège and Dado of Verdun (DDChS 65 and 81, both for the church of Liège). However, in both cases Robert is also mentioned, who seems to have had a personal connection to the church of Liège. See chapter III.2.1. It was only Reginar's son Gislebert who tried to extend his influence over the see of Liège, an endeavour over which he fell out with Charles. On Reginar's limited power in Lotharingia, see Goetz, Dux, 362-364, 367-369, $376-379,397-400$ and summarising 404-408. The few sources we have only show Reginar acting as a (powerful) count, only intervening in affairs directly concerning himself or his abbacies.

383 DChS 72. On Berengar being Reginar's son-in-laws see Le Jan, Famille, 453. Wigeric married Cunigunde, daughter of Reginar and Ermentrude, Charles the Simple's niece. On Count Wigeric, see last Hlawitschka, Ahnen I,2, 224-231. Nonn's, Urkunde, hypothesis that Wigeric was Count Odacar's son, followed by Le Jan, Famille, 184 and 384, n. 18, has been denied by Hlawitschka due to the charter evidence being forgeries and the missing connections between Odacar and Wigeric in the Liber Memorialis of Remiremont.

384 Recueil Stavelot-Malmédy I, $\mathrm{N}^{\circ}$ 50, 120-121. 6th April 907.

385 Recueil Stavelot-Malmédy I, N 51,122 . 1st June 911.

386 See also Goetz, Dux, 351 for Reginar's network. Furthermore, he remarks that Reginar hardly ever acted alone, but always cooperated with other equal nobles.

387 DDChS 67 and 68. On DChS 67 see Vercauteren, Note and Bauer, Lotharingien, 106-111.

388 This Theoderic may have been the son Gerulf and brother to Waltger, a count in Friesland. Parisot, Royaume, 584 and 590 argues against this identification, since Waltger appears in one of Conrad I's diplomas, intervening on behalf of the church of Utrecht in 914 (DKoI 24), which indicates that they opposed Charles up until 916, when both were present at a judicium at Herstal (DChS 84). In this context, however, it may be worth pointing out examples like that of Richard and Boso in the 880s, two brothers who were not pursuing the same politics. Family bonds were certainly strong, yet do not necessarily mean that members of the same familiy always worked together.

389 Vercauteren, Note, 102. 
Matfrids around Metz. ${ }^{390}$ While none of the diplomas preserved indicates their presence at Charles' court at that time, it, nevertheless, seems highly probable that were in contact. Next, he met with Bishop Drogo of Toul and Count Ricuin of Verdun ${ }^{391}$ as well as Abbess Rotrude of Andlau, ${ }^{392}$ indicating the extension of his network to the south of Lotharingia. The composition of this group reveals a distinctive shift in the circle of nobles in close contact with Charles in comparison with Louis the Child. The church of Cambrai had been favoured by Zwentibold ${ }^{393}$ and Ricuin had belonged to his last supporters. ${ }^{394}$ Both, however, fell out of favour under Louis and do not once appear in his diplomas. Stephen was then granted the right to erect a castle, install a market and the right to issue coins at a place close to the holdings of his family. ${ }^{395}$ Ricuin probably gained decisive influence over Saint-Mihiel, on whose behalf he intervened twice and was described as "most noble man." ${ }^{396}$ Drogo's predecessor at Toul, Ludelm, had been close to both Zwentibold and Louis, ${ }^{397}$ yet Drogo himself did not appear at Louis' court ${ }^{398}$ while he received two diplomas from Charles. ${ }^{399}$ These examples indicate that Charles sought out allies amongst those whose ambitions had been curbed by Louis. By allowing these nobles access to his court, Charles satisfied their ambitions and therefore tied them to his own rule. This method, however, did not work on all occasions, notably so in the regions described by Jens Schneider as "Bruchlinien," Alsace and Friesland. ${ }^{400}$ Strasbourg and its Bishop Otbert stood with Conrad ${ }^{401}$ and so did Bishop Radbod of Utrecht ${ }^{402}$ - the former's church last having been in contact with Arnulf, the latter's with Zwentibold. ${ }^{403}$

Different from these cases is that of Bishop Stephen of Liège, the former abbot of Saint-Mihiel. Stephen had been close to both Zwentibold and Louis the Child,

390 DChS 69, Metz. On his way back to the West, Charles passed again through Metz (DChS 73).

391 DDChS 70 (Drogo), 71 (Drogo and Ricuin) and 73 (Ricuin).

392 DChS 125. On this diploma, see de Font-Réaulx, Diplômes, 44 and Schieffer, Urkunden Zwentibolds und Ludwigs des Kindes, 201.

393 DZ 23 and two deperdita (Schieffer, Urkunden Zwentibolds, 5), issued for Bishop Dodilo of Cambrai.

394 DZ 27, 23rd January 899.

395 DChS 67 with Vercauteren, Note.

396 DChS 73 for the monk Uncrin of Saint-Mihiel (here also the vir nobilissimus, 164) and 83.

397 DZ 17 and a deperdita (Schieffer, Urkunden Zwentibolds, 5); DLCh 7 and a deperdita (Schieffer, Urkunden Ludwigs des Kindes, 80).

398 Drogo had succeeded Ludelm in 906, leaving about four years for him to appear at Louis' court (Regino, Chronicon, 152-153). Ludelm died 11th September. See Parisot, Royaume, 570, n. 1.

399 DChS 70 and 71.

400 Schneider, Suche, 108.

401 Conrad issued diplomas at Strasbourg in 912 and 913. DDKoI 5 and 17. The Annales Alamannici $(912,188)$ report that the city was burned down following the outbreak of hostilities between Charles and Conrad.

402 Bishop Radbod of Utrecht seems to have had connections to the Konradiner. DKoI 24 and Heidrich, Adelsgeschlecht, 68. Büttner, Heinrich, 12, Große, Bistum, 20-21 and van Vliet, Kringen, 153.

403 DA 88 and DZ 9. On the positive memory of Zwentibold in Utrecht, see Hartmann, Lotharingien, $139-140$. 
requesting diplomas for both his abbey and his new bishopric. ${ }^{404}$ Now his church was granted some smaller abbeys on the Meuse and the Demer at the request of Reginar, Robert of Neustria and another Robert. ${ }^{405}$ The presence of both of these men indicates how well-connected Stephen was within the highest ranks of the nobility. But what is more, Stephen was also related both to the Matfrid family and Charles himself ${ }^{406}$ and had long had contacts with the Western realm. Before he had become bishop of Liège, he appears to have aimed for another (unknown) bishopric, using a connection to Archbishop Fulk to gain the see, albeit without success. ${ }^{407}$ But his relation to Charles himself becomes visible long before 912. At the beginning of his reign, Charles issued a diploma for Saint-Mihiel. ${ }^{408}$ While this diploma has to be read in the context of the relations between Charles and Zwentibold and Charles and Robert, ${ }^{409}$ the choice to issue a diploma for this abbey was most probably also due to the relation between the king and its abbot-Stephen. ${ }^{410}$ Now Charles not only issued a diploma for the church of Liège, but also confirmed a donation made to a monk at Saint-Mihiel, which had initially been granted by Louis the Child on behalf of Stephen. ${ }^{411}$ The bishop of Liège is, like Reginar, one example of a noble who preserved his influence at court and was perhaps able to extend it; undoubtedly, very much like Reginar, due to his earlier connections to Charles.

While Reginar and Stephen were easily integrated within Charles' rule, Archbishop Ratbod of Trier, Reginar's old rival, appears to have been reluctant to acknowledge Charles as the new king. Like other Lotharingian bishops, his origins lay in the east of the regnum, in his case in Alemannia. ${ }^{412}$ Maybe it was due to these connections that he remained absent from Charles' court until August 913, when he met with the king at Thionville, on Charles' way back to the Western realm. ${ }^{413}$ Ratbod probably waited to see whether the new king in the East, Conrad, would be able to successfully challenge Charles. ${ }^{414}$ Only when it became clear that the

404 Stephen appears in DZ 8 and DLCh 36 and 50. Saint-Mihiel and Liège received, without him being mentioned, the diplomas DDZ 3 and 24 as well as DLCh 55, 57 and 62.

405 DChS 65.

406 DChS 81, 181: ...nostre consanguinitati affinis dilectissimi...

407 Flodoard, HRE IV, c. 7, 396.

408 DChS 11, 13th February 898.

409 See below.

410 Hlawitscka, Lotharingien, 171-172.

411 DChS 73 and DLCh 36.

412 Hlawitschka, Lotharingien, 182. Another example is Bishop Robert of Metz, whose roots were in Bavaria. Archbishop Hermann of Cologne was bound to the East by his interests in the bishopric of Bremen.

413 DChS 74, 13th August 913. Charles' next diploma (DChS 76, 16th January 914) was issued at Attigny.

414 Conrad tried to regain control of Lotharingia in 912 and 913 . Annales Alamannici 912 (Cod. Modoetiensis), 188: Karolus in Alsatia et Chonradus in Hlodarios et facta fide ficta Chuonradus in Hlodarios iterum usque ad aquas et Hlodarique in Argentinam civitatem eaque vastata et conbusta est. And 913 (Cod. Tur.), 190: ...iterum Chuonradus cum exercitu regnum Hlutharingorum ingressus est. See also DDKoI 5 and 17. 
Carolingian would prevail did Ratbod seek him out-long after Charles had given a number of abbeys originally belonging to the church of Trier to Reginar. The diploma celebrating Ratbod's entry into Charles' service ${ }^{415}$ was a carefully produced textual object, written and designed not in the royal but the archiepiscopal chancellery ${ }^{416}$ Its preamble referred to Gelasian doctrine, calling upon the king as a partner of the church of God, ${ }^{417}$ thus laying down the basis of the alliance: as long as Charles protected the Church, the archbishop would stand at his side. ${ }^{418}$ The diploma also displayed a new monogram and seal, both modelled after examples from Charlemagne and Louis the Pious. ${ }^{419}$ These references may have been inspired by Charles' interests in the early Carolingians, as can be seen from the use of the intitulatio rex Francorum, vir illustris. At that point, however, Charles had already given up the use of vir illustris. ${ }^{420}$ Therefore, it may indeed have been the case that monogram and seal had also been made as a gift for Charles in the archiepiscopal chancellery. In any case, they were only used in this one diploma. This newly found concord between Charles and the archbishop was celebrated by another singular event. Ratbod, who was made the king's new archchaplain, ${ }^{421}$ also acted as his archchancellor, despite this position being already occupied by Heriveus. If he had hoped to regain the position he had held under Louis the Child, that is to say, to act as archchancellor in all cases involving Lotharingian recipients, Ratbod was to be disappointed. The royal Lotharingian chancellery had

415 DChS 74.

416 Schieffer, Kanzlei, 139-140; Bautier, Chancellerie, 21, n. 1 and Patzold, Episcopus, 88. Theodulf probably also wrote DDLCh 59 and 76. See also Lauer, Recueil Charles III, XXXVIIIXLVI.

417 DChS 74, 165-166: Cum totum sanctae Dei aecclesiae corpus sacerdotalis provisione et amministratione regalique tuitione procurari unumque sentire concorditer regia majestas cum ministris Domini debeat, aequum fore censemus pontificum nostrorum petitionibus pro aecclesiasticis negotiis subplicantium assensum praebere quorum orationibus nos et regni nostri statum incunctanter credimus suffragari.

418 On the Gelasian doctrine in the Carolingian age, see Anton, Synoden; Delaruelle, En relisant; Ladner, Aspects; Benson, Doctrine and Sassier, Auctoritas. On the Gelasian doctrine in Charles' diplomas, see Patzold, Episcopus, 88-90 and Koziol, Politics, 488-492. Three of Charles' diplomas refer to the doctrine in their preambles: DDChS 40 (901, for the church of Noyon), 74 and 106 (920, for the church of Cambrai). Trying to make any deductions concerning Charles' own convictions based on these diplomas is extremly problematic. Font-Réaulx, Diplômes, 42, doubted the genuineness of DChS 40; Guyotjeannin, Episcopus, 40 considered it "profondément interpolé." It seems that the diploma, as Lauer, Recueil Charles III, XIV assumed, was at least not written in Charles' chancellery. DChS 74, in turn, was composed not in the royal, but the archiepiscopal chancellery of Trier, similar to DChS 106, which seems to have been edited at Cambrai (Lauer, Recueil Charles III, 252, n. 5 and Duvosquel, Cession, 176). Concerning these last two, it should also be noted that both were issued under very particular political circumstances, DChS 106 just after Charles had reconciled with the nobles in 920 (see below, chapter III.2.2).

419 Lauer, Recueil Charles III, LXXVIII-LXXIX for the monogram and XLVII-XLVIII for the seal. See also above.

420 See above.

421 Usually, the office of archchaplain appears to have been held by the archbishops of Cologne. Since Zwentibold, however, the office appears to have been vacant. Schieffer, Kanzlei, 139. 
come to an end, ${ }^{422}$ and there was to be only one royal chancellery-the one under the archbishop of Reims.

\section{III.2.1.6 A king of two regna?}

As we have seen, Charles' initial Lotharingian network contains no surprises but ties in with the one of Louis the Child, extending it to include those nobles who had risen under Zwentibold but lost their position under his successor. Charles maintained close contact with its nobles after his initial journey to the regnum Hlotharii from late 911 until $913 .{ }^{423}$ He returned there for a second visit from the second half of 915 to the first half of $916^{424}$ and again in the second half of $917 . .^{425}$ Two years later, in 919, Charles again spent at least several months in Lotharingia in the context of the approaching conflict with Reginar's son Count Gislebert. ${ }^{426}$ This conflict and its implications also caused his expeditions in the following years, up until the revolt of the nobles in the West in 922. Charles' itinerary is of course very sparse since the number of preserved diplomas is quite small. Nevertheless, trying to estimate the durations of his visits in Lotharingia and comparing them to his visits in the West, the king appears to have spent less than one third of his time between 914 and 919, a period covering the outbreak of the conflict with Gislebert but not the beginning of Charles' struggle with the West Frankish nobles, in Lotharingia. ${ }^{427}$ Within this same period, after the initial journey and the following concentration of diplomas, but before the deep ruptures of his reign beginning in 920, eight out of thirty diplomas Charles issued went to Lotharingian recipients, less than one third. ${ }^{428}$ We have already remarked that Charles reacted to the acquisition of his new realm with an increase of his diplomatic activity while the number of recipients from the Western realm remained more or less stable. ${ }^{429}$ Both Charles' visits during these years and his increase in contacts with nobles point towards the last phase of his reign, which was marked by his efforts to find a

422 Schieffer, Kanzlei, 142.

423 DDChS 67, 68, 69, 70, 71, 125, 72, 73 and 74. Charles first diploma in Lotharingia dates to 20th December 911, his last to 13th August 913. His return to the West is documented by DChS 76 issued at Attigny, 16th January 914.

424 DDChS 81, 82, 83, 84, 85, dating from 25th August 915 to 9th April 916. DChS 80, 7th July 915 shows Charles at Compiègne, DChS 86, 7th June 916 at Attigny.

425 DDChS 90 and 91, 26th July 917. 28th May 917 Charles issued DChS 89 at Attigny and DChS 92 14th March 918 at Compiègne.

426 DDChS 100, 101, 103 and 104, dating from 16th June 919 to 20th August 919. DChS 102, showing Charles at Tours-sur-Marne, is a forgery (see Lößlein, Diplôme). On 30th March 919 the king was at Soissons (DChS 99), where his presence is again indicated by DChS 105, 20th January 920.

427 Based on his itinerary, a careful but generous approach allows us to estimate that in 915 and 916 Charles in total spent ten months in Lotharingia, in 917-918 six months and in 919 another six. This adds up to 22 months over a period of six years, or about $30.5 \%$ of his time. Therefore, we have to disagree with Mohr, Geschichte, 16; Hlawitschka, Lotharingien, 202 and Schneidmüller, Tradition, 135 who argue that Charles favoured Lotharingia and put his main emphasis there. 
balance between Robert, the other nobles from the West and those from his newly acquired regnum.

While the numbers of Charles' diplomas and his itinerary certainly help us to understand how the balance shifted after 911, they also limit our view to a certain degree since a distinction between the two regna may be too sharp to illustrate the actual realities. As we have already argued, nobles from both realms had interests in and connections to each other. The church of Reims possessed various properties within Lotharingia which became the reason for a conflict with Count Erlebald. ${ }^{430}$ Reginar possessed property in the Western realm, Robert was related to nobles within Lotharingia ${ }^{431}$ and had his own contacts to the Liège area, contacts that became traceable again in 919 when Count Berengar sent a legation to him. ${ }^{432}$ Richard's family also had interests in the region. Richard's son Boso acquired the estates of his father's sister Richilde, the second wife of Charles the Bald, land held in precaria from the abbey of Gorze, ${ }^{433}$ furthermore pursued claims on the property of her daughter Rothild ${ }^{434}$ and later took control of the abbeys Remiremont and Moyenmoutier, ${ }^{435}$ thus becoming one of the most powerful figures in southern Lotharingia. Finally, nobles from both regions acted together, as in the case of the rebellion against Charles in 922, when Robert's son Hugh concluded an alliance with Reginar's son Gislebert. ${ }^{436}$ Hence, noble relations did not stop at the borders, interests and connections were highly intertwined between the two regna.

The same image is also provided by the royal charters. Counts and bishops from the frontier area crossed the borders on various occasions, ${ }^{437}$ but also those living further away from the border followed the king. For example, a diploma issued at Gondreville shows Richard, Robert and Abbot Wicheramnus intervening for the latter's abbey of Saint-Philibert of Tournus. ${ }^{438}$ Two others were issued at Herstal: one for Abbot Acfred of San-Esteban of Bagnoles, confirming his abbey's rights, ${ }^{439}$ and another for Robert for Saint-Martin of Tours. ${ }^{440}$ Reginar also travelled to the West, visiting the king at Attigny where Charles issued a diploma

430 Flodoard, HRE IV, c. 16, 408.

431 We remember the death of Megingaud, Odo's (and therefore also Robert's) nephew. See chapter III.2.1.4, n. 299. For the Robertian family connections, see Werner, Robertiens, 14-16 and Depreux, Comte, 391-392.

432 Vita Gerardi abbatis Broniensis, c. 5, 657-658. The legation was sent in July 919. Misonne, Gérard, 25.

433 On Boso, see Nightingale, Monasteries, 39-50, Robbie, Emergence, 75 and Hlawitschka, Herzog, $432-433$.

434 Flodoard, Annales 929, 43-44. The conflict over the disputed land probably started earlier. Nightingale, Monasteries, 49.

435 Nightingale, Monasteries, 41-42 with n. 15 and 16.

436 Flodoard, Annales 922, 8 and 11.

437 For example Raoul de Gouy (DChS 106, Herstal) and Bishop Stephen of Cambrai (DChS 112, Noyon). See also the witness list of DChS 100 for further examples.

438 DChS 82.

439 DChS 85.

440 DChS 101. 
for Echternach. ${ }^{441}$ Furthermore, nobles from both regna can be seen cooperating in royal charters. The counts Raoul de Gouy ${ }^{42}$ and Sigard of the Liugau requested a diploma for the church of Cambrai ${ }^{443}$ and there are of course also the already mentioned diplomas for the Liège, featuring both Reginar and Robert. ${ }^{444}$

In this context, it is interesting to analyse the lists of nobles in two of Charles' diplomas noting judgements in Lotharingia, as well as in the treaty of Bonn made with Henry the Fowler. The first diploma, dating to 916, marks the restoration of the abbey of Süsteren to Prüm ${ }^{45}$ and notes the presence of four bishops, fourteen counts and a number of other witnesses. ${ }^{446}$ However, among them only one, Raoul de Gouy, came from the Western realm. At the assembly of Herstal in 919 where Saint-Servais of Maastricht was withdrawn from Gislebert and restored to the church of Trier, ${ }^{447}$ five bishops and eleven counts are accounted for, ${ }^{448}$ at least four of them from the West. ${ }^{449}$ The numbers at Bonn are similar, with five bishops and ten counts, ${ }^{450}$ among whom three were from Francia. ${ }^{451}$ Within these groups, nobles from the Western realm are underrepresented in comparison with those from Lotharingia. However, the Treaty of Bonn followed a ceasefire ${ }^{452}$ and did not require the presence of all of Charles' nobles, but rather those directly involved with matters along the border-like the archbishops of Cologne and Trier or the bishop of Utrecht. The judgements were most of all regional affairs involving mainly those nobles concerned with the matter. ${ }^{453}$ They allowed the king to display the power

441 DChS 76.

442 Raoul de Gouy, count of Ostrevent, was the son of Odo's supporter Count Hucbald with Heilwich, daughter of Eberhard of Friuli. On him, see Grierson, Origine, 108-123.

443 DChS 106.

444 DDChS 65 and 81.

445 DChS 84.

446 DChS 84, 189: Rotgarius archiepiscopus, Herimannus archiepiscopus, Dado episcopus, Stephanus episcopus, Widricus comes palatii, Richuinus comes, Gislebertus, Matfridus, Beringarius comes, Theodericus comes, Reinherus comes, Erleboldus comes, Ruodolfus comes. Otto comes, Cunradus comes, Walcherus comes, Sigardus comes, Letardus comes... On the identifications, see Parisot, Royaume, 616-617.

447 DChS 100.

448 DChS 100, 230: Hęc sunt [nomi]na eorum quoque qui prefatum contulerunt judicium, videlicet episcoporum: Wiridus, Dado, Raubertus, Abbo, Stephanus; sed comitum: Matfridus, Segardus, Otto, Fulbertus, Cristianus, Erkengeros, Isembardus, Huntgerus, Ecfridus, Ermenfridus, Walterus, item Walterus... See Parisot, Royaume, 626 with n. 2.

449 Bishops Robert of Noyon and Abbo of Soissons; Counts Erkanger and Ecfrid, possibly also Ermenfrid.

450 MGH Const. I, No 1, 1-2: Episcopi ex parte domni regis Karoli: Herimannus archiepiscopus Agrippinae quae modo est Colonia vocitate, Rodgerus archiepiscopus Trevirorum, Stephanus praesul Cameracorum, Bouo episcopus Catalaunensium, Baldricus Traictensium episcopus. Haec nomina comitum: Matfredus, Erkengerus, Hagano, Boso, Waltkerus, Isaac, Ragenberus, Theodricus, Adalardus, Adelelmus.

451 Bishop Bovo of Châlons as well as the counts Erkanger and Adelelm. On Adelelm, successor of Count Altmar at Arras, see Kéry, Errichtung, 248.

452 Flodoard, Annales 921, 5-6.

453 On the origin of participants in assemblies, see Eichler, Reichsversammlungen, 75-76. While it is in most cases impossible to determine their origin, in some cases assemblies seem to have had a specific regional character. 
necessary to enforce the decisions taken there, again making the presence of nobles from the West not specifically necessary. In this context we should also take into consideration that Western nobles may have been present but unrecorded on these occasions. For example, Robert is attested to have been at Herstal only a fortnight after the judgement of 919, which makes it likely that he had also attended the assembly dealing with the case of Saint-Servais. ${ }^{454}$ Indeed, if Charles had need for the presence of nobles from both regna, he was certainly able to call upon them. In a letter to the bishops of his realm concerning the succession issue of the see at Liège, ${ }^{455}$ he referred to an assembly that had taken place earlier, involving no less than sixteen archbishops and bishops as well as marchiones, counts and other nobles from his realm. ${ }^{456}$ Charles' Lotharingia only consisted of nine bishoprics, ${ }^{457}$ indicating that there must have also been bishops from the Western regnum present, most likely from the archdiocese of Reims. Charles' reference to marchiones points towards a large assembly with nobles from both realms since, after the death of Reginar in 915, the only men we know of carrying this title were Robert and Richard. ${ }^{458}$

As the evidence suggests, there was no clear distinction between the nobles from the two regna. Connections at all levels were manifold and it seems that Charles made no distinction between them. The strongest indication of such a policy is the royal chancellery. Under Louis the Child, a specific chancellery for Lotharingian affairs under Archbishop Ratbod of Trier had existed. Charles, as we have seen, put an end to this. Heriveus appears as chancellor in all diplomas, whether they were issued for Western or Lotharingian recipients, and so did his successor Roger of Trier. There are exceptions when the archbishop of Trier appears in the chancellor position already before 919, yet these cases are very few. ${ }^{459}$ Charles did not intend to make a distinction between the two regna: he saw himself as ruling over one single realm.

\section{III.2.1.7 The later years}

With these observations in mind, we can now turn to Charles' network after 913. Robert remained central, with thirteen appearances in royal diplomas, ${ }^{460}$ as did Archbishop Heriveus of Reims. They were not the only nobles from the West to

The judicium dates to Pentecost Sunday, 13th June 919 (DChS 100). Robert received a diploma for Tours on 27th June 919 (DChS 101).

455 MGH Capit. II, N² 290, 378-381, newly edited in MGH Conc. VI, N², 41-48.

456 MGH Conc. VI, $\mathrm{N}^{\circ}$ 2, c. 2, 45: Cum quidam pestiferi viri, ut supra memoravimus, a nostra fidelitate deviarent, convocavimus archiepiscopos praesules XVI nostri regni, nonnullos etiam proceres, marchiones et comites optimatesque, ut eorum consilio, auctoritate atque virtute tantae vesaniae resisteremus.

457 Cologne, Liège, Utrecht, Trier, Metz, Toul, Verdun, Cambrai and Strasbourg.

458 DChS 102, 242, does name a William marchio. The diploma, however, is a forgery. See Lößlein, Diplôme.

459 DDChS 74, 84 and 93.

460 DDChS 65, 9, 77, 78, 81, 82, 89, 92, 94, 98, 101, 105 and 110. 
have kept their positions at court however. Count Heribert II intervened together with Bishop Abbo of Soissons and Robert on behalf of the latter's abbey SaintGermain-des-Prés in $918 .{ }^{461}$ By that point, Heribert had married a daughter of Robert, ${ }^{462}$ indicating that relations between the two had become closer. ${ }^{463}$ However, Heribert was also count of the Mézerais, where the abbey of Croix-SaintOuen (that was now given to Saint-Germain) was situated and his presence, as well Abbo's, ${ }^{464}$ may have been simply the result of his own involvement in the affair. In any case, there is a second occasion to take into consideration. As Flodoard tells us, when the West Frankish nobles started their rebellion in 922, Heribert was with Charles, accompanying him out of Laon to Lotharingia. ${ }^{465}$ Being at the king's side at this crucial moment certainly indicates that Heribert belonged to Charles' inner circle. Next to these nobles, Richard's family was still present at court: not only the marchio himself ${ }^{466}$ but also two of his sons, Hugh the Black ${ }^{467}$ and Boso; ${ }^{468}$ although Richard's overall presence at court can hardly be compared to the period just after 900. Furthermore, a number of Charles' earliest supporters seem to have maintained their contact with the king: Erkanger, Ecfrid and Ermenfrid, all of whom appear in the lists of witnesses. ${ }^{469}$ However, caution is necessary concerning this list of men, since quite a long time had passed between their earlier and their later appearances and it is rather likely that the earlier bearers of the names had died and hence are not identical with the later ones. ${ }^{470}$ In any case, at least Erkanger and Ermenfrid seem to have been in close contact with the king. Erkanger also accompanied Charles to Bonn, and Ermenfrid intervened at Aachen on behalf of the abbey of Brogne. ${ }^{411}$ Last among those present both before and after 912 was Anskeric's successor as bishop of Paris, Theodulf. Charles now confirmed his

DChS 92.

462 On the marriage, see Schwager, Graf, 68 and Exkurs III, 401-402, against the hypothesis that Heribert's wife was the same Adelaide who appears DChS 57. On this hypothesis, see also Settipani, Préhistoire, 225, n. 242.

463 Schwager, Graf, 68.

464 Werner, Untersuchungen V, 100 has pointed out the close connection between Abbo and Heribert, based on DChS 92 and Flodoard, who indicates that in 926 Abbo acted as Heribert's legate to the pope (Flodoard, HRE IV, c. 20, 411-412) in affairs concerning the archbishopric of Reims. Flodoard's account certainly points towards a close cooperation between the bishop and the count in 926. However, we should be careful in assuming that events following the deposition of Charles can be projected back before 923. DChS 97 certainly shows them cooperating, yet their cooperation can be explained by their natural involvement in such a matter. On Abbo's own position at court, see below.

465 Flodoard, Annales 922, 8.

466 DChS 82.

467 DChS 79.

468 Boso is listed as fourth among the counts accompanying Charles in the treaty of Bonn. MGH Const. I, $\mathrm{N}^{\circ} 1,1-2$.

469 DChS 100. Erkanger was also present at Bonn. MGH Const. I, N 1, 1-2.

470 See Parisot, Royaume, 626 with n. 2 for Erkanger and Misonne, Diplôme, 70 with n. 6 for Ermenfrid.

471 DChS 127. On the diploma, see Misonne, Diplôme. 
restoration of property to the church of Paris, as well as a donation made by the bishop to Saint-Cloud. ${ }^{472}$

Within Lotharingia, three factions can be made out: those centred on the old rivals Reginar, the Matfrid family and the church of Trier, from 916 onwards represented by its new archbishop Roger. The most influential of these groups was at first the group around Reginar. The count himself received one more diploma before his death in 915 for his abbey of Echternach ${ }^{473}$ and intervened in a second one together with Robert for the church of Liège. ${ }^{474}$ His death marked the beginning of the end for his faction's influence at court, with the Matfrid family subsequently on the rise. The first sign of this shift was the first assembly at Herstal in 916, where the abbey of Süsteren was restored to Prüm under Abbot Richer, one of the Matfrid brothers. It has been proposed that this moment should be seen as the beginning of the conflict between Charles and Reginar's son Gislebert since Süsteren was situated in the latter's heartland and might have even been taken from Prüm by him or someone close to him. ${ }^{475}$ However, the case is less clear than it appears at first glance. Erich Wisplinghoff has remarked on the presence of Gislebert and his brother Reginar at the assembly, yet assumed that they had been forced to give their consent. ${ }^{476}$ However, the two brothers were by no means the only ones belonging to Reginar's old network present at Herstal. Among the witnesses we also find his two sons-in-law, Berengar, who he had introduced to Charles' court in 912 when they intervened together on behalf of a priest from Berengar's county on Easter Sunday, ${ }^{477}$ and Wigeric, who had become the king's new count of the palace. Of the first seven counts appearing in the diploma, four can thus be directly linked to Reginar's old faction and two of them, Wigeric and Gislebert, were even named before Matfrid. It is also likely that Count Ricuin of Verdun was related to this group, whose initial appearances in Charles' diplomas were followed by another one for Saint-Mihiel in late $915 .{ }^{478}$ Ricuin and Wigeric had been in contact already during Zwentibold's reign, when both of them intervened on behalf of the church of Trier. ${ }^{479}$ After Wigeric's death, Ricuin married his widow Cunigunde, ${ }^{480}$ tying him closer to Reginar's family. When the conflict between the king and Gislebert broke out, Ricuin appears to have remained neutral

473 DChS 76.

474 DChS 81.

475 Wisplinghoff, Untersuchungen, 464.

476 Wisplinghoff, Untersuchungen, 464.

477 DChS 72 (12th April 912).

478 DChS 83 (27th November 915).

479 DZ 27.

480 Hlawitschka, Ahnen I,2, 204-206. 
at first. ${ }^{481}$ In 921, he entered into conflict with Charles, ${ }^{482}$ although he appears to have been forced to give in shortly afterwards. ${ }^{483}$ His son Otto, on the other hand, seems to have been one of Gislebert's closest supporters, fighting with him against Charles ${ }^{484}$ and witnessing the count's charters. ${ }^{485}$ Their earlier connection to Wigeric and Cunigunde, as well as their later support for Gislebert, indicate that in 916 they most probably were also among those supporting the count. Hence, the assembly at Herstal marks a slight rise of influence for the Matfrid family, yet the presence of no less than six of the members of Reginar's circle certainly underlines the political weight they still possessed at the royal court.

Gislebert's position at court, however, seems to have differed significantly from Reginar's. No diplomas mentioning him in central positions are preserved and after 916 he appears only as the usurper of Saint-Servais in the diplomas restoring the abbey to the church of Trier. ${ }^{486}$ Why did Gislebert not inherit his father's position at Charles' side? The main reason for this may have been the particular nature of Reginar's importance for the king. As we have argued, this importance was based not on the count's possessions, but on the personal network that he offered Charles access to. Gislebert, on the other hand, does not seem to have inherited his father's position in this network. In contrast to his father, only one of his private charters dating to Charles' reign was signed by a witness, by the aforementioned Count Otto, Ricuin's son. ${ }^{487}$ Richer's description of Gislebert's revolt matches this impression. When the count prepared for conflict with Charles, he distributed landed property among the higher nobles and gifts of gold and silver among the lower ones. ${ }^{488}$ Richer's account, of course, has to be treated with utmost care, yet, nevertheless, he seems to confirm that Gislebert, in contrast to his father, did not possess a strong network of personal contacts upon which he could rely on. He first had to create one to further his interests. Once this network was created and a modus vivendi with the king had been found, Gislebert indeed appears to have gained the same acknowledgement by the king as his father. In the already

While Ricuin does not appear at Herstal in 919, his son Otto figures among the witnesses (DChS 100). This seems to indicate that, at this moment, he had decided to remain neutral, his son's presence allowing him to keep his ties with the king while demonstrating his own unwillingness by his absence.

482 Flodoard, Annales 921, 5-6.

483 Richer, Historiae I, c. 27, 65.

484 Flodoard, Annales 922, 7.

485 Recueil Stavelot-Malmédy I, N 55, 132-133.

486 DChS 100 and 103 (13th June and 9th July 919). DChS 100 reads Noverit igitur omnium sancte Dei ecclesie fidelium, nostrorum videlicet praesentium ac futurorum industria quoniam vir venerabilis nobisque admodum fidelis Rotgerus Treverensis ecclesiae archiepiscopus sepius plangendo adiit celsitudinem nostram, dicens quod abbatia sancti Servatii, quae est constructa in Trajecto, in comitatu Maseland, quam dedit per suum preceptum sibi commissae Treverensi ecclesiae Arnulfus rex, sed violentia Rageneri comitis et filii ejus Giselberti a predicta Treverensi ecclesia jam olim esset injuste ablata.

487 Recueil Stavelot-Malmédy I, N 55, 132-133.

488 Richer, Historiae I, c. 36, 71. 
mentioned private charter Gislebert signs as " $d u x$, count and abbot." 889 That this, in fact, reflected the king's own position and was not simply a sign of Gislebert's aspirations can be deduced from the charter's dating line, reading "in the 9th year of the reign of the most pious lord, King Charles" ${ }^{490}$ and thus not only acknowledging Charles as the ruling king, but also, and in contrast to Gislebert's previous charters, ${ }^{491}$ attributing him with an epithet in the superlative. The presence of Bishop Baldric of Utrecht, whose brother's wife descended from Gislebert's family, ${ }^{492}$ at Charles' court during these years ${ }^{493}$ may also be a sign of the count's growing influence.

From 916 onwards, however, Reginar's rivals were on the rise. Count Matfrid was present at Herstal in 916 and 919 as well as at Bonn in 921. His growing importance is best reflected in his position within the lists drawn up on these occasions. In 916 he was still fourth among the counts; in the other two he was first. ${ }^{494}$ His brother Richer also rose at Charles' court. He received the diploma restoring Süsteren to Prüm in 916 and three years later, upon his request, Charles renewed the privileges given to the abbey by his predecessors. ${ }^{495}$ This diploma not only demonstrates Richer's access to the king, but describes the relationship between Charles and the abbey in a very significant manner. In contrast to the diploma he issued in 916, Charles now makes mention of the abbey's founder Pippin and his own relation to him, ${ }^{496}$ thus emphasising his own connection to Prüm and its abbot. Hence, it is not surprising that, not long after, Richer became Charles' candidate for the episcopal see of Liège in succession to Bishop Stephen, after the previous candidate, Hilduin, declared for Gislebert, ${ }^{497}$ thus ensuring that the Matfrids continued to act as a counterweight to the Reginarids in the region. Besides them, Stephen of Liège ${ }^{498}$ continued to be close to the king. After Charles' initial grant for his church, issued at the intervention of Robert and Reginar, the king restored a forest in 915 , again at the request of these two men. ${ }^{499}$ In this second case, however, there was also another member of the Matfrid family present: Bishop

489 Recueil Stavelot-Malmédy I, N 55, 133: dux, comes et abbas.

490 Recueil Stavelot-Malmédy I, N 55, 133: ... anno XI regni domni Karoli piissimi regis...

491 Recueil Stavelot-Malmédy I, N 53, 126 (14th April 915): anno IIII regni Karoli gloriosi regis and $\mathrm{N}^{\circ} 54,130$ (915-923): regnante Karolo rege.

492 Althoff, Amicitiae, 186, based on MGH Poetae Lat. V,2, $\mathrm{N}^{\circ}$ 26, 295. Balderic later joined Henry the Fowler's side, like Gislebert. Althoff, Amicitiae, 187 and DHI 27.

493 Balderic features among those accompanying Charles at Bonn in 921. MGH Const. I, N 1, 1-2.

494 DDChS 84 and 100; MGH Const. I, N $1,1-2$.

495 DChS 104 (20th August 919).

496 DChS 104, 247: ... inclitus ac venerabilis Richarius, abba Prumiensis monasterii, quod divae memoriae Pippinus, quondam rex Francorum, proattavus noster; suggessu et consensu Bertradae auguste conjugis suae, in honore domni et salvatoris mundi ejusque sanctissime matris genitricis Mariae, in juris sui proprietate a fundamentis extruxit...

497 On this conflict see, Zimmermann, Streit.

498 On his relation to the Matfrids, see chapter III.2.1.4, n. 339.

499 DChS 81. 
Dado of Verdun, whose sister had married Count Matfrid. ${ }^{500}$ Dado's appearance with Robert and Reginar shows the importance he enjoyed at court, as does his participation in both assemblies at Herstal, where he was named third and second among the bishops ${ }^{501}$ Like Dado, Stephen may have also been present on the latter occasion. Unfortunately, however, neither diploma names the bishoprics of those attending and the Bishop Stephen appearing in them may have been his namesake at Cambrai.

Finally, the two assemblies at Herstal also mark the ascent of Ratbod's successor as archbishop of Trier, Roger. The first one in 916 shows him as the first of the participants in the judgements in favour of Prüm. ${ }^{502}$ More significantly, however, this assembly is also the first of three exceptions prior to 919, in which the archbishop replaced Heriveus as archchancellor. ${ }^{503}$ While these appearances mark a distinctive influence, his position appears significantly strengthened again in 919, when Charles and the second assembly of Herstal withdrew Saint-Servais from Gislebert and restored the abbey to the church of Trier. Not even a month later, when Charles confirmed the judgement of Herstal in another diploma, Roger also became Charles' sole archchancellor, a position he seems to have kept up until the battle of Soissons. ${ }^{504}$ The timing of his ascent to this central position was certainly no coincidence. The conflict between Charles and Gislebert did not begin with the assembly of Herstal. On the contrary, the judgement must have been prepared some time in advance, gathering supporters and concluding new alliances against the count. Roger, due to his position at the head of the church of Trier and to the rivalry between him and Gislebert, presented himself as the ideal ally and was therefore bound to the king in two ways: through the handing over of SaintServais and through his appointment to one of the most central positions at court, that of archchancellor.

Charles' rule thus saw the continuation of the rivalries between the three most powerful factions, the Reginarids, the Matfrids and the church of Trier. Reginar's death marks the beginning of a shift away from his faction in favour of the

500 Hlawitschka, Anfänge, 71-73.

501 DDChS 84 and 100.

502 DChS 84.

503 DDChS 93 (28th April 918) and 96. The latter diploma is dated by Lauer, Recueil Charles III, 221 to a period between 918 and 923, 1st June, based on his assumption that Roger became archchancellor during that year. Font-Réaulx, Diplômes, 43, corrects this to 1st June 921 since the notary Gauzlin became Bishop of Toul in 922 and Roger, according to him, only became archchancellor in 921. Using the date of Roger becoming sole archchancellor of the realm to establish the date, however, is extremely problematic due to his earlier appearances in this position. We date this diploma to 917 or 918 since it appears to be strongly connected to the passing of Charles' first wife Frederuna (10th February 917, see DChS 89). After her death, the king started issuing a series of diplomas establishing memorial services on her behalf. This practice ends roughly one year later, in 918. See below.

504 From DChS 103 (9th July 919) onwards, only Roger appears as archchancellor in Charles diplomas. See also Schieffer, Kanzlei, 145, who considers DChS 102 (a forgery) as the starting point. Roger's last appearance is in DChS 121 (15th June 922). 
Matfrids; and in 919, when the conflict with Gislebert broke out, increasingly in favour of Roger, although without casting the Matfrids aside. On the contrary, Charles appears to have successfully integrated both factions since nothing indicates any conflicts between the two. However, we should not focus solely on these factions. The diplomas from the two assemblies of Herstal and the Treaty of Bonn contain long lists of participants-bishops, counts and men without titleindicating the broad support Charles enjoyed. While, undoubtedly, not all of them had significant influence at the royal court, some certainly did since they reappear several times or can be traced in the royal diplomas. For example, Archbishop Hermann of Cologne features in 916 and $921 .^{505}$ His involvement in the succession at Liège ${ }^{506}$ may be explained by the see belonging to his archdiocese, although his own position in the case seems rather dubious. Hermann ordained Hilduin, yet later claimed that he had been forced to do so. ${ }^{507}$ Hermann's actions were probably due to the influence of Gislebert and Henry the Fowler, who controlled large parts of his archdiocese, ${ }^{508}$ before he changed his course for Charles' side. Present at Bonn, he also organised a synod on behalf of Charles and Henry in $922,{ }^{509}$ which had originally been planned to be a grand meeting involving both kings, yet fell rather short of the high expectations due to the rebellion of the West Frankish nobles which kept Charles away. ${ }^{510}$ Hermann's actual position at Charles' court is hard to establish. He did cooperate with the king and his position in between the realms probably made him the ideal mediator between the interests of the two kings-hence also his presence at Bonn. Yet, this very same position probably also made him an unreliable ally for Charles, leading to the ordination of Hilduin at a time when the king himself was preoccupied with the nobles in the West. ${ }^{511}$ While Hermann undoubtedly wielded some influence at court, we should also not overemphasise his position. Others were more important.

Besides the archbishop, we should also note a number of counts. Theoderic, count of Kimmen, may have already been in contact with Charles in $912 ; 512$ later he accompanied the king at Herstal in 916 and Bonn while his brother Walker was also present in $919 .{ }^{513}$ Theoderic, however, also received a royal grant in 922, just after Charles had been forced to abandon his position at Reims against Robert's

505 DChS 84 and MGH Const. I, N 1, 1-2.

506 Hermann asked Hilduin to present himself in front of a synod (MGH Conc. VI, No 2, c. 7, 47). Pope John X asked Hermann to come to Rome on the same matter. MGH Conc. VI, No 3, A, 53-55 and B, 55-56.

507 Flodoard, Annales 920, 4; MGH Conc. VI, N² 2, c. 2, 45.

508 Zimmermann, Streit, 23-24. On the position of the archbishop of Cologne between Lotharingia and the Eastern realm, see chapter III.2.1.4.

509 MGH Conc. VI, N 4, 68.

510 See the editor's comment, MGH Conc. VI, N ${ }^{\circ} 4,57-58$.

511 Flodoard, Annales 920, 4.

512 See chapter III.2.1.5, n. 388.

513 DDChS 84 and 100; MGH Const. I, N $1,1-2$. 
army and his own forces started to disintegrate. ${ }^{514}$ These frequent appearances indicate that the brothers were close to the king and the 922 diploma is a safe sign that they remained loyal to Charles even in times of crisis. Huntger of Vimeu, who was present in $919,{ }^{515}$ was probably less influential, yet at least also had access to king, as is demonstrated by a diploma issued at his request. ${ }^{516}$ Probably closer to Charles was Count Erlebald of the pagus Castriciensis. Like Huntger, he was present in $916,{ }^{517}$ shortly after he had intervened together with Ricuin on behalf of Saint-Mihiel. ${ }^{518}$ In 920, however, Erlebald entered into conflict with the church of Reims. When he was excommunicated and his situation became desperate, he fled to Charles, yet was killed before reaching him. ${ }^{519}$ That he sought help from the king points towards close relations-he had access to him and could hope to profit from such a move, even against one of Charles strongest supporters, Archbishop Heriveus. This deduction is further confirmed by Charles' actions after the count's death. The year after, at the synod of Trosly, the king intervened to demand, against common practice, his posthumous reconciliation. ${ }^{520}$

The connection between Erlebald and Charles already points us towards a last group of nobles that emerged during the second half of Charles reign. The central documents for this group are two diplomas dating to 920 and $921 .{ }^{521}$ The first one shows the counts Hagano, Raoul de Gouy and Sigard intervening on behalf of Bishop Stephen of Cambrai and his church; the second the bishops Abbo of Soissons and Stephen of Cambrai together with the counts Hagano, Helgaud of Ponthieu and Raoul, supporting a judgement in favour of the king's brother-inlaw, ${ }^{522}$ Bishop Bovo of Châlons, and his church. Apart from Count Helgaud, all of these men appear to have held elevated positions within the circle around the king, marked by their frequent appearances in Charles' diplomas-even setting aside their appearances in the judgements and at Bonn. Stephen of Cambrai received no fewer than four royal charters, ${ }^{523}$ Abbo made two interventions, both of them for important abbeys (Saint-Germain-des-Prés and Saint-Maur of Fossés ${ }^{524}$ ), Raoul and Sigard each made another two, ${ }^{525}$ while Hagano's position as Charles' intimate companion is well known and will be addressed later. A number

514 DChS 121 (15th June 922). Flodoard, Annales 922, 9.

515 DChS 100.

516 DChS 111.

517 DChS 84.

518 DChS 83 (27th November 915).

519 Flodoard, Annales 920, 2-3.

520 Flodoard, Annales 921, 5. See also Schröder, Synoden, 211.

521 DChS 106 (8th September 920) and 112 (20th September 921).

522 See DChS 95.

523 DDChS 67, 68, 128 and 106. Furthermore, he was present at Bonn and possibly also at both assemblies of Herstal.

524 DDChS 92 (for Saint-Germain-des-Prés) and 108 (for Saint-Maur of Fossés). He was also present at Herstal in 919.

525 Raoul: DDChS 80 and 106. He was also present at Herstal in 916. Sigard: DDChS 128 and 106. He was present at both assemblies at Herstal. 
of these cases show some of these nobles working together, thus strengthening the image of a group cooperating with each other. For example, one of the diplomas for the church of Cambrai shows Sigard intervening together with Count Isaac of Cambrai ${ }^{526}$ while the diploma for Saint-Maur features Hagano alongside Abbo. ${ }^{527}$ Comital intervention per se is nothing special in Charles' diplomas. Yet, the number of the appearances of these men is singular.

In contrast to counts, bishops very rarely intervene, ${ }^{528}$ and Abbo appears to have been in an especially influential position at court. The abbey Saint-Maur, for which he intervened together with Hagano, had been founded by Adelaide's great-grandfather, as Charles' diploma does not fail to mention. ${ }^{529}$ Even in the 920s, it was closely linked to her family, its abbot Rumald being her kinsman and the abbacy reserved for family members. ${ }^{530}$ In the diploma, Abbo, Hagano and Rumald are mentioned to have restored and reformed the abbey, ${ }^{531}$ thereby linking the former two to Charles' family even closer than by their joint intervention and emphasising their proximity to the king. Abbo's intervention for Saint-Germain-des-Prés, on the other hand, shows him acting together with both Robert, its abbot, and Heribert II, in whose county were located the honores that Charles handed over to the abbey, ${ }^{532}$ and thus close to the most powerful man of the realm and another, who would become one of its leading nobles once Charles had been deposed. ${ }^{533}$ In fact, Abbo, the "excellent" and "most reverent bishop",534 appears to have been one of the central men of the realm. When the Western counts assembled to force Charles to dismiss Hagano as his councillor, they did so at Abbo's see, Soissons. ${ }^{535}$ This choice certainly was not made at random, but may point to the bishop's central role in these events. Either he had a part in organising the assembly or Soissons was chosen because the nobles expected Abbo to be able to mediate between them and the king - or both. Indeed, Abbo's importance did not end with Charles' rule. The bishop became Robert's archchancellor and, after Robert's death, Raoul's. ${ }^{536}$ Both seem to have highly valued his connections to the nobility of Francia and placed some trust in him. But his position did not depend on his connections to the royal court. When Heribert II, after the death of Archbishop Seulf of Reims, installed his infant son in the see, Abbo aligned himself with the

DChS 128.

DChS 108.

Clear cases are only DChS 10, with Honoratus of Beauvais and Rudolf of Laon intervening for Saint-Denis, and DChS 81, with Dado of Verdun supporting a request for the church of Liège.

DChS 108, 260: ... qua continebatur qualiter ipsum monasterium Bego, genitricis nostrae proavus... DChS 108.

DChS 108.

DChS 92. See also chapter III.2.1.7, n. 464.

On Heribert II's later career, see Schwager, Graf.

DDChS 92, 211 (eximio episcopo) and 108, 259 (praesul reverentissums).

Flodoard, Annales 920, 2.

Dufour, Recueil Robert et Raoul, XXV-XXVII. 
count, agreed to the appointment and obtained the vicariate for the archdiocese for himself. ${ }^{537}$

Like Abbo, Stephen appears to have been well connected within the nobility. In the first diploma he received from Charles for his church, three counts intervened on his behalf, Guarner, Theoderic and Letard; ${ }^{538}$ while in later ones we find, besides Hagano, Raoul and Sigard, Count Isaac of Cambrai, who had already been in contact with Louis the Child and Reginar. ${ }^{539}$ Stephen thus provided Charles with access to his own network, with Letard and Isaac also appearing at Herstal in 916 and at Bonn respectively. ${ }^{540}$ Moreover, one of the diplomas issued for him describes him as "the entire realm's strenuous man," ${ }^{541}$ a choice of words that probably points towards his heavy involvement in the daily affairs of the royal court, probably similar to Abbo's. After Charles' deposition, however, Stephen's influence, unlike Abbo's, seems to have declined. A conflict with Isaac ensued that only ended about 25 years later, when Otto I withdrew all comital rights from Isaac and handed them to Stephen's successor, Fulbert. ${ }^{542}$ For the time being, Stephen probably was able to keep the count at bay. A synod at Trosly judged Isaac liable to pay a fine for burning down one of the bishop's castles. ${ }^{543}$ However, Stephen's influence appears to have been on the decline. The judgement of the synod may also have been due to the presence of Heribert II, who also had been attacked by Isaac. More importantly, however, Stephen appears neither in the diplomas of Henry the Fowler nor of Otto I. Only his successor Fulbert seems to have reentered royal favour. ${ }^{544}$

\section{III.2.1.8 Liberty of choice?}

As we have seen, the network of Charles' later years differs considerably from the one Charles possessed before the acquisition of Lotharingia. Most of Charles' early supporters had died. Archbishop Fulk, Bishop Anskeric and Count Heribert I of Vermandois had all passed away during the first decade of the 9th century and were succeeded by Heriveus, Theodulf and Heribert II. Relations between the king and these successors, however, appear to have differed fundamentally from those with their predecessors. Theodulf was still in contact with the king, yet only played a minor role at court. Heribert II's number of appearances is rather limited and they do not, apart from his appearance with Robert and Abbo, reveal any

Dufour, Recueil Robert et Raoul, XXV-XXVII and Flodoard, HRE IV, c. 20, 411.

DChS 67.

DDChS 128 (Isaac and Sigard) and 106 (Hagano, Raoul and Sigard). On Issac's earlier contacts, see chapter III.2.1.5, n. 361.

DDChS 84 and MGH Const. I, N $1,1-2$.

DChS 106, 253-254: ...vir quippe totius regni strenuus...

DO I 100 (30th April 948). On this conflict, see also Prinz, Klerus, 183.

Flodoard, Annales 924, 24-25. See also Flodoard, HRE IV, c. 19, 410-411 and Schröder, Synoden, $\mathrm{N}^{\circ} 37,216-218$.

DDO I 39 and 100. 
specific political weight. Yet he was present at Charles' side in 922, a circumstance indicating that he was close to the king. Heriveus finally did play a central role at court; however, whether his influence was comparable to that of Fulk seems doubtful, especially since the latter's position was occupied by Robert. Within the Lotharingian nobility, Charles appears to have been caught up in rivalries predating his reign, balancing between the factions of Reginar and his son Gislebert, the Matfrid family and the church of Trier.

From the interplay between these different groups, the extent to which Charles was at liberty to choose those around him becomes visible. The old group around Fulk had surrounded Charles since his first coronation in 893 and could build their claim to be close to him on their support during these years. Dismissing them would have meant, especially in the beginning, the loss of Charles' entire support base. This situation changed with Fulk's death, creating at the same time a vacuum of power and an opportunity for the king to decide on his future allies. His choices, however, were limited, the only two options being the powerful Richard or the even more powerful Robert. Here, Charles fell victim to a development that had occurred since the times of Charles the Bald: the rise of the marchiones. In Lotharingia, a similar situation had evolved. Here as well, Charles had to find a balance between the different claims to have access to the circle surrounding him. The circumstances were already in place and the king had to work within them by balancing between the different factions after the initial alliance with Reginar had ceased to exist with the latter's death.

This, however, is not to say that Charles did not have any agency when it came to choosing those around him. After the acquisition of Lotharingia, a new group of nobles arose, composed of men from both regna, most of whom appear to have had a very close relationship with Charles. The nature of these relationships may indicate that their position at the king's side was less due to their actual power and more the result of the king inviting them to his court. Within this group, Hagano is of course the prime example of a noble being elevated by the king. But likewise, Abbo may also have owed his position to the king. Nothing is known about him or how he became bishop of Soissons, and so the proposition that he was Charles' choice for the see must remain speculation based on his later influence at court. ${ }^{545}$ Yet, he was only one example of how the king could use episcopal succession to install men of his choice in key positions around the realm. Three, possibly four, men belonging to the royal chancellery or chapel are known to have become bishops, and the sees they occupied were spread throughout the realm. Heriveus, of course, became archbishop of Reims. Herluin, who succeeded Heriveus as notary in the

545 Lauer, Recueil Charles III, 258, identifies Abbo as a relative of Charles' mother Adelaide, which would make it quite possible that the king was indeed involved in his appointment. This, however, appears to be based on a misreading of DChS 108. See Werner, Nachkommen, 434, n. 19 and Dufour, Recueil Robert et Raoul, XXV, n. 6. Against this reading Koziol, Politics, 524, although without giving any argument. 
royal chancellery, ${ }^{546}$ might be identical with the namesake who became bishop of Beauvais during the 900s. At Girona, Guigo, a man who had been educated at the royal palace, became bishop in $908 .{ }^{577}$ And finally, fourteen years later, Gauzlin, up until this moment Charles' notary, was appointed bishop at Toul ${ }^{548}$ after the see had been vacant for some time. As at Reims and at Girona, where Archbishop Arnust undoubtedly played a central role in the choice of Guigo ${ }^{549}$ here as well we can note local cooperation with the king. After Bishop Drogo's death, ${ }^{550}$ the canons of Toul sought out Charles at Duisburg. Soon after, the king issued a diploma in their favour and about a fortnight later Gauzlin was anointed. ${ }^{551}$ In two other cases, relatives of Charles became bishops. Frederuna's brother Bovo became bishop at Châlons ${ }^{52}$ and in 913 at Strasbourg, Gauzfrid, one of Charles' nephews, succeeded Bishop Otbert, yet died soon after. ${ }^{53}$ In both cases, the sources do not provide details of the circumstances of their appointments. However, their connection to Charles makes it highly likely that he was involved.

Episcopal successions did not occur very frequently and, given the different groups that struggled to raise their own candidate to a see, the few occasions in which we can actually trace royal influence may not be surprising. Two cases, however, do betray the particular interests of the king in having men of his choice appointed. The first was at Strasbourg, where, after the death of Gauzfrid, a noble Lotharingian called Ricuin ${ }^{554}$ became bishop. As the records of the synod of Hohenaltheim in 916 tell us, this had happened without the consent of the metropoli$\tan$ of the archdiocese, the archbishop of Mainz. Ricuin was requested to present himself at the synod yet failed to do $\mathrm{so}^{555}$ - did he, like his predecessor, belong to Charles' supporters; and was he therefore opposed by the elites of the Eastern realm? Such an interpretation appears, at least, not to be unfounded, making it likely that he was one of Charles' candidates. ${ }^{556}$ More obvious is the case of Liège after Bishop Stephen's death. As Harald Zimmermann has argued, ${ }^{557}$ it seems that at first the clergy and people of Liège elected Hilduin, assuming that he was an acceptable candidate for the king. Charles, however, appears never to have confirmed Hilduin, himself at that moment being occupied by the problems with the West Frankish nobles. Instead of waiting for the confirmation, Hilduin appears

546 Lauer, Recueil Charles III, XIX.

547 Catalunya Carolingia V,1, N 127, 147-148; HGL V, N 35, cols. 124-125. Schröder, Synoden, $\mathrm{N}^{\circ} 26,178-179$ and Magnou-Nortier, Société, 332-333.

548 Lauer, Recueil Charles III, XIX-XX and Flodoard, Annales 922, 7 and the editors comment in n. 3.

549 Koziol, Politics, 496.

550 28th January 922, see Lauer, Flodoard, 7, n. 3.

551 See Lauer, Flodoard, 7, n. 3. Drogo died 28th January 922. 4th Mars 922 Charles issued the diploma (DChS 114), Gauzlin was anointed 17th March of the same year.

552 DChS 95, 219-220: ...pro Bovone praesule, fratre Frederonae nostrae conjugis...

553 Erkanbald, Bischofsliste II, 37 (MGH Poetae Lat. V,2, 512). See Dümmler, Geschichte III, 593.

554 Erkanbald, Bischofsliste II, 38 (MGH Poetae Lat. V,2), 512.

555 MGH Conc. VI, $\mathrm{N}^{\circ} 1,34$, c. 29.

556 Similar also Büttner, Heinrich, 10-11.

557 Zimmermann, Streit, who we follow here. 
to have allied himself with Gislebert and Henry the Fowler, both attempting to exploit Charles' momentary weakness to extend their influence in Lotharingia. When the king had managed to stabilise his position however, Charles did his best to remove Hilduin and replace him with Abbot Richer of Prüm, calling upon a general assembly, initiating a synod and finally also involving Pope John $\mathrm{X}$ in the matter. ${ }^{558}$ The king's effort speaks volumes about how seriously he took such cases and how far he would go to protect his interests if he felt that they were threatened.

Hence, episcopal elections were a field used by Charles to increase his influence and a field where his agency in installing men of his choice becomes apparent. The choices he made on these occasions reveal the considerations he had to take into account. Richer at Liège belonged to the Matfrid family and the conflict between the king and Gislebert ensuing around the bishopric certainly overlapped with the rivalry between the two factions. By choosing Richer, Charles made certain that he had the support of the Matfrids against Reginar's son and his supporters. In the other cases, the king probably did not install his candidates against the resistance of the local elites. This, undoubtedly, also applies to the circle surrounding Charles and the choices the king made in who he invited there. Some, like Robert, were able to claim access to this circle due to the position they held within society; others, like Fulk and Heribert, due to old connections or, like Bovo, because they were relatives; while, finally, another group had access to this circle due to their personal connections to the king. These different categories did not exclude each other and there would certainly have been cases when a noble could claim a position within the circle based on his own power as well as his personal relation to the king. However, as the problems surrounding the integration of Robert of Neustria again demonstrate, the question of access to the circle was not limited to the direct relations between the king and the respective nobles. When making his choice, Charles needed to take into consideration the interests of those already within the circle. In the case of Robert, Archbishop Fulk's interests were opposed to giving the marchio the position he desired and therefore his integration only succeeded after Fulk's death. When the Lotharingian nobles needed to be integrated under Charles' rule, it was, in turn, Robert's interests that were at stake. The king's reaction to this becomes clear in the two diplomas that show Robert and Reginar intervening together on behalf of the church of Liège, with Charles carefully balancing between the two men. Hence, the network surrounding Charles was a fragile construction dependant on his ability to mediate between the different interests of the various nobles. Integrating new men into the network was therefore always a difficult and dangerous endeavour, threatening to offset the balance between the individuals and factions already present within the network. We will have to keep this in mind when we now turn to the role his family and friends played in royal politics.

558 MGH Conc. VI, $\mathrm{N}^{\circ}$ 2, c. 2, 45 and c. 7, 47 as well as the letters A and B, 53-56 with Zimmermann, Streit, $26-27$. 


\section{III.2.2 Family and friends}

\section{The queens}

When Charles became king, the opportunities offered by his family connections were rather limited. Of his five siblings, his half-brothers Louis and Carloman, as well as his sisters Hildegard, Gisela and Ermentrude, three were already dead, ${ }^{559}$ leaving only one niece, Ermentrude's daughter Cunigunde and more distant relatives. Hence, the main role at court fell to Charles' mother Adelaide and, after her, to his wives Frederuna and Eadgifu and their relatives. At court, the queen occupied a central role. ${ }^{560}$ According to Hincmar, she was in charge of the royal household and had access to the royal treasury, a position that connected her to the dealings at court. ${ }^{561}$ Given her position at the king's side, the queen was considered to be one of the most influential members of the royal court, expected to act as a mediator and to intercede in front of the king on behalf of others, most importantly her own family and friends. ${ }^{562}$ Depending on her character and abilities, a queen could become one of the key figures of the realm, strongly influencing its affairs. ${ }^{563}$ Interventions by queens, however, were rather rare compared to the overall number of royal diplomas - with the notable exception of Charles' mother Adelaide. ${ }^{564}$ From 898 until her death in $901^{565}$ she intervened no fewer than eleven times, featuring in only slightly less than a third of the diplomas issued during these years. ${ }^{566}$

Should we take the high number of her appearances as a sign of her special importance to Charles and of her playing a key role at court? The epithets used to describe her are the common ones used for queens, "dearest," (carissima) "most beloved" (dilectissima) and "sweetest," (per)dulcissima ${ }^{567}$ with the exception of the "venerable" (venerabilis), ${ }^{568}$ which might indicate that Adelaide had entered a convent. ${ }^{569}$ These diplomas went to a large group of recipients, containing likewise known but her name. See Settipani, Préhistoire, 317-318.

560 A general overview of current research on queenship is provided by Zey, Frauen, 10-15.

561 Hincmar, De ordine palatii, c. 5, 72-74. See also Erkens, Esther, 15-16.

562 Nelson, Queenship, 199-202 and Görich, Mathilde, 260, 266 and 271.

563 Nelson, Queenship, 203 and Erkens, Esther, 17. General studies on the role of queens are provided by Hartmann, Königin, esp. 162-179 and Fößel, Königin (with an emphasis on the post-Carolingian periods).

564 Erkens, Esther, 20-21. On the role of the king's mother, see Verdon, Veuves.

565 18th November, probably 901 since after that year she disappears from the sources. See Werner, Nachkommen, 453.

566 DDChS 10, 11, 14, 15, 22, 23, 27, 32, 35, 39 and 41.

567 Before 898 DChS 5 and 7, 6 and 10 (carissima), from 898 onwards DDChS 10, 32, 35 and 39, 16, 68, 75 and 83 (dilectissima) and DDChS 14, 15 and 41,25, 27 and 50 (dulcissima). The same epithets were, for example, used for Charles the Bald's wives Ermentrude (DDChB 12, 189, 212, 223, 248, 269, 277 and 278) and Richilde (DDChB 416 and 433).

568 DDChS 11, 22, 23 and 27, 18, 43, 46 and 57.

569 On the connection of the epithet to ecclesiastical institutions see Brunner, Fürstentitel, 201. 
abbeys, churches and laymen. On all but two ${ }^{570}$ of these occasions, Adelaide appears together with other nobles, either petitioning or intervening alongside her. It is remarkable that none of these interventions were for relatives; of friends, only Charles' early supporters Count Erkanger ${ }^{571}$ and Count Ecfrid appear, the latter together with Charles' cousin Count Hugh of Maine. ${ }^{572}$ This last diploma, however, is a highly political one, marking the alliance between the king and Hugh against Robert of Neustria. ${ }^{573}$ This may point us towards a reason for Adelaide's frequent appearances, as there seems to be a pattern behind them. Her first intervention after 898 saw her together with bishops Honoratus of Beauvais and Rudolf of Laon, two former allies of Odo. ${ }^{574}$ In 900, she appears in the first diploma issued for Richard the Justiciar ${ }^{575}$ and in 901 she supported Count Ermenfrid of Amiens. ${ }^{576} \mathrm{In}$ all of these cases, the diplomas issued mark newly forged alliances. In this context, it is interesting to note that Adelaide only intervened on Richard's behalf once, although four more diplomas were issued on behalf of the marchio shortly afterwards. ${ }^{577}$ Were her appearances limited to these occasions? At first glance, the diplomas for the recipients in Septimania seem to speak against such a conclusion. Adelaide intervened twice for the church of Narbonne, in both 898 and in $899,{ }^{578}$ and supported another petition of Archbishop Arnust of Narbonne for a fidelis called Stephen and his wife Anne. ${ }^{579}$ However, the latter two of these cases took place at the assembly of Tours-sur-Marne, an event of special political importance for Charles that gave him the opportunity to present himself as king in front of a greater audience..$^{50}$

All in all, it seems that Adelaide only intervened at moments of great political significance, when a certain message needed to be conveyed, giving her appearances a strong symbolic weight. The question remains, however, whether this symbolism was a reflection of her political importance. None of the diplomas names Adelaide as queen. Instead, she is presented as "our mother" (genitrix nostra), ${ }^{581}$ placing the emphasis on her personal connection to Charles. ${ }^{582}$ However, her ap-

DDChS 11 (for Saint-Mihiel) and 22 (for San-Juan-de-las-Abadesas).

572 DChS 35.

573 See above.

574 DChS 10. See above.

575 DChS 32

576 DChS 41.

577 DDChS 33, 31, 38 and 8. In 902, when DChS 43 was issued, Adelaide had already died.

578 DDChS 14 and 23.

579 DChS 27.

580 See above.

581 DChS 5, 6; DChS 7, 10; DChS 10, 16; DChS 11, 18; DChS 14, 25; DChS 15, 27; DChS 22, 43; DChS 23, 46; DChS 27, 57; DChS 32, 68; DChS 35, 75; DChS 39, 83; DChS 41, 90.

582 Charles' diplomas betray a certain reluctance to apply the title regina. Even his wife Frederuna is only once mentioned as such and only in the first diploma issued after her death (DChS 87, 14th February 917). In this, his diplomas differ considerably from those of Charles the Bald, which frequently attribute the title. An example of a king's mother carrying the title queen is 
pearance would only have had significant value, if she occupied a central position at her son's side and if this was generally known and acknowledged. Therefore, it seems plausible that her frequent interventions were indeed a sign of her importance within Charles' inner circle. This allows us to cast some further light on the changes that the royal network underwent during the first years of his reign. The death of Archbishop Fulk in 900 had not only deprived Charles of his most central advisor, but also provided him with the opportunity to fully integrate Robert into his rule by granting him the position formerly occupied by the archbishop. However, the king's choice did not fall on Robert but on Richard, with Adelaide intervening in the very first diploma celebrating this new alliance. It seems reasonable to assume that she, although for different reasons than Fulk, was likewise opposed to Robert: shortly after her death, relations between Charles and Richard appear to have started to deteriorate rapidly, leading to Richard leaving the court and finally to the integration of Robert. ${ }^{583}$ With Adelaide's death, opposition to Robert at court seems to have come to an end. Although his mother's death certainly meant a loss for Charles, it did increase his liberty to pursue his own policies towards Robert.

Several years after Adelaide's death, Charles married Frederuna. ${ }^{54}$ Not much is known about her family. The argument that she was a sister of Mathilde of Saxony, Henry the Fowler's wife, ${ }^{585}$ has been convincingly refuted by Eduard Hlawitschka. ${ }^{586}$ Frederuna has also been seen as a Lotharingian noblewoman, based on the assumption of a connection through kinship between her and Charles' later intimate, the Lotharingian Count Hagano. ${ }^{587}$ This hypothesis is based on two of Charles' diplomas for the canons of Compiègne, both issued after Frederuna's death, which see Hagano intervening on her behalf $f^{58}$ and included in prayer services with the king, Frederuna and her brother Bovo. ${ }^{589}$ However, as Philippe Depreux argues, this is circumstantial evidence and falls short of proving anything, especially when considering the case of Bishop Stephen of Liège. ${ }^{590}$ The latter

Otto I's mother Mathilde, who is often addressed as such in her son's diplomas (e. g. DO I 186, 228 and 328).

583 See chapter III.2.1.3.

584 Probably in early April 907, given the indication of their marriage in DChS 56 (19th April 907).

585 Eckhardt, Funde, followed by Werner, Nachkommen, 457. Similar also Sielaff, Fridrun. Eckardt tries to identify Mathilde's sister Friderun with Charles' wife Frederuna. Eckardt bases his hypothesis on three arguments: a) Thietmar calls Henry Charles' nephew; b) The name of Frederuna's brother Bovo was common among the Liudolfinger family; c) Bishop Berengar of Cambrai, Bovo's nephew, is known to be a relative of Otto I (Gesta Episcoporum Cameracensium, c. 80, 431).

586 Hlawitschka, Kontroverses, 45-50. Hlawitscka argues for a close kinship between the two, but refutes Eckardt's hypothesis on several points: a) the St-Gall litanies for Mathilde's family do not mention either Frederuna nor her brother Bovo; b) while Frederuna already died in 917, Friderun lived until 971; c) a possible confusion of Bishop Berengar of Cambrai with his namesake of Verdun, the latter in fact being a relative of Otto I. 
was addressed in another diploma as "our most beloved kinsman by marriage,"591 indicating that he was considered as belonging to Charles' family-something that is never done in the case of Hagano, despite his frequent appearances. ${ }^{592}$ The connections of Frederuna's brother Bovo may provide more clues. As Flodoard tells us, in 956, Bovo's nephew Berengar became Bishop of Cambrai. ${ }^{593}$ This same Berengar is described by the Gesta Episcoporum Cameracenisum as a relative of Otto I. ${ }^{594}$ Bovo's East Frankish roots may have also been the reason why his death was noted by the Merseburg necrology. ${ }^{595}$ In this context, another hypothesis, first proposed by Reinhard Wenskus, is worth making note of. Allegedly, Bishop Bovo of Châlons was identical to a monk named Bovo at Corvey. ${ }^{596}$ And indeed the Catalogus abbatum Corbeiensium does mention a Bovo episcopus for the abbacy of yet another Bovo, Bovo II (900-916). ${ }^{597}$ These years coincide with the beginning of Bovo's episcopate at Châlons. According to the episcopal catalogue of the church of Châlons, after Mancio's death in 910, a certain Letoldus occupied the see for four years, ${ }^{598}$ meaning that Frederuna's brother Bovo became bishop around 913. However, whether this Bishop Bovo really belonged to the same family as the abbot, the Ekbertiner, as Wenskus proposes, seems rather uncertain, with the shared name Bovo apparently being the only reason for this hypothesis. ${ }^{599}$ What seems clear is that Bovo and, therefore, also Frederuna, descended from an important Saxon family, somehow related to the Ottonians-this may have been the Ekbertiner or the Popponids, in whose family the name Bovo was also common; 600 but this question must remain open.

Two diplomas from 907 mark the marriage and the ascent of the new queen. The first, dating to 19th April, tells us that, according to the law and with the consent of his advisors, Charles had taken a young noblewoman called Frederuna for his wife and made her his consors regni ("partner in rule"). ${ }^{601}$ With this diploma,

591 DChS 81 (25th August 915), 181: ...nostre consanguinitati affinis dilectissimi...

592 Depreux, Comte, 389-390.

593 Flodoard, Annales 956, 143.

594 Gesta Episcoporum Cameracensium, 431: ...vir siquidem ex nobili parentela Germaniae ortus sed et Ottonis imperatoris proxime consanguineus. On this connection, see also Althoff, Königsfamilien, 339, B 185.

595 See Althoff, Konvent, 30, n. 9.

596 Wenskus, Stammesadel, 249-250. See also Ravaux, Evêques.

597 Catalogus Abbatum Corbeiensium, 275.

598 The catalogue is printed by Duchèsne, Fastes III, 93-95. According to him, the catalogue is extremely precise and credible. See Duchèsne, Fastes III, 99 for the year of Mancio's death, based on the catalogue. Benner, Châlons-en-Champagne, 43, dates Bovo's episcopat to 911/913-947, succeeding Letoldus (908/909-911/913).

599 Unfortunately Wenskus only referred to Wilmans, Kaiser-Urkunden, 301 in this context. Wilmans, however, does not mention the monk/bishop Bovo. Wenskus' hypothesis therefore seems to be based on the frequency of the name Bovo in the Ekbertiner family mentioned by him in this context. Wenskus, Stammesadel, 248-250.

600 Wenskus, Stammesadel, 248-250.

601 DChS 56, 122: Eorum itaque admonitionibus sollicitati et consiliis exortati quamdam nobili prosapia puellam, nomine Frederunam, communi dumtaxat consensu fidelium, Deo, ut credimus, cooperante, 
Charles granted his bride a dowry, ${ }^{602}$ consisting of two palaces ${ }^{603}$ belonging to the royal fisc: Corbeny, including his own foundation of Saint-Pierre, which he had constructed for the relics of Saint Marcoul only a year before; ${ }^{604}$ and Ponthion. The second diploma, issued a month later, saw Frederuna intervening together with Abbess Gisela of Nivelles, the daughter of Lothar II, Robert of Neustria, a Countess Adelaide, the counts Altmar and Erkanger as well as the fidelis Robert on behalf of bishop Anskeric of Paris and his Church, granting the church the abbey of Saint-Pierre of Rebais, previously held by the bishop. ${ }^{605}$ As we have already discussed, this diploma seems to be a kind of who-is-who of the realm, displaying Charles' family and his most important advisors. The use of the consors regni, a very uncommon expression for West Frankish diplomas, ${ }^{606}$ as well as the presentation of Frederuna within the circle of the most influential nobles of the realm, both indicate that Charles intended to let Frederuna partake in the political affairs of the realm.

Early in the 10th century, two new ordines were created dealing with the coronation of the queen ${ }^{607}$ One of them derives the position of the queen from her marriage to the king by pointing out the positive effects for her people of the marriage between the Jewish queen Esther and the Persian king, Ahasuerus/Xerxes. ${ }^{608}$ This is basically the same reasoning also to be found in Charles' first diploma for Frederuna, in which her new importance is derived from the marriage to him: he made her the consors regni because she had become his wife. ${ }^{609}$ If we find the same thought pattern in Charles' diploma as well as the ordo, can we assume a direct connection between the two? It seems at least likely that Frederuna was crowned and anointed queen and that the ordine was created or used for this occasion.

These first diplomas show the importance the marriage had for Charles and that he appears to have at least intended to make his wife part of his rule. However, Régine Le Jan argues that the queen's dowry was too limited to one region to allow her to completely fulfil the role as a consors regni. ${ }^{610}$ While we cannot argue against the limited distribution of the dowry, we should not forget that Charles

secundum leges atque statuta priorum nobis nuptiali conubio sociavimus regnique consortem statuimus. For the meaning of consors regni, see for example Fößel, Consors regni, 83.

602 On the queen's dowry, see Hartmann, Königin, 158-160 and Le Jan, Douaires.

603 See also Bautier, Itinéraires, 108-109.

604 DChS 53.

605 DChS 54 (21st May 907).

606 Erkens, Esther, 23. While common in Italy and (later) the Ottonian empire, within the West the expression is otherwise only used in diplomas of Charles the Bald, DDChB 269 and 299. See him also for the importance of this expression.

607 MGH Font. Iur. Germ. IX, N 3, 6-9 and XI as well as Schramm, Krönung, 141-149. Both were created at the beginning of the 10th century in Western Francia.

608 MGH Font. Iur. Germ. IX, No 3, c. 2, 8-9.

609 See chapter III.3.2.2, n. 601 and Erkens, Esther, 24. Nelson, Rites, 311-312 sees a connection of the ordo to the marriage between Charles' son Louis IV and Otto I's sister Gerberga in 939, pointing out its incorporation into Ottonian pontificials in Italy and Germany.

610 Le Jan, Douaires, 474. On the actual control of the queen over her dowry, see Althoff, Probleme. 
himself mostly appears to have remained within Francia, the very same region where he chose to endow his wife. Hence, the size and distribution of the dowry do not help us when establishing Frederuna's influence at court. More promising is the evidence of the royal diplomas. Up until her death in 917, only one diploma is preserved mentioning her. In 915, Count Raoul de Gouy and the fidelis Etbert intervened on her behalf in front of the king, asking him to donate some land at Compiègne to her to construct a chapel for Saint Clement. ${ }^{611}$ While a low number of interventions does not necessarily indicate that the queen was without influence at court ${ }^{612}$ her absence from the diplomas, especially compared to the presence of Charles' mother Adelaide, is remarkable. Her connection to Raoul de Gouy indicates that she was part of the link between Charles and this special circle of close associates around him. Except for this, only the appointment of her brother Bovo as bishop of Châlons may give us an indication of her importance, assuming that he owed his position to her influence with the king.

Despite the lack of evidence from the diplomas issued during her lifetime, Frederuna appears to have been very close to Charles. Before her death, Charles' diplomas twice connect her spiritual welfare to measures taken by the king. ${ }^{613}$ Immediately after her death on 10th February $917,{ }^{614}$ for about sixteen months, each of Charles' diplomas either dealt with Frederuna's last wishes or established prayer services on her behalf. ${ }^{615}$ Frederuna's donation of Corbeny to Saint-Remy was confirmed, ${ }^{616}$ Ponthion given to Saint-Corneille, ${ }^{617}$ some property to her chaplain Mauger ${ }^{618}$ and other estates to her foundation of Saint-Clement, ${ }^{619}$ with two of the latter cases emphasising her wish ${ }^{620}$ or even letting her appear as petitioner. ${ }^{621}$

611 DChS 80 (7th July 915).

612 Erkens, Esther, 22.

613 DDChS 64 (17th June 910 or 911, 146: ...pro nostra tantummodo salute conjugisque nostrae Friderunae...) and 83 (27th November 915, 187: Et ob hoc pro remedio animae nostrae conjugis Friderunae...).

614 DChS 89 notes this day for her death.

615 The only exception is DChS 93 (28th April 918), which donates Charles' foundation Saint-Vaubourg at Attigny to Saint-Corneille. This diploma mentions no prayer service, only the treasurer and the bailiff are requested to pay five solidi for a meal served the day of Charles' coronation and later his deathday. On memorial services in general and also particularly for Frederuna, see Ewig, Gebetsdienst.

616 DChS 87 (14th February 917).

617 DChS 91 (26th July 917).

618 DChS 95 (26th May 918).

619 DDChS 95 and 96 (1st June 917 or 918) Lauer dated this diploma to 1st June 918-923; Font-Réaulx, Diplômes, 43 to 921, based on the beginning of the episcopate of Gauzlin in 922, Archbishop Roger of Trier only acting as sole chancellor from 921 onwards and the diploma being edited by the same person as DChS 110. Roger of Trier, however, occasionally acted as chancellor already before 919 (see chapter III.2.1.3). Furthermore, Font-Réaulx reasons to assume the same editor remain in the dark. The donation made on behalf of Frederuna on the other hand points to a connection to this period after her death, which leads us to believe that it was issued during this time.

620 DChS 91, 207: ...volumus fieri quod conjunx nostra Frideruna carissima nostram flagitavit crebrius clementiam ut, post discessum suae hujus vitae, praeceptum nostrae corroborationis...

621 DChS 95, 218-219: ... agnoscat industria quoniam praefata nostra conjunx celsitudinem serenitatis nostrae adiens, humiliter deprecata est... 
Prayer services for Charles, her and their children were installed at Saint-Remy, ${ }^{622}$ at Saint-Denis for himself, her and Robert, ${ }^{623}$ at Saint-Germain-des-Prés for Charles and her, ${ }^{624}$ at Saint-Corneille for her ${ }^{625}$ and at Saint-Clement for Charles, her, Bovo and Hagano. ${ }^{626}$ This latter was the last diploma mentioning her or her death, ${ }^{627}$ letting her appear as if she was still among the living and marks the high point and end of this period.

Frederuna's death appears to have left a deep impression on Charles, making us believe that, indeed, a deep connection existed between him and his wife. If this was indeed the case, we can assume that her influence on him was rather large. Yet, in contrast to Adelaide, Frederuna only appears twice connected to important nobles: once just after her marriage in a diploma that probably was meant to show her at the centre of the court and a second time eight years later, with two men who seem to have belonged to the circle of men close to the king. Her appearances are rare and do not signify any new alliances or moments of special political importance-apart from her own wedding. Within the wider network of Charles' political relations, Frederuna, therefore, does not seem to have played a major role. As the first diplomas for her indicate, Charles had certainly intended to make her part of his rule, yet, based on the lack of interventions from her side, we must assume that she did not fulfil that role, possibly because of a lack of interest on her side. ${ }^{628}$

Unlike Frederuna's origins, those of Charles' second wife Eadgifu are well known. She was the daughter of Edward the Elder, king of the Anglo-Saxons. ${ }^{629}$ Due to this connection it has been suggested that, by marrying her, Charles had tried to strengthen his connections to Baldwin of Flanders, who had married Ælfthryd, a daughter of Alfred the Great and aunt to Eadgifu; and their son Arnulf. ${ }^{630}$ While such a connection may indeed have played a role, other concerns probably were of greater importance. Viking incursions had by no means ended with the Treaty of Saint-Clair-sur-Epte and still posed a major threat. In this context, a report from the Anglo-Saxon Chronicle is most interesting: "And that same year [916] Earl Thurcetel went across the sea to France, along with the men

623 DChS 89 (28th May 971). This diploma presents a remarkable case. Being preserved as an original, we can note that the prayer service for Frederuna was added after the diploma's original draft. See also McNair, Development, 88. For a facsimile of the original, see Lot and Lauer, Diplomata Karolinorum VI, N²0.

624 DDChS 92 (14th March 918) and 94 (15th May 918).

625 DChS 90 (26th July 917).

626 DChS 95 (26th May 918).

627 Setting aside DChS 96, which is difficult to date and only mentions her as the founder of SaintClement. See chapter III.2.2, n. 619.

628 On the importance of individual character traits for queens and her power at court, see Erkens, Esther, 17.

629 Nelson, Eadgifu and Hlawitschka, Ahnen II, 292-293. On the Anglo-Saxon position concerning this marriage, see MacLean, Marriage, 30-31.

630 See for example Kalckstein, Geschichte, 145-146 and Settipani, Préhistoire, 325, n. 911. 
who were willing to serve him, with King Edward's peace and support." ${ }^{631}$ While this is the only mention of such an event, it, nevertheless, appears that not only Northmen used England unhindered as a basis for ventures into the West Frankish realm, but also that at least some of them enjoyed the support of the king. Bearing this in mind, Charles' marriage to the daughter of the same king only a few years later ${ }^{632}$ may be seen in a different light. A marriage alliance with Edward tied the king to Charles and would, undoubtedly, put an end to Edward's support for the Northmen heading to the coasts of the West Frankish realm. Therefore, it seems safe enough to assume that the choice of Charles' bride can also be read in the context of his policies to protect the realm from Viking incursions-not the first time was such an alliance concluded, as Charles the Bald had married his daughter Judith to King Æthelwulf of Wessex to strengthen the alliance between the two against the Northmen. ${ }^{633}$

Of Eadgifu's role at court, however, the sources make no mention at all. She appears neither in the narrative accounts, setting back in around 919, nor in Charles' diplomas. In regard to the effort Charles had made to introduce Frederuna to the court and the elites of the realm, the latter is rather surprising. It has been suggested that the king transferred Frederuna's original dowry to her, ${ }^{634}$ yet this seems rather unlikely, given that he had confirmed Frederuna's donations of the same dowry to Saint-Remy and Saint-Corneille only in 917. ${ }^{635}$ That Eadgifu was certainly capable and interested in influencing royal politics has been shown by Simon MacLean, ${ }^{636}$ yet all the evidence we have only accounts for her later years. Any judgement on her importance at Charles' court is a mere assumption and we must therefore refrain from drawing any conclusions.

\section{Kinsmen and marriage alliances}

As we have already seen, we can find a number of Charles' relatives at court. Count Aledramnus, a relative of Charles' father Louis, ${ }^{637}$ was an early supporter; Count Hugh of Maine, Charles' cousin, an important ally against Robert. Others such as Charles' nephew Gauzfrid and his brother-in-law Bovo were installed as bishops. There are also a number of other examples of how Charles furthered the interests of his kinsmen and how he constructed new relations with nobles important to him. The most obvious example is certainly Count Wigeric, who

631 Anglo-Saxon Chronicle, MS A, 916, 66: 7 py ilcan geare for Purcytel eorl ofer sa on Froncland mid pam mannum pe him geloestan woldon mid Eadweardes cynges fripe 7 fultume. Translation by Whitelock, Anglo-Saxon Chronicle, 64.

632 Between 917 and 919 (Nelson, Eadgifu), probably in 918 (Settipani, Préhistoire, 325). The earlier date is given by Frederuna's year of death, the later by the beginning of Flodoard's annals, which does not mention the marriage.

633 Hartmann, Königin, 193.

634 MacLean, Difference, 182-185.

635 DChS 87 concerning Corbeny and Saint-Remy, DChS 91 for Ponthion and Saint-Corneille.

636 MacLean, Difference.

637 See chapter II.1. 
was married to Cunigunde, Reginar Longneck's daughter with Charles' half-sister Ermentrude ${ }^{638}$-Wigeric, therefore, was Charles' nephew. Wigeric's first appearance was in a diploma for the church of Liège, issued at the request of Reginar and Robert as well as another Robert. ${ }^{639}$ In this diploma, the abbey of Hastières, held by Wigeric, was given to the church of Liège. Charles and Reginar, however, made sure that Hastières, as well as another abbey already belonging to the church, were to be held by Wigeric, his wife and their son until the last of them had died. ${ }^{640}$ More importantly, however, Wigeric also became Charles' new count of the palace. ${ }^{641}$ His proximity to the king is also clear from the first assembly held at Herstal in 916, when he was named first of the counts listed as participants in the judgement. ${ }^{642}$ Of Wigeric's further actions, nothing is known. He died before 922, leaving his widow Cunigunde to marry Count Ricuin of Verdun. ${ }^{643}$ His position as count of the palace, however, placed him in direct vicinity to the king which granted him access to the inner circle and established a second connection between Charles and the Reginars.

Wigeric's marriage to Charles' niece points us to the king's own female offspring. As the Genealogica dictata a Carolo Rege tells us, Charles had a number of daughters from his first wife Frederuna as well as from one or more of his concubines, ${ }^{644}$ allowing him to construct marriage alliances with men of his choice. A number of these connections can be traced in the sources, although some of them are rather problematic to assess. In Alberic of Trois-Fontaines' 13th century chronicle, for example, Raoul de Gouy is mentioned to have been married to Louis IV's sister-hence Charles' daughter. ${ }^{645}$ The famous poem Raoul de Cambrai, probably composed a little earlier, during the reign of PhilippeAuguste (1180-1223), ${ }^{646}$ names Alais, sister of King Louis, as his wife. ${ }^{647}$ While the Genealogica does not name an Alais, it does list an Alpais as a natural daughter of Charles $^{648}$ - close enough to make an identification possible. However, since both sources only date roughly 300 years after Charles' death, doubts are allowed. And it seems indeed, as Philippe Grierson has argued, that Raoul was not married to Alpais, but to Eldegarde, the daughter of Count Ermenfrid. ${ }^{649}$

639 DChS 65 (912-913).

640 DChS 65, 148.

641 DChS 84, 189: Widricus comes palatii.

642 DChS 84.

643 On the date and the marriage, see Hlawitschka, Ahnen I, XIII, 2, 200-207.

644 Witger, Genealogia, 303: Karolus rex genuit ex Frederuna regina, Hyrmintrudim, Frederunam, Adelheidim, Gislam, Rotrudim et Hildegardim; ex concubina vero Arnulfum, Drogonem, Roriconem et Alpaidim. Denique vero defuncta Frederuna regina, sibi sotiavit alteram in coniugium reginam nomine Otgivam, ex qua genuit filium eliganti forma Hludovicum nomine.

645 Alberic of Trois-Fontaines, Chronicon, 763.

646 Kay, Raoul de Cambrai, LXXIII.

647 Raoul de Cambrai, 72, v. 946-947; 217, v. 3382-3383 and 310, v. 5022.

648 See chapter III.2.2, n. 644.

649 Grierson, Origine, 101-104. 
Yet, tracing Alpais is not futile. Indeed, it seems that she married another noble close to Charles, Count Erlebald of Castriciensis, ${ }^{650}$ who, in 921, sought the king's help against the church of Reims and who Charles posthumously tried to free from excommunication. Therefore, Erlebald's flight to Charles and the king's efforts on his behalf appear in a different light: Erlebald was his son-in-law, someone particularly close to the king. Also a second marriage of Charles' daughters can be traced. Otto the Great's count of the palace, Gottfrid, was, as Eduard Hlawitschka has shown, married to a certain Ermentrude who, in turn, appears to be identical with Charles' daughter of the same name. ${ }^{651}$ Gottfrid was the son of none other than Count Gerhard, ${ }^{652}$ one of the Matfrid brothers and therefore a member of a leading Lotharingian noble family belonging to the king's most important supporters. Nothing indicates when this marriage took place; however, it seems very likely that it had been arranged by Charles-after his deposition, the Matfrid family would have had nothing to gain from such an alliance. Of Charles' other daughters, only one more can traced in this context: Gisela, of whom Dudo of Saint-Quentin claims that Charles married her to the Viking leader Rollo. However, since this supposed marriage relates more to Charles' policy towards the Northmen, we will return to this problem later on. In any case, we can note that Charles made use of his daughters to construct or reinforce links to a number of nobles important to him. In this respect, Charles' practice differed considerably from that of his great-great-grandfather Charlemagne and Louis the German, who intended their daughters to join convents, yet fell in line with Louis the Pious and most of his descendants. ${ }^{653}$

\section{Close friends}

As we have seen, to some extent Charles' circle was made up of relatives, such as Bovo of Châlons; but more importantly, by nobles of his choice, such as Raoul de Gouy, Stephen of Cambrai and Abbo of Soissons. Within the latter group, we also find, as mentioned, a certain Hagano, who Flodoard introduces to us as "his councillor, whom he had elevated from mediocrity." ${ }^{654}$ Who was this man that the king was not willing to dismiss, even when threatened with the defection of a significant group of nobles? Most often, scholars have taken Flodoard's words as the basis of their interpretations and, in addition, assumed that he was of Lotharingian

650 Werner, Nachkommen, 461. The marriage between Erlebald and Alpais was originally proposed by Vanderkindere, Formation II, 206-207, based on a charter issued by the count naming his wife Alpais and the proximity between the Charles and Erlebald.

651 Hlawitschka, Ahnen I,2, 261 with Hlawitschka, Anfänge, 57-58 and 68-69. For Ermentrude, see chapter III.2.2, n. 644.

652 Hlawitschka, Ahnen I,2, 260.

653 On the various daughters of Carolingian kings and their roles, see Schieffer, Töchter and Hartmann, Königin, 189-195.

654 Flodoard, Annales 920, 2: Pene omnes Franciae comites regem suum, Karolum, apud urbem Suessonicam, quia Haganonem consiliarium suum, quem de mediocribus potentem fecerat, dimittere nolebat, reliquerunt. 
origin. ${ }^{655}$ This hypothesis seems to be based on his first appearance in the sources in 916, when he figures as third among the participants without title, the proceres, in the judgement of Herstal. ${ }^{656}$ Since all the bishops and counts participating in the judicium appear to have been Lotharingian nobles, it seems not too speculative to assume that the same applies for the proceres. This conclusion however, given that almost nothing is known about these men, must be treated with utmost care, even more so as the assembly of 919, also at Herstal, was visited by West Frankish nobles. ${ }^{67}$ Regarding Hagano's "mediocre" origins, the account of Folcuin of SaintBertin may be of help. His Gesta, composed forty years after Charles' deposition, differ slightly from Flodoard in that they describe Hagano as someone "whose lineage and nobility were unknown to the Franks." 658 Two conclusions can be drawn from this account: a) Hagano's origins were not necessarily mediocre but b) they were either unknown to the nobles of the Western realm or they chose to ignore them. In both cases, Hagano appears not to have been a member of the highest echelons of the aristocracy, but someone who had joined the king from the outside. While this does not necessarily mean that Hagano was a Lotharingian noble, it makes it much more likely that, at the very least, he was not from Francia. Concerning Hagano's family, two hypotheses have been developed by scholars. Hagano has long been considered a relative of Charles' wife Frederuna, yet, as we have argued, this appears to be unfounded. ${ }^{659}$ The second hypothesis, however, sees in him a member of the Haganonide family, based in the Middle Rhine in the vicinity of Worms and Mainz ${ }^{660}$ and with connections to the Matfrid family. ${ }^{661}$ It is probably here, in the border region between Lotharingia and the East Frankish realm, where we can find Hagano's origins-by no means mediocre, since his ancestors appear to have served Charlemagne ${ }^{662}$ and Louis the Pious. ${ }^{63}$

655 See, for example, Eckel, Charles, 99; Le Jan, Famille, 60; Depreux, Comte.

656 DChS 84. See Parisot, Royaume, 628-629.

657 See chapter III.2.1.6.

658 Folcuin, Gesta Abbatum S. Bertini Sithiensium, c. 99, 625: Qui confirmatus in regno, quendam Haganum, cuius genus et nobilitas ignorabatur a Francis, super omnes diligendo extulit et hunc familiarius ceteris sibi consiliarium ascivit. Quod videntes Franci, non leviter ignoti hominis amicitias tulerunt.

659 See above.

660 Le Jan, Famille, 59-60 and Depreux, Comte, 390-391. On the Haganonide family in the area, attested since the 7th century, see Gockel, Königshöfe, 296-297.

661 Depreux, Comte, 388-389 discusses this theory based on the Vita Gerardi abbatis Broniensis (c. 1, 656: Pater eius Stantius ex prosapia Haganonis Austrasiorum ducis prosatus, mater autem Plictruidis nuncupata domni Stepheni Tungrorum episcopi soror traditur extitisse germana.). Stephen's relation to the Matfrid Gerhard is confirmed by DLCh 57. See also above. A connection between Hagano and the Matfrid family may also be indicated by an entry in the Liber Memorialis of Remiremont, showing Hagano next to the count of the palace Gottfrid, Bishop Richer of Liège, Matfrid and Ermentrude. Hlawitschka, Anfänge, 72. Liber Memorialis Remiremont, 85 fol. 39r: IIII kal. april. obiit Godefridus comes; XII kal. ... obiit Otlint; X kal. iuli obiit Richerus episcopus; XIIII kal. sept. obiit Matfridus; VIIII kal. ... Haganon anniversarius; Adelardus. Ermentrut, Gerart, Godefrit...

662 Codex Laureshamensis $\mathrm{N}^{\circ} 3,273$.

663 Urkundenbuch Coblenz N 62 70. Metz, Reichsgut, 152-154. 
Hagano's ascent was, as mentioned, marked by his appearance at Herstal in 916, when he featured inconspicuously among the proceres. Eighteen months after the assembly, he makes his second appearance, intervening in a diploma for SaintCorneille ${ }^{664}$ and one year later his third, this time making requests for Frederuna's chaplain Mauger and her foundation of Saint-Clément. ${ }^{665}$ Both diplomas reveal a very special relationship with Charles. The first shows Hagano as the one who is requesting donations and privileges for the souls of the deceased Frederuna as well as Charles' own, ${ }^{666}$ while in the second Hagano is included in the prayer service installed for Charles and Bovo. ${ }^{667}$ Hence, Hagano's ascent takes place in direct connection with some of the most intimate diplomas Charles issued for his deceased queen, which seems to indicate a very private connection between the two, probably developed over the death of his beloved wife. ${ }^{668}$

Flodoard tells us that early in 920-undoubtedly in late January-the Frankish nobles left Charles because he was unwilling to dismiss Hagano. ${ }^{669}$ Given the evidence of the two diplomas, it seems safe to assume that Charles denied their request because of the special bond that had developed between the two-Hagano had become a friend, his intimate, someone he deeply cared for. Richer gives us a very interesting description of the relation between the two: "the same [Hagano] alone served the king while the magnates remained far away, and often in public he took the king's hat from his head and put it on his own." ${ }^{70}$ Richer is, of course, not a reliable source and should not, by any means, be taken literally. Nevertheless, his words seem to capture the relation between the king and his friend, at least as it was seen from the outside. Richer's description of Hagano as the only one having access to Charles while the nobles remained distant is definitely wrong-in 919 alone, Charles issued six diplomas, among them one for Robert of Neustria and another relating to the second assembly at Herstal. ${ }^{671}$ Nevertheless, if Charles and Hagano spent a lot of time together, this might have been perceived negatively, giving rise to rumours among the nobles that someone who they thought of as being an outsider, or at least not belonging to their own networks, had gained an unreasonable amount of influence over the king and the decisions made at court. This image might have been further fuelled by Hagano's promotion. In 916 he was

664 DChS 90, 26th July 917.

665 DChS 95, 26th May 918.

666 DChS 90, 204-205.

667 DChS 95, 219-220. For Frederuna a separate prayer service is established.

668 See also McNair, Development, 87-89.

669 See chapter III.2.2, n. 654. These events are the first Flodoard makes note of in 920. On 20th January 920 Charles issued a diploma at Soissons (DChS 105) - the same city where the nobles assembled and therefore undoubtedly connected to the assembly.

670 Richer, Historiae I, c. 15, 51-52: Nam cum multa benignitate principes coleret, precipua tamen beatitudine Haganonem habebat, quem ex mediocribus potentem effecerat, adeo ut magnatibus quibusque longe absistentibus ipse regio lateri solus hęreret, pilleum etiam a capite regis sepissime sumptum, palam sibi imponeret.

671 DDChS 99, 100, 101, 103, 104 and 75. 
among the proceres, in 917 Charles' diploma depicts him as "our fidelis" and in 918 as "our fidelis and venerable count." ${ }^{\prime 2}$ Hagano might, of course, have inherited the title from someone within his family, yet, given his close relation with Charles, it seems likely that the king granted it to his companion as a sign of his favour.

As Flodoard informs us, seven months after the assembly of Soissons, Archbishop Heriveus was able to mediate a settlement between Charles and the Frankish nobles. ${ }^{673}$ One would expect that the conditions of the settlement involved Hagano in some way and, indeed, the position of Charles' intimate appears significantly changed from that moment onwards. In fact, at the end of Flodoard's putative seven-month period, Charles issued a diploma at Herstal showing the counts Raoul de Gouy and Sigard intervening together with Hagano for the church of Cambrai. ${ }^{674}$ This diploma is only the first in a series, followed by three more in 921, in which Hagano features. The first one, issued for the abbey of Fossés in April, shows him together with Bishop Abbo of Soissons and Abbot Rumald; the second one, in August, with Count Ermenfrid for the abbey of Brogne; the third one as one of the participants in a judgement in favour of the church of Châlons, alongside the counts Helgaud and Raoul de Gouy as well as the bishops Abbo of Soissons and Stephen of Cambrai ${ }^{675}$ Indeed, the first diploma from 920 is also the first one to show the group of nobles drawing their influence from their special relation to Charles acting together, although all of them had previously been in the king's vicinity. Given that this was the first diploma issued after the reconciliation with the nobles from the Western realm and given Hagano's own presence in it, it seems to carry special meaning. Undoubtedly this was a reaction to the reproaches the nobles articulated at Soissons and reflected the settlement negotiated thereafter.

Nothing is actually known about the terms agreed upon between Charles and the nobles, yet they must have included something about the relation between the king and his intimate. Since Flodoard fails to provide us with any details, we have to rely on the evidence of the royal diplomas in which, from September 920 on, Hagano becomes much more visible. Charles, as it would appear, had changed his tactics concerning Hagano. The two of them certainly continued to be extremely close: in 921 Hagano was included in a memorial service for the king, Frederuna and her relatives. ${ }^{676}$ Yet at the same time Charles now let Hagano openly participate in the political decisions taken at court, using those nobles most attached to himself to introduce his intimate into the networks of the Frankish nobility. The outsider was meant to become an accepted member of the circle at court, his relation with

672 DChS 90 (26th July 917), 205 (...fideli nostro Haganone...) and DChS 95 (26th May 918), 219 (... fidele nostro ac venerabili comite Aganone...).

673 Flodoard, Annales 920, 2.

674 DChS 106 (8th September 920).

675 DDChS 108 (22nd April 921, for Saint-Maur of Fossés), 127 (27th August 921, for the abbey of Brogne) and 112 (20th September 921, judicium for the church of Châlons). 
the king publicly displayed to end any possible rumours. The next step would have been to widen this circle, and indeed Hagano features among Charles' supporters in the treaty of Bonn. ${ }^{677}$ This was not an unreasonable strategy: Hagano was not the first friend Charles had introduced to the highest circles. ${ }^{678}$ In 898 , Charles issued a diploma for a certain Theodosius, granting him property in Septimania. ${ }^{679}$ This diploma was requested by a fidelis called Robert. This same Robert also appears in a number of other diplomas: in 904, he intervened in royal charter in favour of Bishop Mancio and the church of Châlons, this time depicted as "our fidelis and highly beloved"; ${ }^{680}$ in 907, he is mentioned in the diploma introducing Frederuna to the court, together with members of Charles' family and some of the highest ranking nobles of the realm, among them Robert of Neustria, Count Erkanger and Bishop Anskeric of Paris, again described as "our beloved"; 681 a diploma issued around 912 shows him as "our beloved" intervening together with two of the most important nobles, Robert of Neustria and Reginar Longneck, on behalf of the church of Liège; ${ }^{682}$ in 915, finally, he appears in a diploma together with Richard the Justiciar, alongside whom he intervened on behalf of the abbey of Tournus. ${ }^{683}$ Nothing more is known about him ${ }^{684}$ but the diplomas, nonetheless, give us the impression of a remarkable man. Carrying no title, yet nevertheless being depicted as "our beloved" (dilectus nobis), he seems to have been close to Charles, a conclusion that is further strengthened by his interventions on behalf of others. At the same time, his position seems to have been accepted by the leading nobles of the realm, most notably of course Robert of Neustria. This Robert was not alone however: in 915, we find another "beloved" fidelis called Etbert in Charles' vicinity, intervening together with Raoul de Gouy on behalf of Frederuna, granting her property to found a chapel in honour of SaintClément at Compiègne. ${ }^{65}$ Like Robert, Etbert seems to have been close to Charles, and like the former, he was accepted by leading members of the court.

Thus, the West Frankish nobility was not generally opposed to Charles' having intimates and to them participating in political affairs at court. What they seem to have opposed, however, was the special relation Charles and Hagano had developed during the years after Frederuna's death. Charles' solution to this problem seems to

677 MGH Const. I, N $1,1-2$.

678 On the king's right to choose his advisors even from lower ranks, see Le Jan, Élites, 418-419 and Le Jan, Introduction, 12-13.

679 DChS 13 (24th June 898).

680 DChS 48 (17th March 904), 106: ... Rotbertus videlicet noster fidelis nobisque admodum dilectus...

681 DChS 57 (21st May 907), 124: ...Rotberti nobis dilecti...

682 DChS 65 (912-913), 148: ... Rotbertus nobis dilectus...

683 DChS 82 (10th October 915). Lauer identified this Robert as Robert of Neustria. However, while the magnate is otherwise always described with one or several of the titles comes, marchio or abbas as well as epithets like dilectus or venerabilis, this Robert is only depicted as fidelis nostri, concording with the aforementioned diplomas.

684 Already Lauer, Recueil Charles III, 123, n. 8 doubted the identification as Count Robert of Troyes. Indeed, the count had already died in 886 and was succeeded by Aleaume (Crété-Protin, Église, 304-306).

685 DChS 80 (7th July 915), 179: ... fideles nostri, videlicet Etbertus noster dilectus atque Rodulfus comes... 
have been the introduction of Hagano into the higher circles of the nobility and the public display of his new role at court. If Hagano was to be accepted by the other nobles, he had to have a position similar to their own. This, however, also meant that Hagano needed to be provided with honores according to his new position within the hierarchy of the nobility. In fact, Flodoard's account contains a number of references that indicate that by 922 Hagano had large resources at his disposal; he could muster a personal retinue strong enough to undertake military operations and had been able to assemble a treasury. ${ }^{686}$ Finally, Charles wanted to give Hagano his own lay abbacy. The king's choice fell on the abbey of Chelles, held by his aunt Rothild. If, however, he had expected to encounter less resistance because of their kinship, he was soon proven wrong. Rothild's daughter was married to Robert of Neustria's son, Hugh the Great, who now intervened. ${ }^{687}$ The conflict soon developed into the rebellion of the West Frankish nobles, leading to the coronation of Robert of Neustria.

\section{III.2.3 The role of the marchiones}

Three men within the Western realm are generally qualified as marchiones: Robert of Neustria, Richard the Justiciar and William the Pious. ${ }^{68}$ The three of them distinguished themselves from the other nobles by concentrating a large number of honores, including important abbeys, in their hands; by installing viscounts within the regions they controlled; and by close cooperation with bishops and abbots within their vicinity. ${ }^{689}$ There certainly were distinctive differences in how these men had come to power, Robert with royal consent taking control of a conglomerate of honores already long in existence, Richard extending his influence by means of violence at a time when royal attention was focused elsewhere; yet the result was rather similar. Karl Ferdinand Werner probably went too far when describing the marchiones as direct deputies of the king, wielding viceroyal power within their regions ${ }^{690}$ and therefore attributing the system a degree of institutionalisation that negates the differences between the different regional hegemonies. ${ }^{61}$ Nevertheless, his approach seems to point in the right direction.

As we have seen above, in Burgundy, Richard had established himself as intermediary, controlling the direct contacts between the local nobility and the king, a position that seems comparable with those of the other marchiones. Such an accumulation of power was nothing new. ${ }^{692}$ As mentioned, the conglomeration

686 See chapter VI.4.

687 Flodoard, Annales 922, 8.

688 On the meaning of the marchio-title, see Stieldorf, Marken, esp. 213-215 for the Western realm under Charles the Simple.

689 For William, see Lauranson-Rosaz, Roi, 426-428.

690 Werner, Westfranken, 738-739 and Werner, Ursprünge, 467-470.

691 Bur, Remarques.

692 Bur, Remarques. 
of honores in Robert's hand, for example, had developed over quite a long time and passed from one magnate to the other. Charles the Fat had built his rule on the cooperation of these magnates, using them as conduits to transmit the royal will into the regions controlled by, for example, Odo and Bernard of Auvergne. ${ }^{693}$ Charles, as we have seen, built his early reign mainly on his old allies, Archbishop Fulk of Reims, Bishop Anskeric of Paris and Count Heribert I of Vermandois. Richard the Justiciar and William the Pious, who had followed their own course during the struggle between Charles and Odo, remained distant at first, waiting to see how Robert of Neustria would act. Only after the latter had paid his allegiance to Charles, did the former two follow.

\section{William the Pious}

A private charter issued by William just before this moment in May 898 has been preserved that is most enlightening about his attitude towards the king. ${ }^{694}$ The charter dates "the year in which Odo, king of the Francs and Aquitanians, died"695 - meaning that five months after Odo's death and Charles' coronation at Reims, William was not yet willing to accept the latter as his new overlord. His attitude towards the new king and his own self-perception becomes even clearer when analysing the charter's legal content. William donated property to the abbey of Brioude, although when it came to the clauses protecting his grant, he made an interesting addition: neither man, nor king, nor count, nor abbot, nor canon or any other person was allowed to estrange the property ${ }^{696}$ While such clauses were common, the addition of the king certainly was not ${ }^{697}$ and betrays the marchio's exceptional self-confidence at that moment. Soon after, William paid his allegiance to Charles and, in 899, he was the first magnate to appear in one of the king's diplomas. Present at the important assembly of Tours-sur-Marne, he served as ambasciator in a diploma Charles issued at the request of William's friend Gerald of Aurillac. ${ }^{698}$ William's support for the king on such an occasion appears to have come at a price. An ambasciator was someone who investigated the justness of a plea to the king, serving at the same time as intermediary on behalf of the petitioner in front of the king. ${ }^{699}$ Hence, like Richard in Burgundy, William acted as

693 MacLean, Kingship.

694 Cartulaire Brioude, $\mathrm{N}^{\circ} 309,313-315$.

695 Cartulaire Brioude, $\mathrm{N}^{\circ} 309,315$ : ... anno quo mortuus est Odo rex Francorum vel Aquitanorum.

696 Cartulaire Brioude, $\mathrm{N}^{\circ}$ 309, 314-315: Nullusque hominum, neque rex, neque comes, neque abbas, neque canonici aut aliqua persona vendendi, concambiandi aut quolibet modo ab ipsa casa alienandi potestatem habeant.

697 A similar phrasing was applied in the foundation charter for Cluny. Recueil Cluny $1, \mathrm{~N}^{\circ} 112$, 124-128 (11th September 910): Placuit etiam huic testamento inseri ut ab hac die nec nostro, nec parentum nostrorum, nec fastibus regie magnitudinis, nec cujuslibet terrene potestatis jugo subiciantur idem monachi ibi congregati; neque aliquis principum secularium, non comes quisquam, nec episcopus quilibet, non pontifex supradicte sedis Romanae...

698 DChS 21. See above, 10-11.

699 Depreux, Bitte, 84-85. 
a layer between the local nobility and Charles, who seems to have acknowledged William's position south of the Loire. Furthermore, a private charter issued by his sister Ava in 901 was signed by William as "princeps and count of the palace," 700 a title that is repeated in 905 in one of his own charters. ${ }^{701}$ Charles had made William his new count of the palace, succeeding or replacing Count Elduin, who had held this office previously. William appears too few times in royal diplomas to conclude that he was in fact an important figure in the palace itself. ${ }^{702}$ The title therefore has another meaning, indicating his proximity to the king and his importance within the hierarchy of the nobles.

The relations between William and the king appear to have faltered around 908. As with Richard, Charles seems to have intervened within William's sphere of influence south of the Loire. The marking point is a diploma the king issued on 5th June 909 for Abbot Regembald of Psalmody. ${ }^{703}$ Next to the abbot, Count Raymond of Nîmes and Albi, an important noble from the South, can also be found in the diploma, he is depicted as "illustrious count and our beloved fidelis"704, a very rare combination of epithets and titles that emphasises his importance for Charles. The Vita Geraldi tells us that Raymond took the nephew of William's friend Gerald prisoner $^{705}$ while his son took the Gothic March from William's successor, two incidents that indicate the rivalry between the two. ${ }^{706}$ From the moment Charles' diploma was issued, there is a shift in the tone of William's private charters. The foundation charter of Cluny, dating to 11th September 910, repeats the exemption of the king from intervening in the abbey's affairs. ${ }^{707}$ Equally important, William now started referring to Odo in his charters, indicating that his grants were made for the wellbeing of his senior, King Odo, ${ }^{708}$ while Charles never received such attention. These mentions of Odo may further indicate that William now was leaning more towards Odo's brother, Robert of Neustria, with whom he had already appeared in a royal diploma in 905, restoring property in the Limousin to Robert's abbey of Saint-Denis. ${ }^{709}$ Similarly, a certain shift also seems to have taken place in favour of Richard the Justiciar. William's private charter from November 916

700 Recueil Cluny I, No 74, 83-84 (29th November 901), 84: princeps et comes palatio.

701 Recueil Cluny I, N 89bis, 833-834 (October 905), 833: Ego Vuilelmus, comes, conspalacius et marchio... The charter is preserved in original (Paris, BNF ms. lat. 11829 n. 2b).

702 Apart from DChS 21 William appears only once more in the royal diplomas, in 905 (DChS 50). DChS 102 is a forgery and would, in any case, not have mentioned William the Pious but his nephew William the Younger.

703 DChS 61.

704 DChS 61, 135: ... illustris comitis ac dilecti fidelis nostri Raimundi...

705 Vita Sancti Geraldi Auriliacensis II, c. 28-29, 232-234.

706 Dunbabin, France, 60; Caille, Vicomtes, 50-51.

707 Recueil Cluny, N 112, 124-128. See chapter III.2.3, n. 697.

708 Recueil Cluny, $\mathrm{N}^{\circ} 112,125$ : ... inde pro anima senioris mei Odonis regis... Similar in charters from May 912 (Acta Sanctorum Benedicti IV, 2, 254) ...pro remdedio animae meae, ... senioris quoque quondam mei Odonis... and from November 916 (Cartulaire Sauxillanges, $\mathrm{N}^{\circ} 126,135-137$, here 135): ... pro remedio anime ... et senioris mei Oddonis... 
seems to have been issued during a large regional assembly, including his nephew William the Younger, two bishops, three abbots, two counts and signing even before the bishops, a certain Boso, who may well be identical with Richard's son. ${ }^{710}$ However, after William's death on 6th July $918,{ }^{711}$ Richard' son Raoul and Robert of Neustria seem to have joined forces to take Berry from William's successor, his nephew William. This enmity seems to have lasted until 924, when William the Younger payed his homage to Raoul, by now the king, in return for having Berry restored; ${ }^{712}$ which at the same time indicates that he did not support Robert and Raoul in the rebellion against Charles.

\section{Richard the Justiciar}

After Richard was replaced by Robert at court in 903, he disappears from the sources for several years. Early in 907, a solution seems to have been found that allowed Richard to return to court. In a diploma issued for the provost of the church of Langres, Otbert, Richard intervened alongside the bishop of the church, Argrim, and his own ally, Manasses. ${ }^{713}$ The importance Charles attributed to Richard's return to court is marked not only by the place the diploma was issuedCompiègne-but also by the date, the 4th April 907 being an Easter Saturday. Hence, the king and the magnate celebrated Easter together in Charles' most important palace. About a year later, Richard again requested a diploma, this time marking the restoration of property to the abbey of Saint-Martin of Autun. ${ }^{714}$ While Richard himself only appears in Charles' diplomas once more-in 915 he visited the king at Gondreville in Lotharingia, supporting the abbot of Saint-Philibert of Tournus alongside the fidelis Robert ${ }^{715}$ — contact with Charles was also had by his sons. In 914, Hugh received property from the king ${ }^{716}$ while Boso accompanied Charles in 921 at Bonn. ${ }^{717}$ The fact that his sons did indeed represent him becomes clear from Richard's private charters. A judgement held in 916 shows Richard in the presence of his three sons, Raoul, Hugh and Boso. The charter making note of the judgement is signed by Raoul, who did so at his father's order and as his deputy, ${ }^{718}$ a procedure that was repeated two years later, ${ }^{719}$ while another charter issued by Richard shows

710 Cartulaire Sauxillanges, $N^{\circ} 126,135-137$. The charter's witnesses read: Ingilberge, Willelmi, Acfredi, Bosoni, Ermoldi episcopi, Hildeberti episcopi, Attonis abbatis, Sigualdi abbatis, Abboni abbatis [...] Rogerii comitis, Utberti vicecomitis...

711 Lauranson-Rosaz, Auvergne, 60.

712 Robbie, Emergence, 86. Flodoard, Annales 924, 19-20.

713 DChS 55 (4th April 907).

714 DChS 59 (8th August 908).

715 DChS 82 (10th October 915).

716 DChS 79 (21st June 914).

717 MGH Const. I, N $1,1-2$.

718 Recueil Robert et Raoul, $\mathrm{N}^{\circ}$ 50, 203: Signum Rodulphi comitis, filii praedicti principis, qui per jussionem praenominati patris sui in conspectu illius et ejus vice firmavit et manu propria signavit.

719 Recueil Robert et Raoul, N 51 (after 1st September 918), 207: Signum Rodulfi, illustris comitis qui per jussionem prenominati patris sui in conspectu illius sua et ejus vice firmavit et manu propria subscripsit. 
all of his sons among the witnesses. ${ }^{720}$ Thus, Richard did his best to integrate his sons into his rule and establish Raoul as his successor in Burgundy.

Richard's importance at Charles' court after his return in 907 is hard to estimate. The effort Charles made with his first diploma in 907 certainly indicates that Richard was still considered to be a key figure within the realm. The newly won cooperation must have involved Charles' acknowledgement of Richard's control over Burgundy and its nobles. The Burgundian elites still held contact with the king: as we have seen, Bishop Argrim of Langres and Abbot Wicheramnus of Saint-Philibert sought out Charles, and the Gesta Pontificum Autissiodorensium mentions that Bishop Geran was on his way to the king in December of 914, when he died at Soissons. ${ }^{721}$ However, in all of these cases, Richard appears to have played a key role. While the Argrim and Wicheramnus were accompanied to Charles by the marchio, Geran seems to have acted with Richard's consent. Thus, all three cases demonstrate Richard's influence over contacts between the local elites and the king. This was probably also his role at court. As with William south of the Loire, Richard acted as mediator between Charles and the Burgundian nobility. While certainly not as influential as Robert, he remained a key figure in the affairs of the realm and was, at times, represented at court by his sons. Whether the, extremely pro-Ricardian, account of the Chronicon S. Benigni Divionensis is accurate in its judgement that Richard had always been loyal to Charles ${ }^{722}$ must remain unclear, yet it may be worth considering that the final rebellion against Charles only occurred after Richard's death and with the aid of his son Raoul, while in 920, during his lifetime, it had still been possible to find an agreement.

Richard's return to court, however, is unlikely to have happened against Robert's will. In fact, during the following years, an increasing level of cooperation between the two can be traced. The first sign of this is their joint campaign against the Northmen leading to the battle of Chartres in 911. From this campaign, a letter is preserved which was copied during the 11th century into a 9th century manuscript: "Count Robert and dux Manasses greet Count Richard. Know that we set off against the Northmen, but not having found them we are returning to Paris sending this to you and enquire whether you will come to us or not."723 We will deal with the campaign itself in our next chapter, for now however, it is important to note that Manasses, Richard's ally whose offensive words had been the final reason for Robert leaving the court in 900, was now working together with that same Robert, undoubtedly on behalf of Richard. This cooperation was seemingly strengthened over the course of the following years. Richard's aforementioned

720 Roserot, Chartes, $\mathrm{N}^{\circ} 13$ (18th May 918), 185.

721 Gesta Pontificum Autissiodorensium I, 199-201.

722 Chronicon S. Benigni Divionensis, 123: Et hoc post mortem Richardi Ducis, qui ab exequutione iustitie cognomen accepit. Ipse namque quamdiu vixit, Carolo regi semper fidelis exstitit.

723 Bibl. commun. Chartres, ms. 92, fol. 38v (printed in Catalogue Chartres, 48): Rotbertus comes et dux Manassae Richardo comiti salutem. Scitote quoniam fuimus perrecti contra Normannos, sed non invenientes regressi sumus Parisius mittentes ad vos et requirimus utrum vos necne venieris ad nos. 
private charter dating to 918 was issued "for the absolution of our lord, the glorious king Odo, and his most noble brother Robert, the illustrious marchio" and "for the peace of our lord Richard, most pious duke, and his most noble wife and their most famous sons." ${ }^{24}$ While the list of people for whose souls the charter had been issued also contains Charles the Bald and his wife Ermentrude, no mention is made of Charles the Simple, not even in the dating. The charter becomes even more interesting when taking into consideration the fact that the restoration of the villa of Tillenay to the church of Autun confirmed by the charter actually also confirmed the terms of a preceding royal diploma, issued by Odo for Bishop Adalgarius in $893 .^{725}$ The 918 charter was the sign of an alliance concluded at this moment, constructing a link via Odo's diploma and indicating their friendship by commemorating their families. ${ }^{726}$ The charter was not the only sign of the new alliance however. Probably around the same time, Richard's son Raoul married Robert's daughter Emma, ${ }^{727}$ strengthening their bond through matrimony. This new alliance was not necessarily aimed against the king: already before 922, Raoul and Robert joined their forces against William the Younger, taking Bourges and the Berry from William the Pious' successor. ${ }^{728}$

\section{Robert of Neustria}

While William and Richard were both very important men for Charles' rule, Robert remained the leading man, whose proximity was apparently sought by both. His central role within the realm is undisputed, but his relations with Charles have recently been reassessed by Geoffrey Koziol. Most commonly, scholars have assumed that, after the initial problems had been solved, Robert and the king cooperated up until around 919, when there was a sudden breakdown in their relations leading to the assembly of Soissons. ${ }^{729}$ However, as Koziol rightfully points out, the absence of news about tensions and conflicts between the king and the marchio between 900 and 919 is not necessarily a sign of Charles' and Robert's good relations, but simply due to the lack of narrative sources for this period. In opposition to the older research, Koziol argues instead in favour of constant tensions because of differing political views concerning kingship and the relations with the Northmen, meaning that there was a direct path leading from the early

724 Recueil Robert et Raoul, N 51 (after 1st September 918), 205: ...sed et pro absolutione domni Odonis gloriosi regis et nobilissimi fratris illius domni Rothberti illustris marchionis... et quiete domni Richardi piissimi ducis et nobilissime conjugis illius ac clarissimorum filiorum illorum et omnium fidelium suorum...

725 DOdo 35. On this diploma and the forgeries produced by Bishop Adalgar of Autun, see Koziol, Politics, 358-361.

726 On the role of prayer requirements in the formation of alliances between nobles, see Althoff, Amicitiae and Ludwig, Krise.

727 Settipani, Préhistoire, 389 with n. 189 and 408. The date of the marriage is unknown.

728 Flodoard, Annales 924, 20.

729 For example Werner, Origines, 493-515 and Sassier, Hugues, chapter 2. 
conflict between Charles and Robert to the later rebellion. ${ }^{730}$ While we will deal with Charles' politics towards the Northmen in the next chapter, at this point it seems necessary to discuss Koziol's arguments concerning Charles' vision of kingship.

Koziol's first argument revolves around Charles' policies towards lay abbacies. Based on Charles' diplomas, he reconstructs a political programme of the king aimed at containing the abuse of power by the lay abbots against their convents and at the protection of the mensae of the abbeys by means of royal control over transactions, with royal diplomas serving as guarantees; hence royal control over the dealings between lay abbots and the monks. ${ }^{731}$ Indeed, as Koziol convincingly shows, it was not uncommon for Charles' diplomas to contain such clauses. The question is, however, whether these measures were directed against the magnates holding these abbeys and whether Charles was indeed as opposed to lay abbacies as Koziol claims. The best way to address this issue is, undoubtedly, to analyse Robert's politics towards his own abbacies. A number of his private charters for Saint-Martin of Tours can help us to shed some light on this issue. In 892, Robert, faced with the resistance of the canons, who threatened to bring the case before the king, returned property to them that his vassal Patericus has usurped. ${ }^{732} \mathrm{~A}$ similar case occurred in 899, when Robert restored a cella to the abbey's hospice, which his brother Odo had given to one of his fideles without having consulted the chapter ${ }^{733}$ - a measure he confirmed again one year later. ${ }^{734}$ Robert, as we can see, was willing to correct former misdealings even if they had been done by himself or his brother and even if this meant giving up some power. Similarly, Robert appears not to have opposed royal interventions in the dealings between abbot and monks. The first example are of course the diplomas and charters concerning Saint-Amand in $906,{ }^{735}$ in which Charles confirmed an exchange between Robert and the monks of the same abbey, an exchange that is laid down more precisely in two private charters issued shortly afterwards, both of them mentioning Charles' approval. ${ }^{736}$ There is also another document showing that Robert was not opposed to royal intervention and was even willing to use the king as guarantor. In 912, he issued a charter for Marmoutier confirming that the abbey was independent from the archbishop of Tours who had tried to bring some of its property under his control and furthermore promising to obtain a royal diploma addressing this problem. ${ }^{737}$ Thus, Robert was neither opposed to restoring property he or his supporters held nor to the king acting as a guarantor if necessary. In this light, it

730 Koziol, Charles, esp. 364-370 and Koziol, Politics, 415-444.

731 Koziol, Politics, 505-511, here esp. 507-508.

732 Recueil Robert et Raoul, $N^{\circ} 37,139-141$. On Robert's favourable politics towards his abbeys along the Loire, especially Saint-Martin of Tours, see Noizet, Ascension, 23-26.

733 Recueil Robert et Raoul, $N^{\circ} 41,155-157$.

734 Recueil Robert et Raoul, $\mathrm{N}^{\circ} 42,157-165$.

735 DChS 54 (7th September 906).

736 Recueil Robert et Raoul, $\mathrm{N}^{\circ} 46,178-181$ and $\mathrm{N}^{\circ} 1,208-210$.

737 Recueil Robert et Raoul, $\mathrm{N}^{\circ} 47,181-186$. On this charter, see also Guyotjeannin, Notice 680-686. 
seems rather questionable whether Charles' and Robert's opinions concerning the management of abbacies really differed fundamentally from each other. Similarly, if Robert really had resented Charles' politics towards the abbeys he held, why would he have consented to the king issuing diplomas expressing these same politics for these very same abbeys?

This brings us to the second issue Koziol identifies as a cause for tensions between the king and the magnate: the right of nobles to participate in ruling the realm. According to him, Robert derived his right to counsel the king from his rank within the hierarchy of the society while for Charles "counsel and consensus were elements in the display of royal majesty," also meaning that the king was at complete liberty to choose his councillors. ${ }^{738}$ Koziol is right to point out that Charles' diplomas convey a very distinctive image of royal majesty, describing even the highest magnates petitioning the king on their knees. ${ }^{739}$ However, at the same time, these very same diplomas also make numerous references to Charles, the king, listening to his advisors ${ }^{740}$ and even though there are others emphasising Charles' majesty, ${ }^{71}$ they, nevertheless, seem to reflect the political reality. As we have seen, those surrounding the king were most often the most powerful men of the realm, old allies and new key figures. Despite all the emphasis on his royal majesty, Charles was very well aware of the political necessities and did his best to include the magnates into his rule. Thus, in 900, we find Robert, Richard and Heribert I at his side, planning a campaign against the Northmen ${ }^{742}$ thus we also find Charles referring to the judgement of the nobles on various occasions $s^{743}$ and surrounded by them when treating with Henry the Fowler at Bonn in $921 .{ }^{744}$ The only time Charles can be seen to contravene this policy was with Hagano, with whom he enjoyed a very close and personal relation. Koziol is certainly right to point out the strain Hagano's position placed on the relations with the nobles. However, as we have argued, Charles reacted to his in a way that acknowledged the nobles' concerns, trying to remove its cause by establishing Hagano within the West Frankish hierarchy. In any case, Hagano was a very special-and isolatedcase that should not overshadow the other evidence provided by the sources.

738 Koziol, Politics, 513.

739 Koziol, Politics, 513, refering to DChS 65, 147-148 (comes Reynerus et demarcus et Rotbertus comes et demarcus ... pronis flagitaverunt genibus).

740 For example DDChS 10, 16 (Quorum congrue petitioni..., aurem clementiae nostrae accomodantes, cum fidelium nostrorum consensu...), 49, 108 (Cujus humillimam peitionem cum consilio regni nostri utriusque ordinis principum mentaliter considerantes...), 53, 115 (... a nostris, tam episcopus quam et laicis, fidelibus responsa accepimus...), 56, 121-122 (Si regum consuetudines antiquorum exequimur necnon patrum mores praecedentium imitamur fideliumque nostrorum benigne consulta suscipimus...), 88, 199 (...consultu fidelium procerum nostrorum, decrevimus...).

741 Koziol, Politics, 514.

742 Annales Vedastini 900, 82.

743 DDChS 84, 89, 100 and 112.

744 MGH Const. I, Nº 1, 1-2. 
Hence, Charles' and Robert's convictions concerning kingship appear not to have differed as much as Koziol claims. As we have argued, the early tensions between the king and the marchio seem to have stemmed from Robert who was aspiring a position at court equal to his standing in the hierarchy of the nobles of the realm. Charles, at first, blocked these aspirations, but not because he insisted on his right to choose those surrounding him, but because the position was already occupied by Archbishop Fulk of Reims. The arising conflict when the vacancy following the latter's murder was not filled by Robert but by Richard, did create a rift throughout the reign. As we have seen, Charles created a network of alliances to contain the marchio. Robert's own reaction to the rising tensions is documented by a private charter issued at Tours in September $900 .{ }^{745}$ Within the witness list, we find a large number of nobles from the region, Archbishop Erbernus of Tours, the bishops Raino of Angers, Fulcher of Nantes and Berno of Orléans, a certain abbot Aimo and, finally, the four viscounts Hatto, Guarnegaud, Fulk and Rainald. The charter was meant as a demonstration of Robert's power, to be conveyed by the king's new archchancellor, Bishop Anskeric of Paris, who signed the charter at the marchio's invitation. ${ }^{746}$ Anskeric's presence, however, also indicates that from the beginning both sides remained in contact with each other, probably trying to negotiate a settlement, and hence that both sides were interested in finding a solution. For the time being, such an accord appears to have been out of reach. Richard's position at court, undoubtedly, was one of the reasons why Robert could not yet be integrated into Charles' rule and, as we have argued, it is also likely that Charles' mother, Adelaide, was opposed to making concessions. By 903, however, after Adelaide's death and the breakdown in relations between Charles and Richard, Robert not only returned to court but also, from now on, was seemingly acknowledged as the leading noble of the realm. ${ }^{77}$

From this moment on, up until Flodoard's account begins, and possibly even after, the sources at our disposal do indicate a general cooperation between the

745 Recueil Robert et Raoul, $\mathrm{N}^{\circ}$ 42, 157-165 (13th September 900, Tours).

746 Recueil Robert et Raoul, $\mathrm{N}^{\circ}$ 42, 164: Askericus, Parisiorum episcopus, hanc auctoritatem, rogante ipso Rotberto comite, firmavi. Next in the list is Bishop Otger of Amiens, who signed the list as episcophilax. Since it is not clear whether he belonged to Robert or was part of Anskeric's embassy, I have refrained from mentioning him here. See also chapter III.2.1.2.

747 The process of his final integration into Charles' rule was probably furthered by Robert's marriage to Beatrix, daughter of Heribert I of Vermandois (on the marriage see Werner, Nachkommen, 458). Unfortunately, the date of the marriage is unknown. Settipani, Préhistoire, 407-408. According to him, Werner argued for 897 as the date since during this year a) Heribert I reconciliated with Robert's brother Odo, b) Robert received the abbey of Morienval in the Vermandois, c) Robert and Beatrix' son, Hugh the Great, was already married in 914 since during this year his brother-in-law Hugh of Maine figured in one of Robert's private charters. However, a) the reconciliation between Odo and Heribert does not necessitate a marriage, $\mathrm{b}$ ) nothing indicates that Morienval passed into Robert's hands in 897 (see below) and, c) Hugh of Maine's presence in Robert's charter does not necessitate that the marriage between his sister and Robert's son had already taken place. It seems to me that any date other date would equally be possible-for example before 893, when Odo furthered Heribert's interests, and likewise around 898 or even only in 903, when Robert and Charles (and hence Heribert), were on good terms. 
king and the marchio. The most interesting evidence for this is, without a doubt, one of Robert's private charters, informing us that the marchio had been absent from Tours for two years because he had been charged by the king with the management of various affairs in the regna of Francia and Neustria. ${ }^{78}$ This corresponds well with an expression used in one of Charles' own diplomas, issued in 915 and depicting Robert as "our Highness' most loyal executor." ${ }^{749}$ Hence, Robert's private charter reflects not only the marchio's view of how he participated in the management of the realm, but also the king's, thus indicating that they indeed mirrored the actual state of affairs.

If we follow the charter dating to 11th November 912, Robert's absence from Tours covered most of the years 911 and 912 , that is to say the time of the campaign against the Northmen leading to the battle of Chartres and Charles' initial voyage to Lotharingia. Concerning the campaign against the Northmen, hardly anything is known at all apart from the battle and the aforementioned letter sent by Robert and Manasses to Richard. ${ }^{750}$ So far, nothing in the sources allowed us to determine the role the king played in this campaign. Robert's charter, however, when read in relation with these events, indicates that Robert and Richard had acted on the king's behalf, instructed by him to protect the realm from the Viking incursion. It is interesting to note that this command falls into a period which is marked by a long absence of diplomas issued for Robert. After the initial period with a high density of diplomas for the marchio, from September $906^{751}$ up until August 911, Robert is only mentioned once in the royal diplomas, namely in 907 , when he appears together with other important nobles for the realm in the charter introducing Frederuna to the highest nobility. ${ }^{752}$ The new diploma, issued 3rd August 911 at Compiègne for Saint-Denis, ${ }^{753}$ only two weeks after the battle of Chartres, ${ }^{754}$ undoubtedly marked the reception of the victorious marchio by the king. Read in the context of Robert's charter, the relations between the two appear to have been strong when no charters were issued.

The high degree of trust between the two is also revealed by the second period of Robert's absence from Neustria marked by his charter, Charles' voyage to Lotharingia. Two royal diplomas mention Robert shortly after the acquisition of

748 Recueil Robert et Raoul, N 47, 181-186 at 184: Domnus Rotbertus [...] gloriosus abbas necnon et comes, propter diversa regnorum Francię atque Neustrię negotia, quibus a rege prepositus erat, ab urbe Turonica fere per biennium defuisset... On this charter, see also Guyotjeannin, Notice and Guillot, Formes, 83, n. 101.

749 DChS 81, 181: ... Rotbertus, nostre serenitatis exequtor fidelissimus...

750 See chapter III.2.3, n. 723.

751 DChS 54 (7th September 906, for Saint-Amand)

752 DChS 57 (21st May 907).

753 DChS 66.

754 20th July 911. Eckel, Charles, 70. 
the new regnum. ${ }^{755}$ Both were probably issued after April $912^{756}$ which, in connection with Robert's charter making no mention of Lotharingia, seems to indicate that Robert only joined the king later on, possibly as late as 913. Hence, Charles, while he himself was absent, charged Robert with the management of affairs in the region that had so far been his most important basis of support. This choice is much less surprising when taking in consideration that Robert had already built up connections within Francia. Charles himself may have installed the marchio as abbot of Saint-Amand in 906, when he issued a diploma for the abbey at Robert's request. ${ }^{757}$ On this occasion, Robert also issued a private charter for the monks, ${ }^{758}$ containing a rather large witness list featuring the new bishop of Noyon, Robert, and five counts, Almanus, Odilard, Hilmeradus, Richer and Erlebald. At least two of them, Odilard and Erlebald, appear to have had close connections to Charles, ${ }^{759}$ the others being unknown. Their relations to the king points towards them acting as witnesses on Charles' behalf, meant to guarantee Robert's concessions to the monks. However, at the same time, the charter also demonstrates that Robert now entered into relations with nobles outside Neustria, allowing him to build up a network of connections within Francia, a network he could use on Charles' behalf to mediate the royal will and carry out the tasks he had been charged with by the king.

The absence of diplomas issued for Robert from 907 to 910 contrasts with the situation after Charles' acquisition of Lotharingia. From 912 until 919, the marchio received seven diplomas for his abbeys and intervened in another three for the

756 Neither of the diplomas carries a dating line. The intitulatio used in both diplomas calls Charles rex Francorum yet already drops the vir illustris which is last used in DChS 72 (12th April 912).

757 DChS 54. Saint-Amand is last recorded to be held by Gauzlin. Koziol, Politics, 502, n. 173 proposes that after him the abbey passed to Abbot Rodulf of Saint-Vaast and Saint-Bertin, arguing against Platelle, Temporel, 61-62, who discarts the arguments in Rodulf's favour. In any case, the first mention of Robert being its abbot is DChS 54, while DChS 18, dating to 899 makes no mention of an abbot and sees Archbishop Fulk acting on behalf of the monks. Koziol proposes that the phrasing of the latter diploma, the monks complaining about their former lay abbots (30: Unde, propter suspectas succedentium rectorum vel aliorum malorum hominum voluntates, prefati monachi per eundem venerabilem archiepiscopum dovete nostram postulaverunt... We should note that the diploma also protects the monks from its abbots, a singular phrasing, 33: nec quelibet humana potestas sine sui periculo discriminis possit eas in alias partes convertere vel detorquere, et ut neque ipsius loci abbas, neque aliquis judex publicus in ecclesias aut loca... juste et legaliter possident) was indeed directed against Robert since it mentions a donation made by Rodulf. This is of course possible, but necessitates rather strong tensions between Charles and Robert at that point, which seems rather unlikely since the diploma falls in a period when Charles' diplomas date in successione Odonis, indicating that relations with Robert were comparably good (though this particular diploma does not mention the in successione Odonis). See also McNair, Development, 64-66, who applies the argument for Saint-Amand only being granted by Charles the Simple also to Saint-Germain-des-Prés.

758 Recueil Robert et Raoul, N 46, 178-181.

759 For Erlebald, see above. Odilard intervened in 905 together with Bishop Rudolf of Laon on behalf of Charles' notary Ernustus (DChS 51). Almanus may be identical with Count Altmar of Arras, which would make him the third. 
churches of Tours and Liège. ${ }^{760}$ The king appears to have reacted to the structural changes in the realm and in the circle surrounding him by publicly demonstrating the accord between him and the most powerful noble of the realm. The two diplomas issued for the church of Liège, showing Robert intervening together with Reginar, can, in this context, be read as a demonstration of Robert's importance and the care Charles attributed to manage the relations between him and the marchio. They are the only examples of Robert intervening on behalf of a church, not only outside his own zone of influence, but also the only examples of Robert intervening together with other nobles. ${ }^{761}$ By these diplomas, Charles demonstrated that, after the acquisition of the new regnum, Robert still occupied the central position at his side, more important than the leading noble from Lotharingia, Reginar Longneck.

Relations between Charles and Robert appear to have peaked (at least for the first time) in 914, when the king issued two diplomas for Saint-Aignan at the marchio's request. ${ }^{72}$ The accumulation of titles and epithets used to describe Robert reached thus-far unprecedented levels: "Robert, our most beloved marchio and abbot." ${ }^{373}$ More important, however, are the circumstances under which the diplomas appear to have been issued. Only two days after these two, another one was delivered, this time for Richard's son Hugh the Black, according to Philippe Lauer issued at Collège (Sarthe). ${ }^{764}$ If Lauer's identification is indeed correct, this would mean that in June 914 Charles, together with Robert and Richard's son, was on a voyage to the very west of his realm, close to the Breton frontier. Since the death of Alan the Great in 907, Brittany had lived through troubled times. ${ }^{765}$ Alan appears to have been succeeded by Count Uurmaelon, ${ }^{766}$ whose death in 913 , along with the destruction of the abbey of Saint-Gwénolé of Landévennec in the centre of the Breton royal lands, marks the breakdown of the internal order of the regnum. In the wake of these events, the Breton clergy appears to have fled to Western Francia, evacuating their relics, while Brittany lay open to the incursions

760 DDChS 77 and 78 (19th June 914), 89 (28th May 917), 92 (14th March 918), 94 (14th May 918 ), 98 (1st December 918) and 101 (27th June 919) as well as DDChS 9 (for the church of Tours, unknown date after April 912, see chapter III.2.3, n. 756), 65 (for the church of Liège, after April 912-915, see chapter III.2.3, n. 756) and 81 (for the church of Liège, 25th August 915). In comparison: in 903, marking Robert's ascent, three diplomas were issued, followed by another three over the course of the next three years: DDChS 45 (25th April 903), 46 (30th April 903), 47 (5th June 903), 49 (13th July 904), 50 (9th February 905) and 54 (7th September 906).

761 Except DChS 57, the diploma introducing Frederuna to the highest circles of the nobility at court.

762 DDChS 77 and 78 (19th June 914).

763 DChS 77, 173: ...Robertus, dilectissimus nobis marchio atque abbas. DChS 78, 175: ... Robertus, videlicet dilectissimus nobis marchio atque abbas... While dilectus is frequently used before (DDChS 45 (admodum dilectus), 47 and 66), it is the first time that the superlative is applied (except for DChS 54, which describes Robert as carissimus).

764 DChS 79 (Actum villa Collega, 21st June 914). DChS 77 and 78 were issued in villa Ruio. On the problem of the identification of these places, see chapter III.1.1, n. 24.

765 Short studies of Britanny during these years are provided by Quaghebeur, Norvège and McNair, Language, who we follow here.

766 Cartulaire Redon, $N^{\circ} 279,226$, dating Gurmabilon regnante Britanniam. 
of the Northmen. These events can hardly have been left unanswered by Charles and Robert and the deliverance of the three diplomas for Robert and Hugh may be the sign of their reaction: a campaign with troops, composed not only of Robert's own men, but also of contingents from Burgundy and Francia to stabilise the frontier and possibly also make territorial gains. This fits well into the picture: before the campaign, Robert had already shown an interest in the Breton frontier. In November 912, Bishop Isaias of Nantes witnessed a charter issued by the marchio ${ }^{767}$ and, in the following year, one of Robert's viscounts, Fulk of Anjou, became count of Nantes, probably after the city had been taken from the Northmen. ${ }^{768}$ Finally, in 921, Robert concluded a treaty with the Northmen operating on the Loire, conceding them Brittany and the pagus of Nantes. ${ }^{769}$ Flodoard's account of these events seems to indicate that Robert at least claimed a certain kind of authority not only over Nantes, which can be explained by his viscount Fulk being count there, but also over Brittany itself. If, in 914, a campaign to the Breton frontier had indeed taken place, this would explain how and when such a claim could have been created. Apart from this (possible) campaign and the two diplomas for Robert, there is also another sign that the cooperation between the king and the marchio had reached a very high level. A private charter issued by Robert in March 914 was witnessed by his son, Hugh the Great, as "Hugh, son of the abbot and count, who, after himself, was already given his honores," that is to say, he had been confirmed as his father's heir. ${ }^{770}$ Hugh's succession in Robert's honores is repeated by a charter supposedly issued two months later, adding that he would hold all of the honores with Charles' consent. ${ }^{771}$ This second charter, however, appears to be a forgery produced in Saint-Martin of Tours. ${ }^{72}$ While this devaluates the charter as a source, we may ask ourselves why the monks would introduce such a phrasing if there had not been a tradition at the monastery recording Charles' role in the succession. Following this reading, it would seem that, early in 914, Charles had indeed confirmed Hugh as Robert's successor, undoubtedly a sign of his favour.

The highest density of royal diplomas for Robert-after 903-is recorded even later, between 917 and 919, when five diplomas were issued by the king. The first two of these diplomas continue the accumulation of epithets and titles attributed to Robert. He is the "abbot and dearest demarcus and our most loyal [fidelis],"773

767 Recueil Robert et Raoul, No 47, 181-186 (11th November 912).

768 Werner, Untersuchungen I, 286-287 (31st March 914). The charter is signed by Fulconis Namnetensis comitis et Andegavensis vicecomitis. In Robert's charter, dating to 11th November 912, Fulk signed without any titles, in contrast to the counts featuring in it before him.

769 Flodoard, Annales 921, 6.

770 Werner, Untersuchungen I, 286-287 (31st March 914), 287: Signum domni Hugonis, filii sui abbatis et comitis cui post ipsum iam sui honores dati erant.

771 Recueil Robert et Raoul $\mathrm{N}^{\circ}$ 48B, 187-199, 192: ... filius noster Hugo, cui post nos cum seniore nostro rege Karolo omnes honores nostros impetratos habemus...

772 See comment of Jean Dufour, Recueil Robert et Raoul N 48B, 188-191.

773 DChS 89 (28th May 917), 201: ... abbas [...] atque demarcus carissimus ac fidelissimus noster Rotbertus... 
the "venerable marchio, namely our realm's counsellor and aid, as well as abbot"774 and even, strangely enough, "our kinsman," who is united with Charles in a prayer service. ${ }^{775}$ The two diplomas again mark Robert's special position at Charles' court, underlined by the third one, issued on Ascension Day at Compiègne. ${ }^{776}$ Interestingly enough, these diplomas fall into the same period as the diplomas indicating the special relation between Charles and Hagano. ${ }^{777}$ It is hard to tell whether these two developments were related to each other. Did Charles try to reinforce relations with Robert to prevent him from being irritated about Charles' intimate? This would imply that the king was aware of the dangers of his favour towards Hagano. Indeed, despite diplomas for Robert still being issued, from May 918 onwards their relations seem to have cooled down. The exuberant epithets used in the first diplomas disappear from May 918 onwards, leaving Robert to be depicted simply as "venerable abbot"778 and "our venerable count and marchio."

This, however, does not mean that irreconcilable differences had now developed between the two. Flodoard's account of the events at Soissons speaks of "almost all of the counts of Francia" who decided to abandon the king because of his councillor Hagano. ${ }^{780}$ Robert is not mentioned, although he was undoubtedly present at the assembly. This is revealed by a royal diploma issued on that occasion at Robert's request for Notre-Dame of Morienval. ${ }^{781}$ The diploma, naming the marchio as its abbot, is the first sign that Robert had taken control of the abbey. Karl Ferdinand Werner assumed that Morienval had passed from its last known abbot Theoderic, the count of Vermandois, directly to Robert. ${ }^{782}$ This assumption is based on the record of the Gallia Christiana, which names Theoderic and after him Robert as lay abbots of Morienval. ${ }^{783}$ This statement, however, is solely based

774 DChS 92 (14th March 918), 211: ...venerabilis marchio, nostri quidem regni et consilium et juvamen simulque abbas...

775 DChS 89, 201: ...consanguinei nostri Rotberti abbatis... Werner, Nachkommen, 424, n. 14 tried to explain this expression with the marriage of Robert's son Hugh with the daughter of Charles' aunt Rothild. Against this reading Settipani, Préhistoire, 407, n. 41, who derives the consanguineus from Charles' grandmother Judith, whose family was related to Robert's mother.

776 DChS 94 (14th May 918).

777 DDChS 90 (26th July 917) and 95 (26th May 918).

778 DChS 94 (14th May 918), 216: ...venerabilis Rotbertus abbas...

779 DChS 98 (1st December 918), 226: ...comes et markyo noster venerabilis Rotbertus.... The last diploma issued during this period, DChS 101, has either been forged or rewritten during the 11 th century, we hence refrain from referring to it in this context.

780 Flodoard, Annales 920, 2: Pene omnes Franciae comites regem suum, Karolum, apud urbem Suessonicam, quia Haganonem consiliarium suum, quem de mediocribus potentem fecerat, dimittere nolebat, reliquerunt.

781 DChS 105 (20th January 920, Soissons).

782 Werner, Gauzlin, 461.

783 Gallia Christiana IX, col. 449: I. Theodericus comes, quo deprecante Carlomannus Caroli Simplicis frater fratribus et sanctimonialibus coenobii Maurinianae-vallis dedit de jure suae proprietatis fiscum, qui vocatur Frasnedus, situm super fluvium Altonae in pago Silvanectensi. II. Rotbertus comes filius Roberti Fortis, frater autem Odonis regis qui Caroli Simplicis minorennis tutor fuerat abbas secularis post Theodericum a Carolo Simplice renovari obtinuit praecepta Caroli Calvi et 
on Charles' diploma, in which Theoderic is named as a former abbot. ${ }^{784}$ Hence, it is possible that Robert did not directly follow Theoderic as abbot, but was given the abbey at a much later point, maybe even only at Soissons in 920. In any case, the diploma, not only being issued at Robert's request but also confirming one of his brother's diplomas, ${ }^{785}$ was a symbol of the continuing cooperation between Charles and Robert and was directed towards the assembly of the counts. This also allows us to cast some doubts on Flodoard's accounts of the events: since the monk does not mention Robert at all in the context of Soissons while the diploma issued at that moment suggests that Charles still enjoyed Robert's support, should we really believe him when he tells us that the reconciliation between the king and the nobles was solely Archbishop Heriveus' doing? It would rather seem that Robert had also been involved in these negotiations, taking the king's side.

For the outcome of the negotiations, Robert certainly was the decisive factor. Mostly isolated at the beginning of Charles' reign, by now he had built up a network covering most the West Frankish realm. We have already seen how he had become close with William the Pious, although this link died with William. ${ }^{786}$ By 920, other connections were more important. Robert's daughter Emma had married Richard's son Raoul, tying the two families close together. ${ }^{787}$ This marriage was probably the result of a development that had started around 907, when Richard returned to court, as shown by a royal diploma issued at his and Manasses' request for Bishop Argrim of Langres, ${ }^{788}$ a development that led to the cooperation of the two marchiones in the campaigns of 911 and 914. The marriage between Raoul, and Emma as well as Richard's private charter of $918^{789}$ mark the end of this convergence, leading to an open alliance that found its first target in William the Younger, from whom Robert and Raoul took the Berry ${ }^{790}$. Probably around the same time, Robert and Richard's sons also appear to have visited Remiremont, where they made an entry in the Liber Memorialis. ${ }^{791}$ And there were other important ties Robert had forged over the past decades. Heribert II of Vermandois mar-

Carlomanni, quae coenobio igne cremato exusta fuerant, XIII cal. Febr. indict. VIII, anno XXVIII, regnante Carolo, redintegrante XXIII, largiore hereditate adeptae VIIII; hic est annus 920.

784 DChS 105, 251: Praetera, Theoderico comite venerabili et abbate jam dicti monasterii depraecante postea, dignus memoria rex Karlomannus, qui noster fuit frater, saepedictae congregationi in pago Silvanectensi dedit de jure suae proprietatis fiscum qui vocatur Fraxinedus, et est situs super flumen Altona, in quo habentur mansi septuaginta in his locus conjacentes... Carloman II's diploma issued on that occasion (DCmII 90) is not preserved. The phrasing of the Gallia Christiana recording Theoderic corresponds exactly with Charles' diploma, as does its account for Robert (apart from Robert's genealogy which is based on a later tradition).

785 DChS 105, 252.

786 See above.

787 See chapter III.2.3, n. 727.

788 DChS 55 (4 $4^{\text {th }}$ April 907).

789 See above chapter III.2.3, with n. 724 .

790 See above chapter III.2.3, with n. 712 .

791 Liber Memorialis Remiremont, fol. 5v, 8, № 6: Ugo com., Boso com., Ruodulfus com., [...], Robret com., Ima com. The entry was probably made shortly after Christmas 921. See Schmid, Quellen, 127-128 and Büttner, Politik, 27-28. 
ried another of Robert's daughters, possibly the Adelaide ${ }^{792}$ appearing in Charles' diploma of $907 .{ }^{793}$ Heribert appears to have witnessed one of Robert's charters for Marmoutiers ${ }^{794}$ and, like Bishop Abbo of Soissons, was also involved in the grant of the abbey of Croix-Saint-Ouen to the monks of Saint-Germain-des-Prés, where Robert was lay-abbot. ${ }^{795}$ While not necessarily a sign of them being alliedCroix-Saint-Ouen was situated in the Mérezais, a county under Heribert's control ${ }^{796}$ - the diploma issued at that occasion certainly shows them cooperating in an important case. The last of the links forged by marriage concerned Robert's son Hugh, who was married to the daughter of Count Roger of Maine and Rothild, hence the sister of Count Hugh of Maine, who we have seen among Charles' allies in $900 .{ }^{797}$ The connections to these three, Richard, Heribert II and Hugh of Maine, as well as those to the counts from Francia witnessing in Robert's private charter from $906,{ }^{798}$ indicate that Robert's position within the West Frankish nobility had changed much in comparison to the beginning of Charles' reign. He had now managed to construct links, even forge alliances, to those men or their successors, who had originally been key members of Charles' own network, supporting the king against the ambitions of the marchio before his integration into the rule in 903. Robert's network was certainly not constructed with the purpose of opposing the king but, without a doubt, the consequence of his position at Charles' side that made the marchio a potential partner for all those who wanted to influence royal politics. Developed over decades, it was an expression of Robert's special importance within the realm and the circle around the king.

After the reconciliation with the West Frankish nobles, Charles' diplomas mainly betray his efforts to stabilise his relations with them. The central role in these efforts seems to have fallen to the circle around Abbo of Soissons, Stephen of Cambrai, Raoul de Gouy and Hagano, for whom the central diplomas were issued during this period. ${ }^{799}$ Robert's role, however, should not be underestimated either. In the case of the episcopal succession at Liège after the death of Bishop Stephen, ${ }^{800}$ Robert seems to have participated in the assembly dealing with the case of Hilduin ${ }^{801}$ and, therefore, supported Charles' politics concerning the siege.

792 On the marriage see, Brandenburg, Nachkommen, 88. For Adelaide, see chapter III.2.1.1, n. 192. See also Settipani, Préhistoire, 408 with n. 44 concerning the possibility of Heribert II's wife being called Liedgardis.

793 DChS 57. Werner, Nachkommen, 458.

794 DRoI 48A (30th May 914).

795 DChS 92 (14th March 918).

796 Werner, Untersuchungen V, 94.

797 Settipani, Préhistoire, 409. Flodoard, Annales 922, 8: ...Rothildis, [...] socrus autem Hugonis... See above for the circumstance of the alliance between the king and Hugh of Maine.

798 See above, Recueil Robert et Raoul, N $46,178-181$.

799 DDChS 106, 108 and 112.

800 19th May 920. Gesta Episcoporum Tungrensium, 201, n. 92.

801 MGH Conc. VI, $\mathrm{N}^{\circ}$ 2, c. 2, 45: Cum quidam pestiferi viri, ut supra memoravimus, a nostra fidelitate deviarent, convocavimus archiepiscopos praesules XVI nostri regni, nonnullos etiam proceres, marchiones et comites optimatesque, ut eorum consilio, auctoritate atque virtute tantae vesaniae 
A royal diploma issued in $921^{802}$ further underlines their continuing cooperation. This is not to say that their relations were not subject to increasing tensions. The decline in the use of epithets and titles to describe Robert in the royal diplomas that set in around 918 is also visible in this new diploma, addressing Robert merely as "venerable abbot" ${ }^{803}$ of Saint-Amand, indicating that the rift between the two was continuing to grow.

Yet even when Charles gave Rothild's abbey Chelles to Hagano and thereby violated the interests of a family now closely tied to Robert's, the relations between the two do not seem to have been irrecoverably damaged. According to Flodoard, the events now unfolded in a number of steps: first, Charles gave Chelles to Hagano. The king having returned from Lotharingia to Laon, Robert's son Hugh met with Heriveus' fideles and certain counts at the villa of Fismes after Easter. After this meeting, he then advanced on Laon, from where Charles withdrew, accompanied by Heribert II and Hagano, ob Haganonis amorem, because of his love for Hagano. Hugh now met with Gislebert and both were called to a colloquium with Robert. Soon after, Charles returned with Lotharingian forces and started to devastate property of the church of Reims, marking the beginning of the armed conflict. ${ }^{804}$ Flodoard's account reads like a progressive escalation. The first meeting of Charles' opponents reads like the creation of a threatening posture, meant to exert pressure on the king. Charles evades this pressure by removing himself from Laon. This is the crucial moment in the development: the king refused to give in and later even started to attack his opponents. The consequence of this royal policy and the ultimate point of no return, but certainly not the original intention of the nobles, was Robert's coronation on 30th June $922,{ }^{805}$ about two months after Hugh's initial advance after Easter. ${ }^{806}$ The decision to depose Charles was certainly

resisteremus. As discussed above (chapter III.2.1.6), the use of marchiones here refers to the magnates from the Western realm, Robert and Richard, the only nobles carrying that title in the royal diplomas after Reginar's death in 915.

802 DChS 110 (11th June 921).

803 DChS 110, 265: ...venerabilis abba [...] Robertus...

804 Flodoard, Annales 922, 7-8: Hugo, filius Rotberti, post Pascha supra Vidulam venit, ubi, apud villam Finimas, Herivei archiepiscopi fideles cum quibusdam Franciae comitibus obvios habuit. Quo cum eisdem super Axonam in pagum Laudunensem profecto propter praedictum Haganonem, cui rex abbatiam Rothildis, amitae suae, socrus autem Hugonis, dederat, nomine Calam, Karolus cum Heriberto et Haganone clam Laudunum egressus, ob Haganonis amorem, hujus causa timoris trans Mosam profectus est. Quem insecutus Hugo cum ceteris pugnatorum duobus milibus usque Mosam, Gislebertum Lothariensem obvium habuit; cum quo a patre, qui eum prosecutus fuerat et super Axonam in pago Laudunensi sedebat, ad colloquium revocatus revertitur. Quo comperto, Karolus, Mosa retransmissa, cum nonnullis qui ad se venerant Lothariensibus, villas Remensis aecclesiae depraedari necnon incendere coepit...

805 Flodoard, Annales 922, 10: Franci Rotbertum seniorem eligunt, ipsique sese committunt. Rotbertus itaque rex Remis, apud Sanctum Remigium, ab episcopis et primatibus regni constituitur. Heriveus, Remorum archiepiscopus, obiit tertia die post consecrationem regis Rotberti, scilicet VI nonas Julii... Hervieus' death hence fell on 2nd July, Robert's coronation on 30th June.

806 See chapter III.2.3, n. 804. Easter 922 concordes with 21st April. 
not a simple one. Robert's only preserved diploma ${ }^{807}$ is, as Geoffrey Koziol expressed it, "a coded defence of Robert's action," ${ }^{008}$ depicting his coronation as a necessity for the wellbeing of the entire realm due to "indispensable reasons." Therefore, in Robert's view, Charles' deposition had not been inevitable but was the last resort. Up until the last moment-the king withdrawing from Laon and taking up arms-he was interested in a continuation of their cooperation. In the end, it was Charles' decision not to respond to the demands of the nobles but to pursue, according to Flodoard because of his love for Hagano, his own policy. With this decision, the basis of their cooperation was shattered.

\section{III.3 Conclusion: The development of Charles' network and its dissolution}

The beginning of Charles' rule was marked by the dominance of the circle of his old supporters from the fight against Odo, most importantly Archbishop Fulk of Reims, Heribert I of Vermandois and with his mother Adelaide probably also playing a central role. Despite the dominance of these men and women, his reign was soon acknowledged by the most powerful men of the realm who had either opposed his claim or pursued their own policies during the years preceding his final ascent to the throne. Robert of Neustria took the leading role here, with Richard the Justiciar and William the Pious following him. However, Robert, in particular, perceived this situation as unsatisfactory. He had been the key figure of Odo's later years, the right hand of the king, a position that now was held by Fulk. During these years, Charles' emphasised his right to rule, although not by underlining the legitimacy of his claim based on his Carolingian descent-in fact, his policy on this matter did not differ from that of his predecessors-but by demonstrating to the realm that he was willing to act like a true king, a protector of the Church. To do so, he used his connections to the nobles of Septimania and the Spanish March, with whom he organised the assembly of Tours-sur-Marne in 899, where he did exactly that: restored ruined churches and protected their interests. While these measures probably had no influence on the actual conditions in the distant South, the assembly of Tours-sur-Marne was, nevertheless, a powerful signal to the realm: Charles was the king, and he was willing to act as one.

The first crisis developed in 900 when Archbishop Fulk was murdered, yet the now vacant position at the king's side was not given to Robert, but to Richard. Robert now left the court and both sides mustered their forces, although most likely without ever actually taking up arms. Robert's integration into Charles' rule

807 DRoI 1 (25th January 923).

808 Koziol, Robert, 250. See also chapter VI.4.

809 Koziol, Robert, 250-252. The diploma's address (DRoI 1, 8) reads Notum autem manet sagacitati omnium fidelium nostrorum, procerum scilicet Francorum, qualiter per divinam clementiam, causis necessariis existentibus, omnium favore principum ad regni gubernacula moderanda regie majestatis sceptra suscepimus. 
followed about three years later, after Adelaide's death, when the relations between the king and Richard seem to have deteriorated severely. At this point Richard disappeared from the court while his position was taken over by Robert, who now became the leading noble of the realm up until the end of Charles' rule. This, however, did not mean that he dominated the circle around the king. On the contrary, members of the group of Charles' old supporters, like Bishop Anskeric of Paris, and their successors, such as Archbishop Heriveus of Reims and Heribert II of Vermandois, can be found present at court during the entire reign, occupying key positions, like the new archbishop of Reims, who succeeded Anskeric as archchancellor. Charles' contacts with local nobles outside Francia, however, remained limited. Just like under his predecessors, petitioners and recipients from Aquitaine are very rare, again with the notable exception of Septimania and the Spanish March. In these latter cases, however, the diplomas issued for nobles from the regions were, with few exceptions, concentrated on the two assemblies at Tourssur-Marne in 899 and 922. In the other regions, most notably in Neustria and Burgundy, communications between the king and the local nobility seem to have been channelled through the local magnates, Robert and Richard respectively. The relationship between Charles and these magnates was, in general, characterised by mutual cooperation, with the king testing out his room for manoeuvre on different occasions. In the early conflict with Robert, Charles constructed a network of alliances keeping the marchio in check; in Richard's case, he directly intervened in his zone of influence; in Aquitaine, he later favoured William the Pious' opponents around Raymond of Toulouse. All in all, Charles' rule during these years seems to have been undisputed and, from 903 , onwards stable.

While between 903 and 911 changes in the network took place only graduallyold members died and were replaced by new ones, as in the case of Theodulf's replacement of Anskeric as bishop of Paris, although not as archchancellor-the acquisition of Lotharingia was followed by major changes in its overall composition and the addition of Lotharingian nobles to the royal contacts. In his new regnum, Charles' rule was based on the cooperation with the already-dominating elites, Reginar Longneck, the Matfrid family and the church of Trier, who had already rivalled for influence at court under Zwentibold and Louis the Child. However, in addition, Charles also established contacts with nobles like Bishop Stephen of Cambrai and Count Ricuin of Verdun who had been staunch supporters of Zwentibold but had lost their influence at court under Louis. Up until his death in 915, Reginar and his network of personal contacts appear to have played a central role in Charles' new network. His death marked a slow turn towards the Matfrid family and the church of Trier, with his son Gislebert and his old party remaining important at least up until 916, when they participated in large numbers at the assembly of Herstal. While the acquisition of Lotharingia resulted in distinctive changes in Charles' network and his itinerary-in addition to Francia, after 911 he also travelled within Lotharingia-its overall impact on his relations to the Western nobles appears to have been rather limited. Charles 
did his best to integrate Robert in particular into his rule and demonstrated publicly that Robert's position as the most important noble remained unchallenged. Diplomatic contacts with the Western realm remained on a constant level and his other supporters from earlier on remain visible and took part in Lotharingian affairs, such as the assembly of Herstal in 919 and the episcopal succession of Liège. These participations are not the only signs that Charles intended to merge his two regna into one. The separate Lotharingian chancellery, founded under Louis the Child, ceased to exist. Archbishop Heriveus of Reims remained sole archchancellor, later succeeded by Roger of Trier. Count Wigeric, married to Charles' niece, became the new count of the palace, replacing William the Pious in this position. Nobles from both regna can be found acting together in royal diplomas, which underlines the existence of strong contacts and common interests across the borders.

The last years of Charles' rule saw the formation of a new group close to the king, centred on the bishops Abbo of Soissons and Stephen of Cambrai as well as Count Raoul de Gouy. First appearing alone in the royal charters, from 920 onwards they can be found acting together. While new to the circle around the king, they appear to have had exceptionally good contacts to the rest of the nobility, especially visible in the case of Abbo, who seems to have played a key role in the relations between Charles and the nobles in early 920 and later became Robert's and Raoul's archchancellor. While this group demonstrates that Charles was able to further nobles of his choosing and to influence the composition of the circle around him, his liberty in doing so was also subject to clear restrictions. Archbishop Fulk's presence at his side had prohibited him from granting Robert the position he desired; while after the acquisition of Lotharingia it was the marchio whose interests the king had to take into consideration. These same limitations also become clear when considering Charles' influence over episcopal successions. While there are a number of examples of him furthering his own interests by promoting his relatives and associates, the case of the succession at Liège also demonstrates that, when encountering serious resistance, he had to ally himself with groups rivalling his opponents, in this case the Matfrid family. Here, Charles appears to have gone even further, tying the family close to him by means of marriage: his daughter Ermentrude married Gottfrid, the son of Gerhard.

His own family members certainly played an important role for Charles. His mother Adelaide's influence in royal politics becomes apparent from the number of her interventions in Charles' diplomas. On the other hand, Charles' first wife, the Saxon noblewoman Frederuna, remains mostly invisible. Intervening together with the highest nobles in 907 shortly after their marriage, in the sources she is mentioned almost exclusively only after her death, when Charles put considerable effort into establishing prayer services for her memory. This points to the close relation they had enjoyed and her importance for him; but her political influence remains indeterminable. The same also applies for his second wife Eadgifu. While 
being politically very active in her later life, during Charles' reign, the sources make no mention of her.

Close to the king, although not a member of his family, was Hagano, the man about whom the sources report that Charles lost his crown because of favouring him over the other nobles. Descending from a family based on the Middle Rhine in the East Frankish-Lotharingian border region, he seems to have made his first appearance in 916. His ascent appears to have taken place in the wake of Frederuna's death, when he acted as intercessor on the deceased queen's behalf in a number of diplomas and was even included in a prayer service with the king, the queen and her brother. Only after the settlement with the nobles following their protest against Hagano in early 920 is he shown acting together with other nobles. It would seem from this development that the protest of the nobles was not directed against Hagano's presence per se, but against the form of his presence at Charles' side. In fact, preceding Hagano, we can already trace other men who seem to have derived their position from their special relationship with the king yet who were accepted by the highest ranks of the nobility. Hence, the problem with Hagano appears to have been the way he and his relation to Charles was perceived by the nobility. The king responded to this problem by trying to introduce his intimate to the nobles and to integrate him into the highest ranks of the nobility. However, despite these efforts, in 922 some of the leading nobles rebelled against Charles. Yet, the crucial point in the breakdown of their relations appears to have been less related to Hagano and the circumstance that Charles violated the interests of a family close to Robert, but that Charles refused to negotiate over the subject at hand.

The rebellion against Charles certainly was not the result of a sudden development but points to a large crisis in the relations between the king and the nobles. Some scholars have argued that this crisis already commenced before $920,{ }^{810}$ when, according to Flodoard's History of the church of Reims, the Hungarians devastated Lotharingia. Charles called the Frankish nobles to aid, but only Archbishop Heriveus responded by mobilising his forces ${ }^{811}$ Flodoard's account, however, is not without problems, the first being the dating of the event. It seems to correspond with the first entry in his Annales, where he reports a Hungarian invasion in Lotharingia. ${ }^{812}$ However, the Annales do not mention Charles' call to arms and it seems possible that the Historia actually refers to an invasion taking place in 917. ${ }^{813}$ Furthermore, certain doubts can be issued whether Flodoard's account in

810 Eckel, Charles, 107, Parisot, Royaume, 628. The connection of these events with the later rebellion has been questioned by Schmitz, Heriveus, 80 with n. 86. According to him, the nobles did not support Charles out of self-interest or a lack of interest in the defence of the realm. In this context, it is worth pointing out the campaigns against the Northmen in 911 and (possibly) in 914 which saw Robert and Richard participating.

811 Flodoard, HRE IV, 14, 407.

812 Flodoard, Annales 919, 1.

813 For example Annales S. Medardi 917,520 (Hungriprimum Rhenum transieruntetusque Burgundiam pervenerunt.), AnnalesS. Vicentii Mettensis 917,157 (Ungariiprimitusregnum Lotharii ingressisunt.) 
the Historia is entirely accurate on this matter. While Flodoard was biased against Charles, ${ }^{814}$ Heriveus is always depicted in a positive manner. ${ }^{815}$ For example, in the chapter describing Heriveus' appointment Flodoard provides an account of Heriveus pontificate: "While he occupied himself with enthusiasm with the spiritual affairs, the temporal goods flowed from all parts, and he dispensed with them with admirable prudence. He conferred the administration of the bishopric to able officers while he busied himself incessantly to the prayer." ${ }^{816}$ This reads much less like an objective account than the description of an ideal bishop, especially when taking into consideration that in the preceding passages Flodoard used quotes from the Liber Pontificalis to describe Heriveus' virtues. ${ }^{817}$ Furthermore, in this same paragraph, Flodoard remarks that Heriveus recuperated property that his predecessors had given away, ${ }^{818}$ failing to mention that, very much like these same predecessors, Heriveus also gave property of the Church to his own kinsmen. ${ }^{819}$ This same method of withholding information while depicting Heriveus as an ideal archbishop can also be found some chapters further on when Flodoard turns to the events of Soissons in 920: "The following year, almost all of the Frankish optimates renounced their king Charles at Soissons... This loyal and pious bishop, always firm in times of danger, courageously took care of the king, leading him from this place and bringing him with him to the city of Reims; and he accompanied him and followed him everywhere just until he had brought back these counts to him and had restored him to his regnum." "820 Again, Flodoard's account reads like a eulogy for Heriveus, emphasising the archbishop's virtue while withholding parts of the history: the central roles Robert of Neustria and Bishop Abbo of Soissons certainly also played in mediating between the king and the nobles.

Hence, Flodoard's bias towards Heriveus and his habit of withholding certain information may also apply in the case of Charles' call to arms against the Hungarians. While it seems unlikely that Flodoard invented the entire affair, it does

and Continuatio Reginonis 917, 155 (Ungarii per Alemanniam in Alsatiam et usque ad fines Lothariensis regni pervenerunt.). See also Schmitz, Heriveus, 80 with n. 86. On the invasion of 917 see Lüttich, Ungarnzüge, 66-68. It is worth pointing out that neither of the sources cited above, nor the later chronicle of Herman of Reichenau (112), mention a Hungarian invasion in 919. On Hungarian invasions in general, see also Fasoli, Incursioni; Fasoli, Points and Kellner, Ungarneinfälle.

814 See Introduction and Jacobsen, Flodoard, 15-16.

815 On Heriveus as an ideal archbishop, see also Sot, Historien, 236-244.

816 Flodoard, HRE IV, 11, 404: Cui sedula intentione sectanti spiritalia affluenter exuberabant temporalia, qua ipse honesta dispensabat prudentia, disponens competentibus episcopium ministerialibus, ipse orationibus incessanter intentus.

817 Jacobsen, Flodoard, 146-147 with n. 27.

818 Flodoard, HRE IV, 11, 404. On this subject, see Schmitz, Heriveus, 65-66.

819 Schmitz, Heriveus, 65-66, based on Flodoard, HRE IV, 18, 410.

820 Flodoard, HRE IV, 15, 408: Sequenti vero anno cum pene cuncti Francorum optimates apud urbem Suessonicam a rege suo Karolo desciscentes propter Haganonem, consiliarium suum, quem de mediocribus electum super omnes principes audiebat et honorabat, eum penitus reliquissent, hic pontifex fidelis et pius atque robustus in periculis semper existens, regem intrepidus ab eodem loco suscipiens ad metatum suum deduxit indeque secum ad urbem Remensem perduxit et per septem fere menses eum prosecutus atque comitatus est, donec illi comites suos eundemque regno restituit. 
seem very likely that he exaggerated or misinterpreted the failure of the nobles to respond to the king's call. For example, Charles would probably first have called upon Lotharingian forces to respond to the invasion. Robert, on the other hand, might have been unable to respond to the call because of the threat still posed by the Northmen-in 919, Flodoard tells us that they once again devastated Brittany. ${ }^{821}$ And finally, given his account of Heriveus' role in 920, it seems rather likely that other nobles also had responded to the call. Of course, these are only assumptions based on Flodoard's way of describing Heriveus' episcopate. Especially when taking into consideration that after the reconciliation the nobles continued to cooperate with Charles, it nevertheless seems inappropriate to take Flodoard's note of the Hungarian invasion as a sign for any deeper problems between Charles and the Frankish nobles at that time.

Therefore, the first indication of a rift between Charles and the nobles seems to have been the confrontation at Soissons early in 920, leading to him being abandoned by the Frankish counts up until the mediation of an agreement seven months later. This event, while without a doubt revealing major problems in the relations between the king and parts of the nobility, should not be overemphasised either. On the one hand, the key figures of the Western realm, Robert, Richard, Heriveus and Abbo did not belong to the opposition that had formed against Charles, nor did the bishops. ${ }^{822}$ On the other hand, after an agreement had been reached, the nobles again cooperated with the king as his diplomas, featuring a rather large number of bishops and counts, as well as the assembly concerning the succession at Liège ${ }^{823}$ and Charles' entourage at the meeting with Henry the Fowler at Bonn ${ }^{824}$ demonstrate. Tensions definitely remained and the nobles most probably were still vigilant about the king, yet nothing indicates that there was an inevitable development leading from the protest of 920 to the rebellion of 922 .

The keys to the dissolution of Charles' network in 922 were certainly the illness and death of Heriveus and the breakdown of relations with Robert, thus depriving Charles not only of two of his most powerful and influential supporters, but also making the latter his opponent. Robert's turn from cooperation to hostility must have placed enormous pressure on Charles' network, since many of his contacts also entertained good relations with Robert. ${ }^{825}$ Thus, Raoul, Richard's son and successor in Burgundy, was married to Robert's daughter Emma. Yet while he decided to support his father-in-law, ${ }^{826}$ Heribert II, likewise married to one of

821 Flodoard, Annales 919, 1. See also Chronique de Nantes, 81-82. See also Koziol, Politics, 525.

822 For Robert and Abbo, see above. Richard's position is not known, yet it seems to me that Flodoard's phrasing Francorum optimates (see chapter III.3, n. 820) and pene omnes Franciae comites regem suum Karolum ... reliquerunt (Annales 922,2) does not point to an involvement of the marchio from Burgundy. These same phrasings also exlude the bishops from the opposition against Charles.

823 See chapter III.2.1.6.

824 MGH Const. I, $\mathrm{N}^{\circ} 1,1-2$.

825 See chapter III.2.3.

826 Flodoard, Annales 922, 8. 
Robert's daughters, remained, for the time being, on Charles' side. ${ }^{827}$ The question over whether to support Charles or Robert must have been a difficult one for the individual nobles. Private charters from the regions south of the Loire dating after the regnal years of Charles even after his deposition reveal the division of the nobles over this question. As Wojciech Falkowski has shown, there were sometimes differing opinions on the matter, even within the same monasteries since their cartularies contain charters dating after both kings. ${ }^{828}$ North of the Loire, in Neustria, Burgundy and Francia, no such datings are preserved, yet there was certainly division among the nobility: Heribert II was not the only one continuing to support Charles. Laon had remained loyal to the king and had to be conquered by Robert, ${ }^{829}$ probably indicating that its bishop, Adelelm, had joined the king's side. On the other hand, the position of Count Roger of Laon is less clear. Given the power of the bishop at Laon, ${ }^{830}$ the circumstance of the city's remaining loyal to Charles does not necessitate that Roger had done likewise. In any case, by 923 , when he took part in the battle of Soissons on Robert's side, ${ }^{831}$ he had opted for the rebels. His support for Robert might have come at a price: in 925, he appears as abbot of Saint-Amand, ${ }^{832}$ formerly held by Robert, who might have given up his abbacy before his death. ${ }^{833}$ Finally, like Roger, Bishop Abbo of Soissons can be made out to have joined Robert's side at an unknown point, in his case before 25th January 923, when he appears as Robert's archchancellor. ${ }^{834}$

The turning point in favour of the rebels, and in the support Charles still enjoyed in Francia, seems to have been reached around Pentecost. ${ }^{835}$ Just before, when Charles' and Robert's armies had been encamped in close vicinity to each other, nobles from Charles' army negotiated with Robert and Raoul. ${ }^{836}$ Charles' reaction was twofold: he moved his army to the vicinity of Reims ${ }^{837}$ and tried to act like a king, demonstrating that he was the protector of the Church and willing to compensate those loyal to him. To do so, he reenacted the assembly that had taken place in June 899 at Tours-sur-Marne: at the same place, around the same time of the year, he again issued numerous charters for recipients from Septimania, the churches of Narbonne and Girona, fideles and abbeys in the region, ${ }^{838}$ as well as a

827 Flodoard, Annales 922, 7-8.

828 Falkowski, Contra legem, 229-233.

829 Flodoard, Annales 922, 9-10.

830 On the power of the bishop at Laon and his relation to the count see Kaiser, Bischofsherrschaft, 581.

831 Flodoard, Annales 923, 13.

832 DRa 7 (6th April 925).

833 Platelle, Temporel, 63.

834 DRoI 1. Dufour, Recueil Receuil Robert et Raoul, XXV-XXVII.

835 At pentecost (9th June), Charles attacked the city of Reims. Flodoard, Annales 922, 9. See below, chapter III.3, n. 841.

836 Flodoard, Annales 922, 9.

837 Flodoard, Annales 922, 9.

838 DDChS 116-120 (5th-7th June 922, Tours-sur-Marne) and probably also D'Abadal, Catalunya II,2 384 and $472-473$. 
diploma for the abbey Saint-Thierry of Reims, ${ }^{839}$ granting Bishop Guigo, the only noble actually attending, "what little is left at the disposition of the royal power" because of the fidelity shown by him. ${ }^{840}$ The message was clear and might have drawn more nobles back to his side, yet after his attack on Reims failed and Laon was captured by Robert's men, the latter's forces “increased each day while those of Charles diminished." ${ }^{81}$ This was probably the moment when nobles like Heribert II of Vermandois ${ }^{842}$ went over to Robert. The opposition against Charles had now reached a point when it became strong enough to claim the right to choose a new king. With Charles having withdrawn to Lotharingia, the "Franks chose Robert as senior and committed themselves to him", thus making him their king. ${ }^{843}$

The Lotharingian nobility seems to have been as divided as the West Frankish. While Flodoard, without going into any further detail, repeatedly emphasises the role of Charles' Lotharingian connections, ${ }^{844}$ he also reports that, on two occasions, Lotharingian nobles left Charles' army to return to their homes ${ }^{845}$ and that on another some of them negotiated separately with Robert ${ }^{846}$ only to rejoin Charles soon after. ${ }^{847}$ Among those remaining loyal to Charles appears to have been Count Theoderic, who, shortly after Charles' failed advances on Reims and Laon, received a diploma from the king. ${ }^{848}$ Likewise, Archbishop Roger of Trier seems to have remained loyal to Charles up until this moment since he features as archchancellor in this very same diploma. Count Gislebert, Reginar Longneck's son, and Count Otto, son of Count Ricuin of Verdun, on the other hand, were obvious allies for the West Frankish rebels since they were already in conflict with

DChS 115 (31st May 922, Tours-sur-Marne).

840 DChS 120, 285: Supra quae praefato episcopo Wigoni suaeque ecclesiae [...] pro remedio animae nostrae ac genitorum nostrorum, ob nimiam etiam fidelitatem quam illum erga nos cernimus habere, largimur perpauca nostrae regali jure competentia potestati...

841 Flodoard, Annales 922, 9-10: Karolus, abnegato sibi introitu Lauduni, resedit super fluvium Saram, et Rotbertus castra metatus est super Aleam; et cum cotidie, copiis Rotberti crescentibus, decrescerent Karoli, clam tandem secedens cum Haganone trans Mosam proficiscitur.

842 Heribert, who at the beginning of the rebellion was at Charles' side (see Flodoard, Annales 922, 7-8), had joined Robert's side during the time of the battle of Soissons (Flodoard, Annales 923, 13).

843 Flodoard, Annales 922, 10: Franci Rotbertum seniorem eligunt, ipsique sese committunt. Rotbertus itaque rex Remis, apud Sanctum Remigium, ab episcopis et primatibus regni consituitur.

844 Flodoard, Annales 922, 8-9 notes Charles crossing the Moselle with forces from Lotharingia to engage in a campaign against the rebells. Flodoard, Annales 922, 9, describes Charles' attack on Reims at Pentecost with Lotharingian troops.

845 Flodoard, Annales 922, 9-10 and 923, 13-14 (after the battle of Soissons).

846 Flodoard, Annales 923, 12, after Robert had met with Henry the Fowler.

847 Flodoard, Annales 923, 13.

848 DChS 121 (15th June 922). While Lauer, Receuil Charles III, 286 and 381, identifies the place of issuance Pladella villa with Bladel, close to Eindhoven, Bautier, Itinéraires, 100, n. 16 argues for Presles-l'Evêque, south of Laon, given that Charles' attack on Laon had taken place only six days earlier (9th June). While, regarding the dangerous position Charles was in that moment, it does not seem impossible that he covered the distance between Laon and Bladel (about $250 \mathrm{~km}$ ) in such a short time (on the travelling speed of kings under such circumstances, see Reinke, Reisegeschwindigkeit), nevertheless, Bautier's identification seems preferable. 
the king. ${ }^{849}$ And indeed Gislebert is mentioned to have met first with Hugh and then with Robert just after the rebellion had broken out. ${ }^{850}$ Later in 922, Hugh led an advance to relieve Gislebert's castrum at Chièvremont, which was besieged by Charles ${ }^{851}$ However, Gislebert's position in the rebellion is less clear than it seems on first glance. Indeed it appears that the king and the count had concluded a peace treaty at some moment before the siege-albeit not a lasting one. ${ }^{852}$

The rebellion, as we have seen, cut deep through Charles' network of support. Setting Robert aside, the extent of the breach between Charles and the nobles becomes clearest when considering the positions of Heribert II of Vermandois and Bishop Abbo of Soissons. They both had belonged to Charles' inner circle and Abbo even appears to have been one of the most influential nobles at court. After the battle of Soissons, despite the death of Robert, Charles was abandoned by his remaining followers while his opponents refused to return into his peace. ${ }^{853}$ As in 897, when Charles had faced a similar situation, he now turned to his last resort: the Northmen of the Loire. ${ }^{854}$ However, as in 897, this alliance did not help to further his cause. The Frankish nobles, having called upon Raoul of Burgundy, blocked the Northmen's path and soon after Charles was captured and imprisoned by Heribert II.

A comparison between the attitude of the Lotharingian nobles to Charles and that of those from the West Frankish realm seems hardly possible due to the nature of Flodoard's account. While emphasising the importance of the Lotharingians for Charles, he fails to mention those West Frankish nobles who continued to support the Carolingian but concentrates on the leading figures, Robert and his son Hugh. As it seems, Charles faced the same problems in Lotharingia that he was facing in the Western realm. From early on, he was losing support and was finally abandoned after the battle of Soissons. However, there also appears to be a distinctive difference. Nobles from Lotharingia, not least Gislebert, returned into the king's peace even after they had turned away from him. The reason for this difference was probably their attitude towards Robert. Robert's own network extended over Neustria, Francia and Burgundy and it was the nobles from these regions who chose him as their king. ${ }^{855}$ In Lotharingia, on the other hand, his influence and the support for his claim, were rather limited. Here, he was not perceived as king but as a potential ally in private conflicts with Charles. Only once Charles was imprisoned, did the Lotharingians look out for a new ruler and again the different interests of the various nobles surfaced. A group of nobles,

849 Flodoard, Annales 922, 7. On the conflict, see chapter VI.3.

850 Flodoard, Annales 922, 8.

851 Flodoard, Annales 922, 11.

852 See chapter VI.3.

853 Flodoard, Annales 923, 13-14.

854 Flodoard, Annales 923, 14.

855 Flodoard, Annales 922, 10. 
among them Bishop Wigeric of Metz, turned to Raoul while soon after Gislebert and Archbishop Roger of Trier called upon Henry the Fowler. ${ }^{856}$

The question remains however: what caused this dissolution of Charles' network? In 920, when the Frankish counts first articulated their reproaches concerning Hagano, they challenged royal power but not Charles' right to rule. Charles' relations with Hagano certainly did play a major role both in 920 and in 922, yet the nobles' concerns do not seem to have been directed against the king's companion. The settlement agreed upon seven months after Soissons did not include Hagano's removal from court and there still seems to have been room for negotiation in 922. Yet, the rebellion of 922 reveals a deep mistrust against the king, a mistrust so deep that, even after Robert's death, the nobles preferred to turn to Raoul instead of returning to Charles. Given the length of Charles' reign at that moment-24 years-and the fact that the rebellion broke out only in 922 and not in 920 , this mistrust must have been a rather recent development, possibly setting in around 918, when the first signs of a cooling down in the relations between Charles and Robert become visible, and rapidly increasing from 920 onwards. The reasons for this mistrust are probably to be found in Charles' actions in the various conflicts during these years, a question that we will address in our last chapter. 



\section{Relations with other rulers}

So far, royal politics have been dealt with as the result of the interaction between the ruler and the nobles around him. While in general correct, in some cases this model proves too narrow since there are also other political actors to take into consideration. Late Carolingian royal politics did not stop at the borders of a ruler's realm but took place in the greater Frankish world (and beyond). Noble networks, including contacts of the rulers to nobles, reached over the borders into the neighbouring realms. Next to political or ecomonical interests this also included family ties, last but not least also between the Carolingian rulers. This means that in certain situations the balance between a ruler and the nobles around him could be influenced by relations with actors outside his realm. Other rulers could become allies as well as enemies, they could intervene in the politics of a realm in one way or another. Archbishop Fulk was all too aware of the possibilities and threats this wider framework offered and tried to play it as best he could when leading Charles the Simple's struggle against Odo. Not only rulers, also the nobles themselves could seek support from the outside. Reginar Longneck seeking Charles the Simple's aid against Zwentibold was only one example of how conflicts between a noble and his ruler could provide a window for intervention. This chapter is dedicated to the different effects of this wider framework on the various West Frankish rulers' politics and to their efforts to make use of the possibilities it provided.

\section{IV.1 Creating cooperation: Louis the Stammerer}

As the first chapter of the treaty concluded between Louis the Stammerer and Louis the Younger at Fouron states, the amicitia agreed upon was only of temporary character because of "some hindering causes." This phrasing points to the ongoing problems that had arisen over the succession of Louis II of Italy, whose regnum had then yet to be divided under the remaining rulers. ${ }^{2}$ Louis the Stammerer was pursuing a policy aimed not only at becoming the ruler of Italy, but in particular at aquiring the imperial crown previously held by his father. When he had met with Pope John VIII at the Synod of Troyes, he had made an initial attempt to secure the crown for himself when he asked the pope to confirm his

1 MGH Capit. II, N²46, c. 1, 169: Ut, quia firmitas amicitiae et coniunctionis nostrae modo quibusdam praepedientibus causis esse non potuit, usque ad illud placitum, quo simul ut conveniamus statutum habemus, talis amicitia inter nos maneat Domino auxiliante de corde puro et conscientia bona et fide non ficta, ut nemo suo pari vitam, regnum aut fideles suos vel aliquid, quod ad salutem sive prosperitatem ac honorem regni pertinet, discupiat aut forsconsiliet.

2 MGH Capit. II, N²46, Preamble, 169. 
father's order handing the realm on to him. ${ }^{3}$ It is certain that Louis was not asking for John to approve his rule in the West Frankish kingdom, for he had already won this when the pope had crowned him a short time earlier; rather, he was seeking John's support in succeeding Charles the Bald as emperor. ${ }^{4}$ Although the pope refused to fulfil the request, the two of them appear to have come to an agreement in private talks shortly afterwards. ${ }^{5}$ In a letter John later sent to Louis, he refered to a secretum which the two of them had agreed upon at Troyes: Louis was to support the pope militarily, while the pope would fulfil his wishes in return. ${ }^{6}$ The first portion of Louis' aid appears to have consisted of Louis sending Boso to accompany John back to Italy, where he remained for several months. ${ }^{7}$ As Johannes Fried has convincingly argued, Louis in turn became John's candidate for the imperial crown. ${ }^{8}$ Louis' imperial ambitions must have been brought up during the negotiations preceding the treaty of Fouron, and it is hardly surprising, given the progress he had already made, that he was unwilling to renounce them. Nevertheless, the overall tenor of the treaty of Fouron was one of friendly cooperation. Both rulers agreed to support each other in the event of Viking incursions ${ }^{9}$ and to protect the property of the churches of each other's realms, ${ }^{10}$ indicating that the intention was to develop a wide-ranging spirit of co-operation between the two rulers.

This image is further strengthened when considering yet another chapter of the treaty that was of special interest for Louis the Stammerer. Not only was the succession of his sons Louis and Carloman secured in this passage, but also the succession of any future sons "whom God's mercy might be willing to give him."1 This was a de facto acknowledgment by Louis the Younger of the official position of the West Frankish court on the validity of both of Louis the Stammerer's marriages. ${ }^{12}$ Yet there is even more to the passage. For one, it is stated that all of Louis' sons should be able to hold the paternal regnum by right of inheritance, passing over the role of the nobility in the question of succession. This impression is strengthened by the second part of the passage, which committed Louis the

3 Annales Bertiniani 878, 227-228.

4 See also Fried, Boso, 207-208.

5 Annales Bertiniani 878, 228: Denique IIII idus praefati mensis Hludouuicus rex quorundam primorum compulsus petitionibus uenit ad apostolici mansionem, et, cum eo familiariter locutus, unacum illo reuersus est ad conuentum episcoporum in exedram juxta mansionem apostolici.

6 MGH Epist. VII, N 187, 149: Secretum, quod Deo auxiliante vobiscum Trecascio existentes habuimus...

7 Annales Bertiniani 878, 230; Annales Vedastini 878, 43; MGH Epist. VII, N 102, 95-96. Further references can be found in $\mathrm{N}^{\circ} 109,110,121$ and 122, 101-102 and 110-111.

8 Fried, Boso.

9 MGH Capit. II, N² 246, c. 2, 169.

10 MGH Capit. II, N² 246, c. $7,170$.

11 MGH Capit. II, N²46, c. 3, 169: Ut, si ego vobis superstes fuero, filium vestrum Hludowicum adhuc parvulum et alios filios vestros, quos Dominus vobis donaverit, ut regnum paternum hereditario iure quiete tenere possint, et consilio et auxilio, prout melius potuero, adiuvabo. Si autem vos mihi superstes fueritis, filios meos Hludowicum et Karlomannum et alios, quos divina pietas mihi donare voluerit, ut regnum paternum quiete tenere possint, similiter et consilio et auxilio, prout melius potueritis, ut adiuvetis rogo.

12 For this problem, see Offergeld, Reges pueri, 355-356 and chapter I.1.1. 
Younger to counsel and aid Louis' heirs. ${ }^{13}$ This agreement seems to reflect Louis the Stammerer's own problems at the time when he had succeeded his father and faced the displeasure of the leading nobles, who resented his attempts to create his own power base independent from them. Were Louis to die, this treaty would not only secure the succession of all of his sons, but also provide them with a powerful ally against the nobles if need should be.

Two other passages, although certainly in line with earlier treaties, ${ }^{14}$ appear to have been motivated by current events. Both kings agreed not to receive "any whisperers and disparagers, envious of our peace and unable to bear the realm's being peaceful, wish[ing] to sow quarrels and contentions and discords between us, ${ }^{\prime 15}$ adding later on that "the peace and quiet of the realm keeps being shaken by rootless men who lack respect for anything and behave like tyrants"; these men were also to be rejected and either "brought to right reason" or pursued by both parties. ${ }^{16}$ For Louis the Stammerer, these passages, at a minimum, secured Louis the Younger's neutrality in his ongoing conflict with Bernard of Gothia, against whom he prepared a campaign early the following year. ${ }^{17}$ According to the treaty, Bernard would henceforth find neither support nor shelter in the Eastern realm, while Louis could request his cousin's help should the marchio turn there.

Thus, the treaty of Fouron strengthened Louis the Stammerer's position considerably, securing not only the succession of his sons but also ensuring that his neighbour would not interfere in his internal affairs. The agreements, of course, were mutual and would deny Louis the opportunity of taking advantage of any problems Louis the Younger might have had at the same time. However, this appears to have been a price he was willing to pay, especially considering that Fouron was only a preliminary meeting, held in preparation for a second, larger one that was to include Louis the Younger's brothers Carloman and Charles. ${ }^{18}$ It seems that the intention was to create a large network that included all the Carolingian rulers

13 On the development of the phrase consilium et auxilium applied here, see Devisse, Consilium.

14 Kolb, Herrscherbegegnungen, 143-144.

15 MGH Capit. II, N²46, c. 4, 169-170: Ut, si aliqui susurrones et detractores et, qui paci nostrae invident et quietum regnum esse non patiuntur, inter nos lites et contentiones atque discordias seminare voluerint, nullus nostrum hoc recipiat aut libenter acceptet; nisi forte hoc ad rationem coram nobis utrisque et communibus fidelibus nostris perducere voluerit. Si vero hoc noluerit, cum nullo nostrum aliquam societatem habeat, sed omnes illum, sicut mendacem et falsatorem et inter fratres volentem seminare discordias, communiter a nobis abiciamus, ne de cetero quisque talia mendacia auribus nostris inferre audeat. Translation by Nelson, Annals, 214.

16 MGH Capit. II, $\mathrm{N}^{\circ} 246$, c. 8, 170: Et quia per vagos et in tyrannica consuetudine inreverentes homines pax et quies regni perturbari solet, volumus, ut, ad quemcumque nostrum talis venerit, ut de his, quae egit, rationem et iustitiam subterfugere possit, nemo ex nobis illum ad aliud recipiat vel retineat, nisi ut ad rectam rationem et debitam emendationem perducatur. Et si rationem rectam subterfugerit, omnes in commune, in cuius regnum venerit, illum persequamur, donec aut ad rationem perducatur aut de regno expellatur vel deleatur. Translation by Nelson, Annals, 215.

17 Annales Bertiniani 878-879, 234.

18 MGH Capit. II, N² 246, c. 5, 170. 
and was designed to stabilise their realms by solving the Italian problem as well as by cooperating against rebellious nobles.

\section{IV.2 Carolingian networks: Louis III and Carloman II}

Louis the Stammerer's early death led to exactly the situation that he had tried to avoid with the treaty of Fouron. His sons became objects of the rivalries between the noble factions around Hugh the Abbot and Gauzlin, which in turn led the latter to invite Louis the Younger to intervene in the Western realm and thus to the support of an external power for a group within the realm. The situation is not as clear cut as it would appear from this characterisation, however. In his last actions, Louis the Stammerer had made it clear that he intended only his oldest son Louis to succeed him while the faction around Gauzlin aimed at realising the treaty of Fouron. ${ }^{19}$ It could even be argued that by his intervention in the West, Louis the Younger acted in accordance with the treaty by coming to the aid of his cousin's sons and ensuring that both of them would succeed their father. However, his motives appear not to have been altogether altruistic. Hincmar sees Louis the Younger's wife Liutgard as a driving force, who, he insinuates, held ambitions to take over the entire Western realm. ${ }^{20}$ While this part of Hincmar's report might simply have served to denounce Gauzlin ${ }^{21}$ by grossly exaggerating the danger to the Western realm and Louis the Stammerer's sons, it nevertheless points towards another result of Louis' intervention: the Western realm lost the part of Lotharingia that had been acquired by Charles the Bald via the treaty of Meersen in 870 to Louis the Younger.

It is interesting to note the difference between the accounts of two of the main sources on the subject. According to Hincmar, it was Gauzlin and his allies who offered the regnum to Louis, ${ }^{22}$ while the Annales Vedastini report that Hugh the Abbot offered Lotharingia to Louis, not to make him come, but to make him leave. ${ }^{23}$ Whether it was Gauzlin or Hugh who was the originator of the cession, it appears to have been supported by both parties-the price that was to be paid for

19 See chapters I and II and Werner, Gauzlin.

20 Annales Bertiniani 879, 238: Audiens autem hoc uxor illius, satis moleste tulit, dicens quia si illa cum eo uenisset, totum istud regnum haberet.

21 On Hincmar's bias against Gauzlin see Werner, Gauzlin, 437.

22 Annales Bertiniani 879, 236-238: Gozlenus et Chuonradus cum illorum, complicibus machinabantur, miserunt Vultarium episcopum Aurelianensem et Goiramnum ac Ansgerum comites ad Hludouuicum apud Viridunum ut ei offerent partem de regno Hlotharii iunioris quam Karolus contra fratrem suum Hludouuicum, ipsius Hludouuici patrem, acceperat... et accepta regni parte sibi oblate, Hludouuicus ad palatium suum Franconofurth rediit.

23 Annales Vedastini 879, 45: Et dum haec aguntur, Hugo abba Waltherum Aurelianensium episcopum misit, obsecrans Hludowico regi, ut partem regni Hlotharii, quam suus genitor Karolo inter se dividendo regnum consensit, acciperet et abiret in regnum suum et pacem suis sineret habere consobrinis. Quod ille audiens, recepta parte regni, abiit in terram suam. 
Louis' intervention. This might have been due to the terms under which the western part of Lotharingia became part of Louis the Younger's realm. Hincmar tells us that after Louis the Younger's death, "the leading nobles from the part of this king's regnum which had been given to this Louis as a lease" 24 were coming to meet Louis III. This phrasing is repeated shortly onwards when Hincmar reports how Hugh the Abbot sought out Charles the Fat, requesting that the emperor "should restore to Carloman, as he himself had promised to do, that part of the kingdom which his brother Louis had received as a lease."25 The two reports specify that western Lotharingia had not been ceded in perpetuity but only temporary-as a lease-and that (as evidenced by Hugh the Abbot's request that Charles the Fat return the region) this lease was probably supposed to end with Louis the Younger's death, at least in the Western leaders' point of view. ${ }^{26}$ Charles the Fat indeed appears to have been involved in the agreement from an early point, ${ }^{27}$ probably to avoid any future tensions over the subject. This circumstance is probably the best example of the relations between the various parties involved and their goals. Louis the Younger wanted to make personal gains from his intervention in the West, a demand that was accepted by the factions around Hugh and Gauzlin as well as by Louis the Stammerer's sons. Yet, at the same time, the idea of cooperation that had been so dominant in the treaty of Fouron still wielded a strong influence over the different parties.

That this cooperation was still highly valued was probably due to the common threats the different rulers now had to face. In 879 the Vikings had returned to the

24 Annales Bertiniani 882, 245-246: Indeque reuersus [Louis III] apud Compendium [...] ubi nuntiatum est quia sobrinus suus Hludounicus, Hludounici regis Germaniae filius, inutiliter sibi et Ecclesiae ac regno uiuens, morti subcubuit. Venientes autem primores partis illius regni quae ipsi Hludouuico in locarium data fuerat, quatenus quae pater et auus illorum habuerunt eis consentiret, uoluerunt se illi commendare. Sed consilio primorum suorum propter sacramenta quae inter eum et Karolum facta fuerunt, non eos in commendationem suscepit, sed scaram hostilem, cui praefecit Theodericum comitem, quasi in adiutorium illorum contra Nortmanos disposuit.

25 Annales Bertiniani 882, 249: A quod placitum Hugo abbas, quibusdam sociis secum assumptis, perrexit pro petitione partis regni quam frater suus Hludouuicus in locarium acceperat, ut, sicut ipse Karolus olim promiserat, Karlomanno restitueret.

26 MacLean, Response, 30-33, following Nelson, Annals, 223 and 225, interprets these passages of the Annals in a different way. According to him, based on her translation, it was Louis III who had leased back western Lotharingia. However, in the context of Louis the Younger's just mentioned death, ipsi Hludouuico in difference to pater et auus illorum and se illi commendari, clearly seems to refer to the former and not to Louis III. Similarly, the second passage directly follows after a description of Charles the Fat's deeds, so frater suus Hludouuicus has to refer to Louis the Younger and not, as Janet Nelson translates, to "Carloman's brother Louis." Our solution also facilitates to explain why the West Lotharingian nobles were not to commend themselves to Louis III in 882 and why the Annales Fuldenses (Mainz continuation, 881, 96) state that a number of locations in western Lotharingia were in the hands of Louis the Younger: At illi instaurato exercitu et amplificato numero equitum plurima loca in regione regis nostri vastaverunt, hoc est Cameracum, Traiectum et pagum Haspanicum totamque Ripuariam, praecipua etiam monasteria, id est Prumiam, Indam, Stabulaus, almundarium et Aquense palatium, ubi in capella regis equis suis stabulum fecerunt.

27 MacLean, Response, 33, argues for the preparations of the campaign against Boso in 880, a view we also take. 
continent, ${ }^{28}$ in Lotharingia Lothar II's illegitimate son Hugh had rebelled ${ }^{29}$ and finally, most importantly for the Western realm, Boso had initiated his own coronation at Vienne. ${ }^{30}$ As Simon MacLean argues, the summits that took place between the various rulers from late 879 until June 880-among them three involving the new kings of the Western realm, Louis III and Carloman II-were meant to settle ongoing disputes and coordinate the actions taken against these threats. ${ }^{31}$ The measures decided upon unfolded over the following months: first, Louis III and Carloman II, with the support of forces provided by Louis the Younger, launched an attack on the rebellious Hugh. From there, this united army turned south into Burgundy against Boso where it was joined by Charles the Fat. ${ }^{32}$ Meanwhile, another army was placed under the command of Gauzlin and other nobles to deal with the Northmen who had installed themselves on the Scheldt. ${ }^{33}$ The Annales Vedastini provide a detailed account of this last campaign which reveals that the extent of cooperation in this theatre of war did not differ from that of the others: the attack led Gauzlin and the others deep into Lotharingian territory-hence into Louis the Younger's realm-where they coordinated their actions with the local forces. ${ }^{34}$ United against common enemies, the joint armies operated over the borders of the regna: this is how far the various kings were willing to cooperate, and shows how much importance they attributed to dealing with these threats.

This cooperation continued over the following years. When Charles the Fat left the siege of Vienne early on, he did so with the approval of Louis and Carloman after both sides had sworn oaths, ${ }^{35}$ oaths that probably also included agreements about Charles' succession ${ }^{36}$ and the two brothers' acknowledgment of his claim to the imperial crown. Later, he rejoined the efforts against Boso, sending forces to deal with the remnants of the rebellion. ${ }^{37}$ And when asked by the pope to release Engelberga, the widow of Emperor Louis II who had been imprisoned to prevent her from supporting Boso, Charles pointed out that he needed the consent of Louis and Carloman before doing so. ${ }^{38}$ Meanwhile in the north, as the Annales Fuldenses

28 See chapter V.1.1.

29 Annales Bertiniani 879, 239; Annales Fuldenses (Mainz continuation) 879, 93. On Hugh and his revolt see Hope, Political development, 86-110.

30 Annales Bertiniani 879, 239.

31 MacLean, Response, 34-35. Louis and Carloman participated in the meetings at Orbe towards the end of 879, Ribemont in February 880 and finally Gondreville. For Orbe: Annales Bertiniani 879, 240. For Ribemont: Annales Bertiniani 880, 240-241. For Gondreville: Annales Bertiniani 880, 242-243.

32 Annales Bertiniani 880, 242-243.

33 Annales Vedastini 880, 47.

34 Annales Vedastini 880, 48.

35 Annales Bertiniani 880, 243.

36 MacLean, Response, 35.

37 Annales Vedastini 882, 52. This Bernard mentioned by the annals appears to have been one of Charles the Fat's men. Hlawitschka, Franken, 147-148 and MacLean, Response, 38 with n. 51.

38 MGH Epist. VII, N²68, 236. 
report, Louis the Younger and Louis III held a "fitting meeting" at Gondreville. ${ }^{39}$ Unfortunately, the annals do not give any details about the discussions. Yet, as Simon MacLean argues, the meeting is reported immediately following to the account of the rebellion of Lothar II's son Hugh, thus making it "fitting" if both kings met to coordinate their measures against this new threat. ${ }^{40}$ These numerous signs of intense cooperation also cast some light on an occurrence already mentioned above. When Louis the Younger died, Lotharingian nobles approached Louis III to commend themselves to him. ${ }^{41}$ As we have argued, the western part of Lotharingia had only been temporarily leased to Louis the Younger and was to revert back to the Western realm upon his death. Thus, while it would have been legitimate for Louis III to accept their commendation, he nevertheless refused their offer. Since Charles the Fat had also been involved in the agreement concerning Lotharingia, it seems safe to assume that it had been negotiated that the regnum should not automatically revert to the West, but that Charles should return it publicly, ${ }^{42}$ an act that Louis did not want to anticipate in order to avoid any unnecessary tensions. Fulfilling his side of the bargain, he, nonetheless, appears to have maintained a certain degree of caution. While he did send back the Lotharingian nobles, he also dispatched an army under Count Theoderic of Vermandois, "as if to help them against the Northmen", ${ }^{43}$ as Hincmar writes. His account, strongly biased against Louis III and the nobles surrounding him, ${ }^{44}$ may not be entirely reliable in this case, falsely implying that there were also other motives behind this campaign. Nevertheless, it seems reasonable to assume that Theoderic's intervention was not only meant to aid the Lotharingians, but also to strengthen links with the local nobility and to emphasise Louis' claim on his father's and grandfather's lands.

This episode also reveals the problems attendant on this cooperation between Louis and Carloman. While they profited enormously from the aid provided by Louis the Younger and Charles the Fat in their fight against Boso, it also limited their ability to pursue their own interests when doing so would have threatened the foundations of this same cooperation. These limitations become even more apparent when taking into consideration Hugh the Abbot's attempt to regain Western Lotharingia from Charles for Carloman II, soon after Louis III's death:

39 Annales Fuldenses (Mainz continuation) 881, 96: Rex cum suo nepote Hludowico apud villam Gundolfi congruum habuit colloquium; inde transiens omne tempus aestivum in Baioaria moratus est.

40 MacLean, Response, 35-37.

41 See chapter IV.2, n. 24.

42 This would also explain why Hugh the Abbot, soon after trying to negotiate the return of western Lotharingia to Carloman, reminded Charles the Fat of his promise. Annales Bertiniani 882, 249: A quod placitum Hugo abbas, quibusdam sociis secum assumptis, perrexit pro petitione partis regni quam frater suus Hludouuicus in locarium acceperat, ut, sicut ipse Karolus olim promiserat, Karlomanno restitueret.

43 Annales Bertiniani 882, 246. After Louis had met with nobles from Lotharingia: [Hludouuicus] scaram hostilem, cui praefecit Theodericum comitem, quasi in adiutorium illorum contra Nortmannos disposuit.

44 See chapter II.1. 
reminded of his own promises, the emperor simply played for time by not commiting himself. ${ }^{45}$ For him, cooperation was seemingly less important than it had been for Louis and Carloman, especially since by now Hugh and Boso had been defeated. Carloman, on the other hand, was not only weakened by the resistence of the nobles of the northern part of his realm to his rule, but also at the same time confronted with the Northmen. ${ }^{46}$ Thus, he lacked the power to challenge the emperor and force him to keep his part of the bargain.

\section{IV.3. Structural weaknesses: Odo}

In comparison to his Carolingian predecessors, Odo's dealings with other rulers started under completely different conditions. Whereas Louis the Stammerer and his sons negotiated as equals, at least in rank, Odo's first meeting with Arnulf of Carinthia only took place because the latter summoned him to a placitum. ${ }^{47}$ According to the Annales Fuldenses, Odo "adopted the sensible plan of saying that he would prefer to hold his kingdom in peace by the grace of the king than to rebel in pride contrary to his fidelity, and coming there humbly to the king he was received with grace." ${ }^{38}$ While certainly the exaggeration of an East Frankish source, its message, nevertheless, concords with that of the Annales Vedastini, which adds some more details. They report that Arnulf received Odo honourably at Worms and, after they had concluded an amicitia, Arnulf sent Odo back to his regnum, asking him to forgive those who had come to him. ${ }^{49}$ Both sources agree that Arnulf was the higher-ranking ruler of the two. This superiority in rank was certainly a question of power, as Arnulf was already a well-established ruler; yet Arnulf's Carolingian blood and consequently more legitimate position must also have played a role. $^{50}$

However, this ignores the question of why Odo would so willingly acknowledge Arnulf as a ruler superior to him in rank. When Odo met with the East Frankish ruler, his own claim to the throne was still challenged by Archbishop Fulk of Reims, Abbot Rodulf of Saint-Vaast and Count Baldwin II of Flanders, who had turned to Arnulf, inviting him to come to the Western realm and take the realm

45 See chapter IV.2, n. 42.

46 See chapter II.2 and below.

47 Annales Vedastini 888, 65-66.

48 Annales Fuldenses (Ratisbon continuation) 888, 116: His auditis rex Franciam peciit habitoque ad Franconofurt generali conventu disposuit adventare Wormaciam. Quod vero Odo comperiens salubri utens consilio contestans se malle suum regnum gratia cum regis pacifice habere quam ulla iactantia contra eius fidelitatem superbire; veniensque humiliter ad regem et gratanter ibi recipitur. Rebus ab utraque parte, prout placuit, prospere dispositis unusquisque reversus est in sua. Translation by Reuter, Annals, 116.

49 Annales Vedastini 888, 66.

50 On the strength of Arnulf's Carolingian heritage, see Kasten, Chancen and Becher, Arnulf. See Brühl, Frankreich, 379 on Arnulf's dominating role in post- 888 politics. 
that was lawfully his. ${ }^{51}$ By gaining Arnulf's acknowledgement, Odo was able to eliminate another claimant to the throne and to deliver a serious blow to the faction opposing him. During the negotiations between Odo and Arnulf preceeding the actual meeting, Baldwin abandoned his allies and commended himself to the king, ${ }^{52}$ a clear sign of the success of this strategy. Apart from this, Odo had even more to gain from Arnulf. As his own ascent to the throne rested on military prowess rather than blood and heritage, and his kingship was being challenged by a part of the nobility and external competitors, he needed to strengthen his position by finding other ways to legitimise his claim. Arnulf's Carolingian descent made him a source of legitimation, a source that Odo could use to negate the difference between himself and his Carolingian predecessors. ${ }^{53}$ Just how important Arnulf's acknowledgment was for Odo is further revealed by his second coronation with a crown sent to him by Arnulf. ${ }^{54}$

The extent to which not only Odo but also Arnulf adjusted their mutual relations in accordance with their own necessities is revealed by events during the time of the struggle between Odo and Charles the Simple. In 894, Arnulf agreed to Charles coming to him and acknowledged him as king-something that cost him nothing but allowed him to demonstrate his superiority over a fellow Carolingian king during a time when he needed to strengthen his own position. ${ }^{55}$ This did not mean that Arnulf now stopped considering Odo a legitimate king as well. Similarly, Pope Formosus had accepted Charles' coronation, congratulating him on his elevation. ${ }^{56}$ Yet, at the same time, Formosus also wrote to the bishops of the Western realm, asking them to join Odo, to keep an armistice and to work on the restoration of peace. ${ }^{57}$ If we can have faith in Flodoard's regesta of the archbishop's letters, even for Fulk, Charles' coronation had not deprived Odo of his crown. In a letter to the pope, Fulk spoke of "the conflict which was going on between the kings Odo and Charles." ${ }^{\text {s }}$ While Odo's legitimacy did not suffer by Charles being acknowledged as king, his position nevertheless took a severe blow, as Charles' claim was now sanctioned as legitimate by the dominant Frankish ruler. To make things worse for Odo, Arnulf went even further and now supported Charles openly with Lotharingian forces, ${ }^{59}$ thus shifting the balance of power against Odo and making Charles' side even more attractive for other potential allies.

51 Annales Vedastini 888, 62. See also Flodoard, HRE IV, c. 5, 381.

52 Annales Vedastini 888, 66.

53 For Odo's legitimation and his preference for Carolingian traditions, see chapter I.1.4.

54 Annales Vedastini 888, 67. On the importance of the second coronation, see Guillot, Étapes, 215-217.

55 See chapter I.2.6.

56 Flodoard, HRE IV, c. 3, 374.

57 Flodoard, HRE IV, c. 3, 374.

58 Flodoard, HRE IV, c. 3, 375: Idem quoque presul Folco nonnulla prefato pape preter premissa reperitur direxisse scripta, tam pro sua vocatione, qua vocabatur ab ipso ad sedem apostolicam, quam pro contentione, que versabatur inter reges Odonem et Karolum...

59 Annales Vedastini 894, 74. 
This was undoubtedly the reason why, the following year, Odo obeyed Arnulf's summons to Worms although this meant that he not only would have to acknowledge Arnulf's superiority once more, but that he also ran the risk that Arnulf would try to act as judge over him and Charles, who had likewise been called because Arnulf "wanted to put an end to this misery between them." ${ }^{.0}$ By coming to Worms, Odo risked that the conflict would be settled to his detriment. Odo gambled, but it paid off when Charles did not come to Worms. Bearing generous presents, he "was received honourably and sent back home with delight." ${ }^{61}$ Thus he was able to publicly demonstrate that his own claim to the throne was as valid as Charles' - or maybe even more valid, since Charles had not turned up-and that Arnulf's support for Charles had ended.

The whole affair reveals how vulnerable Odo's position had become and how the internal problems of his rule influenced his relations with other kings. The second meeting between Odo and Arnulf was the direct result of the latter's intervention in the affairs of the Western realm, an intervention that forced Odo to again acknowledge Arnulf's superiority in rank and take an enormous risk that might have severely threatened his position. This vulnerability becomes even more apparent when, after the meeting at Worms, Charles allied himself with Zwentibold, who then intervened in the Western realm. ${ }^{62}$ In contrast to his father, Zwentibold appears not to have been interested in gaining prestige but in gaining territory, for that was promised to him by his new allies. This difference allows us to draw some conclusions about Odo's military strength in comparison to his eastern neighbour. Odo, faced with the alliance between Charles and Zwentibold, withdrew over the Seine, indicating that his forces were not sufficient to challenge his opponents. Soon afterwards, however, Charles' supporters and Zwentibold fell out with each other, leading to Odo's return and Zwentibold's quick withdrawal to his own regnum. Odo was strong enough to deal with an isolated opponent, but not with an alliance between the two.

Thus, Odo's relations with other rulers are revealed to have suffered from two major problems: Arnulf's superior rank and the conflict with Charles. While Odo was at first able to profit from the former by strengthening his own legitimation via Arnulf's acknowledgement, later on this same constellation turned against him when Arnulf recognised Charles' claim as legitimate and allied himself with him. Now it was Odo's Carolingian rival who profited. Moreover, the conflict between Odo and Charles led to Zwentibold's intervention in the Western realm,

60 Annales Vedastini 895, 75: Constricti vero hi qui sequebantur Karolum-nam Odo rex eis quicquid in Francia habuerant tulerat-Burgundiam acriter depopulati sunt. Venitque clamor eorum ad aures Arnulfi regis. Qui missos in Franciam mittens iussit, ut Odo et Karolus ad eum venirent, quatinus tantae calamitatis malum inter eos finiret.

61 Annales Vedastini 895, 75: Odo vero rex strenuis secum assumptis viris ire ad regem perrexit Arnulfum multisque honoribus eum honoravit. Rex vero illum cum honore excoepit atque cum laetitia ad sua remisit, filiumque suum rex Arnulfus in praesentia Odoni regis nomine Zuendebolchum benedici in regem fecit eique concessit regnum quondam Hlotharii.

62 Annales Vedastini 895, 76. 
threatening not so much Odo's rule as the territorial integrity of his realm. This was the exact situation that Louis the Stammerer had feared and tried to avoid with the treaty of Fouron, a situation that is strongly reminiscent of Louis the Younger's intervention in the Western realm, which lead to the loss of the western part of Lotharingia.

\section{IV.4 Possibilities and limits of royal power: Charles the Simple}

As in Odo's case, Charles the Simple's relations with other kingdoms initially aimed at legitimising his claim to the throne by gaining Arnulf's acknowledgement. A number of Archbishop Fulk's letters reveal the problems Charles was facing in this context. In the first one, addressed to Arnulf himself, Fulk expresses his concerns about Arnulf being biased against Charles. ${ }^{63}$ The failure of his endeavour becomes apparent from a second letter, this time addressed to Pope Formosus, asking for his support on the same matter, ${ }^{64}$ while a third one shows that Arnulf had not only refused to come to Charles' aid but even taken a hostile attitude towards his supporters and got his hands on property belonging to the church of Reims. ${ }^{65}$ Yet, while getting Arnulf's acknowledgement was certainly important for Charles, this goal was not the principal factor in their early relations. In contrast to Odo, Charles had a strong claim to the throne based on his Carolingian descent, a claim that was immediately recognised, if not by Arnulf, then at least by the pope who congratulated him on his coronation. ${ }^{66}$ While Arnulf's acknowledgment was very still valuable for Charles, Fulk's letters reveal a second aspect that seems to have carried more weight: the need for the actual material support that Arnulf could provide.

When Arnulf changed course in 894 and invited Charles to come to Worms, this was a great success for the young king, even if, like Odo before and again soon after, he had to acknowledge Arnulf's superiority in rank. The Annales Vedastini's description of this occasion emphasises this factor even more than the East Frankish account provided by the Annales Fuldenses. Seemingly, Arnulf granted Charles his father's regnum. ${ }^{67}$ This phrasing is most interesting since it reveals the complexity of the relations between the two rulers. Firstly, the mention of Charles

63 Flodoard, HRE IV, c. 5, 380-383: Arnulfo regi Transrenensi litteras mittens pro causa regis Karoli, quem parvulum adhuc unxerat in regem, reddit causas eius provectionis eo, quod audierat motum fuisse animum ipsius Arnulfi contra se pro hac perpetratione...

64 Flodoard, HRE IV, c. 3, 375.

65 Flodoard, HRE IV, c. 3, 375.

66 Flodoard, HRE IV, c. 3, 374.

67 Annales Vedastini 894, 74: Arnulfus vero rex benigne suum excepit consobrinum eique regnum paternum concessit adiutoresque ei delegavit hos qui erant ex superiori Francia. Annales Fuldenses (Ratisbon continuation), 894, 125: Wormacia habitum est generale conventum; ibi inter alia Karolus puer indole iuventutis, Hludowici Karoli de occidentali Francia regis filii filius, nepos regis, ad eum veniens, quem rex cum dilectione suscepit et ab solvit. 
receiving his father's realm demonstrates that his claim was independent and not reliant on receiving it from Arnulf. Secondly, the circumstance that Charles received the realm from Arnulf once again underlined the latter's superior position as well as his status as a source of justice and legitimation, the same source that Odo had used five years earlier. Thirdly, the act appears to have created a bond between Arnulf and Charles, requiring Arnulf to impose the judgement he had just spoken. And indeed Arnulf now provided Charles with "helpers" from Lotharingia to aid his cause. The price Charles had to pay for this help was even higher than the acknowledgement of Arnulf's superior rank. As another letter from Fulk reveals, he also had to make a promissio about which nothing further is known. ${ }^{68}$

In the following year, when Arnulf called both Odo and Charles to come to him, Fulk's letter and the reference to this promissio was at first the only response from Charles' side. The reasoning behind this decision was probably that Charles had nothing to gain from the renewal of his public submission under Arnulf and that his independence would be questioned if he obeyed the summons. Only when it became known that Odo had in fact gone to Arnulf did Fulk react, quickly preparing for a journey to Worms, yet losing his baggage with the gifts for Arnulf to Odo, who was already returning to the West. ${ }^{69}$ Fulk's visit was probably meant as a compromise: Charles would again acknowledge Arnulf's superiority, yet lose none of his own prestige by avoiding a meeting in person. In any case, Fulk set out too late, and the assembly of Worms was already over. The winner on this occasion was Odo, whose claim was publicly strengthened by the demonstration of the good relations between him and Arnulf.

Setting aside the fact that Odo's position had been strengthened, the setback for Charles appears to have been only a minor one. While not receiving any more help from Arnulf, he was able to secure an alliance with Zwentibold, who immediately intervened in the Western realm and joined his forces with Charles, forcing Odo to retreat behind the Seine. ${ }^{70}$ Just like Arnulf's, Zwentibold's aid came at a price, in his case in the form of a promise for territorial gains. This again reveals the underlying problem of Charles' relations to other rulers during these years: while his claim was quickly acknowleged, he depended on external aid to actually impose it against Odo. This considerably weakened his position in negotiations, forcing him to make rather large concessions. Furthermore, while he depended on his partners, they could cease their support for him without the risk of losing anything. This was why Zwentibold could plot against Charles during the siege of Laon before retreating to Lotharingia: he had nothing to fear from Charles but could hope to gain even more by strengthening his ties to Charles' other supporters. There was, however, one exception to this rule. In late 895 , after the alliance regnum sibi contradiderat, promisisset manere inconvulsam...

69 Annales Vedastini 895, 75-76; Regino, Chronicon 895, 143.

70 Annales Vedastini 895, 76. 
with Zwentibold had been dissolved and negotiations between Charles and Odo had commenced ${ }^{71}$ Charles met with Emperor Lambert and King Rudolf of Upper Burgundy at Remiremont. ${ }^{72}$ All three of them were under considerable pressure at that moment and in dire need of allies, ${ }^{73}$ so for the first time Charles' position was as strong as his partners'. However, nothing appears to have come from this meeting. This was probably not only due to the fact that none of the three rulers had any forces to spare, but also because Lambert and Rudolf had a different enemy than Charles: Arnulf. Setting aside this outcome, the meeting, nevertheless, points again to another characteristic of Charles' relations to other rulers during these years: that he faced no problems in being accepted as one of them.

\section{Lotharingia}

Charles' major problem during these years, his dependence on external help, was solved the moment he came to an accord with Odo and soon after became the sole ruler of the Western realm. His politics changed immediately: after a request from Reginar Longneck and his allies, he invaded Zwentibold's regnum. ${ }^{74}$ Managing to liberate the besieged Durfos, he marched on Aachen, Nimwegen and Prüm, taking possession of the old Carolingian palaces, ${ }^{75}$ but when faced with Zwentibold's newly gathered forces, he had to conclude an armistice and return home. While the campaign demonstrates Charles' determination to make the most of the opportunities presented to him, it also reveals the limits of his power. The basis of his support in Lotharingia consisted only of Reginar Longneck and his allies, and he was unable to rally more of the local nobility to his cause. Moreover, his own forces were apparently insufficient to challenge Zwentibold's rule over the regnum.

However, the affair did not end when Charles left Lotharingia. Early in 899, Zwentibold met with legates sent by Charles and Arnulf at St Goar. The exact proceedings of the conference are unknown. Regino of Prüm only states that "later events brought more clearly into the light what was discussed at this meeting in private, when the king wasn't present." ${ }^{\prime 76}$ Nevertheless, some observations can be made. Charles' legation consisted not only of his archchancellor Anskeric, but also of Count Odacar, who had fallen out with Zwentibold alongside Reginar. ${ }^{77}$ Odacar's presence points to one of the reasons behind the meeting: the ongoing

71 Annales Vedastini 895, 76 and 77.

72 Liber Memorialis Remiremont, 21, fol. 11v: Karolus rex iuuenis, Lanbertus imperator, Rodolfus rex, Rampo, Vuitbertus, Rotrudis, Adeldrudis, Siifridus, Gotdofridus, Manases, Eldigarius ep., Folco ep., Uuilerius, Lehutaldus. For the dating and identifications, see Hlawitschka, Lotharingien, 147-152.

73 See chapter I.2.6 and Hlawitschka, Lotharingien, 145-155.

74 Annales Vedastini 898, 80-81; Regino, Chronicon 898, 146.

75 Schneidmüller, Lothringenpolitik, 6-7.

76 Regino, Chronicon, 899, 146-147: Zuendibolch colloquium habuit cum optimatibus Arnulfi et Caroli et suis apud sanctum Goarem; ex regno Arnulfi interfuerunt Hattho archiepiscopus, Cuonradus et Gebehardus comites, ex parte Caroli Haschiricus episcopus et Odacar comes. Quid vero in eodem conventu seorsum sine presentia regis pertractatum sit, postea eventus rei luce clarius manifestavit.

77 See also chapter III.2.1.4. 
conflict between the Lotharingian king and the group around Reginar. Charles' being invited to take part in the meeting allows us to conclude that his alliance with Reginar had not ended with his withdrawal from Lotharingia but continued on, and that he was considered as a power in his own right who needed to be involved in efforts to restore peace in the regnum. Charles' actual influence on the proceedings at St Goar is impossible to discern. It would seem that no final peace was made with Zwentibold, as both kings met later that year at Cambrai to make peace. ${ }^{78}$ The conflict between Zwentibold and Reginar and his allies appears to have remained unresolved as well, since the king renewed his attacks on them at Durfos and soon after tried to have them excommunicated. ${ }^{79}$ Finally, it also appears highly unlikely that Charles took part in the negotiations over Zwentibold's future as Regino hints at in his phrasing. ${ }^{80}$ If he had been involved in these secret proceedings, and therefore had known that Zwentibold's fate had already been decided upon, he would hardly have deemed it necessary to conclude a separate treaty with him some time after. Hence, Charles appears to have played only a secondary role at St Goar, a conclusion further emphasised by the location of the meeting on the Rhine, the border between Lotharingia and the East Frankish kingdom, indicating that Zwentibold and Arnulf were the primary participants. For Charles, however, this probably hardly mattered. For him, the situation had changed completely. Now it was he who could take advantage of the others' weakness. While his anwer to Reginar's and his allies' call had brought him no immediate gain, it had not harmed his position either.

Having dealt with Charles' first incursion into Lotharingia, we must now address one of the central questions concerning his reign, his ambitions to add this regnum to his rule. Charles had a long history of relations with this region. During the years of the fight against Odo, Lotharingia had served as a refuge on more than one occasion; in 898, as we just have seen, Charles responded to Reginar's appeal for aid; and in late 911 he finally acquired the regnum. Consequently, scholars have often argued that Charles had a strong ambition to add the lands of his Carolingian ancestors to his realm. ${ }^{81}$ Since these ambitions would have had a major impact on Charles' politics, it seems necessary to reevaluate the arguments on which these conclusions are based and to compare Charles' position in regard to Lotharingia with those of his predecessors.

"Count Reginar, however, went to King Charles and swearing his allegiance to him, he persuaded him and his fideles to invade Zwentibold's realm." ${ }^{2}$ According

78 Annales Vedastini 899, 81.

79 Regino, Chronicon 899, 147.

80 For the connection between Regino's phrasing and Zwentibold's downfall, see for example Hartmann, Lotharingien, 136-137.

81 For example Parisse, Lotharingia, 313; Schneidmüller, Lothringenpolitik, 6-7; Bruand, Francie, 25; Koziol, Politics, 484.

82 Annales Vedastini 898, 80: Ragnerus vero comes venit ad regem Karolum et fidem ei promittens suasit illi atque suis fidelibus invadere regnum Zuendebolchi. 
to this report of the Annales Vedastini and the very similar one composed by Regino of Prüm, ${ }^{83}$ in 898 the initiative for Charles' invasion of Lotharingia lay not with the king, but with Reginar Longneck. Reginar, until that moment one of the most influential nobles at Zwentibold's court, had not only lost his position at the Lotharingian king's side, but also been relieved of his honores and banned from the realm. ${ }^{84}$ That he turned to Charles is hardly surprising for a number of reasons. Relations between Charles and Zwentibold had probably been tense ever since the siege of Laon, when the alliance between the two kings quickly deteriorated before it finally broke over rumours that Charles was to be murdered, ${ }^{85}$ even if Charles was still able to seek refuge within Zwentibold's realm. The tensity of their relation becomes apparent from one of Charles' early diplomas, issued for the abbey of Saint-Mihiel close to Verdun. ${ }^{86}$ In this diploma, at the request of his mother, Charles granted property in the Verdunois and the Charpeigne to the monks. Charles' grant was no more than a confirmation of an earlier diploma of Zwentibold issued about three years earlier at Trosly-Loire, west of Laon, ${ }^{87}$ at the time of Zwentibold's campaign into the West Frankish realm. This can hardly be a coincidence. Given that Zwentibold's diploma was issued either at a time when the two kings were allied or at least shortly after, it is most likely that Charles knew of the earlier grant. The monks of Saint-Mihiel had nothing to gain from a second grant of the same property made by a king who was not even their ruler. On the other hand, for Charles the issuance of the diploma made sense. By doing so, he could send Zwentibold a message that the events of Laon had not been forgotten and also that he was able to lure Zwentibold's supporters from his side, just as the Lotharingian king had done with Charles' allies Reginar and Baldwin. SaintMihiel's cooperation on this occasion can be easily explained: its abbot, Stephen, had strong ties not only to Charles himself, being related to him by marriage, ${ }^{88}$ but also to Archbishop Fulk, with whom he appears to have cooperated to become bishop. ${ }^{89}$ When Reginar sought aid against Zwentibold outside of Lotharingia, he could not only point to his earlier marriage to Charles' sister-a rather weak argument, given that she had already died and that he had abandoned Charles at Laon-he could also count on their common enmity towards Zwentibold.

While Charles' motives for invading Lotharingia can be partly sought in the fallout from events at Laon, his actions also reveal that he intended to make the most out of the opportunity presented to him by the invitation of Reginar and his allies. According to Regino, he marched to Aachen, then to Nijmegen before

83 Regino, Chronicon 898, 146: Rege ab obsidione recedente prefati comites Carolum adeunt et eum cum exercitu in regnum introducunt.

84 Regino, Chronicon 898, 145. On Zwentibold's turn against Reginar see Beumann, Kurswechsel.

85 Annales Vedastini 895, 76.

86 DChS 11 (13th February 898).

87 DZ 3 (14th August 895).

88 In DChS 81, 181, Stephen is adressed as nostre consanguinitati affinis dilectissimi by Charles, indicating him being a relative by marriage.

89 Flodoard, HRE IV, c. 7, 396. 
finally turning to Prüm. ${ }^{90}$ By taking control of the old Carolingian palaces, especially the one at Aachen, which was so closely associated with Charlemagne and Louis the Pious, ${ }^{91}$ he could legitimate his claim to rule over Lotharingia. ${ }^{92}$ His position in the regnum, however, appears to have been rather isolated and limited to his alliance with the group around Reginar. The rest of the Lotharingian nobility seems to have either remained loyal to Zwentibold who was able to muster sufficient force to confront Charles and bring about an armistice; ${ }^{93}$ or to have been oriented towards the East Frankish realm. ${ }^{94}$ This becomes apparent at the meeting of St Goar during the following year when Charles, as we have argued above, was not included in the negotiations between the Lotharingian nobles and Arnulf's legation concerning the deposition of Zwentibold. Charles' retreat to the West and the subsequent treaty of Cambrai hence appear as the result of a realistic assessment of his overall position in the regnum, leading to the conclusion that there was nothing to gain for the moment. This assessment probably also influenced his decision not to intervene in Lotharingia when the local nobles turned away from Zwentibold. When Zwentibald's downfall had been decided upon at St Goar, it is likely that the future course of the regnum and its allegiance to the East Frankish ruler also had been determined at that moment. ${ }^{95}$

Regrettably, we lack corresponding narrative accounts for 911, the year when Charles finally acquired Lotharingia. Only the Annales Alemannici report that during this year, the leading Lotharingian nobles broke away from Louis' reign, which, since the annals note Louis the Child's death only in 912, seems to indicate that the Lotharingian nobles might have renounced Louis the Child as their king even before his death on 24th September $911 .{ }^{96}$ Whether this was the case or not, over a month appears to have passed until the question of succession was resolved. The Annales Prumienses note the 1st November as the start of Charles' rule over

90 Regino, Chronicon 898, 146.

91 On the importance of Aachen, see Falkenstein, Pfalz and Margue, Nous, 416-417.

92 Schneidmüller, Lothringenpolitik, 6-7.

93 Regino, Chronicon 898, 146.

94 Archbishop Ratbod of Trier originated from an Alemannian family, as did Bishop Robert of Metz while Bishop Baltram of Strasbourg came from Bavaria. The archbishop of Cologne was highly involved in the East by trying to incorporate the bishopric of Bremen into his archdiocese. Additionally, several counts appear to have had interests across the border: Count Burchard, who had married Megingaud's widow, appears to have held counties in both realms while the Matfrids held possessions in the Speyergau. Hlawitschka, Lotharingien, 182.

95 Hauck, Ottonen, 49 and Hartmann, Lotharingien, 137 emphasise the influence of the Konradiner family over the future course of Lotharingia at this moment.

96 Annales Alamannici 911 and 912, 55: Hlotharium principes a Hludovico rege divisi. Parisot, Royaume 578-579, Sproemberg, Politik, 125-126, Mohr, Geschichte, 15 and Brühl, Deutschland, 399-403 argue for a moment only after the death of Louis. Hlawitschka, Lotharingien, 196-198, Schneidmüller Lothringenpolitik, 9-10, Bund, Thronsturz, 497 and Bauer, Lotharingien, 16, who we follow here, argue for a Königsverlassung despite the unreliability of the Annales Alamannici. Eckel, Charles, 94 gives the period from June to September 911. 
Lotharingia, ${ }^{97}$ which coincides with the time frame between 10 th October and 27 th November deduced by Philippe Lauer based on an analysis of Charles' diplomas; ${ }^{98}$ while Conrad's coronation at Forchheim only took place between (probably) 7th and 10th November. ${ }^{99}$ However, Charles only arrived at Metz 1st January 912, ${ }^{100}$ so over three months after Louis' death and two after he had become king of Lotharingia. For example in 869 , Charles the Bald had quickly reacted to Lothar II's death 6th August 869 at Piacenza and arrived at Metz already 5th of September. ${ }^{101}$ Charles the Simple, it would seem, was simply not prepared to move towards the east, indicating that he was rather surprised by the events and hence was not directly involved in them.

Lotharingia submitting to Charles' rule at that point indicates that some major changes had taken place since the earlier period. The first change was the rise of Reginar Longneck, who had become the most influential noble within Lotharingia over the course of Louis the Child's reign. ${ }^{102}$ His rise had been directly tied to the death of Count Gebhard, who had been described by one of Louis' diplomas as $d u x$ of Lotharingia, ${ }^{103}$ a rise that undoubtedly brought him in conflict with Gebhard's family, the Konradiner, the family dominating the circle around the East Frankish king. ${ }^{104}$ In this conflict, Reginar was joined by the Matfrid family, whose attempt to extend their influence in Lotharingia had been thwarted by Louis and his allies. ${ }^{105}$ Two of the three major factions within the regnum would hence not support the succession of Conrad, ${ }^{106}$ and the third, the church of Trier, remained hesitant. Furthermore, a number of changes in important positions had taken place. At Liège, one of Charles' relatives, Stephen, ${ }^{107}$ had become bishop. The latter, formerly abbot of Saint-Mihiel, had also been close to the Matfrid family, ${ }^{108}$ a connection he now undoubtedly brought into Charles' new network. ${ }^{109}$ In ad-

97 Annales Prumienses, 1292, mistakenly recording Louis instead of Charles: Eodem etiam anno Ludowicus rex regnum Lotharii suscepit Kal. Nov. Becher, Von den Karolingern, 254 speaks of an "open situation."

98 Lauer, Recueil Charles, LXXXVI.

99 Brühl, Deutschland, 399 and 403 with n. 298.

100 DChS 69. DDChS 67 and 68 (20th December 911) give a villa Cruztiaco, which probably was located in Alsace or the Saarland. See Kienast, Vasallität, 520.

101 Annales Bertiniani 869, 156-157.

102 On these developments, see chapter III.2.1.4.

103 DLCh 20, 126: ... Kebehart, dux regni qui a multis Hlotharii dicitur...

104 On their position, see Offergeld, Reges pueri, 547-555.

105 Parisot, Royaume, 569; Hlawitschka, Lotharingien, 191.

106 On Conrad's succession, see Becher, Von den Karolingern, esp. 254-255. According to him, Conrad was elected since he was a member of the dominating group.

107 DChS 81, 181: Interventu Stepheni venerabilis Tungrorum episcopi, nostre consanguinitati affinis delectissimi.

108 DLCh 57, 184, names Stephen ipsius [Count Gerhard] proximus affini, pointing to a kinship by marriage between him and the Matfrid family.

109 The earliest contact between Charles and Stephen is probably marked by DChS 65 for the church of Liège, dating to 912-915 (against Lauer (911-915) and Font-Réaulx, Diplômes, 43 (912-913). The diploma using the rex Francorum, yet without the vir illustris, it probably dates after 12th April 912, the last time the rex Francorum, vir illustris is preserved. Why Font-Réaulx would 
dition, Bishop Dodilo of Cambrai who had always followed a more independent policy ${ }^{110}$ and supported Zwentibold against Charles, ${ }^{111}$ had been succeeded by another Stephen. This new bishop was seemingly more cooperative, being among the first to receive a diploma from Charles. ${ }^{112}$ Stephen of Cambrai also represents yet another group of nobles who had earlier on belonged to Zwentibold's network but then lost their influence under Louis the Child's reign-nobles that now joined Charles' side. ${ }^{113}$

Hence, within Lotharingia there were a number of factions that would opt for Charles for different reasons: rivalry with the Konradiner, personal relations with Charles, dissatisfaction with their own influence at court. These different factions prepared the field for Charles and provided him with the support necessary not only to take over the rule, but also to defend it against the Konradiner attempts to regain control over the regnum or at least over some of its parts. Two of these attempts can be traced by the Annales Alamannici: a first encounter between the two kings appears to have taken place close to Strasbourg, where Conrad issued a diploma in March 912, ${ }^{114}$ when both kings seem to have concluded a treaty. ${ }^{115}$ However, since the annals refer to a breach of faith around the same time, this treaty appears not to have lasted long and was followed by an attack of Conrad on Aachen. ${ }^{116}$ Meanwhile, at Strasbourg a strong pro-Carolingian party appears to have existed-maybe the reason why Conrad had moved there: to maintain control over the city. With Conrad's absence from Strasbourg, Charles' allies in the south appear to have become active, attacking and devastating the city, ${ }^{117}$ albeit without being able to hold it: Conrad returned there in March 913. ${ }^{118}$ Nevertheless, within Strasbourg, the pro-Carolingian party seems to have won the upper hand. After the inhabitants had killed Bishop Otbert, they elected Charles' nephew Gauzfrid. ${ }^{119}$ Gauzfrid died soon after and was replaced with Ricuin, a Lotharingian noble who in 916 at the synod of Hohenaltheim, while himself being absent, was

consider 913 to be the latest possible year during which the diploma was delivered is not clear. 915 corresponds with the year of Reginar Longneck's death at whose request the diploma was issued).

110 See Archbishop Fulk's remarks against him. Flodoard, HRE IV, c. 6, 390 and 392.

111 DZ 23. See also Schieffer, Kanzlei, 32 and Bauer, Lotharingien, 106. Bauer refuses Schieffer's assumption that the diploma reflects Dodilo's aid for Zwentibold against Charles, but agrees on it being aimed against the king of the Western realm.

112 Vercauteren, Note, 102. Vercauteren also brings forward the hypothesis that it was Charles who installed Stephen on the siege of Cambrai. While this may indeed be possible, considering that Cambrai was part of the archdiocese of Reims, it cannot be further proven.

113 See chapter III.2.1.4.

114 DKoI 5.

115 Annales Alamannici 912, 188: Karolus in Alsatia et Chonradus in Hlodarios et facta fide ficta Chuonratus in Hlodarios iterum usque ad Aquas et Hlodariique in Argentinam civitatem eaque vastata et conbusta est.

116 Annales Alamannici 912, 188.

117 Annales Alamannici 912, 188.

118 DKoI 17 and Annales Alamannici 913, 190: Iterum Chuonradus cum exercitu regnum Hlutharingorum ingressus est.

119 Dümmler, Geschichte III, 593 with n. 1. 
accused by Conrad's supporters of being elected uncanonically, ${ }^{120}$ which seems to indicate that he as well prefered to side with Charles. ${ }^{121}$ The loss of Strasbourg also marked the end of Conrad's efforts to regain control over at least parts of Lotharingia. It is clear that local support played a central role in Charles' success in taking over and defending Lotharingia.

However, the question remains as to whether Charles pursued an active policy to influence conditions in his favour. Given the lack of narrative accounts, we have to rely on the reconstruction of the chronology to draw any conclusions. As we have seen, a rather long period of time passed between Louis' death and Charles' arrival in his new regnum, indicating that he was not prepared to act quickly. This is not to say that Charles was not using his contacts within the Lotharingian nobility to influence their decision in his favour, yet, nevertheless, the initiative appears to have lain with the nobles, not with him. ${ }^{122}$

The events of 898 and of 911 follow the same pattern: Lotharingian nobles approached Charles and offered him the rule over the regnum, a call to which Charles reacted positively, ready to defend his claim. The circumstance that the nobles took the initiative does not mean that Charles did not carry any ambitions towards Lotharingia, however. Quite the contrary, the nobles turning to him was undoubtedly due to the fact that they expected a positive response from his side. However, the question is how grand his ambitions actually were. In this context, a number of arguments have been brought forward. Based on Charles' itinerary and the number of Lotharingian nobles in his diplomas after the acquisition of the regnum, it has been assumed that Charles felt a deep attachment to the lands of his ancestors. ${ }^{123}$ This seems problematic for two reasons. First, how, based on the sources we have, can we distinguish between sojourns and contacts motivated by personal attachment and those necessitated by political circumstances? Second, as we have argued in the previous chapter, setting aside the times when those stays were definitely due to political necessities, contacts with Lotharingia appear to been on a reasonable level, while those with nobles from the Western realm remained stable. ${ }^{124}$

Another argument is based on the genealogy dictated by Charles to the canons of Saint-Corneille of Compiègne ${ }^{125}$ According to Geoffrey Koziol "its details are unmistakably oriented to Charles' Lotharingian aspirations. Thus, while not-

120 MGH Conc. VI, N 1, 34. According to Fuhrmanns commentary (MGH Conc. VI, 1-2), it appears that the Frankish and Swabic bishops dominated the synod of Hohenaltheim. See also Büttner, Heinrich, 10-11.

121 On these events, see Bührer-Thierry, Évêques, 191-194.

122 See also Eckel, Charles, 94, Parisot, Royaume, 576-581 (who argues that the Lotharingian nobles saw in Charles the last Carolingian and therefore their legitimate king), Sproemberg, Politik, 125; Büttner, Heinrich, 10 and Mohr, Geschichte, 15. Only Büttner, Geschichte, 147 sees the initiative on Charles' side.

123 Schneidmüller, Lothringenpolitik, 12-13.

124 See chapters III.1.1, III.2.1.5 and III.2.1.6.

125 Witger, Genealogia. 
ing all Louis the German's sons, it only traces the descent of Carloman, through whom Lotharingia passed via Arnulf to Zwentibold and Louis the Child. Further attesting to Charles' insistence on legitimacy, it also notes Zwentibold's illegitimacy."126 While the genealogy indeed only follows Carloman's lineage and ignores the offspring of Louis the German's other sons, this has nothing to do with any Lotharingian aspirations on Charles' side. Indeed, there is a far simpler explanation for why the genealogy is constructed the way it is: it is focused on the West Frankish lineage, which is described in large detail, naming all the offspring of the successive rulers including the names and titles of their mothers. All the other lineages only name those sons who were crowned rulers, ignoring daughters and illegitimate children. ${ }^{127}$ Also, while the genealogy does mention Zwentibold's birth by a concubine-indeed revealing Charles' sense of legitimacy-this is hardly a sign that he claimed Lotharingia. By naming Zwentibold, Charles added him to those he acknowledged not only as belonging to the family, but also as a legitimate ruler.

In the context of Charles' Lotharingian ambitions, Koziol furthermore points to the names of Charles own illegitimate offspring, his sons Arnulf and Drogo, both carrying names "distinctive to the Lotharingian side of his family." 28 Both names certainly have a Lotharingian touch, as their first bearers had been Arnulf, the Carolingian progenitor, and Drogo, an illegitimate son of Charlemagne, both of whom had been bishops of Metz. However, in both cases there are alternative readings. According to Karl Ferdinand Werner, of seventeen illegitimate sons of Carolingian rulers, four were called Arnulf, three Hugh and two Drogo, while all other names only appear once. ${ }^{129}$ While there certainly were other potential choices, as is shown by the name of Charles' third son, Rorico, Arnulf in particular appears to have been a far too common choice of name to use as an argument for Lotharingian aspirations on Charles' side. In the case of Drogo-his name being rather uncommon-it is worth pointing out another possible reason. The first bearer of this name was bishop of Metz and one of Louis the Pious most important advisors $^{130}$ and it might have been that Charles hoped for his illegitimate son to occupy a similar role under his own, yet unborn, heir, ${ }^{131}$ although this has to remain mere speculation.

While the sources thus do not provide any further insight into Charles' actual ambitions, it is worth comparing his endeavours to acquire Lotharingia with those of his brothers. As we have noted above, the western part of the regnum,

126 Koziol, Politics, 480 with n. 84.

127 See chapter III.1.3.

128 Koziol, Canons, 176 and Koziol, Politics, 480 and 484.

129 Werner, Nachkommen, 418.

130 On him, see Pfister, Drogon, and Depreux, Prosopographie, 163-167.

131 Becher, Arnulf, 667, concerning Charles the Bald's choice to name one of his twins by Richilde Drogo. 
which Charles the Bald had acquired for himself in the treaty of Meersen, ${ }^{132}$ had fallen to Louis the Younger in the wake of his intervention in the Western realm. On two occasions, these sons made efforts to regain control of this area which had apparently been intended to revert to them upon Louis the Younger's death. ${ }^{133}$ Louis, on the one hand, refused the Lotharingian nobles who were trying to commend themselves to him, but, on the other hand, sent an army to the regnum under Count Theoderic of Vermandois, one of his most important advisors, supposedly to protect Lotharingia from the Northmen. This, however, was probably not the only reason. By showing his face in Lotharingia and demonstrating his willingness to act in a royal manner by fighting the Vikings, he ensured that his claim on his father's part of Lotharingia remained visible. While he did not want to jeopardise the cooperation established between the various Carolingian rulers by acting without the consent of the new East Frankish ruler, Charles the Fat, he nevertheless betrayed his ambition to regain the lost territory. After Louis' death, it fell to his brother Carloman to secure his father's heritage. Under his rule, Hugh the Abbot sought out Charles the Fat to remind him of the treaty his father had concluded and to have the western part of Lotharingia returned to him. Like Charles the Simple, his brothers Louis and Carloman had strong ambitions to re-acquire parts of Lotharingia. In the light of these earlier developments, it even seems possible that the new addition to the dating clauses of Charles' diplomas, the largiore vero hereditate indepta ("attaining [his] larger inheritance"), did not so much refer to a general claim based on him being the last remaining Carolingian king, but rather to a very specific one, based on the fact that at least the western part of Lotharingia had belonged to his father and should never have remained part of the East Frankish realm. This is of course highly speculative, yet given Charles' highly developed sense for history and legitimacy ${ }^{134}$ it may not be too far fetched to assume that these thoughts may have played a role in the creation of the dating formula. Be that as it may, Charles appears to have carried the same ambitions as his brothers, the main difference being the means he was able and willing to use.

\section{The treaty of Bonn}

As with Lotharingia, the context of Charles' ambitions also plays a central role in the assessment of his last treaty ${ }^{135}$ with another ruler, Henry the Fowler, the treaty of Bonn concluded in November 921. The text of the treaty itself, preserved in the West Frankish version, ${ }^{136}$ is rather short, consisting of only four chapters. The first

132 MGH Capit. II, N² 250, 191-192.

133 See chapter IV.2.

134 Koziol, Politics, e.g. 479-481 and 498.

135 While it is difficult to imagine that Charles did not meet other rulers between 899 and 921, the few sources we have remain silent.

136 MGH Const. I, Nº 1, 1-2. 
of them gives the time and place of the meeting, the second and third the reciprocal promises of an amicitia between the two kings, and the fourth names the witnesses. Very much like the meeting at Cambrai, the meeting at Bonn-actually on the Rhine itself-was at the border between the regna of the rulers, demonstrating the equality of Charles and Henry. This equality is also portrayed in the text itself, addressing both kings with very similar titles: Charles is the domnus et gloriosissimus rex Francorum occidentalium, Henry the domnus et magnificentissimus rex Francorum orientalium, which emphasises that both rulers were considered as Frankish kings of the same rank. ${ }^{137}$ This negation of the difference between the Carolingian Charles and the non-Carolingian Henry has often been interpreted by scholars as a "defeat" for Charles who, by this treaty, would have had to give up any plans of restoring the old Frankish empire, as well as the claim of being superior to his East Frankish neighbour. ${ }^{138}$ This reading depends on two assumptions: that Charles indeed attempted to extend his realm in the east and that he did not acknowledge Henry as his equal.

In this context, Charles' new title after the acquisition of Lotharingia has often been read as a sign of his imperial ambitions, with the rex Francorum expressing not only his claim on Lotharingia, but also on the Eastern realm. ${ }^{139}$ Herwig Wolfram, on the other hand, pointed out that rex Francorum might indeed have had a different meaning. According to him, rex Francorum drew its meaning much less from Charlemagne than from the union of the old Carolingian core lands between Seine and Rhine, Francia. Read in this context, the new title would hence not express a claim on the Eastern realm but a "voluntary self-restraint." 140 Given the ambiguity of the new title, it is best to analyse whether Charles made any efforts to extend his rule over the East Frankish realm. Two episodes are most revealing about this issue. After the acquisition of Lotharingia, Charles successfully managed to install his own candidate in the see of Strasbourg, thus securing the city against Conrad $\mathrm{I},{ }^{141}$ a policy that has been read as a sign that he attempted to add

137 See also Ehlers, Anfänge, 30-31.

138 Voss, Herrschertreffen, 47, Schneidmüller, Lothringenpolitik, 17 ("Insgesamt gesehen war der Bonner Vertrag eine Niederlage Karls, der trotz hervorragender Titel Heinrich I. und seinen linksrheinischen Besitz anerkennen musste”), Brühl, Deutschland, 434.

139 In different degrees Tellenbach, Tradition 191; Schieffer, Rheinische Lande, 12-13; Folz, Idée, 54-55; Mohr, Geschichte 15-16; Schneidmüller, Tradition, 132-134; Werner, Origines, 450; Brühl, Deutschland, 161; Bauer, Lotharingian; 17, Jarnut, Konrad, 270 and Schneider, Suche, 120. Ehlers, who first also followed this interpretation (Ehlers, Tradition), more recently promoted a different view. Ehlers, Geschichte, 21-22 and Anfänge, 26-27.

140 Wolfram, Herrschertitel, 123-124 and Ehlers, Anfänge, 26-27 and Geschichte, 21. On the various possible meanings of Francia see Brühl, Deutschland, 83-130, who provides a detailed study of the sources and also offers an overview of older studies. On the longevity of the usage of Francia for Lotharingia, see Ewig, Beobachtungen, 349-356; Goetz, Perception, 122 and Margue, Nous, 397. As Lugge, Gallia, 55-56 has shown, Lothar II and Zwentibold were sometimes addressed as rex Francorum. Similar also Margue, Nous, 398, for Otto I and Henry II.

141 See above. 
Alsace, belonging to the East Frankish realm, to his rule ${ }^{142}$ However, Alsace was one of the "Bruchlinien" mentioned by Jens Schneider, ${ }^{143}$ a region on the border between Lotharingia and the East whose status was ambiguous. ${ }^{144}$ Charles' efforts to gain control over this region were hence based on a maximalist interpretation of the borders of Lotharingia and were not an endeavour to extend his rule over the East Frankish realm.

The second episode directly preceeds the treaty of Bonn and sees Charles attacking in the area of Worms. According to the continuator of Regino's chronicle, Charles, by this attack, wanted to usurp Alsace, the parts of Francia along the Rhine, and Mainz. ${ }^{145}$ The reliability of this account seems problematic. He misdates the event to 923 and fails to put the attack in its proper context by claiming to have had insight into the king's motivation for the attack. In fact, Charles' campaign was only the response to a preceeding intervention by Henry in Lotharingian affairs. When Charles advanced against Reginar Longneck's son Gislebert in late 919, according to Richer of Saint-Remi, the latter fled to Henry's court. ${ }^{146}$ It seems safe to assume that early in 920, when Charles had been abandoned by the West Frankish counts, Henry supported Gislebert's return to Lotharingia. During the same time he was furthermore involved in the succession of Liège, where, as Charles' letter to the bishops of the realm claims, he pressured Archbishop Hermann of Cologne into ordaining Gislebert's ally Hilduin as bishop. ${ }^{147}$ Hence, Charles' advance against Henry was hardly due to an ambition to extend his rule over the East Frankish realm but a reaction to Henry's attempts to increase his influence within Lotharingia during a moment of Charles being vulnerable. This is of course not to say that Charles might not have harboured any hopes to do so and, given how he acquired Lotharingia. ${ }^{148}$, it seems indeed highly likely that if such an opportunity had presented itself to him he would have seized it. Yet, despite any claims indicated by his new title, his actual policies do not betray any claims over more than Lotharingia.

The very circumstance that Charles made no attempt to extent his rule to the East does not mean that he did not claim a superior status to Henry based on his Carolingian heritage. As we have argued in the previous chapter, ${ }^{149}$ Charles possessed a strongly developed sense of legitimacy when it came to his own family, yet this same sense did not carry over into a special emphasis of his heritage

142 Schneidmüller, Lothringenpolitik, 14-1,5 n. 105.

143 Schneider, Suche, 108. See chapter III.2.1.4.

144 See also Zotz, Elsass.

145 Continuatio Reginonis 923, 157: Karolus Alsatiam et partes illas Franciae iuxta Rhenum usque Mogontiam sibi usurpaturus usque Paternisheim villam iuxta Wormaciae hostiliter pervenit. Unde fidelibus regis Heinrici Wormaciae coadunatis aliter, quam decuerat regem, aufugit. Charles' attack in the vicinity of Worms is also confirmed by Flodoard, Annales 920, 3.

146 Richer, Historiae I, c. 37-38, 71-73.

147 MGH Conc. VI, N² 2, c. 2, 45.

148 See below.

149 See chapter III.2.1.4. 
within royal diplomas in comparison to those of his predecessors. To determine how Charles perceived the non-Carolingian Henry, it is best to evaluate the ways Charles dealt with other non-Carolingian rulers before the treaty of Bonn. As we have seen, Charles had already allied himself with two of these rulers during the years of his fight against Odo, Emperor Lambert of Spoleto and Rudolf of Upper Burgundy. The entry made at Remiremont records Karolus rex iuuenis, Lanbertus imperator and Rodolfus rex, making, apart from the emphasis on Charles' youth, no distinction between the three rulers. ${ }^{150}$ Furthermore, Charles' contact to Emperor Berengar needs to be mentioned. A letter from Pope John X to Archbishop Hermann of Cologne concerning the succession at Liège indicates that Berengar intervened for Charles' candidate Richer in front of Pope John X, ${ }^{151}$ most probably at Charles' request even if the letter itself fails to mention this circumstance. ${ }^{152} \mathrm{Be}$ rengar was a logical choice if Charles wanted someone to represent his interests at the papal court. John and Berengar entertained good relations with each other that had already resulted in an alliance between the two probably in late 914 and Berengar's coronation as emperor by the pope a year later. ${ }^{153}$ By the time of the dispute at Liège, both cooperated against a certain Hubert who appears to have been in conflict with the church of Rome. ${ }^{154}$ Berengar as a son of Louis the Pious' daughter Gisela ${ }^{155}$ had Carolingian blood himself, yet in how far this influenced the relation between him and Charles stands open to debate-he does not appear in the genealogy of the Carolingians dictated by Charles to the canons of Compiègne. ${ }^{156}$ In any case, Berenger intervening in favour of Charles' candidate indicates that the two of them were probably also on good terms with each other. Nothing further is known about this contact, yet it seems reasonable to assume that Berengar's lack of a Carolingian father again did not considerably determine their relation. Finally, Charles' handling of his own non-Carolingian predecessor Odo needs to be taken in consideration. As mentioned, there are only four mentions of Odo in Charles' diplomas, in addition to a number of dating clauses early in his reign reading in successione Odonis ("in succession to Odo"). ${ }^{157}$ Three of these mentions are confirmations of diplomas issued by King Odo (Odo rex $)^{158}$ while the fourth is to include Odo in a memorial service ordered by Charles. ${ }^{159}$ While some of these mentions were most likely due to the influence of Odo's brother Robert, at least on one occasion Charles confirmed one of his predecessor's diplomas without Robert

150 Liber Memorialis Remiremont, fol. 11v, 21.

151 MGH Conc. VI, N³, letter A, 54.

152 Zimmermann, Streit, 26.

153 Zimmermann, Papstregesten, $\mathrm{N}^{\circ} 33,11$ and $\mathrm{N}^{\circ} 38-40,13$.

154 MGH Conc. VI, N³, letter B, 56.

155 On Berengar's family and career, see Feller, Exercice, 130-132.

156 Witger, Genealogia.

157 DDChS 13, 14, 19, 20 and 22-26.

158 DDChS 60, 75 and 105.

159 DChS 49, 109: ...et ipsa die in memoriam nostri et Odonis regis atque Rotberti praedecessorumque eorum... 
being present. ${ }^{160}$ The Remiremont entry, Charles' dealing with Berengar as well as his diplomas hence show no signs of Charles claiming any kind of superiority over non-Carolingian rulers. Charles dealing with Henry the Fowler as a peer seems to be in line with his general policy.

With the reading of the treaty of Bonn as a defeat for Charles dismissed, a new assessment based on the political circumstances can be attempted. For Charles, the treaty came at the end of a development which had started with the confrontation with the Western nobles at Soissons in early 920. After they had finally come to a settlement, he moved to Lotharingia, coming to an accord with Count Gislebert, who had taken the opportunity to have himself elected princeps in Charles' absence. Charles then went on to attack Worms which was, according to Regino's continuator, a futile attempt. The following year saw Charles active in Lotharingia again, neutralising Gislebert's ally Count Ricuin of Verdun before concluding a truce with Henry. ${ }^{161}$ In the context of the unresolved conflict with Gislebert and his allies - shortly after the treaty of Bonn Charles again attacked the count ${ }^{162}$ the amicitia with Henry gains new importance. First, Henry acknowledged that Lotharingia was under Charles' rule, ${ }^{163}$ thus securing the regnum from further incursions of the East Frankish king. Second, Charles undercut Gislebert's alliance with Henry by making his own alliance with the East Frankish king. ${ }^{164}$ The treaty of Bonn, despite lacking any precise agreements about further cooperation, considerably increased Charles' room for manoeuvre, allowing him to pursue an aggressive policy against Gislebert. Similarly, the treaty also allowed Henry to concentrate on his unresolved internal problems with Burchard of Swabia and especially Arnulf of Bavaria, who had not yet acknowledged Henry as king. ${ }^{165}$ However, the treaty should not be reduced to a mere tactical measure for both sides. Charles and Henry did indeed intend to cooperate on a wider scale. In 922, a synod assembled at Koblenz, organised by the two kings. ${ }^{166}$ With Coblenz being located within Lotharingia, it seems that originally an assembly far larger than the one that actually took place had been intended, for only Archbishop Hermann of Cologne was present from Charles' side. By the time of the synod, the rebellion of the West

160 DChS 60 for Notre-Dame de La Grasse.

161 We turn to these conflicts in detail in chapter VI.2.

162 Flodoard, Annales 922, 7.

163 Brühl, Deutschland, 434.

164 On the bond created by an amicitia, see Althoff, Amicitia and Epp, Amicitia.

165 Büttner, Heinrich, 18-20.

166 MGH Conc. VI, N 4, 57-74, here 68: Anno dominicae incarnationis DCCCCXXII apud Confluentiam iussu venerabilium principum, Karoli videlicet et Heinrici regum reverentissimorum, congregati sunt episcopi numero VIII: Herimannus Agrippinae archiepiscopus, Herigerus Mogontiae archiepiscopus, Thiado Wirziburgensis, Liutharius Mimidanensis, Dodo Osnebruggensis, Richgauwo Wormaciensis, Rihwinus Strazburgensis, Vnwano Paderbrunnensis cum abbatibus aliisque sacri ordinis viris quam plurimis. 
Frankish nobles had probably already commenced, so that Charles and his allies' focus was drawn away from the meeting. ${ }^{167}$

However, this rebellion also demonstrates the limits of the new cooperation between the two kings. Some time after Robert's coronation, he and Robert met at the Ruhr, in turn concluding an amicitia. ${ }^{168}$ In the wake of this amicitia, it is probable that an entry in the Liber Memorialis of Remiremont was created, featuring not only Robert and Henry, but also King Rudolf II of Upper Burgundy, ${ }^{169}$ which demonstrates how quickly Robert's kingship was acknowledged by other rulers and reveals how well he was connected even beyond the borders of the West Frankish realm. Karl Schmid, based on a number of other entries in the Liber Memorialis, has managed to cast some light on the background of this amicitia. In the wake of the death of a certain Count Guntram 25th December 921, a considerable number of nobles from the West and East Frankish realms as well as Lotharingia appear to have met at Remiremont to memorate the deceased. Among these nobles, Schmid identified not only Robert's son Hugh the Great, but also the sons of Richard the Justiciar as well as members of the Konradiner and other important East Frankish noble families. ${ }^{170}$ If Schmid's identifications are correct, Robert possessed influential allies at Henry's court, most importantly members of the Konradiner family. ${ }^{171}$ The Konradiner in turn, as we have seen, had lost their leading position in Lotharingia when it had fallen to Charles ${ }^{172}$ and it seems likely that they now mediated between Henry and Robert to loosen the West Frankish control over the regnum. However, the strength of this network should not be overemphasised either. Henry did not come to Charles aid, although, according to Widukind, the latter had asked him for his support, sending him a relic of Saint Dionysos after the lost battle of Soissons, ${ }^{173}$ probably a reference to the treaty of Bonn where they had sworn their oaths on relics. ${ }^{174}$ Yet, neither did Henry intervene on Robert's behalf. Thus, Henry's treaty with Robert is strongly reminiscent of Arnulf acknowledging both Odo and Charles as rulers and in fact the amicitia between the two may

167 MGH Conc. VI, N $4,57-58$.

168 Flodoard, Annales 922, 12. On the identification of the river with the Ruhr, see Büttner, Heinrich, 26, arguing for a meeting at the border between Lotharingia and the East Frankish realm.

169 Liber Memorialis Remiremont, fol. 6v, 9: ... Einricus rex ... Ruodulfus rex ... Ruotbertus rex...

170 Schmid, Quellen, 130-138.

171 Schmid, Quellen, 132 and 136.

172 Chapter III.2.1.5.

173 Widukind, Res gestae I, c. 33, 45-46: Quando vero rex Renum transierat ad dilatandum super Lotharios imperium suum, occurrit ei legatus Karoli, et salutato eo verbis humillimis: 'Dominus meus', inquit, 'Karolus, regia quondam potestate preditus, modo privatus, misit me ad te demandans, quia nichil ei ab inimicis circumvento iocundius, nichil dulcius esse possit quam de tui magnifici profectus gloria aliquid audire, fama virtutum tuarum consolari. Et hoc tibi signum fidei et veritatis transmisit'; protulitque de sinu manum preciosi martyris Dionisii auro gemmisque inclusam. 'Hoc', inquit 'habeto pignus foederis perpetui et amoris vicarii...' The episode is later repeated by Thietmar of Merseburg, Chronicon I, c. 23, 30, in a slightly modified version, making Henry saving Charles. On Thietmar's depiction of Henry as Charles' nepos, see Eckhardt, Funde, 14-19.

174 Schmid, Quellen, 141-142. MGH Const. I, N 1, c. 2, 1. 
not have meant more than Henry recognising Robert as king. While the treaty of Bonn had not brought a new age of cooperation for Charles, it had at least secured Henry's neutrality.

Thus, two different phases of Charles' relations with other rulers can be distinguished: before and after he became sole ruler of the Western realm. Before 898, as with Odo, the acknowledgment of his new rank by other rulers played a certain role, yet in contrast to Odo, this role was of rather minor importance. Charles' own claim was strong enough that further legitimation was a bonus, not a necessity. Instead, his relations were marked by his need for actual material support, weakening his position in negotiations and forcing him to make significant concessions to his potential partners. However, once became sole ruler this image changes radically and Charles became the first West Frankish ruler since Charles the Bald who was able to exploit opportunities presented to him by conflicts between neighbouring rulers and their nobility. In this context, comparison with his brother Louis III, who had refrained from doing so, allows insight into the way the possibilities and limits of royal power in regard to relations to other rulers differed between the various rulers. Where his brother had had to take into consideration the impact of his actions on the cooperation established between him and the other Carolingian kings, Charles was at liberty to pursue his own interests. However, at the same time Charles also missed out on the stabilising effects such cooperation could have had on his position. When the tide began to turn and his own rule was weakened by a number of conflicts with the nobles, it was Henry the Fowler who took the opportunity presented to him by intervening in Charles' realm. Charles, as it seems, was very well aware of this problem and its potential effect on his own rule. His reaction was the treaty of Bonn, a treaty that aimed at preventing Henry from intervening in West Frankish affairs, but also at establishing a new cooperation from which Charles, if need should arise, could draw further support. Therefore, Bonn seems like an attempt to revive the period following the treaty of Fouron, increasing Charles' room for manoeuvre in relations with his nobles while limiting his possibilities to exploit opportunities to extend his rule-a price he seems to have paid willingly, given that there is no indication he had ambitions to do so even before the treaty.

\section{IV.5 Conclusion}

A number of factors determined the possibilities and limits of royal power when dealing with other rulers. First, the strength of a ruler's claim to the throne had a large impact on their relations with others. This is especially apparent in Odo's case, as his claim's weakness made it necessary for him to seek Arnulf's acknowledgement as another source of legitimation to strengthen his position within the West Frankish realm. In this context, the support of the nobles for a ruler also played a crucial role. Charles the Simple, in need of allies, had to acknowledge 
Arnulf's superiority in rank and had to make further concessions, just as Odo did. If a lack of support turned into open conflict between the king and the nobles, situations were created that gave other rulers the opportunity to intervene in these conflicts. This could of course work both ways: while the succession question in the West Frankish realm after Louis the Stammerer's death, as well as the rebellion against Odo and the conflict between Charles the Simple and Gislebert led to interventions from Louis the Younger, Arnulf, Zwentibold and Henry the Fowler, Charles the Simple profited from conflicts within Lotharingia and the East Frankish realm to extend his rule over the neighbouring regnum. However, the success of such interventions depended not only on the weakness of the opposition, but most of all on the support the intervening ruler could muster himself. Charles was only able to acquire Lotharingia when a large number of nobles from the regnum turned to him. However, relations between the various rulers were not only marked by rivalry and attempts to extend their influence. On the contrary, the treaty of Fouron between Louis the Stammerer and Louis the Younger shows strong signs that it was aimed at a large scale cooperation, including the attempt to prevent nobles from seeking support in neighbouring kingdoms against their rulers. This very same cooperation was then realised under Louis III and Carloman II against the threat posed by Boso of Vienne. However, while strengthening their position against Boso considerably, this alliance also had its downside, as it prevented Louis and Carloman from pursuing their interests in the western part of Lotharingia against Charles the Fat. Unhindered by such restrictions, Charles the Simple was able to acquire the regnum, yet he also lacked the support he could have drawn on from a similar alliance during his last years-a situation he tried to ameliorate with the treaty of Bonn. In the end, the necessity for such alliances depended on the support the king received from his nobles. If these relations were strong, such cooperation was unnecessary. If they were weak, they could serve the king in the ensuing conflicts. 


\section{The Viking problem}

When Charles the Simple became king, Viking warbands had already been raiding Frankish shores for over a century. In the 790s, small groups had started ravaging trading centres and monasteries. The overall size of these groups started increasing from the 840s onwards, soon ranging up to armies of several thousand men. ${ }^{2}$ At the same time, the number of active groups increased, with the Vikings from then on attacking several places simultaneously and penetrating the continent deeper and deeper via the rivers while ranging on horseback into the countryside. ${ }^{3}$ Instead of returning home after each campaign, they now remained in the country, erecting secure camps for their ships and themselves to pass the winter months, which indicates their high level of organisation. ${ }^{4}$ In the late 860s in England, one of these groups grew even more in strength, forming what is now known as the "Great Army." When the resistance organised by King Alfred became stronger and the army suffered a defeat at Edington, this army turned towards the continent, arriving on the Scheldt in $879 .^{5}$

However, one hundred years of ravaging and plundering also meant that there had been one hundred years of contact between the Northmen and the Franks. From the early 9th century onwards, Viking leaders were present at Frankish royal courts and pledged their allegiance to Frankish rulers. ${ }^{6}$ Almost all of them became Christian, baptism in combination with godparenthood not only serving to establish peace, but also to create a personal bond between the parties involved, putting the baptised in an inferior position to his godfather. ${ }^{7}$ In most cases, these ties proved to be effective, with the respective Northmen becoming loyal supporters of the kings whose courts they had joined. ${ }^{8}$ However, these cases only represent a small part of the contacts that existed between the Vikings and the Franks: both sides treated with each other and exchanged emissaries, treaties were concluded

1 The standard work on the Viking incursions is still Musset, Invasions. Since then (but also before) an abundance of studies have been published. Most important for our own work are Sawyer, Welt; D’Haenens, Invasions; Zettel, Bild; Searle, Kinship; Boyer, Vikings; Lund, Allies; Bauduin, Normandie; Baudin, Monde and Mohr, Wissen. Collections of articles include Bauduin, Fondations; Flambard Héricher, Progression and Pierre, Naissance. A good overview is offered by Coupland, Vikings.

2 For the number of ships reported by the sources, see Coupland, Vikings, 194. On the Viking ships and the number of men they carried, see D'Haenens, Invasions, 69-72 and Bill, Navires, 41. On the organisation of the Viking bands, see Mohr, Wissen, 198-204.

3 Coupland, Vikings, 195-196. A good example is the Loire, where Viking attacks are reported at Nantes in 843, at Tours in 853, Orléans in 856 and at Fleury in 865.

4 Musset, Invasions, 209.

5 Coupland, Vikings, 194-195. On the Great Army, see also Mestdagh, Vikingen and McLeod, Beginning.

6 Coupland, Poachers.

7 Lynch, Godparents, 169-192 and Coviaux, Baptême, 71-75.

8 Coupland, Poachers. 
and efforts were made to convert the Northmen. ${ }^{9}$ In fact, as Pierre Bauduin argues, the Northmen were increasingly integrated into Frankish society, with their leaders entering into competition with the elites of the realm and these latter in turn becoming intermediaries between the Vikings and the king. ${ }^{10}$

The sheer extent of the Viking incursions meant that, over the course of the 9th century, dealing with them became one of the most important challenges faced by Frankish kings. Kings were presented with a number of options for action. Campaigning against the Northmen was one of them, ${ }^{11}$ yet insufficient considering that the Vikings were often simultaneously active in different theatres, most importantly in the Western realm along the Loire and the Seine. ${ }^{12}$ This soon necessitated the delegation of defence to individual nobles who were put in charge of newly created marches protecting the rivers and the adjacent regions..$^{13}$ One of them was along the Loire where Charles the Bald installed Robert the Strong as leader, providing him with the resources and authority to defend the valley independently from the king. ${ }^{14}$ However, in both cases direct military actions seeking to encounter and defeat the enemy proved rather fruitless. The Northmen, aiming for profit and not for battle, ${ }^{15}$ preferred to avoid engagements by travelling through inaccessible areas and retreating when facing a hostile army. When it actually came to battle, victories were certainly won, yet proved insufficient due to the Northmen simply scattering and later regrouping. ${ }^{16}$ An alternative strategy was to prevent the Vikings from entering vulnerable areas, for example by occupying the river banks when a Viking fleet arrived or by blocking the river with fortifications. ${ }^{17}$ The last option the rulers had was not to fight the Northmen, but to use existing contacts to negotiate a tribute-a strategy that in fact turned out to be the most effective way to remove the Vikings from the realm. ${ }^{18}$ While this solution was unpopular among the churches who had to provide a large part of the sums paid to the Northmen, it, nevertheless, appears to have been a valid political option actually sought by the

9 Bauduin, Monde franc, esp. 225-341.

10 Bauduin, Monde franc, 297. More cautious Plassmann, Wirkmächtigkeit, 74-75, arguing that the integration was limited to the Viking leaders themselves and did not include those under their command. On early Viking settlements and their integration into the Frankish kingdoms, see Goetz, Landnahmepolitik.

11 On the Carolingian armies mustered by the kings in defence of the Vikings, see Coupland, Army, 54-63.

12 Searle, Kingship, 15-60, distinguishes between the Scheldt, the Loire, Brittany and the Seine.

13 On the mostly negative interpretation of these measures by scholars, reading them as a sign of the weakness of royal power, see Kleinjung, Bedrohung.

14 Kleinjung, Bedrohung, 25. As Karl Ferdinand Werner, Untersuchungen V, 97-98, proposed, a second march around Paris and along the Oise under the command of Heribert I of Vermandois may have been created by Odo.

15 Searle, Kingship, 15.

16 Coupland, Army, 66-69.

17 Coupland, Army, 63-66 and Coupland, Bridges.

18 Coupland, Tribute. 
rulers. ${ }^{19}$ Fighting and negotiating were thus closely connected to each other. If the former could not drive the Northmen from the realm, at least an advantage could be won over them that could be used when treating with them. ${ }^{20}$

These were also the strategies available to the West Frankish rulers succeeding Charles the Bald who were faced with the Great Army that had formed in England over the course of the past decades and now turned to the continent. Louis the Stammerer and his sons, Charles the Fat, Odo and Charles the Simple all had to decide in which way they wanted to react to this incursion. In this regard, Fernand Vercauteren described a shift of responsibility for defence, or at least for the actual measures taken, from the various rulers towards the local nobility, ${ }^{21}$ a view that has been challenged by Simon MacLean for Charles the Fat. ${ }^{22}$ Measures taken by the king remained important and in the following two sections we will analyse these measures, their effectiveness and the role of the nobles in their implementation.

\section{V.1 Viking incursions and royal measures in protection of the realm}

\section{V.1.1 Going on the offensive: Louis the Stammerer-Charles the Fat}

\section{Louis the Stammerer}

During Louis the Stammerer's reign, still preceding the arrival of the Great Army on the continent, Viking activities are only reported along the Loire where they had been installed since around $862 .{ }^{23}$ Despite the defence of the region falling under the purview of the local marchio, Hugh the Abbot, ${ }^{24}$ in early 878 Louis crossed the Seine for a campaign against the Northmen. Hincmar's report about the circumstances around the campaign casts some light on this decision. According to him, Louis' intervention was not the result of royal initiative, but of a request for aid from Hugh the Abbot himself. ${ }^{25}$ Yet, the call for aid against the Northmen appears to have been only one of the reasons for Hugh's appeal, in addition to

19 Keller, Négociation. Both scholars rightly emphasise that tribute payments were not necessarily the result of Frankish weakness leaving the rulers negotiating them no other choice, but a valid political option.

20 See Abel, Danegeld, 184-186 for Alfred the Great's dealings with Guthrun, aguing that "the key to Alfred's successful peacemaking was a demonstration of military power sufficient to cow Guthrun into at least temporary submission.”

21 Vercauteren, Comment.

22 MacLean, Charles.

23 Vogel, Normannen, 347.

24 This circumstance is probably also the cause for Louis the Stammerer's negative image in the Miracula S. Benedicti I, 86-87, noting that following his father's death the Northmen encountered hardly any resistence while attributing the defense of the abbey to Hugh the Abbot.

25 Annales Bertiniani 878, 222: Ac [Hludouuicus rex], suadente Hugone abbate ac markione, perrexit ultra Sequanam, tam pro auxilio Hugonis contra Nortmannos quam et pro eo quod filii Gozfridi castellum et honores filii Odonis quondam comitis inuaserunt, ac quia Imino, frater Bernardi 
the conflicts that had broken out with the sons of Gauzfrid and Emeno. The multitude of problems occurring at the same time seems to have overstrained Hugh's resources, necessitating Louis' intervention in the region. Indeed, while Hincmar mentions nothing about any measures taken against the Northmen, he does report that Louis solved the conflict with Gauzfrid, thus casting some light on the king's priorities. Soon after, Louis received word that Pope John VIII had crossed the Alps. Wishing to meet with him, he left the Loire again. ${ }^{26}$ While his departure was certainly due to John's arrival, it, nevertheless, appears that Louis considered the region secure enough to leave the defence to the local forces under Hugh. This impression is further strengthened when taking into consideration the measures the king initiated after the meeting with the pope at Troyes. Instead of returning to the Loire, he first met with Louis the Younger at Fouron before starting to prepare a campaign against Bernard of Gothia. ${ }^{27}$ For Louis, the Viking threat was of low priority, his actions revealing only that he was able to intervene if local defences were insufficient to deal with the current situation.

This image also persists during the period immediately following Louis' death. The Annales Bertiniani report one campaign in the same region towards the end of 879, after the meeting between Louis and Carloman with Charles the Fat at Orbe: "When they returned home from their journey, it was reported to them that the Northmen who were in the Loire were devastating the land. And setting off immediately, they met them on the day of Saint Andrew and many of them were killed and even more drowned in the river Vienne and according to God's will the Frankish army returned home victorious and safe."28 There are a number of points to be made about this campaign. First, considering the young age of Louis and Carloman, it seems hardly likely that it was they who mobilised the army and led it into battle. As we have argued, just after Louis the Stammerer's death the brothers were in the hands of the group around Hugh the Abbot, the same man who was in charge of the march along the Loire. ${ }^{29}$ The reaction to the Viking raids and the mustering of forces was hence most probably his and his allies' doing. Furthermore, it is interesting to note the timing of the campaign. Gauzlin and Count Conrad had already called Louis the Younger into the realm and only the sickness of the latter's brother Carloman had prevented him from coming to the Western realm where, to complicate matters even more, Boso's rebellion had al-

markionis, Ebrocensem ciuitatem usurpans, multas depraedationes circumcirca in illis regionibus exercebat, insuper et Eiricum more Nortmannico depraedari praesumpsit.

26 Annales Bertiniani 878, 222-223; Annales Vedastini 878, 43.

27 Annales Bertiniani 878, 230 and 879, 234. Before the campaign, the Northmen had advanced as far as Saint-Benoît-sur-Loire. Vogel, Normannen, 347-348.

28 Annales Bertiniani 879, 240: Cum quo apud Vrbam, antequam montem Iouis transiret, Hludouuicus et Karlomannus loqui perrexerunt.[...] ipsisque reuersis ab eodem itinere, nuntiatum est eis quod Nortmanni qui erant in Ligeri terreno itinere terras illas depraedabant; et statim moti in illas partes, in die missae sancti Andreae eos inuenientes, multos ex eis occiderunt et plures in Vencenna fluuio immerserunt, et exercitus Francorum Deo uolente cum uictoria incolomis remeauit.

29 See chapter II.2 and Offergeld, Reges pueri, 357-362. 
ready started. Given this background, it may well have been that the campaign was not only meant to deal with the threat posed by the Northmen-a task that Hugh had to fulfil in any case-but also to strengthen the position of Hugh's group by demonstrating their ability to protect the realm. The Northmen at the Loire were probably the best target for such a purpose: a well-known threat, yet not one that was overly strong, given the low priority that Louis the Stammerer had attributed to dealing with them. In any case, this early campaign under Louis and Carloman, like the one of their father, was probably rather limited, without any larger mobilisation of forces, a mere prologue to the challenges soon to be posed by the Great Army.

\section{Louis III}

When the first forces of the Great Army arrived on the continent in 879, they entered the Scheldt and installed themselves at Ghent to pass the winter, using this base to plunder the surrounding area, ${ }^{30}$ a group of them going even as far as besieging Reims, as one of Hincmar's letters indicates. ${ }^{31}$ This explains the readiness of the new West Frankish kings and the nobles around them to cooperate with Louis the Younger on this matter. The first sign of this cooperation followed directly on from the treaty of Ribemont in February 880, when Louis and his army, on the way back from the meeting, engaged Viking forces at Thiméon. While the reports of Hincmar, the Annales Vedastini and Regino of Prüm seem to indicate that this encounter was the result of chance rather than planning, ${ }^{32}$ the Annales Fuldenses suggest the opposite. According to them, after Ribemont Louis the Younger turned his army to drive out the Northmen from the Scheldt. ${ }^{33}$ This reading would explain why Hugh the Abbot was with the army and indicate that the Viking incursion at the Scheldt was perceived as a common threat that needed to be dealt with by joint forces. This view is further encouraged by the next campaign during the summer of the same year. In the wake of the large-scale

30 Annales Vedastini 879, 44-45 and 880, 46. For further sources indicating the return of the Vikings, see Vogel, Normannen, 264-266.

31 Flodoard, HRE III, c. 23, 319. According to Schrörs, Regesten, $N^{\circ} 485,587$, n. 163, the letter dates to January 880 .

32 Annales Vedastini 880, 46-47: Post haec Hludowicus parat redire in regnum suum, occurritque Nortmannis a praeda revertentibus. Et facta congressione apud Timiomum nobiliter eos vicisset, nisi contigisset Hugonem filium suum ibi ruere. Nam Godefridus rex Danorum illum interfecit. Quo mortuo omisit rex illos insequi. Multi quoque nobiles illius gentis ibi corruerunt, caeteri, qui evasere, rediere ad castra sua. Hugo quoque abbas fuit in illo proelio. Annales Bertiniani 880, 241: Et inueniens Hludouuicus in itinere Nortmannos, Domino opem ferente, magnam partem ex illis occidit exercitus suus, sed in Saxonia magnum dampnum de fidelibus suis per Nortmannos sustinuit. Regino, Chronicon 879, 115: Facta itaque pactione datisque sacramentis cum in regnum idem rex reverteretur, repente obviam habuit Nortmanorum innumeram multitudinem iuxta Carbonariam in loco, qui vocatur Thimiun, $\mathrm{cu}$ ingenti preda ad classem repedantem.

33 Annales Fuldenses (Mainz continuation) 880, 94: Rex Hludowicus [...] postea in Galliam profectus filios Hludowici ad se venientes suscepit totumque regnum Hlotharii suae ditioni subiugavit. Inde ad expugnandos Nordmannos, qui in Scalta fluvio longo tempore residebant, convertit exercitum initoque certamine plus quam quinque milia ex eis prostravit. 
cooperation against Lothar II's son Hugh in Lotharingia and Boso in Burgundy, the various rulers had also agreed to join forces against the Northmen installed at Ghent. This time, the major part of the forces appears to have come from the Western realm: Gauzlin and many others were ordered to advance against the Northmen. Arrived at the Scheldt, Gauzlin tried to coordinate his attack with the local forces. However, the manoeuver appears to have failed and the army was routed. Gauzlin now appears to have come to the conclusion that his remaining forces were insufficient to take any further measures and disbanded them, leaving the north-east of the realm open to the Northmen. ${ }^{34}$ While the circumstance that both Western kings went south seems to indicate that fighting Boso was given priority over the Viking threat, the fact that one of the leading nobles of the realm led the army against the Northmen nevertheless indicates how seriously this campaign was taken.

Gauzlin's defeat led to a change in these priorities. Louis III now returned to Francia, leaving Boso to his brother Carloman. ${ }^{35} \mathrm{It}$ is interesting to note the change of tone in the sources from this moment on. The Annales Vedastini now emphasise the king's role in gathering a new army and leading these forces against the Northmen. ${ }^{36}$ While this does not necessarily indicate a change in his relations to the nobles surrounding him-as Thilo Offergeld has shown, from the moment of their coronation, Louis and Carloman appear as independent, mature rulers in the narrative sources despite the continuing dominance of the nobles ${ }^{37}$-there, nevertheless, seems to have been a significant change following Gauzlin's defeat. In their extremely different reports of the battle of Saucourt, both Hincmar and the Annales Vedastini ascribe a crucial role to Louis' leadership. According to Hincmar, when the battle was developing in the Franks' favour, it was "Louis himself [who fled] with his men [...], though no one was pursuing them," thus revealing the divine judgement. ${ }^{38}$ The Annales Vedastini, on the other hand, report that it was the king himself, who turned the flight of his men into a victory by bringing them to stand and fight. ${ }^{39}$ While this certainly did not mean that Louis now

34 Annales Vedastini 880, 47 and 48-49. For the coordinated attack on Hugh and Boso, see chapter IV.2.

35 Annales Vedastini 880, 49. On the raids following Gauzlin's defeat, see Vogel, Normannen, 270-272.

36 Annales Vedastini 881, 50: Interim Hludowicus rex gravi dolore contristatus, videns regnum deleri, convocato exercitu praeparat se ad proelium.

37 Offergeld, Reges pueri, 381-382.

38 Annales Bertiniani 881, 244: De quibus non modicam partem occisis ceterisque fugatis, et ipse Hludounicus una cum suis retrorsum, nemine persequente, fugam arripuit, diuino manifestante iudicio quia quod a Nortmannis fuerat actum non humana sed diuina uirtute patratum extiterit. Translation by Nelson, Annals, 222.

39 Annales Vedastini 881, 50: Contra quos rex ire perrexit obviavitque eos in pago Witmau, in villa quae dicebatur Sathulcurtis, et commissum est proelium. Moxque Nortmanni fugam ineunt atque dictam villam deveniunt; quos rex insecutus est gloriosissimeque de eis triumphavit. Et patrata victoria ex parte coeperunt gloriari suis hoc actum viribus et non dederunt gloriam Deo. Paucique Nortmanni ex dicta villa egressi, omnem exercitum vertit in fugam, pluresque ex eis, videlicet usque ad centum homines, interfecerunt; et nisi rex citius equo descendens locum resistendi et audaciam suis donaret, omnes turpiter ex eodem loco fugiendo abirent. 
acted completely on his own-according to Hincmar, soon after the battle Louis, urged by some of his advisors, constructed a fort at Estruy, ${ }^{40}$ indicating again the influence of the nobles around the king-his crucial role in the battle appears as a sign of increased responsibility in the affairs of the realm. The battle of Saucourt undoubtedly was a major success for Louis, ${ }^{41}$ demonstrating his ability to muster sufficient resources to successfully challenge the Northmen, yet it appears not to have led to any agreements with the Northmen, who now retreated to Ghent before turning to the Maas where they erected a new camp at Elsloo. ${ }^{42}$

Louis' next campaign, this time not against the Northmen at the Scheldt, against whom he detached an army under Theoderic of Vermandois, ${ }^{43}$ led him across the Seine towards the Loire to expel the Northmen from his realm. The region should have been under the protection of Hugh the Abbot's march. The king's activity in this region may be explained by two reasons: First, like under Louis the Stammerer, the forces of the march may not have sufficed to deal with the Northmen and the Bretons at the same time, thus necessitating the king's intervention. Second, the absence of Hugh the Abbot from the region, him being Carloman's main advisor, may have led to a lack of leadership that was now compensated by Louis taking command himself. Instead of using force, Louis now opted for a diplomatic strategy and concluded an amicitia with the Viking leader Hasting. ${ }^{44}$ A number of factors may have contributed to this decision. Having split his forces, Louis' army may simply not have been sufficiently large for a military encounter. In fact, it seems likely that Louis had intended to reinforce his troops by forming an alliance with the Breton leaders-according to Hincmar, meeting with them was also a reason for him to cross the Seine. ${ }^{45}$ Finally, it seems that for him the Loire theatre was only of secondary importance to Louis. Having secured the Loire by turning Hasting and his men away from the region to aim for other regions at the sea ${ }^{46}$ probably the Breton north coast ${ }^{47}$ Louis next seems to have planned to move again against the Northmen in the north-east who had again extended their raids into the Western realm. At the moment of his unexpected death, the nobles of Francia had already assembled an army ready for a campaign, an army that was now taken over by Louis' brother Carloman, who left his own forces in Burgundy to continue the fight against Boso. ${ }^{48}$ It may have been due to this combination-a lack of resources to achieve

40 Annales Bertiniani 881, 244-245.

41 On the perception of the Louis' victory, see also Regino, Chronicon 883, 120 and the celebratory text of the Ludwigslied. On this poem, see Fouracre, Context; Green, Ludwigslied; Schneider, Northmanni and Lebecq, Vikings.

42 Annales Vedastini 881, 50-51.

43 Annales Bertiniani 882, 246.

44 Annales Vedastini 882, 52. Similar the Sermo in tumulatione SS Quintini, 272.

45 Annales Bertiniani 882, 246.

46 Annales Bertiniani 882, 247.

47 Vogel, Normannen, 351-352.

48 Annales Bertiniani 882, 246-247. 
a military solution combined with Louis' focus on defending the Francia-that, in this case, he chose to opt for a seemingly purely diplomatic solution, allowing him to quickly return to the East.

\section{Carloman II}

In contrast to his brother's, Carloman's measures against the Northmen were strongly affected by his relations with the Northern nobles. ${ }^{49}$ According to Hincmar, in September Carloman was still with the army that had been assembled for his brother's next campaign against the Northmen..$^{50}$ However, in November, when noting Hugh the Abbot's embassy to Charles the Fat, he remarks that the latter's "absence brought the utmost harm to this realm, since Carloman lacked the resources to mount resistance to the Northmen once certain magnates of this kingdom withdrew their support," leaving the realm open for the Northmen who now attacked Laon and Reims. ${ }^{51}$ This would indicate that the nobles turned away from the king at some point between September and early November, leaving the king, according to the archbishop of Reims, without the necessary forces to defend the realm. However, the Annales Vedastini report that in October Carloman moved against the Northmen who had installed themselves in the Condé, from where they ravaged up to the Somme..$^{52}$ Carloman's campaign without the support of these nobles lead to a victory at Avaux, helping to assert the gravity of Hincmar's reproach against Hugh the Abbot. ${ }^{53}$ Carloman was by no means left defenceless, but was able to challenge the Northmen. However, as both Hincmar and the Annales Vedastini note, the king's victory did not put an end to the incursion. Carloman instead withdrew to Compiègne, leaving the Northmen to extend their ravaging up to the Oise. Hence, the threat posed by the king and his army was not sufficient to force the Northmen from the realm and he also appears either not to have pursued a diplomatic solution or failed to implement one.

Reinforcements brought by Hugh the Abbot reenabled Carloman to campaign again during the winter of $882 / 3$, yet again without forcing the Northmen out of the realm or leading to successful negotiations while instead Saint-Quentin and Arras were plundered. ${ }^{54}$ The Northmen ravaging Flanders during the summer, in autumn 883 Carloman raised a new army to attack them in the Vimeux. This time the Northmen did not retreat but turned on the king both from land and from the river, forcing Carloman to quickly withdraw over the Oise and thus opening the

49 See chapter II.2.

50 Annales Bertiniani 882, 247.

51 Annales Bertiniani 882, 249-250: Sed absentia illius in isto regno maximum detrimentum fecit, quia Karlomannus non habuit unde Nortmannis posset resistere, quibusdam regni primoribus ab ipsius auxilio se retrahentibus. Quapropter usque circa Laudunum castellum uenerunt, et quae in gyro ipsius castelli erant depraedati sunt et incenderunt, disponentes Remi uenire, indeque per Suessiones et Nouiomagum pergentes, ad praefatum castellum expugnatum redire et regnum sibi subicere.

52 Annales Vedastini 882, 52.

53 Annales Vedastini 882, 53; Annales Bertiniani 882, 250.

54 Annales Vedastini 882, 53 and 883, 53. 
river up to the Seine to them. ${ }^{55}$ The catastrophic outcome of the campaign led to a massive shift of power within the realm, both in regards to the relations between the different noble factions as well as those factions and the king. The report of the Annales Vedastini is straightforward: "Meanwhile, because the king was a juvenile, all of the magnates assembled at the palace of Compiègne to confer about what they should do."56 In regard to the disaster of the campaign, Carloman, whatever his position might have been before, was now set aside and the nobles, or, as we have argued, the faction around Hugh the Abbot as well as Gauzlin, but not yet the nobles from Francia, ${ }^{57}$ took over. This points to the complexity of the situation. Without the support of the local nobility, the royal forces were not sufficient to deal with the Viking threat. This left two options: either to integrate the nobles who had been so far excluded from the circle around the king into the rule, or to change the strategy to address the Viking problem. In fact, they implemented both, negotiating a treaty with the Northmen that offered them a tribute of 12.000 pounds of silver in exchange for them leaving the realm as well as an armistice until the payment was due ${ }^{58}$ and integrating the nobles from Francia into its implementation. ${ }^{59}$ However, if they were now willing to set aside their rivalries, why would they not have continued to seek a military solution with their newly united forces? It is hard to imagine that such a solution was not brought up during the meeting at Compiègne; yet, it would seem that they had evaluated the probable outcome of such an endeavour and had come to the conclusion that they would fare better by seeking a diplomatic settlement. If this was the case, this reveals how powerful the Northmen had become and how royal power was now limited even if it could rely on the united support of the nobles.

Carloman's role in these negotiations is difficult to ascertain. The report of the Annales Vedastini clearly states that the initiative for the change of course lay with the leading nobles. However, was Carloman really too young at that time not to fulfil his role as king? Examining this passage of the annals, Thilo Offergeld has pointed out that Carloman was already 17 years old and, hence, old enough to rule. According to him, exaggerating the king's young age was a pretext to overrule him in this matter-up until that moment, Carloman is portrayed as able to rule and lead an army. ${ }^{60}$ Following Offergeld's reading, this would mean that the aggressive strategy previously used against the Northmen was indeed the king's choice, yet that after his failure to protect the North a shift had taken place in the circle around him, leading to him being overruled. Nevertheless, the king appears

55 Annales Vedastini 883, 54.

56 Annales Vedastini 884, 55: Interim, quia rex iuvenis erat, omnes principes Compendio palatio conveniunt tractaturi, quid illis esset agendum.

57 See chapter II.2.

58 Annales Vedastini 883, 54 and 884, 55. Both entries report an assembly of the Frankish nobles and a mission of the baptised Viking Siegfrid to the Northmen (late 883 and early 884 respecitvely). This is certainly a duplication of the events.

59 See chapter II.2.

60 Offergeld, Reges pueri, 396-397. 
to have been involved in the proceedings shortly afterwards. According to Regino of Prüm's chronicle, upon Carloman's death, despite having been paid the tribute, the Northmen returned to the Western realm arguing that they had concluded the treaty with the king and that his successor was to pay the same amount if he wanted them to leave. ${ }^{61}$ This points to a more central role of the king in the proceedings than the previous account of the Annales Vedastini indicates. It would seem that, since Carloman was considered as a partner in the deal, he had adapted his own course to that of the nobles and played his part in the negotiations. However, his position in regard to the nobles does not appear to have recovered entirely. When the tribute for the Northmen was collected, the Franks assembled an army in case that the Northmen did not leave the realm despite having received the tribute. Command over the army was then given to Carloman, who followed the Northmen up to the moment they embarked. Yet, there is a slight change in the phrasing used by the Annales Vedastini describing these events. It was "the king and the Franks" who followed the Northmen and it were "those Franks who were with Carloman" who returned to their homes once the Northmen were gone. ${ }^{62}$ The same phrasing is also used by the annals for Charles the Simple and the nobles supporting him during the fight against Odo, thus indicating the dominance of the circle around him. ${ }^{63}$ It would have been interesting to see how Carloman's relation to the nobles might have developed from this point on, especially after the threat posed by the Northmen had been lifted from the realm. However, his death shortly afterwards meant not only that Charles the Fat now became ruler of the Western realm, but also that the Northmen immediately returned to the Western realm.

Carloman's reign demonstrates the dependence of the king on the support offered by the nobles in the case of his politics towards the Northmen. While he was able to assemble forces sufficient to challenge them in the field without the support of the nobles from the northern part of the realm, these forces, nevertheless, appear to have been too small to prevent the Northmen from their ravages into the realm and, if he had had such intentions, to improve his position in negotiations. Failures in protecting the realm could lead to a massive shift in the balance of power between the nobles and the king, which, in turn, could result in a takeover of responsibilities by the nobles around the king. At the same time, this takeover, and the subsequent change of strategy leading to a diplomatic solution, also reveal how limited military means actually were even if the nobility stood united.

61 Regino, Chronicon 884, 122.

62 Annales Vedastini 884, 55-56: Tandem soluto tributo, mense Octobrio finiente adunantur Franci, ut, si Nortmanni inmutari fidem vellent, eis resisterent. Nortmanni vero sua castra incendunt atque ab Ambianis recedunt. Rex vero et Franci transito Hisa lento itinere eos insequuntur. Praedicti vero Dani iter agentes Bononiam veniunt ibique agentes consilium, quid sibi faciendum esset, pars illorum mare transiit, atque pars Luvanium in regno quondam Hlotharii, ibique sibi castra statuunt ad hiemandum. Franci vero qui cum Karlomanno fuerant redierunt ad sua loca.

63 Offergeld, Reges pueri, 454-456. 
Seemingly, they estimated their chances to secure the realm by military means too small to pursue this strategy any further.

\section{Charles the Fat}

For Charles the Fat, these framework conditions differed considerably. First, the Northmen, upon leaving Carloman's realm, had split into two groups, one sailing to England, the other one erecting a camp at Leuven and probably uniting with other Northmen who had, up until this moment, remained beyond the Scheldt, ${ }^{64}$ thus reducing the threat they posed, at least to a certain degree. Furthermore, Charles could rely not only on West Frankish forces, but also on those from Lotharingia, the East Frankish realm and Italy. ${ }^{65}$ However, at the same time, this also meant that he had to protect a much larger area and deal with a multiplying number of problems. Mobilising troops from one part of his realm to protect another meant that they had to operate far from their homes, putting a strain on supplies and requiring difficult coordination. Charles' first measures reveal the whole complexity of this situation. Although he was absent, he ordered forces from the Western realm and Lotharingia to move against the Northmen at Leuven. ${ }^{66}$ When these Northmen turned towards the Seine, another army was assembled, consisting of forces from Neustria and Burgundy and put under the command of Ragenold of Maine, ${ }^{67}$ yet it dissolved after his death. ${ }^{68}$ In the absence of the emperor, the West Frankish nobles now initiated their own measures, constructing a fort at the Oise to block the river and putting it under the command of Count Aledramnus as well as fortifying Paris. ${ }^{69}$ The role of the emperor in these different actions is hard to grasp. While the Annales Vedastini clearly state that the early mobilisation and attack on the Northmen at Leuven was initiated by Charles, when it comes to the assembly of the second army under the command of Ragenold, they remain silent. The large-scale cooperation of forces from different regions under the command of a noble otherwise invisible in the sources, however, does seem to indicate that this was the emperor's doing as well. On the other hand, the defensive measures taken after Ragenold's death seem to have been taken at the initiative of the nobles-at least in the case of the fortification of Paris, the Annales Vedastini indicate Gauzlin was responsible. ${ }^{70}$

Annales Vedastini 884, 55-56. The presence of other Northmen beyond the Scheldt is also indicated by the Annales Vedastini $(884,55)$, reporting that after the armistice had been concluded the Northmen devastating the north-east of the realm had ceased their attacks.

65 See MacLean, Kingship, 121, for Charles' ability to mobilise forces across his various regna.

66 Annales Vedastini 885, 56-57; Regino, Chronicon 884, 122.

67 See chapter II.3.

68 Annales Vedastini 885, 57.

69 Annales Vedastini 885, 57-58.

70 Annales Vedastini 885, 57-58. Simon MacLean, Kingship, 106, assumes that the construction of the fort at the Oise was done at Charles' command. While Aledramnus, who was put in command of the fort, was certainly among the emperor's important supporters in the Western realm (see chapter II.3), the sources do not mention any involvement from Charles in the matter. 
This interplay between measures initiated by local leaders and the emperor also characterises the events around the siege of Paris. While the defence of the city was led by Gauzlin and Odo, the emperor mobilised forces from his other regna to relieve the besieged. His first response to the Viking assault appears to have been quickly organised, with an army lead by Duke Henry arriving at Paris in spring $886,{ }^{71}$ again revealing Charles' ability to delegate the defence to trusted men if it seemed necessary to him. When the first campaign failed, in the late summer of 886 he himself led a second army to the Western realm, his presence indicating the importance he now attributed to the situation..$^{72}$ Charles forces appear to have been of considerable size, strong enough to force the Northmen to abandon one of their camps and to withdraw their forces over the Seine. However, instead of attacking them, he initiated negotiations, agreed to pay a tribute and opened up Burgundy for them to spend the winter. ${ }^{73}$ Charles' decision to negotiate has often been interpreted by scholars as a sign of his military weakness and related to his deposition a year later. ${ }^{74}$ However, Simon MacLean argues that there are no signs in the contemporary sources that Charles' reputation had suffered from this change of strategy. In fact, as he continues, the treaty must have been the result of a strategy discussed with the leading West Frankish nobles. ${ }^{75}$ As lack of military strength was apparently not the issue, there must have been other reasons for this decision. The Annales Vedastini report that negotiations were initiated because winter was approaching. ${ }^{76}$ Given the size of Charles' army, supply would have become a serious problem during the following months, ${ }^{77}$ making it necessary to disband at least some of his forces, if not send the entire army home. Hence, negotiating might have been a necessity dictated by the circumstances, the only means to ensure the end of the siege if it had not been the emperor's intention from the beginning. In this context, it is worth pointing out that Gauzlin had already opened negotiations with one of the Viking leaders, Siegfrid, during the siege and concluded an amicitia. ${ }^{78}$ This group of Vikings seems not to have taken part in Charles' treaty since they did not turn towards Burgundy but entered the Oise ${ }^{79}$ leaving the realm before the tribute had been delivered ${ }^{80}$ Hence,

71 Annales Vedastini 886, 59.

72 Annales Vedastini 886, 61-62; Regino, Chronicon 887, 125-126 and 127. On the composition of this army, containing contingents from Nevers, Tours, Auxerre, Orléans, Langres and Troyes, see MacLean, Kingship, 101.

73 Annales Vedastini 886, 62. Abbo, Bella II, v. 332-341, 90, is remarkably silent about these events, jumping directly from Charles' arrival to the treaty itself.

74 Musset, Invasions, 161; Schieffer, Karolinger, S. 184; Vercauteren, Comment and Bautier, Règne, 140-157.

75 MacLean, Kingship, 56-58 and 107.

76 Annales Vedastini 886, 62: Indeque coeperunt, quia hiems imminebat, missi ad invicem discurrere, ut imperator pacem cum Danis faceret.

77 On the problem of supplying armies, see Leyser, Warfare, 45-47.

78 Annales Vedastini 886, 59-60.

79 Annales Vedastini 886, 62-63.

80 Annales Vedastini 887, 63. 
paying off the Northmen was considered a valid option by at least some of the leading West Frankish nobles-support Charles could count on when opening negotiations.

The special situation of Charles the Fat's reign, with the emperor ruling over all of the Carolingian regna, reveals three layers of measures that dealt with the Viking threat. In the wake of royal absence from the West, the defence organised by the local nobility surfaces much more than in the previous periods. In this context, the case of the fortress constructed at the Oise is of particular interest since command over it was given to Count Aledramnus. ${ }^{81}$ In the early 880 s, Aledramnus and his brother, Count Theoderic of Vermandois, controlled a block of honores north of Paris and repeatedly appear in the sources as leaders of operations against the Northmen, indicating that they were key figures in the defence of the region. ${ }^{82}$ This development was continued under Odo when Theoderic's honores were passed on to Heribert I of Vermandois, who subsequently often appears as one of the leaders of, as Karl Ferdinand Werner phrased it, the Oise line. ${ }^{83}$ At the same time, both of them, as well as Heribert later on, can be seen in close contact with the emperor, ${ }^{84}$ thus revealing how closely linked these different layers of organisation actually were. In support of the local defence, Charles furthermore mobilised troops from other parts of his realm, delegating command to suitable commanders while he was needed elsewhere. The top layer, finally, consisted of Charles' direct intervention with even greater forces. While there was certainly no lack of effort made in the defence of Paris, its outcome reveals the limits of such purely military measures. Even with the resources of the entire empire at his disposal, forcing the Northmen to leave the realm appears to have been impossible, making a diplomatic solution preferable to Charles and the leading nobles of the West Frankish realm.

81 Annales Vedastini 885, 57-58.

82 MacLean, Charles, 86-89 and MacLean, Kingship, 106-107.

83 Werner, Untersuchungen V, 97-98 with n. 40, followed by Bauduin, Normandie, 112-113. When assessing Heribert's role as local commander of the newly created march to protect Paris, Werner may indeed have overestimated the count's position. While Heribert certainly held the respective counties, his leadership in the defence against the Northmen appears questionable. The only occasion that Heribert is actually mentioned in this context is in 900, when he joined Charles the Simple, Robert and Richard at the Oise to discuss the next campaign (Annales Vedastini 900, 82: Rex vero cum Rothberto et Richardo atque Heriberto coepit sermocinari de Nortmannis, quid agerent.). His presence there can also be explained by him being one of Charles' most important supporters and does necessitate a special role in the defence. Indeed, there are no signs in the sources on which such an interpretation could be based. Werner is right to point out the independent actions of his son Heribert II, yet all of these examples fall under the reign of Raoul who, in contrast to Charles, was often absent from the Francia. Hence, while under Raoul such a command is plausible, it hardly seems to have been necessary under Charles, the king being able to intervene himself most of the time.

84 See chapter II.3. 


\section{V.1.2 Strategies of containment: Odo}

Odo appears as the diametrical opposite to Charles the Fat, a ruler whose resources were mostly based on his Neustrian possessions, with limited support from the nobility and a legitimacy deficit. Odo's first campaigns reveal the restrictions placed on him by these structural problems. While his victory against the Northmen at Montfauçon boosted his reputation considerably, resulting in Arnulf inviting him to a placitum and acknowledging him as king, ${ }^{85}$ this battle appears not to have had any major impact on the activities of the Northmen. Meaux was besieged and burnt down, its remainders serving as base for the Northmen over the summer. ${ }^{86}$ In the meantime Odo fell back on a defensive strategy, using his army to protect Paris from the advancing Northmen without initiating any further measures against them. ${ }^{87}$ At this point, his lack of offensive action may have been due to his need to stabilise his reign: from his defensive position at Paris he moved to Reims to be crowned with a crown sent by Arnulf while early in the next year he went to Aquitaine to treat with Ramnulf of Poitiers and receive his submission. ${ }^{88}$ This does not mean that Odo completely abandoned the defence against the Northmen. When he moved to Aquitaine, the Annales Vedastini report that he only took a few men with him-which may indicate that he left his army in the North to monitor Viking activities - and, furthermore, that "he hastened back to Francia" because of them..$^{89}$ However, at the same time he seems to have been unable to prevent the Northmen from entering the Loire where they now devastated "Burgundy, Neustria and a part of Aquitaine without encountering resistance."90 The measures Odo took against the Northmen upon their return to the Seine mark the beginning of a slightly adjusted approach to the Viking problem. While he moved against them, he opened negotiations and bought their withdrawal from the city, making them turn towards Brittany. ${ }^{91}$ Over the course of the past years, especially during the siege of Paris, Odo must have been able to closely study the

85 Annales Vedastini 888, 65: Sed dum illi haec agerent, contigit Odoni regi per Dei misericordiam inopinata victoria. Nam die nativitatis sancti Iohannis baptistae cum parvo exercitu Danorum exercitum obviavit super Axonam fluvium commissoque proelio mox victor extitit. Quae victoria non modicam illi contulit gloriam. Post haec ab Arnulfo convocatur ad placitum. See also chapter IV.3.

86 Annales Vedastini 888, 66.

87 Annales Vedastini 888, 67: Circa autumni vero tempora Odo rex adunato exercitu Parisius venit, ibique castra metati sunt prope civitatem, ne iterum ipsa obsideretur. Nortmanni vero per Maternam in Sequanam regressi indeque navigantes et iter per terram facientes, Luvam fluvium ingressi, circa eius littora sedem sibi firmant. Odo vero rex Remis civitatem contra missos Arnulfi perrexit, qui ei coronam, ut ferunt, misit, quam in aecclesia Dei genitricis in natale sancti Brictii capiti impositam, ab omni populo rex adclamatur.

88 Annales Vedastini 889, 67.

89 Annales Vedastini 889, 67: Aquitanios itaque rex ex parte receptos, festinavit propter Nortmannos redire in Franciam.

90 Annales Vedastini 889, 67: Dani vero more suo Burgundiam, Neustriam atque partem Aquitaniae, nullo resistente, igne et ferro devastant.

91 Annales Vedastini 889, 67-68. 
Northmen and come to a realistic assessment of the options he now had in regard to their strength and his own resources, preferring to act defensively rather than to attack and to seek diplomatic solutions when possible.

This more careful approach to the Viking threat also becomes visible over the course of the following year when the Northmen returned to the Seine, splitting in two groups, one entering the Oise, the other under Hasting operating at the Somme. Odo appears to have fancied standing a better chance against these weaker forces, as he tried to attack a part of the first group before again falling back to his defensive strategy, assembling an army at the Oise to prevent the Northmen from roaming deeper into the realm. ${ }^{92}$ While this strategy had its advantages, effectively protecting a large part of the realm by limiting Viking mobility, it also had its drawbacks as it revealed Odo's incapacity to drive them away from the areas they were currently threatening. This resulted in a conflict of interests with the local nobles, as demonstrated by the case of Abbot Rodulf of Saint-Vaast, who now concluded an agreement with Hasting, allowing the latter to circumvent Odo. ${ }^{93}$ While Rodulf changed his mind shortly afterwards and instead attacked the Northmen, the case, nevertheless, reveals how problematic Odo's strategy was. It was probably also due to the pressure placed on him by this event that during the following year Odo made new offensive efforts, trying to deal with the various Viking groups. The results were hardly encouraging. While he managed to deprive one group of their plunder (although without actually being able to pin them down, possibly forcing them into Lotharingia), ${ }^{94}$ his attempt to attack a second group at Amiens led to his army being put to flight. ${ }^{95}$ These campaigns reveal the dilemma of Odo's situation. Containing the Northmen was the best strategy, yet one that needed the support of the local nobility, support that appears to have been increasingly uncertain, especially in regard to the conflicts breaking out over the course of the following year. This lack of support from the local nobility was probably why Odo now reverted back to an offensive strategy, a decision that was facilitated by the Northmen splitting up their forces. However, at the same time, the Northmen avoided open battle: they moved through almost impassable terrain and scattered

92 Annales Vedastini 890, 68: Brittanni vero viriliter suum defensavere regnum atque afflictos Danos Sequanam redire compulerunt. Imminente vero festa omnium sanctorum Dani per Sequanam Hisam ingressi Noviomagum petunt ad statuenda sibi castra hiemalia. Illis vero qui per terram iter agebant occurrit rex Odo circa Germaniacum; sed propter loci incommoditatem nil eis damni intulit. Nortmanni vero coeptum iter peragentes castra sibi adversus civitatem statuunt. Alstingus autem cum suis Argova super Sumnam sedem sibi firmavit. Odo vero rex adunato exercitu super littora Hisae fluminis resedit, ne regnum libere devastarent.

93 Annales Vedastini 890, 69: Alstingus vero per dolum pacem fecit cum Hrodulfo abbate, ut libere posset ire quo vellet. Praedictus vero Alstingus die sollempnitatis sancti Iohannis ewangelistae venit adversus castrum sive monasterium sancti Vedasti. Hrodulfus vero abbas timens, ne multitudo qui Noviomum erat cum eis adveniret, et insidias timens - quod etiam Alstingus mandaverat_populum retinuit, sed cognita veritate post eorum discessum multum doluit. Frequentibus vero incursionibus exterruit eos, nec ausi sunt postea ita adversus praedictum venire castrum.

94 Annales Vedastini 891, 69-70.

95 Annales Vedastini 891, 70. 
when pinned down, only to regroup soon after while at the same time exploiting any opportunity offered to them. In the end, the withdrawal of the Northmen was not brought on by Odo's measures, but by a famine in Francia. ${ }^{96}$

Odo's caution surfaces again four years later when the Northmen returned to the Seine. At this point, his attention was still turned to the conflict with Charles the Simple, a circumstance that the author of the Annales Vedastini does not fail to remark on: "And because the king busied himself with other affairs, he increased the great evil coming on him and the realm."97 Abbo of Saint-Germain went even further, accusing Odo of not caring at all and neglecting "the sheep sent to him by Christ," thus forsaking his own honour. ${ }^{98}$ While Abbo's harsh critique certainly was an overstatement, Odo indeed only became active again during the following year when he tried, without success, to attack a group returning from their raid. The group appears to have been rather small since "for fear of the size of [Odo's] army" they retreated into the Seine. ${ }^{99}$ However, Odo's general assessment of his chances against them appears to have remained unchanged. From the Seine, the Northmen ravaged over the course of the summer, apparently again without encountering much resistance. Later that year, Odo, while now having pacified the realm and hence being able to give the Viking threat his full attention, nevertheless decided not to challenge the Northmen but to, as in 889 , conclude a treaty "to ransom the realm." 100 While this last treaty has often astonished scholars who attribute its conclusion to Odo being weakened by sickness ${ }^{101}$-an explanation that would be backed by his death following soon after-it appears to be in line with the earlier measures taken by Odo. He had mostly favoured a defensive strategy, attacking only splinter groups while paying off larger armies without seeking battle. The Northmen returning to the Seine appear to have soon increased in

96 Annales Vedastini 892, 72.

97 Annales Vedastini 896, 78: Ac per idem tempus iterum Nortmanni cum duce Hundeo nomine et quinque barchis iterum Sequanam ingressi; et dum rex ad alia intendit, magnum sibi et regno malum accrescere fecit.

98 Abbo, Bella II, 110, v. 587-595:

Rex audit, nec curat, Odo; per verba respondit.

$O$, quam responsi facinus! Non ore dedisti

Tale tuo. Demon certe proprium tibi favit.

Non tua mens procurat oves Christo tibi missas.

Longius ille tuum forsan nec curet honorem.

Haec ubi fata receperunt probitate neglecti,

Exultant hilares, barcas agitantque per omnes

Gallia quis amnes fruitur, terram pelagusque

In dicione tenent, totum tutore ferente.

99 Annales Vedastini 897, 78: Post haec usque Mosam in praeda exierunt, nullo sibi resistente. A praeda vero illis revertentibus occurrit regis exercitus, sed nil profecerunt. Verum Nortmanni ad naves reversi, timentes multitudinem exercitus, ne obsiderentur, in Sequanam redierunt, ibique toto demorantes aestate praedas agebant, nullo sibi resistente.

100 Annales Vedastini 897, 79: Nortmanni vero iam in multitudine fidentes omnes reliquias regni ferro et igne devastant. Unde rex misit ad eos, regnum redimere volens; et facto placito super Ligerem hiemandi gratia pergunt.

101 For example Vogel, Normannen, 375. Last Offergeld, Reges pueri, 444. 
strength, shifting the balance of force in their favour. Odo, given the limitations of his resources, always carefully weighed his options. As the military ones seemed too risky, he chose the diplomatic solution.

\section{V.1.3 Return to the old strategies: Charles the Simple}

Charles the Simple abandoned the caution shown by Odo and reverted back to the approaches shown by his brothers, trying to attack the Northmen. When they returned from the Loire, where they had passed the winter, Charles mustered an army and pursued them. While the Annales Vedastini describe the size of his forces as a "small army," it seems to have been strong enough to be considered a serious threat by the Northmen who, after a first encounter that left many of them wounded, averted further contact by once again marching through barely passable terrain. ${ }^{102}$ Similarly, it may have been due to his return to Francia after his campaign into Lotharingia over the summer that they chose to pass the winter in Burgundy where they were defeated by Richard the Justiciar and forced back to the Seine. ${ }^{103}$ Furthermore, Charles also appears to have been able to pin them down to the river since the Annales Vedastini only report further raids in November 899, when Charles had to deal with Baldwin II of Flanders, who taken possession of Péronne. ${ }^{104}$ This observation makes it possible to draw some conclusions about the balance of power between the king and the Northmen. Charles' army, if the account of the Annales Vedastini is not to be completely dismissed, was rather small. Yet, at the same time, it was strong enough to be considered a serious threat by the Northmen, who only started to move again when Charles had to turn his army away from them. Apparently, the Viking forces Charles had to deal with in Francia were not as strong as the ones Odo had faced in the preceding years. Unfortunately, the narrative sources remain silent about any groups leaving the army, but it seems possible that a part of the Northmen had either not returned to Francia from the Loire in 898 or had left the realm over the course of the winter. Hence, Charles' room for manoeuvre appears to have increased considerably, especially when he was able to join his forces with those of Robert, Richard and Heribert in early summer 900 when they met at the Oise to deal with the Northmen remaining there. ${ }^{105}$ However, at this point, his attention was drawn away from the

102 Annales Vedastini 898, 79-80: Nortmanni vero verno tempore rediere ad naves, vastatam Aquitaniae partem atque Neustriam, insuper plurima eversa castra, interfectis habitatoribus. [...] Post haec rex Karolus cum exercitu parvo Nortmannis a praeda revertentibus in pago Vitmau iuxta quandam... insecutus, aliquibus suorum interfectis plurimisque vulneratis, Nortmanni more solito loca inoportuna tenentes rediere ad naves.

103 Annales Vedastini 898, 80. For Richard's battle at Argentueil see also Chronicon S. Benigni Divionensis, 113; Annales S. Columbae Senonensis 899, 104; Chronicon S. Petri Vivi Senonensis, 70. See Vogel, Normannen, 381, n. 2 for further references.

104 Annales Vedastini 899, 81.

105 Annales Vedastini 900, 81-82. 
Northmen once again when the conflict with Robert broke out. Hence, Charles, during these early years of his reign, appears to have been capable of dealing with the Viking threat, yet, like his predecessors, still did not possess the resources to force the Northmen to leave the realm for longer periods of time. Whether cooperation with Robert and Richard would have changed the balance of power in his favour has to remain open. However, the cooperation of these nobles points also to another observation. During these early years, nothing indicates that Charles attempted to negotiate with the Northmen. Yet, since Robert, Richard and Heribert provided forces for the return to the rather offensive strategy previously mainly shown by his brothers, this seems to indicate that they supported this strategy and might even point to them being reluctant to negotiate, as Odo so often had preferred to do.

With the end of the Annales Vedastini, only small traces of the Viking incursions and the royal measures to keep them in check remain. ${ }^{106}$ Edward the Elder's victories over the Northmen in 909 and 910 probably led to an increase in Viking activity on the Continent around the same time. ${ }^{107}$ Burgundy appears to have been targeted in 910, when the abbey of Saint-Colombe of Sens was fortified ${ }^{108}$ and Bishop Madalbert of Bourges was killed by the Northmen. ${ }^{109}$ This incursion was probably the prelude to the campaign of 911, which lead to the battle of Chartres and the subsequent treaty of Saint-Clair-sur-Epte. While a number of sources mention the battle, ${ }^{110}$ the only one providing further detail is Dudo of Saint-Quentin to whose account we will turn shortly. What seems to be clear from these sources is the leading role of both Robert of Neustria and Richard the Justiciar (as well as, according to Dudo, Ebalus Manzer of Poitiers) ${ }^{111}$ in the victory. The participation of the first two seems certain since there is also a letter preserved demonstrating their efforts to coordinate their forces before the battle. ${ }^{112}$ None of these sources provide any indication about Charles' involvement in the campaign. However, the question is which form such an involvement would have taken. Louis the Stammerer, when crossing the Seine, only reacted to a call from Hugh the Abbot, Louis III's intervention in the area also included negotiations

106 Vogel, Normannen, 384, argued that the absence of reports concerning the Northmen most likely indicates that they remained on the continent, since otherwise there would be records of their movements. While this is certainly possible, the silence of the sources may equally indicate that they turned to Britain or Britanny.

107 McNair, Development, 72.

108 Annales S. Columbae Senonensis 910, 104.

109 Annales Masciacenses 910, 169. It may be that the report of the Gesta Pontificum Autissiodorensium $(\mathrm{I}, 195)$ of a battle between Bishop Geran of Auxerre and the Northmen refers to this incursion as well.

110 Among others: Annales S. Columbae Senonensis 911, 104; Chronicon S. Petri Vivi Senonensis, 70; Flodoard, HRE IV, c. 14, 407.

111 Dudo, De moribus II, c. 21, 160-161 and c. 24, 164.

112 Bibl. commun. Chartres, ms. 92, fol. 38v. Catalogue Chartres, 48: Rotbertus comes et dux Manassae Richardo comiti salutem. Scitote quoniam fuimus perrecti contra Normannos, sed non invenientes regressi sumus Parisius mittentes ad vos et requirimus utrum vos necne venieris ad nos. 
with the Bretons. In fact, Robert appears to have been quite capable of defending the Loire on his own. Probably in 903, Tours was attacked and burnt down by Vikings ${ }^{113}$ while from 915 onwards the Loire again appears to have been penetrated by the Northmen who used the river mainly for raids into Brittany. ${ }^{114}$ This latter group was likely the same one that Robert fought in 921 before ceding Brittany and the pagus of Nantes to them in return for the conversion. ${ }^{115}$ On none of these occasions do the sources report any involvement from Charles' side, the last one even seems to indicate that Robert enjoyed some liberty when it came to negotiating peace deals. ${ }^{116}$ This liberty was nothing new. ${ }^{117}$ Already Robert the Strong had negotiated a tribute payment with a group of Northmen allied with the Breton Salomon ${ }^{118}$ and also Hugh the Abbot appears to have concluded a treaty without the king, baptising a number of Northmen. ${ }^{119}$ At least on the latter occasion, Charles the Bald appears to have given his consent only afterwards. Furthermore, as we have seen, also Gauzlin, in absence of Charles the Fat, negotiated an agreement with Siegfrid, one of the Viking leaders besieging Paris, paying him a tribute for agreeing to an amicitia. Just like in the former two cases, also Robert may have intended to ask for Charles the Simple's confirmation of the deal. Thus, in the case of the campaign leading to the battle of Chartres, it seems likely that while Robert and Richard were in charge of the forces, they, nevertheless, acted in Charles' name and probably with him an overseeing role. ${ }^{120}$ As we have argued in the previous chapter, based on one of Robert's private charters, ${ }^{121}$ it appears that Robert acted on the king's behalf when fighting the Northmen. If this was indeed the case, the campaign leading to the battle of Chartres would be an example of how Charles was able to coordinate forces from different parts of his realm in an attempt to organise an appropriate response to the incursion. Charles' ability to do this would be confirmed if the diplomas issued in June 914 during a couple of days are indeed the signs of a campaign against the Breton march in the wake of the

113 Chronicon Turonese Magnum, 107. The editor also makes mention of a note in a tenth-century manuscript at the library of Tours, reading: Anno incarnactionis dominiciae DCCCC III, II kalendas Julii, missa videlicet Sancti Pauli apostoli, regnante Karolo filio Hludovici Balbi, post obitum domni Odonis regis in anno VI, et Rotberti abbatis anno XV, iterum succensa est venerabilis basilica Sancti Martini Turonis cum XXVIII aliis ecclesiis ab Heric et Baret Nortmannis cum toto castello et burgis. On the Viking incursions and Tours, see Gasnault, Tombeau and Noizet, Chanoines.

114 Vogel, Normannen, 400-401.

115 Flodoard, Annales 921, 6.

116 Sassier, Hugues, 82.

117 On negotiations between Frankish nobles and Northmen in general, see Neifeind, Verträge, 43-45.

118 Annales Bertiniani 862, 89-90.

119 Annales Bertiniani 876, 206.

120 It was common practice for Carolingian kings to delegate military commands to leading nobles. Scharff, Gott, 277-283.

121 Dufour, Recueil Robert et Raoul, N 47, 181-186 (11th November 912), 184: Domnus Rotbertus [...] gloriosus abbas necnon et comes, propter diversa regnorum Francię atque Neustrie negotia, quibus a rege prepositus erat, ab urbe Turonica fere per biennium defuisset... On this charter, see also Guyotjeannin, Notice and Guillot, Formes, 83, n. 101. See chapter III.2.3. 
breakdown of order in Brittany due to a Viking incursion, with the participation of forces from Neustria and Burgundy. ${ }^{122}$

While the examples of 900, 911 and 914 demonstrate Charles' ability to mobilise and coordinate forces in defence of the realm, on another occasion he does not seem to have been able to do this as easily. Flodoard's account in the Historia Remensis Ecclesiae concerning the Hungarian invasion of Lotharingia reports that Charles' call to arms was only answered by Archbishop Heriveus of Reims. ${ }^{123}$ As we have argued above, Flodoard's report appears to have been grossly exaggerated and constructed in a way to portray Heriveus in the best light possible. ${ }^{124}$ Nevertheless, it would appear that, on this occasion, the response to Charles' call was only a limited one. His first call would undoubtedly have gone to his Lotharingian supporters and only after that to his West Frankish men because the Hungarian attack came from the east. Indeed, Flodoard only speaks of the "great men of the Franks" (proceres Francorum) failing to respond, a designation that does not necessarily include the nobles from Lotharingia. ${ }^{125}$ It may even be the case that Heriveus joined the king's forces early on not because he had been called, but out of his own interest since the church of Reims had property in Lotharingia. ${ }^{126}$ Be that as it may, Flodoard's report remains unsatisfactory, not even reporting whether the king's measures against the Hungarians were crowned with success or resulted in failure.

However, military campaigns were not the only means the king used to protect his realm from the Northmen. As we have mentioned above, the Anglo-Saxon chronicle reports a Viking war leader in England, Earl Thurcetel, preparing for a venture into the West Frankish realm with the consent and aid of King Edward. ${ }^{127}$ In this context, Charles' marriage with Edward's daughter Eadgifu takes on a new meaning, namely that of an alliance between the two kings in the shadow of the Viking incursions which prevented Edward from giving further aid to Northmen aiming for Charles' regnum. This marriage reveals that Charles was willing to follow other ways than his predecessors, to break out of the old patterns of military

122 See chapters III.1.1 and III.2.3.

123 Flodoard, HRE IV, 14, 407.

124 See chapter III.3.

125 Flodoard, HRE IV, 14, 407. At least in his annals Flodoard draws a clear line between Franks and Lotharingians. For example Flodoard, Annales 920, 2: ...pene omnes Franciae comites regem suum, Karolum, [...] reliquerunt. Opposed to 4: ...Giselberto, quem plurimi Lotharienses principem, relicto Karolo rege, delegerant ordinavit. And 922, 10: Franci Rotbertum seniorem eligunt... Versus Flodoard, Annales 922, 10: Lotharienses quidam regrediuntur ad sua, quidam cum Karolo pergunt. And 11: Rotbertus filium suum, Hugonem, in regnum Lotharii mittit cum aliquo Francorum agmine... as to Flodoard, Annales 922, 11. Hugo, acceptis obsidibus a quibusdam Lothariensibus, ad patrem remeavit.

126 For example Flodoard, HRE IV, c. 6, 388. Archbishop Fulk to Archbishop Hermann of Cologne: Intimat preterea res quasdam Remensis ecclesie in ipsius parochia perverso iure a quibusdam pervasoribus possideri.

127 Anglo-Saxon Chronicle, MS A, 916, 66: 7 py ilcan geare for Purcytel eorl ofer sa on Froncland mid pam mannum pe him geloestan woldon mid Eadweardes cynges fripe 7 fultume. See chapter III.2.2.2. 
campaigns and paying tribute by thinking further ahead and depriving at least some Northmen of their base and hence hampering their raids into his realm.

Thus, Charles dealt with the Viking threat on several levels. In terms of military measures, he appears to have been able to mobilise sufficient forces to challenge the Northmen and pin them down. If necessary, he was able to rely on forces from the entire realm, revealing the full extent of his possibilities. However, at the same time, these large scale operations also reveal his limitations: carrying them out depended on the cooperation of the leading nobles. If one of them stood against him, his ability to defend the realm suffered a serious blow, not only because he then was missing part of his support, but also because, as in the case of Baldwin, he needed to shift his attention away from the Northmen and concentrate on the nobles opposing him. As under his predecessors, military operations appear to have yielded mixed results at best and were not able to achieve a durable solution. It is altogether more interesting that Charles appears to have come to that same conclusion and tried to pursue new strategies. Depriving the Northmen of their bases in England was one of these means. Another was the adoption of a new diplomatic strategy, to which we will now turn.

\section{V.2 Diplomatic solutions}

\section{V.2.1 Dudo's De moribus et actis primorum Normanniae ducum}

Raising armies and trying to defeat the Northmen were only one means of dealing with the Viking threat. Another one, seemingly much more effective, was to come to an agreement with them. As we have seen above, apart from Louis the Stammerer, each of the kings concluded treaties with the Northmen, involving the payment of a tribute for the safety of the realm. ${ }^{128}$ Charles the Simple is not reported to have made such payments, yet given the absence of narrative sources for almost 20 years of his reign, this is hardly surprising, and it cannot be taken as evidence that Charles' politics differed from those of his predecessors. In fact, Charles concluded at least one treaty with the Northmen, the treaty of Saint-Clairsur-Epte, which was probably agreed upon in the wake of the battle of Chartres in 911 and followed by the settlement of the Vikings in Normandy. The main source for these events is Dudo of Saint-Quentin's work De moribus et actis primorum Normanniae ducum, ${ }^{129}$ a highly problematic narrative account of the foundation of the duchy of Normandy. Dudo belonged to a Frankish cultural milieu, had strong links to a church in the old Carolingian heartlands ${ }^{130}$ and seems to have been

128 A concisive account of the treaties between Northmen and Francs is provided by Neifeind, Verträge. As he (Verträge, 22) has pointed out, none of these are preserved in written form.

129 Lair, De moribus.

130 Labande, Historiographie, 759-760 and Duby, Ordres, 108 argue for Reims. Shopkow, World, argues for Liège. 
strongly influenced by Bishop Adalbero of Laon to whom he dedicated his work. ${ }^{131}$ A canon at Saint-Quentin, he was sent by Albert of Vermandois as an ambassador to Richard I, for whom he then served as deacon. After Richard's death, he served his son and successor Richard II as chaplain and chancellor. Thus, he was integrated in the Norman court and acquainted with its procedures. ${ }^{132}$ Richard I had commissioned the De Moribus, and the commission was renewed after his death in 996 by his son Richard II and half-brother Raoul, count of Ivry. The first version was probably drafted between 996 and 1015, with a revision following afterwards. ${ }^{133}$ Dudo used written accounts, first of all Flodoard's Annales, but his chief informants were members of the ducal family: Raoul of Ivry, Richard I's half-brother, the duchess Gunnor and probably also Archbishop Robert. ${ }^{134}$

Dudo's De moribus was criticised vehemently by Henry Prentout, who described him as "Poète et rhéteur, amateur de pittoresque, voilà trois défauts impardonnables chez un historien; ajoutons-y le goût du délayage, le besoin de raconter en six pages ce qui pouvait se dire en quelques lignes, la manie d'introduire dans sa narration des dialogues, des discours..."135 Since then Dudo has been treated more kindly by scholars ${ }^{136}$ who have revealed the ideological background of De moribus as a lineage-story of the Dukes of Normandy. ${ }^{137}$ While this emphasis on the literary character of Dudo's work in general has shifted the focus away from the question of how far his account is based on historical events, ${ }^{138}$ the problem has not been forgotten entirely by scholars, leading to very different assessments. ${ }^{139}$

An interesting case study which serves to shed some light on this problem is Pierre Bouet's on Dudo's depiction of the Viking Hasting, the main character of De moribus' first book. He argues that none of Hasting's actions were invented by Dudo. In fact, allusions to most events Dudo has Hasting participate in can be found in other sources. However, Dudo not only changed the chronology, but also used Hasting as a symbolic figure of wrongdoing by ascribing the devastation caused by other Viking leaders such as Oscar, Siegfrid, Björn, Ragnar and Hundeus to him. ${ }^{140}$ This, of course, renders his whole account extremely problematic as a source of hard facts. But we should not rely on the case of Hasting to discern the

131 Duby, Ordres, 108-112 and Bauduin, Normandie, 64.

132 Baudiun, Normandie, 63-64.

133 Bauduin, Normandie, 64. Contrary to Bauduin, the poetry in the Historia Normannorum appears not to have been added later on but to have been part of the original design. Pohl, Dudo, 254.

134 Bauduin, Normandie, 64-66 and Searle, Kinship, 65-66 and 93-97. On her, see also Van Houts, Countess. On Dudo's written sources, see also Shopkow, World, 24-25.

135 Prentout, Étude, 19-20.

136 See the studies of Labande, Historiographie.

137 Davis, Normans, 50-62; Bates, Normandy, XIV-XVII; Searle, Fact, 119-137 and Kinship, 61-67; Jordan, Role, 53-62; Lifshitz, Dudo, 101-120 and Shopkow, History, 68-63.

138 Shopkow, World, 19-20.

139 See Bouet, Négociations, 90, in favour of Dudo being a critical historian and hence a valuable source versus Bauduin, Normandie, 62-63, according to whom these expectations are too high.

140 Bouet, Hasting, 216-217. A comparison of Dudo's account with other sources is also offered by Prentout, Étude, 48-59 and 64-82. 
reliability of the entire account of De moribus. Did Dudo apply the same technique to the main character of his second book, Rollo? According to Dudo's account, Rollo first appears in the Frankish world when he installs himself at Walcheren, ${ }^{141}$ an event that probably reflects the arrival of the Great Army from England in 879. ${ }^{142}$ His subsequent move to the Scheldt and the occupation of Condé during the winter ${ }^{143}$ are also reported by the Annales Vedastini for the years 880-882, referring to an incursion led by Siegfrid and Gottfrid. ${ }^{144}$ Count Reginar being captured by Rollo on this occasion undoubtedly stems from Regino's account, who reports the same for a certain count Eberhard in 880. ${ }^{145}$ The following turn of Rollo towards the Seine, dated to 876 by Dudo, ${ }^{146}$ also finds a double correspondence in the contemporary sources. For the very same year the Annales Bertiniani note the arrival of about 100 Viking ships entering the river 16th September ${ }^{147}$ although in accordance with the following events described by Dudo more match the advance of the Northmen on Paris in $885 .{ }^{148}$ In reaction to the incursion, the Franks are then said to have gathered an army under the command of Ragenold and to have sent Hasting to treat with Rollo ${ }^{149}$ - Ragenold is also named as the Frankish leader by the Annales Vedastini ${ }^{150}$ while Hasting is undoubtedly a reference to Siegfrid, who was sent to deal with the Northmen attacking Amiens the year before. ${ }^{151}$ Even an allusion to the mockery of Dudo's Northmen can be found in the Annales, namely at Leuven in $885 .{ }^{152}$ Rollo's march on and siege of Paris, including the death of Ragenold, ${ }^{153}$ are equally well known from other sources ${ }^{154}$ although Rollo does not appear in them. Thus, like Hasting, Dudo's Rollo appears to be constructed out of several other, often unknown Viking leaders raiding the Francia during the 870 s and 880s. The general tenor of this construct, however, is diametrically opposed to that of Hasting. Dudo's description of Rollo raiding into Burgundy and along the Loire preceding the battle of Chartres for example can also be traced in the contemporary Frankish sources. ${ }^{155}$ Yet, Dudo adds some new aspects that portray Rollo, although still a pagan, in the best light possible: "Some of his men went

141 Dudo, De moribus II, c. 9, 149. Our analysis follows the ones provided by Prentout, Étude and Christiansen, Dudo.

142 Annales Vedastini 879, 44-45. Christiansen, Dudo, 189, n. 145.

143 Dudo, De moribus II, c. 9, 150.

144 Annales Vedastini 880-882, 46-53. Prentout, Étude, 163-167 and Christiansen, Dudo, 190, n. 151.

145 Regino, Chronicon 881, 117. Prentout, Étude, 166.

146 Dudo, De moribus II, c. 11, 151-152.

147 Annales Bertiniani 876, 207. Christiansen, Dudo, 190, n. 156.

148 Annales Vedastini 885, 57.

149 Dudo, De moribus II, c. 13, 154-155.

150 Annales Vedastini 885, 57. See also chapter II.3.

151 Annales Vedastini 884, 55.

152 Dudo, De moribus II, c. 13, 154-155. Annales Vedastini 885, 56-57. Christiansen, Dudo, 191, n. 165.

153 Dudo, De moribus II, c. 14-16, 155-158.

154 Annales Vedastini 885-886, 56-63, and Abbo, Bella. See Christiansen, Dudo, 192, n. 171 and 172 for further details.

155 See chapter V.1.3, n. 108 and 109. 
to Burgundy; they sailed up the Yonne to the Saône, laying waste the lands next to the rivers everywhere as far as Clermont, and pushed on into the province of Sens, and returned to meet Rollo at Saint-Benoit, ravaging everything. However, on seeing the monastery of Saint-Benoît, Rollo refused to defile it, nor would he allow that province to be despoiled, for Saint Benedict's sake." 156 Even the battle of Chartres is reinterpreted, since in Dudo's presentation it is not a defeat but rather a non-victory in which Rollo ordered a tactical retreat. ${ }^{157}$ As Eric Christiansen puts it: Rollo was Dudo's "Viking Aeneas, following a destiny first laid down by Vergil for the Roman precursor," developing through baptism "into a Clovis, benefactor of the churches and divinely-sanctioned conqueror." 158

\section{V.2.2 The treaty of Saint-Clair-sur-Epte}

Dudo's technique of rearranging and relabelling his sources while mixing them with actual events makes his account of the treaty of Saint-Clair-sur-Epte highly problematic, which means that each term needs to be evaluated in the context of other sources. According to Dudo, the terms agreed upon consisted of a donation of the land between the Epte and the sea, to be held in perpetuity as personal property, as well as Brittany to live from since their new lands had been left uncultivated for a long time. Rollo then swore an oath of fealty by placing his hands between those of the king and in turn received Charles' daughter Gisela as his wife. The ceremony was to be concluded by Rollo kissing the foot of the king, however, as he was unwilling to do so, he ordered a warrior to act in his stead. Instead of kneeling down, the warrior remained standing, raised Charles' foot to his lips and kissed it, causing the king to fall on his back. ${ }^{159}$ Directly connected to the treaty was Rollo's baptism which took place some time after the meeting at Saint-Clair-sur-Epte. ${ }^{160}$

156 Dudo, De moribus II, c. 21, 161: Sui autem in Burgundiam pergentes, perque Ionam in Sigonam navigantes, terrasque amnibus affines usque Clarum-Montem undique secus devastantes, Senonis provinciam invaserunt, atque cuncta depopulantes ad Sanctum Benedictum contra Rollonem revenerunt. Videns autem Rollo monasterium Sancti Benedicti, illud contaminare noluit, nec praedari illam provinciam propter sanctum Benedictum permisit. Translation by Christiansen, Dudo, 42.

157 Dudo, De moribus II, c. 23, 162: Rollo vero, more soliteo constanter irruit super illos atque, in primo apparatu belli, superavit, fortiter dimicans illos. ... Cernens autem se Rollo inter utrumque exercitum stare, seque non praevalare suosque decrescere, transiens per medium illorum, coepit ab eis declinare, ne praeoccuparetur morte.

158 Christiansen, Dudo, XIX. On the origins of the historical Rollo, see Douglas, Rollo; Musset, Origine and Renaud, Vikings, 47-55.

159 Dudo, De moribus II, c. 28, 168-169 and c. 29, 169. On this kiss, see Hattenhauer, Aufnahme, 22-37 and Bauduin, Rituel. Both admit that this ritual could have taken place, but disbelieve the form reported by Dudo, a position that we share.

160 Dudo, De moribus II, c. 30, 170. 
In general, baptism seems to have been a prerequisite for a treaty between Carolingians and Northmen. ${ }^{161}$ And, in fact, Flodoard notes that Christianisation was part of the agreement. ${ }^{162}$ The conversion itself is well documented and has been made subject of a study by Olivier Guillot. ${ }^{163}$ Here, two sources are central, a letter from Archbishop Heriveus of Reims to his colleague, Wido of Rouen ${ }^{164}$ and another one from Pope John X to Heriveus. ${ }^{165}$ Both letters are part of an exchange originating at Rouen, in which Wido first seems to have asked the other archbishop what to do with the Northmen who, despite having been baptised, repeatedly fell back on their pagan habits. Heriveus then brought the matter to John $\mathrm{X}$ and, having received his reply, composed his advice in form of 23 chapters. It is hardly surprising that the conversion of the Northmen did not come without difficulties and took at least several years. As Guillot has emphasised, this was an evolutionary process, and, in the end, a successful one. ${ }^{166}$

Flodoard also mentions another part of the treaty: a donation of land, several pagi by the sea devastated by the Vikings, as well as the city of Rouen and all its dependencies. ${ }^{167}$ This is further confirmed by a royal diploma issued in 918, indicating that a part of the possessions of the abbey of Croix-Saint-Ouen in Mérezais at the Eure had earlier been given to Rollo and his companions. ${ }^{168}$ Lucien Musset has tried to reconstruct the borders of the territories ceded to the Vikings and deduced that they were constituted more or less by the rivers Bresle, Epte, Eure and Avre in the east and south, while nothing is known about the western frontier. ${ }^{169}$ The devastation of this area as described by Flodoard cannot be doubted, given the frequency of the Viking incursions of the preceding decades. ${ }^{170}$ According to Jacques Le Maho, during the early years of Odo's reign, due to this constant threat,

161 On the role of baptism in Franco-Viking relations, see Lynch, Godparents, 169-192 and Coviaux, Baptême, 71-75.

162 Flodoard, HRE IV, c. 14, 407.

163 Guillot, Conversion.

164 BNF lat. 4280 A fol. 102-106. Referred to by Flodoard, HRE IV, c. 14, 407.

165 Zimmermann, Papsturkunden, Nº 38, 65-67 (JL 3553).

166 Guillot, Conversion, 104.

167 Flodoard, HRE IV, c. 14, 407.

168 DChS 92. On the possessions of Croix-Saint-Ouen see Bauduin, Normandie, 124-125

169 Musset, Considérations, 404-405. See 406-407 for more detail since the frontier did not follow the run of the rivers. The river Bresle as frontier is deduced from a meeting between Charles, Heribert II of Vermandois and William Longsword in 927 at Eu (Flodoard, Annales 927, 39). Musset seems to assume that it had been chosen for the meeting because it was situated at the frontier. Frontier meetings were common between parties of equal standing (for royal meetings, see Voss, Herrschertreffen, 39-64). Making the Bresle the frontier therefore requires that Heribert II and William Longsword considered each other as equals, something that we cannot prove. The Eure is deduced from Charles' diploma of 918 (DChS 92) and the proximity of Croix-Saint-Ouen to the river. The Avre can only be traced as frontier from 935 onwards. The only safe deduction seems to be the Epte, which is given not only by Dudo, but also by Flodoard (Annales 923, 16).

170 For an account, see Bauduin, Normandie, 97-99 and Le Maho, Seine, 21-23. Against this view, arguing for a strong continuity among the local population, see Bates, Normandy, 11 and McNair, Politics, 310 . 
Rouen was transformed into a "ville-refuge." 171 The fortifications supposedly were restored and a large part of the rural population sought refuge there, while the domains they had abandoned fell under royal control. ${ }^{172}$ If this was indeed the case, this would undoubtedly have facilitated the treaty concluded between Charles and Rollo. Royal control over a large part of the territory, as well as its deserted state, would have ensured that the interests of Frankish nobles were hardly affected and the abandoned villages could then have been occupied by the Northmen, if they had not already done so. ${ }^{173}$

The cession of land is commonly assumed to have been tied to another condition, the protection of the Seine from further Viking incursions by Rollo and his men. ${ }^{174}$ The basis for this assumption is Charles' diploma of 918 which states that the monks of Saint-Germain were given the land of Croix-Saint-Ouen, "apart from the parts which we have given to the Northmen at the Seine, that is to say Rollo and his companions, for the protection of the realm." 175 However, the phrasing "for the protection of the realm" is rather ambiguous. While it may indeed indicate that Rollo was charged with preventing other Northmen from entering the Seine, it may as well simply be a phrasing used to legitimise the ceding of land per se-to protect the realm from Rollo himself. ${ }^{176}$ This question leads us to examine what role Rollo played within the political hierarchy of the realm from this point onwards. ${ }^{177}$ For Karl Ferdinand Werner, Rollo was made count of Rouen and, the pagus being part of Neustria, put under the jurisdiction of Robert. ${ }^{178}$ Pierre Bauduin, on the other hand, interprets Rollo as a marchio in his own, who was

171 Le Maho, Installations, 157. Critical on Le Maho's assumption that Odo had a hand in this development Bauduin, Normandie, 110-111, pointing out that the royal hand in these developments is hardly reflected by the sources.

172 Le Maho, Installations, 158-159 and 161-164.

173 Le Maho, Seine, 27-32, proposes that already before 911 the territory between the sea and the Andelle had been ceded to another group of Northmen as part of Charles' treaty with Hundeus. However, his argumentation is based on a lost source probably used by Dudo and on a hoard found at Saint-Pierre-des-Fleurs which is brought in connection with the account of the Annales Vedastini. The latter, however, do not give the slightest indication that land had been ceded at that moment. Furthermore, it appears doubtful that Charles at that moment-he had sought refuge in Lotharingia-would have been able to make anything else but promises. If such a cessation had been agreed upon, it would have had to be made by Odo. The hoard definitely confirms Viking presence at that moment, but this does not necessarily mean that it had been with royal consent. Werner, Origines, 442 and Bauduin, Normandie, 111 argue for a Viking occupation of the regions at the mouth of the Seine from about 900. In fact, despite the devastation, there appears to have been a strong continuity in terms of settlement and the new settlers were soon integrated into the existing structures. Musset, Essai, 97-102.

174 See for example Bauduin, Normandie, 133-134.

175 DChS 92, 211: ... praeter partem ipsius abbatię quam annuimus Normannis Sequanensibus, videlicet Rolloni suisque comitibus, pro tutela regni.

176 See also Searle, Rivalries, 203-204 and Searle, Kingship, 43.

177 In favour of an immediate integration: Lot, Fidèles, 177-185; Brühl, Deutschland, 395-398; Bates, Normandy, 149-150 and Neveux, Normandie, 29-33.

178 Werner, Observations, followed by McKitterick, Frankish Kingdoms, 237 and Sot, Historien, 216. Against this reading, see Helmerichs, Princeps. 
installed by Charles to act as counterweight to Robert. ${ }^{179}$ Both readings assume that in the wake of the treaty Rollo had become a fully integrated member of the Frankish nobility. Yet, Charles' diploma does not refer to him as comes or marchio but plainly as Rollo. The same is also true of the main narrative source of the time, the writings of Flodoard, who is usually very precise about the application of titles. As Eleanor Searle points out, for him Rollo and his son William Longsword are "chieftain [princeps] of the Norse," but never comes. ${ }^{180}$ Concerning the integration of Rollo into the structures of the realm, we should also take the actual content of the diploma into consideration. Pierre Bauduin argues that the land was given to Rollo in alodo et in fundo ("as an allod and property"), a phrasing that implies the unconditional and permanent character of the donation. ${ }^{181}$ However, these expressions are only applied by Dudo ${ }^{182}$ and not, as Bauduin seems to imply, by Charles' diploma. Hence, the legal foundations of the ceding are entirely unknown. From what the sources are able to tell us, it seems that Rollo's position in the realm was in fact far less formalised than often assumed. This is not to say that Rollo did not become or had not already become integrated into Frankish society. Indeed, he was no stranger to the leading nobles of the adjoining counties. Several years before 911 he had already taken a woman called Poppa ${ }^{183}$ as his companion who had given birth to his son William. According to Dudo, Poppa was the daughter of a certain Berengar, possibly an Unruoching. ${ }^{184}$ Following the tradition of the Annals of Jumieges however, Poppa was the daughter of Count Wido of Senlis and sister to Bernard. ${ }^{185}$ The question of her heritage has yet to be answered, ${ }^{186}$ but, as Pierre Bauduin has emphasised, the important point is that by this relation Rollo was introduced into the Frankish networks of alliances and parentage. ${ }^{187}$

These networks lead to the final part of Dudo's report of the treaty of SaintClair-sur-Epte, namely the marriage between Rollo and Charles' daughter Gisela. Marrying his daughter off to Rollo would certainly have tied the latter even more strongly to the king than his conversion and the donation of land. Yet, was Rollo really important enough to enter into a marriage alliance with Charles? Dudo certainly does his best to portray Rollo as an all-powerful Viking warleader. Yet, the political reality appears to have been rather different. When Charles opened

179 Bauduin, Chefs normands, 189.

180 Searle, Kinship, 45. McNair, Politics, 312, questions the existence of a count of Rouen even before the Norman settlement.

181 Bauduin, Chef normands, 182. Translation by Christiansen, Dudo, 49.

182 See chapter V.2.2, n. 159.

183 On her see Keats-Rohan, Poppa and Bauduin, Normandie, 129-132.

184 Dudo, De Moribus II, c. 16, 157. Merlet, Origine, 551-552. On the Unruochings see Werner, Adelsfamilien, 133-137.

185 Annales de Jumièges 912, 51.

186 Nelson, Normandy, 11-12, argues against Poppa's existence based on the unreliability of Dudo's account.

187 Bauduin, Normandie, 132. 
negotiations with the Northmen after the battle of Soissons, his principal target appears to have been Ragenold, the leader of the Vikings at the Loire. When he reacted to Charles' call, Flodoard reports that was joined "by many from Rouen"188_ Rollo is not mentioned at all. Later that year, these Northmen from Rouen concluded a treaty with Heribert II of Vermandois, Archbishop Seulf of Reims and other Frankish nobles, granting them more land beyond the Seine which was confirmed by King Raoul shortly afterwards. ${ }^{189}$ Flodoard does not mention Rollo either at this point or during the following year, although the Northmen he speaks of are clearly from Rouen. ${ }^{190}$ Even when these Northmen broke the treaty the following year, Flodoard again only calls them "Northmen from Rouen," again without mentioning Rollo ${ }^{191}$ and continues to do so for the subsequent campaign against them. ${ }^{192}$ Only when Raoul directly attacked the Northmen within their territory is Rollo finally mentioned, this time as their princeps, sending troops from Rouen in support of a praesidium threatened by the Frankish army. ${ }^{193}$ Flodoard's account seems to indicate that Rollo's control over the Northmen at Rouen was rather limited at this point, that he was only one leader among others and that these others were able to operate independently from him. ${ }^{194}$ Viking armies were heterogeneous groups, consisting of numerous warbands under their own leaders who had joined for some time, but could always fall apart again to pursue their own

188 Flodoard, Annales 923, 15: Interea Ragenoldus, princeps Nordmannorum qui in fluvio Ligeri versabantur, Karoli frequentibus missis jampridem excitus, Franciam trans Isaram, conjunctis sibi plurimis ex Rodomo depraedatur.

189 Flodoard, Annales 923, 17-18.

190 Flodoard, Annales 924, 19: Anno DCCCCXXIIII incipiente, fit exactio per Franciam pecuniae collaticiae, quae Nordmannis pacto pacis daretur... 24: Nordmanni cum Francis pacem ineunt sacramentis per Hugonem et Heribertum comites, Seulfum quoque archiepiscopum, absente rege Rodulfo, ejus tamen consensu terra illis aucta, Cinomannis et Baiocae pacto pacis eis concessae. That this Ragenold was not included in these negotiations becomes apparent from another passage: Ragenoldus cum suis Nordmannis, quia nondum possessionem intra Gallias acceperat, terram Hugonis inter Ligerim et Sequanam depopulatur. (Flodoard, Annales 924, 24-25).

191 Flodoard, Annales 925, 29: Nordmanni de Rodomo foedus quod olim pepigerant irrumpentes...

192 Flodoard, Annales 925, 30-31: Nordmanni usque ad Noviomagum praedatum veniunt, et suburbana succendunt. Castellani cum suburbanis egredientes Nordmannos repellunt, sternunt quos poterant, partem suburbii liberant. Baiocenses interim terram Nordmannorum, ultra Sequanam, depraedantur. Quo comperto, Parisiaci et ipsi quoque, cum quibusdam fidelibus Hugonis, filii Rotberti, et quorumdam castellorum oppidanis, partem quamdam pagi Rotomagensis qui possidebatur a Nordmannis, cis Sequanam depopulati sunt, villis succensis, pecoribus abductis, nonnullis etiam Nordmannorum interfectis. Heribertus comes interea, cum paucis Francorum, quia parum adhuc herbae inveniebatur equis, transitum Nordmannis prohibendi gratia, super Isaram residebat. Nordmanni, terrae suae cognita vastatione, in sue festinant redire.

193 Flodoard, Annales 925, 31: Rodulfus interea de Burgundia revertitur in Franciam, et ut se ad bellum contra Nordmannos praeparent Francis banno denuntiat. Heribertus igitur, expeditione coepta contra Nordmannos, cum militibus Remensis aecclesiae, Arnulfus quoque comes et ceteri maritimi Franci praesidium quoddam Nordmannorum aggrediuntur; quo etiam Rollo, princeps eorum, mille Nordmannos, praeter ipsius inhabitatores oppidi, ex Rodomo transmiserat.

194 Similar also Eleanor Searle, Rivalries, 208-213, who extends the argument of a weak Rollo and William Longsword into the 940s. 
goals. ${ }^{195}$ Hence, it seems plausible to assume that early on, Rollo's position among the Northmen now settling around Rouen was not a dominant one and that his rise over the other leaders only took place when their new home was threatened by the Frankish forces and he took charge of the defence.

If Rollo's position among the Northmen was indeed a weak one, a marriage to Charles' daughter appears rather unlikely. Of course, such a marriage would not have been unprecedented. In 882, the Viking leader Gottfrid, upon concluding a treaty with Charles the Fat, was not only ceded territory in Frisia in return for becoming a Christian, but also married to a Carolingian princess, the illegitimate daughter of Lothar II and Waldrada. ${ }^{196}$ Yet, this same case also underlines why Dudo's account is so problematic when it comes to the marriage: Gottfrid's bride was called Gisela. It would be absolutely clear that Dudo was appropriating Gottfrid's career for his image of Rollo if the genealogy dictated by Charles to the canons of Compiègne did not mention a Gisela among his own daughters. ${ }^{197}$ While it is impossible to tell whether Dudo's account is correct or not, we have to refrain to point out that the marriage was rather unlikely.

Hence, the treaty of Saint-Clair-sur-Epte appears to have consisted of two main parts: the cession of land, centred on Rouen; and the Christianisation of the Northmen. Given that the treaty was concluded in the wake of the victory at Chartres and Rollo's apparently weak position amongst the Northmen up until the early 920s, it seems doubtful that becoming Christian should have been the only condition for the grant of land. Settling the Northmen at Rouen, controlling the lower Seine and access not only to Paris but also to the river systems leading deep into the realm, put Rollo's Northmen in a position from where they could block the river to other invaders. At the same time, strong personal bonds were created by means of baptism and the grant, which tied the Viking leader close to Charles and his supporters. There was a risk that the Northmen would break the treaty and return to their old habits, yet at the same time this risk appears to have been calculable. The battle of Chartres had proven that West Frankish forces were now sufficiently strong to defeat the Northmen while Rollo himself was too weak to disturb the balance of power within the realm. Hence, it seems plausible that protecting the realm was indeed part of treaty.

\section{V.2.3 Using an old solution in a new way}

Saint-Clair-sur-Epte was not the first treaty concluded between the Franks and the Northmen. After the death of Charles the Bald, five are recorded by the sources.

195 Keller, Négotiation, 103.

196 Annales Vedastini 882, 51-52; Annales Fuldenses (Mainz continuation) 883, 100.

197 Witger, Genealogia, 303. 
When dealing with the Northmen along the Loire, Louis III concluded an amicitia with the Viking leader Hasting, making them leave the realm. ${ }^{198}$ After Carloman II's disastrous campaign of 883 , the nobles took over and negotiated the payment of a tribute for the withdrawal of the Northmen. ${ }^{199}$ Charles the Fat, having arrived with a large army to lift the siege of Paris, did the same, additionally opening Burgundy for them to pass the winter. ${ }^{200}$ Odo dealt with them twice, paying a tribute for their withdrawal from the realm, ${ }^{201}$ and the second time (similarly to Charles the Fat) giving them access to the Loire as well. ${ }^{202}$ These treaties reveal a remarkably consistent pattern. First of all, they were all aimed at removing the Northmen from the realm. This diplomatic strategy proved remarkably successful, yet only helped to bring short- to mid-term relief. For example, Carloman II's untimely death lead to the immediate return of the Northmen to Francia who claimed that the treaty just concluded had lost its validity with the king's death. Similarly, Odo's first treaty only lasted for a short period, for the Northmen returned to the realm after having been repulsed by the Bretons. Second, all of these treaties appear to have been concluded under very similar circumstances. When Charles the Fat bought off the Northmen, he did so because the upcoming winter season rendered the continuation of the campaign impossible. Louis III's treaty with Hasting appears to have been concluded because the king had split up his army, leaving him with insufficient forces. Similarly, Odo fell back on diplomatic solutions because he estimated himself too weak to militarily expel the Northmen. Finally, Carloman II's treaty was the consequence of his disastrous defeat. In all of these cases, the rulers had reached the limits of their military capacities, rendering them incapable of achieving their goal of removing the Northmen from the realm by means of force. Saint-Clair-sur-Epte was different to these treaties in every respect. Negotiated during a moment of military superiority, it was not aimed at making the Northmen leave, but at making them stay and protect the realm. The treaty was not without precedents. The treaty concluded between Charles the Fat and Gottfrid after the siege of Asselt appears to have been quite similar: apart from marrying into the Carolingian family, Gottfrid was also baptised and given control over Frisia. ${ }^{203}$ Yet, even this treaty was the consequence of having to abandon the siege because of supply problems and a disease outbreak in the Frankish camp. ${ }^{204}$ Hence, Saint-Clair-sur-Epte appears as a conscious decision to try a new strategy in dealing with the Viking problem, a strategy that apparently paid off for the next decade. According to Flodoard, the Northmen only broke their part of the bar-

198 Annales Vedastini 882, 52.

199 Annales Vedastini 883, 54 and 55. See chapter V.1.1.

200 Annales Vedastini 886, 62. See chapter V.1.1.

201 Annales Vedastini 889, 67-68.

202 Annales Vedastini 897, 79.

203 Annales Vedastini 882, 51-52; Annales Bertiniani 882, 247-248; Regino, Chronicon 882, 119-120; Annales Fuldenses (Mainz continuation) 882, 98-99. On Gottfrid and Frisia, see also Coupland, Poachers, 108-112, and Besteman, Danish rule. 
gain in 923, and this was only because they were then incited to do so by Charles himself. ${ }^{205}$

Such a change in policy raises the question of which role of the nobles around the king played in its prevalence. Geoffrey Koziol argues that the treaty primarily reflects Charles' own policy towards the Northmen, pointing out the alliances the king concluded in 897 and $923 .{ }^{206}$ However, these two examples are extremely problematic. On both occasions, Charles was in a desperate situation, having lost most of his supporters whilst facing overpowering enemies. Only under these circumstances did he reach out to the Northmen as potential allies. As soon as he became king, the measures he took in the defence of the realm against the Northmen did not differ from those of his predecessors. Robert, on the other hand, is portrayed by Koziol as having been a resolute enemy of the Northmen and opposed to any treaty with them. ${ }^{207}$ Yet, Robert concluded a treaty extremely similar to SaintClair-sur-Epte in 921 with the Northmen at the Loire, granting them Brittany and the pagus of Nantes in return for their conversion. ${ }^{208}$ More importantly, Robert was directly involved in the proceedings at Saint-Clair-sur-Epte where he acted as Rollo's godfather ${ }^{209}$ and thus became the personification of the bond between the Northmen and the Franks. If Robert had indeed opposed the treaty, Charles would certainly have taken this position himself-he had done this already earlier in the case of Hundeus.

Yet, Hundeus' case points to some other changes in the attitude of leading nobles towards the Northmen. Archbishop Fulk had harshly condemned Charles'

205 Flodoard, Annales 923, 16-17: Itta fluvio transito, ingressus est terram, quae dudum Nordmannis ad fidem Xpisti venientibus, ut hanc fidem colerent et pacem haberent, fuerat data; [...] ipsi Nordmanni pacem quam pepigerant, propter promissiones Karoli, qui eis latitudinem terrae pollicitus fuerat, infregere, caedibus et igne devastat.

206 Koziol, Charles, 364 and Koziol, Politics, 433-439. To these two occassions, Koziol furthermore adds the attacks of the Northmen along the Loire in 898 and 921, assuming that they were at least partially initiated by Charles. As for 898 , Odo himself had directed the Northmen to the Loire when he concluded a treaty with them during the previous year. Whether this meant that they were free to plunder the region does not become clear from the account of the Annales Vedastini, yet the treaty has strong parallels with the one concluded by Charles the Fat in 886 who opened Burgundy to the Northmen besieging Paris. But even if this was not the case, the Northmen may have considered the treaty rendered invalid by Odo's death as they had done after Carloman's. As for 921, again no source indicates Charles' involvement. Given the problems with the Frankish nobles of the previous year, it seems indeed very unlikely that Charles would launch such an attack on Robert at this very moment. In the same manner Brunterc'h, Archives 1, 332, also argues that the treaty of Saint-Clair-sur-Epte was Charles' doing, "les grands et au premier chef Robert se sont alors écartés devant le roi.” Brunterc'h's position is based on the phrasing of DChS 92, showing "que c'est Charles le Simple et lui seul" who had ceded the land to Rollo and his compagnions. While it is correct that the phrasing of the diploma only refers to Charles himself, we should not forget that, with the diploma being issued by the king, it only tells the reader about the way Charles wanted the treaty and his role in it to be remembered, not the actual political circumstances.

207 Koziol, Politics, 435-437.

208 Flodoard, Annales 921, 6.

209 Dudo, De moribus II, c. 30, 170. Dudo's account seems to be confirmed by a diploma of Duke Richard I (DDN 3, $18^{\text {th }}$ March 968, 3: memoria avi me Roberti patrisque mei bone memorie Willelmi.). 
alliance with the Northmen, ${ }^{210}$ seemingly opposing any dealings with "the enemies of God." However, after Fulk's death his successor Heriveus appears to have pursued a programme of converting the Northmen, seemingly even preceding the treaty of Saint-Clair-sur-Epte, as is apparent from Flodoard's Historia Remensis Ecclesiae: "[Heriveus] vigorously laboured towards the appeasement and the conversion of the Northmen, until finally, after the battle which Robert fought against them at Chartres, they started to receive the Christian faith..."211 It seems that by the early 900 s a strong lobby had developed within the circle of the most important nobles around the king who now supported the very ideas the treaty of Saint-Clair-sur-Epte stood for. Within the context of the possibilities and limits of royal power, Charles' options for dealing with the Viking threat had increased in comparison to his predecessors.

\section{V.3 Conclusion}

When dealing with the Vikings, the cooperation of the nobles played a central role for the rulers, although in military matters it was far from decisive. Carloman's and Odo's victories were won by small armies while Carloman's second campaign ended in disaster despite him now being supported by Hugh the Abbot; and Charles the Fat, although he probably had the largest army of this time at his disposal, chose to negotiate instead of fighting. In any case, the results of seeking direct confrontation were mostly limited when it came to securing the realm against the Northmen-even Louis III's victory of Saucourt only lead to a temporary shift of Viking activity to Lotharingia. One way to deal with this problem was a defensive strategy aimed at containing the Northmen in a specific area, as practised by Odo. Here however, the support and cooperation of the nobles became indispensable, as Odo's attempts failed when Abbot Rodulf opened private negotiations. When it came down to making the Northmen actually leave the realm, negotiations with the Northmen proved to be far more successful than the use of force. Yet, apart from Odo, the rulers appear to have reverted back to this strategy only under specific circumstances. Hasting, with whom Louis III concluded an amicitia, operated along the Loire, which was apparently only considered a secondary theatre of war by the king. Carloman's treaty with the Northmen was the result of the nobles taking over after a disastrous campaign. Charles the

210 Flodoard, HRE IV, c. 5, 384-385: Karolo regi suo scribens indignatur valde sibi perlatum, quod pravis quorundam consiliis vellet idem rex se sociare Nordmannis, ut illorum auxilio ad regni decus obtinendum iuvari posset. [...] Sciatis enim, quia, si hoc feceritis et talibus consiliis adquieveritis, numquam me fidelem habebitis, sed et, quoscumque potuero, a vestra fidelitate revocabo et cum omnibus coepiscopis meis vos et omnes vestros excommunicans eterno anathemate condempnabo.

211 Flodoard, HRE IV, c. 14, 407: De Nordmannorum quoque mitigatione atque conversione valde laboravit, donec tandem post bellum, quod Rotbertus comes contra eos Carnotenus gessit, fidem Christi suscipere ceperunt concessis sibi maritimis quibusdam pagis cum Rotomagensi, quam pene deleverant, urbe et isdem subiectis. 
Fat may have chosen to pay tribute to the Northmen because he probably would have run into severe problems in supplying his army. Odo, on the other hand, acting mainly defensively, seems to have considered negotiations an important part of his strategy to protect the realm from further incursions. In general, the rulers appear to have enjoyed the support of the nobles when negotiating-or, as Carloman's example demonstrates, may have even been forced by them to enter into them. However, Charles the Simple renouncing Odo's cautious strategy and returning to the more aggressive approach, as previously shown by his brothers and Charles the Fat, was supported by the leading nobles of his realm, among them also Odo's brother Robert. It seems that there were limits on how far the nobles were willing to accept negotiations as an essential part of the measures taken against the Northmen and that these limits had been reached under Odo. The cooperation of these nobles with Charles also points to another observation: similar to his predecessors, Charles the Simple was able to coordinate large-scale operations. That Charles was not in military command of at least the campaign in 911 did not mean that these men acted on their own accord, but that Charles had delegated the task of defending the realm to them, similar to Gauzlin under Louis III and Carloman or Henry under Charles the Fat. It was also due to their support that Charles was able to implement a distinctive change in strategy. The treaty of Saint-Clair-sur-Epte, negotiated from a position of strength in the wake of a major military victory, was no longer aimed at having the Northmen leave the realm, but at their settlement and conversion. 



\section{Conflicts, rebellions and the role of trust}

Over the past decades, the way conflict situations are interpreted has significantly changed. Conflicts are no longer read as a sign of the weakness of the medieval state, but acknowledged as an important part of the existing social order and a common experience. ${ }^{1}$ For example, Charlemagne's reign was, as Janet Nelson phrases it, "one goddamned crisis after another." In fact, conflicts between noble factions competing with each other or the king was one of the driving forces of politics throughout the entire Carolingian period. ${ }^{3}$ This change in reading is directly linked to the importance now attributed to social ties. Within conflicts, the opponents were usually not strangers to one another, but, as members of the same noble society, connected to each other by a complex system of social relations, which made solving the conflicts much more a question of social interaction than of legal dispute. ${ }^{4}$ Equally important, both parties were also part of larger social networks, networks they could manipulate to their own benefit "by mobilising groups that could be formed on the basis of kinship, lordship, common residence, association with a cult centre [...] or other social ties"s since these ties were often considered more important than the question of whether a claim was legally justified or not. ${ }^{6}$

The first section of this chapter focuses on two ways in which these social ties determined the possibilities and limits of royal power in conflict situations, analysing the way they influenced the rulers' strategies of bringing the respective conflicts to an end. Firstly, it is worth emphasising again that only a very limited number of nobles had direct access to the ruler. ${ }^{7}$ These nobles constituted the links between the ruler and his opponents, thus enabling communication between the opposing parties at any given time. Furthermore, they participated in the decisionmaking process at court, ${ }^{8}$ meaning that they were able to directly influence the way the king addressed the conflict in question. Secondly, since the studies of Gerd Althoff, the existence of certain rules, or rather norms, ${ }^{9}$ in the dealings between king and nobles has been generally accepted by scholars. ${ }^{10}$ These norms, although never written down but commonly only referred to in very general terms, constituted a framework when it came to deciding upon actions. ${ }^{11}$ Thus, in conflicts,

1 Goetz, Mediävistik, 194-195.

2 Nelson, Difference, 172.

3 Goldberg, Struggle, 8.

4 Patzold, Konflikte, 199-200.

5 White, Feuding, 258.

6 Keller, Begrenzung, 86.

7 Althoff, Verwandtschaft, 196-197.

8 See Introduction.

9 Buc, Review, 253.

10 Althoff, Spielregeln. For the impact and discussion of the concept see Kamp, Macht, esp. 1-10.

11 Kamp, Macht, 4. 
these norms constituted a common ground which allowed the opposing parties to come to terms with each other. ${ }^{12}$ In the interpretation of these norms there certainly was room for manoeuvre, ${ }^{13}$ yet it was common for both kings and nobles to overstep these boundaries, ${ }^{14}$ which, in turn, led to an atmosphere of mistrust. ${ }^{15}$

In modern research, trust as a concept and the role it played in medieval rule have received surprisingly little attention, and only recently German scholars have paid it particular attention. ${ }^{16}$ Trust, or rather, interpersonal trust ${ }^{17}$ (given that Carolingian rule was primarily based on relations between individuals), is defined as an expectation concerning the future behaviour of another person. This expectation serves as a basis for one's own decisions in regard to actions which may be influenced by the other person, taking into consideration the risk that the other may indeed act differently but assessing this risk as minor. ${ }^{18}$ Thus, when deciding about future actions, trust narrows down one's options by providing a guideline which

12 Althoff, Königsherrschaft.

13 Patzold, Konflikte and Inter pagensium.

14 Buc, Krise.

15 Kamp, Macht, 10-11; Reynolds, Trust, 2-3; Frevert, Vertrauen, 28-29.

16 Hirschbiegel, Nahbeziehungen, 48-76, provides a detailed overview. The importance of trust (and mistrust) as a political ressource has recently been demonstrated by Timmer, Vertrauen for the late Roman republic. The importance of trust throughout the middle ages has been questioned by Luhmann, Vertrauen. He argues that the medieval society, being one organised in rather small groups which were characterised by a natural and emotional familiarity, had no need for pragmatically and politically oriented trust. In this, he is followed by Weltecke, Gab es Vertrauen, who proposes that it had only become possible to take the risk of trusting when institutional frameworks provided by economy and politics developed, which created a general sense of security which allowed indivuals to operate more freely than during earlier times. Against Luhmann, see Weinfurter, Lehnswesen, 448; against Weltecke, see Althoff, Einführung, 250, and Hirschbiegel, Nahbeziehungen, 69-72, who argue for trust being a general phenomenon throughout the times, a position we share.

17 Reemtsma, Vertrauen, 35. Different (though closely connected to) from social trust, which describes the general readiness to trust other people. Putnam, Bowling Alone, 136. Interpersonal trust can further be divided into cognitive trust, which is based on former experiences with the other person, and affectional trust, which primarily rests on emotions. Cook and Gerbasi, Trust, 223-224. The latter mostly occures in very close relationships (Cook and Gerbasi, Trust, 219-220 and Hardin, Conceptions, 3-4). When talking about (interpersonal) trust, we refer to cognitive trust.

18 See Althoff, Einführung, 249, Frevert, Vertrauen, 8-9 and Hirschbiegel, Nahbeziehungen, 54-56, with further references. Very similar to the concept of trust is the concept of confidence. Following Luhmann, Familiarity, 97-99, like trust also confidence is defined as an expectation about the future which may be disappointed. However, different from trust, confidence leaves the individual no choice since the risk that the future will develop in a different way than expected is minimal while the individual at the same time has no choice about not being confident. This definition still leaves some room for interpretation: according to Luhmann, this kind of confidence also applies to politics; citizens have no other choice than being confident that politicians will do anything to avert war (to quote one of his examples). This has been criticised by Reemtsma, Vertrauen, 38-39, who argues that citizens in fact do have a choice by choosing to change their leaders. He proposes a more restrictive approach, offering the example of natural laws: since humans have no influence on them and the risk of them failing being practically non-existent, humans have no choice but to be confident that they apply. 
helps to predict the behaviour of other people. ${ }^{19}$ According to Jan Hirschbiegel, interpersonal trust depends on four prerequisites which cover the different layers between an individual and the community in which it is embedded: first, a general readiness to trust someone else; second, a specific readiness to trust a person which is based on one's experiences with this person and their reputation; third, the so-called structural trust, that is to say the framework provided by the social groups the individuals are part of; and fourth, systemic trust, which is defined by the social, cultural, religious, political or otherwise impersonal frameworks characterising society as a whole. ${ }^{20}$

In regard to Carolingian rule and our own study, the second point is of particular interest since it refers to a certain dynamic in the development and loss of trust, a dynamic which could be influenced by the ruler's actions. These actions do not only have an impact on the degree of trust between the ruler and the particular noble involved, but also on the way he was perceived, that is to say how trustworthy he was considered to be by other nobles. ${ }^{21}$ Actions, even if they were only directed at a single noble, could damage the trust between the ruler and wider circles of the nobility and thus lead to a crisis of trust, potentially threatening his rule in general. Scholars have identified two dimensions which determine how an individual's trustworthiness is perceived: first, their competence or reliability in performing a certain task or action in an appropriate manner and second, their integrity, honesty and commitment to take other parties' interests into consideration. ${ }^{22}$ In the first chapter we argued that the rebellion against Odo in 892 was in part due to a crisis of trust. One of the examples brought forward was the case of Baldwin, who refused Odo's offer regarding the return of his deceased cousin Rodulf's abbeys when the king requested him come to court and rely on the royal generosity. This refusal aptly illustrates the nature of this crisis: it was rooted in doubts about Odo's integrity as a king. Yet, there is also an example of a crisis of trust caused by lack of competence: when the nobles took over from Carloman II in late 883 , this was the consequence of his disastrous campaign against the Northmen in the Vimeux ${ }^{23}$-Carloman was seemingly still trusted as far as his behaviour conformed to societal norms; yet, he was not trusted when it came to leading against the threat posed by the Northmen.

This brings us to the following sections of this chapter, which revolve around the role of trust in the case of rebellion. While conflicts usually developed over changes within the hierarchy of nobles, often revolving around the distribution of

19 Luhmann, Vertrauen, 23-24; Marzano, Confiance, 53-54 and Weltecke, Gab es Vertrauen, 73. Against the pure rational choice approach pursued, for example, by Harding, Trust, Marzano rightly emphasises the non-rational aspects of trust such as the unconditional trust of children.

20 Hirschbiegel, Nahbeziehungen, 60-61.

21 On third-party effects of trust relations, see Burt and Kneez, Kinds and Hardin, Trust and Trustworthiness, 139-142.

22 Cook and Gerbasi, Trust, 222-223.

23 See chapters II.3 and V.1.1. 
honores, questions of rank and-directly connected with these two-political influence at the royal court, ${ }^{24}$ the parties involved accepted the ruler's final authority. However, this changed in Odo's case, when Fulk and his allies crowned Charles the Simple king. They questioned the former's right to rule and attempted to replace him with another king-in other words, they rebelled. ${ }^{25}$ Régine Le Jan has described these rebellions as signs of a crisis of royal power, ascribing them to the reaction of the noble elites to royal policies attempting to interfere with what they perceived as their natural privileges. ${ }^{26}$ While there certainly was a crisis of royal power, at least in the case of the rebellion against Odo's there appear to have been other reasons too-not least a lack of trust in him. In addition to the rebellion against Odo, Western Francia, from the death of Charles the Bald to the end of the reign of Charles the Simple, saw two more such attempts to replace the ruler, with Boso being crowned in opposition to Louis III and Carloman II; as well as Robert of Neustria's rebellion against Charles the Simple. ${ }^{27}$

In the second section of this chapter, conflict situations are analysed in regard to the kings' actions and whether these actions may have contributed to a loss of trust in the respective rulers by wider circles of the nobility. However, royal actions could not only damage a ruler's reputation but also help in building trust. This could be done in a number of ways: creating kinship was one means, concluding an amicitia another, ${ }^{28}$ and symbolic actions could also be used in such ways. ${ }^{29}$ The third section of this chapter deals with a special type of these symbolic actions which are closely tied to conflict situations: rulers aiming to do justice in various ways by making use of capitularies, judicial assemblies and restorational acts. Doing justice allowed the king and the magnates to cooperate and thus to strengthen the bond tying them together since justice was spoken in consensus. ${ }^{30}$ By doing so, they legitimised the existing social order as well as the position of the various protagonists within the hierarchy. ${ }^{31}$ This last point emphasises the inherent symbolical power of pronouncing justice. The king, receiving his realm from God, was responsible for its welfare and order which made him the supreme judge. The ideal of ruling was identical with doing justice, that is to say, respecting the law, being a judge and fighting injustice. ${ }^{32}$ Thus, doing justice could be used as a tool to legitimate rule and a means to restore lost trust in the king. Finally, the last section

24 Keller, Begrenzung, 84-86; Goldberg, Struggle, 10.

25 On the terminology of conflicts, see Brunner, Gruppen, 14-39.

26 Le Jan, Élites, 419.

27 Since the nobles did not aim to replace Carloman as a king in 883 but recognised his position, we refrain from categorising these events as rebellion.

28 Weinfurter, Lehnswesen, 448.

29 The results of a congress held at Münster in 2004 on the subject are published in Frühmittelalterliche Studien 39 (2005). In this context it is worth noting that the congress was organised around the assumption that symbolic actions had an impact on building trust (Althoff, Einführung, 248).

30 Krah, Herrschaft, 325.

31 Le Jan, Justice, 149.

32 Oudart, Roi. 
deals with the rebellions breaking out against Louis the Stammerer's sons in 879 and against Charles the Simple in 922, analysing them in regard to the role trust in the king played in their emergence.

\section{VI.1 Solving conflicts: The role of interest groups}

A perfect example of how nobles present at the royal court could influence the outcome of conflicts between nobles and the king is provided by the case of Count Gauzfrid and Louis the Stammerer. Probably early in 878, Count Gauzfrid's sons seized the stronghold and honores of the deceased Count Odo from his son. In response, Hugh the Abbot requested Louis the Stammerer's aid against them. ${ }^{33}$ The conflict appears to have been quickly resolved. "Some of the royal counsellors who were friends of [Gauzfrid]" 34 mediated between him and the king. Gauzfrid and his sons presented themselves at the royal court, returned the stronghold and honores and received both of them back by a royal grant. In return, Gauzfrid brought a group of Bretons into the service of the king. A number of observations can be made here. First, the problem leading to the conflict between Gauzfrid and the king was not actually his usurpation of property, but the fact that he had circumvented the royal prerogative of controlling the distribution of honores. Once Gauzfrid acknowledged the position of the king, the conflict could be resolved. Second, the crucial role of Gauzfrid's connections at court can be discerned. Karl Ferdinand Werner was undoubtedly correct in pointing out that one of these connections was Gauzfrid's brother, Gauzlin. ${ }^{35}$ Seemingly, Gauzlin's influence at this point of his career was strong enough to outweigh any opposition presented at court by the connections of Count Odo's son, which made the entire matter a question of acknowledging Louis' own interest, something that was acceptable for Gauzfrid.

The same mechanism, namely the influence of a powerful group of nobles at court, can also be discerned in another conflict during Louis the Stammerer's reign, although with the opposite effect. Early in his reign, Bernard of Gothia and his brother Emeno became embroiled in conflict with the king, the former preventing Archbishop Frotar of Bourges from entering his city ${ }^{36}$ and the latter seizing Évreux and devastating the surrounding country. ${ }^{37}$ Both were excommunicated at

33 Annales Bertiniani 878, 222. On Count Odo, see Levillain, Essai, 174-177. On this request, see also chapter II.1 and V.1.1.

34 Annales Bertiniani 878, 222: Sed miserante Domino aliquantulum [Hludouuicus rex] conualescens, satagentibus quibusdam consiliariis suis et amicis Gozfridi, uenit ad eum isdem Gozfridus, adducens secum filios suos, ea conditione ut castellum et honores quos inuaserant Hludounico regi redderent et postea per concessionem illius haberent. Tunc Gozfridus partem de Brittonibus ad regis fidelitatem conuertit.

35 Flodoard, HRE III, c. 24, 324. Werner, Gauzlin, 417.

36 MGH Epist. VII, N 149, 126. On this conflict see also Oexle, Bischof, 202-204.

37 Annales Bertiniani 878, 222. 
the synod of Troyes, ${ }^{38}$ and Bernard at least lost his honores, which were distributed amongst Louis the Stammerer's supporters ${ }^{39}$ he also became the target of a military campaign organised by the king. ${ }^{40}$ In 880 , after Louis' death, the Annales Fuldenses note Bernard's submission, ${ }^{41}$ which happens to be also his last appearance in the sources. Apparently, the conflict was resolved by means of force. If negotiations did take place, they failed.

All this is surprising since it seems that the highest circles responded with sympathy to Bernard's cause and this support could have been used to come to terms with the king, as in Gauzfrid's case. ${ }^{42}$ Frotar's own position at Bourges was a rather difficult one. Starting off as bishop of Bordeaux, Frotar had abandoned his see in flight from the Northmen, first transferring to Poitiers, then to Bourges. ${ }^{43}$ These transfers had been highly disputed. Frotar found a backer in Charles the Bald ${ }^{44}$ and Pope John ${ }^{45}$ yet his case was still open in 878 when it was discussed again at the synod of Troyes. ${ }^{46}$ Bernard could use this dispute as an argument for his own case and, indeed, he defended his actions by claiming that he wanted to prevent Frotar from opening Bourges to the enemies of the king. ${ }^{47}$ Pope John VIII, while certainly not agreeing with Bernard's measures, appears at least not to have been biased against him. In a letter from June 878 , he did ask Bernard to keep his vassals from hindering Frotar and to wait for the judgement of the synod; yet he addressed him as "[our] beloved son Bernard, most noble marchio," thus indicating that Bernard still enjoyed his favour. ${ }^{48}$ Only afterwards did John change his position and request Bernard several times to present himself with some of his men to be judged at the synod. ${ }^{49}$

In contrast to the pope, Hincmar appears to have remained sympathetic to Bernard's cause until the very end. The archbishop appears to have despised Frotar,

38 Annales Bertiniani 878, 222; MGH Epist. VII, N²142, 122.

39 Annales Bertiniani 878, 229-230. On the circle receiving the Bernard's honores, see chapter II.1.

40 Annales Bertiniani 879, 234: [Hludouuicus] uolens ire in partes Augustiduni ad comprimendam rebellionem Bernardi markionis, usque ad Trecas perrexit.

41 Annales Fuldenses (Mainz continuation) 880, 95.

42 On the role of mediators in conflict situations between nobles and the king, see Kamp, Friedensstifter, 125-128.

43 Annales Bertiniani 876, 204.

44 DChB 409 (13th July 876) names Frotar Biturignesis aecclesiae archiepiscopus.

45 MGH Epist. VII, N 14, 12-13: De quorum numero quia Frotharius, Burdegalensis dudum antistes, ut testatur vestra fraternitas, extat, necessario duximus eundem virum alii ecclesię preponendum et incardinandum, Bituricensi videlicet, que et vacans esse nobis denuntiata est, et tanti viri digna regimine, ne per minus idoneum rectorem salubre salvarum animarum desit ei pręsidium et nos econtra ingentis culpe involvamur annexu, si tanto urguente discrimine tante minus consulamus ecclesię, propugnatori hanc probabili minime committentes.

46 Annales Bertiniani 878, 227.

47 MGH Epist. VII, N 135, 119: Relatu videlicet hominis pontificio nostro nuntiatum est, quod Frotharius venerabilis episcopus civitatem Beturicam inimicis vestri senioris domni Hludouuici gloriosi regis tradere maluerit, ideo illi ipsam contendere studueras.

48 MGH Epist. VII, N 155, 129: Dilecto filio Bernardo nobilissimo marcionum.

49 MGH Epist. VII, N 135, 118-119. 
who had supported the primacy of Archbishop Ansegisus of Sens against his own claim, and denounced him as a lickspittle. ${ }^{50}$ For him, Frotar was the Archbishop of Bordeaux, not of Bourges. ${ }^{51}$ His opposition to Frotar may be the reason why he seems to have taken a favourable position towards Bernard. He certainly did not actively support him for a letter to Gauzlin clearly shows that he did in fact want Bernard's endeavour to end. ${ }^{52}$ Yet it is remarkable that he omits Bernard's excommunication from his account at the proceedings at Troyes, noting only the distribution of his honores during a meeting between Louis and the group around Hugh the Abbot. ${ }^{53}$

Like Gauzfrid, Bernard's and Emeno's most important connection at court was Archchancellor Gauzlin, their uncle ${ }^{54}$ In his letter, Hincmar urged Gauzlin to influence Bernard to cease his efforts, ${ }^{55}$ which indicates the existence of a closer relation between the two. Probably not long after, Gauzlin and Bernard appear to have acted together in Burgundy where they are recorded as having visited the abbey of Saissy together..$^{56}$ The failure of this connection to secure a settlement with the king was undoubtedly directly related to Gauzlin's rivalry with the group around Hugh the Abbot which managed to dominate the circle around the king approximately at the same time as Bernard's and Emeno's excommunication. ${ }^{57}$ This conclusion is confirmed by Hincmar's comments on the matter, which indicate that Emeno was excommunicated at the instigation of certain bishops and with the king's backing, ${ }^{58}$ which is certainly a reference to Hugh and his allies. The rivalry between the two groups and the outcome of the conflict reveal the mechanisms active at the royal court. Louis acted in concord with a group of nobles powerful enough to outweigh Bernard's support. Louis himself might have accepted a settlement with Bernard-in a diploma for the church of Barcelona issued after

50 Annales Bertiniani 876, 202: Et cum imperator et legati apostolici satis egerint ut absolute archiepiscopu reponderent se oboedituros de primatu Ansigisi sicut apostolicus scripsit, aliud nisi ut praedictum est responsum ab eis extorquere non potuit, excepto quod Frotarius Burdegalensis episcopus, quoniam a Burdigala ad Pictauis indeque ad Bituricum fauore principis contra regulas se contuilt, per adolationem respondit quod imperatori placere cognouit.

51 Annales Bertiniani 878, 227: ...Frotario Burdegalensi episcopo... On Hincmar's objections to episcopal transfers, see Sommar, Hincmar.

52 Flodoard, HRE III, c. 24, 324: Gozlino pro Bernardo, nepote ipsius, qui seditionem contra regem moliri ferebatur, hortans, ut ab hac intentione studeat eum revocare et ut ipse Gozlinus pro nullo carnali affectu a recta via declinet. See also below.

53 Annales Bertiniani 878, 229-230.

54 Emeno and Bernard were the sons of Gauzlin's sister Bilechildis. Flodoard, HRE III, c. 24, 324 with Annales Bertiniani 878, 222. Werner, Gauzlin, 406. On the Rorgonid family, see Werner, Adelsfamilien, 137-142.

55 Annales Bertiniani 878, 227.

56 Translatio S. Baudelii, 111: Interea accidit ut memorabilis Gothorum princeps Bernardus cum avunculo suo Gauzleno tunc inclito abbate, futuro autem episcopo, idem monasterium adventaret.

57 See chapter II.1.

58 Annales Bertiniani 878, 228: Et post excommunicatinem Hugonis, Hlotharii filii, et Iminonis ac complicum eorum, uim facientibus quibusdam episcopis, et consentiente rege... 
Bernard's excommunication he is still depicted as "our marchio"59 - yet this group undoubtedly blocked any attempt made in this direction. This would also explain why Bernard ignored the summonings to the synod of Troyes: faced with the growing opposition against him, he probably feared his was an already lost cause.

Powerful interest groups at court which blocked the resolution of a conflict can also be made out under Charles the Simple. According to the Annales Vedastini, early in 899 Count Baldwin II of Flanders invaded Péronne "against the will of the king." ${ }^{\prime 0}$ The wording chosen here seems to indicate that before Baldwin had taken up arms, he had claimed at least this town at court, yet been refused by Charles. The fate of Péronne appears to have been closely related to that of Saint-Quentin. Again according to the Annales Vedastini, Saint-Quentin had belonged to the son of one of Odo's closest supporters, Count Theoderic of Vermandois, before it was captured by Baldwin's brother Rodulf. ${ }^{61}$ Odo had reacted to this capture by planning an attack not only on Saint-Quentin but also on Péronne, ${ }^{62}$ a circumstance that led Karl Ferdinand Werner to the assumption that the latter had also belonged to Theoderic's son. ${ }^{63}$ If this assumption is correct, this would explain why Charles refused Baldwin's request. At some moment after Odo had taken Saint-Quentin, it ended up in the hands of Count Heribert I of Vermandois, ${ }^{64}$ either after the latter had abandoned Charles and submitted to Odo or after Charles had become sole king. Given that it seems most likely that Baldwin would have renewed his claim when the honores were about to be redistributed, it does appear probable that it was Charles who granted them to his close supporter Heribert. However, Baldwin and Heribert had already been enemies before, possibly because of Rodulf's death at Heribert's hands. When the Frankish nobles assembled after Odo's death to put Charles back on the throne, Baldwin abstained from appearing in person, sending only a legation, according to the Annales Vedastini because of Heribert's presence at the royal court. ${ }^{65}$ Charles granting Heribert the honores was undoubtedly the consequence of their close relationship ${ }^{66}$ and served to secure royal control in the area. At the same time however, this same relation also blocked Charles from accommodating Baldwin if he did not want to estrange Heribert.

This relation probably also explains the aggressiveness of Charles' strategy against Baldwin. Saint-Vaast was quickly besieged and Baldwin's men defending the castrum, after having been excommunicated, were forced to give up the

59 DLS 17 (9th September 878, Troyes), 55: ...Bernardus marchio nostro...

60 Annales Vedastini 899, 81: Balduinus vero contra regis voluntatem Perronam invasit, sed sub celeritate amisit.

61 Annales Vedastini 895, 77.

62 Annales Vedastini 895, 77 and 896, 78.

63 Werner, Untersuchungen V, 89, followed by Schwager, Graf, 29.

64 Werner, Untersuchungen V, 91-92.

65 Annales Vedastini 898, 79: Balduinus vero propter Heribertum venire distulit, attamen missos dirigit, qui regi innotescerent se illi fidelem esse, sicut dignum erat.

66 See chapters I.2.2. and III.2.1.1. 
abbey. ${ }^{67}$ Baldwin, in turn, appears to have attempted to strengthen his position by seeking help outside the realm from Zwentibold, who, after Charles' campaign into Lotharingia during the previous year, had only concluded an armistice with the king and was likely to need allies if the hostilities were renewed. ${ }^{68}$ This connection would explain why Baldwin was present at Cambrai when Charles and Zwentibold met a little after the fall of Saint-Vaast. However, if Baldwin had expected actual support from Zwentibold he was to be disappointed. Zwentibold's own political problems inside Lotharingia encouraged him to conclude a peace treaty with Charles and Baldwin was consequently forced to submit to the king, reconcile with Heribert, give up Saint-Vaast ${ }^{69}$ and return further property to the church of Noyon. ${ }^{70}$

This defeat, however, did not prevent Baldwin from renewing his efforts. During the following year he approached Charles to try to regain his lost honores. Yet, this time he was opposed not only by Heribert, but also by Archbishop Fulk, ${ }^{71}$ hence by two of Charles' most important supporters. After Baldwin's submission at Cambrai, Charles had granted Saint-Vaast to the archbishop, who, in turn, had traded it with Count Altmar for Saint-Medard of Soissons. ${ }^{72}$ Fulk was, nonetheless, undoubtedly concerned by Baldwin's approach: should Charles return SaintVaast to the count, his deal with Altmar would undoubtedly be revoked. While Charles had tightened his control over the north-east of the realm by giving the abbey to one of his most trusted advisors, he had also strengthened the opposition against Baldwin at his court and thus he had limited his options for coming to a lasting agreement with the count even more. The circumstance that Baldwin, despite facing such powerful opposition, nevertheless made this attempt, points to an important factor in his relations to the king. It seems unlikely that he would have made the effort to approach Charles if he had not imagined the chance of having his honores returned to him, especially since he had already made a similar attempt during the previous year. His chances of achieving a positive outcome set aside, his attempts, nevertheless, indicate that his relation with the king was better than the ongoing conflict might otherwise convey. Despite having lost Saint-Vaast in the previous encounter, Baldwin hence still appears to have been confident that

67 Annales Vedastini 899, 81.

68 See chapter IV.4.

69 Annales Vedastini 899, 81.

70 DChS 2, 3: Deprecatus est etiam quatinus res [...] quamque Balduinus comes inique quondam moliebatur auferre... The diploma misses a dating line, yet the restoration of property estranged by Baldwin indicates that it was probably issued at this moment. The property had already been an issue in 892, when Archbishop Fulk mentioned them in a letter to Baldwin (Flodoard, HRE IV, c. 7, 397).

71 Annales Vedastini 900, 81-82: Balduinus vero perrexit ad ipsum placitum, volens sibi regem reblandiri, ut terram, quam ei tulerat, redderet. Cumque hoc contradiceret Fulcho atque Heribertus... More detailed Regino, Chronicon 903, 149-150: Quod Balduinus aegre ferens misit ad iam dictum episcopum [Fulk] Winemarum, obsecrans, ne honores, quos hactenus tenuerat atque possederat, ipse cupiditate ductus sibi usurparet; insuper etiam ingentia dona pollicitus est, si eius ope et interventu prefatam possessionem optinere posset. Sed cum episcopus minime assensum preberet...

72 Flodoard, HRE IV, c. 10, 402. See also Annales Vedastini 899, 81. 
there was a chance that Charles would act in his best interest-in other words, he trusted the king.

However, Charles' second refusal may have overstrained this trust, since only a couple of days later Baldwin's men murdered Fulk. ${ }^{73}$ Surprisingly, this murder did not result in an escalation of the conflict, but was followed by a settlement between Charles and the count. Only the actual murderers were excommunicated by a synod under Fulk's successor Heriveus ${ }^{74}$ while Baldwin himself received SaintBertin, an abbey he had previously claimed for himself, ${ }^{75}$ from the hands of the king. ${ }^{76}$ This complete change in policy can be explained by a number of factors. Fulk's death had weakened the opposition against Baldwin at court and provided Charles with Saint-Bertin, an abbey that Baldwin had also attempted to bring under his control. Furthermore, Fulk's murder led to political turmoil and the crisis with Robert of Neustria. ${ }^{77}$ Confronted with Robert, Charles could probably not afford a conflict with Baldwin; at the same time, he needed to grow his basis of support in order to stabilise his rule. Therefore, compensating Baldwin was a necessity, the logical consequence of the political circumstances, and reveals how changes in the circle around the king could open up new options. However, the settlement should not be read as Charles finally yielding to Baldwin. While the count did receive Saint-Bertin, he had to give up his claim on Saint-Vaast, which remained in the hands of Count Altmar. ${ }^{78}$

Whereas the conflict between Charles and Baldwin was again marked by the presence of strong interest groups at the court blocking an earlier agreement, its prehistory, the conflict between Baldwin and Odo, demonstrates the importance of trust between king and noble as a determining factor. After the death of Abbot Rodulf of Saint-Vaast and Saint-Bertin, the monks of the Saint-Vaast had sent Count Ecfrid to the king to enquire after his will. However, only some days later, at the instigation of a certain Everbert, instead of waiting for Odo's response, they invited Rodulf's cousin Baldwin to take over their abbey, ${ }^{79}$ thus pre-empting the royal will. This, and not the actual control of the abbey, now became the central issue. After having arrived at Saint-Vaast, Baldwin turned to the king, asking for his consent, not only to hold Saint-Vaast, but also Rodulf's other abbey, Saint-Bertin. ${ }^{80}$

73 Annales Vedastini 900, 82; Flodoard, HRE IV, c. 10, 402-403; Regino, Chronicon 903, 149-150; Folcwin, Gesta Abbatum S. Bertini Sithensium, c. 98, 624.

74 Flodoard, HRE IV, c. 10, 403: Denique Winemarus, eius interemptor, ab episcopis regni Francorum cum suis complicibus excommunicatus et anathematizatus insuper insanabili a deo percussus est vulnere ita, ut computrescentibus carnibus et exundante sanie vivus devoraretur a vermibus et, dum propter immanitatem fetoris nullus ad eum accedere posset, miserrimam vitam miserabili decessu finivit.

75 See below.

76 Folcwin, Gesta Abbatum S. Bertini Sithensium, c. 98, 625: Baldwinus autem post haec abbatiam optinuit regia donatione.

77 See chapters III.2.1.1 and III.2.1.2.

78 Hermann, Untersuchungen, 82.

79 Annales Vedastini 892, 70-71.

80 Annales Vedastini 892, 71; Folcwin, Gesta Abbatum S. Bertini Sithensium, c. 98, 624. 
According to the Annales Vedastini, Odo responded "that first [Baldwin] should let [Odo] assume power over his property that God had given to him and come to him, confident to find him in benign mood." ${ }^{81}$ This phrasing seems to indicate that Odo, while insisting on his royal prerogative of controlling the distribution of honores, was nevertheless willing to acknowledge Baldwin's claim and proposed a solution that strongly resembles the settlement between Louis and Gauzfrid. ${ }^{82}$ However, Baldwin refused this proposal and the king's subsequent attempts to negotiate a settlement failed, ${ }^{83}$ with the count's interest in acknowledging Odo's prerogative seemingly having been very limited. According to the annals, Baldwin's legation to Odo was only the result of Everbert's counsel while, after Odo had refused him, all further attempts to negotiate appear to have originated at the royal court. ${ }^{84}$

As we have argued, Baldwin's position appears to point to a deeper problem with Odo's rule at this moment, namely the existence of a strong sentiment of mistrust against the king within the nobility. ${ }^{85}$ Baldwin's refusal to come to court, to give up control over Saint-Vaast and to rely on the royal generosity indicates that he did not trust Odo to protect his interests, that is to say, to acknowledge his claim over his cousin's honores. This view was probably reinforced by developments at Rodulf's other abbey, Saint-Bertin. While the monks of Saint-Vaast had opted for Baldwin, those at Saint-Bertin turned to Odo upon hearing that the count had claimed their abbey in order to express their opposition. Supported by Archbishop Fulk, they obtained the right to elect their new abbot, with their choice falling on Rodulf's predecessor-the very same Fulk. ${ }^{86}$ Meanwhile, Baldwin's position at Saint-Vaast was probably also not as strong as he would have liked it to be. As the initial legation under Count Ecfrid shows, there was a party among the monks of Saint-Vaast whose loyalty towards Baldwin was questionable and who instead favoured a royal decision on the matter, thus providing an opening for Odo, should he wish to deny Baldwin's claim. If Baldwin had already harboured doubts about Odo's intentions, the development at Saint-Bertin had certainly not improved his hopes that, should he give up control over Saint-Vaast, the king would grant him the abbey.

Probably around the same time as the conflict for Rodulf's abbeys was developing, Odo appears to have attempted to install his ally Altmar as count of Poitiers, which led to a confrontation with the Ramnulfides and thus diverted a part

81 Annales Vedastini 892, 71: Odo vero rex respondit, ut sineret illum prius esse potestativum de suo, quod Deus illi concessit, et veniret ad se, fidens benignum erga illum se inventurum fore.

82 Another example for this practice is the restitution of estranged possessions to the pope by Wido of Spoleto in 882 at an assembly at Ravenna under Charles the Fat, only to receive them back immediately after. Dümmler, Geschichte III, 186 and 218-219.

83 Annales Vedastini 892, 71.

84 Annales Vedastini 892, 71.

85 See chapter I.2.3.

86 Folcwin, Gesta Abbatum S. Bertini Sithensium, c. 98, 624. 
of the royal attention away from Baldwin. ${ }^{87}$ In addition, Baldwin was able to win further support from one of Odo's own relatives, his uncle Adalelm's son Walker, who the king had entrusted with the castrum of Laon. ${ }^{88}$ Hence, for Baldwin, taking up arms against the king seemed to be the preferable option, especially if he considered Odo to be unreliable in his promises.

Once Baldwin started to act hostile towards Odo, the king initiated a number of measures against the count. The first half of these measures consisted in creating new channels of communication which not only served to continue to negotiate, but also to increase moral pressure on Baldwin through the threat of excommunication. This task was performed by Archbishop Fulk, who, together with a number of his suffragans, advised Bishop Dodilo of Cambrai to get in contact with the count $^{89}$ and, after this attempt as well as a letter of himself on the same subject, ${ }^{90}$ had failed, organised a synod where Baldwin's excommunication was decided upon. ${ }^{91}$ Fulk's involvement was certainly due to Baldwin falling under his spiritual jurisdiction as archbishop of Reims. Yet, there was probably more to it. Fulk and Baldwin had been allied against Odo in $888^{92}$ and appear to have maintained this connection over the course of the years-when Fulk himself rebelled against Odo shortly after, this alliance was renewed. Odo might have aimed to use this connection to mediate an agreement with Baldwin while hoping that their rivalry for Saint-Bertin would prevent the archbishop from siding with Baldwin. In any case, Odo underestimated Fulk's own political agenda: the archbishop suspended Baldwin's excommunication, ${ }^{93}$ thus easing the pressure placed on the count. Odo's second measure aimed at isolating Baldwin from his allies. Laon was taken and Walker captured and executed..$^{94}$ After this was done, Odo made an attempt to attack Baldwin directly in Flanders, yet was outmanoeuvred and forced to withdraw. ${ }^{95}$ The further development of the conflict was determined by the creation of new alliances and their dissolution, which strongly influenced the balance of power. Fulk's rebellion drew Odo's focus away from him and enabled Baldwin and his brother Rodulf to go on the offensive and take Saint-Quentin ${ }^{96}$ when Odo was forced back over the Seine by Zwentibold's intervention. ${ }^{97}$ However, when the alliance broke and Charles' supporters opened negotiations with Odo, the latter

87 See below.

88 Annales Vedastini 892, 72; Regino, Chronicon 892, 139.

89 Flodoard, HRE IV, c. 6, 391.

90 Flodoard, HRE IV, c. 7, 396-397.

91 Flodoard, HRE IV, c. 7, 397. The account of the Annales Vedastini 892, 71 (Post haec Balduinus castrum refirmat et parat se ad resistendum. Episcopi vero illum excommunicaverunt.) is misleading. On the synod see also Schröder, Synoden, $N^{\circ} 8,116-122$. See chapter I.2.1.

92 Annales Vedastini 888, 65. See also chapter I.1.4.

93 Flodoard, HRE IV, c. 7, 397.

94 Annales Vedastini 892; Regino, Chronicon 892, 139-140.

95 Annales Vedastini 892, 71-72.

96 Annales Vedastini 895, 77.

97 Annales Vedastini 895, 76. 
immediately turned back against Baldwin and besieged Saint-Vaast. ${ }^{98}$ The attack was accompanied by the renewal of negotiations, this time with Odo's brother, Robert, serving as mediator. ${ }^{99}$

These events cast some further light on the relations between Odo and Baldwin. When the king arrived at Saint-Vaast, Baldwin's men, who garrisoned the fort and the abbey, asked for peace and offered hostages while sending envoys to the count to ask for his orders. In the meantime, since the return of the envoys took more time than anticipated, Odo asked the gates to be opened and occupied both places. When Baldwin's envoys finally arrived, accompanied by Robert, the king ordered his men to leave the fort and return it to the count's men. ${ }^{100}$ Commonly this is interpreted as the conclusion of peace, with an agreement over Baldwin's possession of Saint-Vaast. ${ }^{101}$ Yet, no such peace is actually recorded and Baldwin's submission only appears to have taken place in $897 .{ }^{102}$ In addition, Odo's next plans were to attack Baldwin's brother Rodulf at Saint-Quentin and Péronne. ${ }^{103}$ It is of course possible that Odo and Baldwin had made their peace at that moment and that Rodulf acted independently of his brother. ${ }^{104}$ Nevertheless, we may propose a different reading: Odo had occupied Saint-Vaast on the condition that he would leave it once Baldwin's will was known. It was a question of trust to open the gates to the king, who then went to pray and listened to a mass at the tomb of Saint Vedast. Considering Baldwin's mistrust of Odo's behaviour, the king's vacation of Saint-Vaast would not have been the consequence of a peace with Baldwin, but a trust-building measure, to demonstrate his integrity. Handing Saint-Vaast back to Baldwin's men would then not have meant that Odo accepted the count's claim but that he now pursued a strategy of re-establishing trust in his person.

However, making peace was complicated by Baldwin and his brother Rodulf having occupied honores belonging to Odo's supporters, most notably

98 Annales Vedastini 895, 76.

99 Annales Vedastini 895, 77. See also chapter II.4.

100 Annales Vedastini 895, 76-77: Odo vero rex Corbeiam venit indeque Atrebatis castrumque seu monasterium sancti Vedasti obsidione vallavit. Sed miseratus Christianitati noluit eum bellando capere. Homines vero Balduini, videntes ei non posse resistere, pacem petunt, obsides regi dant, ad sauum dirigunt seniorem, ut, quid illis agendum sit, insinuet. Et dum moram facit his qui missus fuerat, rex iussit sibi aperiri portas, ingressusque monasterium seu castellum ad limina perrexit sancti Vedasti coramque eius sepulchro humi prostratus devotissime oravit ac uberrime flevit, inibi etiam missam audivit, gratias agens Deo. [...] Missi vero Balduini regressi cum Rotberto egerunt ea quae senior illorum iussit. Statimque rex iussit illis reddi claves castelli omnesque suos iussit exire, et ita homines Balduini recipere ipsum castrum.

101 E.g. Kienast, Vasallität, 478; Offergeld, Reges pueri, 439.

102 Annales Vedastini 897, 79: Balduinus etiam Rothberto faciente venit ad regem; quem rex honorifice suscepit, et de omnibus quae iusserat illi rex satis illi fecit, et ita remisit eum rex ad sua.

103 Annales Vedastini 895, 77: Rex vero ab Atrebatis disponit ire ad Sanctum Quintinum et Perronam. Nam Sancti Quintini castrum, per noctem tradendo eum abintus, tulerat Rodulfus filio Theoderici.

104 Up until this point however, Baldwin and Rodulf appear to have been close to each other: In 892, Baldwin left Saint-Vaast to his brother to defend it (Annales Vedastini 892, 71). In 895, they left Charles' side together to ally themselves to Zwentibold (Annales Vedastini 895, 76). 
Saint-Quentin, honores they now had to give up. ${ }^{105}$ Rodulf in particular appears to have been opposed to this, which led the negotiations to fail. ${ }^{106}$ Only when Odo had taken Saint-Quentin and Péronne from Rodulf's men and Rodulf himself had been killed by Heribert $\mathrm{I},{ }^{107}$ was a final accord between the king and Baldwin mediated by Robert. ${ }^{108}$ The solution they agreed upon appears to have been in direct response to the initial problems which had led to the outbreak of the conflict. Baldwin came to the court-something he had previously avoided doing-and was honourably received. Then he "satisfied the king in everything he ordered him to do," ${ }^{109}$ which is undoubtedly a reference to returning Saint-Vaast to the king, thus acknowledging Odo's royal prerogative to control the distribution of the honores. The Annales Vedastini do not mention that Odo then granted the abbey to Baldwin, yet from their report for 899 it becomes clear that the count remained in possession. ${ }^{110}$ Odo's success in asserting his interests was certainly due to his military superiority after Baldwin had isolated himself from his allies and Odo had come to terms with Charles and his supporters. Furthermore, Rodulf's death had solved the problem of another party blocking a resolution due to their own interests. Finally however, a crucial role fell to Robert's mediation. He represented a new communication channel trusted by both parties and was seemingly able to restore Baldwin's trust in the king. Trust, like the presence of interest groups at the royal court, hence played a decisive role in the capacities of a ruler to resolve a conflict by means of negotiation.

\section{VI.2 Rulers and nobles: Breaches of trust}

In all the cases presented so far, the kings do seem to have had limited direct interests in the conflicts. If any such interests are visible at all, they appear to have been focused on maintaining control over the distribution of the honores in question. At the root of these conflicts were the efforts of individual nobles to extend their influence which thus infringed on this royal prerogative or clashed with the interests of powerful noble groups at the royal court. If peaceful resolutions were blocked, this was either due to the influence of these groups or due to a lack of trust in the king by the opposing party. However, there are also those cases to consider in which the initiative appears to have rested mainly with the ruler him-

105 See chapter I.2.5.

106 Annales Vedastini 896, 77: Odo rex placitum cum suis fidelibus habuit, volens partem regni, quam eius fideles tenuerant, Karolo concedere. Sed Rodulfus comes omne illud placitum disrupit.

107 Annales Vedastini 896, 78.

108 Annales Vedastini 897, 79: Balduinus etiam Rothberto faciente venit ad regem; quem rex honorifice suscepit, et de omnibus quae iusserat illi rex satis illi fecit, et ita remisit eum rex ad sua.

109 See chapter VI.1, n. 108.

110 Annales Vedastini 899, 81: Karolus rex obsedit castrum Sancti Vedasti, et habitatoribus excommunicatis omnibus, hi qui ipsum castrum tenebant missos dirigunt ad Balduinum et, quamvis non voluntarie, obsides regi dederunt, dato spatio ad sua exportanda. 
self, be it because he wanted to pursue his own interests or because he was under the impression that the circumstances forced him to intervene with the current order. One of these conflicts arose over the control of the county of Poitiers after the death of Ramnulf II on 5th August 890. ${ }^{111}$ Ramnulf had left an illegitimate son, Ebalus Manzer, ${ }^{112}$ as his heir. ${ }^{113}$ The latter's claim appears to have been acknowledged by Odo since Ebalus was able to donate property to Saint-Martin of Tours for the sake of his father's, his uncles' and his own soul, immediately receiving said property back in precarium along with the villa of Doussay in the pagus of Poitiers and another vicaria on 10th October $891,{ }^{114}$ an exchange that hardly could have taken place without the king's consent even if he does not appear in the charter issued on that occasion. The matter, however, was complicated by the claim of Count Altmar, whose father Emenon had previously held the city. ${ }^{115}$ According to Ademar of Chabannes, Odo did indeed grant Poitiers to Altmar after Ramnulf's death. ${ }^{116}$ However, given that Ebalus Manzer and Odo were still on good terms in October 891, it seems that this did not happen immediately after Ramnulf's death, but probably in late 891 or early 892 . Since in the charter recording his donation to Saint-Martin of Tours Ebalus only describes himself as "Ebalus, as yet blossoming in youthful age" without giving any title, ${ }^{117}$ it would indeed appear that the countship had remained vacant from Ramnulf's death up until Altmar's appointment as count.

However, the succession at Poitiers cut deep into the structures of Odo's rule. Altmar was related to Odo and was one of his close associates. ${ }^{118}$ Hence, the grant can be seen as a sign of royal favour resulting from this close relation. Yet, at the same time Ebalus Manzer himself was also very well connected at court, with his uncle Ebolus ${ }^{119}$ being the abbot of Saint-Denis and Odo's archchancellor. ${ }^{120}$ Thus, satisfying Altmar's claim meant that Odo estranged another one of his close supporters since Ebolus and his brother Gauzbert now entered into conflict with the king. ${ }^{121}$ This act probably damaged Odo's reputation as a ruler who could be

111 Chronicon sancti Maxentii Pictavensis, 371. Different Regino, Chroncon, 892, 140 (Post haec in Aquitaniam profiscitur contra Ramnulfum et fratrem eius Gozbertum et Ebolum abbatem de sancto Dionisio et alios nonnullos, qui eius imperiis obtemperare rennuebant, ut eorum insolentiam reprimeret.), indicating that Ramnulf was still alive in 892.890 , however, is to be prefered, see Auzias, Aquitaine, 440 with n. 71 and Bautier, Recueil Eudes, XXIV with n. 1.

112 On Ebalus Manzer, see Prell, Comtes, 37-42.

113 Ademar, Chronicon III, c. 21, 141.

114 Bautier, Recueil Eudes, 227-233. On the history and role of this villa, see Depreux, Dimension, 357-359.

115 Ademar, Chronicon III, c. 21, 141. Kienast, Vasallität, 461 with n. 1631.

116 Ademar, Chronicon III, c. 21, 141.

117 Recueil Eudes, 230: ...ego Ebolus, juvenili adhuc aetate florens... See also Favre, Eudes, 146.

118 On Odo and Altmar, see chapter II.4.

119 Ramnulf and Ebolus were brothers. Regino, Chronicon 892, 140 with Annales Vedastini 892, 73.

120 Bautier, Recueil Eudes, XXIII-XXV. Ebolus last appears in DOdo 27 (15th July 891), with Anskeric appearing as his successor only in DOdo 30 (30th September 892).

121 Annales Vedastini 892, 72; Regino, Chronicon 892, 140. 
trusted by demonstrating that proximity to the king was not sufficient to protect one's interests. The situation became even more complicated when William the Pious, another one of Ramnulf's relatives with whom he had entertained a close relation, ${ }^{122}$ was also drawn into the ensuing conflict. According to Ademar of Chabannes, upon his death Ramnulf had entrusted his son Ebalus to William's close friend Gerald of Aurillac, who, in turn, brought him to William. ${ }^{123}$ It may have been due to this opposition including some of the most important Aquitanian nobles that Odo revoked his previous decision to grant Poitiers to Count Altmar and instead entrusted his brother Robert with the city's defence. ${ }^{124}$ The wording used by Abbo of Saint-Germain, who is the only source reporting about this event, may indicate that Robert was not made count of Poitiers but only temporarily installed up until a settlement between the different parties could be reached. Be it as it may, this new decision in turn led to a conflict with Altmar, who attacked Odo's forces and then rushed to take Poitiers. ${ }^{125}$ Within a short period of time, Odo had thus estranged not only one, but two of his close supporters. If Odo's previous decision to disinherit Ebalus Manzer had already been perceived as a breach of trust, this one probably deepened the mistrust against him even more.

Odo's reaction to the opposition appears to have been delayed by the evolving conflict with Baldwin II of Flanders, which kept him in Francia up until autumn 892 before he engaged in a campaign to manage the problems south of the Loire. ${ }^{126}$ The sources make no mention of negotiations, yet, it may be that, at least in William's case, Odo had hoped for a peaceful settlement. According to Abbo of Saint-Germain, the king only deprived William of his honores after their armies had met at the opposing shores of a river without engaging, ${ }^{127}$ possibly indicating that up until this moment he had intended to come to terms with William yet had been rejected by the count. While Ebolus and Gauzbert were quickly killed, ${ }^{128}$ the

122 Ademar, Chronicon III, c. 21, 141: ...Rannulfus [...] habuit amiciciam cum propinquo suo Willelmo, comite Arvernis... For William's and Gerald's close relation, see for example Vita Sancti Geraldi Auriliacensis I, c. 34, 182.

123 Ademar, Chronicon III, c. 21, 141: Hac de causa [Rannulfus] a rege Odono potius timore quam honore honorabatur, dumque regalem aulam assiduaretur, veneno nectus, in extremis sancto Geraldo, ibi tunc presenti, parvulum filium suum Eblum commisit tutantum. ... Regressusque a palatio sanctus Geraldus, clam subductum filium Rannulfi a Pictavis, Willelmo comiti Arvernis credidit nutrendum, cui consanguineus erat. On Ademar's claim that Odo had poisoned Ramnulf II, see Werner, Ademar, 312-314, who argues for a later invention.

124 Abbo, Bella II, 106, v. 545-546:

Nam libuit regi dare propugnacula fratri

Rotberto Pictavis, Ademaro tamen haud sic.

125 Abbo, Bella II, 106, v. 535-538 and 106-108, v. 546-547.

126 On the moment of the campaign and the royal itinerary, see Bautier, Recueil Eudes, 132-138, convincingly arguing against Favre, Eudes, 141-148, who argued for two campaigns, the first one taking place in summer 892 .

127 Abbo, Bella II, 108, v. 548-553.

128 Annales Vedastini 892, 73. Abbot Ebolus was killed 2nd October 892. Molinier, Obituaires I, 274 and 327 and Bautier, Recueil Eudes, XXV with n. 1. 
conflict with William continued, the count, in turn, killing Odo's ally Hugh, who had been granted William's honores. ${ }^{129}$

However, over the course of 893 , a settlement was found not only with William but also with Altmar. This was probably due to two political developments which shifted the balance of power against Odo. First, early in 893 Fulk and his allies crowned Charles the Simple as king, thereby directly threatening Odo's right to rule. Second, in the wake of this rebellion, William and Altmar concluded an alliance, joining up with Richard the Justiciar to take advantage of the situation. ${ }^{130}$ Given that Altmar had taken control of Poitiers (which was also claimed by Ebalus Manzer), this alliance may seem surprising since it indicates that William had acknowledged Altmar's position and, hence, disregarded his protégé's interests. Undoubtedly, this had been made possible by the deaths of Abbot Ebolus and Gauzbert and might have been facilitated if Altmar, in turn, guaranteed Ebalus access to his father's property in the region. Thus, political pressure on Odo increased considerably and the king decided to appease his opponents. William gained the abbey of Saint-Julien of Brioude by a royal grant ${ }^{131}$ whereas Altmar was again confirmed as count of Poitiers ${ }^{132}$ and resumed his position within the circle around Odo shortly after, ${ }^{133}$ acts that served to strengthen the bond between these nobles and the king and that probably were also aimed at restoring trust in Odo because they demonstrated that he was willing to do his opponents justice and to make generous grants to restore peace. While Altmar regained his position in the circle around the king, William's future position is more difficult to discern. It seems that he at the very least remained neutral over the course of the next years, even if he displayed a rather self-confident attitude. ${ }^{134}$ The alliance between him and Altmar probably broke soon after. The Vita Geraldi reports a number of clashes between the count and Gerald of Aurillac, with William coming to the latter's aid: ${ }^{135}$ while in 902 William probably supported Ebalus Manzer's return to Poitiers which forced Altmar out of the city. ${ }^{136}$ However, for the time being Ebalus Manzer's interests appear to have once again been disregarded, undoubtedly because the deaths of his uncles had deprived him of his support. In a private charter issued in 897, Robert granted the villa of Doussay to the canons of Saint-Martin

129 Abbo, Bella II, 108, v. 551-561.

130 Annales Vedastini 893, 73-74: Post pascha Domini Fulcho archiepiscopus et Heribertus comes assumentes Karolum regem cum omni exercitu disponunt ire contra Odonem regem, veneruntque contra eos Richardus, Willelmus et Hadamarus, habueruntque exercitum copiosum. See chapter I.2.5.

131 See chapter I.2.5.

132 Kienast, Vasallität, 464.

133 DOdo 50 (after 15th October 893), granting Saint-Hilaire of Poitiers to Bishop Egfred of Poitiers at the request of fideles nostri ac marchiones, dilecti Hrobertus scilicet atque Adamarus (192). See also chapter II.4.

134 See chapters II.4 and III.2.3.

135 Vita Sancti Geraldi Auriliacensis I, c. 35, 182-184; c. 36, 184-186; c. 38, 186-188.

136 Chronicon S. Maxentii, 68: Anno DCCCCII. Pictavis nocte ingreditur Eblus. William supporting Ebalus Manzer on this occasion is also assumed by Auzias, Aquitaine, 450. 
of Tours, ${ }^{137}$ the very same villa that had been given in precarium to Ebalus Manzer in 891. In the conflict evolving around the succession at Poitiers, Odo's early decisions appear to have been motivated firstly by wanting to protect the interests of a noble close to him and secondly by trying to reverse his mistake. Both times he violated the interests of members belonging to his inner circle and therefore betrayed the trust placed in him as ruler that being close to him meant that he would act according to their interests. These actions were probably as badly received by them as by the rest of the nobility and thus contributed to the general loss of trust that was part of the rationale of the rebellion against him.

This same failure to take into consideration how his actions were perceived by the nobles also marks the behaviour of Charles the Simple in his conflict with Count Gislebert. The first sign of this conflict is the diploma recording the second assembly of Herstal in June 919, which notes a judgement of the scabini of the royal palace in favour of Archbishop Roger and which returned the abbey of Saint-Servais of Maastricht, "previously unjustly taken from this church by means of violence by Count Reginar and his son Gislebert" to the church of Trier. ${ }^{138}$ At this point, the conflict around Saint-Servais already had a long prehistory, with its possession repeatedly changing from Reginar to the church of Trier and back, each time marking how the political influence of the rivalling parties had changed at the royal court. ${ }^{139}$ Like Odo's grant of Poitiers to Count Altmar, the restoration of Saint-Servais to the church of Trier also meant the interests of a close supporter by the king were being protected. The reasons why Charles turned against Gislebert, who, some years earlier, still figured prominently among his supporters, ${ }^{140}$ are difficult to determine. Following Richer's description of Gislebert, ${ }^{141}$ scholars often assume that the conflict was the result of Gislebert's ambition to become king ${ }^{142}$ or $d u x$ of Lotharingia, ${ }^{143}$ or at least to increase his political room for manoeuvre in the context of the coronation of Henry the Fowler in the East Frankish realm which had taken place shortly before. ${ }^{144}$ His political ambition seems certain. As

137 Dufour, Recueil Robert et Raoul, N 40 (27th March 897).

138 DChS 100 (13 $3^{\text {th }}$ June 919), 230: ...sed violentia Rageneri comitis et filii ejus Giselberti a predicta Treverensi ecclesia jam olim esset injuste ablata.

139 See chapter III.2.1.4.

140 DChS 84 (19th January 916), see chapter III.2.1.7.

141 Richer, Historiae I, c. 35-36, 70-71: Hic [Giselbertus] cum esset clarissimo genere inclitus, et Heinrici Saxonię ducis filie Gerberge matrimonio vel coniugio nimium felix, in nimiam pre insolentia temeritatem preceps ferebatur, in disciplina militari ex audatia nimius, adeo ut quodcumque inevincibile, appetere non metueret [...] Talis itaque in regem nimia animositate ferebatur. Parisot, Royaume, 631, is undoubtedly correct in dating Gislebert's return to Lotharingia to the first half of 920 since Flodoard (Annales 920, 4, see below, chapter VI.2, n. 145), reports that during this time Gislebert was chosen princeps by a part of the Lotharingian nobility. He is also correct in refusing Henry's role as mediator since he and Charles were enemies at the time.

142 Boshof, Lotharingien, 146.

143 Parisot, Royaume, 624; Sassier, Hugues, 81; Koziol, Politics, 426.

144 Hlawitschka, Lotharingien, 203. 
Flodoard reports, during the period of Charles' problems with the West Frankish nobles after the assembly of Soissons in January 920, Gislebert was elected princeps by Lotharingian nobles, ${ }^{145}$ seemingly after he had created a network of support by distributing honores among them if Richer is to be believed. ${ }^{146}$

Gislebert's ambitions to recover at least his father's position at court ${ }^{147}$ and in particular his rivalry with the church of Trier certainly played a central role in the conflict between him and the king. Yet, in regard to its development, it appears to be too limiting to attribute the outbreak and the development of the conflict solely to these ambitions, for this fails to take Charles' own interests into proper consideration. The assembly at Herstal demonstrates how much support Charles was able to muster at that moment against Gislebert: five bishops and twelve counts ${ }^{148}$ among them Count Sigard from Gislebert's own sphere of influence ${ }^{149}$ and Otto, the son of Count Ricuin of Verdun, who had married Gislebert's halfsister Cunigunde, ${ }^{150}$ which probably indicates that his father also did not oppose the king's course. Just how powerful this network was becomes apparent from Charles' success. Gislebert was soon also excommunicated ${ }^{151}$ and, according to Richer, chased out of the realm to Henry the Fowler's court. ${ }^{152}$

Of course, the fact that Charles was prepared at that moment does not necessitate that he had taken the initiative in the conflict. Yet, the further development of the relations between him and Gislebert nevertheless betrays that the conflict was at least as determined by Charles' interests as by the counts. Gislebert, who had probably returned from his exile during the first half of 920 when Charles had to deal with the nobles of the Western Francia, was subdued and restored to a part of his honores ${ }^{153}$ However, once peace had been restored, Charles started to advance against Gislebert's former allies. Bishop Hilduin of Liège, who had supported the count, was replaced by a Matfriding, Abbot Richer of Prüm. ${ }^{154}$ Next came Henry the Fowler, with whom Charles, after an encounter at Worms, ${ }^{155}$ concluded first an

145 Flodoard, Annales 920, 4: ...Giselberto, quem plurimi Lotharienses principem, relicto Karolo rege, delegerant... On Flodoard's use of princeps, see Jacobsen, Titel.

146 Richer, Historiae I, c. 36, 71: Meditabatur quoque regis abiectionem admodum, ac plurimum id pertractabat apud eos qui in Belgica potiores videbantur non quidem Rotberto, sed sibi regnum affectans, sua quoque principibus pene omnia distribuens. Et maiores quidem prediis et ędibus egregiis inclite donabat, mediocres autem auri et argenti talentis efficaciter illiciebat. Fit itaque multorum ex Belgica cum eo consensus.

147 See chapter III.2.1.7.

148 DChS 100. See chapter III.2.1.7. For the identifications, see Parisot, Royaume, 626 with n. 2.

149 Parisot, Royaume, 634.

150 See chapter III.2.1.7.

151 MGH Conc. VI, N² $2,45$.

152 Richer, Historiae I, c. 37-38, 71-73.

153 Richer, Historiae I, c. 38-39, 72-73. Richer's claim that Gislebert only returned to Lotharingia after a few years is rendered impossible by Flodoard's report that Charles pursued him in Lotharingia over the course of winter 921/922. See below.

154 On the succession at Liège, see Zimmermann, Streit and chapters III.2.1.8 and IV.4.

155 Continuatio Reginonis 923, 157; Flodoard, Annales 920, 3; Flodoard, Annales 921, 6. 
armistice and then a peace treaty ensuring at least his future neutrality. ${ }^{156}$ Last on the list was Count Ricuin of Verdun, who appears to have switched his support over to Gislebert, but now lost a number of fortified places to Charles before he submitted and was re-accepted into the king's favour. ${ }^{157}$ With Gislebert now isolated, Charles renewed the hostilities, chasing him and Ricuin's son Otto over the course of the winter up until Lent $922 .{ }^{158}$

In either of these cases, Gislebert may have been the initiator and not Charles. Yet, in regard to Charles' activities, this seems rather improbable. Gislebert's success was tied to the crisis of Charles' reign, a crisis that had passed by September 921 and resulted in his submission. After his submission, his position had further deteriorated, which made it even more unlikely that a renewal of the conflict would result in a success for him. This only changed when the rebellion against Charles broke out, forcing the king to concentrate his forces in the West against Robert and his supporters. ${ }^{159}$ However, this was only after hostilities between the king and the count had already been renewed. Therefore, it seems indeed safe to assume that the initiative had rested with Charles. Gislebert made use of this opportunity to improve his position by allying himself with the rebels. ${ }^{160}$ However, soon afterwards, he abandoned them again when he came to an agreement with the king, as indicated by a charter he issued 25th August 922. ${ }^{161}$ The charter, confirming the exchange of property between a certain Guntbert and Gislebert's abbey of Stavelot, was signed by him as " $d u x$ Gislebert, count and abbot."162 A private charter does not necessarily reflect the position of the king, especially one which was issued during times of conflict. Yet, the dating line of this charter reads "in the 11th year of the reign of the most pious lord, King Charles,"163 indicating that Gislebert and the king had indeed come to an agreement. The concurrence of the count acknowledging Charles once again as his king, honouring him as "most pious" (piissimus) while calling himself $d u x$, further gives rise to the conclusion that Charles, confronted with the rebellion, had sought refuge in appeasing Gislebert by this time granting him what he desired: the position as Lotharingia's leading noble. Gislebert, given that Charles had already broken the earlier settlement, was probably wary of the king by now, yet his doubts were probably overcome by the

156 Flodoard, Annales 921, 6; MGH Const. I, Nº 1, 1-2. See chapter IV.4.

157 Flodoard, Annales 921, 5-6; Richer, Historiae I, c. 27, 65. For the connection between Charles’ advance against Ricuin and the conflict with Gislebert, see also Ewig, Rheinlande, 207.

158 Flodoard, Annales 922, 7.

159 Flodoard, Annales 922, 7-8.

160 Flodoard, Annales 922, 8: Quem insecutus Hugo cum ceteris pugnatorum duobus milibus usque Mosam, Giselbertum Lothariense obvium habuit; cum quo a patre, qui eum prosecutus fuerat et super Axonam in pago Laudunensi sedebat, ad colloquium revocatus revertitur.

161 Halkin and Roland, Recueil Stavelot-Malmédy I, N 55, 132-133. See also chapter III.2.1.7.

162 Halkin and Roland, Recueil Stavelot-Malmédy I, N 55, 133: Gilebert dux, comes et abbatis, qui hanc precariam manu propria firmavit et firmare rogavit et jussit scribi.

163 Halkin and Roland, Recueil Stavelot-Malmédy I, N 55: ... anno XI regni domni Karoli piissimi regis... 
gains he could make through the new agreement. However, this peace did not hold either. For the second half of 922 Flodoard notes only a single campaign, namely Charles besieging Gislebert's castrum of Chièvremont and Hugh the Great hurrying to its relief and receiving hostages from Gislebert after its rescue. ${ }^{164}$ Because Gislebert's ambitions had been satisfied by Charles in the previous settlement and because the count himself was apparently considered so untrustworthy and weak by Hugh that he had to provide hostages, it again seems safe to attribute the renewal of the conflict to the king, despite the fact that he already faced the rebellion.

Hence, the conflict between Charles and Gislebert appears to have been, possibly initiated, but certainly twice renewed by the king. Who was the driving force behind these actions? Charles' allies, most of all the church of Trier and the Matfrid family and their rivalry with Reginar's son, certainly played an important role. Yet, it seems safe to assume that neither of them opposed the first settlement with Gislebert. Archbishop Roger and Count Matfrid both accompanied Charles at Bonn when he concluded the treaty with Henry the Fowler ${ }^{165}$ and the former continued to serve as royal archchancellor at least up until June $922{ }^{166}$ Furthermore, Roger and Gislebert cooperated in 923 when they invited Henry the Fowler to come to Lotharingia. ${ }^{167}$ As the rivalries between them do not seem to have constituted an insurmountable obstacle to a settlement of the conflict, the source for its constant renewal appears to have been with Charles himself. The support Charles was able to gain against Gislebert indicates that his reasons were initially widely accepted by the nobles of the realm. Therefore, it seems improbable that the outbreak of the conflict would have been badly perceived by the majority of the nobles supporting Charles' rule. However, it appears that Charles considered the subsequent settlements with Gislebert mere temporary arrangements which would gain him time to strengthen his position before attacking again. As trust is a matter of being predictable and reliable, each renewal of the conflict probably undermined the trust Charles enjoyed among the nobles, or at least among those already harbouring doubts against him. Faced with the rebellion, Charles, like Odo, tried to improve his position by coming to terms with his opponent. Unlike Odo however, he then broke these settlements and thus further damaged his reputation instead of trying to restore trust in himself by keeping his side of the bargain and displaying himself as a reliable ruler.

164 Flodoard, Annales 922, 11: Rotbertus filium suum, Hugonem, in regnum Lotharii mittit cum aliquo Francorum agmine, protper Capraemontem, Gisleberti castrum, obsidione liberandum, quod Karolus premebat obsessum. Quo comperto, Karolus obsidionem relinquit, et Hugo, acceptis obsidibus a quibusdam Lothariensibus, ad patrem remeavit.

165 MGH Const. I, Nº 1, 1-2.

166 Roger makes his last appearance in DChS 121 (15th June 922), which is also the last diploma issued by Charles.

167 Flodoard, Annales 923, 18. 


\section{VI.3 Speaking justice: Symbolic acts}

While royal actions could undermine the relations between the king and the nobles when they were perceived as violations of the existing norms, rulers could also aim to strengthen trust by performing acts of justice. The most striking records of kings actively trying to do justice are certainly the capitularies, "legislative texts that recorded the decisions reached by kings in discussion with their leading men, and communicated them to a wider political community." ${ }^{168}$ Among the West Frankish kings ruling after the death of Charles the Bald, only Carloman II appears to have issued any capitularies. The first was issued 22nd February 883 at Compiègne, ${ }^{169}$ comprising only three very short chapters on robbery. The second capitulary followed about a year later in March 884 at the assembly of $\operatorname{Ver}^{170}$ and this time not only added a lengthy introduction but also extended the chapters, again mostly on robbery, to fourteen. Most of these chapters contain nothing new but only repeat old capitularies on how to pursue and judge robbers, ${ }^{171}$ quick excommunication being the most important measure. The lack of capitularies during the late Carolingian era has often been interpreted as a sign of institutional weakness. ${ }^{172}$ This view has recently been challenged, not at least by Steffen Patzold, who argues that capitularies did not serve to uphold order by recording texts of normative significance but that instead they were meant to create order by instructing people to behave in a moral way and thus prevent arising conflict. ${ }^{173}$ Even if this new reading might be considered as going too far in negating the legal character of the capitularies, it, nevertheless, becomes apparent that there seems to have been more to these texts than mere collections of newly drafted laws.

As François Bougard has observed, the capitularies issued in Italy towards the end of the 9th century became more and more formulaic and repetitive in nature; he argues that their function was not only pragmatic, but also symbolic. In regard to new kings, capitularies seem to have been drafted less to ensure justice was done in practice, but to restate the moral foundations of traditional kinship and to demonstrate an intention of good government. ${ }^{174}$ Hence, it is not surprising that Charles the Bald, for example, issued two capitularies shortly after the had taken over the Italian realm ${ }^{175}$ for both served to strengthen his rule there. Carloman's capitularies were not issued at the beginning of his reign in 880 but three years

168 MacLean, Legislation, 395. See also Ganshof, Recherches; Geiselhart, Kapitulariengesetzgebung; Pössel, Authors.

169 MGH Capit. II, N² 286, 370-371.

170 MGH Capit. II, N² 287, 371-375.

171 Dümmler, Geschichte III, 231.

172 MacLean, Legislation, 396.

173 Patzold, Normen, 349-350. For the debate around the nature and purpose of capitularies, see furthermore Schneider, Bedeutung; Schneider, Schriftlichkeit; Bühler, Wort; McKitterick, Herstellung; Bougard, Justice; Mordek, Kapitularien.

174 Bougard, Justice, 25-29 and 52.

175 MGH Capit. II, N 220 and 221, 98-104. 
later. However, the first one was issued about half a year after Carloman had taken over the northern part of the realm in succession to his brother Louis, at a moment when the Northern nobles had already turned away from him and withheld their support against the Northmen. ${ }^{176}$ The second, more impressive capitulary was issued at exactly the same moment, when an accord between Carloman and the nobles had finally been reached. Thus, both were issued at moments when Carloman needed to present himself in the best light, confirm his willingness to rule as his predecessors had done-in fact, the second capitulary is full of references to them ${ }^{177}$ - and to establish order and justice in the realm. Interpreted in this context, the main intent of these capitularies was therefore much less to ensure justice was done on the ground. ${ }^{178}$ Instead they served to create the image of a king who was aiming to bring order to the realm in cooperation with the nobles around him at a moment when his own rule was or had been challenged by parts of the nobility. In short, they were issued to build trust in Carloman.

Where capitularies dealt with general problems, kings also delivered justice in person. Judicial assemblies are the most obvious example, although records of them are quite rare. ${ }^{179}$ From Louis the Stammerer, Louis III and Charles the Fat in the Western realm none are preserved, of Carloman II we have one, ${ }^{180}$ from Odo three ${ }^{181}$ and from Charles the Simple four. ${ }^{182}$ From Charles the Bald's reign, by way of comparison, only five have been preserved, ${ }^{183}$ meaning that, compared to the length of the reigns, the number of such judicia remained more or less unchanged.

176 See chapters II.2 and V.1.1.

177 MGH Capit. II, $\mathrm{N}^{\circ}$ 287, 372. For example Ch. 1: Volumus itaque, ut palatium nostrum more praedecessorum nostrorum et Dei cultu et regali honore, sed et religionis habitu et unanimitatis concordia atque pacis ordine stabiliatur et in eodem palatio nostro pax praedecessorum nostrorum sanctionibus servata per omne regnum nostrum exequenda proferatur. 2: Decernimus igitur, [...] ut, secundum quod in capitulis antecessorum continetur, legali multetur iudicio tripla compositione peracta cum dominico banno. 3: Quodsi ausu temerario venire contempserit, vi ad nostram praesentiam adducatur subdendus praedecessorum nostrorum sanctionibus. 4: Placuit etiam nobis et fidelibus nostris, ut, quicumque infra regnum nostrum aliquid rapuerit aut depraedatus fuerit, omnia in triplum componat et bannum dominicum persolvat et insuper publicam poenitentiam inde faciat, sicut in capitulari antecessorum continetur.

178 Offergeld, Reges pueri, 380, argues that the capitularies, being issued so shortly in succession and with both dealing with the same problem, probably had hardly any effect at all on the ongoing problems of the realm.

179 Nelson, Dispute Settlement, 52. See also Wormald, Making, 70-76. The rarity however only refers to judicial assemblies recorded by royal diplomas. On the other hand, those mentioned by private charters are rather abundant. Hence, the lack of such assemblies in royal diplomas is no indicator for a breakdown of the judicial system. See also Bougard, Justice (Settimana), 153 for Charles the Fat's reign in Italy.

180 DCmII 50.

181 DOdo 30. The other two judicial assemblies known from Odo's reign are not recorded by royal diplomas. Bautier noted one under DOdo 19, yet the only source referring to it is a private charter issued some time after. The other one is noted by the Annales Vedastini $(892,72)$ and the chronicle of Regino of Prüm $(892,139-140)$ and deals with the death sentence against Odo's relative Walker. On the implications of this problem, see below.

182 DDChS 84, 89, 100 and 112.

183 Depreux, Absence, 11 with n. 37, refering to DDChB 40, 228, 236, 258 and 314. 
However, if these numbers are compared to those of diplomas issued by the different rulers, a trend towards an increasing number of judicial assemblies per number of diplomas is noticeable for Charles the Simple: 4 out of 120 diplomas, or $3.3 \%$, make note of them compared to 5 out of 468 , or $1 \%$, for Charles the Bald. ${ }^{184}$ This increase in regard to the overall number of issued diplomas points towards the importance Charles attributed to these assemblies. This is an interesting observation, given that, according to Richer's description of Charles' character, one of the king's two faults was to neglect his jurisdictional duties. ${ }^{185}$ Of course Richer is a rather problematic source, yet this same reproach also surfaces in a chapter of the acts of the synod held at Trosly in 909 by Archbishop Heriveus and his suffragans. ${ }^{186}$ In this chapter, phrased as a mirror for princes and probably meant for Charles to read, ${ }^{187}$ the importance of jurisdiction is especially emphasised. ${ }^{188} \mathrm{Be}-$ ing close to Charles, Heriveus, in particular, would have been very well aware of the king's flaws and shortcomings and the chapter can hence be read as a direct response to these.

In this context, it is worth making some further comments. Especially during Odo's reign, judicial acts are often only referred to by sources not originating at the royal court, but by regional ones. A very interesting example of this is the notice of a local placitum held in April 890 at Nîmes. ${ }^{189}$ The notice narrates that Bishop Gibert of Nîmes had approached Odo, asking him to intervene in a conflict between his church and a certain Genesius, who, according to the bishop, had usurped the villa of Bizac, which had been given to the church by a woman called Bligardis about twelve years earlier; the notice further adds that Genesius, in order to obtain a confirmation of his claim from the count, had forged letters by the king. Odo had then tasked Count Raymond of Nîmes with investing the matter, which, in turn, led to said placitum. For the reigns following the death of Charles the Bald, this is the only time that such a case is reported. Does this mean that Odo was the only king to be approached by nobles from distant regions who sought royal justice in such cases? This seems rather unlikely and there are indeed some traces of, if not identical, at least similar cases. For example, in 916, Charles

184 Depreux, Absence, 11 for Charles the Bald's numbers.

185 Richer, Historiae I, c. 14, 50: Duplici morbo notabilis, libidinis intemperans, ac circa exsequenda iuditia paulo neglegentior fuit.

186 Schmitz, Konzil, 187; Sassier, Royauté, 200. For the synod, see, next to the works of Schmitz, also Schröder, Synoden, N²9, 189-196.

187 Schmitz, Konzil, 176.

188 MGH Conc. V, N 58, c. 2, 507-511. For example: Tanta quippe debet esse rex pręditus virtutis et iustite auctoritate, ut iniustum vel malum aliquid molientes solo intuitu formidolose maiestatis dissipet, ne ad meditatum facinus progredi audeant. [...] Regale vero ministerium specialiter est populum dei gubernare et regere cum equitate et iustitia et, ut pacem et concordiam habeant, studere. [...] Unde oportet, ut ipse, qui iudex est iudicum, causam pauperum ad se ingredi faciat et diligenter inquirat, ne forte illi, qui ab eo constituti sunt et vicem eius agere debent in populo, iniuste aut negligenter pauperes oppressiones pati permittant.

189 DOdo 14. Cartulaire Nîmes, $N^{\circ} 5,10-13$. For the dating to 890 and not 892, see Bautier, Recueil Eudes, 66-67. 
the Simple was approached by Abbot Acfred of San-Esteban of Bagnoles at whose request he issued a diploma confirming the possessions of his abbey. ${ }^{190}$ However, Bagnoles was in dispute with the abbey of Saint-Polycarpe over some property that was now confirmed by Charles' diploma as belonging to the former ${ }^{191}$ Like in the case of Bishop Gibert, an ecclesiastical institution distant from the royal court hence sought out the king in a judicial dispute. Furthermore, we may also point out the conflict between Count Erlebald of Castriciensis and the church of Reims, which resulted in the count trying to seek out Charles yet being killed before he was able to meet him. ${ }^{192}$ Another noble, albeit this time one close to Charles, ${ }^{193}$ approached the king to obtain justice. These examples indicate that Odo's case was in fact not special in its nature, but only due to the circumstance that sources have been preserved making note of it. This circumstance leads to the cases when royal diplomas did make note of royal judicial decisions. The loss of diplomas certainly contributes to the overall low number of such references, yet cannot solely explain them. Instead, it would seem that the royal chancellery only went through the effort of drafting a diploma under very particular circumstances, which would signal the special importance of these cases and their recordings for the rulers.

Carloman II's judicium is referred to by one of his earliest diplomas, issued 12th January 881 at a villa Caciacum. ${ }^{194}$ The diploma reports that Carloman, at the request of Bishop Abbo of Nevers, restored the villa of Cours to the bishop's church after having held a "general council" (commune consilium) with the "great and first men of our palace," which is most probably a reference to a judgement made at the royal court by a judicial assembly. ${ }^{195}$ The first point to note is the moment the diploma was issued. In January 881 , about nine months had passed since the assembly of Amiens where the West Frankish realm had been divided between Carloman and his brother Louis, ${ }^{196}$ so the assembly took place already well into Carloman's reign. However, the diploma recording the judgement is only the second one preserved from Carloman's reign, the first one having been issued in 30th November $880 .{ }^{197} \mathrm{~A}$ rather long time had passed until Carloman actually started delivering diplomas. The timing, however, appears to be tied to an actual change in politics. Despite the partition of the realm, from Amiens onwards, the two brothers had always remained together, meeting with the East Frankish rulers at Gondreville and then campaigning against Lothar II's son Hugh as well as

191 For this dispute, see Bautier, Recueil Eudes, 34-36.

192 Flodoard, Annales 920, 2-3.

193 See chapter III.2.1.7.

194 DCmII 50. On the villa, see Bautier, Recueil Louis II, Louis III et Carloman II, XLVII.

195 DCmII 50, 127: Agentes itaque commune consilium cum proceribus atque primoribus palatii nostri... See also Bautier's commentary to the diploma, 126.

196 Annales Bertiani 880, 241.

197 DCmII 49. 
Boso. ${ }^{198}$ Louis left Carloman in the South to celebrate the holiday at Compiègne only a short time before Christmas. ${ }^{199}$ The deliverance of diplomas begins at about the same moment when Carloman actually started to be the only king around, ${ }^{200}$ marking the starting moment of his sole reign. In this context, the judicial assembly gains a new weight. Very much like capitularies, such assemblies served to strengthen the king's legitimacy and his bond with the nobility, ${ }^{201}$ they were, following François Bougard, a recurring "ritual of auto-affirmation." 202 Like his later capitularies in the North, the assembly can be seen as a demonstration of Carloman's willingness to actively bring justice to the realm in cooperation with his leading nobles at the beginning of his reign-a means to strengthen trust in his rule. In addition to such thoughts, there also might have been a second reason behind this assembly. As Robert-Henri Bautier has proposed, the property restored to the church of Nevers might have previously been in the hands of Boso. ${ }^{203}$ Hence, the restoration was not only a symbol of justice, but also a sign that Carloman was willing to distribute Boso's honores among those who supported him. In this context, another of Carloman's diplomas is of interest. In May 881, he again restored property, this time to the church of Orléans. ${ }^{204}$ This property, the villae of Chautay, Germigny-sur-Loire and Marzy, formed a block with the villa of Cours restored at the judicial assembly and probably belonged to Boso as well, ${ }^{205}$ thus emphasising Carloman's message to the nobles. These are of course only assumptions since, apart from the location of the villae in the Berry and the Nivernais (within the vicinity of Boso's power base), there is no actual evidence that they had been held by Boso before.

Like Carloman, Odo also held a judicial assembly early in his reign, at some point before 22nd March $890 .{ }^{206}$ It dealt with the appeal of a certain Ricbert, who up to this point had held property belonging to Saint-Martin of Tours. This property had originally been rented out by the monks to the archbishop of Tours, who had bequeathed it to his relative Ricbert. Ricbert, in turn, appears to have maltreated his coloni, who took legal action against him. In a local judicial assembly under the

198 Annales Bertiniani 880, 242: Inde Compendium redientes, ibi Pascha Domini celebrauerunt, et post haec per Remum et Catalaunis iuitates ad placitum condictum mediante Iunio apud Gundulfi uillam obuiam suis sobrinis uenerunt. [...] In quo placito communi consensu inuentum est ut ispi reges Hludounici quondam filii ad Attiniacum redirent cum scara Hludounici Germaniae regis, et Hugonem Hlotharii iunioris filium impeterent. [...] Indeque cum hoste [...] praedicti reges [...] in Burgundiam uersus Bosonem per mensiem Iulium a Trecas ciuitate perrexerunt...

199 Annales Vedastini 880, 49.

200 Charles the Fat, who had joined Louis and Carloman against Boso, had already returned to Italy. Annales Bertinaini 880, 243.

201 MacLean, Legislation, 399.

202 Bougard, Justice (Settimana), 153.

203 Bautier, Recueil Louis II, Louis III and Carloman II, XLVI.

204 DCmII 53.

205 Bautier, Recueil Louis II, Louis III and Carloman II, XLVI.

206 DOdo 19, although Bautier points out that there was not necessarily a diploma recording the judgement. 
provost of Suèvres, the priest and archtreasurer Berno and the scholarum magister Odalricus of Saint-Martin, at the request of these coloni, Ricbert had been ordered to restore the property to the abbey. Ricbert's appeal to Odo failed, instead the king confirmed the previous judgement in accord with his brother Robert and "other nobles residing in the vicinity" ${ }^{207}$ and furthermore condemned Ricbert to compensate the monks by handing over some property (which, in turn, he was allowed to keep until his death). Hence, this judicial assembly appears to have had a very local character, as it not only revolved around a centre of Robertian power, but also invoked his brother and local nobles. ${ }^{208}$ The impression that this assembly was indeed only of minor political importance for Odo is furthermore emphasised by the circumstance that it appears not to have been recorded by a royal diploma, but was only afterwards referred to by a private charter noting the execution of the judgement. ${ }^{209}$

Another of Odo's judicial assemblies is also referred to only later on. A diploma issued for the abbey of Montiéramey ${ }^{210}$ notes a royal placitum held at Verberie where the three archbishops Fulk of Reims, Walter of Sens and Wido of Rouen, together with the bishops Dido of Laon, Honoratus of Beauvais and Riculf of Soissons, had investigated the case of the monk Aginus who claims, against Montiéramey, the abbey of Saint-Sauveur of Alfa for himself. While this assembly was certainly more important than the previous one for Saint-Martin of Tours, the question remains why Odo only referred to it in a diploma issued 30th September 892, in which he confirmed the judgement. At this moment, Odo's reign had entered a critical stage, as the king was in conflict with a number of powerful nobles: Baldwin II of Flanders, the Aquitanian nobles supporting Ebalus Manzer and probably at this point Count Altmar as well. As we have argued, at this moment Odo was facing a severe crisis of trust, which directly led to directly to the rebellion around Fulk. Odo was in dire need of rebuilding lost trust and the diploma confirming the judgement in favour of Montiéramey may have been his intended means for this, as it would show him as king who acted in concord with his nobles, enforcing justice within his realm.

This image depicted in Odo's diploma can also be found in some of Charles the Simple's. His first recorded judicial assembly dates to 19th January 916 and revolves around the abbey of Süsteren. ${ }^{211}$ The abbey had originally been given by Arnulf to the priest and artist Siginand, ${ }^{212}$ who, in turn, appears to have asked to pass on Süsteren to the abbey of Prüm while keeping it as a precarium. ${ }^{213}$ Zwentibold

207 DOdo 19, 85: ...caeteri pernobiles in circuitu residentes...

208 On parties in judicial conflict participating in such assemblies as judges, see Nelson, Dispute Settlement, 53-54.

209 Favre, Eudes, pièce justificative $N^{\circ}$ IV, 239-242.

210 DOdo 30 (30th September 892).

211 DChS 84.

212 DA 85.

213 DZ 2. 
had then confirmed this donation, and left Süsteren with Siginand, but it was to revert to Prüm upon his death. ${ }^{214}$ However, after that, according to Charles' diploma, Süsteren had "in unjust and violent efforts of the powerful been taken from him."215 Charles, "after many and almost countless reclamations without effect"216 now used the occasion to submit the case to an assembly at Herstal with the participation "of the entire realm, of bishops, counts and proceres as well as judges of varying power and a conventum of all the nobles, all of them our fideles," ${ }^{217}$ subsequently naming them-four bishops, fourteen counts and seventeen others. ${ }^{218}$ Following their judgement, he then restored Süsteren to Prüm. Unfortunately, the sources do not reveal the identity of those powerful men who had managed to bring the abbey into their possession. ${ }^{219}$ However, the message of the diploma was not only a demonstration of how Charles was willing to do justice in accord with the nobles around him, but also, and probably more importantly, a display of the powers backing him in this case. Thus, the diploma became a very concrete political statement, showing how close he had become to the Matfrid family, whose member Richer had become abbot of Prüm. Both, the display of power as well as the alliance with the Matfrid family, indicate that the opponent was someone with considerable political weight. And indeed, Charles' intervention appears not to have been the end of the conflict between this unknown party and Prüm, although it has to remain open when it resurfaced. In 949, Otto the Great again dealt with the problem, copying Charles' diploma in large parts, including the phrasing about the general assembly and adjusted only the name of the place and the names of participants. ${ }^{220}$

Three years later, this display of power and cooperation was repeated, again at Herstal. ${ }^{221}$ This time it was the church of Trier to which, by judgement of the "scabini of our palace and by attestation of all of our fideles,"222 the abbey of SaintServais, previously given to the church by Arnulf, was restored. This time the adversary is noted: Reginar Longneck and his son Gislebert are said to have unjustly and violently taken the abbey from the church. ${ }^{223}$ The naming of Reginar and Gislebert is not the only difference from the previous diploma however. Mark

214 DZ 2.

215 DChS 84, 189: ...pontentiorum injusto violentoque conamine ei ablata est.

216 DChS 84, 189: ... post multas et pene innumeras reclamationes sine effectu...

217 DChS 84, 189: ...habito generali placito apud Haristallium, in conventu totius regni, tam episcoporum quam comitum et procerum ac judicum diversarum potestatum omniumque conventu nobilium, cunctorum fidelium nostrorum...

218 See chapter III.2.1.7.

219 On the hypothesis of Wisplinghoff, Untersuchungen, 464, that these had been men close to Gislebert, see chapter III.2.1.7. Also Koziol, Politics, 515, sees the judgement in the context of Gislebert.

220 DOI 111.

221 DChS 100 (13th June 919).

222 DChS 100, 230: ... scabinorum palatii nostri et attestatione omnium fidelium nostrorum...

223 DChS 100:...sed violentia Rageneri comitis et filli ejus Giselberti a predicta Treverensi ecclessia jam olim esset injuste ablata. 
Mersiowsky may have gone too far by denying the charter the character of a royal diploma and calling it a Gerichtsurkunde; ${ }^{224}$ however, the diploma is certainly different from a normal royal diploma. The list of witnesses, featuring five bishops, twelve counts and eighteen scabini, is not included in the narratio this time, but added to the end of the charter. Furthermore, the diploma is sealed with a special seal $^{225}$ and lacks the royal monogram. ${ }^{226}$ In fact, about a month later, Charles issued another diploma confirming the judgement of Herstal, ${ }^{227}$ indicating that the first diploma had not been drawn up with the same intention as the one from 916. Nevertheless, the assembly as such and its record certainly were symbols of Charles' power at this moment and a signal to his supporters that he had their interests at heart-a means to improve trust in his rule.

The detailed naming and the number of the nobles partaking in these two judicial assemblies is what makes these two different from the two others recorded by Charles' diplomas. The first of these other diplomas ${ }^{228}$ records the petition of Robert of Neustria for his abbey Saint-Denis 28th May 917, requesting that Charles returned the villa of Lagny-le-Sec, which had been granted to the abbey by King Dagobert ${ }^{229}$ but then had been "unjustly taken from them and for a long time been possessed by others." ${ }^{230}$ Charles, acknowledging the justness of his reclamation ${ }^{231}$ and following the judgement of bishops, counts and others of his optimates ${ }^{232}$ then restored the villa to Saint-Denis. However, the importance of the diploma in fact does not lie in the judgement, but in the way it is constructed around the relation between Charles and Robert. The latter is the "dearest demarcus and our most loyal [fidelis] Robert," later furthermore noted as "Abbot Robert, our kinsman." 233 Finally, the diploma also adds the installation of a prayer service, not only for Charles, but also for Robert. ${ }^{234}$ The judgement in favour of Saint-Denis is only an addition to this demonstration of proximity between the king and the marchio, which shows how Charles was correcting very old injustice for his closest supporter. Read in this way, the diploma recording the judgement was a political statement similar to the two assemblies of Herstal: it was a demonstration of the support the king enjoyed at this very moment, yet one focused on the relation between Charles and Robert.

224 Mersiowsky, Urkunde, 227.

225 Lauer, Recueil Charles III, XLIX, according to Mersiowsky, Urkunde, 227, a "Gerichtssiegel."

226 See Schieffer, Kanzlei, table 11.

227 DChS 103 (9th July 919).

228 DChS 89.

229 In fact it appears to have been King Theuderic III who granted the villa Lagny-le-Sec to SaintDenis (DMerov 131).

230 DChS 89, 201: ...injuste ei abstracta fuerat et longo tempore ab aliis possessa...

231 DChS 89, 201: Cujus petitionibus atque justis reclamationibus ac deprecationibus faventes...

232 DChS 89, 201: ...per judicium episcoporum ac comitum, necnon et aliorum optimatum nostrorum

233 DChS 89, 201: ...demarcus carissimus ac fidelissimus noster Rotbertus... and ...abba Rotbertus, consanguineus noster...

234 DChS 89, 201: ... ita tamen ut quamdiu advixerimus pro stabilitate salutis nostre et consanguinei nostri Rotberti abbatis septem specialium salmorum melodiam cotidie decantent... 
The last judicium noted by one of Charles' diplomas took place in September 921. ${ }^{235}$ This time, it was the brother of his deceased wife Frederuna, Bishop Bovo of Châlons, who informed him that some property had been estranged from his church. At the request and following the judgement of a number of his fideles, his counts and bishops, ${ }^{236}$ Charles then restored said property. Like the diplomas recording the judicia of Herstal, this one adds the names of the fideles participating in the judgement: the counts Hagano, Helgaud and Raoul de Gouy, as well as the bishops Abbo of Soissons and Stephen of Cambrai-most of them belonging to the group of nobles which had formed around Charles in the last years before the final rebellion of $922 .{ }^{237}$ If the judgement recorded by the diploma was meant as a demonstration of power, it was a rather inept one. The number of participants was so small that it would undoubtedly have been reasonable to do without naming them and leave it to the general terms of fideles, counts and bishops that are also to be found in the diploma recording the judgement for Robert. Given that it would have been easily possible to do so, it seems as if the reference to them was indeed intentional. What mattered was not their number, but their names: they were meant to be seen. As we have argued, from September 920 onwards, seven months after the assembly of Soissons, Hagano's appearance in royal diplomas changed significantly, now acting together with other nobles, seemingly in an effort to integrate him in the network of the nobles around Charles. ${ }^{238}$ Hagano appearing in this diploma was another step in this direction, showing him acting together with other nobles and taking part in the judicial procedures at court. Like the previous ones, also this last diploma recording a judicium was hence an important political statement by Charles.

However, judicial assemblies and their recordings were only one part of the king doing justice. As Philippe Depreux has pointed out, royal diplomas dealt with a number of judicial problems very similar to the decisions taken at these assemblies, such as settling disputes and restoring unjustly withdrawn freedom or, most importantly, property. ${ }^{239}$ Up until Odo's reign, a surprising number of these latter went to the church of Autun. ${ }^{240}$ Louis the Stammerer, at the request of Bishop Adalgarius and Count Theoderic the Chamberlain, restored the villa of Bligny-sur-Ouche, which previously had been passed over to the count of Autun. ${ }^{241}$ Louis' diploma was copied by Carloman II, replacing only the property restored, the villa of Teigny. ${ }^{242}$ Again, it saw Adalgarius and Theoderic acting

DChS 112 (20th September 921).

DChS 112, 268: Cujus petitioni libentissime faventes deprecantibus et adjudicantibus fidelibus nostris, comitibus nostris atque episcopis...

See chapters III.2.1.7, III.2.1.8 and III.2.2.

See chapter III.2.2.

Depreux, Absence, 10.

DLS 29, DDCmII 49 and 68, DDOdo 21 and 35. For Boso, see Charmasse, Cartulaire Autun II, $\mathrm{N}^{\circ} 1,85-86$. DProv 17 is a forgery, see Bautier, Receuil Eudes, CXLIV-CXLVI.

DLS 29 (23rd January 879).

DCmII 49 (30th November 880). 
together, this time supported by the new count of Autun, Richard. The first two also appeared together, assisted by Count Ansgar of Oscheret, in Carloman's second restoration, this time of the villa Marigny. ${ }^{243}$ The diplomas reveal how well connected Adalgarius was within the elite of the nobility, as he not only acted with one of the central figures of Louis the Stammerer's and Carloman II's reignTheoderic the Chamberlain ${ }^{244}$-but was also able to obtain restitutions from the honores belonging to the count of Autun with the support of that very same count. Moreover, after Louis' death Adalgarius had belonged to Boso's supporters, and even became his archchancellor. ${ }^{245}$ Seemingly, this had not damaged his position within the West Frankish elite. Under Odo, Adalgarius continued to use his influence to obtain restitutions for his church, albeit with differing results. At his request, Odo returned Congy, Servigny and Savigny, held by the noble lady Emma, to the church of Autun, ${ }^{246}$ yet when the lady presented royal diplomas confirming her claim to the domains, Odo, after he had consulted his fideles, returned the property to her, and decided that she was to hold them until her death when they should finally fall back to the church. ${ }^{247}$ Adalgarius, who pursued an aggressive course by using his influence at court to increase the wealth of his church even if his claim was not entirely justified, finally is also revealed by Odo's other restoration to him. With the support of Odo's brother Robert and by presenting a number of charters as evidence for his claim, he obtained the villa of Tillenay. ${ }^{248}$ While the diploma itself is genuine, apparently the evidence brought forward on this occasion by Adalgarius appears to have been forged. ${ }^{249}$ Geoffrey Koziol argues that this circumstance was actually known by Odo who decided to ignore it to tie Adalgarius, one of the key players in Burgundy, closer to him ${ }^{250}$ - the bishop later even became his new archchancellor. Yet, even if this was not the case, the restorations obtained by Adalgarius reveal how a key figure of politics could use his connections to influence the royal judgement in his favour.

Similar to Adalgarius, Bishop Geilo of Langres also seems to have profited from his connection to Charles the Fat to increase the wealth of his church by receiving not only grants, but also by having property restored. On three occasions he managed to have honores restored, the abbeys of Moutier Saint-Jean ${ }^{251}$ and Saint-Seine, ${ }^{252}$ as well as the villa of L'Ormeau. ${ }^{253}$ However, powerful nobles using their connections to influence royal justice was only one half of the story.

DCmII 68 (6th March 883).

244 See chapters II.1 and II.2.

245 See chapter II.2.

246 DOdo 21.

247 DOdo 22.

248 DOdo 35.

249 Bautier, Recueil Eudes, CXLI-CLIII.

250 Koziol, Politics, 359-361.

251 DChF 129.

252 DChF 153.

253 DChF 147. 
The first diploma restoring an abbey to the church of Langres-the second one being an exact word-by-word copy-uses some exceptional language to describe the situation. According to the diploma, the abbey had been "taken away [from the church of Langres] in tyrannical and sacrilegical temerity of the principes as well as in known presumption without any respect for the allmighty God" and later adds that this had been done by violent means. ${ }^{254}$ This was far from the other wording usually used in diplomas restoring property which, if at all, normally only pointed out that said property had been unjustly taken away. ${ }^{255}$ While the diploma was written by a West Frankish scribe, probably from Langres, ${ }^{256}$ it nevertheless seems that it was drawn up in the royal chancellery since there is a broad consistency between its arenga as well as parts of the formulae with two other diplomas issued for the church of Dijon, which would indicate that the scribe must have either known them or used a common template. ${ }^{257}$ Hence, the diploma transmits a very clear message originating at the royal court on the willingness of the emperor to protect the interests of those who supported him. However, the question is to whom this message was addressed. Both diplomas for the church of Langres using these phrasings were not issued in the West Frankish realm, but in the East, at Lorsch and Schlettstadt. On both occasions, nothing in the sources indicates the presence of a larger assembly of nobles other than those who usually were with the king. Hence, were these diplomas meant especially for Geilo, as a sign of the strength of the relations between him and Charles? Given the number of restitutions made by Charles to West Frankish institutions-apart from the three for the church of Langres he also restored property to those of Lyon, ${ }^{258}$ Châlons ${ }^{259}$ and the abbey of Saint-Vincent of Mâcon ${ }^{260}$-it seems reasonable to assume that the restitutions were indeed aimed at a wider audience also in the Western realm and supposed to build trust in the emperor by demonstrating his efforts to further the interests of those loyal to him.

In using this strategy, he certainly was not alone. The last restitution made by Carloman II, also for the church of Châlons, transported a very similar message. Delivered 13th March 884 at Compiègne, therefore at the same time he had issued his second capitulary, he restored the abbey of Saint-Sulpice to the church. ${ }^{261}$ The

254 DChF 129, 207: ...quorundam principum tyrannica sacrilegaque temeritate atque inlicita praesumptione sine omnipotentis Dei respectu substractae fuissent... and ...quod quorundam principum tyrannica sacrilegaque temeritas per violentiam abstulerat...

255 For example DChF 150, 242: ... iniuste abstractas fuisse... and DChF 151, 243: ... aliquas res iniuste ablatas...

256 Kehr, Urkunden Karls III., 184 and 206; Mersiowsky, Urkunde, 179-180.

257 Kehr, Urkunden Karls III., referring to DDChF 117 and 118.

258 DDChF 123, 150 and 151. Another diploma notes the restoration of property to the church of Reims (DChF 106). Since it was issued before Charles became ruler over the West Frankish realm, we omit it here.

259 DChF 150.

260 DChF 151.

261 DCmII 76. 
way the diploma depicts Bishop Berno, its petitioner and recipient, is most striking. He is not only the one "who from the beginning of our reign excelled, being most useful and loyal to us in council and aid," but also the one who "decided to remain within this same loyalty."262 This loyalty was then rewarded by what appears to have been a longstanding problem for the church of Châlons, to have the abbey of Saint-Sulpice returned to it. Already back in 859 and again in 875 , Charles the Bald had restored the same abbey to the church, then held by a certain Bernard and a certain Geoffrey respectively, yet both times under the reservation that Saint-Sulpice remained with its current holders up until their death. ${ }^{263}$ This same reservation was now also renewed by Carloman, this time for a certain Rothard. While Charles the Bald's diplomas betray nothing about Bernard and Geoffrey, Carloman's reveals a bit more about Rothard, who appears as "our vasallus and judge." ${ }^{264}$ Was it possible that on all three occasions the kings or their local representatives had lain hands on Saint-Sulpice to grant it to their own followers? If this was indeed the case, Carloman's diploma, despite the reservation, would be a symbol of how far for his closest followers, those who remained loyal to him, he was willing to correct injustice even caused by himself-undoubtedly the best way build trust while starting into the new era of his reign.

Similarly, Odo's first restoration ${ }^{265}$ also coincides with one of the crucial moments of his reign, the great assembly at Orléans in June 889 where nobles from Septimania and Aquitaine were present. The villa of Doussay, apparently a large estate to which twenty other villae were dependent, was restored to the monks of Saint-Martin of Tours. ${ }^{266}$ Unfortunately, no diploma confirming the restoration has been preserved, the only trace of Odo's act being a private charter issued by Ebalus Manzer 10th October $891 .^{267}$ According to this charter, it had been Charles the Bald who had originally restored the villa to the monks, yet "after a long time, [it was] maliciously usurped by Magenarius, after him unjustly held by his son Osbert, but then again, during the reign of Lord King Odo, at the city of Orléans, in the presence of his proceres, restored to us." ${ }^{\text {"268 }}$ This same language was also applied in Odo's other preserved restoration, this time for the church of Narbonne, ${ }^{269}$ noting that fiscal property that had been bestowed to the church for a long time and

262 DCmII 76, 198: ... qui nobis in principio regni nostri et consilio et auxilio satis proficuus et fidelis extitit atque in eadem fidelitate perseverare decrevit...

263 DDChB 212 and 381.

264 DCmII 76, 198: ...vasallus et judex noster Rothardus...

265 DOdo 9.

266 Bautier, Recueil Eudes, 228.

267 Bautier, Recueil Eudes, Appendice III, 227-233.

268 Bautier, Recueil Eudes, Appendice III, 231-232: ...post multum tempus, Magenarius dolo usurpavit et, post eum, filius ejus Osbertus, injuste tenuit, sed rursus, domni Odonis regis imperio, Aurelianis civitate, nobis restitutam in praesentia suorum procerum...

DOdo 24 . 
unjustly usurped by the comital power was now being returned by the king. ${ }^{270}$ Hence, it seems safe to assume that Odo's restoration for Saint-Martin also emphasised him as a ruler who corrected ancient injustice and protected the interests of those close to him.

Like his predecessors, Charles the Simple used restitutional acts to portray himself as a king who brought justice to his supporters in crucial moments of his reign. One of his first diplomas, issued at the request of Bishop Lambert of Liège for his church on 26th September 894, spoke of parts of the fisc of Arches in the Porcien which had been taken from said church by "force of arms and violence,"271 but were now restored by Charles, who had just been acknowledged by Arnulf as king and had returned with Lotharingian forces to the West. The two assemblies of Tours-sur-Marne in 899 and 922 also saw restitutions. In a diploma for the abbey Notre-Dame of La Grasse, Charles not only confirmed a large number of specific properties, but also those which had been estranged from the abbey. ${ }^{272}$ The diploma was in large parts a copy of one of Charles the Bald; ${ }^{273}$ but Philippe Lauer remarked that this particular phrase had been significantly changed from reliqua quae ibi collatae fuerunt ("the remaining [property] which then had been bestowed [to them]") to reliqua quae ibi ablatae fuerunt ("the remaining [property] which then had been taken away [from them]"). ${ }^{274}$ This change certainly had been intentional, demonstrating to those present at the assembly how Charles was willing to protect the interests of those who supported him. However, the actual impact of this phrase was certainly minimal. La Grasse could use Charles' confirmation in their favour, yet if they did, they still had to present evidence that the disputed property had indeed belonged to them. In contrast to this diploma where the restitution of property was only one phrase at the end of a long list of confirmations and hence hardly the centre of attention, the diploma issued in 922 was drafted around this very act. This time the monks of Saint-Thierry of Reims approached Charles and presented the king a diploma of Charles the Bald confirming them in the possession of the domain of Marzelle, protesting that "their living had been unjustly withdrawn from them." ${ }^{275}$ Charles, who acknowledged their protest as justified, by his power then returned the villa to them. ${ }^{276}$ With Robert's army encamped only a few miles away, Charles once again tried to build trust by portraying himself as a just king who protected the church in its need and corrected injustice. ${ }^{277}$

270 DOdo 24, 112: Fiscos vero qui sunt in Biterrensi comitatu sancto Paulo confessori a longo tempore collatos et a potestate comitali injuste usurpatos plenissime reddidimius...

271 DChS 5, 6: ... quod vi atque violentia sibi ac ecclesiae sue fuissent ablate...

272 DChS 20, preserved as original.

273 DChB 340.

274 DChS 20, 39 with n. b. Lauer, Recueil Charles III, 37, n. 2.

275 DChS 115, 273: ... reclamantes victui eorum injuste eam esse subtractam...

276 DChS 115, 273: Quorum reclamationem cognoscentes veram esse, potestate nostra prefatam villam eis reddidimus...

277 In this context it is worth pointing out another diploma issued at the first assembly of Tours-sur-Marne, DChS 24 (6th June 899). In this diploma Archbishop Arnust of Narbonne 
However, this highly symbolic potential of restitutional acts may not only have served to strengthen royal rule by building trust with the receiving party, but at times also have been considered a breach of trust by a third one. Among the first diplomas issued by Charles the Simple at Richard the Justiciar's request was one for Bishop Herfrid of Auxerre and his church, which restored the villa of Cravant sur l' Yonne. ${ }^{278}$ As we have argued, Richard tried to channel the contact between the local Burgundian nobility and the king, installing himself as the only mediator. ${ }^{279}$ In doing so, he also presented himself as the only means to obtain justice from the king, as demonstrated by this restoration, which was obtained at his intervention. However, in 902, Charles did not only interact directly with Herfrid-that is to say without Richard being present-he also again restored property to Herfrid's church, this time the villa of Mailly-sur-l'Yonne which had been "once unjustly taken away."280 By doing so, Charles hence not only circumvented Richard, but also demonstrated to the Burgundian nobles that he himself was in fact still the source of justice and not Richard, thus further adding to the attack on Richard's position. In front of this background, it is probably not surprising that, once Richard had returned to court a few years later, Charles again restored property at Richard's request, this time to Saint-Martin of Autun, ${ }^{281}$ and thus again confirmed Richard as the authority who was to be addressed if royal justice was needed.

Hence, doing justice was a highly symbolic tool used by the rulers to strengthen their position by building trust in moments of political change and turmoil. Carloman II's capitularies are the most prominent examples, with the second one being issued at the heights of the difficulties between him and the nobility from the northern part of the realm. Similarly, the only reference to a judicial assembly in one of Odo's diplomas dates to September 892 when Odo's reign was shaken by the conflicts in Aquitaine and with Baldwin II of Flanders. As it seems, these rulers made use of judicial acts to portray themselves as just rulers, acting in accord with the nobles around them to bring order to the realm and thus to build trust in their rule. This image changes to some extent under Charles the Simple. He used judicial acts as well-most importantly the late diploma for the monks of SaintThierry of Reims in the context of the second assembly of Tours-sur-Marne-to

is shown complaining about incursions of lay officials within his diocese (DChS 24, 49: ...quod in sua parrocia seu, in cunctis episcopiis qui in suffragio ipsius positi sunt gravissima, quedam contra jura canonum atque instituta legum increverit consuetudo, adeo ut comites atque judices seu ministri illorum sacerdotes Domini sive reliquos ecclesie ministros ad placitum suum violenter ducere et fidejussores tollere atque eos more laicorum distringere presumant...). Charles reacted to this complaint, among other measures, by protecting the clerics of the archdiocese from coercive measures as well as the jurisdiction of lay officials. While not a restorational act, its message concords with the later one for the monks of Saint-Thierry of Reims.

278 DChS 31 (after 30th June 900). DChS 33 (30th June 900) restores the mint to the church of Autun. However, this passage appears to be an interpolation. Bautier, Recueil Eudes, CLII, n. 1.

279 See chapters III.1.2 and III.2.3.

280 DChS 42 (14th March 902), 92: ... holim injuste a prefata ecclesia abstractum...

DChS 59 (8th August 908). 
demonstrate that he was a ruler who corrected old injustice for those loyal to him. Yet, the most prominent examples for such acts, the judicial assemblies of Herstal, which predate these events, emphasise not so much the justice of the king than the wide support Charles enjoyed. The diplomas issued on these occasions were undoubtedly symbols of royal justice, yet, more importantly, they were symbols of royal power directed against the king's opponents. While the number of diplomas recording judicial assemblies is rather small, those making note of restitutions is far bigger. Much more than in the former, in the latter the influence of the recipients becomes visible, with a number of nobles enjoying a particularly close position to the ruler which benefitted them numerous times. Charles the Fat especially appears to have used restitutional acts to tie West Frankish nobles to himself. Yet, restitutional acts were at times also used for the symbolic value inherent to them, issued at moments of particular political importance to transport the image of a ruler who protected the interests of and brought justice to those loyal to him.

\section{VI.4 Against the king: Questioning the right to rule}

Rebellions against the ruler were nothing uncommon in the Frankish world, even if they differed in motivation and scope. The first rebellion to be examined here is the one which developed over the succession of Louis the Stammerer and led to the coronation of Boso of Vienne. According to Hincmar, the rebellion was due to the ambitions of Boso's wife Ermengard: "She declared that, as the daughter of the emperor of Italy and the one-time fiancée of the emperor of Greece, she had no wish to go on living unless she could make her husband a king." ${ }^{282}$ Regino of Prüm, on the other hand, notes that "[Boso] disregarded the adolescent sons of Louis [the Stammerer], disdaining them as if they were of inferior birth because on Charles' order their mother had been spurned and repudiated." ${ }^{283}$ Despite the differences in the accounts, an important observation can be drawn from them: both describe Boso as the central figure of the rebellion. This becomes even more evident when we also take the rest of their accounts in consideration:

282 Annales Bertiniani 879, 239: Interea Boso, persuadente uxore sua, quae nolle uiuere se dicebat, si, filia imperatoris Italiae et desponsata imperatori Greciae, maritum suum regem non faceret... Translation by Nelson, Annals, 219.

283 Regino, Chronicon 879, 114: [Boso] pro nihilo ducens adulescentes filios Ludowici et velut degeneres despiciens, eo quod iussu Caroli eorum genitrix spreta atque repudiata fuerit. Translation by MacLean, History, 180.

284 Annales Bertiniani 879, 239: [Boso] [...] partim comminatione constrictis, partim cupiditate illectis pro abbatiis et uillis eis promissis et postea datis, episcopis illarum partium peruasit ut eum in regem ungerent et coronarent. Translation by Nelson, Annals, 219.

285 Regino, Chronicon 879, 114: Denique nonnullos episcopos partim minis partim suasionibus in societatis foedera colligit et Lugdunum ingressus ab Aureliano eiusdem urbis metropolita et aliis pontificibus in regem super prefatum Burgundiae regnum inunguitur... 


\section{Annales Bertiniani 879}

So Boso persuaded the bishops of those parts to anoint and crown him king. He had partly browbeaten them by threats and partly won them over because they were greedy for the abbeys and estates he promised them, and which he gave them afterwards. ${ }^{284}$

\section{Regino, Chronicon 879}

Partly by persuasion and partly through threats [Boso] rallied several bishops to make alliance with him and after he had entered Lyon he was anointed as king of Burgundy by Aurelian, metropolitan of that same city, and some other bishops. ${ }^{285}$

According to both accounts, not only was Boso the driving force behind the rebellion, but there also was no stronger opposition against Louis III and Carloman II. Indeed, it was Boso himself who had to rally support to be crowned king. From these accounts, it would appear that the rebellion was not due to the young kings infringing on what Boso had perceived to be his privileges, but the result of his (or, according to Hincmar, his wife's) ambitions. However, Regino's report corresponds with Boso's electio in which Boso claimed that after Louis the Stammerer's death the throne had become vacant due to the lack of suitable persons. ${ }^{286}$ Boso disputed the existence of legitimate kings per se. This leads us to the second important observation: the rebellion did not break out as the result of a crisis of trust in the brothers and their rule (as did the one against $\mathrm{Odo}^{287}$ ), but because Boso wanted to become king himself. ${ }^{288}$ This was not a rebellion against Louis and Carloman, it was "Boso's rebellion."

This impression is further strengthened when analysing the support Boso was able to rally. As Robert-Henri Bautier, based on the witness list of Boso's electio, has demonstrated, this support originated in the east and south-east of the realm, including the archbishops of Aix, Arles, Lyon, Vienne, Tarentaise and Besançon along with a number of their suffragans as well as Abbot Geilo of Tournus. ${ }^{289}$ Of these men, only four can be traced at Louis the Stammerer's court: Archbishop Aurelian of Lyon, Bishop Adalgarius of Autun, Bishop Lambert of Mâcon and Abbot Geilo. ${ }^{290}$ Of these, Aurelian and Geilo were connected to Boso who had previously intervened on their behalf. Hence, at least among the higher clergy, Boso's support rested mostly on men who do not appear to have been taking part in royal politics. It is probable that some of them hoped to increase their influence on the affairs of the realm by being close to the new king. After the coronation, the archbishops of Vienne and Arles as well as the bishops of Valence and Grenoble can be seen at Boso's court. ${ }^{291}$ However, key positions at Boso's new court were occupied by men who had already been influential under Louis the Stammerer.

286 MGH Capit. II, N² 284 C, 368: ... idoneas personas [...] non invenientes... See chapter I.1.1.

287 See chapter I.2.3.

288 See also Bautier, Origines, 49-50, who points out that Boso's declaration of Mantaille shows no signs of any territorial restrictions but was aimed to demonstrate his claim for the entire realm.

289 Bautier, Origines, 50-51.

290 DDLS 19, 20, 26, 27, 29 and 33. See chapter II.1.

291 DDProv 20 (Vienne), 21 (Arles), 22 and 24 (Valence) as well as 25 (Grenoble). 
Aurelian crowned Boso, ${ }^{292}$ Adalgarius became the new archchancellor and Geilo was promoted to bishop of Langres. ${ }^{293}$ This may not be much of a surprise since Boso could hardly ignore important nobles such as these when it came to distributing honours and honores. Yet, at the same time, this limited the possibilities of advancement for his other supporters which makes it rather doubtful whether this was indeed the dominating motivation behind their support. In fact, it seems that Boso's network was extremely fragile, with several of these men soon defecting from his side and turning to Carloman, most notably Adalgarius ${ }^{294}$ and Geilo, ${ }^{295}$ but also the bishops of Marseille ${ }^{296}$ and Valence. ${ }^{297}$ From the small support Boso enjoyed among those previously influential at Louis the Stammerer's court as well as the circumstance that their reintegration under Carloman's rule was apparently unproblematic, it would appear that their decision to take part in Boso's rebellion was less motivated by a rejection of Louis the Stammerer's sons or their political ambition, but by their personal relation to Boso and the promises and threats he made, as stated by Hincmar and Regino.

This underlines the importance of Boso's motives for the rebellion even more. On these motives, Stuart Airlie has brought forward an intriguing explanation. Boso was related to the Carolingian family in multiple ways. He was married to the daughter of Emperor Louis II, Charles the Bald had married his sister Richilde, his aunt Theutberga had married Lothar II. According to Airlie, Boso, also being showered with offices by Charles the Bald, had been turned "into what we might call an honorary Carolingian,"298 going even as far as to speculate that Charles might have considered naming Boso as his successor. ${ }^{299}$ However, with Charles' death, Boso's extraordinary position changed. Boso remained one of the central men of the realm, yet his position was nowhere near as exalted as before. ${ }^{300}$ With Louis the Stammerer's succession further deepening the division among the rivalling noble groups, the pressure on Boso's position, which was based on his relations to the king and the other nobles, increased even further. According to Airlie, it was this threat that caused Boso's rebellion: "He had risen spectacularly high. He had nowhere to go but down."301

The character of Boso's rebellion and of his support for it had a significant impact on Louis III's and Carloman II's capacity to handle it. First, if Airlie's

292 Regino, Chronicon 879, 114.

293 See chapter II.1.

294 DCmII 49.

295 DCmII 56.

296 DCmII 72.

297 DCmII 85.

298 Airlie, Nearly Men, 32-34, quotation 33. On Boso's earlier career, see also Lauranson-Rosaz, Francia, 317-320.

299 Airlie, Nearly Men, 34.

300 Airlie, Nearly Men, 34. See chapter II.1. for a detailed study and Fried, Boso for an analysis of Boso's relations to the pope.

301 Airlie, Nearly Men, 35. 
explanation is accepted, this means that their rule was not challenged by a larger group of nobles who questioned their right to rule, but by a single man who feared the loss of his political position and activated his personal connections to tackle the issue. This entails that his supporters were not principally opposed to the brothers' rule and that their turning away from Boso and rehabilitation under the brothers' regime was possible. This is a very strong contrast to the opposition Odo encountered, which even endured considerable military setbacks. Second, in terms of opposition against Louis and Carloman, Boso's rebellion, despite his ability to muster a large number of nobles in his support, was rather limited and fragmented. ${ }^{302}$ The groups of nobles who had dominated Louis the Stammerer's politics remained largely intact and now supported Louis III and Carloman II in suppressing Boso's revolt, providing them with sufficient resources to overcome the rebels. While it still took two years of siege to capture Boso's stronghold of Vienne, ${ }^{303}$ nothing indicates that the rebellion posed as much of a challenge to Louis and Carloman as Fulk and his allies posed for Odo. Finally, Boso's rebellion occurred at a moment when the Carolingian monopoly on the throne was still unchallenged ${ }^{304}$ and stirred up an alliance of the Carolingian rulers as a response. ${ }^{305}$ Boso, in contrast to Charles the Simple against Odo, could not hope to win further support from rulers outside the West Frankish realm. His position remained isolated while Louis and Carloman could rely on the help of their peers to take out the rebellion.

While the rebellion Louis III and Carloman II faced differed considerably from the one Odo had to deal with, the one against Charles the Simple appears to have been the result of a development rather similar to the one that had brought him to the throne. In chapter III we have emphasised the cooperation and support Charles enjoyed from important members of the nobility even during the crisis of 920 and up into the rebellion. However, this emphasis should not distract from the fact that his relations to an increasing number of nobles were deteriorating, swelling the ranks of an opposition forming against him. As argued, the aim of this opposition was at first not to question his right to rule, but to press him for a change of policy, as parts of the nobility had already attempted to do in early 920 at the assembly of Soissons. This only changed over the course of 922 when Charles evaded negotiations with the opposition led by Robert and his son Hugh. From this moment on, key members of the circle around him, like Count Heribert II of Vermandois and Bishop Abbo of Soissons, turned away from him, which indicates how much he had lost the trust of even the nobles closest to him. The conflict with Gislebert may serve to help to explain the development of this crisis of trust, yet this reading is not unproblematic. The reasons for the outbreak of the conflict and

302 On the fragmentation of his support see, Bautier, Origines, 49-50 and Castelnuovo, Élites, 383-392.

303 Annales Bertiniani 880, 243 and 882, 247.

304 Airlie, Semper fideles, 139-140.

305 See chapter IV.2 and MacLean, Response. 
Charles' role in it are far from certain. Charles renewed the conflict twice, yet the second time the rebellion had already taken its course while the first time also only occurred in the period after the assembly of Soissons. Hence, while the renewals of the conflict may serve to explain the deterioration of the relations with the other nobles, they cannot explain its cause. This only changes if we assume that the behaviour demonstrated by Charles over the course of the conflict was not an isolated occurrence but to a certain degree symptomatic in situations when he felt that his interests were at stake.

As demonstrated, favouring Hagano certainly did not mean that Charles did not listen to other nobles either. Yet, Hagano's special proximity to the king combined with his origin outside the circles of the West Frankish nobility were perceived as infringement on the privilege of the leading nobles to counsel Charles, based not on their personal relation to him, but on their prestige and rank. Elevating men of his own choice to advisors may have been rooted in Carolingian tradition ${ }^{306}$, yet at least in the late Carolingian era it posed considerable problems $\mathrm{s}^{307}$, as a number of similar cases demonstrate. Geneviève Bührer-Thierry has analysed the reproaches in the Mainz continuation of the Annales Fuldenses ${ }^{308}$ against Charles the Fat's closest councillor, his archchancellor Bishop Liutward of Vercelli. ${ }^{309}$ As with Hagano, the Mainz author attacked Liutward because of his (supposedly) humble origins, being elevated by the ruler, and only by the ruler instead of by right of rank, to his side. ${ }^{310}$ Again, similar to Hagano, Liutward was furthermore accused of being extremely familiar with Charles the Fat ${ }^{311}$ and even, according to Regino of Prüm, of being the emperor's only councillor. ${ }^{312}$ To this example we might add the reproaches against Zwentibold, who, again according to Regino, was blamed for listening to advisors who were not noble and even to women. ${ }^{313}$ Reproaches of

306 Le Jan, Élites, 418 and Royauté, Introduction, 12-13. See also Airlie, Bonds and Innes, Government, 86. Falkowski, Contra Legem, 235, on the other hand argues for the right of the high nobles to partake in the decision to elevate a man.

307 Innes, Government, 86 points out that even under Charlemagne such elevations were often disruptive. Similar Airlie, bonds, 197-199, for Louis the Pious' reign.

308 Annales Fuldenses (Mainz Continuation) 887, 105: Qui priscis temporibus, id est ex quo rex in Alamannia constitutus est, quendam de suis ex infimo genere natum nomine Liutwartum supra omnes, qui erant in regno suo, exaltavit, ita ut Aman, cuius mentio facta est in libro Hester, et nomine et dignitate praecelleret. Ille enim post regem Assuerum erat secundus, iste vero prior imperatori et plus quam imperator ab omnibus honorabatur et timebatur...

309 For Liutward, see Keller, Sturz and MacLean, Kingship, 178-191.

310 Bührer-Thierry, Conseiller, 113-115.

311 Bührer-Thierry, Conseiller, 115-116 and 119-121.

312 Regino, Chronicon 887, 127: Et primo quidem Liudwardum episcopum Vercellensem, virum sibi percarum et in administrandis publicis utilitatibus unicum consiliarium, obiecto adulterii crimine, eo quod reginae secretis familiarius, quam oportebat, inmisceretur, a suo latere cum dedecore repulit.

313 Regino, Chronicon 900, 148: Dum haec in Germania aguntur, inter Zuendibolch et primoribus regni inexpiabilis oritur dissensio propter assiduas depredationes et rapinas, quae in regno fiebant, et quia cum mulieribus et ignobilioribus regni negotia disponens honestiores et nobiliores quosque deiciebat et honoribus et dignitatibus expoliabat. 
such violations of the nobles' prerogative to counsel the king are thus revealed as a central argument when it came to defining "bad kingship."314

After Soissons, Charles adjusted his policy by attempting to publicly integrate Hagano into the noble hierarchy. From this point of view, Soissons was a compromise that suited the interests of the king, who was to keep his intimate at court. However, in his efforts to provide Hagano with a position that would allow him to gain the acknowledgement of the other nobles and to occupy the position at the king's side, Charles probably went too far. Flodoard reports that Robert's son Hugh started to advance on Laon because Charles had granted the abbey of Chelles, belonging to Charles' aunt Rothild who also happened to be Hugh's mother-in-law, to Hagano. ${ }^{315}$ Charles choosing Chelles may have been motivated by his relation to Rothild: Taking the abbey from his aunt, he may have hoped not to inspire any more discontent among the nobles. Seemingly, however, he had underestimated the weight of Rothild's connection to the Robertians, as well as the amount of dissatisfaction that had already accumulated at this point.

Yet, Chelles probably was only the tip of the iceberg. After Hugh's advance, Flodoard's account is full of hints about the position Hagano now occupied. After the outbreak of the conflict, Hagano's "accomplices" took the fortress of Epernay. ${ }^{316}$ Richard the Justiciar's son Hugh the Black, when just about to join Robert, encountered "200 men who were with Hagano"3177 who were about to plunder possessions of the church of Reims. Flodoard's wording is rather ambiguous: were these Hagano's own men or were these forces Hagano had been able to raise from contacts he had made over the past years? In any case, the report seems to indicate that Hagano had now risen to a position from where he was able to contribute to the war effort. Furthermore, at Laon Hagano appears to have amassed some treasures that were distributed by Robert after he taken the city. ${ }^{318}$ Combined with the grant of Chelles, these passages indicate that Charles had indeed tried to furnish Hagano with the resources necessary to enter the highest ranks of the nobility. Yet, even if this was not the case, it seems that Charles' relation to Hagano was still perceived as especially close. Flodoard uses strong indicators to describe this relation. "Because of his love for Hagano,"319 he tells us, Charles departed Laon,

314 Nelson, Bad Kingship, 19.

315 Flodoard, Annales 922, 7-8: Karolo denique Laudunum regresso, Hugo, filius Rotberti, post Pascha supra Vidulam venit, ubi, apud villam Finimas, Herivei archiepiscopi fideles cum quibusdam Franciae comitibus obvios habuit. Quo cum eisdem super Axonam in pagum Laudunensem profecto propter praedictum Haganonem, cui rex abbatiam Rothildis, amitae suae, socrus autem Hugonis, dederat, nomine Calam, Karolus cum Heriberto et Haganone clam Laudunum egressus, ob Haganonis amorem, hujus causa timoris trans Mosam profectus est.

316 Flodoard, Annales 922, 9: ...et castrum Sparnaci direptum est ab Haganonis complicibus.

317 Flodoard, Annales 922, 9: Hugo interea, filius Richardi, ad Rotbertum veniens ducentos circiter ex his, qui cum Haganone erant, obvios habuit in villas episcopii Remensis abeuntes praedari.

318 Flodoard, Annales 922, 9-10: Audito denique quod hi qui cum Rotberto erant Laudunum captum haberent, et thesauros Haganonis, qui inibi erant, dispertiti essent...

319 Flodoard, Annales 922, 8: ob Haganonis amorem. 
evading the encounter with Hugh. After Laon had fallen to Robert, "Charles together with Hagano" hurried to retake the city. ${ }^{320}$ Soon after, again "with Hagano", he retreated over the Meuse. ${ }^{321}$ For Flodoard, Hagano was always with Charles, he accompanied the king on all occasions, he was his support and his downfall. The same image can also be found in Folcwin's report, although much more compressed: "Confirmed in his reign, [Charles] elevated a certain Hagano, whose lineage and nobility were unknown to the Franks, esteeming him over everyone else and calling upon him in council in a more familiar way than the others. The Franks, seeing this, not lightly endured this unknown man's friendship; and they were incensed against the king about this and they strove to attack him at the royal city of Laon." ${ }^{322}$ Folcwin simplifies the events by omitting the assembly of Soissons, yet the key message is the same as Flodoard's: Charles' efforts to integrate Hagano in the noble hierarchy had not been enough to pacify the nobles because at the same time he had failed to resolve the other issue at stake, namely to normalise the relations with his intimate. ${ }^{323}$

Charles' adherence to his relation to Hagano reveals a distinctive obstinacy in pursuing his own interests despite the resistance demonstrated by the nobles and the threat this resistance constituted for his rule. This appears to be the same obstinacy as revealed by his renewals of the conflict with Gislebert. 'Obstinacy' is perhaps too strong a word, but certainly the years of fighting against Odo had already been marked by a characteristic persistence, as Charles faced constant setbacks yet also made constant efforts to gain new allies. ${ }^{324}$ During these early years the circle of nobles supporting Charles and leading the rebellion against Odo played an important role. Charles' final act however-turning to Hundeus and his Northmen-took place after these nobles had submitted to Odo. Thus, the alliance with the Northmen was probably Charles' own decision in his efforts to prolong the fight against his opponent. Although this alliance had triggered Archbishop Fulk to harshly criticise Charles, threatening him to end his support and to

320 Flodoard, Annales 922, 10: Karolus cum Haganone Laudunum contendit.

321 Flodoard, Annales 922, 10: Et cum cotidie, copiis Rotberti crescentibus, decrescerent Karoli, clam tandem secendes cum Haganone trans Mosam proficiscitur.

322 Folcwin, Gesta Abbatum S. Bertini Sithensium, c. 99, 625: Qui confirmatus in regno, quendam Haganum, cuius genus et nobilitas ignorabatur a Francis, super omnes diligendo extulit et hunc familiarius ceteris sibi consiliarium ascivit. Quod videntes Franci, non leviter ignoti hominis amicitias tulerunt; regique ob hoc infensi, insidias ei in Lugduno regia civitate tetenderunt.

323 In this context, it is worth mentioning an anomaly within Charles' diplomas. From 31st May 922 (DChS 115) onwards, a certain Hagano appears as royal notary, replacing Gauzlin, who had become bishop of Toul (Lauer, Recueil Charles III, XXV). It has been suggested that this Hagano is identical with Charles' intimate (Koziol, Politics, 468). Given that we know nothing about Hagano's past and education, this is certainly a possibility. However, it seems rather improbable that there was no other man within the royal chancellery (still led by Archbishop Roger of Trier) to be up to the task and we therefore argue that the matching names are a mere coincidence.

324 See chapters I.2.5 and I.2.6. 
excommunicate him, ${ }^{325}$ Charles, in a very similar situation in 923 , reverted back to this strategy. When after the battle of Soissons he was not only abandoned by his Lotharingian forces but his negotiations with Heribert II of Vermandois, Archbishop Seulf of Reims and other important nobles of the Western realm also failed, he again appears to have sought support among the Northmen, both from the Loire and the Seine. ${ }^{326}$ The decision to turn to the Northmen certainly reveals how desperate his situation was at that point, yet it again also demonstrates Charles' determination to pursue his interests to the last, with total disregard for any consequences this might have on his relations with the nobles. This persistence in pursuing his interests may also be what Richer alluded to when, in his characterisation of Charles, he attributed to the king "a lack of self-control over his lusts." 327 Gerhard Schmitz and Yves Sassier have also noted this as a strong theme in the already mentioned second chapter of the acts of the synod of Trosly ${ }^{328}$ where it is emphasised that only someone who was able to control himself could legitimately rule over others. ${ }^{329}$ It is of course impossible to tell whether this reproach for a lack of self-control and the persistence shown by Charles had the same roots, yet it is tempting to assume that both were connected.

If this persistence was indeed symptomatic of Charles' behaviour, it may serve to explain the crisis of trust against him leading to the rebellion. This crisis certainly evolved over time and culminated further throughout the rebellion up until Charles was captured by Heribert II of Vermandois. Its full extent is revealed in the aftermath of the battle of Soissons. Robert had been killed, yet the primates of the realm, among them Heribert II and Archbishop Seulf of Reims, continued to deny Charles' right to rule, rejecting his request to be reacknowledged by them, turning instead to Robert's son-in-law Raoul, son of Richard the Justiciar, on whom they

325 Flodoard, HRE IV, c. 5, 384-385: Karolo regi suo scribens indignatur valde sibi perlatum, quod pravis quorundam consiliis vellet idem rex se sociare Nordmannis, ut illorum auxilio ad regni decus obtinendum iuvari posset. [...] Sciatis enim, quia, si hoc feceritis et talibus consiliis adquieveritis, numquam me fidelem habebitis, sed et, quoscumque potuero, a vestra fidelitate revocabo et cum omnibus coepiscopis meis vos et omnes vestros excommunicans eterno anathemate condempnabo.

326 Flodoard, Annales 923, 14: Karolo dehinc Heribertum comitem, Seulfum archiepiscopum, ceterosque regni primates multis legationibus ut ad se revertantur exorat; quod illi renuentes, pro Rodulfo in Burgundiam transmiserunt, qui ocius cum multa suorum manu illis occurrit. Auditoque Franci quod Karolus ad se venire Nordmannos mandasset, ne illi conjungerentur, inter Karolum atque Nordmannos super Isaram fluvium cum Rodulfo medii resederunt. And 15: Interea Ragenoldus, princeps Nordmannorum qui in fluvio Ligeri versabantur, Karoli frequentibus missis jampridem excitus, Franciam trans Isaram, conjunctis sibi plurimis ex Rodomo, depraedatur.

327 Richer, Historiae, I, 14, 50: Duplici morbo notabilis, libidinis intemperans, ac circa exsequenda iuditia paulo neglegentior fuit.

328 Schmitz, Konzil, 187; Sassier, Royauté, 200. For the synod, see along with the works of Schmitz also Schröder, Synoden, $N^{\circ} 29,189-196$.

329 MGH Conc. V, $\mathrm{N}^{\circ}$ 58, c. 2, 508: Debet itaque rex primo vitam suam aequo moderamine regere et, ut quidam sapiens ait, refrenare libidinem, spernere voluptates, iracundiam tenere ac ceteras animi pestes a se repellere. Tunc vere rex dici et alios digne poterit regere, cum ipse improbissimis dominis dedecori aut turpitudini parere desierit. 
called to become their new king. ${ }^{330}$ While at the outbreak of the rebellion Charles still had the support of some parts of the nobility, at its end he was so deeply mistrusted that even the death of his opponent could not convince the nobles to treat with him again.

Yet, there is a problem with this explanation. Given that Charles' persistence can be already made out at the beginning of Charles' reign, it would seem likely that this behaviour would have marked his entire rule. However, early on, in the wake of the turmoil caused by Archbishop Fulk's murder and a couple of years later when Richard the Justiciar was replaced by Robert of Neustria at court, Charles' actions instead betray a great degree of political flexibility. A settlement with Baldwin II of Flanders was sought and Robert was finally successfully integrated into the rule. After this, the diplomatic evidence indicates strong support for Charles' rule among the nobles throughout the reign up until the beginning of the rebellion. If it was indeed Charles' persistence that caused the deterioration of his relations with the nobles, during the years preceding Soissons a development must have taken place that either strengthened this trait or lifted restrictions that so far had ensured that its effects on his relations to the nobles remained rather limited. This change would most likely have taken place in Charles' direct vicinity, in the circle of men and women in direct contact with him and with influence on his actions. Frederuna's death in 917 and Hagano's rise are both conveniently close to explain such a change, ${ }^{331}$ yet given the lack of evidence they-like any other possible explanations-are mere speculation.

Be that as it may, Charles, like Odo in 892, appears to have lost the trust of the nobles. However, unlike Charles, Odo had managed to suppress the revolt against him. Superiority in resources certainly played a crucial role here, enabling him step by step to bring his opponents' possessions under his control and finally force them to surrender to him. ${ }^{332}$ At first, Charles' forces may have been sufficient to reach a stalemate with Robert's army, as can be seen from the development of the first campaign where neither side tried to attack the other. ${ }^{333}$ Yet, while Charles' and Robert's armies were encamped in close proximity to each other, Robert's allies were able to deal Charles' position a serious blow by taking Laon while his

330 Flodoard, Annales 923, 14.

331 Hagano's influence on Charles is similarly depicted by Koziol, Politics, 469, who assumes "that Hagano was telling Charles what Charles already deeply believed...”, thus strengthening Charles' belief in his heritage and his enmity towards Robert of Neustria.

332 Annales Vedastini 897, 77. See chapter I.2.7.

333 Flodoard, Annales 922, 8-10: Quo comperto, Karolus, Mosa retransmissa, cum nonnullis qui ad se venerant Lothariensibus, villas Remensis aecclesiae depraedari necnon incendere coepit... Rotbertus igitur, super Maternam fluvium [...] procedit obviam: quem subsequens Karolus cum Lothariensibus Maternam transiit... Rotbertus etiam, praefato Rodulfo cum Burgundionibus veniente, fluvium transiens subter Sparnacum, non longius tribus leugis ab exercitu Karoli castra metatus est. [...] Hinc Rotbertus apud Calmiciacum, et Karolus circa Remis castra metati sunt. 
own army appears to have suffered from frequent defections. ${ }^{334}$ This constant loss of support seems to have shifted the balance of power more and more against Charles, which explains why in 923 he attempted to take Robert by surprise before his opponent was able to fully muster his forces. ${ }^{335}$ Yet, military superiority was only one of the reasons for Odo's success. As we have argued, Odo also managed to restore trust in him when he returned Saint-Vaast to Baldwin II of Flanders in 895 and used a seemingly highly regarded mediator, his brother Robert. Charles also made such efforts yet these efforts failed-probably because of their innate character.

The aim of the second assembly of Tours-sur-Marne was to demonstrate that Charles was still king and willing to act as one, protecting the Church and rewarding loyalty. ${ }^{336}$ His diploma for the monks of Saint-Thierry issued at the same occasion showed him correcting old injustices. ${ }^{337}$ However, these measures probably failed to address a central part of the problem. Based on Charles' diplomas, Geoffrey Koziol has attempted to describe Charles' understanding of his position as a king. "He creates an image of monarchy [...] in which a ruler stands 'gloriously' apart from and above margraves, listening graciously as they come before the royal majesty to present their entreaties, 'craving on bended knee'” 338 This analysis is not unproblematic. First, the formula describing petitioners approaching Charles on their knees is used only on very rare occasions. ${ }^{339}$ Second, this language is also used by Charles' predecessors and hence nothing particularly special. ${ }^{340}$ And third, Koziol at the same time dismisses the more frequent references to consensus in Charles' diplomas ${ }^{341}$ as mere "elements in the display of royal majesty," arguing that for Charles they were simply "components of ceremonial of kingship that displayed a kingdom's proper order under a king's protecting, beneficent majesty." ${ }^{342}$ Accordingly, no one would have been able to claim the

334 Flodoard, Annales 922, 9-10: Audito denique quod hi qui cum Rotberto erant Laudunum captum haberent [...] Karolus cum Haganone Laudunum contendit. Lotharienses quidam regrediuntur ad sua quidam cum Karolo pergunt. [...] Et cum cotidie, copiis Rotberti crescentibus, decrescerent Karoli, clam tandem secedens cum Haganone trans Mosam proficiscitur.

335 Flodoard, Annales 923, 13: Karolus cum suis Lothariensibus inducias, quas nuper a Rotberto acceperant, infringentibus Mosam transiens ad Atiniacum venit et, antequam Rotbertus suos fideles adunare potuisset, super Axonam insperate ubi Rotbertum sub urbe Suessonice sedere compererat, adiit; et in crastinum, die dominica, hora iam sexta praeterita, Francis dehinc illa die proelium non sperantibus, plurimis quoque prandentibus, Karolus Axonam transiit, et super Rotbertum cum armatis Lothariensibus venit.

336 See chapter III.1.3.

337 See chapter VI.3.

338 Koziol, Politics, 513.

339 DDChS 71, 79 and 99.

340 As Koziol indicates earlier on, the formular goes back to Charles' predecessors. Koziol, Politics, 486 with n. 104, referring to DCmII 78, 79, 80, 81, 88 and 93bis as well as DChF 119, 120 and 154. For further criticism on Charles' references to his ancestors and the Gelasian doctrine, see chapters III.1.3 and III.2.1.5.

341 Such expressions can be found for example in DDChS 10, 49, 53, 56, 57, 88, 89, 109 and 114.

342 Koziol, Politics, 513. 
right to counsel the king because of his birth or office-these positions were to be given by Charles and him only. ${ }^{343}$ Yet, as we have shown, Charles held contact with a large number of nobles throughout his reign, carefully treating them according to their ranks and integrating them into his rule. ${ }^{344}$ Hence, references to consensus need to be taken as serious expressions of the way Charles ruled. Nevertheless, Koziol's description of the image created in Charles' diplomas cannot simply be dismissed. His description of the image of distance between the ruler and the nobles depicted in the diplomas is accurate.

As Laurent Feller has observed, in 919 a new feature appears in Charles' diplomas which tied royal grants to the loyalty of the recipient. ${ }^{345}$ This is a feature that also appears in the diplomas issued at Tours-sur-Marne. The diploma issued for Bishop Guigo's church of Girona referred to the great loyalty shown by the bishop before granting him the remnants of the royal fisc. ${ }^{346}$ On the other hand, the Tours-sur-Marne diplomas lack any references to consensus. They only show Bishop Guigo approaching the king, to make requests to Charles' royal majesty. ${ }^{347}$ Even the restoration of property to the monks of Saint-Thierry saw only Charles deciding about the justness of their cause: "Acknowledging their claim to be true, through our power we return them said villa with everything belonging to it." 348 Hence, Charles' message in these diplomas was clear: loyal service was to be rewarded, but providing this reward was only his own choice.

Hereby, he differed from Odo and his brother Carloman, who issued diplomas under similar circumstances. ${ }^{349}$ Odo's diploma from September 892, which noted the previous judgement against the monk Aginus, shows the king acting in front of and in accordance with his fideles. Abbot Erkanger of Montiéramey is said to have approached Odo "in the presence of our fideles." Odo further confirms the judgement made by the bishops at the royal placitum of Verberie, again noting to have acted "with the consens of our fideles." 350 This is similar to Carloman's capitulary from 884, which was delivered at the moment of the reintegration of the nobles from the northern part of the realm and, while emphasising his position

343 Koziol, Politics, 513.

344 See chapter III.

345 Feller, Exercice, 142-143. Feller names DDChS 99, 102 (a forgery) and 111.

346 DChS 120, 285: Supra quae praefato episcopo Wigoni suaeque eclesiae [...] pro remdio animae nostrae ac genitorum nostrorum, ob nimiam etiam fidelitatem quam illum erga nos cernimus habere, largimur perpauca nostrae regali jure competentia potestati...

347 For example DChS 116, 274-275: Idcirco noverit [...] quoniam accedens ante presentiam nostram venerabilis presul Gerundensis ecclesię, Guigo nomine, expetiit a nostra mansuetudine ut... Cujus petitionem benigne suscipientes, concedimus...

348 DChS 115, 273: Quorum reclamationem cognoscentes veram esse, potestate nostra prefatam villam eis reddidimus cum omnibus ad eam pertinentibus.

349 See chapter VI.3.

350 DOdo 30, 134: Quodcirca noverit [...] quoniam, adiens celsitudinem nostram, quidam monachus, Aginus nomine, qui cellam quam Sadrevertus abbas a serenissimo pie recordationis Karolo imperarore decertaverat, ante presentiam fidelium nostrorum, repetiit. [...] Cujus [abbas Erchenerius] petitionem ratam invenientes, una cum consensu fidelium nostrorum, id fieri decrevimus... 
as king, ${ }^{351}$ also shows him acting together with those around him. ${ }^{352}$ This point is further stressed by the diploma issued only a few days later, which restored the abbey of Saint-Sulpice to the church of Châlons at the request of its bishop, Berno. While the diploma emphasises Berno's loyalty in council and aid, ${ }^{353}$ it also informs that the king acted at the "suggestion and request" of two others of his fideles, Bishop Angelwinus of Paris and Count Theoderic of Vermandois, two of the leading nobles who had previously distanced themselves from his rule. ${ }^{354}$ Like Odo, Carloman too, facing a severe crisis of his rule, stressed his cooperation with the nobles. Compared to this, the message Charles sent with the diplomas issued at Tours-sur-Marne was most likely the wrong one. ${ }^{355}$ If he wanted to restore trust in him, he needed to demonstrate not only that he was willing to act as a king, but to act in accordance with those around him, by listening to their counsel. Just how central this point had become is further demonstrated by the only diploma preserved by Robert, issued in January 923. As Geoffrey Koziol has noted, ${ }^{356}$ this diploma addresses this exact same subject by replacing the common address "to the faithful of the church of God and of ourself" (fideles eccelsiae Dei et nostri) with "Let it remain known to the sageness of all our faithful, that is, the leading men of the Franks..." ${ }^{357}$ In contrast to Charles, Robert thus portrayed himself as someone who cooperated with the nobles, listening to their sage counsel. This was undoubtedly a direct response to the former's failed policy.

Yet, despite Charles' shortcomings in addressing the reproaches brought against him by the nobles, questioning his right to rule appears to have been a difficult decision for the nobles. Robert's diploma, although it makes references to the rebellion by claiming that he had become king "because of indespensable reasons," 358 fails to go into any further detail and carefully avoids to name Charles at all, thus becoming "an embarrassed reflection on the circumstances that had brought Robert to the throne." ${ }^{359}$ Furthermore, some time after Charles

351 See chapters II.2 and VI.3.

352 MGH Capit. II, No 287, 371: Karlomannus gratia Dei rex omnibus venerabilibus episcopis, abbatibus, comitibus, iudicibus omnibusque sanctae Dei ecclesiae et nostris fidelibus. Cum ad palatium Vernis anno dominicae in carnationis DCCCLXXXIV, anno autem regni nostri quinto, indictione secunda, mense Martio convenissemus et pars fidelium nostrorum nobiscum, placuit, ut quaedam statuta sacrorum canonum necnon quaedam capitula antecessorum nostrorum renovarentur...

353 DCmII 76, 198: ... qui nobis in principio regni nostri et consilio et auxilio satis proficuus et fidelis extitit...

354 ...hoc idem quoque cum eo suggerentibus et deprecantibus fidelibus nostris, venerabili scilicet Angelwino Parisiorum episcopo et Teuderico comite valde nobis dilecto.

355 See also Görich, Misstrauen, who demonstrates that symbolic actions could fail in building trust when relations were dominated by mistrust and one of the parties acted under certain convictions which blocked the right choice of symbolic actions.

356 Koziol, Robert, 250-251.

357 DRoI 1, 8: Notum autem manet sagacitati omnium fidelium nostrorum, procerum scilicet Francorum, qualiter per divinam clementiam, causis necessariis existentibus, omnium favore principum ad regni gubernacula moderanda regie majestatis sceptra suscepimus. Translation by Koziol, Robert, 250.

358 See chapter VI.4, n. 357. Own translation.

359 Koziol, Robert, 249. 
had been captured, a synod under the new archbishop Seulf took place at Reims, condemning the participants of the battle of Soissons to a harsh penitence of three years. ${ }^{360}$ Besides Seulf, the bishops Abbo of Soissons, Adelelm of Laon, Stephen of Cambrai, Adelelm of Senlis and the newly ordinated Airard of Noyon were present, thus a mixture of Robert's and Charles' former supporters, ${ }^{361}$ as well as legates from the other bishops of the archdiocese of Reims. Interestingly, the synod makes no differentiation between the men who had followed Charles and those who had followed Robert, treating them exactly the same way. Worries among the clergy about a new war among the nobility may indeed have played a role in the decision, ${ }^{362}$ yet, nevertheless, one might wonder why Robert's supporters-the very same who after his death still refused Charles and called for Raoul-would have agreed to be placed on the same level with their opponents. Like Robert's diploma, the notice reporting the synod refrains from bringing forward any reproaches against Charles. This silence points towards an underlying problem for the nobles opposing Charles. Whatever the accusations against him might have been, questioning his right to rule meant to rebel against the legitimate king. As Wojciech Falkowski's study shows, at least south of the Loire, the division among the nobility whether Charles' deposition had been legitimate or not continued to exist at least up until his death in $929 .{ }^{363}$ But even in the North the question of Charles' kingship remained to be a problem. When his captor Heribert II of Vermandois entered into conflict with King Raoul in 927, he used this kingship as a political lever, threatening Raoul's position by reinstalling Charles and letting the Northmen pay their allegiance to him. ${ }^{364}$ During the following year, although according to Flodoard under the pressure of the Northmen, other counts and bishops followed their example. ${ }^{365}$ The episode was only short-lived as Charles was returned to his prison by Heribert as soon as his dispute with Raoul had been settled, ${ }^{366}$ yet it reveals that the idea of Charles being king was still vivid enough to be exploited politically. What was the nature of this power behind Charles' claim to the throne? As we have argued, Charles' Carolingian descent had been a powerful argument when used against Odo who was lacking this kind of legitimacy. After Raoul's death in 936, it was Robert's son Hugh the Great who, instead of

360 On the penitence, see Schröder, Synoden, 215.

361 See chapters III.2.1.7, III.2.3 and III.3.

362 Eckel, Charles, 127; Lauer, Robert, 13.

363 Falkowski, Contra legem, 229-233. See also chapter III.3.

364 Flodoard, Annales 927, 39-40: At Heribertus Karolum de custodia ejecit secumque in pagum Veromandinsem, scilicet ad Sanctum Quintinum, deduxit. [...] Karolus igitur cum Heriberto colloquium petit Nordmannorum, ad castellum quod Auga vocatur, ibique se filius Rollonis Karolo committit et amicitiam firmat cum Heriberto.

365 Flodoard, Annales 928, 41: Filius tamen Heriberti, Odo, quem Rollo habebat obsidem, non redditur illi, donec se committit Karolo pater cum aliis quibusdam Franciae comitibus et episcopis.

366 Flodoard, Annales 928, 43: Hugo et Heribertus ad Heinricum, colloquii causa, proficiscuntur; indeque revertentes, obviam pergunt regi Rodulfo. Rursusque Heribertus se illi committit, iterum redacto sub custodia Karolo. 
taking the crown for himself, recalled Charles' own son Louis IV from England to succeed on his father's throne. ${ }^{367}$ The only argument speaking in favour of Louis was, very much like in his father's case, his Carolingian heritage. This was probably what Charles could rely on most-his undeniable claim, for the legitimacy of his kingship was based on his descent. The fact that the nobles nevertheless decided to oppose him is less of a sign that this idea had faded, but points towards the degree of the loss of trust in Charles.

\section{VI.5. Conclusion}

In this chapter, we have emphasised the role of two factors in the relations between the king and the nobles: the existence of powerful groups of influence and the necessity for the king to be trusted by the nobles who supported his rule. In conflict situations, either factor could limit the options of the king when deciding upon a strategy. Thus, Charles the Simple, when dealing with Count Baldwin II of Flanders, faced the same problem as his father Louis the Stammerer against Bernard of Gothia, for his closest allies prevented him from finding a peaceful arrangement with his opponent. In both of these cases, the nobles in question were rivals of those in conflict with the king, either for influence at the royal court or for the contested honores. Thus, it became impossible for the rulers to find a settlement with their opponents that did not at the same time violate the interests of their supporters. While in Louis the Stammerer's case the conflict was finally resolved by the superiority in resources the king and his allies were able to muster, leading to Bernard's deposition, in Charles' case it was the removal of the nobles blocking a solution that opened the way for the final settlement.

However, such a settlement required a certain degree of trust between all the parties involved. As the case of Odo and Baldwin shows, the lack of trust could have a similar effect as the presence of rivalling groups dominating the circle around the king. Under these circumstances, it was impossible to come to terms with each other, although this time not from the king's perspective, but from the perspective of the noble who appears to have deeply mistrusted Odo. There were ways to overcome such obstacles: for example, Charles the Simple chose to recompense Count Gislebert by finally elevating him to a position similar to his father Reginar's, something he had refrained from doing up until that moment. This offer must have been too tempting for Gislebert to resist, although he, after Charles had already broken an earlier agreement, had no reason to trust the king. Odo, on the other hand, finally resolved his conflict with Baldwin by a combination of military superiority and trust-building measures, which made the count finally admit to the royal prerogative to control the distribution of honores. 
A loss of trust, such as it is visible in the case of Odo and Baldwin, was not per se necessarily problematic, at least not as long as it remained an isolated case. However, it could become an issue if the mistrust against the king spread within the nobility, especially if it reached the inner circle around the king with the most powerful nobles and his closest advisors, that is to say, when it developed into a severe crisis of trust. The decades around the turn from the 9th to the 10th century saw a number of such crises: when Carloman II suffered a disastrous defeat against the Northmen in 883 , the nobles appear to have mistrusted his ability to deal with the Viking threat to a such degree that they took the matter into their own hands, although without denying Carloman's right to rule, still acknowledging him as king. On the other hand, in the cases of Odo and Charles the Simple, the crises of trust appear not to have evolved due to a lack of trust in their capacities to deal with a specific problem, but because of what the nobles perceived as transgressions against the norms of kingship. The conflicts we have analysed in this chapter either betray already existing mistrust of singular nobles against their king or were cases of royal actions that were probably perceived as "bad kingship" by wider circles of the nobility, undermining their trust in the rulers and all occurring around the same time the rebellions against the rulers were developing.

While this proximity in time is unproblematic in Odo's case since his conflict with Baldwin as well as the one arising over the succession at Poitiers ${ }^{368}$ predate the rebellion against him, in Charles' case the connection between his actions against Gislebert and the loss of trust in him causes some problems. While the conflict started before the deterioration of his relations with ever larger parts of the nobility, at least until the outbreak of the rebellion he appears to have had considerable support against the count. In any case, his last renewal of the conflict only took place when he was already fighting the rebels and thus cannot have contributed to the crisis. However, these actions are likely to have been symptomatic for Charles' behaviour also in other situations, betraying an obstinacy when it came to pursuing his interests against those of the nobles around him. This obstinacy can, for example, also be seen in his adherence to his intimate Hagano. After Soissons he did come to terms with the nobles and made efforts to publicly integrate Hagano into the noble hierarchy. The agreement they had found was a compromise, protecting the royal interest of keeping Hagano at court as well as the interest of the nobles, who would not accept an outsider close to the king. Yet, while Charles provided Hagano with the honores linked to an elevated position at court and thus aimed to integrate him further into the highest ranks of the nobility, he failed to address the second main issue the nobles had had with his intimate: his overly close relation with the king. In his persistence to keep Hagano close to him, Charles did not meet the expectations of the nobles arising from the previous agreement. Whether it were his actions against Gislebert or his policy in the case of Hagano, Charles

368 For more examples of Odo's actions that probably were probably perceived as breaches of the norms, see chapter I.2.3. 
failed to present himself as a reliable ruler who had the interests of the nobles at heart and thus undermined their trust in him.

Trust could be built by symbolic measures as in particular ways of doing justice. For example, Carloman II's second capitulary was issued after his defeat against the Northmen, just at the very moment when an agreement with nobles from the North had been reached. This is hardly a coincidence since at the same time he also issued a diploma recording a royal judgement in favour of one of his supporters-one example of how references to judicial assemblies were used by the various rulers to demonstrate the royal will to do justice in cooperation with the nobles. Finally restorational acts also fall within this category. While less frequent, if the occasion presented itself, like the references to the judicial assemblies, they were issued to portray how a ruler was bringing justice to those supporting him, remedying old injustice and thus strengthening trust in him. However, while the protection of the interests of those close to the ruler by royal justice was a characteristic common to the acts of all rulers, there was also a second characteristic in which Charles the Simple's acts differed from those of his predecessors. While Carloman and Odo emphasised their cooperation with the nobles, in his later acts Charles failed to so. The diplomas recording the judgements of Herstal, with their long lists of participants, are certainly reminiscences to the royal cooperation with the nobility. Yet, especially Charles' last restorational act issued at Tours-sur-Marne for the monks of Saint-Thierry of Reims, at a moment when the rebellion was already in full progress, is of a different nature. While still stressing the power of the king to bring justice, it focuses on the loyalty of the recipients to the king and not on his cooperation with them. In an atmosphere of deep mistrust against Charles, this was undoubtedly the wrong message. Trust could not be built by calling upon unconditional loyalty as a king's prerogative, but only by demonstrating the willingness to integrate the nobles into the rule and therefore to allow them a certain degree of control over the royal politics by their participation in the decision-making process, especially since this participation was perceived as one of their most important privileges by the leading nobles of the realm. 



\section{Conclusion}

Charles the Simple became king of the West Frankish realm because a strong opposition had formed against his predecessor Odo. The Robertian had, despite his efforts, failed to fully integrate his early opponents into his rule. Once Odo's reign started to suffer from a severe crisis of trust, these men acted as a rallying point for others. For this opposition, Charles possessed an advantage over Odo that made him an ideal candidate to replace the Robertian: his Carolingian blood. In a world in which the idea of Carolingian kingship was still prevalent, Charles' descent could be used as a powerful argument in the political discourse. This did not entail that Odo was to be disposed as a king. It merely meant that with Charles there now existed an alternative for all those discontent with the Robertian's rule. Both of them, Charles and Odo, were now kings, acknowledged by their peers as well as by the nobles, and even acknowledging each other. Thus, Charles' succession to Odo presents itself as a pragmatic solution to the conflict between the different parties, which took the fragile position of Odo and the weakness of a claim his brother Robert might have had to follow him on the throne into consideration.

Royal power being the result of the interaction between the king and the nobles, the king's ability to manipulate the network of nobles around him can be used as a means to measure the possibilities and limits of said power. Charles' early years reveal certain limitations to this ability: close to him were those who had already supported him during the years of the fight with Odo. However, at the same time, the presence of these nobles hindered the full integration of powerful men like Robert of Neustria or Richard the Justiciar. They did acknowledge Charles as king and cooperated with him initially, yet did not belong to his inner circle, which was dominated by those early supporters. This led to a fragile balance which ended only after the murder of Archbishop Fulk, and thereby the creation of a vacuum of power at the royal court that was filled first by Richard and then by Robert. A ruler not being able (or willing) to act against the interests of a powerful group of nobles was nothing new however. When his father Louis the Stammerer attempted to create his own basis of power after the death of Charles the Bald, the leading nobles of the realm forced him to abandon his plans and to rule with them instead. These men then created networks which dominated royal politics over the next few years, up until the reign of Charles the Fat.

This does not mean that the rulers were unable to promote nobles of their choosing. The presence of men like Count Robert of Troyes under Carloman II or the fidelis Robert under Charles the Simple indicates that there was room at court for men who drew their importance from their personal relation to the king. However, these men needed to be accepted by the other nobles already present in the circle around the king. In fact, in most cases nobles whose influence increased under the various rulers either appear to already have had connections to the circle dominating the court or soon created such contacts. This pattern is 
also revealed during the rule of Charles the Fat. The emperor certainly did make efforts to install men of his own choosing in the West Frankish realm, yet in most cases his choice fell on men like Odo and Bishop Geilo of Langres, both of whom had strong connections to the networks that had dominated politics under Louis the Stammerer and his older sons. This kind of policy, while it limited the pool of choices, also had distinctive advantages. These men were not only well connected among the local nobility and thus ideal candidates to serve as power brokers for the rulers, they were also well connected among those nobles already present at court, thus facilitating their integration into the hierarchy there.

This latter point was especially problematic. Not only Charles the Simple early in his reign, but also Odo had to cope with the problem of having to integrate different groups of nobles into his rule. Like Charles, Odo also was supported by a distinctive group of nobles, nobles who, after he had become king, occupied the innermost layer of the circle around him. Accepting new nobles into this circle meant that adjustments to the existing hierarchy had to be made, necessarily leading to conflicts between the interests of those already present and those newly joining. For both Odo and Charles, this posed a problem almost impossible to solve since their closest supporters already occupied the positions the men who were to be newly integrated into the rule claimed for themselves. Odo's efforts finally failed, contributing the rebellion breaking out against him. Charles was more successful, winning room for manoeuvre although only through the death of one of his most important supporters, Archbishop Fulk.

Indeed, for large parts of his reign, Charles the Simple demonstrated a remarkable capacity to mediate between the interests of the individual nobles and his own. The integration of the Lotharingian nobility meant that a completely new group of nobles-or better, several new groups-had to be integrated into the circle around the king. Charles not only managed to find a balance between these different groups, to deal with their rivalries and use them to his advantage when pursuing his goals within Lotharingia, but he also managed to do this without neglecting the interests of the West Frankish nobles at his court. Concerning the latter, he increased his efforts and kept especially Robert of Neustria close at his side, thus making sure that the necessary adjustments to the hierarchy at court were accepted by the West Frankish nobles and found the general consent. Similarly, when a group of new nobles rose to influence at the royal court around 920, Charles appears to have managed this transition without creating major discontent among the other nobles. Again, however, it is worth noting that most of the nobles added to the circle around the king on these occasions were already well established and often connected to those already present at the royal court. Nevertheless, adjustments to the existing hierarchy had to be made and Charles appears to have succeeded in implementing them in cooperation with the circle of nobles around him. Charles' capacity in these matters becomes especially evident when comparing his success with the problems his brother Carloman encountered once he had taken over the rule in the northern part of the realm. Early on, Carloman 
failed to take the interests of these nobles into consideration and to make the necessary adjustments to the circle around him, which led them to withdraw from court and left Carloman with only very limited means to deal with the Viking threat.

If necessary, it was certainly possible to rule without the support or even against important nobles and their networks - at least for a certain time. In the early 900 s, when Charles the Simple was faced with Robert's opposition, he managed to create a counterweight against the marchio by forging new alliances and extending his own basis of support. However, situations like this one were extremely unstable and needed a certain amount of political flexibility if new developments occurred that shifted the balance of power. In Carloman's case, his defeat against the Northmen brought the final change. In Charles', it was his conflict with Richard the Justiciar that made it necessary to finally satisfy Robert's claim to occupy a position at court adequate to his position within the noble hierarchy of the realm.

Situations like this were also extremely dangerous because they provided other rulers with the opportunity to intervene on the behalf of the ruler's opponents. Thus, Odo's own vulnerability in the conflict with Charles was exploited by Arnulf and Zwentibold while Charles' conflict with Count Gislebert was followed by activities of Henry the Fowler in Lotharingia. Of course, this also worked the other way round. Charles the Simple intervened twice in Lotharingia when parts of the local nobility were looking for allies against their ruler (or, in 911, against the possibility of a king from the rivalling Konradiner family) outside the borders of the regnum - the second time with success, due to the support he could muster among the local nobles. Louis the Stammerer had attempted to avert such situations by concluding a treaty with Louis the Younger which prohibited interventions of this kind. This worked rather well when soon after his death Boso had himself crowned king, which led to the creation of a system of alliances among the Carolingian rulers aimed at crushing the rebellion. However, at the same time, this same system of alliances made it impossible for Louis III and Carloman II to effectively pursue their interests in Lotharingia. Charles the Simple appears to have been well aware of the advantages and disadvantages of this system. When his rule started to become unstable towards the early 920 s, he attempted to revive the old cooperation by initiating a new one with Henry the Fowler. While much less effective than the earlier alliances, this cooperation at least secured Henry's non-intervention after the rebellion had broken out against Charles.

However, while such situations of instability existed during certain periods, for most of the time Charles the Simple appears to have enjoyed the support of at least large parts of the nobility. This is especially evident from his policy towards the Northmen. Charles was, very much like his predecessors, able to muster large armies consisting of contingents from the various parts of his realm. However, this ability should not be confused with military success on the battlefield: large armies were as little guarantee for victory as small ones were for defeat. Nor should it be confused with the capacity to secure the realm solely by military means, as 
this was a task at which none of Charles' predecessors had succeeded. However, it does demonstrate that the nobles supported Charles' strategy of dealing with the Viking threat. This had not always been the case under his predecessors: after Carloman's disastrous campaign against the Northmen, the nobles around him enforced a diplomatic solution. Similarly, the local nobles allowed the Northmen to move freely in exchange for their own safety, thus undermining Odo's defensively oriented strategy which was aimed at containing the raiders rather than defeating them. The support of the nobles in Viking matters not only becomes evident in the military measures, but also in diplomacy. Negotiating deals with the Northmen was known as an effective means to remove them from the realm and it was frequently used by the West Frankish rulers. As such, Charles' treaty of Saint-Clair-sur-Epte followed their example, containing elements already used by his predecessors. Nevertheless, being concluded in the wake of major military victory, it marked a distinctive change in strategy which could only have been implemented in accordance with the leading nobles.

Charles was able to raise forces from different parts of the realm, yet this ability very much depended on the cooperation of a small number of nobles. Forces from Neustria and Burgundy, led by Robert of Neustria and Richard the Justiciar, the two men who controlled large parts of these regions, won the battle of Chartres. The existence of powerful nobles like these two was nothing new. Men like them had risen before through their connections with the rulers and by royal will and consent. Boso, to name but one example, had been one of them. Under Louis the Stammerer and his older sons, Hugh the Abbot and Gauzlin had dominated the politics of the realm together with their networks. As long as the rulers were able to secure the cooperation of these men, this was even an advantage since these powerful nobles served as perfect conduits of royal power. Thus, the decreased range of royal travels that can be noted for Charles the Simple's reign in comparison to his predecessors did not mean that the regions now not visited anymore were outside the range of royal power. Especially in Burgundy, previously a region with manifold royal contacts to the local nobility and repeated royal presence, Richard the Justiciar now served as an intermediary and power-broker for the king.

Yet, while Robert and Richard undoubtedly played a key role in Charles' reign, his dependency on them appears to have been much smaller than those of Louis the Stammerer and his sons on the alliances around Hugh the Abbot and Gauzlin. The circles around Charles' father and brothers appear to have consisted almost exclusively of members of these alliances, with a strong tendency to also absorb those who the kings themselves had elevated into their networks. This changed over the course of Charles the Fat's reign, leading to a politically fragmented nobility which supported different claimants to the throne after his death. This condition persisted over the course of Odo's reign into the one of Charles the Simple, contributing to the rebellion against the former and causing Charles' initial problems with Robert. Yet, at the same time, at least for Charles this fragmentation also provided him with more room for manoeuvre after the death of Archbishop 
Fulk. His power was not solely dependent on the cooperation of Robert or Richard (though their cooperation greatly increased his options), it was also and mainly founded on a network of less powerful nobles, first from the Francia, then also from Lotharingia. Here, Charles forged links by marriage and patronage. Wigeric certainly owed his promotion to count of the palace to his marriage to Charles' niece, as did Count Erlebald, who married one of Charles' daughters. Richer of Prüm and Charles' former notary Gauzlin became bishops because Charles aimed at promoting men of his choice to important positions. Bishop Stephen of Cambrai and Count Ricuin of Verdun regained influence at the royal court which they had lost under Louis the Child. These ties helped Charles to keep the balance of power within the realm.

In the end, Charles was deposed because he failed to maintain the good relations not only with the most powerful men of the realm, but also with those other nobles. At the core of this development was a crisis of trust in Charles, whose actions in the late 910s started to transgress the boundaries of what was politically possible and opportune. Charles, like Odo in 892 , was not trusted anymore because he violated the interests of the nobles while pursuing his own. This loss of trust went deep, estranging even those nobles from him who had previously belonged to his most important supporters. This situation was exacerbated by another development. In contrast to the early years of his reign, the fragmentation of the leading ranks of the nobility had been overcome. While this did not mean that another system of alliances had been created that dominated royal politics, it did mean that the old rivalries that had shaped politics within the realm around 900 had come to an end. Over the course of Charles' reign, Robert, who served as rallying point for the rebels, had forged links to other leading nobles, including the family of Richard the Justiciar and Count Heribert II. These links now became active, drawing more and more of Charles' supporters over to the rebels.

At first, the rebellion was certainly not aimed at Charles' deposition and Robert's elevation to the throne. Charles' claim to the throne was still a strong one and the question of whether to deny his right to rule deeply divided the nobility. Indeed, it seems much more likely that the goal of the opposition was to take control of the royal politics, with Charles remaining king. It was Charles' own refusal to negotiate that initiated the escalation of the conflict. This refusal was in line with his persistence to pursue his own interests to the detriment of those of the nobles during the last years of his reign, even if it meant bending or breaking earlier agreements-a persistence that led to the creation and intensification of the crisis of trust in him. The possibilities and limits of royal power in the late Carolingian age were defined by the cooperation of the nobles and Charles, by neglecting this need to create consensus while overemphasising his royal will and majesty, deprived himself of the foundations of his rule. 



\section{Bibliography}

\section{Primary Sources}

Abbo, Bella Parisiacae Urbis, ed. Henri Waquet, Abbon. Le Siège de Paris par les Normands (Les classiques de l'Histoire de France au moyen âge, 20), Paris 1942.

Actus pontificum Cenomannis in urbe degentium, ed. Gustave Busson and Ambroise Ledru (Archives historiques du Maine, 2), Le Mans 1901, Permalink: https://gallica.bnf. fr/ark:/12148/bpt6k736761 (accessed 22.06.2018).

Adalbert of Magdeburg, Continuatio Reginonis, ed. Friedrich Kurze, Reginonis Abbatis Prumiensis Chronicon cum Continuatione Treverensi (MGH SS rer. Germ., 50), Hanover 1890, 154-179, Permalink: http://www.mgh.de/dmgh/resolving/MGH_SS_ rer._Germ._50_S._154 (accessed 22.06.2018).

Ademar of Chabannes, Ademari Cabannensis Chronicon, ed. Pascale Bourgain, Richard Landes and Georges Pon, Corpus Christianorum (Continuatio Mediaevalis, 129,1), Turnhout 1999.

Adrevald of Fleury, Miracula Sancti Benedicti I, ed. Eugène de Certain, Les miracles de Saint Benoît, Paris 1858, 1-89, Permalink: https://gallica.bnf.fr/ark:/12148/bpt6k1026692. image (accessed 22.06.2018).

Alberic of Trois-Fontaines, Chronicon, ed. Paul Scheffer-Boichorst, (MGH SS, 23), Hanover 1874, 631-950, Permalink: http://www.mgh.de/dmgh/resolving/MGH_SS_23_S._631 (accessed 22.06.2018).

Anecdota novissima. Texte des vierten bis sechzehnten Jahrhunderts, ed. Bernhard Bischoff (Quellen und Untersuchungen zur lateinischen Philologie des Mittelalters, 7), Stuttgart 1984.

Annales Alamannici, ed. Walther Lendi, Untersuchungen zur frühalemannischen Annalistik. Die Murbacher Annalen. Mit Edition, Freiburg 1971.

Annales Bertiniani, ed. Felix Grat, Jeanne Vielliard and Suzanne Clémencet, Annales de Saint-Bertin, Paris 1964.

Annales Fuldenses sive Annales regni Francorum orientalis, ed. Friedrich Kurze (MGH SS rer. Germ., 7), Hanover 1891, Permalink: http://www.mgh.de/dmgh/resolving/ MGH_SS_rer._Germ._7_S._II (accessed 22.06.2018).

Annales Masciacenses, ed. Georg Heinrich Pertz (MGH SS, 3), Hanover 1839, 169, Permalink: http://www.mgh.de/dmgh/resolving/MGH_SS_3_S._169 (accessed 22.06.2018).

Annales Prumienses, ed. Oswald Holder-Egger (MGH SS, 15,2), Hanover 1888, 1289-1292, Permalink: http://www.mgh.de/dmgh/resolving/MGH_SS_15,2_S._1289 (accessed 22.06.2018).

Annales S. Columbae Senonensis, ed. Georg Heinrich Pertz (MGH SS, 1), Hanover 1826, 102-109, Permalink: http://www.mgh.de/dmgh/resolving/MGH_SS_1_S._102 (accessed 22.06.2018).

Annales S. Germani Parisiensis, ed. Georg Heinrich Pertz (MGH SS, 3), Hanover 1839, 166-168, Permalink: http://www.mgh.de/dmgh/resolving/MGH_SS_3_S._166 (accessed 22.06.2018).

Annales S. Medardi Suessionensibus, ed. Georg Waitz (MGH SS, 26), Hanover 1882, 518-522, Permalink: http://www.mgh.de/dmgh/resolving/MGH_SS_26_S._518 (accessed 22.06.2018). 
Annales S. Vicentii Mettensis, ed. Georg Heinrich Pertz (MGH SS, 3), Hanover 1839, 155-160, Permalink: http://www.mgh.de/dmgh/resolving/MGH_SS_3_S._155 (accessed 22.06.2018).

Annales Vedastini, ed. Bernhard von Simson, Annales Xantenses et Annales Vedastini (MGH SS rer. Germ., 12), Hanover 1909, 40-82, Permalink: http://www.mgh.de/dmgh/ resolving/MGH_SS_rer._Germ._12_S._40 (accessed 22.06.2018).

Anselm of Liège, Gesta Episcoporum Tungrensium, ed. Rudolf Koepke (MGH SS, 7), Hanover 1846, 189-234, Permalink: http://www.mgh.de/dmgh/resolving/MGH_ SS_7_S._189 (accessed 22.06.2018).

Capitula electionis Hludowici Balbi Compendii facta, ed. Alfred Boretius and Victor Krause (MGH Capitularia regum Francorum, 2), Hanover 1897, N² 283, 363-365, Permalink: http://www.mgh.de/dmgh/resolving/MGH_Capit._2_S._363 (accessed 22.06.2018).

Capitulare Carisiacense, ed. Alfred Boretius and Victor Krause (MGH Capitularia regum Francorum, 2), Hanover 1897, N 281, 355-361, Permalink: http://www.mgh.de/dmgh/ resolving/MGH_Capit._2_S._355 (accessed 22.06.2018).

Cartulaire de Brioude, ed. Henri Doniol, Clermont-Ferrand/Paris 1863, Permalink: http:// www.mdz-nbn-resolving.de/urn/resolver.pl?urn=urn:nbn:de:bvb:12-bsb10006282-2 (accessed 22.06.2018).

Cartulaire de l'abbaye de Montiéramey, ed. Charles Lalore (Collection des principaux cartulaires du diocese de Troyes, 7), Paris 1890, Permalink: https://gallica.bnf.fr/ ark:/12148/bpt6k289165 (accessed 22.06.2018).

Cartulaire de l'abbaye de Redon en Bretagne, ed. Aurélien de Courson, Paris 1863, Permalink: https://gallica.bnf.fr/ark:/12148/bpt6k289165 (accessed 22.06.2018).

Cartulaire de l'église d'Autun connu sous le nom de Cartulaire rouge, ed. Anatole de Charmasse (Documents inédits pour servir à l' histoire de l'Autunois, 1), 3 vols., Paris and Autun 1865-1900, Permalink: http://nbn-resolving.org/urn:nbn:de:bvb:12-bsb00072861-7 (accessed 25.06.2018).

Cartulaire de l'église de Notre-Dame de Paris, ed. Hercule Guéraud, Jules Marion and Augustin Deloye (Collection des cartulaires de France, 4-7), 4 vols., Paris 1850, URL: https://archive.org/details/cartulairedelgl01catgoog (accessed 22.06.2018).

Cartulaire de Sauxillanges (Chartularium Celsinaniasense), ed. Henri Doniol, ClermontFerrand 1864, URL: https://archive.org/details/cartulairedesau00donigoog (accessed 22.06.2018).

Cartulaire du chapitre de l'église cathédrale Notre-Dame de Nîmes, ed. Eugène GermerDurand, Nîmes 1874, URL: https://archive.org/details/cartulaireducha00durgoog (accessed 22.06.2018).

Cartulaire général de Paris I: 528-1180, ed. Robert de Lasteyrie, Paris 1887, Permalink: https://gallica.bnf.fr/ark:/12148/bpt6k47571 (accessed 22.06.2018).

Cartulaire noir de la cathédrale d'Angers, ed. Charles Urseau, Paris 1908, Permalink: https://gallica.bnf.fr/ark:/12148/bpt6k91429w.texteImage (accessed 22.06.2018).

Catalogus abbatum Corbeiensium ab a. 822 ad a. 1147, ed. Oswald Holder-Egger (MGH SS 13), Hanover 1881, 274-277, Permalink: http://www.mgh.de/dmgh/resolving/MGH_ SS_13_S._274 (accessed 22.06.2018).

Catalunya Carolingia II, ed. Ramón d'Abadal i de Vinyals (Memòries de la Secció HistòricoArqueològica, 76), 2 vols., Barcelona 1958.

Catalunya Carolingia V,1, ed. Jaume Sobrequés i Callicó (Memòries de la Secció HistòricoArqueològica, 61,1), Barcelona 2003.

Chronicon Prioratus S. Launomari de Magenciaco apud Arvernos, ed. Jean Mabillon (Acta Sanctorum Ordinis Sancti Benedicti in saeculorum classes distribute, 4,2), Paris 1680, 254-257, URL: https://books.google.fr/books?id=Yf3ef37fligC (accessed 22.06.2018). 
Chronicon S. Benigni Divionensis, ed. Émile Bougaud and Joseph Garnier, Analecta Divionensia, Dijon 1875, 1-228, Permalink: https://gallica.bnf.fr/ark:/12148/bpt6k28994z (accessed 22.06.2018).

Chronicon sancti Maxentii Pictavensis, ed. Jean Verdon, La chronique de Saint-Maixent (751-1140) (Les Classiques de l'Histoire de France au Moyen Âge, 33), Paris 1979.

Chronicon Sancti Petri Vivi Senonensis, ed. Robert-Henri Bautier, Chronique de SaintPierre-le-Vif de Sens dite de Clarius (Sources d'histoire médiévale), Paris 1979.

Chronicon Turonese magnum, ed. André Salmon, Recueil de chroniques de Tourraine, Paris 1854, 64-161, Permalink: https://gallica.bnf.fr/ark:/12148/bpt6k36177w.texteImage (accessed 22.06.2018).

Codex Laureshamensis, ed. Karl Glöckner (Arbeiten der Historischen Kommission für den Volksstaat Hessen), vol. 1, Darmstadt 1929, Permalink: http://nbn-resolving.de/ urn:nbn:de:bsz:16-diglit-203059 (accessed 22.06.2018).

Conventus Mantalensis, ed. Alfred Boretius and Victor Krause (MGH Capitularia regum Francorum, 2), Hanover 1897, № 284, 365-369, Permalink: http://www.mgh.de/dmgh/ resolving/MGH_Capit._2_S._365 (accessed 22.06.2018).

Die Kaiser-Urkunden der Provinz Westfalen, ed. Roger Wilmans and Friedrich Philippi, 2 vols., Münster 1867-1881, Permalink: http://www.mdz-nbn-resolving.de/urn/resolver. pl?urn=urn:nbn:de:bvb:12-bsb10019872-6 (accessed 22.06.2018).

Die Konzilien der karolingischen Teilreiche 843-859, ed. Wilfried Hartmann (MGH Conc., 3), Hanover 1984, Permalink: http://www.mgh.de/dmgh/resolving/MGH_Conc._3_S._ II (accessed 22.06.2018).

Die Konzilien der karolingischen Teilreiche 875-911, ed. Wilfried Hartmann, Isolde Schröder and Gerhard Schmitz (MGH Conc., 5), Hanover 2012.

Die Konzilien Deutschlands und Reichsitaliens 916-1001, ed. Ernst-Dieter Hehl (MGH Conc., 6), 2 vols., Hanover, 1987-2007, Permalink: http://www.mgh.de/dmgh/resolving/ MGH_Conc._6,1_S._II (accessed 22.06.2018).

Die Urkunden Arnolfs, ed. Paul Kehr (MGH Diplomata regum Germaniae ex stirpe Karolinorum, 3), Hanover 1940, Permalink: http://www.mgh.de/dmgh/resolving/ MGH_DD_Arn_S._II (accessed 22.06.2018).

Die Urkunden der Merowinger, ed. Theo Kölzer (MGH Diplomata regum Francorum e stirpe Merovingica), 2 vols., Hanover 2001, Permalink: http://www.mgh.de/dmgh/ resolving/MGH_DD_Mer._1_S._t02 (accessed 22.06.2018).

Die Urkunden Karls III., ed. Paul Kehr (MGH Diplomata regum Germaniae ex stirpe Karolinorum, 2), Berlin 1937, Permalink: http://www.mgh.de/dmgh/resolving/MGH DD_Karl_S._II (accessed 22.06.2018).

Die Urkunden Konrad I. Heinrich I. und Otto I., ed. Theodor Sickel (MGH Diplomata regum et imperatorum Germaniae, 1), Hanover 1879-1884, Permalink: http://www.mgh.de/ dmgh/resolving/MGH_DD_K_I_/_DD_H_I_/_DD_O_I_S._t01 (accessed 22.06.2018).

Die Urkunden Lothars I. und Lothars II., ed. Theodor Schieffer (MGH Diplomata Karolinorum, 3), Berlin and Zürich 1966, Permalink: http://www.mgh.de/dmgh/ resolving/MGH_DD_Lo_I_/_DD_Lo_II_S._II (accessed 22.06.2018).

Die Urkunden Ludwigs des Frommen, ed. Theo Kölzer (MGH Diplomata Karolinorum, 2), Wiesbaden 2016.

Die Urkunden Pippins, Karlmanns und Karls des Großen, ed. Engelbert Mühlbacher (MGH Diplomata Karolinorum, 1), Hanover 1906, Permalink: http://www.mgh.de/ dmgh/resolving/MGH_DD_Kar._1_S._II (accessed 22.06.2018).

Die Urkunden Zwentibolds und Ludwigs des Kindes, ed. Theodor Schieffer (MGH Diplomata regum Germaniae ex stirpe Karolinorum, 4), Hanover 1960, Permalink: http://www. mgh.de/dmgh/resolving/MGH_DD_Zw_/_DD_LK_S._II (accessed 22.06.2018). 
Diplomata Karolinorum: Recueil de reproductions en fac-similé des actes originaux des souverains Carolingiens conservés dans les archives et bibliothèques de France, vol. 6: Charles le Gros, Eudes et Charles le Simple (885-922), ed. Ferdinand Lot and Philippe Lauer, Paris 1942.

Dudo of Saint-Quentin, De moribus et actis primorum Normanniae ducum, ed. Jules Lair (Mémoires de la société des antiquaires de Normandie, 23), Caen 1865, Permalink: https://hdl.handle.net/2027/msu.31293015895208 (accessed 22.06.2018).

Erkanbald, Straßburger Bischofsliste, ed. Karl Strecker, Die lateinischen Dichter des deutschen Mittelalters (MGH Poetae latini V,1), Leipzig 1937.

Flodoard, Annales, ed. Philippe Lauer, Les Annales de Flodoard (Collection de textes pour servir à l'étude et à l'enseignement de l'histoire, 39), Paris 1905, URL: https://archive. org/details/lesannalesdeflod00floduoft (accessed 22.06.2018).

Flodoard, Historia Remensis Ecclesiae, ed. Martina Stratmann (MGH SS, 36), Hanover 1998, Permalink: http://www.mgh.de/dmgh/resolving/MGH_SS_36_S._II (accessed 22.06.2018).

Folcwin, Gesta Abbatum Sithiensium, ed. Oswald Holder-Egger (MGH SS, 13), Hanover 1881, 600-635, Permalink: http://www.mgh.de/dmgh/resolving/MGH_SS_13_S.600 (accessed 22.06.2018).

Formosus, Ad Anscherium Parisiensem Episcopum, ed. Giovanni Domenico Mansi (Sacrorum Conciliorum nova et amplissima collectio, 18), Venice 1773, col. 110, URL: http://www.documentacatholicaomnia.eu/20vs/200_Mansi/1692-1769,_Mansi_JD,_ Sacrorum_Conciliorum_Nova_Amplissima_Collectio_Vol_018_(1),_LT.pdf (accessed 22.06.2018).

Gallia Christiana in provincias ecclesiasticas distribute, ed. Denis de Sainte-Marthe, vol. 4, Paris 1728, URL: https://books.google.de/books?id=4ILPAwMbPw4C (accessed 22.06.2018).

Gallia Christiana in provincias ecclesiasticas distribute, ed. Denis de Sainte-Marthe, vol. 9, Paris 1751, URL: https://books.google.de/books?id=qHVHZg7itAEC (accessed 22.06.2018).

Gesta Berengarii imperatoris, ed. Ernst Dümmler, Halle 1871, Permalink: http://www.mdznbn-resolving.de/urn/resolver.pl?urn=urn:nbn:de:bvb:12-bsb11008497-5 (accessed 22.06.2018).

Gesta Episcoporum Cameracensium, ed. Ludwig Conrad Bethmann (MGH SS, 7), Hanover 1846, 393-489, Permalink: http://www.mgh.de/dmgh/resolving/MGH_SS_7_S._393 (accessed 22.06.2018).

Gesta Episcoporum Tullensium, ed. Georg Waitz (MGH SS, 8), Hanover 1848, 631-648, Permalink: http://www.mgh.de/dmgh/resolving/MGH_SS_8_S._631__(accessed 22.06.2018).

Gesta Pontificum Autissiodorenisum, ed. Guy Lobrichon, Pierre Bonnerue and Noëlle Deflou-Leca, Les gestes des éveques d'Auxerre (Les Classiques de l'Histoire de France au Moyen Âge, 42), vol. 1, Paris 2006.

Graf Ricfrid, ed. Karl Strecker, Grabschriften (MGH Poetae latini V,2), Leipzig 1937, N²6, 295-296.

Grand Cartulaire du chapitre Saint-Julien de Brioude. Essai de restitution, ed. Anne Baudot and Marcel Baudot (Mémoires de l'Académie des sciences, belles-lettres et arts de Clermont-Ferrand, 2, 35), Clermont-Ferrand 1935.

Hincmar of Reims, De ordine palatii, ed. Rudolf Schieffer and Thomas Gross (MGH Fontes iuris in usum scholarum, 3), Hanover 1980, Permalink: http://www.mgh.de/dmgh/ resolving/MGH_Fontes_iuris_3_S._2 (accessed 22.06.2018). 
Hincmar, Ad Carolum III. Imperatorem, ed. Jacques Paul Migne (Patrologia Latina, 125), Paris 1852, cols. 989-994, Permalink: https://gallica.bnf.fr/ark:/12148/bpt6k5504332f/ f495.image (accessed 22.06.2018).

Hincmar, Ad Ludovicum Baldum regem, ed. Jacques Paul Migne (Patrologia Latina, 125), Paris 1852, cols. 983-989, Permalink: https://gallica.bnf.fr/ark:/12148/bpt6k5504332f/ f492.item (accessed 22.06.2018).

Hincmar, Ad Ludovicum III regem, Balbi filium, ed. Jacques Paul Migne (Patrologia Latina, 126), Paris 1852, cols. 110-117, Permalink: https://gallica.bnf.fr/ark:/12148/ bpt6k54942649/f55.image (accessed 22.06.2018).

Histoire générale de Languedoc V, ed. Joseqh Vaissète and Claude de Vic, Toulouse 1875, Permalink: https://gallica.bnf.fr/ark:/12148/bpt6k298496c (accessed 22.06.2018).

Hludowici Iunioris et Hludowici Balbi conventio Furonensis, ed. Alfred Boretius and Victor Krause (MGH Capitularia regum Francorum, 2), Hanover 1897, Nº 246, 168-170, Permalink: http://www.mgh.de/dmgh/resolving/MGH_Capit._2_S._168 (accessed 22.06.2018).

Hludowici regis Arelatensis electio, ed. Alfred Boretius and Victor Krause (MGH Capitularia regum Francorum, 2), Hanover 1897, N 289, 376-378, Permalink: http:// www.mgh.de/dmgh/resolving/MGH_Capit._2_S._376 (accessed 22.06.2018).

Hugh of Flavigny, Series abbatum Flaviniacensium, ed. Georg Heinrich Pertz (MGH SS, 8), Hanover 1848, 502-503, Permalink: http://www.mgh.de/dmgh/resolving/MGH SS_8_S._502 (accessed 22.06.2018).

Karoli II. capitulare Papiense, ed. Alfred Boretius and Victor Krause (MGH Capitularia regum Francorum, 2), Hanover 1897, N²21, 100-104, Permalink: http://www.mgh.de/ dmgh/resolving/MGH_Capit._2_S._100 (accessed 22.06.2018).

Karoli II. imperatoris electio, ed. Alfred Boretius and Victor Krause (MGH Capitularia regum Francorum, 2), Hanover 1897, N 220, 98-100, Permalink: http://www.mgh.de/ dmgh/resolving/MGH_Capit._2_S._98 (accessed 22.06.2018).

Karoli III. capitula de Tungrensi episcopatu proposita, ed. Alfred Boretius and Victor Krause (MGH Capitularia regum Francorum, 2), Hanover 1897, $\mathrm{N}^{\circ}$ 290, 378-381. Reedited in: Die Konzilien Deutschlands und Reichsitaliens 916-1001, ed. Ernst-Dieter Hehl (MGH Conc., 6), Hanover 1987-2007, 44-48, Permalink: http://www.mgh.de/ dmgh/resolving/MGH_Conc._6,1_S._44 (accessed 22.06.2018).

Karolomanni capitula Compendii de rapinis promulgata, ed. Alfred Boretius and Victor Krause (MGH Capitularia regum Francorum, 2), Hanover 1897, $\mathrm{N}^{\circ}$ 286, 370-371, Permalink: http://www.mgh.de/dmgh/resolving/MGH_Capit._2_S._370 (accessed 22.06.2018).

Karolomanni capitulare Vernense, ed. Alfred Boretius and Victor Krause (MGH Capitularia regum Francorum, 2), Hanover 1897, N²87, 371-375, Permalink: http://www.mgh.de/ dmgh/resolving/MGH_Capit._2_S._371 (accessed 22.06.2018).

Karolomanni conventus Carisiacensis, ed. Alfred Boretius and Victor Krause (MGH Capitularia regum Francorum, 2), Hanover 1897, No 285, 369-370, Permalink: http:// www.mgh.de/dmgh/resolving/MGH_Capit._2_S._369 (accessed 22.06.2018).

La Chronique de Nantes (570 environ-1049), ed. René Merlet (Collection de textes pour servir à l'étude et à l'enseignement de l'histoire, 19), Paris 1896, Permalink: https:// gallica.bnf.fr/ark:/12148/bpt6k55624v/fl.image.texteImage (accessed 22.06.2018).

Les Annales de l'abbaye Saint-Pierre de Jumièges, Chronique universelle des origines au XIIIe siècle, ed. Jean Laporte, Saint-Wandrille 1954.

Les plus anciens documents originaux de l'abbaye de Cluny, ed. Hartmut Atsma, Sébastien Barret and Jean Vézin (Monumenta palaeographica medii aevi, Series Gallica), vol. 1, Turnhout 1997. 
Letter from Robert of Neustria and dux Manasses to Richard the Justiciar, ed. Henri Omont, Auguste Molinier, Camille Couderc and Ernest Coyecque (Catalogue général des manuscrits des bibliothèques publiques de France, XI), Chartres/Paris 1900, 48, URL: https://archive.org/stream/cataloguegnrllfranuoft\#page/48/mode/2up (accessed 22.06.2018).

Liber memorialis Romaricensis, ed. Eduard Hlawitschka, Karl Schmid and Gerd Tellenbach (MGH Libri memoriales, 1), 2 vols., Dublin 1970, Permalink; http://www.mgh.de/dmgh/ resolving/MGH_Libri_mem._1:1_S._II (accessed 22.06.2018).

Mainzer Urkundenbuch, ed. Manfred Stimming and Peter Acht, 2 vols., Darmstadt 1932-1971.

Obituaires de la province ecclésiastique de Sens, ed. Auguste Molinier (Recueil des historiens de la France. Obituaires, 1), vol. 1, Paris 1902, Permalink: https://gallica.bnf. fr/ark:/12148/bpt6k59033.image (accessed 22.06.2018).

Odo of Cluny, Vita Sancti Geraldi Auriliacensis, ed. Anne-Marie Bultot-Verleysen (Subsidia hagiographica, 89), Bruxelles 2009.

Ordo für die Krönung der Königin, im Ottonischen Pontifikale auch für die Kaiserin bestimmt (westfränkisch, um 900), ed. Reinhard Elze, Die Ordines für die Weihe und Krönung des Kaisers und der Kaiserin (MGH Font. Iur. Germ., 9), Hanover 1960, $\mathrm{N}^{\circ}$ 3, 3-9, Permalink: http://www.mgh.de/dmgh/resolving/MGH_Fontes_iuris_9_S._3 (accessed 22.06.2018).

Pactiones Aquenses, ed. Alfred Boretius and Victor Krause (MGH Capitularia regum Francorum, 2), Hanover 1897, N 250, 191-192, Permalink: http://www.mgh.de/dmgh/ resolving/MGH_Capit._2_S._191 (accessed 22.06.2018).

Pactum cum Karolo rege Franciae Occidentalis, ed. Ludwig Weiland (MGH Constitutiones et acta publica imperatorum et regum, 1), Hanover 1893, $\mathrm{N}^{\circ} 1,1-2$, Permalink: http:// www.mgh.de/dmgh/resolving/MGH_Const._1_S._1 (accessed 22.06.2018).

Papsturkunden I: 896-996, ed. Harald Zimmermann, 2nd ed.,Vienna 1988.

Raoul de Cambrai, Chanson de geste du XIIe siècle, ed. Sarah Kay, Paris 1999.

Recueil des actes d'Eudes, roi de France, 888-898, ed. Robert-Henri Bautier (Chartes et diplômes relatifs à l'histoire de France), Paris 1967.

Recueil des actes de Charles II le Chauve, ed. Georges Tessier (Chartes et diplômes relatifs à l' histoire de France), 3 vols., Paris 1943-1955.

Recueil des actes de Charles III le Simple, ed. Philippe Lauer (Chartes et diplômes relatifs à l'histoire de France), Paris 1940-1949.

Recueil des actes de Louis II le Bègue, Louis III et Carloman II, Rois de France (877-884), ed. Felix Grat, Jacques de Font-Réaulx, Georges Tessier and Robert-Henri Bautier (Chartes et diplômes relatifs à l'histoire de France), Paris 1978.

Recueil des actes de Louis IV roi de France (936-954), ed. Philippe Lauer (Chartes et diplômes relatifs à l' histoire de France), Paris 1914.

Recueil des actes de Pépin Ier et de Pépin II rois d'Aquitaine (814-848), ed. Léon Levillain (Chartes et diplômes relatifs à l'histoire de France), Paris 1926.

Recueil des actes de Robert Ier et de Raoul (922-936), ed. Jean Dufour (Chartes et diplômes relatifs à l' histoire de France), Paris 1978.

Recueil des actes des ducs de Normandie de 911 à 1066, ed. Marie Fauroux (Mémoires de la Société des antiquaires de Normandie, 36), Caen 1961.

Recueil des actes des rois de Provence (855-928), ed. René Poupardin (Chartes et diplômes relatifs à l' histoire de France), Paris 1920. 
Recueil des actes du prieuré de Saint-Symphorien d'Autun de 696 à 1300, ed. André Déléage, Autun 1936.

Recueil des chartes de l'abbaye de Cluny, ed. Auguste Bernard and Alexandre Bruel, 6 vols., Paris 1876-1903, Permalink: https://gallica.bnf.fr/ark:/12148/bpt6k28908j (accessed 22.06.2018).

Recueil des chartes de l'abbaye de Saint-Benoît-sur-Loire, ed. Maurice Prou and Alexandre Vidier (Documents publiés par la société historique et archéologique du Gatinais, 5), 2 vols., Paris 1900-1907, Permalink: https://gallica.bnf.fr/ark:/12148/bpt6k112307j/f106. image.texteImage (accessed 22.06.2018).

Recueil des chartes de l'abbaye de Stavelot-Malmédy, ed. Joseph Halkin and Charles G. Roland (Commission royale d'histoire, Publications in-quarto, 36, 1-2), 2 vols., Bruxelles 1909-1930.

Regino of Prüm, Chronicon, ed. Friedrich Kurze, Reginonis Abbatis Prumiensis Chronicon cum Continuatione Treverensi (MGH SS rer. Germ., 50), Hanover 1890, 1-153, Permalink: http://www.mgh.de/dmgh/resolving/MGH_SS_rer._Germ._50_S._II (accessed 22.06.2018).

Registrum Iohannis VIII. papae, ed. Erich Caspar, in: Epistolae Karolini Aevi 5 (MGH Epistolae, 7), Berlin 1927, 1-272.

Richer of Reims, Historiae, ed. Hartmut Hoffmann, Richeri Historiarum Libri IIII (MGH SS, 38), Hanover 2000, Permalink: http://www.mgh.de/dmgh/resolving/MGH SS_38_S._II (accessed 22.06.2018).

Roserot, Alphonse, Chartes inédites des IXe et Xe siècles appartenant aux archives de la Haute-Marne (851-978), in: Bulletin de la Société des Sciences historiques et naturelles de l'Yonne 51 (1897), 161-209.

Series abbatum s. Amandi Elnonensis, ed. Georg Waitz (MGH SS, 13), Hanover 1881, 386, Permalink: http://www.mgh.de/dmgh/resolving/MGH_SS_13_S._386 (accessed 22.06.2018).

Sermo in tumulatione SS. Quintini, Victorici, Cassiani, ed. Oswald Holder-Egger (MGH SS, 15,1), Hanover 1887, 271-273, Permalink: http://www.mgh.de/dmgh/resolving/ MGH_SS_15,1_S._271 (accessed 22.06.2018).

The Anglo-Saxon Chronicle MS A, ed. Janet Bately, in: The Anglo-Saxon Chronicle. A collaborative edition, vol. 3, ed. David Dumville and Simon Keynes, Cambridge 1986.

The Cartulary of Flavigny, 717-1113, ed. Constance B. Bouchard, Cambridge 1992.

Thietmar of Merseburg, Chronicon, ed. Robert Holtzmann, Die Chronik des Bischofs Thietmar von Merseburg und ihre Korveier Überarbeitung (MGH SS rer. Germ. N.S., 9), Berlin 1935, Permalink: http://www.mgh.de/dmgh/resolving/MGH_SS_rer._ Germ._N._S._9_S._II (accessed 22.06.2018).

Translatio S. Baudelii, ed. Léopold Delisle (Recueil des historiens des Gaules et de la France, 9), Paris 1874, 111-112, Permalink: https://gallica.bnf.fr/ark:/12148/bpt6k501279/ f256.image (accessed 22.06.2018).

Translatio S. Mederici, ed. Léopold Delisle (Recueil des historiens des Gaules et de la France, 9), Paris 1874, 110-111, Permalink: https://gallica.bnf.fr/ark:/12148/bpt6k501279/ f255.image (accessed 22.06.2018).

Urkundenbuch zur Geschichte der jetzt die Preussischen Regierungsbezirke Coblenz und Trier bildenden mittelrheinischen Territorien I: Von den ältesten Zeiten bis zum Jahre 1169, ed. Heinrich Beyer and Leopold von Eltester, Coblenz 1860, Permalink: http:// nbn-resolving.org/urn:nbn:de:bvb:12-bsb10012604-6 (accessed 13.11.2018). 
Visio Karoli III., ed. Georg Waitz (MGH SS, 10), Hanover 1852, 458, Permalink: http://www. mgh.de/dmgh/resolving/MGH_SS_10_S._458 (accessed 22.06.2018).

Vita Gerardi abbatis Broniensis, ed. Lothar von Heinemann (MGH SS, 15, 2), Hanover 1888, 654-673, Permalink: http://www.mgh.de/dmgh/resolving/MGH_SS_15,2_S._654 (accessed 22.06.2018).

Vita S. Mederici Abbatis Aeduensis, ed. Jean Mabillon (Acta Sanctorum Ordinis Sancti Benedicti in saeculorum classes distributa, 3,1), Paris 1672, 8-15, URL: https://books. google.fr/books?id=4319GGiT54oC (accessed 22.06.2018).

Vita Sancti Theodardi sive Audardo, Archiepiscopo Narbonensi in Gallia, ed. Société des Bollandistes, Acta Sanctorum Maii, vol. 1, Antwerp 1680, 141-156, Permalink: https:// gallica.bnf.fr/ark:/12148/bpt6k6036w/f267.item (accessed 25.09.2018).

Widukind, Rerum Gestarum Saxonicarum Libri Tres, ed. Paul Hirsch and Hans Eberhard Lohmann (MGH SS rer. Germ., 60), Hanover 1935, Permalink: http://www.mgh.de/ dmgh/resolving/MGH_SS_rer._Germ._60_S._II (accessed 22.06.2018).

Witger, Genealogia Arnulfi Comitis, ed. Ludwig Conrad Bethmann (MGH SS, 9), Hanover 1851, 302-304, Permalink: http://www.mgh.de/dmgh/resolving/MGH_SS_9_S._302 (accessed 22.06.2018).

\section{Secondary Sources}

Abadal i de Vinyals, Ramón d', Els primers comtes Catalans, Barcelona 1958.

Abels, Richard P., Paying the Danegeld. Anglo-Saxon peacemaking with Vikings, in: Philip De Souza and John France (eds.), War and peace in ancient and medieval history, Cambridge 2008, 173-192.

Adam, Hildegard, Das Zollwesen im fränkischen Reich und das spätkarolingische Wirtschaftsleben. Ein Überblick über Zoll, Handel und Verkehr im 9. Jahrhundert (Vierteljahrschrift für Sozial- und Wirtschaftsgeschichte. Beihefte, 126), Stuttgart 1996.

Airlie, Stuart, Bonds of power and bonds of association in the court circle of Louis the Pious, in: Peter Godman and Roger Collins (eds.), Charlemagne's heir. New perspectives on the reign of Louis the Pious (814-840), Oxford 1990, 191-204. Reprinted in: Stuart Airlie, Power and its problems in Carolingian Europe (Variorum Collected Studies Series, 1010), Farnham 2012, part VI, 191-204.

Airlie, Stuart, 'Semper fideles'? Loyauté envers les Carolingiens comme constituant de l'identité aristocratique, in: Régine Le Jan (ed.), La royauté et les élites dans l'Europe carolingienne (début IXe siècle aux environs de 920) (Collection Histoire et littérature régionales, 17), Villeneuve d'Ascq 1998, 129-143. Reprinted in: Stuart Airlie, Power and its problems in Carolingian Europe (Variorum Collected Studies Series, 1010), Farnham 2012, part VIII, 129-143.

Airlie, Stuart, The nearly men. Boso of Vienne and Arnulf of Bavaria, in: Anne J. Duggan (ed.), Nobles and nobility in medieval Europe. Concepts, origins, transformations, Woodbridge 2000, 25-41. Reprinted in: Stuart Airlie, Power and its problems in Carolingian Europe (Variorum Collected Studies Series, 1010), Farnham 2012, part XI, 1-19.

Airlie, Stuart, The palace of memory. The Carolingian court as political centre, in: Sarah R. Jones, Richard B. Marks and others (eds.), Courts and regions in medieval Europe, Woodbridge 2000,1-20. Reprinted in: Stuart Airlie, Power and its problems in Carolingian Europe (Variorum Collected Studies Series, 1010), Farnham 2012, part VII, 1-23. 
Airlie, Stuart, Les élites en 888 et après, ou comment pense-t-on la crise carolingienne? In: François Bougard, Laurent Feller and Régine Le Jan (eds.), Les élites au haut Moyen Âge. Crises et renouvellements (Collection Haut Moyen Âge, 1), Turnhout 2006, 425-437.

Althoff, Gerd, Adels- und Königsfamilien im Spiegel ihrer Memorialüberlieferung. Studien zum Totengedenken der Billunger und Ottonen (Münstersche MittelalterSchriften, 47), Munich 1984.

Althoff, Gerd, Der Corveyer Konvent im Kontakt mit weltlichen und geistlichen Herrschaftsträgern des 9. und 10. Jahrhunderts, in: Karl Schmid (ed.), Der Liber Vitae der Abtei Corvey (Veröffentlichungen der Historischen Kommission für Westfalen, 40/2,2), Münster 1989, part II, 29-38.

Althoff, Gerd, Königsherrschaft und Konfliktbewältigung im 10. und 11. Jahrhundert, in: Frühmittelalterliche Studien 23 (1989), 265-290.

Althoff, Gerd, Colloquium familiare - Colloquium secretum - Colloquium publicum. Beratung im politischen Leben des früheren Mittelalters, in: Frühmittelalterliche Studien 24 (1990), 145-167.

Althoff, Gerd, Verwandte, Freunde und Getreue. Zum politischen Stellenwert der Gruppenbindungen im früheren Mittelalter, Darmstadt 1990.

Althoff, Gerd, Amicitiae und Pacta. Bündnis, Einigung, Politik und Gebetsgedenken im beginnenden 10. Jahrhundert (Schriften der MGH, 37), Hanover 1992.

Althoff, Gerd, Probleme um die dos der Königinnen in 10. und 11. Jahrhundert, in: Michel Parisse (ed.), Veuves et veuvages dans le haut Moyen-Age. Table ronde organisée à Göttingen par la Mission Historique Française en Allemagne, Paris 1993, 123-132.

Althoff, Gerd, Zur Einführung, in: Gerd Althoff (ed.), Formen und Funktionen öffentlicher Kommunikation im Mittelalter (Vorträge und Forschungen, 51), Stuttgart 2001, 7-9.

Althoff, Gerd, Die Macht der Rituale. Symbolik und Herrschaft im Mittelalter, 2nd ed., Darmstadt 2013.

Althoff, Gerd, Spielregeln der Politik im Mittelalter. Kommunikation in Frieden und Fehde, 2nd ed., Darmstadt 2014.

Althoff, Gerd, Verwandtschaft, Freundschaft, Klientel. Der schwierige Weg zum Ohr des Herrschers, in: Gerd Althoff (ed.), Spielregeln der Politik im Mittelalter. Kommunikation in Frieden und Fehde, 2nd ed., Darmstadt 2014, 185-198.

Althoff, Gerd, Kontrolle der Macht. Formen und Regeln politischer Beratung im Mittelalter, Darmstadt 2016.

Anton, Hans Hubert, Synoden, Teilreichsepiskopat und die Herausbildung Lotharingiens (859-870), in: Hans Hubert Anton and Burkhard Apsner (eds.), Königtum, Kirche, Adel. Institutionen, Ideen, Räume von der Spätantike bis zum hohen Mittelalter, Trier 2002, 421-468.

Apsner, Burkhard, Vertrag und Konsens im früheren Mittelalter. Studien zur Gesellschaftsprogrammatik und Staatlichkeit im westfränkischen Reich (Trierer historische Forschungen, 58), Trier 2006.

Auge, Oliver, Handlungsspielräume fürstlicher Politik im Mittelalter. Der südliche Ostseeraum von der Mitte des 12. Jahrhunderts bis in die frühe Reformationszeit (Mittelalter-Forschungen, 28), Ostfildern 2009.

Auzias, Léonce, L’Aquitaine carolingienne. 778-987, Paris 1938.

Baccou, Philippe, Les débuts de Robert le Fort. Une chronologie à réviser? In: Francia. Forschungen zur westeuropäischen Geschichte 36 (2009), 265-276, DOI: https://doi. org/10.11588/fr.2009.0.44948 (accessed 22.06.2018). 
Barbier, Josiane, Palatium, fiscus, saltus. Recherches sur le fisc entre Loire et Meuse du VIe au Xe siècle, Paris 1994 (unpublished $\mathrm{PhD}$ thesis).

Barbier, Josiane, Le fisc du royaume franc. Quelques jalons pour une reflexion sur l'État au haut Moyen Âge, in: Walter Pohl and Veronika Wieser (eds.), Der frühmittelalterliche Staat. Europäische Perspektiven (Forschungen zur Geschichte des Mittelalters, 16), Vienna 2009, 271-286.

Barbier, Josiane and Laurent Morelle, De la séduction des actes aberrants. Autour du dernier diplôme de Charles le Simple (Compiègne, 29 juillet 923), in: Laurent Jégou, Sylvie Joye, Thomas Lienhard and Jens Schneider (eds.), Faire lien. Aristocratie, réseaux et échanges compétitifs. Mélanges en l'honneur de Régine Le Jan, Paris 2015, 325-342.

Barral Altet, Xavier and Claudie Duhamel-Amado (eds.), Saint-Guilhem-le-Désert dans l'Europe du haut Moyen Âge. Actes de la table ronde d'août 1998, Montpellier 2000, 75-82.

Barth, Rüdiger E., Der Herzog in Lotharingien im 10. Jahrhundert, Sigmaringen 1990.

Barton, Richard E., Power and lordship in Maine (c. 890-1110), Santa Barbara 1997 (unpublished $\mathrm{PhD}$ thesis).

Bates, David, Normandy before 1066, London 1982.

Baudot, Marcel, L'abbaye de la Croix-Saint-Ouen à l'époque carolingienne, d'après le témoignage d'un diplôme de Carloman II, in: Bibliothèque de l'École des Chartes 141 (1983), 5-21.

Bauduin, Pierre, La première Normandie (Xe-XIe siècles). Sur les frontières de la haute Normandie. Identité et construction d'une principauté, Caen 2004.

Bauduin, Pierre (ed.), Les fondations scandinaves en Occident et les débuts du duché de Normandie. Actes du colloque de Cerisy-la-Salle (25-29 septembre 2002), Caen 2005.

Bauduin, Pierre, Chefs normands et élites franques fin IXe-début Xe siècle, in: Pierre Bauduin (ed.), Les fondations scandinaves en Occident et les débuts du duché de Normandie. Actes du colloque de Cerisy-la-Salle (25-29 septembre 2002), Caen 2005, 181-194.

Bauduin, Pierre, Autour d'un rituel discuté. Le baisement du pied de Charles le Simple au moment du traité de Saint-Clair-sur-Epte, in: Elisabeth Lalou, Bruno Lepeuple and Jean-Louis Roch (eds.), Des châteaux et des sources. Archéologie et histoire dans la Normandie médiévale. Mélanges en l'honneure d'Anne-Marie Flambard Héricher, Mont-Saint-Aignan 2008, 29-47.

Bauduin, Pierre, Le monde franc et les Vikings. VIIIe-Xe siècle, Paris 2009.

Bauer, Thomas, Lotharingien als historischer Raum. Raumbildung und Raumbewußtsein im Mittelalter (Rheinisches Archiv, 136), Cologne 1997.

Bautier, Robert-Henri, La prétendue dissidence de l'épiscopat catalan et le faux concile de Portus, in: Bulletin philologique et historique (1961), 477-498. Reprinted in: RobertHenri Bautier (ed.), Recherches sur l'histoire de la France médiévale. Des Mérovingiens aux premiers Capétiens (Variorum Collected Studies Series, 351), Aldershot 1991, part VI, 477-498.

Bautier, Robert-Henri, Le règne d'Eudes (888-898) à la lumière des diplômes expédiés par sa chancellerie, in: Comptes rendus. Académie des Inscriptions et Belles-Lettres 2 (1961), 140-157.

Bautier, Robert-Henri, Aux origines du royaume de Provence. De la sédition avortée de Boson à la royauté légitime de Louis, in: Provence historique 23 (1973), 41-68. Reprinted in: Robert-Henri Bautier (ed.), Recherches sur l'histoire de la France médiévale. 
Des Mérovingiens aux premiers Capétiens (Variorum Collected Studies Series, 351), Aldershot 1991, part V, 41-68.

Bautier, Robert-Henri, La chancellerie et les actes royaux dans les royaumes carolingiens, in: Bibliothèque de l'École des Chartes 142 (1984), 5-80.

Bautier, Robert-Henri, Les diplômes royaux carolingiens pour l'église de Langres et l'origine des droits comtaux de l'évêque, in: Les cahiers haut-marnais 167 (1986), 145-177.

Bautier, Robert-Henri, Les itinéraires des souverains et les palais royaux en "France occidentale" de 877 à 936, in: Annie Renoux (ed.), Palais royaux et princiers a moyen âge. Actes du colloque international tenu au Mans les 6-7 et 8 octobre 1994, Le Mans 1996, 99-110.

Becher, Matthias, Von den Karolingern zu den Ottonen. Die Königserhebungen von 911 und 919 als Marksteine des Dynastiewechsels im Ostfrankenreich, in: Hans-Werner Goetz and Simon Elling (eds.), Konrad I. - Auf dem Weg zum Deutschen Reich? Bochum 2006, 245-264.

Becher, Matthias, Arnulf von Kärnten. Name und Abstammung eines (illegitimen?) Karolingers, in: Uwe Ludwig and Thomas Schilp (eds.), Nomen et Fraternitas. Festschrift für Dieter Geuenich zum 65. Geburtstag (Ergänzungsbände zum Reallexikon der Germanischen Altertumskunde, 62), Berlin and New York 2008, 665-682.

Becher, Matthias, Dynastie, Thronfolge und Staatsverständnis im Frankenreich, in: Walter Pohl and Veronika Wieser (eds.), Der frühmittelalterliche Staat. Europäische Perspektiven (Forschungen zur Geschichte des Mittelalters, 16), Vienna 2009, 183-200.

Becher, Matthias, Gedanken zur Einführung, in: Matthias Becher and Alheydis Plassmann (eds.), Streit am Hof im frühen Mittelalter (Super alta perennis. Studien zur Wirkung der Klassischen Antike, 11), Göttingen 2011, 9-16.

Bedos-Rezak, Brigitte M., Ritual in the royal chancery. Text, image, and the representation of kingship in medieval French diplomas (700-1200), in: Heinz Duchhardt, Richard A. Jackson and David J. Sturdy (eds.), European monarchy. Its evolution and practise from Roman Antiquity to modern times, Stuttgart 1992, 27-40.

Benner, Sonja, Châlons-en-Champagne. Die Stadt, das Chorherrenstift Toussaint und das Umland bis zur Mitte des 14. Jahrhunderts (Trierer historische Forschungen, 55), Trier 2003.

Benson, Robert L., The Gelasian doctrine. Uses and transformations, in: George Makdisi, Dominique Sourdel and Janine Sourdel-Thomine (eds.), La Notion d'autorité au Moyen Âge. Islam, Byzance, Occident. Colloques internationaux de La Napoule, session des 23-26 octobre 1978, Paris 1982, 13-44.

Besteman, Jan, Danish rule in west Frisia. A failed Normandy in the 9th century, in: Guido Helmig, Barbara Scholkman and Matthias Untermann (eds.), Centre - region periphery. Medieval Europe Basel 2002. 3rd international conference of medieval and later archaeology, vol. 1, Hertingen 2002, 446-452.

Beumann, Helmut, König Zwentibolds Kurswechsel im Jahre 898, in: Rheinische Vierteljahrsblätter 31 (1966/67), 17-41. Reprinted in: Helmut Beumann, Jürgen Petersohn and Roderich Schmidt (eds.), Ausgewählte Aufsätze aus den Jahren 1966-1986. Festgabe zu seinem 75. Geburtstag, Sigmaringen 1987, 429-453.

Beyer, Hartmut, Urkundenübergabe am Altar. Zur liturgischen Dimension des Beurkundungsaktes bei Schenkungen der Ottonen und Salier an Kirchen, in: Frühmittelalterliche Studien 38 (2004), 323-346. 
Bill, Jan, Navires et navigation en Occident à l'époque viking, in: Anne-Marie Flambard Héricher (ed.), La progression des Vikings, des raids à la colonisation (Publications de l'Université de Rouen, 334/Cahiers du GRHIS, 14), Mont-Saint-Aignan 2003, 27-56.

Boehm, Laetitia, Rechtsformen und Rechtstitel der burgundischen Königserhebungen im 9. Jahrhundert. Zur Krise der karolingischen Dynastie, in: Historisches Jahrbuch 80 (1960), 1-57. Reprinted in: Eduard Hlawitschka (ed.), Königswahl und Thronfolge in fränkisch-karolingischer Zeit (Wege der Forschung, 247), Darmstadt 1975, 325-398.

Bonenfant, Paul, Aux origines de Malines, in: Dancwerc. Opstellen aangeboden aan Prof. Dr. D. Th. Enklaar ter gelegenheid van zijn 65. verjaardag, Groningen 1959, 96-108.

Boshof, Egon, Lotharingien-Lothringen. Vom Teilreich zum Herzogtum, in: Alfred Heit, Günter Birtsch and Alfred Haverkamp (eds.), Zwischen Gallia und Germania, Frankreich und Deutschland. Konstanz und Wandel raumbestimmender Kräfte. Vorträge auf dem 36. Deutschen Historikertag, Trier, 8.-12. Oktober 1986 (Trierer historische Forschungen, 12), Trier 1987, 129-153.

Bouchard, Constance B., Patterns of women's names in royal lineages, ninth-eleventh centuries, in: Medieval prosopography 9, 1 (1988), 1-32.

Bouchard, Constance B., The Bosonids or rising to power in the late Carolingian Age, in: French Historical Studies 15 (1988), 407-431.

Bouchard, Constance B., "Those of my blood". Constructing noble families in medieval Francia (The middle ages series), Philadelphia 2001.

Bouet, Pierre, Les négociations du traité de Saint-Clair-sur-Epte selon Dudon de SaintQuentin, in: Anne-Marie Flambard Héricher (ed.), La progression des Vikings, des raids à la colonisation (Cahiers du GRHIS, 14), Mont-Saint-Aignan 2003, 83-104.

Bouet, Pierre, La Normandie médiévale. Hasting. Le Viking pervers selon Dudon de SaintQuentin, in: Annales de Normandie 62, 2 (2012), 215-234.

Bougard, François, Geneviève Bührer-Thierry and Régine Le Jan, Les élites du haut Moyen Âge. Identités, stratégies, mobilité, in: Annales 4 (2013), 1079-1112.

Bougard, François, La justice dans le royaume d'Italie de la fin du VIIIe siècle au début du XIe siècle (Bibliothèque des Écoles Françaises d'Athènes et de Rome, 291), Rome 1995.

Bougard, François, La justice dans le royaume d'Italie aux IXe-Xe siècles, in: La giustizia nell'alto medioevo, secoli IX-XI (Settimane di studio del Centro italiano di studi sull'alto medioevo, 44), Spoleto 1997, 133-176.

Bougard, François, Laurent Feller and Régine Le Jan (eds.), Les élites au haut Moyen Âge. Crises et renouvellements (Collection Haut Moyen Âge, 1), Turnhout 2006.

Bourgeois, Émile, Le capitulaire de Kiersy-sur-Oise (877). Étude sur l'état et le régime politique de la société carolingienne à la fin du IXe siècle d'après la législation de Charles le Chauve, Paris 1885 (reprinted Geneva 1974).

Brandenburg, Erich, Die Nachkommen Karls des Grossen I.-XIV. Generation, Leipzig 1935.

Bruand, Olivier, De la Francie à la France. Les pouvoir supérieurs. Rois et princes, XeXIe siècle, in: Geneviève Bührer-Thierry and Thomas Deswarte (eds.), Pouvoirs, Église et société dans les royaumes de France, de Bourgogne et de Germanie de 888 aux premières années du XIIe siècle, Paris 2008, 21-28.

Brühl, Carlrichard, Hinkmariana II, in: Deutsches Archiv für Erforschung des Mittelalters 20 (1964), 55-77, Permalink: http://resolver.sub.uni-goettingen.de/purl?PPN345858735_0020 (accessed 22.06.2018).

Brühl, Carlrichard, Fodrum, Gistum, Servitium regis. Studien zu den wirtschaftlichen Grundlagen des Königtums im Frankenreich und in den fränkischen Nachfolgestaaten 
Deutschland, Frankreich und Italien vom 6. bis zur Mitte des 14. Jahrhunderts (Kölner historische Abhandlungen, 14), Cologne 1968.

Brühl, Carlrichard, Eine Fälschung auf den Namen Karls des Einfältigen für das Nonnenkloster St-Andoche zu Autun, in: Historisches Jahrbuch 91 (1971), 384-393.

Brühl, Carlrichard, Karolingische Miszellen, in: Deutsches Archiv für Erforschung des Mittelalters 44 (1988), 355-389, Permalink: http://resolver.sub.uni-goettingen.de/ purl?PPN345858735_0044 (accessed 22.06.2018). Reprinted in: Carlrichard Brühl, Aus Mittelalter und Diplomatik. Gesammelte Aufsätze, vol. 3, Hildesheim 1997, 33-53.

Brühl, Carlrichard, Deutschland-Frankreich. Die Geburt zweier Völker, 2nd ed., Cologne and Vienna 1995.

Brunner, Karl, Die fränkischen Fürstentitel im neunten und zehnten Jahrhundert, in: Herwig Wolfram (ed.), Intitulatio II. Lateinische Herrscher- und Fürstentitel im 9. und 10. Jahrhundert (Mitteilungen des Instituts für Österreichische Geschichtsforschung. Ergänzungsband, 24), Vienna 1973.

Brunner, Karl: Oppositionelle Gruppen im Karolingerreich (Veröffentlichungen des Instituts für Österreichische Geschichtsforschung, 25), Cologne and Vienna 1979.

Brunterc'h, Jean-Pierre, Archives de la France I (Ve-XIe siècle), Paris 1994.

Brunterc' h, Jean-Pierre, Naissance et affirmation des principautés au temps du roi Eudes. L'exemple d'Aquitaine, in: Olivier Guillot and Robert Favreau (eds.), Pays de Loire et Aquitaine de Robert le Fort aux premiers Capétiens. Actes du colloque scientifique international tenu à Angers en septembre 1987, Poitiers 1997, 69-116.

Buc, Philipp, Review of Althoff, Gerd, Die Macht der Rituale. Symbolik und Herrschaft im Mittelalter, Darmstadt 2003, in: Cahiers civilisation médiévale 48 (2003), 251-253.

Buc, Philipp, Die Krise des Reiches unter Heinrich IV., mit und ohne Spielregeln. "Par malvais roi est mains frans hom honnis" (Raoul de Cambrai, v. 650), in: Claudia Garnier and Hermann Kamp (eds.), Spielregeln der Mächtigen. Mittelalterliche Politik zwischen Gewohnheit und Konvention, Darmstadt 2010, 61-94.

Bühler, Arnold, Wort und Schrift im karolingischen Recht, in: Archiv für Kulturgeschichte 72 (1990), 275-296.

Bührer-Thierry, Geneviève, Le conseiller du roi. Les écrivains carolingiens et la traduction biblique, in: Médiévales 12 (1987), 11-23.

Bührer-Thierry, Geneviève, Évêques et pouvoir dans le royaume de Germanie. Les Églises de Bavière et de Souabe 876-973, Paris 1997.

Bührer-Thierry, Geneviève, L'épiscopat en Francie orientale et occidentale à la fin de IXe siècle. Substitut ou soutien du pouvoir royal? In: Régine Le Jan (ed.), La royauté et les élites dans l'Europe carolingienne (début IXe siècle aux environs de 920) (Collection Histoire et littérature régionales, 17), Villeneuve d'Ascq 1998, 347-364.

Bührer-Thierry, Geneviève, Épiscopat et royauté dans le monde carolingien, in: Wojciech Falkowski and Yves Sassier (eds.), Le monde carolingien. Bilan, perspectives, champs de recherches. Actes du colloque international de Poitiers, Centre d'Études supérieures de Civilisation médiévale, 18-20 novembre 2004 (Culture et société médiévales, 18), Turnhout 2009, 143-156.

Bulliot, Jacques-Gabriel, Essai historique sur l'abbaye de Saint-Martin d'Autun de l'Ordre de Saint-Benoît, 2 vols., Autun 1849.

Bund, Konrad, Thronsturz und Herrscherabsetzung im Frühmittelalter (Bonner historische Forschungen, 44), Bonn 1979.

Bur, Michel, La formation du comté de Champagne, v. 950-v. 1150 (Annales de l'Est. Mémoires, 54), Nancy 1977. 
Bur, Michel, Remarques sur la formation des principautés en France (IXe-XIIIe siècles), in: Centralismo y descentralización. Modelos y procesos históricos en Francia y España. Coloquio Franco-Español Madrid, 10-14 octubre 1984, Madrid 1985, 215-232. Reprinted in: Michel Bur, La Champagne médiévale. Recueil d'articles, Langres 2005, $27-44$.

Burt, Ronald S. and Marc Kneez, Kinds of third-party effects on trust, in: Rationality and Society 7/3 (1995), 255-292.

Büttner, Heinrich, Geschichte des Elsaß I. Politische Geschichte des Landes von der Landnahmezeit bis zum Tode Ottos III. (Neue deutsche Forschungen. Abteilung Mittelalterliche Geschichte, 8), Berlin 1939.

Büttner, Heinrich, Heinrichs I. Südwest- und Westpolitik (Vorträge und Forschungen. Sonderband, 2), Konstanz and Stuttgart 1964.

Caille, Jacqueline, Vicomtes et vicomtés de Narbonne des origines au début du XIIIe siècle, in: Hélène Débax (ed.), Vicomtes et vicomtés dans l'Occident médiéval, Toulouse 2008, 47-60.

Castelnuovo, Guido, Les élites des royaumes de Bourgogne, milieu IXe-milieu Xe siècle, in: Régine Le Jan (ed.), La royauté et les élites dans l'Europe carolingienne (début IXe siècle aux environs de 920) (Collection Histoire et littérature régionales, 17), Villeneuve d'Ascq 1998, 383-408.

Charrier, Jean Bernard, Madeleine Chabrolin and Bernard Stainmesse, Histoire de Nevers I. Des origines au début du XIXe siècle, Le Coteau 1984.

Chastang, Pierre, Lire, écrire, transcrire. Le travail des rédacteurs de cartulaires en BasLanguedoc (XIe-XIIIe siècles) (CTHS histoire, 2), Paris 2001.

Chaume, Maurice, Les origines du Duché de Bourgogne. Partie I. Histoire politique, Dijon 1925 (reprint Aalen 1977).

Christiansen, Eric, Dudo of St Quentin. History of the Normans. Translation with introduction and notes, Woodbridge 1998.

Collins, Roger, Pippin I and the Kingdom of Aquitaine, in: Peter Godman and Roger Collins (eds.), Charlemagne's heir. New perspectives on the reign of Louis the Pious (814-840), Oxford 1990, 363-389. Reprinted in: Roger Collins, Law, culture and regionalism in early medieval Spain, Aldershot 1992, part XII, 363-389.

Cook, Karen S. and Alexandra Gerbasi, Trust, in: Peter Hedstrom and Peter Bearman (eds.), The Oxford Handbook of Analytical Sociology, Oxford 2009, 218-243.

Coupland, Simon, The fortified bridges of Charles the Bald, in: Journal of medieval history 17 (1991), 1-12.

Coupland, Simon, The Vikings in Francia and Anglo-Saxon England to 911, in: Rosamond McKitterick (ed.), The new Cambridge medieval history, vol. 2, Cambridge 1995, 190-201.

Coupland, Simon, From poachers to gamekeepers. Scandinavian warlords and Carolingian kings, in: Early medieval Europe 7 (1998), 85-114. Reprinted in: Simon Coupland, Carolingian coinage and the Vikings. Studies on power and trade in the 9th century, Ashgate 2007, part XII, 85-114.

Coupland, Simon, The Frankish tribute payments to the Vikings and their consequences, in: Francia. Forschungen zur westeuropäischen Geschichte 26/1 (1999), 57-75, URL: http:// francia.digitale-sammlungen.de/Blatt_bsb00016303,00067.html (accessed 22.06.2018). Reprinted in: Simon Coupland, Carolingian coinage and the Vikings. Studies on power and trade in the 9th century, Ashgate 2007, part XIV, 57-75.

Coupland, Simon, The Carolingian army and the struggle against the Vikings, in: Viator 35 (2004), 49-70. 
Coviaux, Stéphane, Baptême et conversion des chefs scandinaves du IXe au XIe siècle, in: Pierre Bauduin (ed.), Les fondations scandinaves en Occident et les débuts du duché de Normandie. Actes du colloque de Cerisy-la-Salle (25-29 septembre 2002), Caen 2005, 67-80.

Crété-Protin, Isabelle, Église et vie chrétienne dans le diocèse de Troyes du IVe au IXe siècle, Villeneuve d'Ascq 2002.

Crozier, Michel and Erhard Friedberg, L'acteur et le système. Les contraintes de l'action collective, Paris 1977.

D’Haenens, Albert, Les invasions normandes en Belgique au IXe siècle. Le phénomène et sa répercussion dans l'historiographie médiévale, Louvain 1967.

Davis, Ralph, The Normans and their myth, London 1976.

De Jong, Mayke, The penitential state. Authority and atonement in the age of Louis the Pious, 814-840, Cambridge 2010.

Débax, Hélène, Stratégies matrimoniales des Comtes de Toulouse (850-1270), in: Annales du midi 100 (1988), 131-151.

Delaruelle, Étienne, En relisant le "De institutione regia" de Jonas d'Orléans. L'entrée en scène de l'épiscopat carolingien, in: Mélanges d'histoire du moyen âge dédiés à la mémoire de Louis Halphen, Paris 1951, 185-192.

Demotz, Bernard, La Bourgogne, dernier des royaumes carolingiens (885-1056). Roi, pouvoirs et élites autour du Léman (Mémoires et documents, 4,9), Lausanne 2008.

Depoin, Joseph, Essai de fixation d'une chronologie des rois mérovingiens de Paris aux VIe et VIIe siècles, in: Bulletin historique et philologique du Comité des Travaux Historiques et Scientifiques 23 (1905), 205-214.

Depreux, Philippe, Prosopographie de l'entourage de Louis le Pieux (781-840) (Instrumenta, 1), Sigmaringen 1997, URL: https://www.perspectivia.net/publikationen/ instrumenta/depreux_prosopographie (accessed 22.06.2018).

Depreux, Philippe, L'absence de jugement datant de règne de Louis le Pieux, in: Annales de Bretagne 108 (2001), 7-20.

Depreux, Philippe, La dimension "publique" de certaines dispositions "privées". Fondations pieuses et memoria en Francie occidentale aux IXe et Xe siècles, in: François Bougard, Cristine La Rocca and Régine Le Jan (eds.), Sauver son âme et se perpétuer. Transmission du patrimoine et mémoire au haut moyen âge (Collection de l'École Française de Rome, 351), Rome 2005, 331-376.

Depreux, Philippe, François Bougard and Régine Le Jan (eds.), Les élites et leurs espaces. Mobilité, rayonnement, domination (du VIe au XIe siècle). Actes de la rencontre de Göttingen des 3, 4 et 5 mars 2005 (Collection Haut Moyen Âge, 5), Turnhout 2007.

Depreux, Philippe, Hiérarchie et ordre au sein du palais. L'accès au prince, in: Dominique Iogna-Prat, François Bougard and Régine Le Jan (eds.), Hiérarchie et stratification sociale dans l'Occident médiéval 400-1100 (Collection Haut Moyen Âge, 6), Turnhout 2008, 305-324.

Depreux, Philippe, Investitures et destitutions aux temps carolingiens, in: Wojciech Falkowski and Yves Sassier (eds.), Le monde carolingien. Bilan, perspectives, champs de recherches. Actes du colloque international de Poitiers, Centre d'Études supérieures de Civilisation médiévale, 18-20 novembre 2004 (Culture et société médiévales, 18), Turnhout 2009, 157-182.

Depreux, Philippe, Le comte Haganon, favori de Charles le Simple, et l'aristocratie d'entre Loire et Rhin, in: Michèle Gaillard, Michel Margue, Alain Dierkens and Hérold Pettiau (eds.), De la mer du Nord à la Méditerranée. Francia Media. Une région au coeur de l'Europe (c.840-c.1050), Luxembourg 2011, 381-394. 
Depreux, Philippe, Bitte und Fürbitte am karolingischen Hof. Zugleich ein Beitrag zur politischen Bedeutung der Ambasciatoren- und Impetratorenvermerke (Mitte 8. bis Mitte 9. Jahrhundert), in: Archiv für Diplomatik 58 (2012), 57-102.

Depreux, Philippe, Überlegungen zu den Rangfaktoren und zur Rangkommunikation im karolingischen Reich, in: Jörg Peltzer (ed.), Rank and order. The formation of aristocratic elites in western and central Europe, 500-1500 (RANK. Politisch-soziale Ordnungen im mittelalterlichen Europa, 4), Ostfildern 2015, 85-98.

Deutinger, Roman, Königsherrschaft im Ostfränkischen Reich. Eine pragmatische Verfassungsgeschichte der späten Karolingerzeit (Beiträge zur Geschichte und Quellenkunde des Mittelalters, 20), Ostfildern 2006.

Devisse, Jean, Essai sur l'histoire d'une expression qui a fait fortune "Consilium et auxilium" au IXe siècle, in: Le moyen âge 74 (1968), 179-205.

Devisse, Jean, Hincmar, archevêque de Reims 845-882, 3 vols., Geneva 1975-1976.

Devroey, Jean-Pierre, The economy, in: Rosamond McKitterick (ed.), The early middle ages. Europe 400-1000 (The short Oxford history of Europe), Oxford 2001, 97-129.

Dhondt, Jan, Études sur la naissance des principautés territoriales en France. IXe-Xe siècle, Brugge 1948.

Dierkens, Alain, Abbayes et Chapitres entre Sambre et Meuse (VIIe-XIe siècles) (Beihefte der Francia, 14), Sigmaringen 1985, Permalink: http://nbn-resolving.org/ urn:nbn:de:bvb:12-bsb00026325-7 (accessed 22.06.2018).

Doubliez, Paul, Le monnayage de l'abbaye Saint- Pierre de Corbie, in: Corbie abbaye royale, volume du 13e centenaire, Lille 1965, 283-310.

Douglas, David C., Rollo of Normandy, in: David C. Douglas, Time and the hour. Some collected papers, London 1977, 121-140.

Duby, Georges, Les trois ordres ou l'imaginaire du féodalisme, Paris 1978.

Duchesne, Louis, Fastes épiscopaux de l'ancienne Gaule II. L’Aquitaine et les Lyonnaises, 2nd ed., Paris 1910.

Duchesne, Louis, Fastes épiscopaux de l'ancienne Gaule III. Les provinces du nord et de l'est, Paris 1915.

Dumézil, Bruno, Culture et politique (II). Gogo et ses amis. Écriture, échanges et ambitions dans un réseau aristocratique de la fin du VIe siècle, in: Revue Historique 643 (2007), 553-593.

Dümmler, Ernst, Die Geschichte des ostfränkischen Reiches III (Jahrbücher der deutschen Geschichte), Leipzig 1888.

Dunbabin, Jean, France in the making, 843-1180, 2nd ed., Oxford 2000.

Dutton, Paul E., The politics of dreaming in the Carolingian empire, Lincoln 1994.

Duvosquel, Jean-Marie, La cession de l'abbaye de Maroilles en Hainaut par Charles le Simple à l'église de Cambrai (920), in: Valenciennes et les anciens Pays-Bas. Mélanges offerts à Paul Lefrancq (Mémoires du Cercle archéologique et historique de Valenciennes, 9), Valenciennes 1978, 175-180.

Eckel, Auguste, Charles le Simple, Paris 1899 (reprint Geneva 1977).

Eckhardt, Karl August, Genealogische Funde zur allgemeinen Geschichte, Witzenhausen 1963.

Eder, Klaus, Societies learn and yet the world is hard to change, in: European Journal of Social Theory 2 (1999), 195-215.

Ehlers, Joachim, Karolingische Tradition und frühes Nationalbewußtsein in Frankreich, in: Francia. Forschungen zur westeuropäischen Geschichte 4 (1976), 213-236, URL: http:// francia.digitale-sammlungen.de/Blatt_bsb00016279,00225.html (accessed 22.06.2018). 
Ehlers, Joachim, Geschichte Frankreichs im Mittelalter, Stuttgart 1987.

Ehlers, Joachim, Die Anfänge der französischen Geschichte, in: Historische Zeitschrift 240 (1985), 1-44. Reprinted in: Joachim Ehlers, Martin Kintzinger and Bernd Schneidmüller (eds.), Ausgewählte Aufsätze (Berliner historische Studien, 21), Berlin 1996, 237-273.

Ehlers, Joachim, Strukturen früher Staatlichkeit. West- und Ostfrankenreich im Vergleich (9./10. Jahrhundert), in: Walter Pohl and Veronika Wieser (eds.), Der frühmittelalterliche Staat. Europäische Perspektiven (Forschungen zur Geschichte des Mittelalters, 16), Vienna 2009, 89-98.

Ehrenforth, Gerhard, Hinkmar von Rheims und Ludwig III. von Westfranken, in: Zeitschrift für Kirchengeschichte 44 (1925), 65-98.

Eichler, Daniel, Fränkische Reichsversammlungen unter Ludwig dem Frommen (Studien und Texte der MGH, 45), Hanover 2007.

Eichler, Daniel, Karolingische Höfe und Versammlungen. Grundvoraussetzungen, in: Matthias Becher and Alheydis Plassmann (eds.), Streit am Hof im frühen Mittelalter (Super alta perennis. Studien zur Wirkung der Klassischen Antike, 11), Göttingen 2011, 121-148.

Endemann, Traute, Markturkunde und Markt in Frankreich und Burgund vom 9. bis 11. Jahrhundert (Vorträge und Forschungen. Sonderband, 4), Konstanz 1964.

Epp, Verena, Amicitia. Zur Geschichte personaler, sozialer, politischer und geistlicher Beziehungen im frühen Mittelalter (Monographien zur Geschichte des Mittelalters, 44), Stuttgart 1999.

Erkens, Franz-Reiner, "Sicut Esther regina”. Die westfränkische Königin als consors regni, in: Francia. Forschungen zur westeuropäischen Geschichte 20/1 (1993), 15-38, DOI: https://doi.org/10.11588/fr.1993.1.58081 (accessed 22.06.2018).

Erkens, Franz-Reiner, Die Bischofswahl im Spannungsfeld zwischen weltlicher und geistlicher Gewalt, in: Franz-Reiner Erkens (ed.), Die früh- und hochmittelalterliche Bischofserhebung im europäischen Vergleich (Archiv für Kulturgeschichte. Beiheft, 48), Cologne 1998, 1-32.

Esch, Arnold, Überlieferungschance und Überlieferungszufall als methodisches Problem des Historikers, in: Arnold Esch (ed.), Zeitalter und Menschenalter. Der Historiker und die Erfahrung vergangener Gegenwart, Munich 1994, 39-69.

Ewig, Eugen, Kaiser Lothars Urenkel, Ludwig von Vienne, der präsumptive Nachfolger Kaiser Karls III., in: Das erste Jahrtausend. Kultur und Kunst im werdenden Abendland an Rhein und Ruhr, Texband I, Düsseldorf 1963, 336-343. Reprinted in: Eugen Ewig and Harmut Atsma (eds.), Spätantikes und fränkisches Gallien. Gesammelte Schriften, vol. 1, Munich 1976, 578-585.

Ewig, Eugen, Beobachtungen zur politisch-geographischen Terminologie des fränkischen Großreiches und der Teilreiche des 9. Jahrhunderts, in: Konrad Repgen and Stephan Skalweit (eds.), Spiegel der Geschichte. Festschrift für Max Braubach zum 10. April 1964, Münster 1964, 99-140. Reprinted in: Eugen Ewig and Hartmut Atsma (eds.), Spätantikes und fränkisches Gallien. Gesammelte Schriften I (Beihefte der Francia, 3), Munich 1976, 323-361.

Ewig, Eugen, Die Rheinlande in der fränkischen Zeit (451-919/31), Düsseldorf 1980.

Ewig, Eugen, Der Gebetsdienst der Kirchen in den Urkunden der späteren Karolinger, in: Hans-Martin Maurer and Hans Patze (eds.), Festschrift für Berent Schwineköper zu seinem siebzigsten Geburtstag, Sigmaringen 1982, 45-86.

Falkenstein, Ludwig, Pfalz und "vicus" Aachen, in: Caspar Ehlers (ed.), Orte der Herrschaft. Mittelalterliche Königspfalzen, Göttingen 2002, 131-181. 
Falkowski, Wojciech, Contra legem regem sibi elegerunt. Les prinicipes régissant l'exercice du pouvoir royal sous le règne de Charle le Simple, in: Cahiers de civilisation médiévale 35 (1992), 227-239.

Falkowski, Wojciech, La monarchie en crise permanente. Les Carolingiens après la mort de Charles le Chauve, in: Wojciech Falkowski and Yves Sassier (eds.), Le monde carolingien. Bilan, perspectives, champs de recherches. Actes du colloque international de Poitiers, Centre d'Études supérieures de Civilisation médiévale, 18-20 novembre 2004 (Culture et société médiévales, 18), Turnhout 2009, 333-356.

Falkowski, Wojciech and Sassier, Yves (eds.), Le monde carolingien. Bilan, perspectives, champs de recherches. Actes du colloque international de Poitiers, Centre d'Études supérieures de Civilisation médiévale, 18-20 novembre 2004 (Culture et société médiévales, 18), Turnhout 2009.

Fasoli, Gina, Le incursioni ungare in Europa nel secolo X (Biblioteca storica Sansoni, 12), Florence 1945.

Fasoli, Gina, Points de vue sur les incursions hongroises en Europe au Xe siècle, in: Cahiers de civilisation médiévale 2 (1959), 17-35.

Favre, Édouard, Eudes. Comte de Paris et roi de France. 882-898, Paris 1893, Permalink: https://gallica.bnf.fr/ark:/12148/bpt6k47454.image (accessed 22.06.2018).

Favre, Édouard, La famille d'Evrard marquis de Frioul, in: Études d'histoire du moyen âge, dédiées à Gabriel Monod, Paris 1896, 155-162.

Feller, Laurent, L'exercice du pouvoir par Bérenger Ier, roi d'Italie (888-915) et empereur (915-924), in: Médiévales 58 (2010), 129-149.

Flambard Héricher, Anne-Marie, La progression des Vikings, des raids à la colonisation (Cahiers du GRHIS, 14), Mont-Saint-Aignan 2003.

Fleckenstein, Josef, Die Hofkapelle der deutschen Könige (Schriften der MGH, 16), 2 vols., Stuttgart 1959-1966.

Folz, Robert, L'idée de l'empire en occident du Ve au XIVe siècle, Paris 1953.

Font-Réaulx, Jacques de, Les diplômes de Charles le Simple, in: Annales de l'Université de Grenoble NS 19 (1943), 29-49.

Fößel, Amalie, Die Königin im mittelalterlichen Reich. Herrschaftsausübung, Herrschaftsrechte, Handlungsspielräume (Mittelalter-Forschungen, 4), Stuttgart 2000.

Fößel, Amalie, From the consors regni to the koenigs husfrouwe? Some comments on the decline of the queens' power in the medieval German empire, in: Éric Bousmar, Jonathan Dumont, Alain Marchandisse and Bertrand Schnerb (eds.), Femmes de pouvoir, femmes politiques durant les derniers siècles du Moyen Âge et au cours de la première Renaissance, Bruxelles 2012, 83-90.

Fouracre, Paul J., The context of the OHG Ludwigslied, in: Medium aevum 54 (1985), 87-103. Reprinted in: Paul J. Fouracre, Frankish history. Studies in the construction of power (Variorum Collected Studies Series, 1024), Ashgate 2012, part IX, 87-103.

Freise, Eckhard, Die "Genealogia Arnulfi comitis" des Priesters Witger, in: Frühmittelalterliche Studien 23 (1989), 203-243.

Frevert, Ute, Vertrauen. Historische Annäherungen, in: Ute Frevert (ed.), Vertrauen. Historische Annäherungen, Göttingen 2003, 7-66.

Fried, Johannes, Boso von Vienne oder Ludwig der Stammler? In: Deutsches Archiv für Erforschung des Mittelalters 32 (1976), 193-208, Permalink: http://resolver.sub.unigoettingen.de/purl?PPN345858735_0032 (accessed 22.06.2018).

Gaillard, Michèle, D’une réforme à l'autre (816-934). Les communautés religieuses en Lorraine à l'époque carolingienne, Paris 2006. 
Ganshof, François Louis, Note sur les origines de l'union du bénéfice avec la vassalité, in: Etudes d'histoire dédiées à la mémoire de Henri Pirenne par ses anciens élèves, Bruxelles 1937, 173-190.

Ganshof, François Louis, La fin du règne de Charlemagne. Une décomposition, in: Zeitschrift für Schweizerische Geschichte 28 (1948), 433-452.

Ganshof, François Louis, Recherches sur les capitulaires, in: Revue historique de droit français et étranger 35 (1957), 33-87 and 196-246.

Garnier, Claudia, Die Kultur der Bitte. Herrschaft und Kommunikation im mittelalterlichen Reich (Symbolische Kommunikation in der Vormoderne), Darmstadt 2008.

Gasnault, Pierre, Le tombeau de saint Martin et les invasions normandes dans l'histoire et dans la légende, in: Revue d'histoire de l'église de France 47 (1961), 51-66.

Geiselhart, Mathias, Die Kapitulariengesetzgebung Lothars I. in Italien (Freiburger Beiträge zur mittelalterlichen Geschichte, 15), Frankfurt a.M. 2002.

Génicot, Léopold, Princes territoriaux et sang carolingien. La Genealogia comitum Buloniensium, in: Léopold Génicot (ed.), Études sur les principautés lotharingiennes (Recueil de travaux d' histoire et de philologie, 6,7), Louvain 1975, 217-306.

Giry, Arthur, Études Carolingiennes, in: Études d'histoire du moyen âge, dédiées à Gabriel Monod, Paris 1896, 107-136.

Glansdorff, Sophie, Comites in regno Hludouici regis constituti. Prosopographie des détenteurs d'offices séculiers en Francie orientale, de Louis le Germanique à Charles le Gros 826-887 (Instrumenta 20), Ostfildern 2011, URL: https://www.perspectivia.net/ publikationen/instrumenta/glansdorff_comites (accessed 22.06.2018).

Glenn, Jason K., Politics and history in the tenth century. The work and world of Richer of Reims (Cambridge studies in medieval life and thought, 4, 60), Cambridge 2004.

Gockel, Michael, Karolingische Königshöfe am Mittelrhein (Veröffentlichungen des MaxPlanck-Instituts für Geschichte, 31), Göttingen 1970.

Goetz, Hans-Werner, "Dux" und "Ducatus". Begriffs- und verfassungsgeschichtliche Untersuchungen zur Entstehung des sogenannten "jüngeren” Stammesherzogtums an der Wende vom 9. zum 10. Jahrhundert, Bochum 1977.

Goetz, Hans-Werner, Zur Landnahmepolitik der Normannen im Fränkischen Reich, in: Annalen des Historischen Vereins für den Niederrhein 183 (1980), 9-17.

Goetz, Hans-Werner, Moderne Mediävistik. Stand und Perspektiven der Mittelalterforschung, Darmstadt 1999.

Goetz, Hans-Werner, "Nobilis”. Der Adel im Selbstverständnis der Karolingerzeit, in: Vierteljahrschrift für Sozial- und Wirtschaftsgeschichte 70 (1983), 153-191. Reprinted in: Hans-Werner Goetz, Anja Rathmann-Lutz, Anna Aurast, Simon Elling, Bele Freudenberg and Steffen Patzold (eds.), Vorstellungsgeschichte. Gesammelte Schriften zu Wahrnehmungen, Deutungen und Vorstellungen im Mittelalter, Bochum 2007, 173-206.

Goetz, Hans-Werner, La perception de l'espace politico-geographique de la Francia Media dans l'historiographie médiévale, in: Michèle Gaillard, Michel Margue, Alain Dierkens and Hérold Pettiau (eds.), De la mer du Nord à la Méditerranée. Francia Media. Une région au cœur de l'Europe (c. 840-c. 1050), Luxembourg 2011, 111-130.

Goldberg, Eric J., Struggle for empire. Kingship and conflict under Louis the German. 817-876 (Conjunctions of religion and power in the medieval past), Ithaca, 2006.

Görich, Knut, Mathilde, Edgith, Adelheid. Ottonische Königinnen als Fürsprecherinnen, in: Bernd Schneidmüller and Stefan Weinfurter (eds.), Ottonische Neuanfänge. Symposion zur Ausstellung "Otto der Große, Magdeburg und Europa”, Mainz 2001, 251-291. 
Görich, Knut, Mißtrauen aus Erfahrung. Mailand und Friedrich II., in: Frühmittelalterliche Studien 39 (2005), 411-429.

Gournay, Frédéric de, Le Rouergue au tournant de l'an mil. De l'ordre carolingien à l'ordre féodal (IXe-XIIe siècle) (Collection Méridiennes), Rodez 2004.

Gravel, Martin, Distances, rencontres, communications. Réaliser l'empire sous Charlemagne et Louis le Pieux (Collection Haut Moyen Âge, 15), Turnhout 2012.

Green, Dennis H., The "Ludwigslied" and the battle of Saucort, in: Judith Jesch (ed.), The Scandinavians from the Vendel period to the tenth century. An ethnographic perspective (Studies in historical archaeoethnology), Woodbridge 2002, 281-302.

Grierson, Philip, La maison d'Evrard de Frioul et les origines du comté de Flandre, in: Revue du Nord 24 (1938), 241-266.

Grierson, Philip, L'origine des Comtes d'Amiens, Valois et Vexin, in: Le Moyen Âge 49 (1939), 81-123.

Große, Rolf, Das Bistum Utrecht und seine Bischöfe im 10. und frühen 11. Jahrhundert (Kölner historische Abhandlungen, 33), Cologne 1987.

Große, Rolf, Saint-Denis. Die Gegenwart der toten Könige, in: Rainer Berndt (ed.), Wider das Vergessen und für das Seelenheil. Memoria und Totengedenken im Mittelalter (Erudiri sapientia, 9), Münster 2013, 227-250.

Guillot, Olivier, La conversion des Normands peu après 911. Des reflets contemporains à l'historiographie ultérieure, in: Cahiers de civilisation médiévale 24 (1981), 101-116 and 181-219.

Guillot, Olivier, Les étapes de l'accession d'Eudes au pouvoir royal, in: George Duby (ed.), Media in Francia. Recueil de mélanges offert à Karl Ferdinand Werner à l'occasion de son 65e anniversaire par ses amis et collègues français, Mauléurier 1989, 199-224. Reprinted in: Olivier Guillot, Arcana imperii (IVe-XIe siècle) (Cahiers de l'Institut d'Anthropologie Juridique, 10), Limoges 2003, 511-536.

Guillot, Olivier, Une "ordinatio" méconnue. Le capitulaire de 823-825, in: Peter Godman and Roger Collins (eds.), Charlemagne's heir. New perspectives on the reign of Louis the Pious (814-840), Oxford 1990, 455-486.

Guillot, Olivier, Formes, fondements et limites de l'organisation politique en France au Xe siècle, in: Il secolo di ferro. Mito e realtà del secolo X (Settimane di studio del Centro italiano di studi sull'alto medioevo, 38), Spoleto 1991, 57-116.

Guillot, Olivier and Yves Sassier, Pouvoirs et institutions dans la France médiévale I. Des origines à l'époque féodale, 3rd ed., Paris 1999.

Guillotel, Hubert, Une autre marche de Neustrie, in: Katharine S. B. Keats-Rohan and Christian Settipani (eds.), Onosmastique et Parenté dans l'Occident médiéval (Prosopographia et genealogica, 3), Oxford 2000, 7-13.

Gulati, Ranjay and Sameer B. Srivastava, Bringing agency back into network research. Constrained agency and network action, in: Daniel J. Brass, Giuseppe Labianca, Ajay Mehra, Daniel S. Halgin and Stephen P. Borgatti (eds.), Contemporary perspectives on organizational social networks (Research in the sociology of organizations, 40), Bingley, 73-93.

Guyotjeannin, Olivier, Une interpolation datant des alentours de l'an Mil et provenant de Marmoutier d'une notice perdue de 912, in: Francia. Forschungen zur westeuropäischen Geschichte 13 (1986), 680-686, URL: http://francia.digitale-sammlungen.de/Blatt_ bsb00016288,00696.html (accessed 22.06.2018).

Guyotjeannin, Olivier, Épiscopus et comes. Affirmation et déclin de la seigneurie épiscopale au nord du royaume de France (Beauvais-Noyon, Xe-début XIIIe siècle) (Mémoires et documents de l'École des Chartes, 30), Geneva 1987. 
Guyotjeannin, Olivier, Jacques Pycke and Benoît-Michel Tock, Diplomatique médiévale (L’atelier du médiéviste, 2), 3rd ed., Turnhout 2006.

Hannig, Jürgen, Consensus fidelium. Frühfeudale Interpretationen des Verhältnisses von Königtum und Adel am Beispiel des Frankenreiches (Monographien zur Geschichte des Mittelalters, 27), Stuttgart 1982.

Hardin, Russell, Conceptions and explanations of trust, in: Karen S. Cook (ed.), Trust in society, New York 2001.

Hardin, Russell, Trust and trustworthiness, New York 2002.

Hardin, Russell, Trust, Cambridge 2008.

Hartmann, Martina, Lotharingien in Arnolfs Reich. Das Königtum Zwentibolds, in: Franz Fuchs (ed.), Kaiser Arnolf. Das ostfränkische Reich am Ende des 9. Jahrhunderts. Regensburger Kolloquium, 9.-11.12.1999, Munich 2002, 122-142.

Hartmann, Martina, Die Königin im frühen Mittelalter, Stuttgart 2009.

Hattenhauer, Hans, Die Aufnahme der Normannen in das westfränkische Reich. SaintClair-sur-Epte AD 911, Hamburg 1990.

Hauck, Karl, Die Ottonen und Aachen, 876 bis 936, in: Wolfgang Braunfels and Percy Ernst Schramm (eds.), Karl der Große. Lebenswerk und Nachleben, vol. 4, Düsseldorf 1967, 39-53.

Hausmann, Friedrich and Alfred Gawlik, Arengenverzeichnis zu den Königs- und Kaiserurkunden von den Merowingern bis Heinrich VI. (Hilfsmittel der MGH, 9), Munich 1987.

Haverkamp, Alfred, Einführung, in: Alfred Haverkamp (ed.), Friedrich Barbarossa. Handlungsspielräume und Wirkungsweisen des staufischen Kaisers (Vorträge und Forschungen, 40), Sigmaringen 1992, 9-47.

Heidrich, Ingrid, Das Adelsgeschlecht der Konradiner vor und während der Regierungszeit Konrads I., in: Hans-Werner Goetz and Simon Elling (eds.), Konrad I. - Auf dem Weg zum Deutschen Reich? Bochum 2006, 59-76.

Heine, Alexander (ed.), Deutschlands Geschichtsquellen im Mittelalter (Wilhelm Wattenbach, Ernst Dümmler, Franz Huf). Auf der Grundlage der 7., von W. Wattenbach begonnen und E. Dümmler herausgegebenen Auflage, neu bearb. und erg. von Franz Huf, vol. 2, Kettwig 1991.

Helmerichs, Robert, "Princeps, comes, dux Normannorum". Early Rollonid designators and their significance, in: The Haskins Society Journal 9 (1997), 57-77.

Helvétius, Anne-Marie, L'abbatiat laïque comme relais du pouvoir royal aux frontières du royaume. Le cas du nord de la Neustrie au IXe siècle, in: Régine Le Jan (ed.), La royauté et les élites dans l'Europe carolingienne (début IXe siècle aux environs de 920) (Collection Histoire et littérature régionales, 17), Villeneuve d'Ascq 1998, 285-299.

Hermann, Tobias, Historisch-diplomatische Untersuchungen zur Frühgeschichte der Abtei St-Vaast (Vedastus) in Arras, in: Archiv für Diplomatik 51 (2005), 49-125.

Hirschbiegel, Jan, Nahbeziehungen bei Hof Manifestationen des Vertrauens. Karrieren in reichsfürstlichen Diensten am Ende des Mittelalters (Norm und Struktur, 44), Cologne 2015.

Hitzbleck, Kerstin, Verflochten, vernetzt, verheddert? Überlegungen zu einem erfolgreichen Paradigma, in: Kerstin Hitzbleck and Klara Hübner (eds.), Die Grenzen des Netzwerks 1200-1600, Ostfildern 2014, 17-40.

Hitzbleck, Kerstin and Klara Hübner, Netzwerkgrenzen, in: Kerstin Hitzbleck and Klara Hübner (eds.), Die Grenzen des Netzwerks 1200-1600, Ostfildern 2014, 7-15.

Hlawitschka, Eduard, Franken, Alemannen, Bayern und Burgunder in Oberitalien (774-962) (Forschungen zur oberrheinischen Landesgeschichte, 8), Freiburg i. Br. 1960. 
Hlawitschka, Eduard, Herzog Giselbert von Lothringen und das Kloster Remiremont, in: Zeitschrift für die Geschichte des Oberrheins 108 NF 69 (1960), 422-465. Reprinted in: Eduard Hlawitschka, Gertrud Thoma and Wolfgang Giese (eds.), Stirps regia. Forschungen zu Königtum und Führungsschichten im früheren Mittelalter. Ausgewählte Aufsätze. Festgabe zu seinem 60. Geburtstag, Frankfurt a.M. 1988, 377-420.

Hlawitschka, Eduard, Lotharingien und das Reich an der Schwelle der deutschen Geschichte (Schriften der MGH, 21), Stuttgart 1968.

Hlawitschka, Eduard, Die Anfänge des Hauses Habsburg-Lothringen. Genealogische Untersuchungen zur Geschichte Lothringens und des Reiches im 9., 10. und 11. Jahrhundert (Veröffentlichungen der Kommission für saarländische Landesgeschichte und Volksforschung, IV), Saarbrücken 1969.

Hlawitschka, Eduard, Textkritisches zur Series abbatum Flaviniacensium, in: Georg Droege, Peter Schöller, Rudolf Schützeichel and Matthias Zender (eds.), Landschaft und Geschichte. Festschrift für Franz Petri zu seinem 65. Geburtstag am 22. Februar 1968, Bonn 1970, 250-265.

Hlawitschka, Eduard, Die Widonen im Dukat von Spoleto, in: Quellen und Forschungen aus italienischen Archiven und Bibliotheken 63 (1983), 20-92. Reprinted in: Eduard Hlawitschka, Gertrud Thoma and Wolfgang Giese (eds.), Stirps regia. Forschungen zu Königtum und Führungsschichten im früheren Mittelalter, Ausgewählte Aufsätze, Festgabe zu seinem 60. Geburtstag, Frankfurt a.M. 1988, 155-226, URL: https://www. perspectivia.net/publikationen/qfiab/63-1983/0020-0092 (accessed 25.09.2018).

Hlawitschka, Eduard, Kontroverses aus dem Umfeld von König Heinrichs I. Gemahlin Mathilde, in: Ernst-Dieter Hehl, Hubertus Seibert and Franz Staab (eds.), Deus qui mutat tempora. Menschen und Institutionen im Wandel des Mittelalters. Festschrift für Alfons Becker zu seinem fünfundsechzigsten Geburtstag, Sigmaringen 1987, 33-54. Reprinted in: Eduard Hlawitschka, Gertrud Thoma and Wolfgang Giese (eds.), Stirps regia. Forschungen zu Königtum und Führungsschichten im früheren Mittelalter, Ausgewählte Aufsätze, Festgabe zu seinem 60. Geburtstag, Frankfurt a.M. 1988, 355-376.

Hlawitschka, Eduard, Kaiser Wido und das Westfrankenreich, in: Gerd Althoff, Dieter Geuenich, Otto Gerhard Oexle and Joachim Wollasch (eds.), Person und Gemeinschaft im Mittelalter. Festschrift für Karl Schmid zum fünfundsechzigsten Geburtstag, Sigmaringen 1988, 187-198.

Hlawitschka, Eduard, Der Thronwechsel des Jahres 1002 und die Konradiner. Eine Auseinandersetzung mit zwei Arbeiten von Armin Wolf und Donald C. Jackman, in: Zeitschrift der Savigny-Stiftung für Rechtsgeschichte. Germanistische Abteilung 110 (1993), 149-248.

Hlawitschka, Eduard, Die Ahnen der hochmittelalterlichen deutschen Könige, Kaiser und ihrer Gemahlinnen. Ein kommentiertes Tafelwerk I. 911-1137 (Hilfsmittel der MGH, 25), Hanover 2006.

Hlawitschka, Eduard, Die Ahnen der hochmittelalterlichen deutschen Könige, Kaiser und ihrer Gemahlinnen. Ein kommentiertes Tafelwerk II. 1138-1197 (Hilfsmittel der MGH, 26), Hanover 2009.

Hope, George A., The political development of the Carolingian kingdom of Lotharingia, 870-925, Glasgow 2005 (unpublished PhD thesis), URL: http://theses.gla.ac.uk/id/ eprint/2847 (accessed 22.06.2018).

Huber, Irene, Der (in)formelle Handlungsspielraum von Eunuchen am Hof der persischen Sasaniden (225-651 n. Chr.), in: Reinhardt Butz (ed.), Informelle Strukturen bei Hof. 
Ergebnisse des gleichnamigen Kolloquiums auf der Moritzburg bei Dresden, 27. bis 29. September 2007 (Vita curialis, 2), Berlin 2009, 193-220.

Huschner, Wolfgang, Die ottonische Kanzlei in neuem Licht, in: Archiv für Diplomatik 52 (2006), 353-370.

Hyam, Jane, Ermentrude and Richildis, in: Margaret T. Gibson and Janet L. Nelson (eds.), Charles the Bald. Court and kingdom. Papers based on a colloquium held in London in April 1979, Oxford 1981, 153-168.

Imbart de La Tour, Pierre, Les élections épiscopales dans l'église de France du IXe au XIIe siècle. Étude sur la décadence du principe électif, Paris 1890 (reprinted Genève 1974).

Innes, Matthew J., State and society in the early middle ages. The Middle Rhine Valley, 400-1000 (Cambridge studies in medieval life and thought, 4, 47), Cambridge 2000.

Innes, Matthew J., What was Charlemagne's government? In: Joanna E. Story (ed.), Charlemagne. Empire and society, Manchester 2005, 71-89.

Jackman, Donald C., The Konradiner. A study in genealogical methodology (Studien zur Europäischen Rechtsgeschichte, 47), Frankfurt a.M. 1990.

Jackman, Donald C., König Konrad, die letzten Karolinger und ihre sächsischen Verwandten, in: Hans-Werner Goetz and Simon Elling (eds.), Konrad I. - Auf dem Weg zum Deutschen Reich? Bochum 2006, 77-92.

Jacobsen, Peter Christian, Die Titel princeps und domnus bei Flodoard von Reims (893/4-966), in: Mittellateinisches Jahrbuch 13 (1978), 50-72.

Jacobsen, Peter Christian, Flodoard von Reims. Sein Leben und seine Dichtung "De triumphis Christi" (Mittellateinische Studien und Texte, 10), Leiden and Cologne 1978.

Janin, Pierre, Heiric d'Auxerre et les Gesta pontificum Autissiodorensium, in: Francia. Forschungen zur westeuropäischen Geschichte 4 (1976), 89-106, URL: http://francia. digitale-sammlungen.de/Blatt_bsb00016279,00101.html (accessed 22.06.2018).

Jarnut, Jörg, König Konrad I. und die Entstehung des mittelalterlichen Deutschen Reiches, in: Hans-Werner Goetz and Simon Elling (eds.), Konrad I. - Auf dem Weg zum Deutschen Reich? Bochum 2006, 265-276.

Jarousseau, Gérard, Les évêques d'Angers et la collegiale Saint-Martin de Tours (fin IVe siècle-Xe siècle), in: Giles Constable and Michel Rouche (eds.), Auctoritas. Mélanges offerts à Olivier Guillot, Paris 2006, 365-384.

Jarrett, Jonathan, Power over past and future. Abbess Emma and the nunnery of Sant Joan de les Abadesses, in: Early medieval Europe 12 (2003), 229-258.

Johanek, Peter, Herrscherdiplom und Empfängerkreis. Die Kanzlei Ludwigs des Frommen in der Schriftlichkeit der Karolingerzeit, in: Rudolf Schieffer (ed.), Schriftkultur und Reichsverwaltung unter den Karolingern. Referate des Kolloquiums der NordrheinWestfälischen Akademie der Wissenschaften am 17./18. Februar 1994 in Bonn, Opladen 1996, 167-188.

Jordan, Victoria, The role of kingship in tenth-century Normandy. Hagiography of Dudo of Saint-Quentin, in: The Haskins Society Journal 3 (1991), 53-62.

Kaiser, Reinhold, Bischofsherrschaft zwischen Königtum und Fürstenmacht. Studien zur bischöflichen Stadtherrschaft im westfranzösischen Reich im frühen und hohen Mittelalter (Pariser Historische Studien, 17), Bonn 1981, URL: https://www.perspectivia. net/publikationen/phs/kaiser_bischofsherrschaft (accessed 25.09.2018).

Kaiser, Reinhold, Royauté et pouvoir épiscopal au nord de la Gaule (VIIe-IXe siècles), in: Hartmut Atsma (ed.), La Neustrie. Les pays au nord de la Loire de 650 à 850. Colloque historique international, vol. 1, Sigmaringen 1989, 143-160, URL : https:// 
www.perspectivia.net/publikationen/bdf/atsma_neustrie_1/kaiser_royaute (accessed 25.09.2018).

Kaiser, Reinhold, Les évêques neustriens du Xe siècle dans l'exercice de leur pouvoir temporel d'après l'historiographie médiévale, in: Olivier Guillot and Robert Favreau, Pays de Loire et Aquitaine de Robert le Fort aux premiers Capétiens. Actes du colloque scientifique international tenu à Angers en septembre 1987, Poitiers 1997, 117-143.

Kalckstein, Karl von, Robert der Tapfere, Markgraf von Anjou. Der Stammvater des kapetingischen Hauses, Berlin 1871.

Kalckstein, Karl von, Geschichte des französischen Königthums unter den ersten Capetingern I. Der Kampf der Robertiner und Karolinger, Leipzig 1877.

Kamp, Hermann, Friedensstifter und Vermittler im Mittelalter, Darmstadt 2001.

Kamp, Hermann, Die Macht der Spielregeln in der mittelalterlichen Politik. Eine Einleitung, in: Claudia Garnier and Hermann Kamp (eds.), Die Spielregeln der Mächtigen. Mittelalterliche Politik zwischen Gewohnheit und Konvention, Darmstadt 2010, 1-18.

Kasten, Brigitte, Königssöhne und Königsherrschaft. Untersuchungen zur Teilhabe am Reich in der Merowinger- und Karolingerzeit (Schriften der MGH, 44), Hanover 1997.

Kasten, Brigitte, Chancen und Schicksale "unehelicher" Karolinger im 9. Jahrhundert, in: Franz Fuchs and Peter Schmid (eds.), Kaiser Arnolf. Das Ostfränkische Reich am Ende des 9. Jahrhunderts. Regensburger Kolloquium 9.-11.12.1999, Munich 2002, 17-52.

Keats-Rohan, Katharine, Poppa "de Bayeux" et sa famille, in: Katharine Keats-Rohan and Christian Settipani (eds.), Onomastique et Parenté dans l'Occident médiéval (Prosopographica et genealogica, 3), Oxford 2000, 140-153.

Kehr, Paul Fridolin, Die Kanzlei Karls III., Berlin 1936.

Keller, Hagen, Zum Sturz Karls III. Über die Rolle Liutwards von Vercelli und Liutberts von Mainz, Arnulfs von Kärnten und der ostfränkischen Großen bei der Absetzung des Kaisers, in: Deutsches Archiv für Erforschung des Mittelalters 22 (1966), 333-384, Permalink: http://resolver.sub.uni-goettingen.de/purl?PPN345858735_0022 (accessed 22.06.2018).

Keller, Hagen, Zwischen regionaler Begrenzung und universalem Horizont. Deutschland im Imperium der Salier und Staufer 1024 bis 1250, Berlin 1986.

Keller, Hagen, Ottonische Herrschersiegel. Beobachtungen und Fragen zu Gestalt und Aussage und zur Funktion im historischen Kontext, in: Konrad Krimm and John Herwig (eds.), Bild und Geschichte. Studien zur politischen Ikonographie. Festschrift für Hansmartin Schwarzmaier zum fünfundsechzigsten Geburtstag, Sigmaringen 1997, 3-51. Reprinted in: Hagen Keller, Ottonische Königsherrschaft. Organisation und Legitimation königlicher Macht, Darmstadt 2002, 131-166 and 275-297.

Keller, Hagen, Die Herrscherurkunden. Botschaften des Privilegierungsaktes - Botschaften des Privilegientextes, in: Comunicare e significare nell'alto medioevo (Settimane di studio del Centro italiano di studi sull'alto medioevo, 52), Spoleto 2005, 231-279.

Keller, Rodolphe, La négociation du tribut entre Francs et Vikings. Jeux et enjeux de pouvoir, in: Laurent Jégou, Sylvie Joye, Thomas Lienhard and Jens Schneider (eds.), Faire lien. Aristocratie, réseaux et échanges compétitifs. Mélanges en l'honneur de Régine Le Jan, Paris 2015, 101-110.

Kellner, Maximilian, Die Ungarneinfälle im Bild der Quellen bis 1150. Von der "Gens detestanda" zur "Gens ad fidem Christi conversa" (Studia Hungarica, 46), Munich 1997.

Kéry, Lotte, Die Errichtung des Bistums Arras 1093/1094 (Beihefte der Francia, 33), Sigmaringen 1994, Permalink: http://nbn-resolving.org/urn:nbn:de:bvb:12-bsb00026805-2 (accessed 22.06.2018). 
Kienast, Walther, Der Herzogstitel in Frankreich und Deutschland (9.-12. Jahrhundert). Mit Listen der ältesten deutschen Herzogsurkunden, Munich/Vienna 1968.

Kienast, Walther, Der Wirkungsbereich des französischen Königtums von Odo bis Ludwig VI. (888-1137) in Südfrankreich, in: Historische Zeitschrift 209 (1969), 529-565.

Kienast, Walther, Die fränkische Vassalität. Von den Hausmeiern bis zu Ludwig dem Kind und Karl dem Einfältigen (Frankfurter Wissenschaftliche Beiträge. Kulturwissenschaftliche Reihe, 18), Frankfurt a.M. 1990.

Kikuchi, Shigeto, Representations of monarchical 'highness' in Carolingian royal charters, in: Jonathan Jarrett and Allan McKinley (eds.), Problems and possibilities of early medieval charters (International medieval research, 19), Turnhout 2013, 187-208.

Kleinjung, Christine, Die äußere Bedrohung und die Schwäche des Staates. Zentralitätskonzepte in den Quellen und in der modernen Historiographie am Beispiel Westeuropas, in: Christine Kleinjung and Stefan Albrecht (eds.), Das lange 10. Jahrhundert. Struktureller Wandel zwischen Zentralisierung und Fragmentierung, äußerem Druck und innerer Krise, Regensburg 2014, 7-27.

Kolb, Werner, Herrscherbegegnungen im Mittelalter, Frankfurt a.M. 1988.

Kölzer, Theo, Diplomatik und Urkundenpublikationen, in: Toni Diederich and Joachim Oepen (eds.), Historische Hilfswissenschaften. Stand und Perspektiven der Forschung, Cologne 2005, 7-34.

Kölzer, Theo, Ein "System reisender Schreiber und Notare" in der Kanzlei Karls des Großen? In: Archiv für Diplomatik 62 (2016), 41-58.

Koziol, Geoffrey, Begging pardon and favor. Ritual and political order in early medieval France, Ithaca 1992.

Koziol, Geoffrey, Charles the Simple, Robert of Neustria, and the vexilla of Saint-Denis, in: Early medieval Europe 14 (2006), 355-390.

Koziol, Geoffrey, Is Robert I in hell? In: Early medieval Europe 14 (2006), 233-268.

Koziol, Geoffrey, What Charles the Simple told the canons of Compiègne. Oral and written transmissions of memory in the Genealogia dictata a Karolo rege, in: Steven Vanderputten (ed.), Understanding monastic practices of oral communication (Western Europe, tenth-thirteenth centuries) (Utrecht studies in medieval literacy, 21), Turnhout 2011, 151-181.

Koziol, Geoffrey, The politics of memory and identity in Carolingian royal diplomas. The West Frankish kingdom (840-987) (Utrecht studies in medieval literacy, 19), Turnhout 2012.

Krah, Adelheid, Herrschaft und Konflikt in karolingischer und ottonischer Zeit, in: Gerhard Dilcher (ed.), Leges - Gentes - Regna. Zur Rolle von germanischen Rechtsgewohnheiten und lateinischer Schriftkultur bei der Ausbildung der frühmittelalterlichen Rechtskultur, Berlin 2006, 321-332.

Labande, Edmond-René, L' historiographie de la France de l'ouest aux Xe et XIe siècles, in: La storiografia altomedievale (Settimane di studio del Centro italiano di studi sull'alto medioevo, 17), Spoleto 1970, 751-791.

Ladner, Gerhart B., Aspects of medieval thought on church and state, in: The review of politics 9 (1947), 403-422. Reprinted in: Gerhart B. Ladner, Images and ideas in the middle ages. Selected studies in history and art, vol. 2, Rome 1983, 435-456.

Lagroye, Jacques, Sociologie politique, Paris 1991.

Lauer, Philippe, Robert Ier et Raoul de Bourgogne rois de France 923-936, Paris 1910.

Lauranson-Rosaz, Christian, L'Auvergne et ses marges (Velay, Gévaudan) du VIIIe au XIe siècle. La fin du monde antique? Le Puy-en-Velay 1987. 
Lauranson-Rosaz, Christian, Le roi et les grands dans l'Aquitaine carolingienne, in: Régine Le Jan (ed.), La royauté et les élites dans l'Europe carolingienne (début IXe siècle aux environs de 920) (Collection Histoire et littérature régionales, 17), Villeneuve d'Ascq 1998, 409-436.

Lauranson-Rosaz, Christian, Les Guillelmides. Une famille de l'aristocratie d'empire carolingienne dans le Midi de la Gaule (VIIIe-Xe siècles), in: Laurent Macé (ed.), Entre histoire et épopée. Les Guillaume d'Orange (IXe-XIIIe siècles). Actes du colloque international organisé par FRAMESPA (UMR 5136) les 29 et 30 octobre 2004, Toulouse 2006, 45-84.

Lauranson-Rosaz, Christian, Francia Occidentalis et Francia Media au deuxième age carolingien, in: Michèle Gaillard, Michel Margue, Alain Dierkens and Hérold Pettiau (eds.), De la mer du Nord à la Méditerranée. Francia Media. Une région au coeur de l'Europe (c. 840-c. 1050), Luxembourg 2011, 315-338.

Lautmann, Rüdiger, Handlungsspielaum, in: Werner Fuchs-Heinritz (ed.), Lexikon zur Soziologie, 5th ed., Wiesbaden 2011, 271.

Lazega, Emmanuel, Appropriateness and structure in organizations. Secondary socialization through dyamics of advice networks and weak culture, in: Contemporary perspectives on organizational social networks. Research in the sociology of organizations 40 (2014), 381-402.

Le Jan, Régine, Famille et pouvoir dans le monde franc (VIIe-Xe siècle). Essai d'anthropologie sociale (Publications de la Sorbonne. Série Histoire ancienne et médiévale, 33), Paris 1995.

Le Jan, Régine, L'aristocratie Lotharingienne. Structure interne et conscience politique, in: Hans-Walter Herrmann and Reinhard Schneider (eds.), Lotharingia. Eine europäische Kernlandschaft um das Jahr 1000. Referate eines Kolloquiums vom 24. bis 26. Mai 1994 in Saarbrücken (Veröffentlichungen der Kommission für Saarländische Landesgeschichte und Volksforschung, 26), Saarbrücken 1995, 71-88.

Le Jan, Régine, Justice royale et pratiques sociales dans le royaume franc au IXe siècle, in: La giustizia nell'alto medioevo, secoli IX-XI (Settimane di studio del Centro italiano di studi sull'alto medioevo, 44), Spoleto 1997, 47-90.

Le Jan, Régine, Introduction, in: Régine Le Jan (ed.), La royauté et les élites dans l'Europe carolingienne (début IXe siècle aux environs de 920) (Collection Histoire et littérature régionales, 17), Villeneuve d'Ascq 1998, 7-16.

Le Jan, Régine, Douaires et pouvoirs des reines en Francie et en Germanie (VIe-Xe siècle), in: Régine Le Jan, Laurent Feller and François Bougard (eds.), Dots et douaires dans le haut Moyen Âge. Actes de la table ronde "Morgengabe, dos, tertia... et les autres..." réunie à Lille et Valenciennes les 2, 3 et 4 mars 2000 (Collection de l'École Française de Rome, 295), Rome 2002, 457-498.

Le Jan, Régine, Le royaume Franc vers 900. Un pouvoir en mutation? In: Pierre Bauduin (ed.), Les fondations scandinaves en Occident et les débuts du duché de Normandie. Actes du colloque de Cerisy-la-Salle (25-29 septembre 2002), Caen 2005, 83-96.

Le Jan, Régine, Élites et revoltes à l'époque carolingienne. Crise des élites ou crise des modèles? In: François Bougard, Laurent Feller and Régine Le Jan (eds.), Les élites au haut Moyen Âge. Crises et renouvellements (Collection Haut Moyen Âge, 1), Turnhout 2006, 403-424.

Le Jan, Régine, Histoire carolingienne et sciences sociales. Quelques perspectives, in: Wojciech Falkowski and Yves Sassier (eds.), Le monde carolingien. Bilan, perspectives, champs de recherches. Actes du colloque international de Poitiers, Centre d'Études 
supérieures de Civilisation médiévale, 18-20 novembre 2004 (Culture et société médiévales, 18), Turnhout 2009, 301-322.

Le Jan, Régine, Les élites carolingiennes et le roi au milieu du IXe siècle. Statut et fidélité, in: Matthias Becher and Stefanie Dick (eds.), Völker, Reiche und Namen im frühen Mittelalter (Mittelalterstudien, 22), Munich 2010, 335-346.

Le Maho, Jacques, Les premières installations normandes dans la basse vallée de la Seine, fin du IXe siècle, in: Anne-Marie Flambard Héricher (ed.), La progression des Vikings, des raids à la colonisation (Publications de l'Université de Rouen, 334/Cahiers du GRHIS, 14), Mont-Saint-Aignan 2003, 153-170.

Le Maho, Jacques, La Seine et les Normands avant 911, in: Michel Pierre (ed.), Naissance de la Normandie. 911. Le traité de Saint-Clair-sur-Epte. 1100e anniversaire, Paris 2013, 19-34.

Lebecq, Stéphane, Les Vikings dans le Nord de la France, la bataille de Saucourt-en-Vimeu (3 août 881) et le Ludwigslied, in: Elisabeth Ridel (ed.), Les Vikings dans l'Empire franc. Impact, héritage, imaginaire (Héritages vikings, 4), Bayeux 2014, 28-32.

Lechner, Johann, Verlorene Urkunden, in: Johann Friedrich Böhmer, Engelbert Mühlbacher and Johann Lechner, Regesta Imperii I. Die Regesten des Kaiserreiches unter den Karolingern 751-918, Innsbruck 1908, 839-873.

Lecouteux, Stéphane, Le contexte de rédaction des 'Annales' de Flodoard de Reims (919-966) 1. Une relecture critique du début des 'Annales' à la lumière de travaux récents, in: Le Moyen Âge 116 (2010), 51-121.

Lecouteux, Stéphane, Le contexte de rédaction des 'Annales' de Flodoard de Reims (919-966) 2. Présentation des résultats de la relecture critique du début des 'Annales', in: Le Moyen Âge 116 (2010), 283-318.

Leistenschneider, Eva, Die französische Königsgrablege Saint-Denis. Strategien monarchischer Repräsentation 1223-1461, Weimar 2008.

Lemercier, Claire, Taking time seriously. How do we deal with change in historical networks? In: Markus Gamper, Linda Reschke and Marten Düring (eds.), Knoten und Kanten III. Soziale Netzwerkanalyse in Geschichts- und Politikforschung, Bielefeld 2015, 183-211.

Lévêque, Pierre, Trois actes faux ou interpolés des comtes Eudes et Robert et du roi Raoul en faveur de l'abbaye de Marmoutier, in: Bibliothèque de l'École des Chartes 64 (1903), 54-82 and 289-305.

Levillain, Léon, L'Abbé Ebles, chancelier du roi Eudes, in: La Correspondance historique et archéologique. Organe d'informations mutuelles entre historiens et archéologues 9 (1902), 359-371.

Levillain, Léon, Essai sur le comte Eudes, fils de Harduin et de Guérinbourg. 845-871, in: Le Moyen Âge 47 (1937), 153-182 and 233-271.

Lewis, Archibald R., The development of southern French and Catalan society, 718-1050, Austin 1965.

Leyser, Karl J., Early medieval warfare, in: Janet Cooper (ed.), The battle of Maldon. Fiction and fact, London 1993, 87-108. Reprinted in: Karl J. Leyser and Timothy Reuter (eds.), Communications and power in the middle ages, vol. 1. The Carolingian and Ottonian centuries, London 1994, 29-50.

Lifshitz, Felice, Dudo's historical narrative and the Norman succession of 996, in: Journal of medieval history 20 (1994), 101-120.

Lößlein, Horst, Les ressources en compétition les conflits concernant Saint-Vaast et Saint-Servais de Maastricht entre les grands et Charles III "le Simple", in: Geneviève 
Bührer-Thierry, Régine Le Jan and Vito Loré (eds.), Acquérir, prélever, contrôler. Les ressources en compétition (400-1100), Turnhout 2017, 207-226.

Lößlein, Horst, Le diplôme de Charles III le Simple pour l'église Saint-Quentin de Narbonne (7 juillet 919). [In preparation]

Lößlein, Horst, Die Urkunden Karls des Einfältigen. [In preparation]

Lot, Ferdinand, Orson de Beauvais, in: Romania 31 (1902), 577-583.

Lot, Ferdinand, Fidèles ou vassaux? Essai sur la nature juridique du lien qui unissait les grands vassaux à la royauté depuis le milieu du IXe jusqu'à la fin du XIIe siècle, Paris 1904.

Lot, Ferdinand, Notes historiques sur “Aye d'Avignon”, in: Romania 33 (1904), 145-162.

Lot, Ferdinand, Mélanges carolingiens. Note sur le sénéchal Alard, in: Le Moyen Âge 21 (1908), 185-201.

Lot, Ferdinand, La Loire, l'Aquitaine et la Seine de 862 à 866 . Robert le Fort, in: Bibliothèque de l'Ecole des Chartes 76 (1915), 473-510. Reprinted in: Ferdinand Lot, Recueil des travaux historiques II (École Pratique des Hautes Études, Sciences Historiques et Philologiques, 5,7), Geneva 1970, 781-818, DOI: https://doi.org/10.3406/bec.1915.448548 (accessed 25.09.2018).

Löwe, Heinz, Hinkmar von Reims und der Apocrisiar. Beiträge zur Interpretation von "De ordine palatii", in: Festschrift für Hermann Heimpel zum 70. Geburtstag am 19. September 1971, vol. 3, Göttingen 1972, 197-225.

Ludwig, Uwe, Krise des Karolingerreiches und Gebetsgedenken. Anmerkungen zum Problem der "Großen Personengruppen" in den frühmittelalterlichen libri vitae, in: François Bougard, Laurent Feller and Régine Le Jan (eds.), Les élites au haut Moyen Âge. Crises et renouvellements (Collection Haut Moyen Âge, 1), Turnhout 2006, 439-456.

Lugge, Margret, "Gallia" und "Francia" im Mittelalter. Untersuchungen über den Zusammenhang zwischen geographisch-historischer Terminologie und politischem Denken vom 6.-15. Jahrhundert (Bonner historische Forschungen, 15), Bonn 1960.

Luhmann, Niklas, Familiarity, confidence, trust. Problems and alternatives, in: Diego Gambetta (ed.), Trust. Making and breaking cooperative relations, Oxford 2000, 94-107.

Luhmann, Niklas, Vertrauen. Ein Mechanismus der Reduktion sozialer Komplexität, 4th ed., Stuttgart 2009.

Lund, Niels, Allies of God or man. The Viking expansion in a European perspective, in: Viator 20 (1989), 45-59.

Lüttich, Rudolf, Ungarnzüge in Europa im 10. Jahrhundert, Berlin 1910.

Lynch, Joseph H., Godparents and kinship in early medieval Europe, Princeton 1986.

MacLean, Simon, Charles the Fat and the Viking Great Army. The military explanation for the end of the Carolingian empire, in: War Studies Journal 3 (1998), 74-95.

MacLean, Simon, The Carolingian response to the revolt of Boso, 879-887, in: Early medieval Europe 10 (2001), 21-48.

MacLean, Simon, Kingship and politics in the late ninth century. Charles the Fat and the end of the Carolingian empire (Cambridge studies in medieval life and thought, 4, 57), Cambridge 2003.

MacLean, Simon, Making a difference in tenth-century politics. King Athelstan's sisters and Frankish queenship, in: Paul J. Fouracre and David Ganz (eds.), Frankland. The Franks and the world of the early middle ages. Essays in honour of Dame Jinty Nelson, Manchester 2008, 167-190.

MacLean, Simon, History and politics in late Carolingian and Ottonian Europe. The chronicle of Regino of Prüm and Adalbert of Magdeburg, Manchester 2009. 
MacLean, Simon, Legislation and politics in late Carolingian Italy. The Ravenna constitutions, in: Early medieval Europe 18 (2010), 394-416.

MacLean, Simon, Cross-Channel marriage and royal succession in the age of Charles the Simple and Athelstan (c. 916-936), in: Medieval worlds 1/2 (2015), 26-44.

Magnou-Nortier, Elisabeth, La société laïque et l'église dans la province ecclésiastique de Narbonne (zone cispyrénéenne) de la fin du VIIIe à la fin du XIe siècle, Toulouse 1974.

March, James and Johan Olsen, Rediscovering institutions, New York 1989.

March, James and Johan Olsen, The logic of appropriateness, in: Robert Goodin (ed.), The Oxford handbook of political science, Oxford 2009, 478-497.

Margue, Michel, "Nous ne sommes ni de l'une, ni de l'autre, mais les deux la fois." Entre France et Germanie, les identités lotharingiennes en question (fin IXe-milieu XIe siècle), in: Michèle Gaillard, Michel Margue, Alain Dierkens and Hérold Pettiau (eds.), De la mer du Nord à la Méditerranée. Francia Media. Une région au coeur de l'Europe (c. 840-c. 1050), Luxembourg 2011, 395-428.

Martindale, Jane, Charles the Bald and the government of the kingdom of Aquitaine, in: Margaret T. Gibson and Janet L. Nelson (eds.), Charles the Bald. Court and kingdom. Papers based on a colloquium held in London in April 1979, Oxford 1981, 109-135. Reprinted in: Jane Martindale, Status, authority and regional power. Aquitaine and France, 9th to 12th centuries, Aldershot 1997, 109-135.

Martindale, Jane, The Kingdom of Aquitaine and the "Dissolution of the Carolingian Fisc", in: Francia. Forschungen zur westeuropäischen Geschichte 11 (1983), 131-192, URL: http://francia.digitale-sammlungen.de/Blatt_bsb00016286,00145.html (accessed 22.06.2018). Reprinted in: Jane Martindale, Status, authority and regional power. Aquitaine and France, 9th to 12th centuries, Aldershot 1997, 131-192.

Marzano, Michela, Qu'est-ce que la confiance? In: Études 412/1 (2010), 53-63, URL: https:// www.cairn.info/revue-etudes-2010-1-page-53.htm (accessed 05.07.2018).

McCarthy, Margaret, Hincmar's influence during Louis the Stammerer's reign, in: Rachel Stone and Charles West (eds.), Hincmar of Rheims. Life and work, Manchester 2015, $110-128$.

McKitterick, Rosamond, The Carolingian kings and the see of Rheims, 882-987, in: Patrick C. Wormald, Donald A. Bullough and Roger Collins (eds.), Ideal and reality in Frankish and Anglo-Saxon society. Studies presented to J. M. Wallace-Hadrill, Oxford 1983, 228-249. Reprinted in: Rosamond McKitterick, The Frankish kings and culture in the early middle ages, Aldershot 1995, part IV, 228-249.

McKitterick, Rosamond, The Frankish kingdoms under the Carolingians 751-987, London 1983.

McKitterick, Rosamond, Zur Herstellung von Kapitularien. Die Arbeit des LegesSkriptoriums, in: Mitteilungen des Instituts für Österreichische Geschichtsforschung 101 (1993), 3-16.

McKitterick, Rosamond, Charlemagne. The formation of a European identity, Cambridge 2008.

McLeod, Shane, The beginning of Scandinavian settlement in England. The Viking 'Great Army' and early settlers, c. 865-900, Turnhout 2014.

McNair, Fraser, The development of territorial principalities between the Loire and the Scheldt, 893-996, Cambridge 2015 (unpublished PhD thesis).

McNair, Fraser, The politics of being Norman in the reign of Richard the Fearless, Duke of Normandy (r. 942-996), in: Early medieval Europe 23 (2015), 308-328, DOI: https:// doi.org/10.1111/emed.12106 (accessed 22.06.2018). 
McNair, Fraser, Vikings and Bretons? The language of factional politics in late Carolingian Brittany, in: Viking and Medival Scandinavia 11 (2015), 183-202.

Merlet, René, Origine de la famille des Bérenger, comtes de Rennes et ducs de Bretagne, in: Mélanges d'histoire offerts à Ferdinand Lot, Paris 1925, 549-561.

Mersiowsky, Mark, Towards a reappraisal of Carolingian sovereign charters, in: Karl J. Heidecker (ed.), Charters and the use of the written word in medieval society (Utrecht studies in medieval literacy, 5), Turnhout 2000, 15-25.

Mersiowsky, Mark, Die Urkunde in der Karolingerzeit. Originale, Urkundenpraxis und politische Kommunikation (Schriften der MGH, 60), 2 vols., Wiesbaden 2015.

Merta, Brigitte, Laien als Empfänger von Königsurkunden des früheren Mittelalters Aspekte und Überlegungen, in: Mitteilungen des Instituts für Österreichische Geschichtsforschung 117 (2009), 245-271.

Merta, Brigitte, ... auctoritate nostra firmiter praecipimus ... in: Mitteilungen des Instituts für Österreichische Geschichtsforschung 123 (2015), 299-316.

Mestdagh, Marcel, De Vikingen bij ons. Het Grote Leger (879-892) in België en Frankrijk, Gent 1989.

Metz, Wolfgang, DaskarolingischeReichsgut.Eineverfassungs- undverwaltungsgeschichtliche Untersuchung, Berlin 1960.

Misonne, Daniel, Le diplôme de Charles le Simple accordant l'immunité à l'abbaye de Brogne, in: Revue bénédictine 73 (1963), 56-72.

Misonne, Daniel, Gérard de Brogne moine et réformateur (†959), in: Revue bénédictine 111 (2001), 25-49.

Mohr, Andreas, Das Wissen über die Anderen. Zur Darstellung fremder Völker in den fränkischen Quellen der Karolingerzeit (Studien und Texte zum Mittelalter und zur frühen Neuzeit, 7), Münster and Munich 2005.

Mohr, Walter, Geschichte des Herzogtums Lothringen I. Geschichte des Herzogtums Groß-Lothringen (900-1048), Trier 1974.

Mordek, Hubert, Karolingische Kapitularien, in: Überlieferung und Geltung normativer Texte des frühen und hohen Mittelalters. Vier Vorträge, gehalten auf dem 35. Deutschen Historikertag 1984 in Berlin (Quellen und Forschungen zum Recht im Mittelalter, 4), Sigmaringen 1986, 25-50.

Musset, Lucien, Les invasions. Les vagues germaniques, Paris 1965.

Musset, Lucien, Considérations sur la genèse et le tracé des frontières de la Normandie, in: Media in Francia. Recueil de mélanges offert à Karl Ferdinand Werner à l'occasion de son 65e anniversaire par ses amis et collègues français, Maulévrier 1989, 309-318. Reprinted in: Lucien Musset, Nordica et Normannica. Recueil d'études sur la Scandinavie ancienne et médiévale. Les expéditions des Vikings et la fondation de la Normandie, Paris 1997, 403-413.

Musset, Lucien, L'origine de Rollo, in: Lucien Musset, Nordica et Normannica. Recueil d'études sur la Scandinavie ancienne et médiévale, les expéditions des Vikings et la fondation de la Normandie, Paris 1997, 383-387.

Neifeind, Harald, Verträge zwischen Normannen und Franken im neunten und zehnten Jahrhundert, Heidelberg 1971.

Nelson, Janet L., The annals of St. Bertin, in: David Ganz, Margaret T. Gibson and Janet L. Nelson (eds.), Charles the Bald. Court and kingdom. Papers based on a colloquium held in London in april 1979, Oxford 1981, 15-39.

Nelson, Janet L., Dispute settlement in Carolingian West Frankia, in: Wendy Davies and Paul J. Fouracre (eds.), The settlement of disputes in early medieval Europe, Cambridge 
1986, 45-64. Reprinted in: Janet L. Nelson, The Frankish World 750-900, London 1996, $51-74$.

Nelson, Janet L., Hincmar of Rheims on king-making. The evidence of the annals of St. Bertin, 861-882, in: János M. Bak (ed.), Coronations. Medieval and early modern monarchic ritual, Berkeley 1990, 16-34. Reprinted in: Janet L. Nelson, Rulers and ruling families in early medieval Europe. Alfred, Charles the Bald and others, Ashgate 1999, part XVII, 16-34.

Nelson, Janet L. (ed.), The annals of St-Bertin, Manchester 1991.

Nelson, Janet L., Charles the Bald, London 1992.

Nelson, Janet L., Kingship and royal government, in: Rosamond McKitterick (ed.), The new Cambridge medieval history, vol. 2, Cambridge 1995, 383-430.

Nelson, Janet L., La mort de Charles le Chauve, in: Médiévales 31 (1996), 53-66.

Nelson, Janet L., Early medieval rites of queen-making and the shaping of medieval queenship, in: Anne J. Duggan (ed.), Queens and queenship in medieval Europe. Proceedings of a conference held at King's College London, April 1995, Woodbridge 1997, 301-315. Reprinted in: Janet L Nelson, Rulers and ruling families in early medieval Europe. Alfred, Charles the Bald and others, Ashgate 1999, part XV, 301-315.

Nelson, Janet L., Making a difference in eighth-century politics. The daughters of Desiderius, in: Alexander C. Murray (ed.), After Rome's fall. Narrators and sources of early medieval history. Essays presented to Walter Goffart, Toronto 1998, 171-190. Reprinted in: Janet L. Nelson, Courts, elites, and gendered power in the early middle ages. Charlemagne and others, Aldershot 2007, part X, 171-190.

Nelson, Janet L., Medieval queenship, in: Linda E. Mitchell (ed.), Women in medieval western European culture, New York 1999, 179-207.

Nelson, Janet L., Eadgifu (d. in or after 951), in: Oxford Dictionary of National Biography, Oxford 2004, URL: http://www.oxforddnb.com.odnb.emedial.bsb-muenchen.de/view/ article/39220 (accessed 28.10.2016)

Nelson, Janet L., Bad kingship in the earlier middle ages, in: The Haskins Society Journal 8 (1996), 1-26. Reprinted in: Janet L. Nelson, Courts, elites, and gendered power in the early middle ages. Charlemagne and others, Aldershot 2007, part VIII, 1-26.

Nelson, Janet L., How Carolingians created consensus, in: Wojciech Falkowski and Yves Sassier (eds.), Le monde carolingien. Bilan, perspectives, champs de recherches. Actes du colloque international de Poitiers, Centre d'Études supérieures de Civilisation médiévale, 18-20 novembre 2004 (Culture et société médiévales, 18), Turnhout 2009, 67-82.

Nelson, Janet L., Normandy's early history since Normandy before 1066, in: David J. Crouch and Kathleen H. Thompson (eds.), Normandy and its neighbours, 900-1250. Essays for David Bates, Turnhout 2011, 3-15.

Neveux, François, La Normandie des ducs aux rois. Xe-XIIe siècles, Rennes 1998.

Nightingale, John B. W., Monasteries and patrons in the Gorze reform. Lotharingia c. 850-1000, Oxford 2001.

Nitschke, Christian and Christian Rollinger, "Network analysis is performed." Die Analyse sozialer Netzwerke in den Altertumswissenschaften. Rückschau und aktuelle Forschungen, in: Markus Gamper, Linda Reschke and Marten Düring (eds.), Knoten und Kanten III. Soziale Netzwerkanalyse in Geschichts- und Politikforschung, Bielefeld 2015, 213-259.

Noizet, Hélène, Pratiques spatiales, représentations de la ville et fabrique urbaine de Tours du IXe au XIIIe siècle. Chanoines, moines et laïcs à Saint-Martin et Saint-Julien, Université de Tours 2003 (PhD thesis). 
Noizet, Hélène, Les chanoines de Saint-Martin de Tours et les Vikings, in: Pierre Bauduin (ed.), Les fondations scandinaves en Occident et les débuts du duché de Normandie. Actes du colloque de Cerisy-la-Salle (25-29 septembre 2002), Caen 2005, 53-66.

Nonn, Ulrich, Die gefälschte Urkunde des Grafen Widerich für das Kloster Hastière und die Vorfahren der Grafen von Luxemburg, in: Rheinische Vierteljahrsblätter 42 (1978), $52-62$.

Oexle, Otto Gerhard, Die Karolinger und die Stadt des hl. Arnulf, in: Frühmittelalterliche Studien 1 (1967), 250-364.

Oexle, Otto Gerhard, Bischof Ebroin von Poitiers und seine Verwandten, in: Frühmittelalterliche Studien 3 (1969), 138-210.

Offergeld, Thilo, Reges pueri. Das Königtum Minderjähriger im frühen Mittelalter (Schriften der MGH, 50), Hanover 2001.

Orren, Karen and Stephen Skowronek, Beyond the iconography of order. Notes for a "new" institutionalism, in: Lawrence C. Dood and Calvin Jillson (eds.), The dynamics of American politics. Approaches and interpretations, Boulder 1994, 311-330.

Oudart, Hervé, Le roi franc et l'idée de justice aux époques mérovingienne et carolingienne, in: Wojciech Falkowski and Yves Sassier (eds.), Le monde carolingien. Bilan, perspectives, champs de recherches. Actes du colloque international de Poitiers, Centre d'Études supérieures de Civilisation médiévale, 18-20 novembre 2004 (Culture et société médiévales, 18), Turnhout 2009, 31-66.

Parisot, Robert, Le royaume de Lorraine sous les Carolingiens (843-923), Paris 1898 (reprinted Geneva 1975).

Parisse, Michel, Généalogie de la Maison d'Ardenne, in: La maison d'Ardenne Xe-XIe siècles. Actes des Journées Lotharingiennes, 24-26 oct. 1980, Centre Univ. Luxembourg, Luxembourg 1981, 9-41.

Parisse, Michel, In media Francia. Saint-Mihiel, Salonnes et Saint-Denis (VIIIe-XIIe siècles), in: Media in Francia. Recueil de mélanges offert à Karl Ferdinand Werner à l'occasion de son 65e anniversaire par ses amis et collègues français, Maulévrier 1989, 319-343.

Parisse, Michel, La Lotharingie. Naissance d'un espace politique, in: Hans-Walter Herrmann and Reinhard Schneider (eds.), Lotharingia. Eine europäische Kernlandschaft um das Jahr 1000. Referate eines Kolloquiums vom 24. bis 26. Mai 1994 in Saarbrücken, Saarbrücken 1995, 31-48.

Parisse, Michel, Lotharingia, in: Timothy Reuter (ed.), The new Cambridge medieval history, vol. 3, Cambridge 1999, 319-327.

Patzold, Steffen, Konflikte als Thema in der modernen Mediävistik, in: Hans-Werner Goetz (ed.), Moderne Mediävistik. Stand und Perspektiven der Mittelalterforschung, Darmstadt 1999, 198-205.

Patzold, Steffen, “...inter pagensium nostrorum gladios vivimus". Zu den "Spielregeln" der Konfliktführung in Niederlothringen zur Zeit der Ottonen und frühen Salier, in: Zeitschrift der Savigny-Stiftung für Rechtsgeschichte. Germanistische Abteilung 118 (2001), 58-99.

Patzold, Steffen, Konsens und Konkurrenz. Überlegungen $\mathrm{zu}$ einem aktuellen Forschungskonzept der Mediävistik, in: Frühmittelalterliche Studien 41 (2007), 75-103.

Patzold, Steffen, Normen im Buch. Überlegungen zu Geltungsansprüchen so genannter 'Kapitularien', in: Frühmittelalterliche Studien 41 (2007), 331-350.

Patzold, Steffen, Episcopus. Wissen über Bischöfe im Frankreich des späten 8. bis frühen 10. Jahrhunderts (Mittelalter-Forschungen, 25), Ostfildern 2008. 
Pfister, Christian, L'archevêque de Metz Drogon (823-856), in: Mélanges Paul Fabre. Études d'histoire du Moyen Âge, Paris 1902, 101-145.

Pierre, Michel (ed.), Naissance de la Normandie. 911. Le traité de Saint-Clair-sur-Epte. 1100e anniversaire (Kronos, 69), Paris 2013.

Plassmann, Alheydis, Die Normannen. Erobern - herrschen - integrieren, Stuttgart 2008.

Plassmann, Alheydis, Die Wirkmächtigkeit von Feindbildern. Die Wikinger in den fränkischen und westfränkischen Quellen, in: Kerstin Hofmann, Hermann Kamp and Matthias Wemhoff (eds.), Die Wikinger und das Fränkische Reich. Identitäten zwischen Konfrontation und Annäherung, Paderborn 2014, 61-83.

Platelle, Henri, Le temporel de l'abbaye de Saint-Amand des origines à 1340, Paris 1962.

Poguntke, Anne, Handlungsspielräume (ost-)römischer Heermeister um 500, in: Mischa Meier and Steffen Patzold (eds.), Chlodwigs Welt. Organisation von Herrschaft um 500, Stuttgart 2014, 397-422.

Pohl, Benjamin, Dudo of Saint-Quentin's Historia Normannorum. Tradition, innovation and memory, Woodbridge 2015.

Pokorny, Rudolf, Ein unerkanntes Brieffragment Argrins von Lyon-Langres aus den Jahren 894/95 und zwei umstrittene Bischofsweihen in der Kirchenprovinz Lyon, in: Francia. Forschungen zur westeuropäischen Geschichte 13 (1985), 602-622, URL: http://francia. digitale-sammlungen.de/Blatt_bsb00016288,00618.html (accessed 22.06.2018).

Pössel, Christina, Authors and recipients of Carolingian capitularies, 779-829, in: Richard Corradini, Rob Mees, Christina Pössel and Philip Shaw (eds.), Texts and identities in the early middle ages (Forschungen zur Geschichte des Mittelalters, 13), Vienna 2006, 253-276.

Poupardin, René, Note sur Ebles, abbé de Saint-Denis, au temps du roi Eudes, in: Achille Luchaire (ed.), Mélanges d'histoire du moyen âge, Paris 1897, 93-98.

Poupardin, René, Le royaume de Provence sous les Carolingiens 855-933, Paris 1901.

Preiser-Kapeller, Johannes, Calculating the middle ages? The project "Complexities and networks in the medieval Mediterranean and the Near East" (COMMED), in: Medieval worlds 2 (2015), 100-127.

Prell, Jan Hendrik, Comtes, vicomtes et noblesse au Nord de l'Aquitaine aux Xe-XIe siècles. Études prosopographiques, historiques et constitutionnelles sur le Poitou, l'Aunis et la Saintonge (Prosopographica et genealogica, 6), Oxford 2012.

Prentout, Henri, Étude critique sur Dudon de Saint-Quentin et son histoire des premiers ducs normands, Paris 1916.

Prinz, Friedrich, Klerus und Krieg im frühen Mittelalter. Untersuchungen zur Rolle der Kirche beim Aufbau der Königsherrschaft (Monographien zur Geschichte des Mittelalters, 2), Stuttgart 1971.

Putnam, Robert D., Bowling alone. The collapse and revival of American community, New York 2000.

Quaghebeur, Joëlle, Norvège et Bretagne aux IXe et Xe siècles. Un destin partagé, in: Pierre Bauduin (ed.), Les fondations scandinaves en Occident et les débuts du duché de Normandie. Actes du colloque de Cerisy-la-Salle (25-29 septembre 2002), Caen 2005, 113-131.

Rau, Reinhold (ed.), Quellen zur karolingischen Reichsgeschichte, Zweiter Teil, Jahrbücher von St. Bertin, Jahrbücher von St. Vaast, Xantener Jahrbücher (Ausgewählte Quellen zur Deutschen Geschichte des Mittelalters. Freiherr vom Stein-Gedächtnisausgabe, 4), Darmstadt 1972. 
Ravaux, Jean-Pierre, Les évêques de Châlons des origines à 1789, in: Mémoires de la S.A.C.S.A.M. 98 (1983), 49-121.

Reemtsma, Jan Philipp, Vertrauen und Gewalt. Versuch über eine besondere Konstellation der Moderne, Hamburg 2008.

Reinke, Martina, Die Reisegeschwindigkeit des deutschen Königshofes im 11. und 12. Jahrhundert nördlich der Alpen, in: Blätter für deutsche Landesgeschichte 123 (1987), 225-251.

Remensnyder, Amy G., Remembering kings past. Monastic foundation legends in medieval Southern France, Ithaca 1995.

Renaud, Jean, Les Vikings et la Normandie, Paris 1989.

Renn, Heinz, Das erste Luxemburger Grafenhaus (963-1136) (Rheinisches Archiv, 39), Bonn 1941.

Renoux, Annie, Architecture, pouvoir et représentation en milieu royal et princier dans la France du nord aux Xe et XIe siècle, in: Caspar Ehlers, Jörg Jarnut and Matthias Wemhoff (eds.), Deutsche Königspfalzen. Beiträge zu ihrer historischen und archäologischen Erforschung 7. Zentren herrschaftlicher Repräsentation im Hochmittelalter. Geschichte, Architektur und Zeremoniell, Göttingen 2007, 25-68.

Resch, Karoline, Die Freiheit des Feldherrn. Der Handlungsspielraum römischer Feldherren. 218-133 v. Chr., Vienna 2010.

Reuter, Timothy, Plunder and tribute in the Carolingian empire, in: Transactions of the Royal Historical Society (Ser. 5) 35 (1985), 75-94. Reprinted in: Timothy Reuter and Janet L. Nelson (eds.), Medieval polities and modern mentalities, Cambridge 2006, 231-250.

Reuter, Timothy (ed.), The annals of Fulda (Manchester medieval sources series, 2), Manchester 1992.

Reynolds, Susan, Trust in medieval society and politics, in: Susan Reynolds (ed.), The middle ages without feudalism. Essays in criticism and comparison on the medieval West, Farnham 2012, part XIII, 1-15.

Riché, Pierre, Les Carolingiens. Une famille qui fit l'Europe, Paris 1983.

Robbie, Steven, The emergence of regional polities in Burgundy and Alemannia c. 888-940. A comparative assessment, University of St Andrews 2011 (unpublished $\mathrm{PhD}$ thesis).

Rosé, Isabelle, Reconstitution, représentation graphique et analyse des réseaux de pouvoir au haut Moyen Âge. Approche des pratiques sociales de l'aristocratie, à partir de l'exemple d'Odon de Cluny († 942), in: Redes, Redes sociales e Historia 21 (2011), 199-272, DOI: https://doi.org/10.5565/rev/redes.420 (accessed 22.06.2018).

Rosenwein, Barbara H., The family politics of Berengar I, king of Italy 888-924, in: Speculum 71 (1996), 247-289.

Saint-Phalle, Edouard de, Comtes de Troyes et de Poitiers au IXe siècle. Histoire d'un double échec, in: Katharine S. B. Keats-Rohan and Christian Settipani (eds.), Onomastique et Parenté dans l'Occident médiéval (Prosopographica et genealogica, 3), Oxford 2000, 154-170.

Sassier, Yves, Recherches sur le pouvoir comtal en Auxerrois du Xe au début du XIIIe siècle (Cahiers d'archéologie et d'histoire, 5), Paris 1980.

Sassier, Yves, Hugues Capet. Naissance d'une dynastie, Paris 1987.

Sassier, Yves, Auctoritas pontificum et potestas regia. Faut-il tenir pour négligeable l'influence de la doctrine gélasienne aux temps carolingiens? In: Claude Carozzi and Huguette Taviani-Carozzi (eds.), Le pouvoir au Moyen Âge. Idéologies, pratiques, représentations, Aix-en-Provence 2005, 213-236. 
Sassier, Yves, Royauté et idéologie au Moyen Âge. Bas-Empire, monde franc, France (IVeXIIe siècle), Paris 2012.

Sattler, Thomas and Stefanie Walter, Wirtschaftspolitischer Handlungsspielraum im Zeitalter der Globalisierung. Eine empirische Untersuchung am Beispiel von Währungskrisen, in: Politische Vierteljahresschrift 49 (2008), 464-490.

Sawyer, Birgit and Peter H. Sawyer, Die Welt der Wikinger, Berlin 2002.

Scharer, Anton, Herrscherurkunden als Selbstzeugnisse? In: Mitteilungen des Instituts für Österreichische Geschichtsforschung 119 (2011), 1-13.

Scharff, Thomas, Gott gnädig stimmen und den Adel im Auge behalten. Die Rolle karolingischer Herrscher im Krieg, in: Martin Clauss, Andrea Stieldorf and Tobias Weller (eds.), Der König als Krieger. Zum Verhältnis von Königtum und Krieg im Mittelalter (Bamberger interdisziplinäre Mittelalterstudien, 5), Bamberg 2015, 265-298.

Schieffer, Rudolf, Bischofserhebungen im westfränkisch-französischen Bereich im späten 9. und 10. Jahrhundert, in: Franz-Reiner Erkens (ed.), Die früh- und hochmittelalterliche Bischofserhebung im europäischen Vergleich (Archiv für Kulturgeschichte Beiheft, 48), Cologne 1998, 59-82.

Schieffer, Rudolf, Die Entstehung des päpstlichen Investiturverbotes für den deutschen König (Schriften der MGH, 28), Stuttgart 1981.

Schieffer, Rudolf, Väter und Söhne im Karolingerhause, in: Rudolf Schieffer (ed.), Beiträge zur Geschichte des Regnum Francorum. Referate beim Wissenschaftlichen Colloquium zum 75. Geburtstag von Eugen Ewig am 28. Mai 1988 (Beihefte der Francia, 22), Sigmaringen 1990, 149-172, URL: http://daten.digitale-sammlungen.de/bsb00026794/ image_1 (accessed 22.06.2018).

Schieffer, Rudolf, Karolingische Töchter, in: Georg Jenal and Stephanie Haarländer (eds.), Herrschaft, Kirche, Kultur. Beiträge zur Geschichte des Mittelalters. Festschrift für Friedrich Prinz zu seinem 65. Geburtstag, Stuttgart 1993, 125-139.

Schieffer, Rudolf, Die Karolinger, 3rd ed., Stuttgart 2006.

Schieffer, Theodor, Die lothringische Kanzlei um 900, in: Deutsches Archiv für Erforschung des Mittelalters 14 (1958), 16-148, Permalink: http://www.digizeitschriften.de/dms/resol veppn/?PID=PPN345858735_0014|log15 (accessed 22.06.2018).

Schieffer, Theodor, Die rheinischen Lande an der Schwelle der deutschen Geschichte, in: Karl Erich Born (ed.), Historische Forschungen und Probleme. Peter Rassow zum 70. Geburtstage dargebracht von Kollegen, Freunden und Schülern, Wiesbaden 1961, $17-31$.

Schmid, Karl, Unerforschte Quellen aus quellenarmer Zeit. Zur amicitia zwischen Heinrich I. und dem westfränkischen König Robert im Jahre 923, in: Francia. Forschungen zur westeuropäischen Geschichte 12 (1984), 119-148, URL: http://francia. digitale-sammlungen.de/Blatt_bsb00016287,00135.html (accessed 22.06.2018).

Schmitz, Gerhard, Das Konzil von Trosly (909). Studien zur Reimser Kirchen- und kirchlichen Rechtsgeschichte, Tübingen 1975 (unpublished $\mathrm{PhD}$ thesis).

Schmitz, Gerhard, Das Konzil von Trosly (909). Überlieferung und Quellen, in: Deutsches Archiv für Erforschung des Mittelalters 33 (1977), 341-434, Permalink: http://resolver. sub.uni-goettingen.de/purl?PPN345858735_0033 (accessed 22.06.2018).

Schmitz, Gerhard, Heriveus von Reims (900-922). Zur Geschichte des Erzbistums Reims am Beginn des 10. Jahrhunderts, in: Francia. Forschungen zur westeuropäischen Geschichte 6 (1978), 59-106, URL: http://francia.digitale-sammlungen.de/Blatt_ bsb00016281,00075.html (accessed 22.06.2018). 
Schmitz, Gerhard, Hinkmar von Reims, die Synode von Fismes 881 und der Streit um das Bistum Beauvais, in: Deutsches Archiv für Erforschung des Mittelalters 35 (1979), 463-486, Permalink: http://resolver.sub.uni-goettingen.de/purl?PPN345858735_0035 (accessed 22.06.2018).

Schneider, Gerhard, Erzbischof Fulco von Reims (883-900) und das Frankenreich (Münchner Beiträge zur Mediävistik und Renaissance-Forschung, 14), Munich 1973.

Schneider, Jens, Les Northmanni en Francie occidentale au IXe siècle. Le chant de Louis, in: Annales de Normandie 53 (2003), 291-315.

Schneider, Jens, Auf der Suche nach dem verlorenen Reich. Lotharingien im 9. und 10. Jahrhundert (Publications du CLUDEM, 30), Cologne 2010.

Schneider, Reinhard, Zur rechtlichen Bedeutung der Kapitularientexte, in: Deutsches Archiv für Erforschung des Mittelalters 23 (1967), 273-294, Permalink: http://www. digizeitschriften.de/dms/resolveppn/?PID=GDZPPN000354465 (accessed 22.06.2018).

Schneider, Reinhard, Schriftlichkeit und Mündlichkeit im Bereich der Kapitularien, in: Peter Classen (ed.), Recht und Schrift im Mittelalter (Vorträge und Forschungen, 23), Sigmaringen 1977, 257-279.

Schneidmüller, Bernd, Die "Einfältigkeit” Karls III. von Westfranken als frühmittelalterliche Herrschertugend. Überlegungen zum Cognomen "simplex", in: Schweizerische Zeitschrift für Geschichte 28 (1978), 62-65.

Schneidmüller, Bernd, Französische Lothringenpolitik im 10. Jahrhundert, in: Jahrbuch für westdeutsche Landesgeschichte 5 (1979), 1-32.

Schneidmüller, Bernd, Karolingische Tradition und frühes französisches Königtum. Untersuchungen zur Herrschaftslegitimation der westfränkisch-französischen Monarchie im 10. Jahrhundert (Frankfurter historische Abhandlungen, 22), Wiesbaden 1979.

Schneidmüller, Bernd, Regnum und Ducatus. Identität und Integration in der lothringischen Geschichte des 9. bis 11. Jahrhunderts, in: Rheinische Vierteljahrsblätter 51 (1987), 81-128.

Schneidmüller, Bernd, Karl III. (893/898-923/929), in: Joachim Ehlers, Heribert Müller and Bernd Schneidmüller (eds.), Die französischen Könige des Mittelalters. Von Odo bis Karl VIII., Munich 1996, 23-35.

Schneidmüller, Bernd, Konsensuale Herrschaft. Ein Essay über Formen und Konzepte politischer Ordnung im Mittelalter, in: Paul-Joachim Heinig, Sigrid Jahns, HansJoachim Schmidt, Rainer Christoph Schwinges and Sabine Wefers (eds.), Reich, Regionen und Europa in Mittelalter und Neuzeit. Festschrift für Peter Moraw, Berlin 2000, 53-87.

Schramm, Percy E., Die Krönung bei den Westfranken und Angelsachsen vor 878 bis um 1000, in: Zeitschrift der Savigny-Stiftung für Rechtsgeschichte. Kanonistische Abteilung 23 (1934), 117-242.

Schramm, Percy E., Der König von Frankreich. Das Wesen der Monarchie vom 9. zum 16. Jahrhundert. Ein Kapitel aus der Geschichte des abendländischen Staates, 2nd ed., Munich 1960.

Schröder, Isolde, Die westfränkischen Synoden von 888 bis 987 und ihre Überlieferung (Hilfsmittel der MGH, 3), Munich 1980.

Schrörs, Heinrich, Hinkmar Erzbischof von Reims. Sein Leben und seine Schriften, Freiburg 1884.

Schwager, Helmut, Graf Heribert II. von Soissons, Omois, Meaux, Madrie sowie Vermandois (900/906-943) und die Francia (Nord-Frankreich) in der 1. Hälfte des 10. Jahrhunderts 
(Münchner Historische Studien. Abteilung Mittelalterliche Geschichte, 6), Kallmünz i. d. Oberpfalz 1994.

Scior, Volker, Das offene Ohr des Herrschers. Vorstellungen über den Zugang zum König in der Karolingerzeit, in: Steffen Patzold, Anja Rathmann-Lutz and Volker Scior (eds.), Geschichtsvorstellungen. Bilder, Texte und Begriffe aus dem Mittelalter. Festschrift für Hans-Werner Goetz zum 65. Geburtstag, Cologne 2012, 299-325.

Searle, Eleanor M., Fact and pattern in heroic history. Dudo of Saint-Quentin, in: Viator 15 (1984), 119-137.

Searle, Eleanor M., Frankish rivalries and Norse warriors, in: Anglo-Norman Studies 8 (1986), 198-213.

Searle, Eleanor M., Predatory kinship and the creation of Norman power, 840-1066, Berkeley 1988.

Settipani, Christian, La préhistoire des Capétiens 481-987 II. L’aristocratie mérovingienne et carolingienne (Nouvelle histoire généalogique de l'Auguste Maison de France, 1,2), Villeneuve d'Ascq 1993.

Shopkow, Leah, The Carolingian world of Dudo of Saint-Quentin, in: Journal of medieval history 15 (1989), 19-37.

Shopkow, Leah, History and community. Norman historical writing in the 11th and 12th centuries, Washington D.C. 1997.

Sickel, Wilhelm, Das Thronfolgerecht der unehelichen Karolinger, in: Zeitschrift der Savigny-Stiftung für Rechtsgeschichte. Germanistische Abteilung 24 (1903), 110-147. Reprinted in: Eduard Hlawitschka (ed.), Königswahl und Thronfolge in fränkischkarolingischer Zeit (Wege der Forschung, 247), Darmstadt 1975, 106-143.

Sielaff, Frithjof, Fridrun, die Frau König Karls des Einfältigen, in: Frithjof Sielaff, Iris Berndt, Gerd Heinrich and Peter Neumeister (eds.), Das Frühe und Hohe Mittelalter. Quellenkritische Beobachtungen, Cologne 2001, 108-114.

Simon, Herbert A., Human nature in politics. The dialogue of psychology with political science, in: American Political Science Review 79(2) (1985), 293-304.

Sommar, Mary E., Hincmar of Reims and the canon law of episcopal translation, in: The Catholic Historical Review 88 (2002), 429-445.

Sot, Michel, Un historien et son église. Flodoard de Reims, Paris 1993.

Sproemberg, Heinrich, Die lothringische Politik Ottos des Großen, in: Rheinische Vierteljahrsblätter 11 (1941), 1-101. Reprinted in: Heinrich Sproemberg, Beiträge zur belgisch-niederländischen Geschichte (Forschungen zur mittelalterlichen Geschichte, 3), Berlin 1959, 111-223.

Staab, Franz, Jugement moral et propagande. Boson de Vienne vu par les élites du royaume de l'Est, in: Régine Le Jan (ed.), La royauté et les élites dans l'Europe carolingienne (début IXe siècle aux environs de 920) (Collection Histoire et littérature régionales, 17), Villeneuve d'Ascq 1998, 365-382.

Stegbauer, Christian, Netzwerkanalyse und Netzwerktheorie. Einige Anmerkungen zu einem neuen Paradigma, in: Christian Stegbauer (ed.), Netzwerkanalyse und Netzwerktheorie. Ein neues Paradigma in den Sozialwissenschaften, 2nd ed., Wiesbaden 2010, 11-19.

Stegmaier, Werner, Philosophie der Orientierung, Berlin 2008.

Stein, Friedrich, Geschichte des Königs Konrad I. von Franken und seines Hauses, Nördlingen 1872.

Stickler, Timo, Der Handlungsspielraum weströmischer Kaiser und Generäle gegenüber den Barbaren an Rhein und Donau, in: Jaroslav Tejral (ed.), Barbaren im Wandel. 
Beiträge zur Kultur- und Identitätsumbildung in der Völkerwanderungszeit, Brno 2007, 29-38.

Stieldorf, Andrea, Marken und Markgrafen. Studien zur Grenzsicherung durch die fränkisch-deutschen Herrscher (Schriften der MGH, 64), Hanover 2012.

Störmer, Wilhelm, Die konradinisch-babenbergische Fehde um 900. Ursachen, Anlaß, Folgen, in: Hans-Werner Goetz and Simon Elling (eds.), Konrad I. - Auf dem Weg zum Deutschen Reich? Bochum 2006, 169-184.

Tajfel, Henri and John C. Turner, The social identity theory of intergroup behavior, in: Stephen Worchel and William G. Austin (eds.), Psychology of intergroup relations, Chicago 1986, 7-24.

Tellenbach, Gerd, Von der Tradition des fränkischen Reiches in der deutschen und französischen Geschichte des hohen Mittelalters, in: Theodor Mayer (ed.), Der Vertrag von Verdun 843. 9 Aufsätze zur Begründung der europäischen Völker- und Staatenwelt, Leipzig 1943, 181-202. Reprinted in: Gerd Tellenbach, Ausgewählte Abhandlungen und Aufsätze II, Stuttgart 1988-1996, 688-709.

Tellenbach, Gerd, Die geistigen und politischen Grundlagen der karolingischen Thronfolge, in: Frühmittelalterliche Studien 13 (1979), 184-302. Reprinted in: Gerd Tellenbach, Ausgewählte Abhandlungen und Aufsätze II, Stuttgart 1988-1996, 503-621.

Tessier, Georges, Diplomatique royale française, Paris 1962.

Tilly, Charles and Robert E. Goodin, It depends, in: Charles Tilly and Robert E. Goodin (eds.), The Oxford handbook of contextual political analysis, Oxford 2006, 334.

Timmer, Jan, Vertrauen. Eine Ressource im politischen System der römischen Republik (Campus Historische Studien, 74), Frankfurt a.M. 2017.

Van Houts, Elisabeth M. C., Countess Gunnor of Normandy (c. 950-1031), in: Collegium medievale 12 (1999), 7-24.

Vanderkindere, Léon, La formation territoriale des principautés belges au Moyen Âge, Bruxelles 1902 (reprinted Bruxelles 1981).

Vercauteren, Fernand, Étude sur les civitates de la Belgique seconde, Bruxelles 1934.

Vercauteren, Fernand, Note critique sur un diplôme du roi de France Charles le Simple du 20 décembre 911, in: Dirk Peter Blok (ed.), Miscellanea mediaevalia in memoriam Jan Frederik Niermeyer, Groningen 1967, 93-103. Reprinted in: Fernand Vercauteren (ed.), Études d'histoire médiévale. Recueil d'articles, Bruxelles 1978, 715-725.

Vercauteren, Fernand, Comment s'est-on défendu, au IXe siècle dans l'empire franc contre les invasions normandes? In: Fernand Vercauteren (ed.), Études d'histoire médiévale. Recueil d'articles, Bruxelles 1978, 39-54.

Verdon, Jean, Les veuves des rois de France aux Xe et XIe siècles, in: Michel Parisse (ed.), Veuves et veuvages dans le haut Moyen-Age. Table ronde organisée à Göttingen par la Mission Historique Française en Allemagne, Paris 1993, 187-198.

Verhulst, Adriaan E., The Carolingian economy, New York 2002.

Vliet, Kaj van, In kringen van kanunniken. Munsters en kapittels in het bisdom Utrecht 695-1227, Zutphen 2002.

Vogel, Walther, Die Normannen und das Fränkische Reich bis zur Gründung der Normandie (799-911) (Heidelberger Abhandlungen zur mittleren und neueren Geschichte 14), Heidelberg 1906.

Vones-Liebenstein, Ursula, Katalonien zwischen Maurenherrschaft und Frankenreich. Probleme um die Ablösung westgotisch-mozarabischer Kirchenstrukturen, in: Rainer Berndt (ed.), Das Frankfurter Konzil von 794. Kristallisationspunkt karolingischer Kultur. Akten zweier Symposien (vom 23. bis 27. Februar und vom 13. bis 15. 
Oktober 1994) anläßlich der 1200-Jahrfeier der Stadt Frankfurt am Main (Quellen und Abhandlungen zur mittelrheinischen Kirchengeschichte, 80), vol. 2, Mainz 1997, 453-518.

Voss, Ingrid, Herrschertreffen im frühen und hohen Mittelalter. Untersuchungen zu den Begegnungen der ostfränkischen und westfränkischen Herrscher im 9. und 10. Jahrhundert sowie der deutschen und französischen Könige vom 11. bis 13. Jahrhundert (Archiv für Kulturgeschichte. Beiheft, 26), Cologne 1987.

Wampbach, Camille, Geschichte der Grundherrschaft Echternach im Frühmittelalter, vol. 1, Luxembourg 1929.

Weinfurter, Stefan, Lehnswesen, Treueid und Vertrauen. Grundlagen der neuen Ordnung im hohen Mittelalter, in: Jürgen Dendorfer and Roman Deutinger (eds.), Das Lehnswesen im Hochmittelalter. Forschungskonstrukte - Quellenbefunde - Deutungsrelevanz (Mittelalter-Forschungen, 34), Ostfildern 2010, 443-462.

Weltecke, Dorothea, Gab es "Vertrauen" im Mittelalter? Methodische Überlegungen, in: Ute Frevert (ed.), Vertrauen. Historische Annäherungen, Göttingen 2003, 67-89.

Wenskus, Reinhard, Sächsischer Stammesadel und fränkischer Reichsadel (Abhandlungen der Akademie der Wissenschaften in Göttingen. Philologisch-Historische Klasse, 93), Göttingen 1976.

Werner, Karl Ferdinand, Untersuchungen zur Frühzeit des französischen Fürstentums (9.-10. Jahrhundert) I-III, in: Die Welt als Geschichte 18 (1958), 256-289. Reprinted in: Karl Ferdinand Werner, Enquêtes sur les premiers temps du principat français (IXe-Xe siècles). Untersuchungen zur Frühzeit des französischen Fürstentums (9.-10. Jahrhundert) (Instrumenta, 14), Ostfildern 2004, 20-87, URL: https://www.perspectivia. net/publikationen/instrumenta/werner_enquetes (accessed 22.06.2018).

Werner, Karl Ferdinand, Untersuchungen zur Frühzeit des französischen Fürstentums (9.-10. Jahrhundert) IV, in: Die Welt als Geschichte 19 (1959), 146-193. Reprinted in: Karl Ferdinand Werner, Enquêtes sur les premiers temps du principat français (IXe-Xe siècles). Untersuchungen zur Frühzeit des französischen Fürstentums (9.-10. Jahrhundert) (Instrumenta, 14), Ostfildern 2004, 88-183, URL: https://www. perspectivia.net/publikationen/instrumenta/werner_enquetes (accessed 22.06.2018).

Werner, Karl Ferdinand, Untersuchungen zur Frühzeit des französischen Fürstentums (9.-10. Jahrhundert) V, in: Die Welt als Geschichte 20 (1960), 87-119. Reprinted in: Karl Ferdinand Werner, Enquêtes sur les premiers temps du principat français (IXeXe siècles). Untersuchungen zur Frühzeit des französischen Fürstentums (9.-10. Jahrhundert) (Instrumenta, 14), Ostfildern 2004, 184-239, URL: https://www. perspectivia.net/publikationen/instrumenta/werner_enquetes (accessed 22.06.2018).

Werner, Karl Ferdinand, Ademar von Chabannes und die Historia pontificum et comitum Engolismensium, in: Deutsches Archiv für Erforschung des Mittelalters 19 (1963), 297-326. Reprinted in: Karl Ferdinand Werner and Werner Paravicini (eds.), Einheit der Geschichte. Studien zur Historiographie (Beihefte der Francia, 45), Sigmaringen 1998, 243-272, URL: https://www.perspectivia.net/publikationen/bdf/paravicini_ werner-einheit (accessed 22.06.2018).

Werner, Karl Ferdinand, Bedeutende Adelsfamilien im Reich Karls des Großen, in: Wolfgang Braunfels and Percy E. Schramm (eds.), Karl der Große. Lebenswerk und Nachleben, vol. 1, Düsseldorf 1964, 83-142. Reprinted in: Karl Ferdinand Werner, (ed.), Vom Frankenreich zur Entfaltung Deutschlands und Frankreichs. Ursprünge, Strukturen, Beziehungen. Ausgewählte Beiträge. Festgabe zu seinem 60. Geburtstag, Sigmaringen 1984, 22-81. 
Werner, Karl Ferdinand, Die Nachkommen Karls des Großen bis um das Jahr 1000 (1.-8. Generation), in: Wolfgang Braunfels and Percy E. Schramm (eds.), Karl der Große. Lebenswerk und Nachleben, vol. 4, Düsseldorf 1967, 403-482.

Werner, Karl Ferdinand, Quelques observations au sujet des débuts du "duché" de Normandie, in: Droit privé et institutions régionales. Études historiques offertes à Jean Yver, professeur honoraire à la Faculté de droit et de sciences politiques de Caen (Publications de l'Université de Rouen, 31), Paris 1976, 691-709. Reprinted in: Karl Ferdinand Werner (ed.), Structures politiques du monde Franc (VIe-XIIe siècles). Études sur les origines de la France et de l'Allemagne, London 1979, part VI, 691-709.

Werner, Karl Ferdinand, Westfranken-Frankreich unter den Spätkarolingern und frühen Kapetingern (888-1060), in: Theodor Schieder (ed.), Handbuch der europäischen Geschichte I. Europa im Wandel von der Antike zum Mittelalter, Stuttgart 1976, 731-783. Reprinted in: Karl Ferdinand Werner (ed.), Vom Frankenreich zur Entfaltung Deutschlands und Frankreichs. Ursprünge, Strukturen, Beziehungen. Ausgewählte Beiträge. Festgabe zu seinem 60. Geburtstag, Sigmaringen 1984, 225-277.

Werner, Karl Ferdinand, Gauzlin von Saint-Denis und die westfränkische Reichsteilung von Amiens (März 880). Ein Beitrag zur Vorgeschichte von Odos Königtum, in: Deutsches Archiv für Erforschung des Mittelalters 35 (1979), 395-461. Reprinted in: Karl Ferdinand Werner (ed.), Vom Frankenreich zur Entfaltung Deutschlands und Frankreichs. Ursprünge, Strukturen, Beziehungen. Ausgewählte Beiträge. Festgabe zu seinem 60. Geburtstag, Sigmaringen 1984, 157-224, Permalink: http://resolver.sub.unigoettingen.de/purl?PPN345858735_0035 (accessed 22.06.2018).

Werner, Karl Ferdinand, Missus-Marchio-Comes. Entre l'administration centrale et l'administration locale de l'Empire carolingien, in: Werner Paravicini and Karl Ferdinand Werner (eds.), Histoire comparée de l'Administration (IVe-XVIIIe siècles) (Beihefte der Francia, 9), Zürich and Munich 1980, 191-241. Reprinted in: Karl Ferdinand Werner (ed.), Vom Frankenreich zur Entfaltung Deutschlands und Frankreichs. Ursprünge, Strukturen, Beziehungen. Ausgewählte Beiträge. Festgabe zu seinem 60. Geburtstag, Sigmaringen 1984, 108-156, URL: https://www.perspectivia.net/ publikationen/bdf/paravicini-werner_administration (accessed 22.06.2018).

Werner, Karl Ferdinand, Les origines (avant l'an mil) (Histoire de France, I), Paris 1984.

Werner, Karl Ferdinand, Les premiers Robertiens et les premiers Anjou (IXe siècle-début Xe siècle), in: Olivier Guillot and Robert Favreau (eds.), Pays de Loire et Aquitaine de Robert le Fort aux premiers Capétiens. Actes du colloque scientifique international tenu à Angers en septembre 1987, Poitiers 1997, 9-65. Reprinted in: Karl Ferdinand Werner (ed.), Enquêtes sur les premiers temps du principat français (IXe-Xe siècles). Untersuchungen zur Frühzeit des französischen Fürstentums (9.-10. Jahrhundert) (Instrumenta, 14), Ostfildern 2004, 251-309, URL: https://www.perspectivia.net/ publikationen/instrumenta/werner_enquetes (accessed 22.06.2018).

Werner, Karl Ferdinand, Naissance de la noblesse. L'essor des élites politiques en Europe, Paris 1998.

Werner, Karl Ferdinand (ed.), Enquêtes sur les premiers temps du principat français (IXe-Xe siècles). Untersuchungen zur Frühzeit des französischen Fürstentums (9.-10. Jahrhundert) (Instrumenta, 14), Ostfildern 2004, URL: https://www.perspectivia.net/ publikationen/instrumenta/werner_enquetes (accessed 22.06.2018).

West, Charles, Reframing the feudal revolution. Political and social transformation between Marne and Moselle, c. 800-c. 1100 (Cambridge studies in medieval life and thought), Cambridge 2013. 
White, Stephen D., Feuding and peace-making in the Touraine around the year 1100, in: Traditio 42 (1986), 195-264. Reprinted in: Stephen D. White, Feuding and peacemaking in eleventh-century France, Aldershot 2004, part I, 195-263.

Whitelock, Dorothy (ed.), The Anglo-Saxon chronicle, London 1961.

Wickham, Chris and Timothy Reuter, Introduction, in: Wendy Davies and Paul Fouracre (eds.), Property and power in the early middle ages, Cambridge 1995, 1-16.

Widder, Ellen, Margarete "Maultasch". Zu Spielräumen von Frauen im Rahmen dynastischer Krisen des Spätmittelalters, in: Julia Hörmann-Thurn und Taxis (ed.), Margarete "Maultasch". Zur Lebenswelt einer Landesfürstin und anderen Tiroler Frauen des Mittelalters. Vorträge der wissenschaftlichen Tagung im Südtiroler Landesmuseum für Kultur- und Landesgeschichte Schloss Tirol, Schloss Tirol, 3. bis 4. November 2006, Innsbruck 2007, 51-79.

Wisplinghoff, Erich, Untersuchungen zur Geschichte des Klosters Prüm an der Wende vom 9. zum 10. Jahrhundert, in: Deutsches Archiv für Erforschung des Mittelalters 55 (1999), 439-475, Permalink: http://resolver.sub.uni-goettingen.de/purl?PPN345858735_0055 (accessed 22.06.2018).

Wolfram, Herwig, Lateinische Herrschertitel im 9. und 10. Jahrhundert, in: Herwig Wolfram (ed.), Intitulatio II. Lateinische Herrscher- und Fürstentitel im 9. und 10. Jahrhundert (Mitteilungen des Instituts für Österreichische Geschichtsforschung. Ergänzungsband, 24), Vienna 1973, 19-178.

Wollasch, Joachim, Gerard von Brognes und seine Klostergründung, in: Revue bénédictine 70 (1960), 62-82 and 224-231.

Worm, Peter, Beobachtungen zum Privilegierungsakt am Beispiel einer Urkunde Pippins II. von Aquitanien, in: Archiv für Diplomatik 49 (2003), 15-48.

Worm, Peter, Alte und neue Strategien der Beglaubigung. Öffentlichkeit und Königsurkunde im frühen Mittelalter, in: Frühmittelalterliche Studien 38 (2004), 297-308.

Wormald, Patrick C., The making of English law. King Alfred to the twelfth century I. Legislation and its limits, Oxford 2001.

Zettel, Horst, Das Bild der Normannen und der Normanneneinfälle in westfränkischen, ostfränkischen und angelsächsischen Quellen des 8. bis 11. Jahrhunderts, Munich 1977.

Zey, Claudia, Mächtige Frauen? Königinnen und Fürstinnen im europäischen Mittelalter (11.-14. Jahrhundert). Zur Einführung, in: Claudia Zey (ed.), Mächtige Frauen? Königinnen und Fürstinnen im europäischen Mittelalter (11.-14. Jahrhundert) (Vorträge und Forschungen, 81), Ostfildern 2015.

Zielinski, Herbert, Böhmer, J. F., Regesta Imperii I. Die Regesten des Kaiserreichs unter den Karolingern 751-918 (926/962) III. Die Regesten des Regnum Italiae und der burgundischen Regna. Tl. 4. Die Regesten der burgundischen Regna 855-1023, Fasz. 1. Niederburgund von 855 bis zur Vereinigung mit Hochburgund, Cologne 2013.

Zimmermann, Harald, Der Streit um das Lütticher Bistum vom Jahre 920-921, in: Mitteilungen des Instituts für Österreichische Geschichtsforschung 65 (1957), 15-52.

Zimmermann, Harald, Böhmer, J. F., Regesta Imperii II. Sächsisches Haus 919-1024 V. Papstregesten 911-1024, 2nd ed., Vienna 1998.

Zotz, Thomas, Das Elsaß. Ein Teil des Zwischenreichs? In: Hans-Walter Herrmann and Reinhard Schneider (eds.), Lotharingia. Eine europäische Kernlandschaft um das Jahr 1000. Referate eines Kolloquiums vom 24. bis 26. Mai 1994 in Saarbrücken (Veröffentlichungen der Kommission für Saarländische Landesgeschichte und Volksforschung, 26), Saarbrücken 1995, 49-70. 



\section{Index}

\section{A}

Abbo, bishop of Nevers 89, 94, 319

Abbo, bishop of Soissons 161, 177, 179, 185, $186,187,188,200,203,220,224,226$, $227,228,230,324,333,342$

Abbo of Saint-Germain 102, 276, 310

Acfred, abbot of San-Esteban of Bagnoles 176, 319

Actard, bishop of Tours 85

Adalard, archbishop of Tours 109, 136

Adalard, count of the palace 22, 23, 79

Adalard the Seneschal 23

Adalbero, bishop of Augsburg 167

Adalbero, bishop of Laon 282

Adalelm, uncle of King Odo 306

Adalgar, bishop of Autun 46, 120, 210

Adalgard, abbess of Sainte-Croix of Poitiers 101

Adalgarius, bishop of Autun 59, 60, 82, 85, $86,89,90,94,95,100,115,117,118,120$, $123,210,324,325,331,332$

Adalung, count 49, 50, 65

Adelaide, countess 151, 152, 195, 220

Adelaide, queen, wife of Louis the Stammerer 2, 22, 23, 24, 25, 26, 27, 29, $34,37,45,48,50,60,64,70,71,83,86$, $88,94,147,156,186,188,191,192,193$, $196,197,213,222,223,224$

Adelaide, wife of Richard the Justiciar 119, 120

Adelelm, bishop of Laon 228, 342

Adelelm, bishop of Senlis 342

Adelelm, count of Arras 177

Adelelm, count of Troyes 105

Ademar of Chabannes 116, 309, 310

Aduvirus, abbot of Notre-Dame of

Amer 117

Ælfthryd, daughter of Alfred the Great 197

Aeneas 284

Æthelwulf, king of Wessex 198

Agambert, bishop 138

Agelmar, bishop of Chalon-sur-Saône 106

Aginus, monk 42, 321, 340

Agio, archbishop of Narbonne 138
Agnes, empress 26

Ahasuerus/Xerxes, Persian king 195

Aimo, abbot 213

Airard, bishop of Noyon 342

Alan the Great 216

Alardus, count 101

Alberich, count 163, 166

Albert of Vermandois 282

Albrada 49

Albuin, count 87

Aledramnus, count, brother of Theoderic of Vermandois 41, 48, 50, 51, 86, 92, 104, $106,108,117,123,153,170,198,271,273$

Alfred the Great, king of Wessex 197, 261,263

Almanus, count 215

Alpais, daughter of Charles the Simple 199, 200

Alpais, daughter of Louis the Pious 22, 23

Altmar, count of Arras 112, 152, 153, 157, $159,195,215,303,304$

Altmar, count of Poitiers 52, 58, 59, 60, $112,113,115,116,117,118,120,305,309$, $310,311,312,321$

Angelrannus, bishop of Meaux 160

Angelwinus, bishop of Paris 46, 97, 98, 99, 341

Anne, wife of the fidelis Stephen 192

Ansbald, abbot of Prüm 88

Ansegisus, archbishop of Sens 26, 85, 86, 301

Ansgar, count of Oscheret 85, 94, 99, 100, $101,105,106,115,123$

Ansgarde, queen, wife of Louis the Stammerer 22, 27, 28, 29, 70, 100, 147

Anskeric, bishop of Paris, archchancellor 46, 47, 50, 51, 53, 68, 69, 71, 107, 109, 113, 115, 117, 151, 152, 155, $156,159,161,179,187,195,204,206,213$, 223, 245, 309

Aquinus, provost of Flavigny 61

Argrim, bishop of Langres 42, 47, 113, 115, 121, 162, 209, 219

Arnaldus, bishop of Toul 88 
Arnulf, duke of Bavaria 257

Arnulf I, count of Flanders 145, 197

Arnulf of Carinthia, emperor 16, 21, 29, 32, $34,35,36,37,38,40,45,48,49,50,51$, $53,54,55,56,62,63,64,65,66,67,68$, $69,71,72,73,114,146,147,148,151,163$, $166,167,172,240,241,242,243,244$, $245,246,248,258,259,260,274,321$, $322,328,349$

Arnulf of Metz 252

Arnulf, son of Charles the Simple 252

Arnust, archbishop of Narbonne 142, 189, 192

Arveus, royal chaplain 93, 94

Atto, viscount 136

Audacher, royal notary 92

Aurelian, archbishop of Lyon 41, 42, 85, $86,89,90,331,332$

Ava, abbess of Sainte-Croix 88

Ava, abbess, sister of William the Pious 60

\section{B}

Baldric, bishop of Utrecht 182

Baldwin II, count of Flanders 35, 36, 40, $42,43,44,48,49,51,52,53,54,55,56$, $57,58,60,62,63,65,69,71,73,75,114$, $118,121,122,150,151,153,156,157,160$, $197,240,241,247,277,281,297,302$, $303,304,305,306,307,308,310,321$, $329,338,339,343,344$

Baltram, bishop of Strasbourg 248 Bathilde, mother of Clothar III 156

Beatrix, daughter of Heribert I of Vermandois 213

Bego, count of Paris 22, 23

Bera, abbot of Saint-Chinian 138

Berengar, archbishop of Narbonne 140

Berengar, bishop of Cambrai 193, 194

Berengar, bishop of Verdun 193

Berengar, count $170,171,176,180$

Berengar, count of Le Mans 73

Berengar, father or brother of Poppa 287

Berengar I, emperor 5, 32, 256, 257

Bernard, deacon of Saint-Julien of Brioude 62

Bernard, king of Italy 50

Bernard of Auvergne, count 79, 80, 83, $84,85,90,94,95,100,104,106,121$, 137,206
Bernard of Gothia, count $80,82,83,84$, $85,89,121,235,264,299,300,301$, 302,343

Bernard, otherwise unknown 327

Bernard, son of Gauzlin 301

Berno, bishop of Châlons 87, 91, 97, 98 , $105,123,327,341$

Berno, bishop of Orléans 213

Berno, priest 321

Bernuin, bishop of Vienne 42

Berta, daughter of Charlemagne 146

Betto, bishop of Auxerre 135

Bilechildis, sister of Gauzlin 301

Biltgerius, abbot of Saint-Philibert of Tournus 115

Björn, Viking leader 282

Bligardis, otherwise unknown 318

Bonifatius, abbot of Sainte-Seine 110

Boso of Vienne, count, dux, king of

Provence 16, 24, 25, 27, 33, 36, 37, 38, $66,70,79,80,82,83,84,85,89,90,91$, $94,95,100,115,119,121,133,158,163$, $171,234,238,239,240,260,264,266$, $298,320,324,325,330,331,332,333$, 349,350

Boso, son of Richard the Justiciar 176, 179, 208

Bovo, bishop of Châlons, brother of Frederuna 161, 177, 185, 189, 190, 193, 194, 196, 197, 198, 200, 202, 324

Bovo I, abbot of Corvey 35

Bovo II, abbot of Corvey 194

Bovo, monk at Corvey 194

Burchard, count 248

Burchard, duke of Swabia 257

\section{C}

Carloman, king 144

Carloman of Bavaria, king 16, 26, 32, 146, $235,252,264$

Carloman II, king of the West Frankish realm $2,5,6,19,22,24,25,26,27,28$, $30,31,32,36,38,39,40,47,70,82,83$, $85,87,90,91,93,94,95,96,97,98,99$, $100,101,102,104,105,106,115,116,121$, $123,128,132,133,134,135,138,139,140$, $143,144,147,149,153,191,234,236,237$, $238,239,240,253,260,263,264,265$, 266, 267, 268, 269, 270, 271, 290, 291, 
292, 293, 297, 298, 299, 316, 317, 319, $320,324,325,326,327,329,331,332,333$, $340,341,344,345,347,348,349,350$

Charlemagne 6, 26, 130, 143, 144, 145, 146, $174,200,201,248,252,254,295,334$

Charles Martel 146

Charles, son of Charlemagne 146

Charles II the Bald, king of the West Frankish realm, emperor 1, 4, 6, 11, $12,15,19,22,23,26,33,38,39,48,70$, $77,79,80,81,85,86,87,88,92,93,96$, $109,114,119,121,122,128,130,132,134$, $135,138,142,143,144,146,147,153,156$, $158,176,188,192,195,198,210,234,236$, $249,252,253,259,262,263,279,289$, $298,300,316,317,318,327,328,332,347$

Charles III the Fat, emperor 2, 6, 16, 19, 28, $29,30,31,32,33,35,37,39,40,46,48$, $64,70,71,87,90,95,97,99,101,102$, $103,104,105,106,107,108,109,110,111$, $113,115,122,123,135,136,148,206,235$, $237,238,239,253,260,263,264,268$, 270, 271, 272, 273, 274, 279, 289, 290, 291, 292, 293, 305, 317, 320, 325, 326, $330,334,347,348,350$

Charles III the Simple, king of the West

Frankish realm 1, 2, 3, 4, 5, 6, 10, 11, 16, $18,19,21,22,23,24,25,26,27,28,29$, $31,32,34,35,36,37,38,39,41,43,44$, $45,46,47,48,49,50,51,52,53,54,55$, $56,57,58,59,60,61,62,63,64,65,66$, $67,68,69,70,71,72,73,74,75,77,117$, $118,120,121,127,128,129,130,131,132$, $134,135,136,137,138,139,140,141,142$, $143,144,145,146,147,148,149,150,151$, $152,153,154,155,156,157,158,159,160$, $161,162,163,164,165,166,169,170,171$, $172,173,174,175,176,177,178,179,180$, $181,182,183,184,185,186,187,188,189$, 190, 191, 192, 193, 194, 195, 196, 197, 198, 199, 200, 201, 202, 203, 204, 205, 206, $207,208,209,210,211,212,213,214,215$, $216,217,218,219,220,221,222,223$, 224, 225, 226, 227, 228, 229, 230, 231, 233, 241, 242, 243, 244, 245, 246, 247, $248,249,250,251,252,253,254,255$, $256,257,258,259,260,261,263,270$, $271,272,273,276,277,278,279,280$, 281, 284, 285, 286, 287, 288, 289, 291,
292, 293, 298, 299, 302, 303, 304, 306, $308,311,312,313,314,315,317,318,319$, $321,322,323,324,326,328,329,330$, $333,334,335,336,337,338,339,340$, $341,342,343,344,345,347,348,349$, 350,351

Charles IV, king of France 26

Clothar III, king of the Franks 156

Clovis, king of the Franks 284

Conrad, count of Paris 33, 80, 81, 84, 89, $91,92,93,107,121,264$

Conrad the Elder, count 167

Conrad I, king of the East Frankish realm $3,142,168,171,172,173,249$, 250, 251, 254

Cunigunde, daughter of Ermentrude and Reginar Longneck 49, 171, 180, 181, 191, 199, 313

\section{D}

Dado, bishop of Verdun 171, 183

Dagobert, king of the Franks 323

Dido, bishop of Laon 41, 42, 50, 52, 53, 65, $115,117,321$

Dodilo, bishop of Cambrai 35, 42, 43, 50, 160, 250, 306

Drogo, bishop of Metz, son of Charlemagne 146, 252

Drogo, bishop of Toul 172, 189

Drogo, son of Charles the Bald 252

Drogo, son of Charles the Simple 252

Dudo of Saint-Quentin 1, 3, 200, 278, 281, $282,283,284,287,289$

\section{E}

Eadgifu, queen, wife of Charles III the Simple 191, 197, 198, 224, 280

Ebalus Manzer, count of Poitiers 52, 118, 278, 309, 310, 311, 312, 321, 327

Eberhard, count 167, 283

Eberhard, duke of Friuli 32, 177

Eberhard, son of Bego 23

Ebolus, abbot of Saint-Germain, archchancellor 46, 52, 56, 102, 109, 113, $114,116,117,118,123,153,309,310,311$

Ecfrid, count $46,47,48,50,51,152,170$, $177,179,192,304,305$

Edward the Elder, king of the Anglo-Saxons 197, 198, 278, 280 
Egfred, bishop of Poitiers 112, 311

Eldefred, provost of Saint-Julien of Brioude 62

Eldegarde, daughter of Count

Ermenfrid 199

Elduin, count of the palace 47, 50, 62, 207

Elefons, bishop 138

Emeno, count 81, 82, 84, 264, 299, 301, 309

Emma, abbess of San-Juan-de-las-

Abadesas 139

Emma, daughter of Robert of

Neustria 210, 219, 227

Emma, noble woman 325

Engelberga, wife of Emperor Louis II 238

Erbernus, archbishop of Tours 213

Erifons, fidelis 100, 101

Erkanger, abbot of Montiéramey 340

Erkanger, count of Boulogne 46, 47, 48,

$50,54,104,152,159,177,179,192$,

195, 204

Erlebald, count of Castriciensis 176, 185, 200, 215, 319, 351

Ermemirus, bishop of Girona 116

Ermenfrid, count of Amiens 156, 170, 177, 179, 192, 199, 203

Ermengard, daughter of Emperor Louis II, wife of Boso of Vienne, mother of Louis the Blind 38, 119, 120, 330

Ermentrude, daughter of Charles the Simple 200, 224

Ermentrude, daughter of Louis the Stammerer and Adelaide 49, 147, 191, 199, 201

Ermentrude, wife of Charles the Bald 23, 191,210

Ernustus, royal notary 154, 159, 215

Esther, Jewish queen 195

Etbert, fidelis 196, 204

Everbert 48, 304, 305

\section{$\mathbf{F}$}

Flodoard of Reims 2, 3, 43, 110, 120, 139, $157,160,161,179,194,200,201,202$, 203, 205, 213, 217, 218, 219, 221, 222, $225,226,227,229,230,241,280,282$, $285,287,288,290,292,313,315,335$, 336,342

Folcwin, abbot of Lobbes 336
Formosus, pope $43,45,46,61,66,67,68$, $72,241,243$

Franco, abbot of Corbie 156

Franco, bishop of Liège 64

Franco, bishop of Nevers 118

Frederuna, queen, wife of Charles the

Simple 129, 151, 183, 189, 191, 192, 193,

194, 195, 196, 197, 198, 199, 201, 202,

203, 204, 214, 224, 225, 324, 338

Frodoynus, bishop of Barcelona 89

Frotar, archbishop of Bourges 82, 84, 85, $86,93,94,99,101,114,116,123,299$, 300,301

Fulbert, bishop of Cambrai 187

Fulcher, bishop of Nantes 213

Fulk, archbishop of Reims, archchancellor 2, 21, 29, 31, 32, 34, 35, $36,38,39,40,41,42,43,44,45,46,47$, $48,49,50,51,52,53,54,55,56,58,59$, $60,61,62,63,64,65,66,67,68,69,70$, $71,72,74,75,96,110,114,120,121,122$, $150,151,153,154,155,157,159,160,163$, $173,187,188,190,193,206,213,215,222$, $224,233,240,241,243,244,247,250$, 280, 291, 292, 298, 303, 304, 305, 306, $311,321,333,336,338,347,348,351$

Fulk the Red, viscount 136, 213, 217

\section{G}

Garnegaud, viscount of Blois 111

Gausfred, possibly father of the counts Gauzbert and Gauzlin 137

Gauzbert, brother of Abbot Ebolus 52, 56, $309,310,311$

Gauzbert, count 137

Gauzfrid 51

Gauzfrid, bishop of Strasbourg 189, 198,250

Gauzfrid, count, brother of Gauzlin 49, 50, $81,84,264,299,300,301,305$

Gauzlin, abbot of Saint-Germain, bishop of Paris, archchancellor 25, 26, 27, 28, 30, $31,33,36,37,39,46,49,71,80,81,82$, $83,84,85,86,88,89,90,91,92,93,96$, 97, 98, 99, 100, 101, 102, 103, 104, 106, $107,108,109,110,113,121,122,123,215$, $236,237,238,264,266,269,271,272$, $279,293,299,301,350$ 
Gauzlin, count of Maine 73, 137, 152

Gauzlin, royal notary, bishop of Toul 189, 196, 336, 351

Gebhard, count 249

Gebhard, count, dux of Lotharingia 165, $167,168,169,249$

Geilo, abbot of Saint-Philibert of Tournus, bishop of Langres 35, 83, 85, 89, 90, $94,95,105,106,113,115,122,123,325$, $326,331,332,348$

Genesius, otherwise unknown 318

Geoffrey, otherwise unknown 327

Gerald of Aurillac, count 116, 137, 170, 206, 207, 310, 311

Geran, bishop of Auxerre 135, 209, 278

Gerard, count of Vienne 23

Gerberga, queen, sister of Otto I, wife of Louis d'Outremer 195

Gerhard, count 164, 166, 167, 168, 200, 201, 224

Gerulf, abbot of Beaulieu 116

Gerulf, count 171

Geruntius, archbishop of Bourges 137

Gibert, bishop of Nîmes 318, 319

Girart de Roussillon 23

Girbald, count 119

Gisela, abbess of Nivelles, daughter of Lothar II 151, 195, 289

Gisela, daughter of Charles the Simple 200, 284, 287, 289

Gisela, daughter of Louis the Pious 256

Gisela, daughter of Louis the Stammerer and Ansgarde 100, 147, 191

Gislebert, father of Reginar Longneck 49

Gislebert, otherwise unknown 73

Gislebert, son of Reginar Longneck, dux of Lotharingia $3,49,129,139,175,176$, $177,180,181,182,183,184,188,190,221$, 223, 229, 230, 231, 255, 257, 260, 312, $313,314,315,322,333,343,344,349$

Goiram, count 85

Gottfrid, count of the palace 200, 201, 224

Gottfrid, Viking leader 283, 289, 290

Gregory, abbot of Saint-Martin of Autun 106

Grimoard, viscount of Paris 156

Gualdricus, bishop of Auxerre 135

Guarnegaud, viscount 136, 213
Guarner, count 170, 171, 187

Guigo, bishop of Girona 141, 189, 229, 340

Gunnor, duchess of Normandy 282

Guntbert, otherwise unknown 314

Gunter, bishop of Le Mans 73

Guntram, count 258

Guthrun, Viking leader 263

\section{H}

Hagano, count 1, 3, 5, 161, 185, 186, 187, $188,193,194,197,200,201,202,203$, 204, 205, 212, 218, 220, 221, 222, 225 , $231,324,334,335,336,338,344$

Hardrad, viscount 111

Harduin, count 22

Harduin, otherwise unknown 168

Hasting, Viking leader 30, 267, 275, 282, 283, 290, 292

Hatto, archbishop of Mainz 160, 167

Hatto, viscount 111, 213

Heilwich, daughter of Eberhard of Friuli 43, 177

Heitilo, bishop of Noyon 35, 49, 50, 91, 153

Helgaud, count of Ponthieu 185, 203, 324

Henry, dux 48, 106, 111, 272, 293

Henry I the Fowler, king of the East

Frankish realm 5, 167, 177, 184, 187, 190, 193, 212, 227, 231, 253, 254, 255, $256,257,258,259,260,312,313$, 315,349

Herbert, count 137

Herfrid, bishop of Auxerre 109, 120, 135, $157,158,329$

Heribert I of Vermandois, count 36, 41, 45, $46,47,48,50,51,54,57,58,68,69,71$, $75,113,114,117,150,151,154,157,187$, 206, 212, 213, 222, 262, 273, 277, 278, $302,303,308$

Heribert II of Vermandois, count 1, 3, 152, $154,159,162,179,186,187,190,219,220$, $221,223,228,229,230,273,285,288$, 333, 337, 342, 351

Herilandus, bishop of Thérouanne 49, 50

Heriveus, archbishop of Reims, archchancellor $3,11,43,154,155,157$, $159,160,161,162,174,178,183,185,187$, $188,203,219,221,223,224,225,226$, $227,280,285,292,304,318$ 
Heriveus, count 137

Herluin, royal notary 155,188

Hermann, archbishop of Cologne 165, 168, $173,184,255,256,257,280$

Hermingard 42

Hildeburg, son of Wulfard and Susanna 23

Hildegard, abbess 42

Hildegard, daughter of Louis the

Stammerer and Ansgarde 22, 147, 191

Hildegard, queen, wife of

Charlemagne 146

Hilderic, abbot of Caunes 138

Hilduin, candidate for the episcopal see of Liège 182, 184, 189, 190, 220, 255, 313

Hilduin, count 47, 101

Hilmeradus, count 215

Hincmar, archbishop of Reims 12, 13, 22, $23,24,25,26,31,39,80,81,82,83,85$, $86,87,88,89,90,91,92,93,95,96,99$, $163,191,236,237,239,263,264,265$, $266,267,268,300,301,330,331,332$

Honoratus, bishop of Beauvais 35, 41, 42, $46,48,50,117,153,154,159,186,192,321$

Hubert, enemy of the Church of Rome 256

Hucbald, count of Senlis 43, 44, 60, 112, $113,114,117,159,177$

Hucbert, viscount 111

Hugh, count 116, 311

Hugh, count of Maine 136, 137, 152, 153, $155,192,198,213,220$

Hugh, son of Charlemagne 146

Hugh, son of Lothar II 238, 239, 240, 266, 319

Hugh the Abbot 25, 26, 27, 28, 30, 31, 33, $36,37,39,71,79,80,81,83,84,85,86$, $87,88,89,90,91,92,93,94,95,96,97$, $98,99,100,101,102,103,107,108,109$, $121,122,123,135,236,237,239,253$, $263,264,265,267,268,269,278,279$, $292,299,301,350$

Hugh the Black, son of Richard the Justiciar 134, 179, 208, 216, 217

Hugh the Great, son of Robert of Neustria 176, 205, 213, 217, 218, 220, 221, 230, 258, 315, 333, 335, 336, 342

Hundeus, Viking leader 54, 69, 70, 282, 286, 291, 336

Huntger, count of Vimeu 185
I

Imo, son of Wulfard and Susanna 23

Isaac, bishop of Langres 41

Isaac, count of Cambrai 169, 171, 186, 187

Isaias, bishop of Nantes 217

J

John, archbishop of Rouen 35

John VIII, pope 23, 70, 82, 233, 234, 264, 300

John X, pope 190, 256, 285

Judith, daughter of Charles the Bald 198

Judith, empress, wife of Louis the Pious 93

Judith, queen, wife of Charles the Bald 218

$\mathbf{L}$

Lambert, bishop of Le Mans 107

Lambert, bishop of Liège 328

Lambert, bishop of Mâcon 89, 331

Lambert of Spoleto, emperor 43, 45, 61, $66,67,68,69,245,256$

Letard, bishop of Mâcon 110

Letard, count 170, 171, 187

Leuthard, count of Paris 23

Liedgardis, possible name of Heribert II's wife 220

Liutgard, queen, wife of Louis the Younger 236

Liutpert, archbishop of Mainz 35

Liutward, bishop of Vercelli 104, 105, 334

Lothar I 49, 138

Lothar II 23, 151, 195, 238, 239, 249, 266, $289,319,332$

Louis the Pious, emperor 6, 93, 146, 174, 200, 248, 252, 256, 334

Louis II, emperor 80, 233, 238, 332

Louis II the German, king of the East

Frankish realm 29, 33, 200, 252

Louis II the Stammerer, king of the West Frankish realm 2, 4, 6, 19, 21, 22, 23, $24,25,26,27,28,29,34,37,38,39,48$, $70,71,79,80,81,82,83,84,85,86,87$, $88,89,90,91,92,93,96,99,100,102$, $111,115,116,121,122,123,128,132,134$, $135,138,139,143,144,146,147,149,152$, $198,233,234,235,236,237,240,260$, 263, 264, 265, 267, 278, 281, 299, 300, $301,305,317,324,325,330,331,332$, $333,343,347,348,349,350$ 
Louis III the Younger, king of the East

Frankish realm 24, 25, 26, 27, 28, 86, $89,90,99,233,234,235,236,237,238$, $239,243,253,260,264,265,349$

Louis III, king of the West Frankish realm $2,5,6,12,19,22,24,25,26$, $27,28,30,31,32,83,85,87,90,91$, $92,93,96,98,99,100,121,122,123$, 132, 143, 147, 153, 191, 234, 236, 237, 238, 239, 240, 253, 259, 260, 263, 264, 265, 266, 267, 268, 278, 290, 292, 293, 298, 299, 317, 319, 331, 332, 333, 348, 349,350

Louis IV the Child, king of the East Frankish realm 29, 36, 49, 146, 148, $160,165,166,167,168,172,173,174,175$, $178,187,223,224,248,249,250,251$, 252, 351

Louis IV d'Outremer, king of the West Frankish realm 195, 199, 343

Louis the Blind, king of Provence 29, 36, $38,41,66,119,120$

Louis VII, king of France 136

Louis X, king of France 26

Ludelm, bishop of Toul 172

M

Madalbert, bishop of Bourges 278

Madelgaud, viscount of Oscheret 120

Magenarius, otherwise unknown 327

Manasses, count, nephew of Richard the Justiciar 61, 120, 121, 134, 155, 158, 162, 209, 214, 219

Mancio, bishop of Châlons 49, 50, 153, 160, 194, 204

Marinus I, pope 39

Matfrid, count $166,167,168,180,182,183$, 201, 315

Mathilde of Saxony, queen, wife of Henry I the Fowler 193

Mauger, royal chaplain 196, 202

Megingaud, count 163, 166, 176, 248

Meginhard, count 169, 171

Milo, count of Langres 105, 115

\section{$\mathbf{N}$}

Norbert, royal notary, son of Bernard of Auvergne 26, 95, 97

\section{O}

Odacar, count 171, 245

Odalricus, scholarum magister of Saint-Martin of Tours 321

Oda, queen, daughter of Count Otto of Saxony, wife of Zwentibold 164, 167

Oda, queen, wife of Arnulf of

Carinthia 146, 167

Odilard, count 159, 215

Odo, abbot of Vézelay 88, 94, 115, 116

Odo, bishop of Beauvais 85, 86, 87, 92

Odo, count 299

Odo, count of Châteaudun 22

Odo, count of Paris, king of the West Frankish realm 2, 6, 16, 19, 21, 25, 29, $32,33,34,35,36,37,38,39,40,41,42$, $43,44,45,47,48,50,51,52,53,54,55$, $56,57,58,59,60,61,62,63,64,65,67$, $68,69,71,72,73,74,75,92,107,108$, 109, 110, 111, 112, 113, 114, 115, 116, 117, $118,120,121,122,123,128,129,132,133$, $134,136,138,139,140,148,149,150,151$, $152,153,154,155,156,157,159,160,163$, 164, 176, 177, 192, 206, 207, 210, 211, 213, 222, 233, 240, 241, 242, 243, 244, $245,246,256,258,259,260,262,263$, 270, 272, 273, 274, 275, 276, 277, 278, 285, 286, 290, 291, 292, 293, 297, 298, $302,304,305,306,307,308,309,310$, $311,312,315,317,318,319,320,321,325$, $327,329,331,333,336,338,339,340$, $341,342,343,344,345,347,348,349$, 350,351

Oirannus, bishop of Senigallia 42

Osbert, son of Magenarius, otherwise unknown 327

Oscar, Viking leader 282

Otbert, bishop of Strasbourg 172, 189, 250

Otbert, count 169, 171

Otbert, provost of Langres 162

Otfrid, bishop of Senlis 160

Otgar, bishop of Amiens 50, 156, 160

Otto, count 167

Otto, count of Saxony 164

Otto, count, son of Ricuin of Verdun 181, $229,313,314$

Otto I the Great, emperor 187, 193, 194, 195, 200, 322 


\section{$\mathbf{P}$}

Patericus, vassus 211

Philippe-Auguste, king of France 199

Pippin, brother of Heribert I of

Vermandois 41, 45, 48, 50, 51, 68

Pippin, father of Heribert I of

Vermandois 46

Pippin, son of count Rudolf 105, 107, 123

Pippin the Hunchback, son of

Charlemagne 146

Pippin the Short, king of the Franks 143, 144

Poppa, mother of William Longsword 287

$\mathbf{R}$

Radulf, count 119

Ragenar, viscount of Auxerre, nephew of

Richard the Justiciar 120, 121

Ragenold, dux of Maine 103, 106, 107, 122, 271, 283

Ragenold, Viking leader 288

Raginelm, bishop of Noyon 91

Ragnar, Viking leader 282

Rainald, viscount 136, 213

Rainardus, fidelis 94

Raino, abbot of Saint-Serge of Angers 136

Raino, bishop of Angers 111, 213

Ramnulf I, count of Poitiers 106

Ramnulf II, count of Poitiers 34, 36, 51, $52,58,112,113,114,116,118,123,274$, 309,310

Rampo, nephew of Richard the Justiciar 120

Rampo, relative of Fulk of Reims 61

Raoul, count of Ivry 282

Raoul de Gouy, count of Ostrevent 176, 177, 185, 187, 196, 199, 200, 203, 204, 220, 224, 324

Raoul, king of the West Frankish realm 3, $186,208,209,210,219,224,227,228$, $273,288,337,342$

Ratbert, bishop of Valence 94, 95

Ratbod, archbishop of Trier, archchancellor 145, 164, 165, 166, 169, $173,174,178,183,248$

Ratbod, bishop of Utrecht 172

Rather, count of Nevers 137

Raymond, count of Nîmes and Albi 137, $138,207,223,318$
Regembald, abbot of Psalmody 207

Reginar Longneck, count, marchio 48, 49, 50, 51, 164, 165, 166, 167, 168, 169, 170, $171,173,174,175,176,177,180,181,182$, $183,187,188,190,199,204,216,223$, $229,233,245,246,247,248,249,250$, $255,283,312,322,343$

Regino, abbot of Prüm 2, 22, 24, 26, 30, 32, $44,45,166,245,246,247,255,265,270$, $283,330,331,332,334$

Ricbert, otherwise unknown 320, 321

Richard I, duke of Normandy 282

Richard II, duke of Normandy 282

Richard the Justiciar, count, marchio 47, $49,54,58,59,60,61,62,63,75,94,95$, $112,115,119,120,121,124,130,134,135$, $137,150,151,152,154,155,157,158,162$, $169,170,171,176,188,192,193,204,205$, 206, 207, 208, 209, 210, 212, 213, 214, $216,219,220,222,223,227,258,273$, $277,278,279,311,325,329,337,338$, $347,349,350,351$

Richer, abbot of Prüm, bishop of Liège $167,180,182,190,201,256,313$, 322,351

Richer, count 215

Richer of Saint-Remi 1, 3, 160, 181, 202, $255,312,313,318,337$

Richgard, empress, wife of Charles the Fat 105

Richilde, empress, sister of Boso and Richard the Justiciar, wife of Charles the Bald 80, 119, 158, 176, 191, 252, 332

Ricuin, bishop of Strasbourg 189, 250

Ricuin, count of Verdun 170, 172, 180, 181, $185,199,223,229,257,313,314,351$

Riculf, bishop of Soissons 41, 42, 49, 160,321

Robert, archbishop of Rouen 282

Robert, bishop of Metz 173, 248

Robert, bishop of Noyon 177, 215

Robert, count of Troyes 100, 101, 105, 123, $147,204,347$

Robert, fidelis $152,173,195,204,208,347$

Robert of Neustria, count, marchio, king of the West Frankish realm 2, 3, 5, $33,50,52,64,73,74,102,108,111,112$, $113,117,118,121,123,130,135,136,137$, $149,150,151,152,153,154,155,156,157$, 
$158,159,160,161,162,163,169,170$, $171,173,176,177,178,179,180,182,183$, $184,186,187,188,190,192,193,195,197$, 199, 202, 204, 205, 206, 207, 208, 209, 210, 211, 212, 213, 214, 215, 216, 217, 218, $219,220,221,222,223,224,225,226$, $227,228,229,230,231,256,258,259$, $273,277,278,279,286,287,291,292$, 293, 298, 304, 307, 308, 310, 311, 314, $321,323,324,325,328,333,335,336$, $337,338,339,341,342,347,348,349$, 350, 351

Robert the Strong, count 32, 33, 106, 107, 108, 109, 262, 279

Rodulf, abbot of Conques 137

Rodulf, abbot of Saint-Bertin and Saint-Vaast 35, 36, 40, 43, 47, 48, 52, $56,57,114,122,215,240,275,292,297$, 304, 305

Rodulf, brother of Baldwin II of Flanders 51, 54, 56, 57, 60, 62, 65, 69, 73, 302, 306, 307, 308

Roger, archbishop of Trier, archchancellor $161,178,183,184,196$, 224, 231, 312, 315

Roger, candidate for the episcopal see of Beauvais 92

Roger, count of Laon 228

Roger of Maine 73, 118, 136, 152, 220

Rollo, Viking leader, princeps 3, 5, 200, 283, 284, 285, 286, 287, 288, 289, 291

Rorico, father of Gauzlin 103

Rorico, son of Charles the Simple 252

Rothaid, daughter of Charlemagne 146

Rothard, vasallus et judex 327

Rothild, sister of Louis the Stammerer, abbess of Chelles 73, 152, 176, 205, 218, 220, 221, 335

Rotrude, daughter of Charlemagne 146

Rotrude, daughter of Charles the Bald, abbess of Andlau 172

Rudolf, bishop of Laon 46, 153, 154, 159, $160,186,192,215$

Rudolf, count 105, 107, 123

Rudolf, count, marchio, king of Upper Burgundy 61, 63, 66, 68, 69, 119, 163, 245, 256

Rudolf II, king of Upper Burgundy 258

Rumald, abbot of Fossés 186, 203

\section{S}

Salomon, Breton leader 279

Sanctio, fidelis of Robert of Neustria 64

Seguin, count of Nevers 137

Servus Dei, bishop of Girona 117

Seulf, archbishop of Reims 162, 186, 288, 337,342

Siegfrid, Viking leader 269, 279, 282, 283

Sigard, count of the Liugau $177,185,186$, $187,203,313$

Sigebod, archbishop of Narbonne 89, 94, 101

Siginand, priest and artist 321, 322

Stephen, abbot of Saint-Mihiel of Verdun, bishop of Liège 161, 167, 171, 172, 173, 182, 189, 193, 201, 220, 247, 249

Stephen, bishop of Cambrai 142, 171, 172, $176,185,187,200,203,220,223,224$, $250,324,342,351$

Stephen, count 166, 167

Stephen, fidelis 192

Stephen V, pope 41,42

Stephen VI, pope 67

Sunifred, abbot of La Grasse 117

Sunyer, count of Ampurias 116, 139

Susanna, daughter of Bego 23

\section{T}

Tedricus, fidelis 152

Tenericus, abbot of Saint-Martin of Mont-Redon 117

Tetbert, count of Meaux 46, 107, 113

Teutbald, bishop of Langres 41, 42, 49, 50, $59,61,119,120,121$

Teutbert, candidate for the episcopal see of Auxerre 109

Theobald, viscount 136

Theodard, archbishop of Narbonne 116

Theodebert, priest 99

Theoderic, abbot of Solignac 116

Theoderic, count of Kimmen 170, 171, 184, 187,229

Theoderic of Vermandois, count, brother of Aledramnus 33, 40, 48, 51, 57, 92, 96, $97,98,99,100,102,104,106,108,111,117$, $122,218,219,239,253,267,273,302,341$

Theoderic the Chamberlain, count 83,85 , $86,87,89,90,91,93,95,96,99,100$, $121,324,325$ 
Theodosius, otherwise unknown 139

Theodrada, queen, wife of Odo $33,40,48$, $92,108,114$

Theodulf, bishop of Paris 159, 179, 187, 223

Theodulf, scribe 145

Theotarius, bishop of Girona 94, 110

Theuderic III, king of the Franks 323

Theutberga, empress, aunt of Boso and Richard the Justiciar, wife of Lothar II 332

Thietmar of Merseburg 258

Throannus, royal notary, bishop of Orléans 111

Thurcetel, Viking leader 197, 280

U

Uurmaelon, Breton count 216

W

Wala, bishop of Auxerre 87

Waldrada, concubine of Lothar II 289

Walker, count 184

Walker, nephew of Odo 41, 52, 53, 115, 306, 317

Walo, bishop of Autun, nephew of Richard the Justiciar 61, 120, 121

Walter, archbishop of Sens 40, 41, 42, 51, $61,91,109,112,113,118,120,121,321$

Walter, bishop of Orléans 85, 94, 99, 109, 112,123

Waltger, count 171

Warnulf, bishop 104

Welf, abbot of Saint-Riquier 93

Wibald, bishop of Auxerre 87

Wicheramnus, abbot of Saint-Philibert of Tournus 176, 209

Wido, archbishop of Rouen 41, 42, 160, 285,321

Wido, count 94, 99, 119, 120, 123, 124
Wido, count of Senlis 287

Wido, noble from Burgundy 94

Wido of Spoleto, emperor 29, 35, 36, 37, $40,45,55,66,67,68,71,94,105,113$, $114,115,119,122,124,305$

Widukind of Corvey 258

Wifred, count 139

Wifred of Cerdagne, archbishop of Narbonne 140

Wigeric, bishop of Metz 231

Wigeric, count of the Bidgau, count of the palace $163,168,171,180,181,198,199$, 224,351

Willebertus, bishop of Châlons 87 William, abbot of Croix-Saint-Ouen 100 William Longsword, son of Rollo 285, 287, 288

William the Pious, count, marchio 47, 58, $59,60,62,75,100,112,115,116,118,119$, $120,137,138,150,159,205,206,207$, 209, 210, 219, 222, 223, 224, 310, 311

William the Younger, nephew of William the Pious, count 138, 207, 208, 210, 219

Wulfard 23

Wulfard, abbot of Flavigny, archchancellor 23, 26, 27, 83, 86, 94, 97, 123

Wulfard, count of Angoulême 23

Wulfard, father of Wulfard and Adalard 23

Wulfgrim, son of Wulfard and Susanna 23

$\mathbf{Z}$

Zwentibold, king of Lotharingia 41, 48, $49,50,54,55,56,62,63,65,66,68,69$, $72,146,148,151,153,164,165,166,167$, $168,172,173,174,175,180,223,233,242$, $244,245,246,247,248,250,252,260$, $303,306,307,321,334,349$ 
The prevalent image of the late Carolingian age is one of decline and fall. Charles III the Simple's (893/898-923) rule, which has hardly received any scholarly attention since the late 19th century, is perceived to have been the classic example of this development. Enthroned by rebels as well as cast down by a rebellion he is said to have been a weak ruler, powerless in the face of the ambitions of the nobles of the West Frankish realm. Yet, what do "weak" and "powerless" mean? In modern scholarship, early medieval rule is understood not as a question of command and obedience but as the result of cooperation between rulers and nobles. Thus, royal actions, such as the defence of the realm against the Northmen, interactions with other rulers or in regard to conflicts with or between the nobles, are reflections of the relations between the ruler and the circle of nobles around him. A ruler's power therefore depended on his ability to integrate the most powerful nobles into his rule, to mediate between their interests and to create consensus over the course of action. Based on this view, a new assessment of Charles the Simple's rule, the circle of nobles around him, the actions taken by him and thus his royal power is provided in this study, with the rules of his predecessors since the death of Charles the Bald in 877 serving as a basis for comparison.

Horst Lößlein prepared his PhD in a cotutelle at the Université de Limoges and the Ludwig-Maximilians-Universität München. His research interests include early medieval kingship, conflicts and norms, diplomatics, ideas and the meaning of legitimacy as well as literacy in the early and high middle ages. He is currently working as a research assistant at the University of Hamburg.

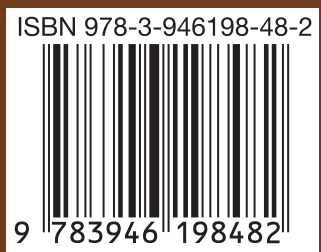

